UNIVERSIDAD DE LEÓN

\title{
EL EMBALSE DE LUNA Y LAS CAUSAS DE DEGRADACIÓN DEL PATRIMONIO.
}

Ana María VILLANUEVA FERNÁNDEZ 


\section{AGRADECIMIENTOS}

En primer lugar, deseo expresar mi más sincero agradecimiento al profesor D. José Luis Avello Álvarez por todas las indicaciones, sugerencias y observaciones que, de una manera dedicada, han contribuido a la redacción e investigación de este trabajo.

Este agradecimiento es también para todos los miembros del Departamento de Patrimonio Artístico y Documental de la Universidad de León, que con gentileza han prestado siempre sus conocimientos y ayuda de una manera desinteresada. Agradecimiento extensible a Inmaculada Rodríguez Casado, responsable del archivo de la C.H.D. sin cuya ayuda generosa no hubiese sido factible la recuperación de muchos de los datos.

Deseo mencionar la buena disposición de las gentes que poblaron el anegado Valle del Luna y a todos aquellos vecinos que abrieron sus puertas y sus vidas para reconstruir el puzle de los sucesos que ocurrieron en el pasado. Especial mención a Eduardo Diez, llave de iglesias, casas y corazones sin cuya ayuda nunca se hubiese llevado a cabo el trabajo de campo.

Del mismo modo muestro mi reconocimiento a la Excma. Diputación de León por la concesión de la Beca de Investigación que ha permitido la financiación para que este proyecto se desarrollase en el ámbito de la Universidad de León.

Por último quisiera cerrar este apartado agradeciendo a mi familia, amigos y compañeros el apoyo prestado especialmente en los momentos más difíciles de este trabajo. 


\section{ÍNDICE}

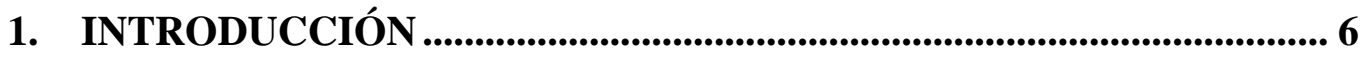

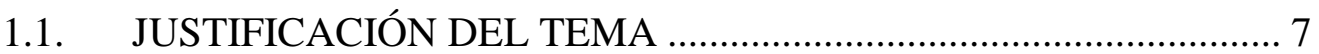

1.2. LÍMITES GEOGRÁFICOS Y CRONOLÓGICOS ............................ 8

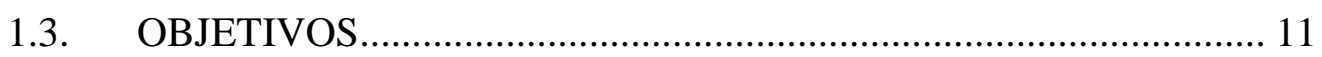

1.4. ASPECTOS METODOLÓGICOS .............................................. 11

1.4.1. BÚSQUEDA DE FUENTES …................................................... 11

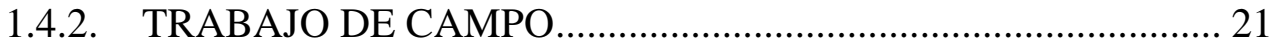

1.4.3. TRABAJO DE GABINETE ......................................................... 24

2. MARCO MEDIOAMBIENTAL E HISTÓRICO .................................... 25

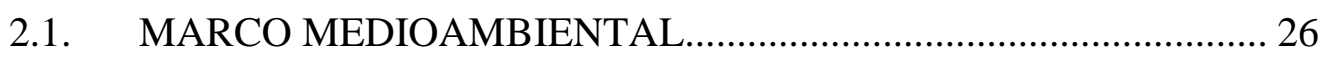

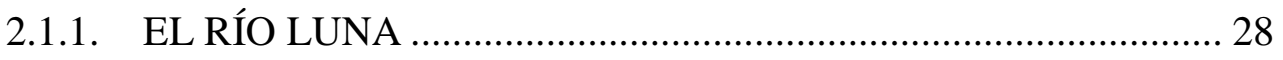

2.2. MARCO ECONÓMICO Y SOCIAL................................................ 30

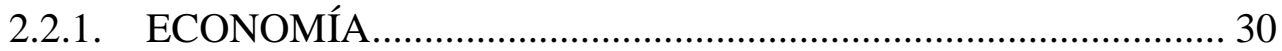

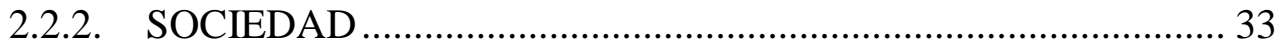

2.3. MARCO HISTÓRICO …............................................................... 37

2.3.1. DE LOS PRIMEROS ASENTAMIENTOS HASTA LA

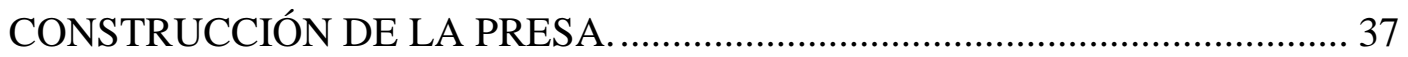

3. EL PATRIMONIO DE LA ZACEL ANTES DE LA INUNDACIÓN . 46

3.1. EL PATRIMONIO ARQUEOLÓGICO ........................................ 48

3.1.1. LOS ESTUDIOS ARQUEOLÓGICOS ...................................... 48

3.1.2. LOS PRIMEROS ASENTAMIENTOS ...................................... 49

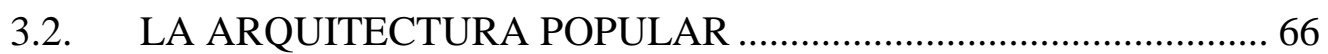

3.2.1. LOS ESTUDIOS SOBRE ARQUITECTURA POPULAR .......... 66

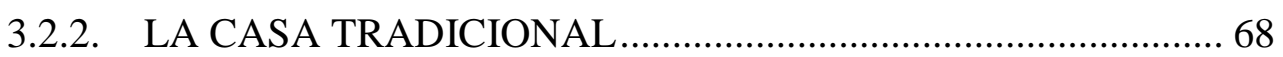

3.2.3. ARQUITECTURA AUXILIAR .................................................. 89

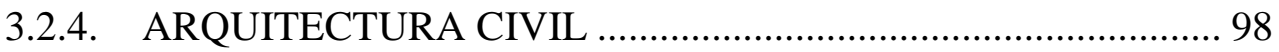

3.3. ARQUITECTURA INDUSTRIAL TRADICIONAL .................... 103

3.3.1. LOS ESTUDIOS SOBRE ARQUITECTURA INDUSTRIAL .. 103

3.3.2. LOS EDIFICIOS INDUSTRIALES .......................................... 104

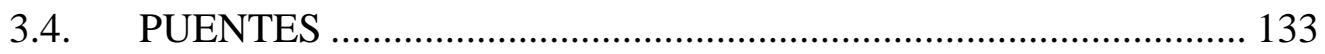

3.4.1. LOS ESTUDIOS SOBRE PUENTES .................................... 133 
3.4.2. LOS PUENTES EN LA ZACEL …………………………...... 135

3.5. ARQUITECTURA RELIGIOSA.................................................. 153

3.5.1. LOS ESTUDIOS SOBRE ARQUITECTURA RELIGIOSA ..... 153

3.5.2. LA IGLESIA EN EL VALLE .................................................. 155

3.5.3. ASPECTOS CONSTRUCITIVOS DE LAS IGLESIAS DE LA

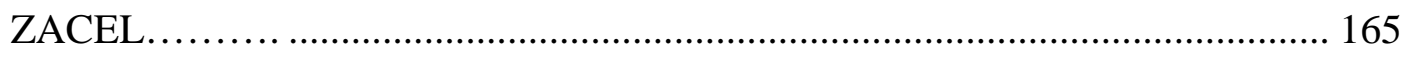

3.5.4. TEMPLOS PARROQUIALES ………………………………... 183

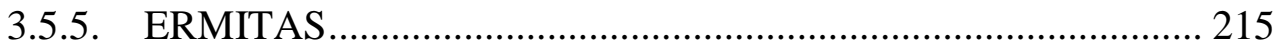

4. LA CONSTRUCCIÓN DE LA PRESA................................................... 234

4.1. LOS ESTUDIOS DE ARQUITECTURA DE PRESAS................... 235

4.2. LA OBRAS HIDRÁULICAS EN EL TERRITORIO ESPAÑOL .. 237

4.3. TIPOLOGÍA DE PRESAS.............................................................. 243

4.4. EL EMBALSE DE BARRIOS DE LUNA ……………………..... 245

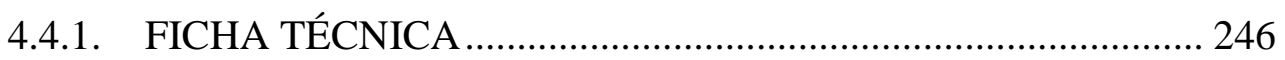

4.4.2. EL PROCESO DE CONSTRUCCIÓN ………………………...... 249

4.4.3. EDIFICIOS INDUSTRIALES …………………………….... 252

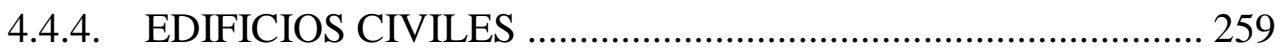

4.4.5. NUEVAS VÍAS DE COMUNICACIÓN................................... 269

5. CAUSAS DE DEGRADACIÓN .......................................................... 276

5.1. LOS ESTUDIOS SOBRE LA DEGRADACIÓN. ……………….... 277

5.2. LA LEGISLACIÓN ESPAÑOLA Y LA PROTECCIÓN DEL PATRIMONIO EN EL EMBALSE DE LUNA ..................................................... 279

5.3. LA DESTRUCCIÓN DEL PATRIMONIO DE LA ZACEL ……... 285

5.3.1. LA DEGRADACIÓN DE LA ZACEL DESDE 1949 A 1964 ... 287

5.3.2. LA DEGRADACIÓN DE LA ZACEL DESDE 1964 A LA

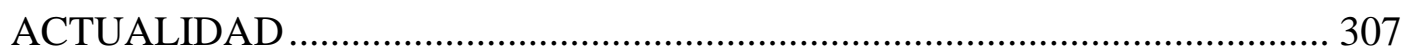

5.4. ARQUITECTURA POSTERIOR AL EMBALSADO..................... 324

5.4.1. LA NUEVA ARQUITECTURA............................................... 325

5.5. NUEVOS MOTORES ECONÓMICOS Y CULTURALES ............ 330

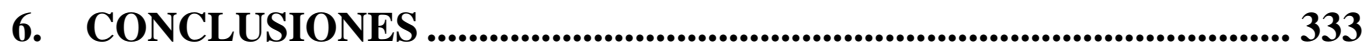

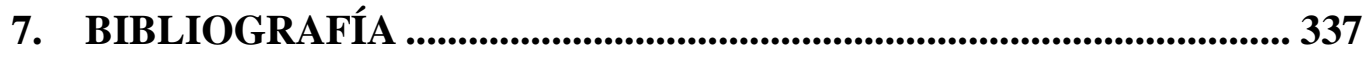




\section{SIGLAS Y ABREVIATRUAS}

\section{Archivos}

A.D.L. Archivo Diocesano de León.

A.G.C.H.D. Archivo General Confederación Hidrográfica del Duero

A.H.P.L. Archivo Histórico Provincial de León.

A.M.B.L. Archivo Municipal del Ayuntamiento de Barrios de Luna.

A.P. Archivo Parroquial

\section{Siglas}

C.H.D. Confederación Hidrográfica del Duero

Coord. Coordinador

Doc/s. Documento/s

D.G.E. Dirección General de Estadística

Ed. Edición

Fol/s. Folios

Fig/s. Figura/s

I.L.C. Instituto Leonés de Cultura

I.N.E. Instituto Nacional de Estadística

Lám/s. Láminas

L.P.A.N. Ley de Patrimonio Artístico Nacional

L.P.H.A.N. Ley de Patrimonio Histórico-Artístico Nacional

L.P.H.E. Ley de Patrimonio Histórico Español

M.T.N. Mapa Topográfico Nacional.

Óp. Cit. Obra citada

$\mathrm{P} / \mathrm{pp}$. Página/s

S/ss. Siguiente/s

T.D. Tesis doctoral

Vol. Volumen

VV.AA. Varios autores

ZACEL. Zona afectada por la construcción del embalse de Luna 
1. INTRODUCCIÓN 


\subsection{JUSTIFICACIÓN DEL TEMA}

Las causas de las grandes pérdidas del patrimonio, la dispersión del mismo, la descontextualización de las piezas y los traslados y destrucciones de los bienes inmuebles, entre otras cuestiones, son hechos que responden a acontecimientos muy dispares como pueden ser las guerras, catástrofes, robos o abandonos premeditados. Cuando se producen unos cambios radicales de estas características en una comunidad, las estructuras sociales, económicas y, por supuesto, patrimoniales se ven afectadas de tal manera que pueden acarrear la pérdida total de la memoria colectiva. Este hecho supondrá que, a la larga, sea muy difícil determinar las causas que llevaron a la desaparición de todos aquellos aspectos que configuraban el patrimonio de un pueblo o de una comarca que hoy ya no existen. Una de las circunstancias que puede llevar a este escenario es la inundación artificial de un espacio.

Durante siglos, la construcción de una presa ha sido considerada un avance y mejora de sociedades desarrolladas capaces de crear grandes reservas de agua para abastecer a poblaciones incluso en períodos de estío. Sus infraestructuras eran conservadas y restauradas para un aprovechamiento tanto humano, como agrícola. Las primeras presas no suponían una destrucción significativa del paisaje, pues su capacidad no era grande y por lo tanto su impacto ambiental era escaso. La localización de las mismas solía ocupar un terreno yermo y sin población, por lo que muy pocos bienes se veían afectados.

El panorama comenzó a cambiar durante el siglo XX y la creación de macropresas que anegaron grandes extensiones de terreno, incluyendo no sólo edificios aislados sino poblaciones completas.

Durante el primer tercio del siglo XX se dio una cierta voz de alarma frente a la pérdida de edificios singulares bajo las aguas. De este modo se puso atención en la importancia de salvar bienes inmuebles destacados. El problema de esta intervención era el coste económico de los traslados y la pérdida de la originalidad de la obra por posibles restauraciones poco respetuosas. A esto hay que añadir que muy pocos edificios eran considerados lo suficientemente representativos como para merecer el esfuerzo de su conservación.

Los cada vez más grandes embalses anegaban mayores y más importantes territorios, pero no será hasta finales de los años sesenta cuando aparezcan las primeras 
reacciones a nivel internacional de defensa del patrimonio inundado. El germen de este movimiento fueron las Recomendaciones sobre la conservación de los bienes culturales que pueden ponerse en peligro debido a la ejecución de obras públicas o privadas de la UNESCO publicadas el 19 de noviembre de 1968, en referencia a la construcción de la presa de Asuán en Egipto. Entre los principios generales del punto 8.e. se advierte que las disposiciones preventivas y correctivas deberían tener por finalidad proteger o salvar los bienes culturales puestos en peligro por obras públicas o privadas que puedan deteriorarlos o destruirlos, por ejemplo... la construcción de embalses con fines de riego, producción de energía eléctrica y prevención de las inundaciones. Añade en su punto 9 que cuando las circunstancias económicas o sociales impongan el traslado, el abandono o la destrucción de los bienes culturales, los trabajos encaminados a salvarlos deberían siempre comprender un estudio detenido de los bienes culturales de que se trate y el registro completo de los datos de interés.

Comienza de este modo una nueva corriente, a nivel no solo europeo sino mundial, de protección del patrimonio anegado por las presas en las que se advierte de la necesidad de crear un registro de todos aquellos bienes trasladados, abandonados o destruidos a causa de la construcción de un embalse. Sin embargo en el caso español la situación fue muy diferente debido a la condición política y económica del momento hasta bien entrada la Democracia.

El tema de esta Tesis Doctoral (T.D.) tiene por objeto el estudio del proceso de degradación del patrimonio arquitectónico afectado por una circunstancia muy poco analizada: la construcción de un embalse. Los aspectos naturales y antropológicos han sido descartados puesto que pertenecen a otras ramas de conocimiento ajenas a la finalidad de este trabajo.

\subsection{LÍMITES GEOGRÁFICOS Y CRONOLÓGICOS}

Para llevar a cabo esta T.D. es imprescindible delimitar un área geográfica y un marco cronológico. La elección de la provincia de León vino determinada por la cercanía y conocimiento personal del territorio y por la adjudicación en 2005 de la Beca de Formación de Personal Investigador convocada por la Excma. Diputación de León en cuyas bases se establecía la necesidad de acotar el estudio a la provincia. Gracias a esta 
beca se pudo desarrollar el trabajo dentro del Departamento de Patrimonio Artístico y Documental de la Universidad de León.

Una vez demarcado el territorio se tomó la decisión de elegir el embalse de la provincia de León que mejor se adecuase a la finalidad de este estudio. Barrios de Luna destacó desde el primer momento debido a tres características fundamentales.

La primera es la cantidad de poblaciones afectadas por la inundación, trece en total, frente a otros embalses como el de Riaño, en el que se anegaron nueve pueblos o el del Porma con ocho.

La segunda característica es la conservación de algunos de sus edificios anegados, pues ninguno fue trasladado a otros lugares y gran parte no fueron demolidos, lo que ha supuesto un verdadero cementerio arqueológico bajo las aguas. Gracias a ello se pueden identificar in situ las estructuras arquitectónicas que configuraban las poblaciones y observar de manera clara el proceso de degradación al que han sido sometidas.

La tercera característica es que Barrios de Luna es el único embalse de la provincia que sufre un vaciado considerable en época estival, ya que sus aguas son aprovechadas para el regadío del Páramo, el uso eléctrico y el consumo humano. Esta circunstancia ocasiona que la mayor parte de las estructuras afloren en períodos de estío, pudiendo observar sus restos durante el estío.

Una vez definida la zona de actuación se hizo imprescindible acotar el espacio de estudio. En primer lugar se tuvo en cuenta el área afectada por la inundación, es decir, el lugar al que llegaban las aguas del embalse. Sin embargo se observó que esta delimitación no era suficiente, pues existían poblaciones no anegadas que fueron igualmente perjudicadas por la construcción de la presa. Así pues se amplió el territorio a todas aquellas otras que tuvieron una pérdida sustancial de gran parte de su patrimonio arquitectónico a causa del embalse. Se desestimaron las que, aunque cercanas a éste, no habían sido privadas de sus edificios y se incluyeron otras que, a pesar de no haber sido inundadas, sufrieron el abandono y la expropiación de su patrimonio arquitectónico.

En el mapa que se muestra a continuación se reflejan los pueblos que han sido incluidos dentro de este estudio. Estos son: Arévalo, Barrios de Luna, Campo de Luna, Casasola, Cosera, Lagüelles, Láncara, Mallo, Miñera, Mirantes, Oblanca, San Pedro y Santa Eulalia. 


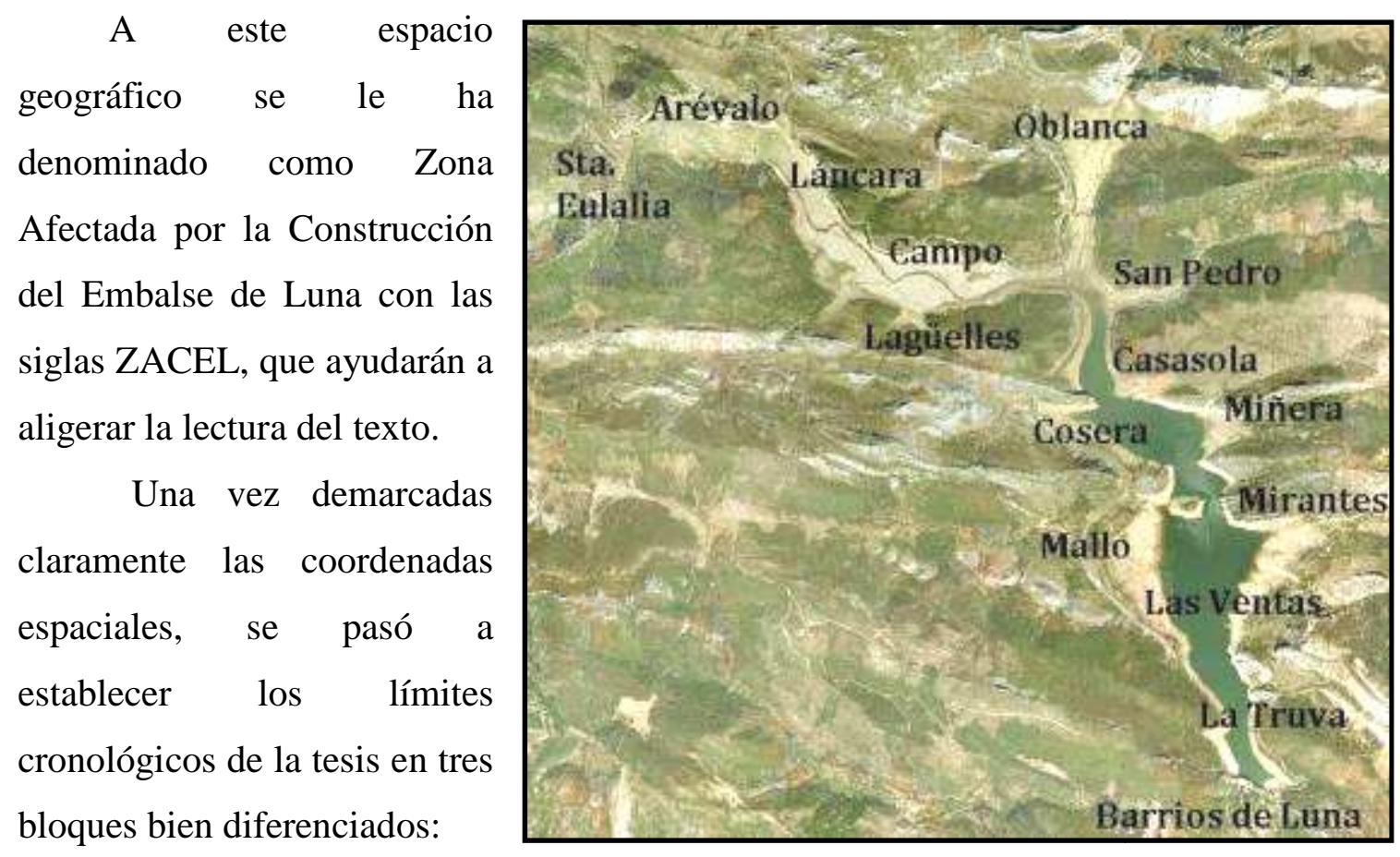

- Antes de la construcción del embalse.

- Durante la realización de las obras.

- Después de la inundación.

Esta diferenciación resultó ser la más apropiada, pues ejercía de hilo conductor para conocer todo el panorama patrimonial de las poblaciones afectadas de una manera ordenada y lógica.

El primer bloque parte de las antiguas civilizaciones asentadas en el Valle del Luna hasta la adjudicación de las obras del embalse el 31 de enero de 1945. Este bloque pretende estudiar y analizar los procesos históricos y artísticos que dieron lugar al patrimonio arquitectónico de la ZACEL en el que se incluyen los yacimientos arqueológicos, la arquitectura tradicional, la industrial y la religiosa.

El segundo bloque comienza con la concesión de las obras del embalse hasta la actualidad y tiene como finalidad el estudio tanto de las construcciones realizadas para la presa como el análisis de los procesos de degradación del patrimonio arquitectónico.

El último bloque hace un repaso por todos los procesos de degradación al que han sido sometidos los bienes inmuebles de la ZACEL desde el cierre de la presa hasta nuestros días. 


\subsection{OBJETIVOS}

Los objetivos que se desean alcanzar en esta T.D. son los siguientes:

- Conocer el patrimonio arquitectónico de la ZACEL antes de la inundación.

- Estudiar el proceso de destrucción que ha sufrido dicho patrimonio desde la construcción de la presa hasta la actualidad.

- Recopilar información de las diversas fuentes para recrear las arquitecturas existentes antes de la expropiación de los terrenos que ocuparía el embalse.

- Analizar el papel de las administraciones con respecto a la protección de los bienes inmuebles.

- Recuperar la memoria histórica de un valle anegado.

- Valorar el patrimonio de la ZACEL y su importancia en la actualidad como un testigo mudo del paso de unas poblaciones vivas a un yacimiento arqueológico.

- Favorecer la gestión cultural de una zona deprimida que posee grandes oportunidades educativas.

\subsection{ASPECTOS METODOLÓGICOS}

Para conseguir los objetivos planteados, la presente T.D. se ha organizado en tres fases bien definidas, la búsqueda de fuentes, el trabajo de campo y el trabajo de gabinete.

\subsubsection{BÚSQUEDA DE FUENTES}

Una vez marcados los objetivos de este trabajo, el siguiente paso consistió en la recopilación de información procedente de bases de datos documentales y bibliográficos junto con otras fuentes cartográficas, fotográficas y orales. El comentario de las fuentes 
en este apartado pretende ser general, puesto que en cada uno de los siguientes capítulos se volverá a hacer una exposición bibliográfica del tema en cuestión.

\section{Fuentes documentales}

La consulta de las fuentes documentales se llevó a cabo en diversos archivos:

Archivo General de la Confederación Hidrográfica del Duero (A.G.C.H.D.). La sección del fondo administrativo de la que se extrajo la mayor cantidad de información fue la serie de expedientes de expropiación del embalse de Barrios de Luna de los diferentes términos afectados y los proyectos de obra desde 1942 hasta la actualidad. El archivo de la Confederación del Duero ha aportado, sin duda, la base de datos más importante que ha facilitado enormemente la labor de esta T.D. A pesar de ser un archivo de carácter técnico y administrativo, el trazado de planos, la descripción de los edificios y las circunstancias de la construcción de la presa han sido el eje del desarrollo del trabajo de esta investigación. De sus fondos se consiguió información referente no solo a la presa, sino también a todos los bienes arquitectónicos que fueron objeto de los procesos de expropiación del embalse y la construcción de las nuevas arquitecturas.

Archivo Histórico Provincial de León (A.H.P.L.). En él se investigaron los Protocolos Notariales conservados del municipio de Murias de Paredes así como el Catastro del Marqués de la Ensenada de 1752 de las poblaciones afectadas por el embalse. La documentación extraída del Catastro sirvió para conocer el nombre de los edificios religiosos, el número de molinos, batanes y otros elementos industriales de la época, así como otros datos poblacionales. En el caso de los Protocolos Notariales, la información obtenida se limitaba a la compra venta de terrenos y a las mandas testamentarias, sin hacer apenas referencia a fundaciones o donaciones de iglesias o bienes religiosos.

Archivo Diocesano de León (A.D.L.). El Archivo Diocesano fue una fuente muy importante de información referida fundamentalmente a los bienes religiosos, aunque también se extrajeron noticias de edificios industriales como molinos y batanes pertenecientes a diferentes parroquias. La consulta se basó en la búsqueda de los fondos parroquiales de las iglesias afectadas por la inundación 
como son los Libros de Fábrica, Libros de Cuentas, Libros de Cofradías y Libros de Capellanías. De sus ficheros se extrajeron datos acerca de la fundación de diversas cofradías y de restauraciones y ampliaciones parroquiales.

Archivo Parroquial de Barrios de Luna, Sena de Luna y Mallo de Luna (A.P.). Los archivos parroquiales apenas aportaron datos relevantes para este estudio, pues la documentación más antigua conservada en las iglesias se fecha años más tarde de la construcción de la presa.

Archivo Municipal del Ayuntamiento de Barrios de Luna. (A.M.A.B.). Su consulta destapó algunos documentos inéditos, sin especial trascendencia para este estudio, referentes al castillo de Luna y a las indemnizaciones percibidas por la construcción de la presa cuya información también se incluía en el archivo general de la C.H.D.

En cuanto a la legislación se revisó la historiografía relacionada con el tema de las presas y pantanos en nuestro país y especialmente la legislación correspondiente con la provincia y la comunidad para establecer de antemano el panorama referente al tema trabajado. El texto principal para el estudio fue la Ley 13 de mayo de 1933 del Patrimonio Artístico Nacional (L.P.A.N) y sus disposiciones posteriores, como las leyes y decretos de 1953, 1955, 1958, 1963 y 1972, hasta la Ley 16/1985, de 25 de junio de Patrimonio Histórico (L.P.H.E.).

\section{Fuentes cartográficas}

El análisis de las fuentes cartográficas antiguas fue muy útil a la hora de conocer la ubicación exacta de los pueblos afectados por el embalse. Los mapas de la zona, levantados una década antes de la inundación del embalse, sacaron a la luz información necesaria para descubrir el sistema urbanístico de las poblaciones inundadas y las comunicaciones entre las mismas. Dentro de los mapas se prestó especial atención a la toponimia que pudiera estar relacionada con yacimientos; como la denominación de Peña Almanzor a la elevación del Castillo de Luna o el Castro de Mallo al asentamiento medieval de la localidad; o para aclarar la procedencia de diversas construcciones desaparecidas como la ermita de S. Juan de Barrios de Luna.

Las fuentes cartográficas examinadas han sido las siguientes: 
Mapa Topográfico Nacional. (M.T.N) 50 Barrios de Luna. $N^{o}$ 102. Año 1945. La consulta de este mapa fue primordial para conocer la estructura no solo de las localidades sino también de su orografía y paisaje. Gracias a este mapa se pudo hacer una estimación de la incidencia del embalse y los núcleos de población que se vieron afectados

Mapa Topográfico Nacional. (M.T.N) 50 Barrios de Luna. $N^{\circ} 102$. Año 2005. La comparación de este mapa topográfico con el anterior ayudó a revelar el cambio ocurrido tras la construcción de la presa y la desaparición de los pueblos que finalmente se vieron aquejados por la inundación.

Visor SIGPAC, Topo Hispania y Google Maps. Estas tres fuentes cartográficas facilitaron la labor de extraer imágenes e información acerca de las condiciones actuales del embalse y los cambios sufridos en las poblaciones.

\section{Fuentes fotográficas}

Los fondos fotográficos fueron especialmente relevantes a la hora de estudiar las características arquitectónicas tradicionales y las religiosas de una manera más adecuada y cercana a la realidad existente. Las imágenes de la construcción de la presa y de todos los edificios levantados ex profeso para ello, ayudó enormemente a conocer el aspecto real de las obras. Su análisis facilitó el conocimiento de las características de la arquitectura la apariencia real que poseían los edificios hoy inundados. En las imágenes se recogió no sólo el aspecto formal de las poblaciones, sino también el proceso de su inundación y las condiciones en las que quedaron algunos de los bienes mientras el agua iba cubriendo las tierras del Valle.

Las fuentes fotográficas consultadas han sido las siguientes:

Fondo fotográfico de la Confederación Hidrográfica del Duero: Embalse de Barrios de Luna. Estas fotografías se centran fundamentalmente en el proceso de construcción de la presa y los edificios realizados para la misma. Gracias a este fondo se ha obtenido información acerca de la técnica constructiva de la presa y los trabajos que se llevaron a cabo durante las obras del embalse.

Fondo fotográfico del Instituto Leonés de Cultura. La consulta de las imágenes, tomadas años antes de la inauguración de la presa y durante la 
inundación de las poblaciones, dio como resultado una gran cantidad de información inédita. Gracias a este archivo se descubrió el aspecto original de los bienes de cada localidad, sus edificios y arquitecturas más importantes. En estas fotografías también se plasmó el estado en el que habían quedado los edificios a la llegada de las aguas y el proceso de inundación.

Fotografía del Vuelo Americano. 20 Mayo 1957. ASTG M ROLL 426. 1370 PMC. La fotografía aérea del vuelo americano reveló el estado del embalse de Barrios un año después de su inundación en el cual se puede ver el trazado original de las comunicaciones que hoy han desaparecido.

Fondos fotográficos particulares. Los archivos fotográficos particulares han ayudado a conocer detalles e informaciones desconocidas acerca de las estructuras arquitectónicas que componían el paisaje de Luna.

\section{Fuentes orales}

Las fuentes orales se han constituido como una de las más importantes a la hora de dar a conocer las causas de degradación del patrimonio de la ZACEL. Las encuestas a los vecinos que habían vivido el proceso de la inundación aportó datos valiosos sobre determinados hechos que fueron obviados por alguna de las fuentes tradicionales. La imposibilidad de encuestar a todas las personas obligó a discriminar determinadas búsquedas individualizadas por poblaciones en favor de gentes que conociesen el panorama general de los pueblos de la ZACEL.

Para extraer la información precisa se creó un modelo de encuesta orientada a saber lo que había existido y los distintos procesos que afectaron a la desaparición o conservación de las obras con los siguientes apartados:

\begin{tabular}{|l|l|}
\hline Término Municipal: & \\
\hline Localidad: & \\
\hline Fecha: & \\
\hline Informante: & \\
\hline Edad y profesión: & \\
\hline
\end{tabular}




\begin{tabular}{|l|l|}
\hline Nombre del edificio & \\
\hline Dueño o patrón & \\
\hline Uso durante el tiempo & \\
\hline Bienes que contenía & \\
\hline Estado anterior a la degradación & \\
\hline Causa de la degradación & \\
\hline Reutilización de los materiales & \\
\hline
\end{tabular}

\section{Bibliografía}

En cuanto a las fuentes bibliográficas, la información más antigua relacionada con el entorno de Luna se encontró en los documentos publicados en los catálogos catedralicios, monacales y nobiliarios. El catálogo de la catedral de Oviedo, estudiado por García Larragueta ${ }^{1}$, y el de León ${ }^{2}$, por Fernández Catón, García Lobo y Martín Fuertes, aportó datos acerca de los bienes, donaciones, herencias y privilegios de determinadas iglesias con respecto al territorio que nos ocupa. De estos catálogos también se extrajeron antecedentes sobre posibles dataciones de los poblados. Junto con los registros catedralicios, los archivos monacales como el de Sta. María de $\operatorname{Arbas}^{3}$ y el de Otero de las Dueñas ${ }^{4}$ contribuyeron a conocer aspectos referentes a donaciones y privilegios de estos centros en la zona de estudio.

Al igual que los archivos religiosos la publicación de catálogos nobiliarios, como el de los Condes de Luna por Álvarez Álvarez y Martín Fuertes ${ }^{5}$, supuso otra fuente de

${ }^{1}$ GARCía LARRAGUETA, Santos. Catálogo de los pergaminos de la catedral de Oviedo. Oviedo, 1957; Colección de documentos de la catedral de Oviedo. Oviedo, 1962.

2 FERNÁNDEZ CATÓN, José María. Catálogo del archivo histórico diocesano de León. Tomo I. León, 1978. GARCÍA LOBO, Vicente. Colección documental del archivo de la catedral de León. León, 1998. MARTÍN FUERTES, José Antonio. Colección documental del archivo de la catedral de León. León, 1995.

${ }^{3}$ GARCÍA LOBO Vicente y José Manuel. Santa María de Arbas. Catálogo de su archivo y apuntes para su historia. Madrid, 1980.

${ }^{4}$ FERNÁNDEZ FLÓREZ, José Antonio y HERRERO DE LA FUENTE, Marta. Colección documental del monasterio de Santa María de Otero de las Dueñas. Vol I (854-1108), Vol II (1109-1300). León, 1999.

5 ÁlVAREZ ÁlVAREZ, César y MARTÍN FUERTES José Antonio. Catálogo del archivo de los condes de Luna. León, 1977; Addenda del Catálogo del Archivo de los Condes de Luna. León, 1982; MARTÍN FUERTES, José Antonio. Los Quiñones Marqueses de Montevirgen: linaje y archivo. León, 2000. 
conocimiento del patrimonio medieval del que se extrajeron noticias sobre pleitos o herencias e imposiciones de los condes con respecto a los vecinos de Luna.

La documentación publicada relacionada con los inventarios estatales en el período moderno aportó datos relacionados con aspectos económicos y su población como es el caso del Diccionario de Sebastián de Miñano ${ }^{6}$. En el Diccionario de Pascual $\mathrm{Madoz}^{7}$ se citan elementos de carácter anecdótico que dieron cierta información relativa fundamentalmente al castillo de Luna y sus leyendas.

Las primeras publicaciones bibliográficas referentes al patrimonio del Valle datan de 1923 y son los estudios de César Morán ${ }^{8}$ correspondientes con el patrimonio arqueológico de la zona. Su obra es sin duda pionera en la investigación arqueológica del norte de la provincia, puesto que por primera vez se recogen noticias acerca de los asentamientos castrenses junto con una descripción de las piezas arqueológicas obtenidas en sus prospecciones. A esta publicación le siguió el Catálogo de Manuel Gómez Moreno ${ }^{9}$ en el que destaca una referencia al castillo de Luna, el desaparecido calvario de la iglesia parroquial de Barrios y los hallazgos del castro de Oblanca y de Barrios. Su descripción es a veces escasa y con un gran componente literario en el que se prima lo legendario sobre lo histórico y lo medieval sobre lo barroco.

Debemos esperar hasta 1956 para encontrar la siguiente publicación relacionada con las poblaciones de la ZACEL como es el libro de Mariano Berrueta ${ }^{10}$ en recuerdo de los pueblos anegados. El autor recopila una escueta información acerca de los caseríos desaparecidos. Su mayor aportación fue la inclusión de fotografías que ilustraron el estado real de los pueblos antes de la inundación.

En los años de construcción de la presa las noticias se localizan exclusivamente en las ediciones del Diario de León y el $A B C$ relacionadas con el tema. El Diario de León se hizo eco de las sucesivas novedades de las obras y del drama de los pobladores que

\footnotetext{
${ }^{6}$ MIÑANO, Sebastián de. Diccionario geográfico-estadístico de España y Portugal. Madrid, 1826-1828. Copia digital. Valladolid: Junta de Castilla y León. Consejería de Cultura y Turismo. Dirección General de Promociones e Instituciones Culturales, 2009-2010.

7 MADOZ, Pascual. Diccionario geográfico, estadístico, histórico de España y sus posesiones de ultramar, Castilla-León. Tomo III. 1845-1850. Ed. Facsímil. Valladolid, 1983.

${ }^{8}$ MORÁN BARDÓN, César. Excursiones arqueológicas por tierras de León. León, 1923; Por tierras de León. Historia, costumbres, monumentos, leyenda, filología y arte. León, 1925; "Excursiones arqueológicas por tierras de León" en Archivos leoneses Revista del centro de estudios e investigación de S. Isidoro. Año III. Julio-Diciembre. Nº 6. León, 1949.

${ }^{9}$ GOMEZ MORENO, Manuel. Catálogo monumental de España: La provincia de León, (1906-1908) Madrid, 1925, Ed. Facsímil. Madrid, 1979.

${ }^{10}$ BERRUETA, Mariano. Riberas del Luna. Ofrenda de despedida a los pueblos de las riberas del Luna que desaparecen en el pantano de Barrios de Luna. León, 1956.
} 
tuvieron que abandonar sus hogares. Los principales artículos aluden a la construcción del embalse y su inauguración por parte del General Franco, aunque otros artículos posteriores se centran en las denuncias de abandono y expolio de las poblaciones inundadas $^{11}$. De la misma manera el $A B C$, periódico por excelencia de la época, describió el embalse de Luna como una gran obra de ingeniería que traería la riqueza y el regadío para las tierras del Páramo ${ }^{12}$. La descripción de los trabajos elevó la importancia de la faraónica obra a un prodigio de la ingeniería del momento.

Tras la construcción de la presa, las primeras obras publicadas fueron de carácter histórico y arqueológico lideradas por José Avelino Gutiérrez González y Cesar Álvarez. La memoria de licenciatura de Gutiérrez González ${ }^{13}$ supuso una recuperación patrimonial de los yacimientos del norte de la provincia en el que se incluía un estudio científico y comparativo de todas las piezas halladas y de los asentamientos defensivos castreños. A esta le seguirían otras monografías relacionados con la etapa antigua y medieval del Valle ${ }^{14}$. Estos estudios fueron un importante paso en el mundo de la investigación por dos aspectos, el primero, rescatar las publicaciones sobre la zona que desde Morán Bardón no habían vuelto a ser estudiadas y el segundo recorrer por primera vez un valle inundado realizando prospecciones, planos y estudios científicos de los yacimientos y piezas arqueológicas allí encontradas.

Durante los años ochenta César Álvarez ${ }^{15}$ contribuyó al conocimiento histórico de la zona a partir del estudio documental de los sucesos históricos de la familia Quiñones. Continuando con esta corriente histórico-arqueológica, a finales del siglo XX y comienzos del XXI se multiplican los artículos de revistas científicas que citan y describen algunas de las piezas arqueológicas de Luna. Destacan obras como los

\footnotetext{
11 "El pantano de los Barrios de Luna" en DIARIO DE LEÓN. 15 -03-1945; E. ALONSO PÉREZ. "Los espectros del embalse de Luna" 21/12/2008; "Paisaje Lunar en el decaído embalse de Luna" 20/02/2006

12 ABC Madrid:" El jefe del estado inauguró el pantano de Barrios de Luna.” 25/09/1956, p. 15.

13 GUTIÉRREZ GONZÁLEZ José Avelino, Poblamiento antiguo y medieval en la montaña central leonesa. León, 1985.

${ }^{14}$ GUTIÉRREZ GONZÁLEZ, José Avelino. La arquitectura militar en el reino de León. Siglos IX al XIII. Valladolid, 1989; Fortificaciones y feudalismo en el origen y formación del Reino Leonés (siglos IXXIII) Valladolid, 1995. "La implantación feudal y las fortificaciones en los orígenes del reino de León" en La fortificación medieval en la Península Ibérica. Actas del IV Curso de Cultura Medieval. Seminario: La fortificación medieval en la Península Ibérica. Centro de estudios del Románico. Aguilar de Campoo, 21-26 de septiembre de 1992. Salamanca, 2001.

15 ÁlvarEZ ÁlVAREZ, Cesar. El condado de Luna en la Baja Edad Media. León, 1982; Castillos, palacios y torres de los Quiñones en la Baja Edad Media leonesa. Castillos medievales en el reino de León. León, 1981.
} 
artículos de Germán Delibes y Julio Fernández ${ }^{16}$ sobre los hallazgos del Bronce en tierras de León y los artículos publicados por Jesús Celis Sánchez y Eduardo Alonso Herrero y Ana Neira Campos ${ }^{17}$ relacionados con objetos y explotaciones de origen romano y prerromano. Una de las últimas investigaciones sobre la historia del Valle son las hechas por la autora ${ }^{18}$ alusivas a la descripción y catalogación de piezas y yacimientos hoy desaparecidos.

Las publicaciones relacionadas con el desarrollo turístico comienzan a ser habituales a finales de los años noventa. En ellas se incluye la historia y costumbres de la comarca junto con un estudio de la flora y fauna. Destaca el texto de César Álvarez Álvarez ${ }^{19}$ y Julio Alonso González ${ }^{20}$ o el libro de Julio Álvarez Rubio sobre la historia y costumbres de los pueblos de la comarca de Luna. En el libro de Agustín Almazán Ceballos $^{21}$ se hace una recopilación de las características de la flora y fauna del lugar, con una breve introducción acerca del embalse basado en los aspectos naturales y no en los artísticos. La obra de Pedro A. Alonso Fernández ${ }^{22}$ nos habla de la riqueza natural del lugar y plantea rutas a pie por la montaña aledaña y los textos de Federico Sanz Rubiales y Óscar Domínguez Cortés ${ }^{23}$ hacen un repaso por todas las presas de la cuenca

\footnotetext{
${ }^{16}$ DELIBES CASTRO, Germán y FERNANDO MANZANO, Julio. "Calcolítico y Bronce en tierras de León” en Cántabros y Astures (Lancia). Universidad de León, 1983, pp. 53-82; Metalurgia de la Edad del Bronce en el piedemonte meridional de la Cordillera Cantábrica. La colección Fontaneda. Valladolid 1999; FERNÁNDEZ MANZANO, Julio. Bronce final en la Meseta Norte española: el utillaje metálico, Soria 1986; "Calcolítico y Edad del Bronce en la provincia de León". Actas del ciclo de conferencias ARQUEOLEÓN. Historia del reino de León a través de la arqueología. León 1993-1994. León, 1996, pp. 29-40.

${ }^{17}$ CELIS SANCHEZ, Jesús. Origen, desarrollo y cambio en la Edad del Hierro de las tierras leonesas. Actas del ciclo de conferencias ARQUEOLEÓN. Historia del reino de León a través de la arqueología. León 1993-1994. León 1996, pp. 41-67; El castillo de los Barrios de Luna. Un yacimiento del Bronce inicial-medio en el occidente de la cordillera cantábrica. Revista Lancia 4. León, 2001, pp. 85-102; ALONSO HERRERO, Eduardo y NEIRA CAMPOS, Ana. Una explotación minera de minium(cinabrio) atribuible a época romana en Miñera( León-España)Revista Lancia 4 (2000-2001) pp. 127-142.

${ }^{18}$ VILLANUEVA FERNÁNDEZ, Ana María. "El redescubrimiento de la lápida visigótica de Barrios de Luna. León. Estudio y contextualización”. En Revista Documenta Instrumenta. No 8, Madrid, 2010, pp. 181-190.; "Los restos de una escultura romana inédita en Rabanal de Luna. León”. en BSAA arqueología. LXXVI., Universidad de Valladolid, 2010, pp. 77-90. "El valor patrimonial de los restos arqueológicos. El Castro de Oblanca. León” en e-rph. Revista Electrónica de Patrimonio Histórico, Estudios generales. Estudios 2. no 10, junio 2012.

${ }^{19}$ ÁLVAREZ ÁLVAREZ, Cesar y ALONSO GONZÁLEZ, Joaquín. Guía del patrimonio cultural de las comarcas de cuatro valles. León, 2001.

${ }^{20}$ ÁLVAREZ RUBIO, Julio. Babia, Laciana, Alto Luna: pueblos, paisajes y paseos, León, 2006.

21 ALMAZÁn CEBAllos, Agustín. Guía de campo del Embalse de Los Barrios de Luna y sus alrededores, Barrios de Luna, 2000.

22 ALONSO FERNÁNDEZ, Pedro. A. "Los Barrios de Luna: embalse”, en Rutas Turísticas por León. León, 1991.

${ }^{23}$ SANZ RUBIALES, Federico y DOMÍNGUEZ CORTÉS, Oscar. Embalses de la Cuenca del Duero, Palencia, 1999.
} 
definiendo sus características técnicas con un pequeño estudio patrimonial de la zona inundada.

Las primeras obras de divulgación referentes a la situación del patrimonio ante la creación de un embalse se reducen a artículos de revistas especializadas como la obra de María Pilar Poblador Muga ${ }^{24}$ en la que se hace un análisis del impacto patrimonial que supuso el proyecto del recrecimiento del embalse de Yesa en la provincia de Zaragoza. Hay que destacar el esfuerzo de algunas publicaciones, como la revista Argutorio, en dar importancia a la conservación del patrimonio anegado por los embalses como se desprende en algunos de sus artículos ${ }^{25}$.

La publicación dirigida por Hortensia Larrén Izquierdo sobre los bienes arqueológicos y monumentales en el embalse del Esla ${ }^{26}$ abrió un nuevo procedimiento de estudio del patrimonio anegado. En este trabajo se aplica una metodología científica, con cierta base arqueológica, que recrea y estudia las características de los edificios inundados a partir de fichas catalográficas con planos de los restos y su estado de conservación. El método de este trabajo se aproxima y adecúa a los propósitos y objetivos que se desean cumplir en esta T.D. por lo que ha sido una guía, aunque no una doctrina, para la estructuración de esta monografía.

En los últimos años se hacen comunes las publicaciones de carácter divulgativo que se centran principalmente en el paisaje y sus gentes. La primera obra de estas características es el libro autobiográfico de Agustín García Suárez ${ }^{27}$ en el que por primera vez se hace un recordatorio del modo de vida y las estructuras que conformaban el Valle, con información adicional sobre el puente de Miñera y fotografías inéditas. Tras esta obra surgen otras como el coleccionable del Diario de León ${ }^{28}$ en el cual se despliega todo un recuerdo de los pobladores del momento junto con un amplio repertorio fotográfico de la época.

\footnotetext{
24 POBLADOR MUGA, María Pilar." Proyecto del recrecimiento del embalse de Yesa y el Camino de Santiago a su paso por la provincia de Zaragoza. El último capítulo de un patrimonio cultural agonizante" en Artigrama, no 15, Zaragoza, 2000, pp. 533-542.

25 GUSTAVO LÓPEZ, David. "El patrimonio de Riaño, de la demolición al olvido" pp 50-52. APARICIO, Juan Pedro. "Derechos, leyes, embalses y nueces" pp 52-53 en Argutorio revista de la Asociación Cultural "Monte Irago", no 19, 2007.

${ }^{26}$ LARRÉN IZQUIERDO, Hortensia, MARTÍN CARBAJO, Miguel Ángel, MISIEGO TEJEDA, Jesús Carlos, SALVADOR VELASCO, Mónica, VIÑÉ ESCARTÍN, Ana I., SANZ GARCÍA, Francisco Javier, MARCOS CONTRERAS, Gregorio José, PÉREZ RODRÍGUEZ, Francisco Javier. Patrimonio arqueológico y monumental en el embalse del Esla (Zamora: tramo, Bretó de la Ribera-Ricobayo). Zamora, 2001.

${ }^{27}$ GARCÍA SUÁREZ, Agustín. Una historia de pantanos. León, 1999.

${ }^{28}$ VVAA. Los pueblos de León. La Crónica 16 de León. León, 1995.VVAA. El siglo en León. Todos los pueblos y sus gentes. León, 2001.
} 
También se multiplican las monografías en formato digital centradas en desarrollar, de manera educativa, una visión sobre las características de los embalses de cada cuenca hidrográfica. Los vídeos realizados por el Ministerio de Medio Ambiente y la Confederación Hidrográfica del Duero pretenden dar a conocer un panorama basado principalmente en el aspecto natural más que patrimonial sobre los embalses y su explotación turística. Destaca la obra de Félix Daroca Santos y Francisco Cantalapiedra Puelles $^{29}$ sobre los pantanos de la provincia de León en el que se da una visión general sobre la construcción de la presa de Barrios, el momento histórico y las condiciones naturales de sus ríos. También hay una pequeña referencia a los pueblos y sus gentes, haciendo hincapié en los aspectos de la cultura tradicional de forma anecdótica.

En cuanto a la webgrafía cabe destacar algunas páginas de internet específicas como http://www.xente.mundo-r.com/luna/index.htm, y www.c.h.d.uero.es que han aportado interesante documentación para este trabajo relacionada con aspectos referentes al embalse de Barrios de Luna.

\subsubsection{TRABAJO DE CAMPO}

Una vez consultadas las fuentes y establecidos los marcos geográfico y cronológico, comenzó el trabajo de campo. La visita al embalse se hizo necesaria para aplicar los conocimientos adquiridos a las características propias del patrimonio de la ZACEL. Se recorrió, a lo largo de varios años, todas las poblaciones perceptibles que se vieron afectadas por el embalse, registrando una serie de datos y fotografías del estado de los bienes y su localización exacta. Evidentemente el final del verano era la única estación del año en la que se podía acceder a las estructuras inundadas debido al descenso del nivel de las aguas. La visita periódica en momentos de estío fue imprescindible para reconocer sobre el terreno los restos y realizar un trabajo de campo describiendo, cuando era posible, cada uno de los elementos que conforman el patrimonio inmueble de la ZACEL.

Durante las primeras visitas se observó el estado de conservación de los bienes que se mantenían en pie y aquellos que se iban deteriorando. En los siguientes viajes se fue registrando su paulatina degradación, apuntando en cada momento las causas que

29 DAROCA SANTOS, F. Coor. CANTALAPIEDRA PUELLES, F. Guión; Embalse de Villameca, Embalse de Riaño y Embalse del Porma. MUNDIMAG realización. Madrid, 2006. 
ocasionaban tal destrucción. En este sentido, la ayuda de las gentes de las poblaciones aledañas y antiguos moradores fue fundamental, pues sólo ellos conocían el destino que sufrieron las diversas arquitecturas.

La toma de fotografías fue indispensable, pues gracias a ellas se pudo obtener información detallada para la presentación del estudio final.

En momentos puntuales se dibujaron planos y alzados de las obras que no habían sido estimadas por los ingenieros de la Confederación del Duero al no quedar anegadas como es el caso de la iglesia de Barrios o la de Mallo de Luna.

De entre las labores de campo destaca la correcta medición con el GPS de algunos de los asentamientos castrenses, siempre que las condiciones del terreno lo permitiesen. Así por ejemplo se han cartografiado por primera vez los castros de Mallo y Oblanca por la topógrafa Consuelo Fernández.

El siguiente paso fue la elaboración de un inventario exhaustivo sobre el patrimonio existente. Para ello se crearon unas fichas metodológicas en las que se plasmó de manera concisa y sencilla el estado de conservación de los bienes inmuebles. La finalidad de las fichas-inventario era la de ajustarlas lo mejor posible a los objetivos del trabajo. Las principales fuentes usadas para la creación de las fichas han sido las siguientes:

-Ministerio de Cultura. Dirección General del Patrimonio Artístico, Archivos y Museos. Centro Nacional de Información Artística, Arqueológica y Etnográfica.

-Junta de Castilla y León. Criterios y Prácticas sobre el Inventario del Patrimonio Etnográfico: Inventario de Construcciones Ganaderas en Navalosa (Ávila) ARATIKOS ARQUEÓLOGOS, S.L.

-Junta de Castilla y León. Inventario del Patrimonio Industrial. Palencia. Servicio de protección del patrimonio histórico.

.Universidad de Valladolid y Junta de Castilla y León. Inventario y Catalogación del Patrimonio Etnográfico. Valladolid. Santa Espina.

Las principales fuentes de referencia fueron las fichas de la Universidad de Valladolid y de la Junta de Castilla y León, pues contenían un apartado especial para la conservación de los bienes. En estas fichas se registraron aspectos relacionados con la degradación del patrimonio así como otros detalles de interés que pudieran servir para la posterior catalogación y estudio de las obras. Siguiendo estas premisas se creó un nuevo modelo que pasamos a describir a continuación. 


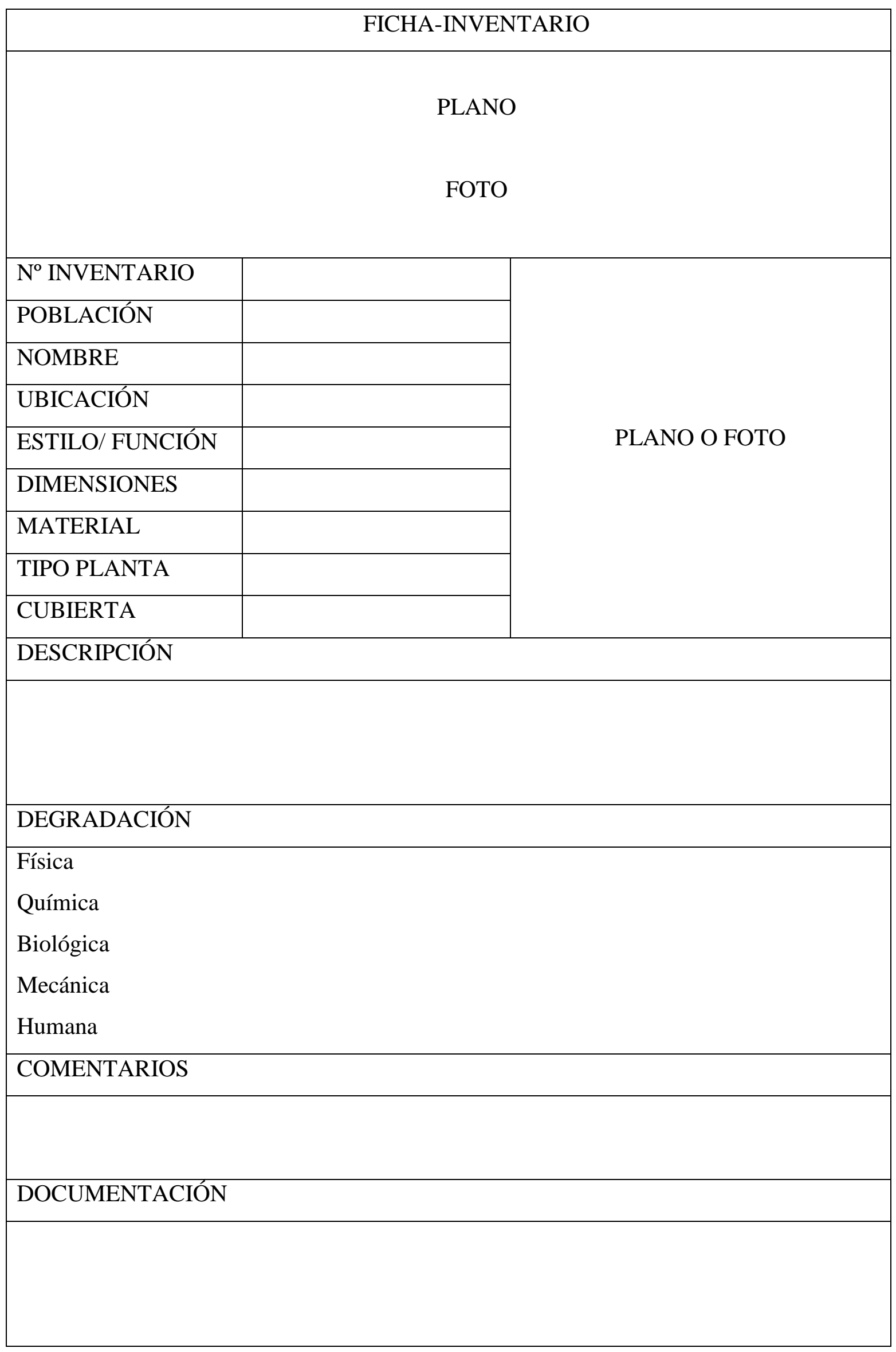


La ficha metodológica comienza con un número de referencia que indica la población a la que pertenece seguido del nombre del bien. A continuación aparece un encabezamiento en el cual se disponen los datos generales de la obra como el nombre, estilo, dimensiones, material y función. En el siguiente apartado se describen las características formales de los bienes. En ocasiones se deja un espacio mayor en una hoja aparte para la el plano y si es posible una fotografía de cómo era antes de la inundación y su estado actual.

Posteriormente se crea un espacio dedicado exclusivamente a los daños sufridos en la obra. Por último se realiza un breve comentario y se añade la documentación consultada.

\subsubsection{TRABAJO DE GABINETE}

Con toda la información extraída se obtuvo un punto de partida y no una meta que, a lo largo de varios años, kilómetros y encuestas personales, originó el actual estudio monográfico.

El primer bloque se basó en la recopilación de todos los bienes de los que constaba la ZACEL antes de la construcción del embalse. Con ello se pretendía recrear el paisaje arquitectónico existente para conocer lo que se vio afectado. En este sentido se han analizado los inmuebles divididos en varios subgrupos: el patrimonio arqueológico, la arquitectura tradicional, la arquitectura industrial tradicional, los puentes y la arquitectura religiosa.

En un segundo bloque se describen los aspectos concernientes a los años de la construcción del embalse y a todos los edificios tanto industriales como civiles construidos ex profeso, su funcionalidad y su estado de conservación actual. También se hace un pequeño repaso por la tipología de presas españolas hasta la actualidad haciendo especial mención al período de construcción de la de Barrios de Luna.

Finalmente se cierra el cuerpo de esta T.D. con el bloque que recrea los pasos dados desde la adjudicación de las labores de la presa hasta la inundación. En este apartado se describen los factores que intervinieron en la destrucción de los bienes desde el inicio de las obras hasta la actualidad. Finaliza con un punto correspondiente a la nueva arquitectura creada a partir de la presa y los nuevos motores económicos y culturales que le son específicos a la ZACEL por el hecho de contener un embalse. 
2. MARCO MEDIOAMBIENTAL E HISTÓRICO 


\subsection{MARCO MEDIOAMBIENTAL}
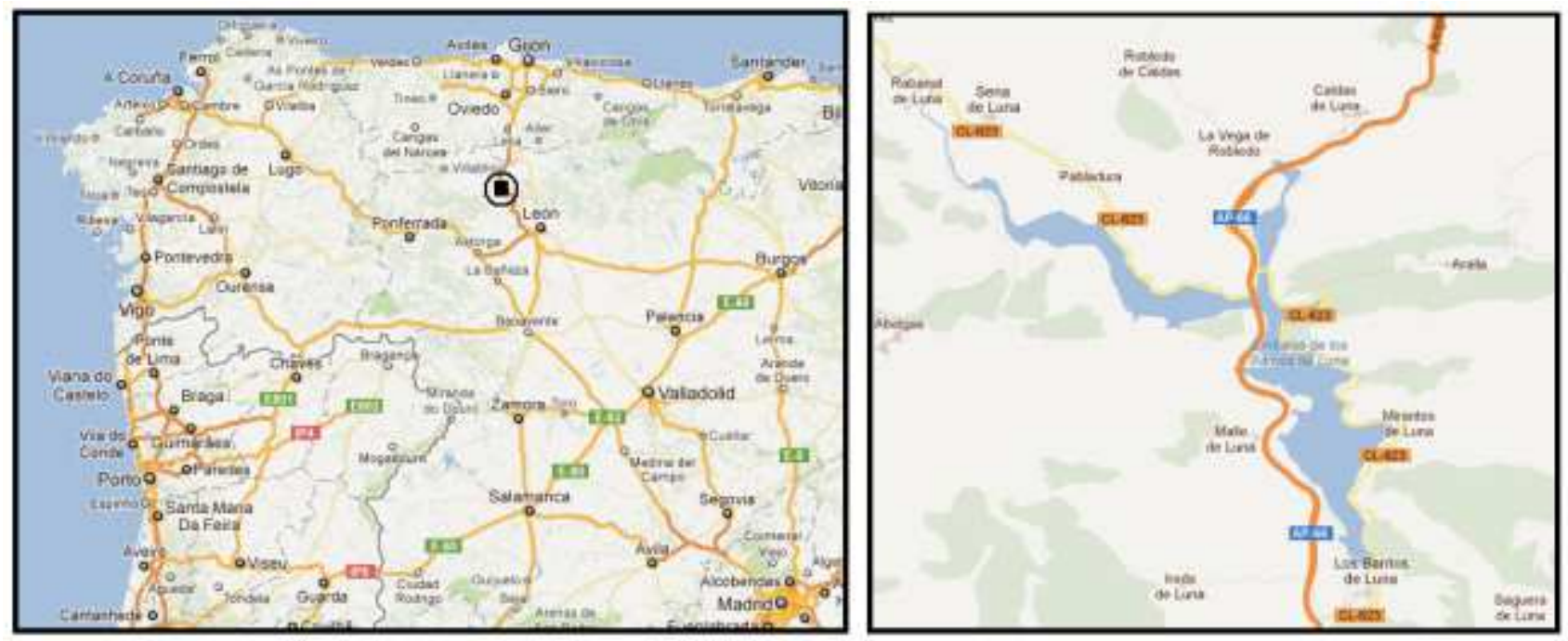

Ilustración 1. Embalse de Luna. Google.maps.

El río Luna discurre por las estribaciones de la vertiente S. de la Cordillera Cantábrica formada por rocas de edades comprendidas entre los 550 y los 250 millones de años. Su recorrido es variable debido al terreno y el poder erosivo del cauce en las estructuras plegadas $^{30}$. Destacan sus grandes valles y cañones abarrancados que están delimitados por altas y escarpadas cumbres ${ }^{31}$. Sobresale la Sierra Blanca, que enmarca el puente de Fernández Casado por el O., con una altura máxima en la Peña de la Cruz de $1588 \mathrm{~m}^{32}$. La altitud media de los municipios que componen el entorno del embalse va desde los 1030 m. de Barrios hasta los 1160 m. de Sena ${ }^{33}$.

El pantano se encuentra sobre una sucesión de materiales sedimentarios pertenecientes al Paleozoico Inferior y terrenos de vega del Cuaternario. Resaltan la cuarcita de Barrios de Luna que contienen fósiles de gran interés geológico. Las rocas aparecen divididas en capas que representan un depósito casi continuo de sedimentos desde el Precámbrico al Devónico y en especial del Paleozoico, con marcas y fósiles de Trilobites y Braquiópodos. Los estratos están dispuestos verticalmente, lo que lo hace único puesto que ofrece una lectura completa de la serie histórica geológica de estos

${ }^{30}$ GARCÍA DE CELIS, Alipio. El relieve de la montaña occidental de León. Valladolid, 1997, p. 25.

${ }^{31}$ Ídem, p.167.

32 PENAS MERINO, Ángel. ALONSO HERRERO, Eduardo. Atlas de león. La Crónica el Mundo de León. León, 2000, p. 59.

${ }^{33}$ Ídem, p. 86. 
períodos $^{34}$. El material más común es la roca caliza del país de color grisácea y de color rosácea cuya calidad ocasionó una explotación continua a lo largo de la historia.

Cabe destacar la importancia de la aparición de minerales que fueron objeto de extracción en la zona desde tiempos pasados, como la mina de antimonio de Mallo, la de cinabrio de Miñera y la de plomo y cobre de Oblanca. Los materiales más blandos y erosionados, como los pizarrosos, se ubican especialmente en el entorno de Mallo de Luna $^{35}$.

El régimen pluviométrico de la zona es bastante estable, puesto que no hay grandes variaciones de unas zonas a otras oscilando entre los 1000 y los $1100 \mathrm{l} / \mathrm{m}^{2}$ año ${ }^{36}$. Las características climáticas de esta cuenca resultaron perfectas para abastecer al pantano durante una media de más de cien días anuales con abundante precipitación en forma de nieve y la aportación de numerosos arroyos que constituyen una parte fundamental de las aguas que van a parar al embalse ${ }^{37}$. El nivel de humedad se ha visto acrecentado tras la construcción de la presa, con una pluviometría de 900 mm a 1235 $\mathrm{mm}$ anuales. La temperatura media anual es de $10^{\circ} \mathrm{C}$ perteneciente a un clima supramediterráneo medio ${ }^{38}$.

La vegetación se caracterizó por la abundancia de bosques de caducifolias hoy bastante mermados debido a la creación del embalse y a su tala para el aprovechamiento de pastizal ${ }^{39}$. Los robledales son las formaciones boscosas más numerosas del Valle. Su madera se empleaba para la construcción de edificios, de aperos de labranza y como combustible. El sabinar de Mirantes es uno de los ejemplos más significativos de la flora del entorno del embalse. Se trata de un bosque abierto, dominado por la sabina albar a la que acompaña un sotobosque muy poco desarrollado en el que proliferan especies propias de ambientes mediterráneos, destacando algunas aromáticas como el tomillo ${ }^{40}$. El sotobosque se sitúa principalmente en las orillas el pantano y en las zonas de alta montaña. Perviven especies de brezales y quejigos en las zonas más elevadas de los puertos y collados, y prados naturales y pastizales en el resto.

\footnotetext{
${ }^{34}$ VVAA. Plan de ordenación de los recursos naturales del espacio natural de los valles de Babia y Luna (León)- anteriormente valle de San Emiliano. Tomo I. Junta de Castilla y León, 2008. p. 48.

${ }^{35}$ PENAS MERINO-ALONSO HERRERO, Atlas, p. 63.

${ }^{36}$ VVAA. Plan de ordenación, p. 20.

${ }^{37}$ A.G.C.H.D. Sección: fondo administrativo. Serie: Obras públicas. Comisión de estudios geológicos para la construcción de obras hidráulicas. Barrios de Luna. № 2121- Año 1929

${ }^{38}$ PENAS MERINO-ALONSO HERRERO, Atlas, p. 69.

${ }^{39}$ Ídem, p. 70.

${ }^{40}$ Ídem, p. 75.
} 


\subsubsection{EL RÍO LUNA}

\begin{tabular}{|l|l|}
\hline \multicolumn{2}{|c|}{ DATOS GENERALES DEL RÍO LUNA ${ }^{41}$} \\
\hline Nacimiento & Peñalba de Cilleros, León. \\
\hline Desembocadura & $\begin{array}{l}\text { Margen izquierda en el río Omaña, } \\
\text { Santiago del Molinillo, León. }\end{array}$ \\
\hline Longitud & $77 \mathrm{~km}$ \\
\hline Cuenca & $739 \mathrm{~km}^{2}$ \\
\hline Aportación media en régimen natural & $456 \mathrm{hm}^{3} /$ año \\
\hline Aportación específica en régimen natural & $0.62 \mathrm{~m}^{3} / \mathrm{m}^{2} /$ año \\
\hline
\end{tabular}

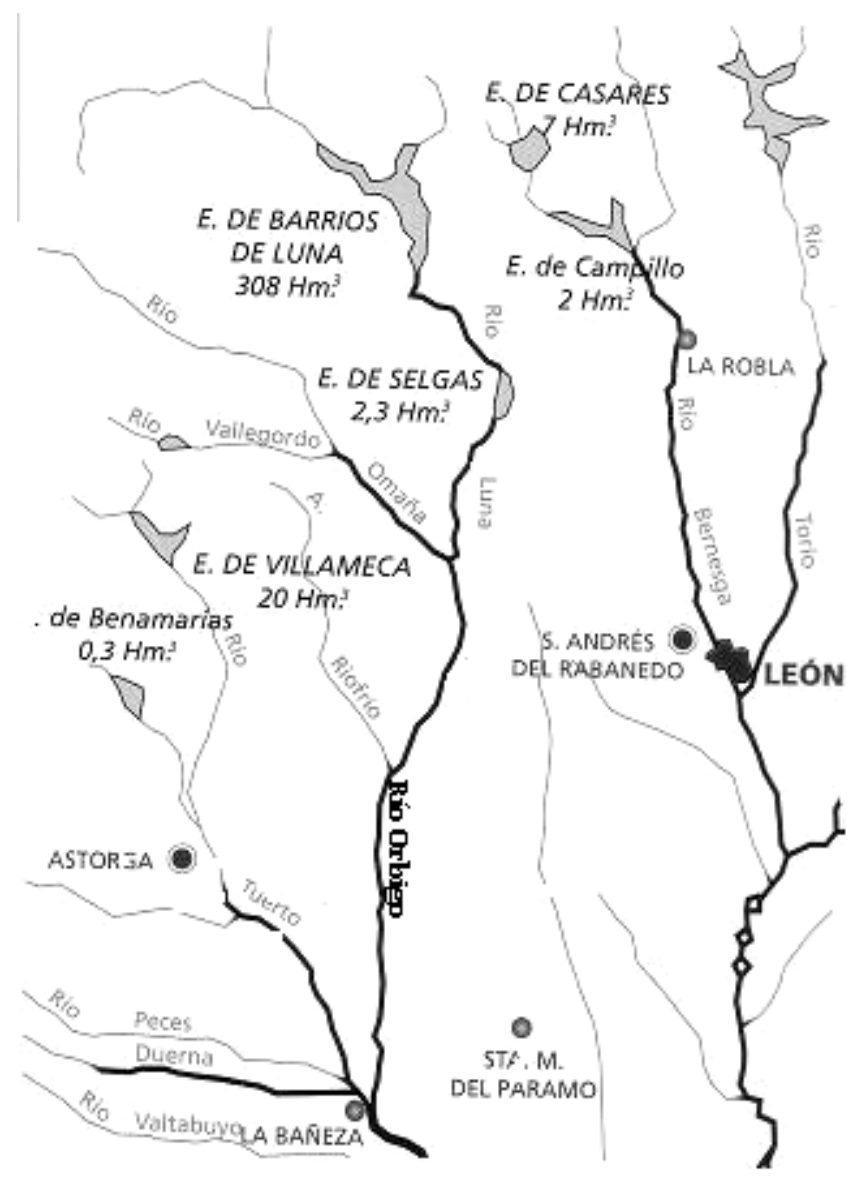

Ilustración 2. Situación geográfica del río Luna. SANZDOMÍNGUEZ, Guías, p. 100.
La región que es motivo de estudio está caracterizada por el río que lo cruza: el Luna. El torrente se sitúa al N. de la provincia de León y da nombre a la comarca del Valle de Luna formada por los municipios de Sena de Luna, Barrios de Luna, Soto y Amio, Carrocera, Santa María de Ordás y Rioseco de Tapia.

Resulta complicado definir de manera exacta el lugar en el que nace el río Luna, pues la gran cantidad de riachuelos que emergen de la zona es motivo de controversia entre las distintas poblaciones del término municipal de Cabrillanes. Apoyándonos en las informaciones dadas por la C.H.D., el río Luna nace en Peñalba de Cilleros, León ${ }^{42}$.

\footnotetext{
${ }^{41} \mathrm{http}: / / \mathrm{www} . c h d u e r o . e s$ El río Duero. Características generales de la cuenca del Duero.

${ }^{42}$ http://www.chduero.es. La Cuenca del Duero.
} 
Éste sigue su curso, denominado por algunos como río Grande, hasta Puente Orugo, San Emiliano, donde se le une el río Torrestío ${ }^{43}$. El cauce del Luna continúa su andadura por Rabanal y Sena hasta Pobladura, lugar donde comienza el embalse. Al llegar al pantano, se le suma otra serie de arroyos como el de Aralla, el de Caldas, el del Cuartero, el de Miñera y el de Oblanca. Pasadas las compuertas del embalse en Barrios de Luna, el río sigue su curso recibiendo las aguas de Selgas de Ordás. En Santiago del Molinillo se une al río Omaña perdiendo ambos su denominación y pasando a adquirir el nombre del río Órbigo, afluente del Esla, que desemboca en el Duero ${ }^{10}$. 


\subsection{MARCO ECONÓMICO Y SOCIAL}

El patrimonio generado en la ZACEL se sitúa dentro de un marco social y económico particular cuyo estudio sirve para comprender las circunstancias de su creación y la gestión del mismo. Por ello, con el fin de encuadrar este apartado, se analiza el contexto en el que se asentaban los bienes inmuebles de las poblaciones afectadas por el embalse. El análisis será general y sin afán innovador, pues este tema no corresponde a nuestra especialidad y tan solo será utilizado para centrarse en los aspectos que puedan explicar las particularidades de los bienes que componen el eje de este estudio.

\subsubsection{ECONOMÍA}

La principal característica económica del territorio es la explotación de los recursos naturales de montaña que han dado cobijo a una población especialmente ganadera desde los tiempos medievales. La ganadería del rebaño ovino y vacuno fueron los modelos de explotación económica esenciales en el Valle que se mantuvieron con arraigo durante siglos. Hoy en día este oficio casi ha desaparecido a causa no sólo de la apropiación de los pastos por el embalse, sino también a la pérdida de los trabajos tradicionales.

El ganado lanar constituía una fuente importante de ingresos a la que seguía la explotación del ganado vacuno, destinado este último fundamentalmente a las labores agrícolas. Los grandes rebaños de ovino pertenecían a terratenientes o monasterios y su aportación económica estaba supeditada al alquiler de los pastos y puertos. La ganadería caballar y asnal apenas tenía repercusión y se utilizaba principalmente para el transporte de mercancías. Finalmente, la cría de gallinas y cerdos suponía un recurso extra para el autoconsumo de las familias.

La agricultura también fue un motor importante dentro de la economía de la zona. Los cultivos más comunes eran los de trigo, los de cebada, los de centeno, las legumbres y otros productos de huerta ${ }^{44}$. La abundancia de molinos en algunas poblaciones como Lagüelles hace pensar en la capacidad cerealística del Valle. La mayoría de estos productos servía para el consumo humano o animal, como la cebada o

\footnotetext{
${ }^{44}$ MADOZ, Diccionario, Barrios de Luna.
} 
centeno. Este último también servía para techar los edificios destinados a cuadras y pajares, por lo que su siembra era muy frecuente. Durante las transformaciones agrícolas del reinado de Carlos III se introdujeron nuevos cultivos como la patata ${ }^{45}$.

Los minifundios eran habituales y se fertilizaban mediante los sistemas de abono animal. El barbecho era la única manera de economizar e impedir la destrucción del suelo, pues las cargas económicas de los impuestos nobiliarios conllevaban en muchos casos un esfuerzo productivo ${ }^{46}$.

El aprovechamiento de los pastos suponía una fuente extraordinaria de ingresos, bien por el alquiler de los mismos para el ganado trashumante o transtermitante, o bien para la venta de forraje ${ }^{47}$. Los pastos pertenecían al régimen comunal y en ellos no se podía labrar ${ }^{48}$. Los prados contaban con una extensión superior a la del terreno cultivable y se situaban especialmente en las riberas y en zonas de alta montaña. El resto del espacio estaba destinado a la explotación del bosque ${ }^{49}$.

La caza era un factor económico considerable dentro de la zona que nos ocupa. La presencia del bosque bajo favorecía la abundancia de especies como corzos, jabalíes, perdices y liebres. Junto con la caza, los cotos de pesca de trucha eran algo común en algunas poblaciones como Campo de Luna ${ }^{50}$ cuya explotación se remontaba a la Edad Media. Su uso y disfrute estaba restringido a los grandes propietarios como los Condes de Luna ${ }^{51}$.

Los oficios más frecuentes desde el siglo XVIII eran los de taberneros, tejedores de paños, canteros, herreros y carpinteros, necesarios para la construcción de casas y $\operatorname{aperos}^{52}$.

Gracias a la mejora de las comunicaciones a lo largo de todo el siglo XIX, las actividades comerciales se hicieron más productivas reportando mayores beneficios para la población. Las tiendas de comercios comenzaron a proliferar y acabaron

\footnotetext{
45 PÉREZ ÁLVAREZ, María José. La montaña noroccidental leonesa en la Edad Moderna. Salamanca, 1996, p. 135.

${ }^{46}$ CONDE GARCÉS, Pantano, p. 22.

${ }^{47}$ MADOZ, Diccionario, Barrios de Luna. La escasez de terrenos cultivables debido a la orografía del terreno, hacía que fuese principalmente la explotación de pastos la que moviese la economía de la zona.

${ }^{48}$ FERRERAS CHASCO, Casildo. El norte de la meseta leonesa: estudio geográfico de un espacio rural. León, 1981, p. 263.

${ }^{49}$ PENAS MERINO-ALONSO HERRERO, Atlas, p. 78.

50 A.H.P.L. Catastro del Marqués de la Ensenada. Interrogatorio, 1752. Campo de Luna. Rollo 43. Campo poseía un pozo propiedad de los condes de Luna a quienes debían pagar un impuesto por pescar. Este pozo de Truchas dio lugar a muchos pleitos por parte de los condes, que se quejaban porque se pescaba de forma furtiva.

${ }^{51}$ ALVAREZ-MARTÍN FUERTES. Catálogo, Doc. 392.

${ }^{52}$ A.H.P.L. Catastro del Marqués de la Ensenada. Interrogatorio, 1752. Rollo 217.
} 
conformando nuevos núcleos como la Venta de la Canela en Mirantes o las Ventas de Mallo ${ }^{53}$ y mejorando las condiciones económicas de otros como San Pedro de Luna. Estos comercios se centraron fundamentalmente en el abastecimiento de las localidades próximas y en hospederías para los viandantes que viajaban a los puertos de montaña. Durante el siglo XX se asentaron en San Pedro una serie de negocios que le dieron cierta prosperidad al ser cruce de varios caminos. Aunque los vendedores ambulantes satisfacían la mayor parte de las necesidades de la población pronto comenzaron a proliferar tiendas dedicadas a droguerías, chocolaterías, carnicerías, lecherías, panaderías y fábrica de gaseosas. Junto a estos establecimientos comerciales existían tabernas propias del común donde se vendía vino y otros licores ${ }^{54}$.

Durante los años de construcción de la presa se multiplicaron las actividades comerciales para abastecer a los obreros y sus familias. Así en Barrios se crearon once cantinas, un cine, un economato, varias casas de comida y salas de fiestas que desaparecieron años más tarde con el final de las obras ${ }^{55}$.

En cuanto al sector industrial, esta zona estuvo regida por las técnicas tradicionales basadas principalmente en la fuerza de los molinos hidráulicos. Estos eran de carácter comunal o privado y poseían en la mayoría de los casos una sola piedra de moler $^{56}$. Algunos de estos molinos como El Molinón o la serrería de la Truva se habían convertido en centros relativamente importantes que exportaban sus productos.

A mediados del siglo XIX se asentó en la zona una creciente economía a partir de la fabricación de paños del país, llamados de Caldas, realizados con lana de oveja ${ }^{57}$. El negocio de los paños se vio incrementado por la pequeña industrialización, lo que repercutió de manera positiva en el desarrollo de la ganadería lanar y por lo tanto de las zonas de pasto. La importancia de este producto se puede observar en la creación de batanes de uso comunal como el desaparecido de Barrios. También se desarrolló una industria basada en la producción de energía a través de centrales eléctricas de propiedad comunal como la central hidroeléctrica de Abelgas.

\footnotetext{
${ }^{53}$ FERRERAS CHASCO, El norte, p.180. Gracias a la construcción del ferrocarril y de la adecuación de caminos a carreteras entre otras obras de infraestructura, la población comienza aumentar a mediados del siglo XIX.

${ }_{54}$ A.H.P.L. Catastro del Marqués de la Ensenada. Interrogatorio, 1752. Rollo 3.

${ }^{55}$ PRIETO SARRO, Ignacio. "Luna y sus gentes”, en El siglo en León. Crónica de cien años. 19002000. León, 2000, p. 341.

56 A.H.P.L. Catastro del Marqués de la Ensenada. Interrogatorio, 1752. Rollo 108.

${ }^{57}$ MADOZ, Diccionario, p 205.
} 
La minería fue otro de los motores económicos que tuvo cierto empuje en la comarca. Los principales yacimientos mineros se encontraban en Oblanca y en Miñera. La mina de Miñera fue utilizada durante la época romana para la extracción de cinabrio. Otros yacimientos destacables los encontramos en Mallo, donde existía una mina de antimonio denominada "La Fernanda",58 que apenas estuvo unos años en funcionamiento antes de la expropiación de los terrenos ocupados por el embalse. Pero la mayor explotación minera se centraba en las canteras de piedra caliza como la de la Venta de la Canela en Mirantes. Hoy en día la explotación continúa de mano de la Empresa Asistencia, Montajes y Estudios "La Tijera" instalada en una zona natural protegida.

En la actualidad, las actividades económicas de Luna se reducen a la explotación de la ganadería vacuna en los pastos de alta montaña y en actividades de ocio y tiempo libre como el club náutico de Mirantes, campings, casas rurales y museos.

\subsubsection{SOCIEDAD}

Las características sociales del Valle del Luna responden a un sistema eminentemente rural en el que prima el patriarcado. Cada edificio estaba compuesto por varias generaciones de la misma familia que podían convivir bajo el mismo techo.

Los núcleos de población de la ZACEL pertenecían a dos municipios diferentes, el de Barrios y el de Láncara. El primero estaba integrado por los siguientes pueblos: Barrios de Luna, Irede de Luna, Mallo de Luna, Miñera de Luna, Mirantes de Luna, Mora de Luna, Portilla de Luna, Sagüera de Luna y Vega de los Caballeros. Ocupaba una superficie de $93,75 \mathrm{~km}^{2} .59$

El municipio de Láncara de Luna contaba con las siguientes poblaciones: Abelgas de Luna, Aralla de Luna, Caldas de Luna, La Vega de Robledo, Pobladura de Luna, Rabanal de Luna, Robledo de Caldas y Sena de Luna. Al quedar anegado el municipio

\footnotetext{
58 A.G.C.H.D. Fondo administrativo. Serie: Expediente de expropiación. Mallo de Luna. Embalse de Barrios de Luna. León. № 5447. Según el informe pericial sobre la expropiación de la mina de Antimonio denominada "Fernanda" ocupada por el embalse de Luna, los ingenieros, en 1925 fue concedido el derecho de explotación que tan sólo duró cinco años.

${ }^{59}$ PENAS MERINO, Ángel. ALONSO HERRERO, Eduardo. El gran atlas de Castilla y León. Edita El Mundo, Junta de Castilla y León, Caja Salamanca y Soria. 1996, p.55.
} 
de Láncara de Luna éste se integró dentro del de Sena de Luna que actualmente posee una extensión de $156,80 \mathrm{~km}^{2}{ }^{60}$

La densidad de población en toda la región de Luna es muy baja, con una media de 3,53 hab./ $\mathrm{Km}^{2}$. Esta situación es muy diferente a la que existía antes de la inundación del embalse, con 14 hab./ $\mathrm{Km}^{2}$ de media ${ }^{61}$. La edad media de la población gira en torno a los 40-50 años, aumentando paulatinamente cada año debido a la emigración de los jóvenes a núcleos más importantes ${ }^{62}$.

En los primeros estudios de población realizados a mediados del siglo XVIII ${ }^{63}$ se observa que no existía una gran densidad, pues los pueblos no pasaban del medio centenar habitantes, estando dedicados especialmente a la agricultura y ganadería de subsistencia. Cien años más tarde los datos recopilados ${ }^{64}$ muestran un considerable aumento de más del $50 \%$ de la población debido especialmente a los avances llevados a cabo como la mejora de las comunicaciones y el comercio. Este incremento pudo deberse a las transformaciones administrativas realizadas durante el reinado de Isabel II en la que Barrios de Luna y Láncara se convirtieron en cabeza de ayuntamiento ${ }^{65}$.

En el siglo XX el número de edificaciones aumenta paulatinamente, a pesar de que no se observa un especial progreso. Aún a mediados de este siglo la emigración a América seguía siendo un factor importante. Algunos vecinos como la familia García Gago reinvirtieron la fortuna obtenida para la creación de numerosas escuelas y la reconstrucción de algunas iglesias como la de Sena de Luna.

Las mejoras económicas y sanitarias del país hacen crecer la población, aunque estos avances se frenan estrepitosamente con la Guerra Civil de 1936 y la posterior posguerra. Con el fin de la contienda la política franquista apoya la natalidad y de este modo se generaliza un aumento de la población ${ }^{66}$.

En 1945 se publica en el $\mathrm{BOE}^{67}$ la adjudicación de las obras para la construcción del embalse de Luna. El 7 de septiembre de 1951 los vecinos de los municipios de

\footnotetext{
${ }^{60}$ Ibídem.

${ }^{61}$ Ibídem.

62 Ídem, p. 83.

${ }^{63}$ A.H.P.L. Catastro del Marqués de la Ensenada. Interrogatorio. 1752.

${ }^{64}$ MADOZ, Diccionario. MIÑANO, Diccionario.

${ }^{65}$ GARCÍA SUÁREZ. Una historia, p.162.

${ }^{66}$ FERRERAS CHASCO, El norte, p.185

${ }^{67}$ BOE del 31 de enero de 1945. "El pantano de los Barrios de Luna" en DIARIO DE LEÓN. Jueves 15 03-1945, p. 4.
} 
Barrios y Láncara comienzan a ser desalojados de sus residencias, aunque esta situación no se generalizó hasta el 16 de diciembre de $1954^{68}$.

Durante los primeros años de las obras del embalse la población aumentó en algunos pueblos como Barrios de Luna, cuyo censo se incrementó un 200\% debido a la llegada de obreros y personal especializado. En la década de los cuarenta trabajaban en el embalse cien operarios siendo precisos más del doble para la buena marcha de las obras, aunque finalmente su número llegó a quintuplicarse. Una vez finalizadas las obras, el volumen de la población cayó estrepitosamente.

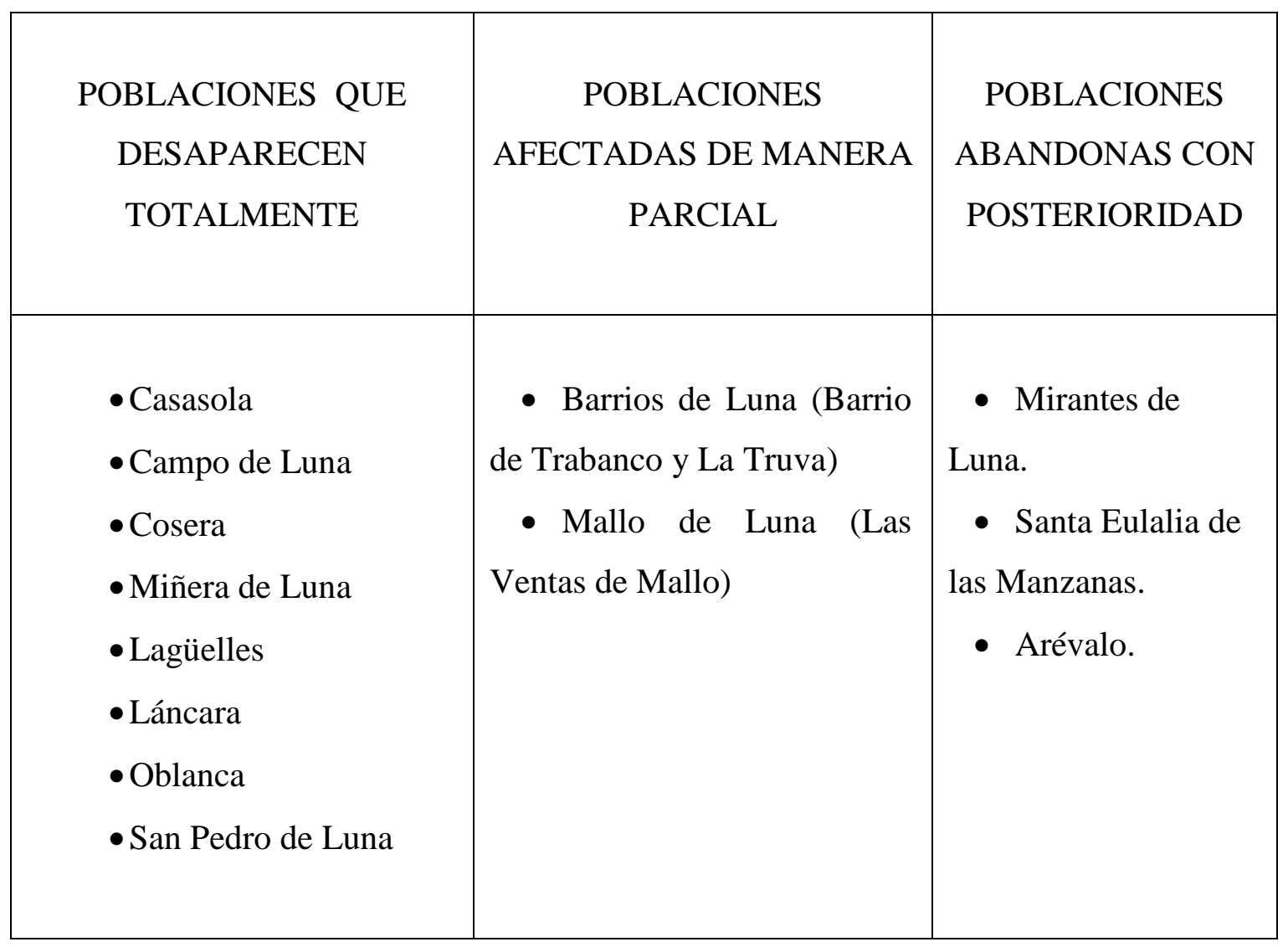

\begin{tabular}{|l|c|}
\hline N. ${ }^{\text {de habitantes de pueblos que desaparecen }}$ & 772 \\
\hline N. ${ }^{\circ}$ de habitantes de pueblos que desaparecen parcialmente & 785 \\
\hline N. ${ }^{\text {total de habitantes a los que afecta el embalse }}$ & $1.557^{69}$ \\
\hline
\end{tabular}

\footnotetext{
${ }^{68}$ BOE 16, diciembre, 1954. Sobre expropiación forzosa del Embalse de Luna. León.
}

${ }^{69}$ CONDE GARCÉS, Pantano, p. 2. 
Tras la inundación de la ZACEL desaparecieron ocho poblaciones, dos más se vieron perjudicadas con la pérdida de alguno de sus barrios y tres fueron abandonadas con posterioridad. En total trece núcleos de población se vieron afectados por la construcción de la presa de Barrios de Luna. Dada la política de la época no se les dio la posibilidad de un nuevo asentamiento en los alrededores del embalse, lo que llevó a una emigración de carácter disperso hacia otras poblaciones cercanas del municipio de Sena, de Barrios, La Magdalena y León ${ }^{70}$.

A partir de los años noventa se ha dado un aumento paulatino en la población del Valle. Ello se debe a la llegada de las personas retiradas que vuelven y de aquellos otros que huyen de la ciudad buscando otras alternativas económicas en el campo. La casi nula existencia de centros de trabajo obliga a la creación de pequeñas empresas basadas en la ganadería y en el sector turístico como casas rurales, campings o el club náutico. El fututo de la zona pasa por un cambio en la política económica de la zona con dos opciones fundamentales, la cría de ganado vacuno de alta montaña y la creación de centros de turismo sostenible.

70 GONZÁleZ, María Jesús. CRISTÓBAL, María Teresa. NISTAL, Pedro Andrés. Movimientos migratorios en el norte de León. Valladolid, 1986, p. 68. 


\subsection{MARCO HISTÓRICO}

El Valle del Luna se enclava dentro de un marco histórico que ha de ser explicado para comprender las circunstancias que lo rodearon y que ocasionaron la creación de su patrimonio. Por ello, a fin de encuadrar este trabajo, se analiza a grandes rasgos, el contexto histórico de una forma generalizada y sin ningún afán innovador. Su narración es simplificada, pues el objeto de este trabajo es delimitar los aspectos más importantes que ocasionaron la creación de los bienes de los que constaba la ZACEL y no su estudio histórico.

\subsubsection{DE LOS PRIMEROS ASENTAMIENTOS HASTA LA CONSTRUCCIÓN DE LA PRESA.}

En este capítulo se hace un breve repaso acerca de los aspectos históricos de la ZACEL desde el Calcolítico, momento en que aparecen los primeros objetos arqueológicos, hasta la actualidad.

El objeto arqueológico más antiguo del que se tiene constancia es un hacha de piedra pulimentada hallada en el paraje de Villar de Cos de Oblanca ${ }^{71}$. La presencia de este objeto no puede adscribirse a un asentamiento propio, pues se encontró de manera individualizada y sin un estudio arqueológico previo. Se desconoce la localización actual de la pieza por lo que tampoco se han podido describir sus características ni fijar su cronología exacta.

No será hasta la Edad del Bronce cuando se multipliquen los objetos arqueológicos asociados a asentamientos definitivos. Estas primeras poblaciones surgen especialmente en las zonas de tránsito natural, como los valles y ríos, o en zonas apartadas con yacimientos minerales ${ }^{72}$. Durante este período el uso de técnicas metalúrgicas más depuradas, como moldes bivalvos, darán lugar a un abanico de tipologías nunca visto en etapas anteriores ${ }^{73}$. Los nuevos modelos alcanzarán una gran difusión en la península gracias al intercambio con otras zonas. Cabe destacar el hacha

\footnotetext{
${ }^{71}$ MORÁN BARDÓN. Por tierras, p. 184.

${ }^{72}$ MUÑOZ AMILIBIA Ana María. "El sustrato de la Edad del Bronce y su proceso evolutivo" en Anales de prehistoria y arqueología, $\mathrm{N}^{\circ} 15,1999$, pp. 7-14, p. 9.

73 BLAS CORTINA, Miguel Ángel. "Nuevos testimonios metalúrgicos de la Edad del Bronce en el centro-occidente de la región cantábrica" en Veleia: Revista de prehistoria, historia antigua, arqueología y filología clásicas. 1991-1992. No 8-9, pp. 109-138.
} 
plana del castro de Oblanca ${ }^{74}$ y el hacha de talón estrecho con apéndices laterales que apareció durante las labores de construcción del Club Náutico de Mirantes ${ }^{75}$. Otros objetos pertenecientes a la Edad del Bronce son un puñal muy deteriorado en Barrios y restos metálicos como un calderito de bronce encontrado en Oblanca.

La Edad del Hierro se enmarca en León de forma general en la denominada "cultura castreña" en la cual se van intercalando aspectos que perduran desde la Edad del Bronce con otros nuevos que continuarán más allá de la conquista romana. La economía está basada en la explotación comunal del territorio y en los recursos agrícolas y ganaderos ${ }^{76}$. El desarrollo del trabajo en metal, con la creación de nuevas técnicas de fundición, supuso una reforma en las pautas de comportamiento social ${ }^{77}$. La producción de objetos se dispara hallándose desde armas defensivas a elementos de adorno que muchas veces están relacionados con la cultura romana ${ }^{78}$. En la zona que nos corresponde encontramos numerosos objetos arqueológicos prerromanos adscritos a este período, como la fíbula anular de Oblanca o las fíbulas de torrecilla y pie vuelto de Barrios de Luna ${ }^{79}$.

La presencia de la civilización romana no supuso un cambio trascendental para las regiones locales y sus formas de vida. En los primeros años de la conquista, en torno al siglo I a.C. apenas hubo movilizaciones militares y las dos culturas se comunicaban a través del mercado de objetos como cerámicas, monedas y otros utensilios. Esto explica la aparición de restos romanos en castros anteriores ${ }^{80}$. Castros característicos de este momento son el Castrín de Sena, donde aparecieron materiales como tégulas y cerámica común romana, el castillo de Barrios de Luna, en el que se encontraron fíbulas romanas, y el castro de Oblanca, en el que se recogieron fíbulas de tipo Omega.

\footnotetext{
${ }^{74}$ Ídem, p. 185.

75 GUTIÉRREZ GONZÁLEZ. Poblamiento, p. 67. Esta hacha puede relacionarse con otra similar aparecida en Aralla de Luna encontrada también por M.A. Fernández. Esta se conserva en el museo de León. FERNÁNDEZ MANZANO, “Calcolítico y Edad del Bronce” p. 37.

${ }^{76}$ SACHEZ BADIOLA, Juan José. El territorio de León en la Edad Media. Poblamiento, organización del espacio y estructura social. (Siglos IX-XIII) Volumen I. León, 2004, p. 203. Las diferentes invasiones, como la visigoda, atestiguan el paso de estas civilizaciones por el valle y la continuidad de los castros como elementos defensivos como el de Oblanca o el de Mallo, cuya estructura pervivió desde los asentamientos de los pueblos cántabros y astures hasta bien entrada la Edad Media.

${ }^{77}$ LLANOS ORTIZ DE LANDALUZE, Armando. "El complejo paso de la Edad del Bronce Final a la Edad del Hierro, en el Cantábrico Oriental" en Estudios de Arqueología Alavesa, 2007. №. 24, pp. 297354.

${ }^{78}$ BOHIGAS ROLDÁN, Ramón. "La Edad del Hierro en Cantabria. Estado de la cuestión” en Zephyrus: Revista de prehistoria y arqueología, Año. 1986-1987. Nº 39-40, pp. 119-138.

${ }^{79}$ GUTIÉRREZ GONZÁLEZ. Poblamiento, p. 226.

${ }^{80}$ Ídem, p. 240.
} 
Las extracciones mineras tuvieron una importancia vital para el establecimiento de castros defensivos y calzadas que pudiesen dar salida a los materiales extraídos. Son numerosos los ejemplos de minas romanas explotadas por toda la geografía hispana probablemente ya conocidas por los pueblos prerromanos, como el Cavadoiro en el término de Mallo, donde se extraía antimonio ${ }^{81}$ o las minas de Oblanca, de plomo $\operatorname{argentífero~}^{82}$. Destaca la mina de Miñera, cuya cronología puede datarse según Alonso Herrero y Neira Campos en torno al siglo II- III d. C. Miñera parece ser una de las principales fuentes de cinabrio astur que mencionan los historiadores romanos en sus textos $^{83}$. El propio topónimo de Miñera nos lleva a relacionarlo con la palabra minera $\mathrm{o}$ miniarum, término latino que designa al cinabrio. ${ }^{84} \mathrm{Su}$ importancia radica en ser la primera mina de este material de la Península Ibérica en la que se constata una técnica extractiva que utiliza el agua mediante el método hidráulico de las arrugias ${ }^{85}$.

Desde el siglo IV, y la caída del Imperio Romano, hay un progresivo desplazamiento de la población desde las áreas urbanas hacia los centros rurales más dispersos cuya producción se basaba en una explotación de los bosques y valles para un uso común de la ganadería ${ }^{86}$. A principios de la Edad Media la población continuaba ocupando los castros como centros de hábitat, tal es las posibilidad del castro de Mallo $^{87}$. De este período han aparecido objetos individualizados como la placa de bronce, hoy perdida, hallada en Oblanca por César Morán ${ }^{88}$ y decorada con una filigrana de características visigóticas.

Cuando Alfonso III reorganiza el territorio, lo puebla sustituyendo los antiguos elementos defensivos de los castros por emplazamiento de castillos roquedos como los de Alba, Gordón y Barrios de Luna ${ }^{89}$. Las principales vías de comunicación se

\footnotetext{
${ }^{81}$ A.G.C.H.D. Fondo administrativo. Expediente de expropiación del embalse de Barrios de Luna.. C/05477-1. No 5447. Año 1961. En Mallo se encuentran los restos de una mina llamada la FERNANDA que extraía antimonio que fue explotada durante los años 1925 a 1930.

${ }^{82}$ BERRUETA. Riberas. Vid: Oblanca

${ }^{83}$ ALONSO HERRERO-NEIRA CAMPOS, Explotación, p.128.

${ }^{84}$ Ibídem.

${ }^{85}$ Ibídem. Alonso y Neira encontraron en las prospecciones de la mina de Miñera de Luna unos posibles estanques de almacenamiento de agua, así como un canal de abastecimiento, por lo que se deriva que el método usado para la extracción del mineral era el mismo que se utilizaba en las Médulas y otros yacimientos, el llamado ruina montium.

${ }^{86}$ GUTIÉRREZ GONZÁLEZ. Fortificaciones, p. 96.

${ }^{87}$ Ídem, p. 93.

${ }^{88}$ MORÁN BARDÓN. Por tierras, p.185.

${ }^{89}$ SACHEZ BADIOLA, Juan José. La configuración de un sistema de poblamiento y organización en el espacio. El territorio de León. (S. IX-XI) León, 2002, p. 165.
} 
defienden a través de puestos como ocurre en el Castro Mayor de Sena y como pudo ocurrir en Mirantes ${ }^{90}$.

El ataque de Almanzor al castillo de Luna, entre el 986 y 991 durante el reinado de Vermudo II $^{91}$, es considerado uno de los hitos históricos más sobresalientes en la historia del Valle, pues la fortaleza resistió el embate, lo que dio pie a numerosos romances y leyendas como la de Bernardo del Carpio. El castillo de Luna siguió siendo protagonista durante toda la Edad Media cuyos principales avatares pasaremos a describir con posterioridad en el capítulo referente al castillo.

Para protegerse de los posibles ataques, los habitantes continuaron ocupando los antiguos castros, como el de Mallo de Luna, y cuevas, como pudo ser la del Arroyo de los Molinos en Mirantes $^{92}$. En el cercano pueblo de Miñera aparecieron, como yacimiento secundario originado por deposición, alrededor de un centenar de piezas cerámicas relacionadas con los restos encontrados en el castillo de Luna y con los galbos descritos por J.A. Gutiérrez. Se trata de una serie de cuellos y bases con una decoración estriada que forman parte principalmente de jarras de cuerpo cilíndrico, asas, platos de paredes oblicuas bien altas, copas y ollas.

La repoblación de gran parte del N. de la península se hizo a partir de la creación de monasterios y por concesiones reales ${ }^{93}$. Los nuevos territorios repoblados se integraron bajo la diócesis de Oviedo gracias a las donaciones regias de Alfonso III y sus sucesores. Es el propio Papa Juan VIII desde Letrán quien concede diversos privilegios a la catedral ovetense en torno al 876 fijando los límites de la diócesis dentro de los cuales se incluyó Coyanza, el río Órbigo, Tierra de Gordón, Valdeordás, Luna y Babia entre otros de la actual provincia de León ${ }^{94}$. La rapidez con la que se extendía el reino en los primeros años de reconquista hacía que pequeños monasterios como el de Tuñón o el de Arbas contasen con grandes extensiones de terreno adscritas bajo su

\footnotetext{
${ }^{90}$ GUTIÉRREZ GONZÁLEZ. Poblamiento, p. 249.

91 GUTIERREZ GONZÁLEZ. Fortificaciones, p. 199. El castillo resistió los envites de Almanzor, convirtiéndose desde ese momento en símbolo de resistencia y denominándose a este enclave como "Peña Almanzor"

${ }^{92}$ GUTIERREZ GONZÁLEZ. Poblamiento, p. 247. El autor considera que la utilización de las cuevas es un recurso común en las zonas de montaña debido al fuerte arraigo de las formas tradicionales de vida que perduraron a pesar de las continuas invasiones. Esta cueva de origen cárstico está situada en el margen derecha del arroyo y en su entrada J.A. Gutiérrez encontró abundantes estratos medievales con restos de cerámica y sílex negro con huellas de lascado.

93 ALCEDO Y DE SAN CARLOS, Marqués de. Los merinos mayores de Asturias (del apellido Quiñones) y su descendencia. Madrid, 1918, pp.191-93. En última instancia, eran propiedad del rey y podía expropiarlas si el noble faltaba contra la autoridad suprema.

${ }^{94}$ GARCÍA LARRAGUETA. Colección, p.41. Doc. 10.
} 
jurisdicción cuyos dominios siguieron ampliándose siglos después ${ }^{95}$. La mesta y especialmente el desarrollo de la ganadería trashumante se convirtieron en las bases económicas de la nobleza y la iglesia que irán incrementando su poder siglos más tarde.

Las familias nobles también vieron acrecentado su poder jurisdiccional gracias a las concesiones regias de licencias para recibir rentas y tributos sobre los territorios asignados. Enrique III otorga a Pedro Suárez de Quiñones en 1396 el concejo de Luna de Suso y de Yuso junto con Caldas ${ }^{96 .}$ Durante el reinado de Juan II, los Quiñones pasan a ser Condes de Luna, en clara referencia al Valle ${ }^{97}$.

Las propiedades de los Luna incluían poblaciones como Lagüelles, Portilla, Sagüera, Barrios, Irede, Mallo, Mora, Mirantes, Miñera, Vega de Robledo, Santa Olaja, Láncara, Aralla, San Pedro, Campo, Garaño y Cosera ${ }^{98}$. El control sobre Luna era total, pues además del poder territorial, ejercían el poder en materia de justicia, de escribanías, de oficios, de yantares, de martiniegas y de recaudación de impuestos a través de los $\operatorname{portazgos}^{99}$.

Son pocos los restos arquitectónicos de época medieval. Las únicas evidencias se encuentran muy destruidas, como el castillo de Luna, o anegadas bajo las aguas, como el puente de San Lorenzo de Miñera y el destruido puente del barrio de Trabanco en Barrios de Luna. Tan solo se conservan restos arquitectónicos tardomedievales en parte de la cabecera de la iglesia de Barrios, pues la casi totalidad de las iglesias de la zona fueron remodeladas con posterioridad.

Las modificaciones territoriales durante la Edad Moderna apenas variaron del período anterior y el señorío, el realengo y el poder eclesiástico seguían ejerciendo potestad sobre los territorios estudiados ${ }^{100}$. Tras la llegada al trono de los Reyes Católicos se pone fin a siglos de disputas sobre el poder de los nobles y sus ambiciones de gobierno, abriéndose una época de pacificaciones internas. Los Quiñones sufrieron

\footnotetext{
${ }^{95}$ SACHEZ BADIOLA. La configuración, p. 209.

${ }^{96}$ MARTÍN FUERTES. Quiñones, p.72. Doc. 4.

${ }^{97}$ ALVAREZ ALVAREZ. Condado, p. 28.

${ }^{98}$ Ídem. p. 317.

99 Ídem. p. 113. Durante el siglo XV, debido al coste de las guerras señoriales, la familia instaura un nuevo pontazgo en Miñera de Luna, multando a aquellos vecinos que no les ayudasen en la contienda como militares o para reconstruir los castillos, además de cargas por contraer matrimonio.

${ }^{100}$ FERRERAS CHASCO. El norte, p.156.
} 
un debilitamiento progresivo con respecto a su pasado medieval ${ }^{101}$ hasta su desaparición con la publicación de la Real Cédula expedida en Aranjuez el 25 de febrero de $1805^{102}$.

La administración de las aldeas continuaba siendo la tradicional de los concejos generales de vecinos, supervisados por el Conde de Luna que aún conservaba algunos privilegios como el impuesto por yantar que ascendía en 1752 a 10 reales de vellón ${ }^{103}$.

A lo largo de los siglos XVIII

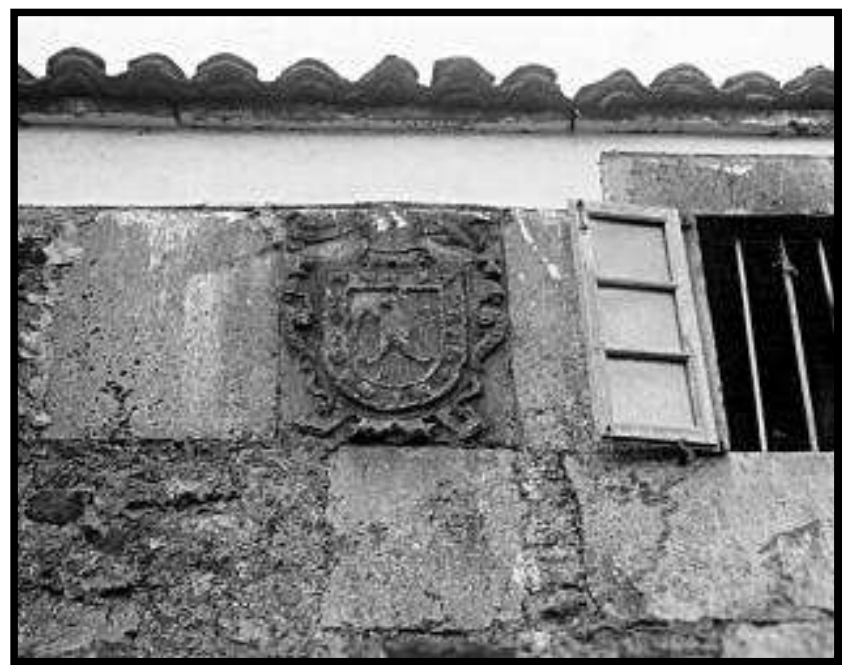

Ilustración3. Casa blasonada con el escudo de los Águila, Lagüelles. Fondos del I.L.C.

y XIX, ciertas familias establecieron una serie de impuestos sobre Luna manteniendo de esta manera su poder territorial. Algunas de las más importantes formaban parte de la rama principal de los Quiñones, como los Quiñones Señores de Sena, Quiñones de Riolago ${ }^{104}$ y los Quiñones marqueses de Montevirgen. Fuera de la rama de los condes de Luna también aparecen los Cienfuegos, los Águila y los Marqueses de Castell-Moncayo ${ }^{105}$. La mayoría de estas familias nobiliarias se instalaron en Luna obteniendo recursos especialmente por el arrendamiento de pastos y puertos, dejando como recuerdo de su poder la distinción en piedra de sus escudos familiares.

En la ZACEL se han podido localizar los escudos nobiliarios de los Águila y los Cienfuegos. El escudo de los Águila se encontraba en un edificio señorial de Lagüelles aunque actualmente ha sido trasladado a una casa particular en Torrebarrio. Está datado en el siglo XVII tallado sobre un bloque de piedra caliza. Uno de los escudos de los

101 ÁLVAREZ ÁLVAREZ. El condado, p. 187. El Conde de Luna consiguió la potestad absoluta sobre los territorios del valle gracias al apoyo brindado por el rey desde la Edad Media y especialmente desde la política de Enrique IV de la familia de los Trastámara.

102 PEREZ LLAMAZARES, Julio. Historia de la Real Colegiata de San Isidoro. León, 1927, p. 94. Todas aquellas posesiones que tuvieran los señoríos sobre la iglesia, quedaban bajo el mandato de la Corona.

103 A.H.P.L. Catastro del Marqués de la Ensenada. Interrogatorio, 1752. Rollo 145. Oblanca.

${ }^{104}$ MARTÍN FUERTES. Quiñones, p.159. Doc. 261. A.H.P.L. Catastro del Marqués de la Ensenada. Interrogatorio, 1752. Rollo 43. Campo de Luna.

105 A.H.P.L. Catastro del Marqués de la Ensenada. Interrogatorio, 1752. Rollo 12. Arévalo. MADOZ. Catálogo, p. 271. El Marqués de Castel Moncayo ejercía el oficio de Alcalde Mayor y Juez ordinario sobre el pueblo y los impuestos que se llevaba el señor de Sena de esta villa era un impuesto por establecimiento de suelo. Sin embargo, también debían pagar a su majestad las contribuciones por derecho de feudo del señor marqués. 
Cienfuegos se encontraba en el suelo de la iglesia de San Pedro, mientras que el otro se conserva en la iglesia parroquial de Barrios de Luna. De la familia Quiñones tan solo se poseen noticias de un escudo en una vieja casona de Lagüelles con un ajedrezado compuesto por siete escaques con veros en azur y ocho de gules ${ }^{106}$.

La iglesia, a su vez, poseía territorios y poder activo en el Valle de Luna. Su principal interés se basaba en el aprovechamiento de los pastos de montaña y en la todavía importante ganadería trashumante ${ }^{107}$. Destacan en este sentido la abadía de Arbas del Puerto, el monasterio de Otero de las Dueñas, la colegiata de San Isidoro de León y el monasterio de Guadalupe en Cáceres que tenían concesiones sobre la explotación de los pastos de los puertos de Luna $^{108}$.

Los postulados de la Contrarreforma ocasionaron uno de los mayores procesos constructivos desde la Repoblación. La casi totalidad de los edificios religiosos fueron transformados para adecuarse a las nuevas necesidades eclesiásticas, lo que privó de la conservación de las antiguas iglesias medievales y de datos sobre su forma y contenido. Este aspecto será estudiado con posterioridad en el apartado referido a la arquitectura religiosa.

En el siglo XVIII se producen una serie de transformaciones gracias a las reformas administrativas, constructivas y económicas de los Borbones ${ }^{109}$. Durante este período se intentaron modernizar las comunicaciones medievales para favorecer el tránsito de mercancías y activar el comercio interior. Las obras consistían en la restauración de las redes viarias y el refuerzo de sus puentes cuyo coste corría a cargo de la población en forma de impuesto de $\operatorname{sisas}^{110}$. Buena parte de los puentes de la ZACEL fueron reparados y restaurados durante este período, añadiendo más arcos en los casos necesarios o sustituyendo los pontones de madera por puentes de piedra.

La invasión francesa supuso el desmoronamiento del Antiguo Régimen y las formas tradicionales arrastradas desde la Edad Media. El Valle del Luna se convirtió en protagonista de algunos hechos bélicos como el tránsito de las tropas francesas durante

\footnotetext{
${ }^{106}$ CIMADEVILLA SANCHEZ, Pío. Repertorio Heráldico Leonés, Vol. III. León, 1996, p.17.

${ }^{107}$ PÉREZ ÁLVAREZ. La montaña, p. 90.

${ }^{108}$ FERRERAS CHASCO. El norte, p. 156.

${ }^{109}$ PÉREZ ÁLVAREZ. La montaña, p. 87.

${ }^{110}$ A.H.P.L. Catastro del Marqués de la Ensenada. Interrogatorio, 1752. Rollo 12. Arévalo.
} 
la invasión napoleónica. Su paso queda patente en la utilización del Monasterio de Otero de las Dueñas como cuartel general de la zona ${ }^{111}$.

Las divisiones impuestas durante el reinado de Isabel II, tras la Restauración Borbónica, variaron el paisaje territorial gracias a la creación de nuevos municipios y la modificación de las viejas jurisdicciones ${ }^{112}$. Los pequeños concejos se englobaron en distritos más grandes que integraban otros pueblos, como es el caso de Barrios de Luna y Láncara que pasaron a formar parte del partido judicial de Murias de Paredes ${ }^{113}$. Durante este período se produce un hecho trascendental para la economía de la zona. En 1836 desaparece la Mesta lo que supone la pérdida monetaria de muchos de estos pueblos dedicados casi en exclusiva al alquiler de los pastos de la ganadería trashumante. $^{114}$.

La proclamación de la I República en 1873 y la posterior restauración borbónica no solucionaron los problemas monetarios del país. Apenas se vuelven a retomar los impulsos económicos en la comarca salvo alguno de carácter minero como la explotación de la mina de Miñera.

La educación durante todo este periodo corrió a cargo de las cátedras religiosas como las de Láncara, Pobladura y Otero de las Dueñas y de las aportaciones particulares en la construcción de las escuelas, tal fue el caso de Paulino García Gago, indiano benefactor del Valle de Luna durante las primeras décadas del siglo $\mathrm{XX}^{115}$.

La Guerra Civil afectó de manera parcial al patrimonio de la ZACEL. El Frente Republicano se encasilló durante 1937 en los pasos montañosos. El mes de septiembre de 1937 los nacionales de la mano del general Mújica tomaron Láncara, Oblanca, Aralla y Caldas y apostaron sus trincheras en San Pedro de Luna y el castillo de Barrios ${ }^{116}$.

\footnotetext{
${ }^{111}$ VIÑAYO GONZÁLEZ Antonio. "El monasterio de monjas cistercienses de Santa María de Otero de las Dueñas”. P 30-32 en León en Madrid. Año III. Diciembre 2000. N ${ }^{\circ}$ 361. Muchos puentes fueron destruidos para evitar el paso de las tropas enemigas al frente, aunque no conocemos datos sobre la destrucción de alguno de ellos en el valle de Luna.

${ }^{112}$ FERRERAS CHASCO. El norte, p.156.

${ }^{113}$ En el valle encontramos dos divisiones, Luna de Yuso y Luna de Suso con Aralla, Campo, Cosera, Garaño, Irede, Láncara, Lagüelles, Mallo, Miñera, Mirantes, Mora, Oblanca, Portilla, Robledo de Caldas, Sagüera, San Pedro, Santa Eulalia de las Manzanas y Vega de Robledo. La desaparición de Láncara bajo las aguas hizo recobrar la antigua capitalidad municipal a Sena de Luna con la incorporación de nuevos núcleos.

${ }^{114}$ FERRERAS CHASCO. El norte, p.164. El problema derivó del a invasión napoleónica y la ruptura de las vías tradicionales del ganado junto con la introducción de nuevas especies más competitivas en los mercados europeos.

115 PRIETO SARRO. Luna, p. 327. Muchas de las escuelas poseían una inscripción dedicada que decía: Paulino García Gago. Benemérito montañés, protector de la enseñanza.

116 SALAS LARRAZABAL, Ramón. "León en la guerra del norte" La guerra civil española en León. León, 1986, p. 335.
} 
La llegada del régimen franquista trajo consigo una serie reformas económicas y sociales que afectaron de manera directa al Valle de Luna. En 1956 se inauguró la construcción del embalse de Barrios y, con él, el fin de la historia de esta tierra que quedó anegada bajos las aguas del pantano. 
3. EL PATRIMONIO DE LA ZACEL ANTES DE LA INUNDACIÓN 
Como se ha explicado anteriormente, la división de esta T.D. se ha organizado en tres bloques bien definidos que corresponden a los tres momentos principales de estudio:

- Antes de la construcción del embalse: el momento en que se levantan gran parte de las construcciones de la ZACEL.

- Durante la realización de las obras: el momento en que se construye la presa y las edificaciones auxiliares a ella.

- Después de la inundación: el momento trascurrido tras la inundación del Valle hasta nuestros días.

En el primer bloque se describe el período que corresponde al patrimonio inmueble del que constaba la ZACEL y que fue afectado de manera directa o indirecta por la construcción y la posterior inundación del Valle. Actualmente, la mayoría de los bienes que contuvo la ZACEL pueden ser analizados desde perspectivas arqueológicas, ya que los restos que hoy observamos pertenecen a un patrimonio destruido como consecuencia de la construcción de la presa. En este primer bloque también se incluyen aquellos bienes que eran considerados como arqueológicos antes de la construcción de la presa y aquellos otros que se han convertido en yacimientos a partir de la inundación. Es por ello que dentro de este apartado se hace un estudio de los bienes inmuebles dividido en:

- El patrimonio arqueológico

- La arquitectura popular

- La arquitectura industrial tradicional

- Los puentes

- La arquitectura religiosa

A pesar de que todo lo que ha quedado anegado puede considerarse como un resto histórico, existieron en el Valle otros asentamientos anteriores a la inundación que llevaban asociados objetos arqueológicos sobre los que se fundamenta el estudio del siguiente capítulo.. 


\subsection{EL PATRIMONIO ARQUEOLÓGICO}

La siguiente exposición trata de sacar a la luz los asentamientos históricos situados tanto dentro como en las inmediaciones del embalse de Barrios de Luna. Con ello se pretende hacer una llamada de atención acerca de la riqueza, el abandono y la falta de publicaciones científicas que aborden la historia arqueológica del Valle de una manera actualizada.

\subsubsection{LOS ESTUDIOS ARQUEOLÓGICOS}

Los estudios arqueológicos referentes al Valle del Luna son escasos y muy concretos. La consulta de las fuentes documentales como el Archivo Provincial de León y los catálogos de diversos archivos religiosos, como los del monasterio de Otero de las Dueñas, la abadía de Arbas, la catedral de Oviedo y León, apenas aportaron datos relevantes acerca de las antiguas poblaciones de la ZACEL ${ }^{117}$.

Las primeras publicaciones que hacen referencia al estudio de los bienes arqueológicos citan elementos de carácter anecdótico con información concerniente al Castillo de Luna y sus leyendas como son las obras de Madoz ${ }^{118}$ y Gómez Moreno ${ }^{119}$. En este último se hace una pequeña referencia a los hallazgos del castro de Oblanca y al de Barrios sin aportar mayor información que la simple cita.

No será hasta el primer cuarto del siglo XX cuando aparezca una figura importante en el estudio arqueológico del Valle como es César Morán ${ }^{120}$. Su trabajo es sin duda pionero en la investigación arqueológica puesto que por primera vez recoge las referencias acerca de los asentamientos castrenses junto con una descripción de las piezas arqueológicas obtenidas en sus prospecciones que posteriormente fueron donadas a los Museos Provinciales.

Debemos esperar hasta los años 80 para encontrar otra importante figura del estudio histórico y arqueológico de esta zona como es José Avelino Gutiérrez González $^{121}$ cuya memoria de licenciatura supuso una recuperación patrimonial y un

117 GARCÍA LARRAGUETA. Catálogo. También se obtuvieron noticias de otras poblaciones hoy desaparecidas como Lezeniangos u Odero en el territorio de Sena Doc. N ${ }^{\circ} 117 \ldots$ in Sena villam quam dicunt Lezeniangos.... $\mathrm{n}^{\circ} 143, \mathrm{n}^{\circ} 148$

${ }^{118}$ MADOZ. Diccionario.

${ }^{119}$ GOMEZ MORENO. Catálogo.

${ }^{120}$ MORÁN BARDÓN. "Excursiones".

${ }^{121}$ GUTIÉRREZ GONZÁLEZ. Poblamiento. 
estudio científico y comparativo de todas las piezas encontradas en el Valle así como los asentamientos defensivos castreños.

El resto de publicaciones hasta la fecha citan y describen algunas de las piezas arqueológicas de Luna. Estas obras se convierten en un inventario de los objetos agrupados según tipologías a nivel provincial. Destacan obras como el artículo de Germán Delibes y Julio Fernández ${ }^{122}$ sobre el Calcolítico y Bronce o el libro de Julio Fernández Manzano ${ }^{123}$ sobre asentamientos del Bronce en el N. de la Meseta.

A comienzos del siglo XXI predominan los artículos publicados en la revista Lancia por Jesús Celis Sánchez y Eduardo Alonso Herrero, Ana Neira Campos y otros $^{124}$ sobre el castillo de Luna y las explotaciones mineras de origen romano en Miñera, respectivamente. Finalmente y como consecuencia de las investigaciones llevadas a cabo en este trabajo, la misma autora ha publicado investigaciones arqueológicas relacionadas con el Valle ${ }^{125}$ que se basan en la recuperación de objetos arqueológicos y la puesta en valor del patrimonio destruido.

\subsubsection{LOS PRIMEROS ASENTAMIENTOS}

Es difícil identificar el período al que pertenecen las primeras colonizaciones del Valle debido a la falta de excavaciones científicas, aunque los primeros asentamientos definitivos parecen remitirse a la Edad del Bronce y del Hierro. Los espacios habitables escogidos son oteros elevados con una superficie plana cuyas dimensiones no alcanzan la hectárea de extensión ${ }^{126}$. La morfología de los castros es ovalada y se adapta a las condiciones del terreno montañoso que también condicionará el material y las técnicas constructivas utilizadas. El sistema defensivo está basado en taludes artificiales o en defensas naturales. Podemos adscribir a este primer período el castro de Oblanca y con cierta cautela el de Barrios.

La romanización trajo consigo la explotación de los recursos naturales mineros ${ }^{127}$. Se continúan utilizando castros anteriores y pudieron crearse otros, como el

\footnotetext{
122 DELIBES CASTRO- FERNÁNDEZ MANZANO. "Calcolítico".

123 FERNÁNDEZ MANZANO, Julio. Bronce final en la Meseta Norte española: el utillaje metálico, Soria, 1986.

${ }^{124}$ CÉLIS SÁNCHEZ. "Castillo” y ALONSO HERRERO-NEIRA CAMPOS. "Explotación."

${ }^{125}$ VILLANUEVA FERNÁNDEZ. "Redescubrimiento"; "Restos"; "El valor".

${ }^{126}$ CÉLIS SÁNCHEZ. "Origen”.

127 OREJAS-SANCHEZ-PLACIDO. "La arqueología” p. 136.
} 
posible asentamiento del Castrín de Sena, cuya función sería la de control del paso de mercancías de las cercanas explotaciones mineras como la de Miñera. Junto a este punto de extracción mineral pudo existir otro emplazamiento castrense denominado el Castrín de Mallo. A pesar de que no se han conservado restos en él, la toponimia y su cercana situación a la explotación de cinabrio y al puente de S. Lorenzo hacen pensar en un posible asentamiento que controlase la salida de productos.

Durante los primeros siglos de la Edad Media las continuas invasiones y la inestabilidad gobernativa en los diferentes momentos históricos ocasionaron que la población siguiese ocupando los castros o se creasen otros nuevos como el de Mallo. Las murallas se convirtieron en un componente imprescindible no solo defensivo, sino también creador de un espacio interno, pues como observamos en el castro de Mallo, su ubicación en una zona muy escarpada no haría necesaria la utilización de defensas artificiales.

Para contrarrestar el ataque musulmán y fomentar el sistema de Repoblación en el antiguo reino, Alfonso III reaprovechó los hábitats o fortificaciones anteriores para levantar una defensa basada en la construcción de castillos ${ }^{128}$. Con el retroceso de la invasión árabe, llevada al límite del río Duero, los castillos se convierten en puestos de control de las principales vías de comunicación N-S de la cordillera. Las fortalezas pasan a ser centros territoriales, presididos y gobernados por los comes y utilizados como prisión o como resguardo del tesoro real ${ }^{129}$. Las escasas posibilidades técnicas y de efectivos humanos imposibilitaban el mantenimiento del elevado número de centros militares, por lo que las responsabilidades defensivas de los castillos pronto recayeron sobre los propios habitantes, aunque el control primordial de los mismos seguía en manos de la corona ${ }^{130}$. El poder local y territorial estaba regentado por tenentes ${ }^{131}$ que poseían funciones judiciales, penitenciarias y fiscales con el cobro de impuestos feudales sobre la circulación de personas y mercancías ${ }^{132}$.

Durante la Baja Edad Media el poderío regio quedó debilitado y las fortalezas pasaron a poder de los nobles cuando las tenencias se hicieron hereditarias gracias a las

\footnotetext{
${ }^{128}$ MORSEL, Joseph. La aristocracia medieval. Valencia. 2008, p.112. Al respecto cabe destacar que el castillo de Barrios fue un enclave romano y anteriormente prerromano cuya situación estratégica sirvió para establecer las nuevas defensas medievales.

${ }^{129}$ SACHEZ BADIOLA. La configuración, p.414. El siguiente poseedor del castillo fue Fromagio Sendínez, que se dedicó al pillaje de estas tierras, por lo que también fue privado de sus bienes.

${ }^{130}$ Ídem, p.167 (C. C.L.- n ${ }^{\circ}$ 695)

${ }^{131}$ MORÁN BARDÓN. Excursiones, p. 67. En 1052 era señor del castillo don Jimeno Velasco.

${ }^{132}$ GUTIERREZ GONZÁLEZ. Fortificaciones, p. 24.
} 
concesiones reales, aunque su pertenencia continuaba en manos de la corona ${ }^{133}$. Las necesidades de la nobleza, de ampliación de territorios y acercamiento a la corte, obligaron a dejar algunas de estas fortalezas en manos de subtenencias y representantes locales ${ }^{134}$.

Tras el final de la Edad Media los castillos se convirtieron en construcciones obsoletas, pues ya no respondían a la poliorcética de la época basada en el uso de la artillería. Su funcionalidad en ocasiones quedaba relegada a cárceles locales y como sombras de un pasado memorable. Su reconstrucción dejó de ser obligatoria para los habitantes de la zona, lo que conllevó a su abandono.

Estos espacios defensivos no volverán a utilizarse sino en periodos muy concretos de enfrentamientos internos. Así el Castro Mayor de Sena ${ }^{135}$ fue utilizado, al igual que el castillo de Luna, para el asentamiento de trincheras durante la Guerra Civil.

Dentro de la ZACEL podemos diferenciar varios emplazamientos de origen prerromano y medieval:

El castro de Oblanca es el asentamiento que proporcionó materiales más antiguos. Los restos encontrados por César Moran, atestiguan la presencia de población desde el Calcolítico hasta la Edad Media ${ }^{136}$. Su identificación ha sido complicada, puesto que gran parte del yacimiento ha sido destruido por la creación de un ramal de la autopista AP-66.

Mallo de Luna conserva el contorno amurallado de su castro con espacios de hábitats que pueden datarse durante los primeros siglos de la Edad Media ${ }^{137}$.

El castillo de Barrios de Luna se originó como un castro prerromano que tuvo continuidad durante la Edad Media y hasta la Edad Moderna como fortificación y que fue una de las cunas del nacimiento del poder de los Quiñones ${ }^{138}$.

\footnotetext{
133 Ídem, p.108.

${ }^{134}$ MORSEL. Aristocracia, p.114.

135 GARCÍA LARRAGUETA. Colección, Doc. 186. 1174, julio. Toro. El castro Mayor de Sena contuvo a comienzos de la Edad Media un castillo propiedad de los reyes y donado a la iglesia ovetense.

${ }^{136}$ MORÁN BARDÓN. Por tierras, p.185.

${ }^{137}$ GUTIÉRREZ GONZÁLEZ. Fortificaciones, p. 26-27.

${ }^{138}$ Ídem, p. 23.
} 


\section{CASTRO DE OBLANCA}

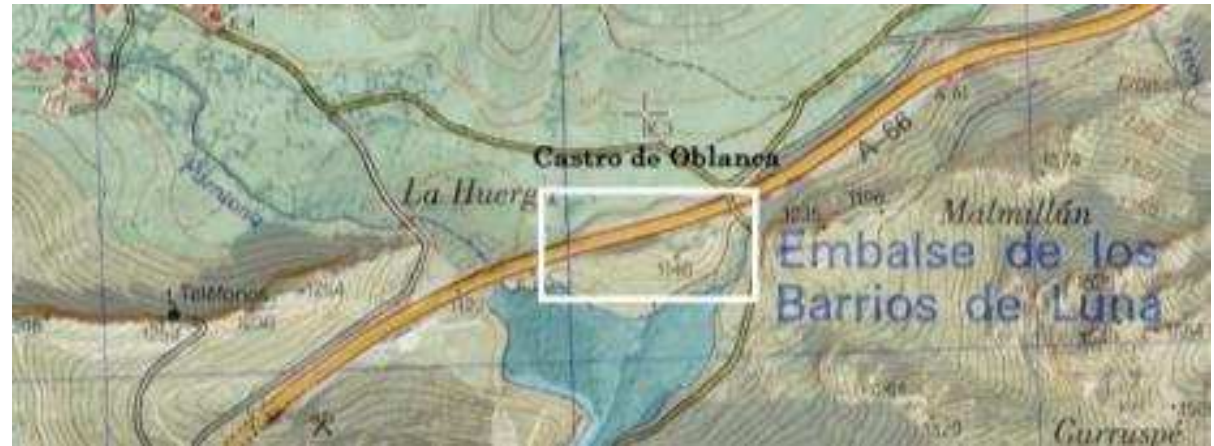

Ilustración 4. Castro de Oblanca. Sig.Pac.

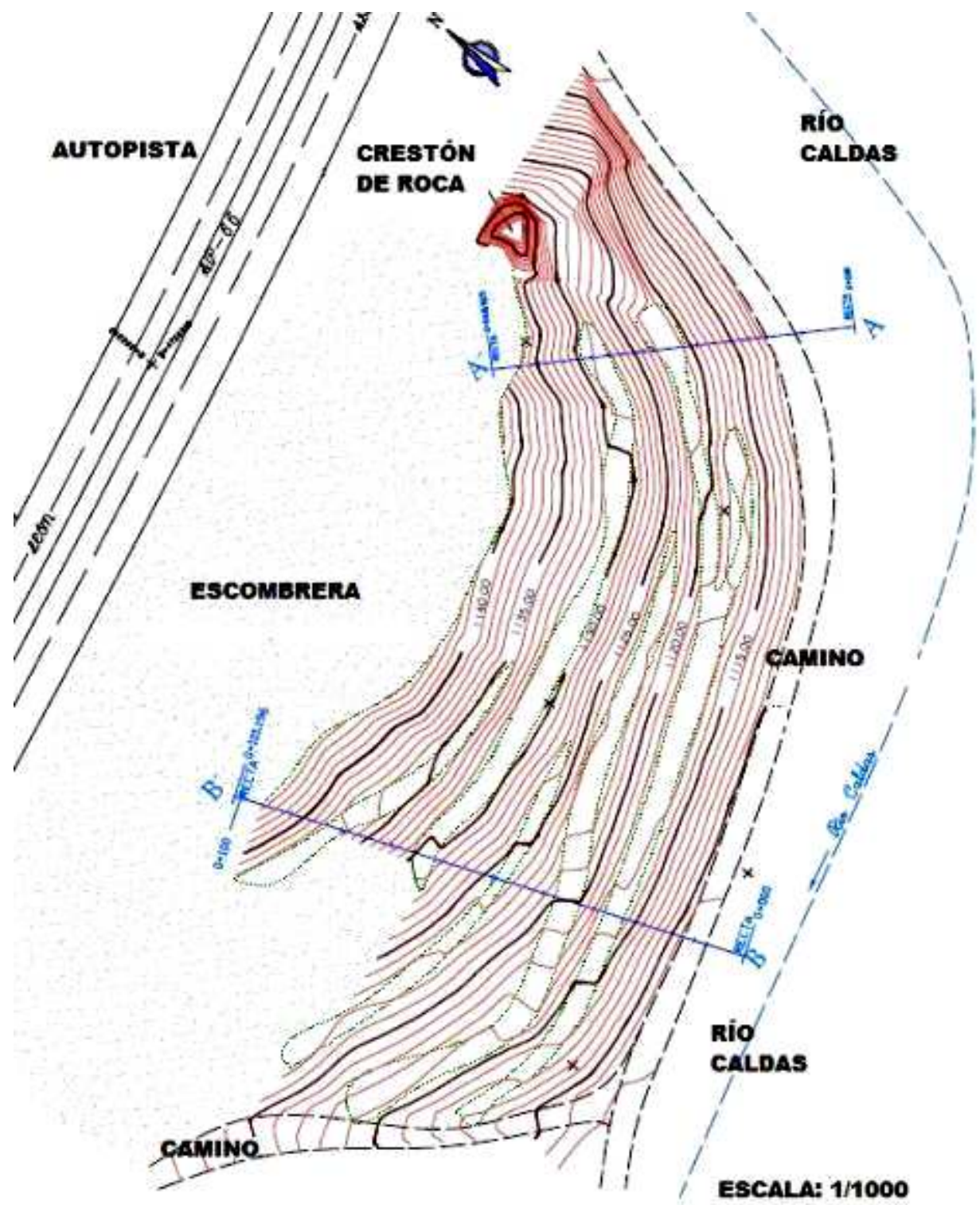


Localidad: Oblanca.

Ubicación: Km 90.200 de la AP 66. Carretera comarcal CV-102.18 junto al cruce de Caldas de Luna y Vega de Robledo, en el paraje denominado Villar del Cos.

Altitud: $1130 \mathrm{~m}$.

Coordenadas: $42^{\circ} 55^{\prime} 11.86^{\prime}$ 'N., 5' 52' 41.19'’O.

Datación: En su interior y cercanías se han encontrado piezas pertenecientes al Calcolítico, Edad del Bronce, Edad del Hierro y Edad Media ${ }^{139}$.

Dimensiones: 157 x $94 \mathrm{~m}$ con un perímetro cercano a los $400 \mathrm{~m}$.

Material: Muros de mampostería sin argamasa.

Defensas: Terrazas artificiales.

$\mathrm{N}^{\mathrm{o}}$ edificios: Desconocido.

Gran parte de la extensión que ocupaba el castro fue destruida por la construcción de la autopista AP 66 en el km 90 a su paso por Caldas. El promontorio fue utilizado como material de relleno y posteriormente como escombrera para las labores de construcción de la autopista.

El castro de Oblanca se ubica sobre un pequeño otero de escasa elevación y de forma abombada que se encuentra junto al río Caldas ${ }^{140}$. A pocos metros existe un antiguo yacimiento minero de cobre que pudo ser el factor que originó el asentamiento. Cuenta como elemento defensivo con una serie de terrazas artificiales que rodean el castro exceptuando la parte E. que se protege por la propia roca natural. Cada una de las terrazas posee una línea de mampuestos sin argamasa que sirvieron de elemento defensivo durante su ocupación.

El objeto más antiguo hallado es un hacha de piedra pulimentada, hoy desaparecida $^{141}$, asociada al Calcolítico de la tipología hacha-escoplo ${ }^{142}$ descubierta por Morán Bardón en la ladera S-O del castro en el paraje denominado Villar de $\operatorname{Cos}^{143}$. En el mismo lugar apareció un hacha de cobre de apéndices laterales pertenecientes al Bronce Final $\mathrm{II}^{144} \mathrm{y}$ un puñal triangular argárico ${ }^{145}$ de pequeñas dimensiones datado

\footnotetext{
${ }^{139}$ MORÁN BARDÓN. Por tierras, p. 184.

${ }^{140}$ GUTIERREZ GONZALEZ. Poblamiento, p. 232.

${ }^{141}$ En la ficha catalográfica del Museo de León se le ha dado un número pero la pieza ha desaparecido.

${ }^{142}$ Ídem, p. 62.

${ }^{143}$ MORÁN BARDÓN. Por tierras, p. 184. Esta pieza fue encontrada junto con un puñal de cobre y un caldero de $3 \mathrm{~cm}$ que en principio no corresponden con el período del hacha.

${ }^{144}$ FERNÁNDEZ MANZANO Julio. "Calcolítico y Edad del Bronce en la provincia de León”. Actas del ciclo de conferencias ARQUEOLEÓN. Historia del reino de León a través de la arqueología. León 19931994. León, 1996, pp. 29-40, p. 80.
} 
entre 1600 a 1200 a.C. ${ }^{146}$. Otro de los objetos hallados es un hacha de bronce de apéndices laterales oblicuos realizada con un molde doble o bivalvo bastante común en la producción metalúrgica de estas hachas ${ }^{147}$. Esta pieza se emparenta con la de Mirantes pertenecientes ambas al Bronce Final $\mathrm{II}^{148}$.

De finales de este período, y entroncado con la Edad el Hierro se encontró un calderito de cobre de $3 \mathrm{~cm}$. de alto y $45 \mathrm{~cm}$. de ancho, descrito por Morán Bardón $^{149}$ y datado por Gutiérrez González en el siglo VII a. C. ${ }^{150}$ y una hebilla anular de tipo Omega ${ }^{151}$ de posible cronología romana.

En la ladera S-O del castro se localizaron sepulturas, ruedas de molino de mano, pulseras de bronce, trozos de vasos de vidrio, restos de mineral de cobre y cuernos de ciervo $^{152}$. Según Gutiérrez González ${ }^{153}$ este lugar puede considerarse como la necrópolis del poblamiento a juzgar por los restos encontrados que parecen datarse en la Edad del Bronce y del Hierro. La aparición de vidrio junto con objetos de bronce y hierro hace suponer las cercanas relaciones con el mundo romano de este castro de Oblanca.

En la peña de la Cuesta, cercana al castro, se halló una filigrana de bronce de características visigodas que podría pertenecer a la hebilla de un cinturón ${ }^{154}$, lo que atestigua la continuidad del poblamiento hasta los primeros siglos de la Edad Media.

\footnotetext{
145 Museo de Salamanca. Bienes depositados por el P. César Morán. Puñal argárico. Ficha 1. 438. Año 1951. Oblanca. Información facilitada por Alberto Bescós Corral, Conservador y Director del Museo.

${ }^{146}$ Esta pieza de bronce se encuentra depositada en los fondos arqueológicos del museo de Bellas Artes de Salamanca. Información facilitada por Alberto Bescós Corral, Conservador y Director del Museo Provincial de Salamanca.

${ }^{147}$ ESPARZA ARROYO, Ángel. "Hacha de apéndices laterales del castro de Fradellos (Rabanales, Zamora) "en Boletín del Seminario de Estudios de Arte y Arqueología: BSAA, Tomo 44, 1978 pp. 346348.

${ }^{148}$ GUTIÉRREZ GONZÁLEZ. Poblamiento, p. 63.

${ }^{149}$ MORÁN BARDÓN. Por tierras, p. 184.

${ }^{150}$ GUTIÉRREZ GONZÁLEZ. Poblamiento, p. 228. Los calderos fueron muy comunes durante la Edad del Hierro en la Cordillera Cantábrica, como los ejemplos de Lois y Villaceid

${ }^{151}$ MORÁN BARDÓN. Por tierras, p. 184

152 GUTIÉRREZ GONZÁLEZ. Poblamiento, p 228.

${ }^{153}$ Ídem, p. 61.

${ }^{154}$ MORÁN BARDÓN. Por tierras, p. 185.
} 
CASTRO DE MALLO

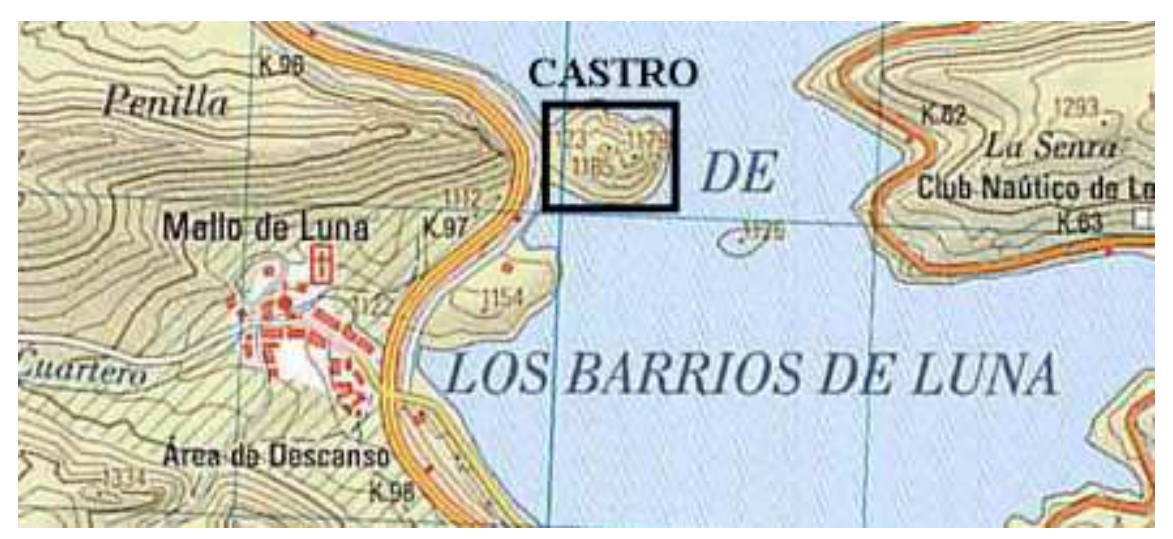

Ilustración 5. MTN50. Barrios de Luna. N 102. 2005

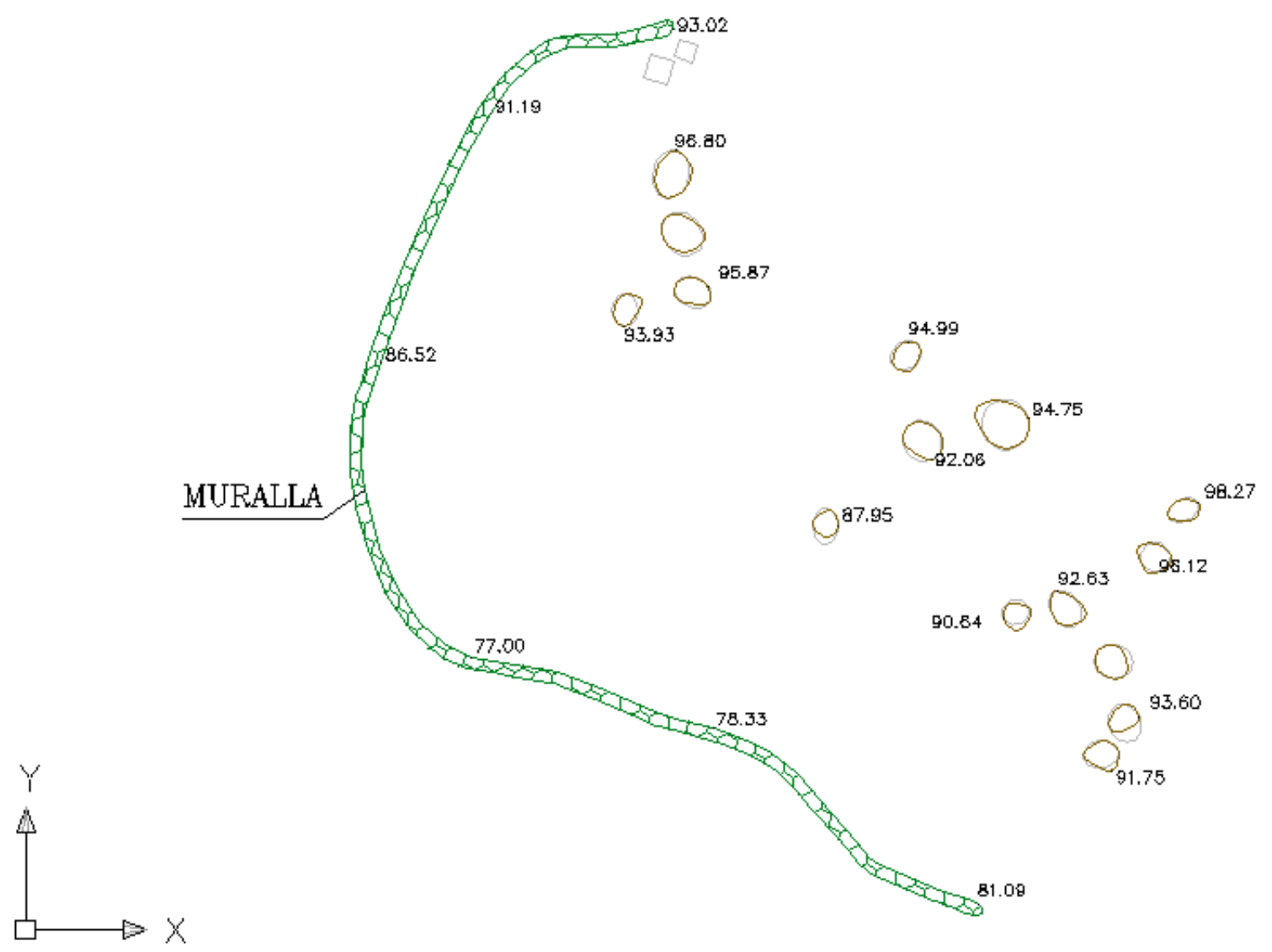


Localidad: Mallo de Luna.

Ubicación: El castro se encuentra al E. de la peña Penilla, sobre una península formada tras la inundación del pantano.

Altitud: $1185 \mathrm{~m}$.

Coordenadas: $42^{\circ} 52^{\prime} 42^{\prime \prime}-05^{\circ} 52^{\prime} 35^{\prime \prime 155}$.

Datación: El origen, según Gutiérrez González ${ }^{156}$, parece remontarse a tiempos prerromanos, aunque a falta de una excavación, su datación más correcta se situaría durante la Alta Edad Media.

Dimensiones: Superficie total de 350 x $110 \mathrm{~m}$.

Material: Mampostería en seco.

Defensas: Muralla de sillarejo y barranco natural.

$\mathrm{N}^{\mathrm{o}}$ edificios: Aproximadamente 17 viviendas.

A falta de una excavación arqueológica, el origen de este castro pudo estar relacionado con el desarrollo medieval del control y apropiación del espacio iniciado por la monarquía astur en tiempos de Alfonso III $^{157}$. Los materiales hallados en las

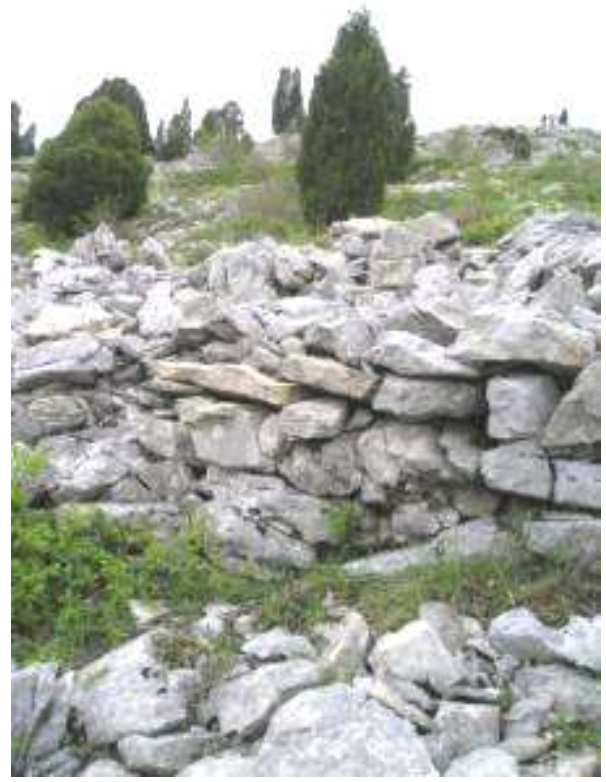

Ilustración 6. Muralla del castro prospecciones corresponden con restos de cerámica altomedieval, así como escorias de hierro ${ }^{158}$. No podemos asegurar la fecha de abandono del asentamiento, ya que durante mucho tiempo sirvió como cabaña de pastores y resguardo del ganado.

El castro de Mallo se sitúa en lo alto de la peña rocosa donde se conservan los restos de lo que fue la muralla y algunos cimientos de planta circular. Presenta cierto orden urbanístico al estar dividido en tres terrazas que se adecúan al terreno $^{159}$.

La muralla es de mampostería en seco de 1 m. de altura máxima conservada y $2.50 \mathrm{~m}$. de anchura en la parte S. del recinto. Esta muralla protege todo el asentamiento excepto en el lado N-E, donde existe un gran barranco infranqueable.

\footnotetext{
${ }^{155}$ MTN50. Barrios de Luna. No 102. 2005.

${ }^{156}$ GUTIÉRREZ GONZÁLEZ. Poblamiento, p. 66.

${ }^{157}$ GUTIÉRREZ GONZÁLEZ. Fortificaciones, p. 24.

${ }^{158}$ GUTIÉRREZ GONZÁLEZ. Poblamiento, p. 66.

${ }^{159}$ Ibídem.
} 
El acceso principal se encuentra en la zona N-O, cuya entrada posee un esquema acodado $^{160}$ que aprovecha el espacio de los crestones rocosos para crear un pasillo interior a modo de muralla doble de $3.50 \mathrm{~m}$. de ancho. Para rellenar el pasillo, y evitar su pendiente, se extrajo la tierra de los crestones con una doble finalidad: mejorar el tránsito por este lugar y aprovechar la defensa de la roca natural.

La entrada hacia el interior se realiza a través de un falso llano flanqueado por dos construcciones cuadradas a modo de torres defensivas de $16 \mathrm{~m}^{2}$. cada una ${ }^{161}$. Estas obras se sitúan en la parte más elevada del castro y la más cercana de la puerta de acceso, por lo que pudieron tener una función militar o jerárquica especial.

Las tres terrazas interiores se han aprovechado para construir las viviendas. Presentan una planta ovalada con muros en mampostería en seco y de dimensiones muy similares de $3 \times 4 \mathrm{~m}$. La primera terraza es la más cercana a la vía principal de entrada. En ella se disponen un grupo de cuatro viviendas de planta ovalada y sillarejo. En la segunda terraza se sitúan otras cuatro construcciones más que se acomodan a las condiciones s del terreno formando, como en el caso anterior, un grupo perfectamente unido y delimitado. En la última terraza se disponen otra serie de edificaciones adosadas a la roca que pudieron ser las más tardías, ya que aún se observan restos de la techumbre de madera.

Los objetos asociados al asentamiento son galbos cerámicos y goterones de escoria que hacen suponer la presencia de actividades artesanales dentro del recinto.

Cercano al castro de Mallo se cita en la toponimia el denominado Castrín. Su estratégica situación en el camino que unía Mallo con Miñera junto al puente de $\mathrm{S}$. Lorenzo pudo ser clave para el establecimiento de un pequeño núcleo de población. Sin embargo, en las tres prospecciones visuales que se han realizado para tal caso, no se ha descubierto ningún resto ni de edificación ni de defensa ni incluso de material arqueológico.

\footnotetext{
${ }^{160}$ Ídem, p. 44

${ }^{161}$ La falta de una excavación arqueológica y la vegetación que crece alrededor de la estructura, dificulta establecer con precisión la forma y dimensiones de la misma.
} 


\section{CASTILLO DE BARRIOS DE LUNA}

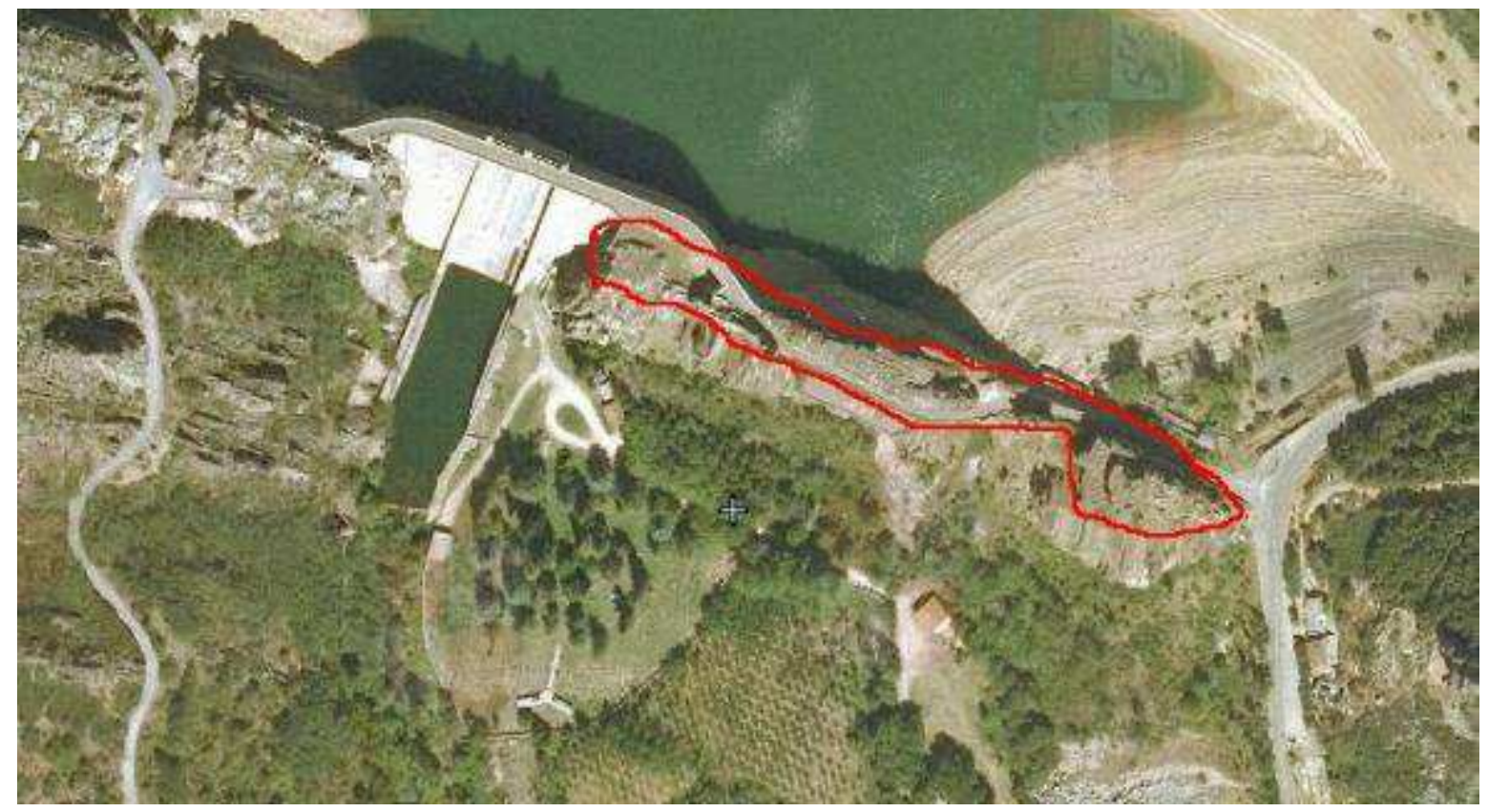

Ilustración 7. Vista aérea del perímetro que ocupaba el castillo de Luna. www.sigpac.es

Localidad: Barrios de Luna.

Ubicación: Sobre el crestón rocoso de cuarcita junto a la pared del embalse.

Altitud: Su altitud máxima es de $1157 \mathrm{~m}$. y la mínima es de $1080 \mathrm{~m}$.

Coordenadas: $42^{\circ} 50^{\prime} 54.87^{\prime}$ N. y $5^{\circ} 51^{\prime} 37.70^{\prime}$ 'O.

Datación: Desde la Edad del Bronce hasta la actualidad.

Dimensiones: $333 \mathrm{~m}$. largo por $40 \mathrm{~m}$. de ancho en su mayor espesor y $690 \mathrm{~m}$. de perímetro.

Material: Sillares y mampostería unidos con argamasa.

Defensas: Muros de mampostería, atalayas y precipicios escarpados.

El castillo de Barrios de Luna se asienta sobre un crestón rocoso de cierta altitud con respecto al terreno circundante, con buenas defensas naturales y una amplia visibilidad sobre los estrechos pasos que otorga una posición de dominio en puntos estratégicos ${ }^{162}$.

La planta del castillo es irregular y se extiende a través de los más de $300 \mathrm{~m}$. del afilado crestón rocoso. Las condiciones del terreno obligan a crear una planta alargada y estrecha de no más de $40 \mathrm{~m}$. de ancho. Los muros están realizados en mampostería con

162 GUTIÉRREZ GONZÁLEZ. Fortificaciones, p. 46. En la zona en la que ya se había asentado castros anteriores como es el caso de Barrios de Luna, sus defensas naturales y artificiales son reaprovechadas. 
mortero de cal y un grosor medio de $1 \mathrm{~m}$. El recinto interior es reducido, ya que debe adecuarse al terreno montañoso sobre el que se asienta. La propia roca servía de materia prima, pues los materiales residuales eran aprovechados para elevar los muros del castillo.

En el siglo XIX aún se mantenía la entrada fortificada del castillo tal y como describe $\mathrm{Madoz}^{163}$ con "paredones muy fuertes (...) y existiendo aún dos puertas de hierro del mismo castillo, una en la cárcel y otra en una casa particular”. Gómez Moreno relataba la entrada al castillo con dos cubos que conducía a la meseta central en la que se conservaba un pasadizo arqueado en la roca y un pozo que surtía agua mediante cañería de barro $^{164}$ hacia el aljibe. Según esta descripción la puerta de entrada podría estar flanqueada por una muralla barbacana con torres de refuerzo a cada lado ${ }^{165}$. A través de esta puerta se accedería al interior por un estrecho sendero denominado la "Senda de los Lirios"166 de unos 80 m. hacia la meseta central que Gómez Moreno

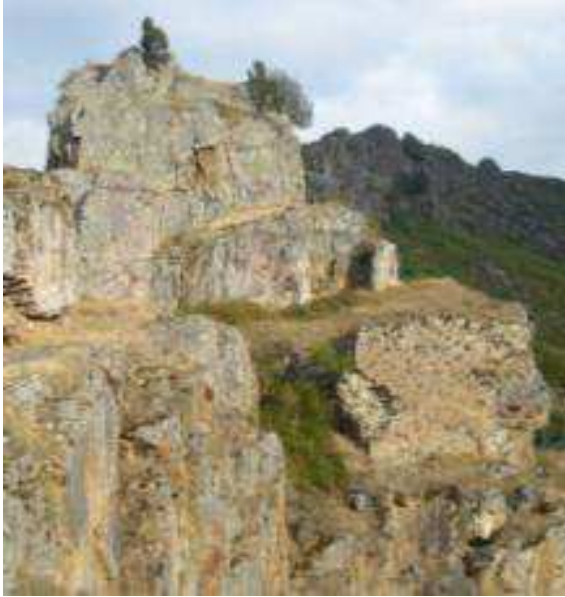

Ilustración 5. Atalaya principal o Torre del homenaje. describió con cimientos en rectángulo de 22.50 por 6 metros que podía ser utilizada como patio de armas ${ }^{167}$. Ángel Suárez, vecino de Barrios, habla de la existencia de un pasadizo en la roca del castillo, conocido ya desde muy antiguo, y que fue cerrado con grandes piedras. Suárez comenta la gran humedad y filtraciones de agua que existían por lo que podría tratarse del aljibe del castillo.

Sobre el gran peñasco de cuarcita se encontraban las dependencias señoriales cuya estructura fue seccionada por la construcción de la carretera que da acceso al embalse. La torre del homenaje o torre principal se situaba en la zona más elevada del escarpe a la cual se accedía por un estrecho pasillo helicoidal. Este paso podía estar delimitado en su origen por un muro de cierre adosado al peñasco justo al final del sendero.

${ }^{163}$ MADOZ. Diccionario, Vid: Barrios de Luna.

${ }^{164}$ GOMEZ MORENO. Catálogo, p.141.

165 VILLENA, Leonardo. "Arquitectura militar en la península Ibérica". en La fortificación medieval en la Península Ibérica. Actas del IV curso de Cultura Medieval, Aguilar de Campo (Palencia), 21-26 de septiembre de 1992, p. 24. Este elemento lo podemos constatar gracias a las descripciones de Gómez Moreno, quien relata la existencia de dos cubos a cada lado de la puerta de entrada.

${ }^{166}$ RODRIGUEZ MORAN Ángel. http://www.xente.mundo-r.com/luna/penaCSS.htm

167 GOMEZ MORENO. Catálogo, p. 141. Este espacio podía ser usado como caballerías o patio de armas, además de contener diversas estancias realizadas en materiales menos duraderos, como la madera. 


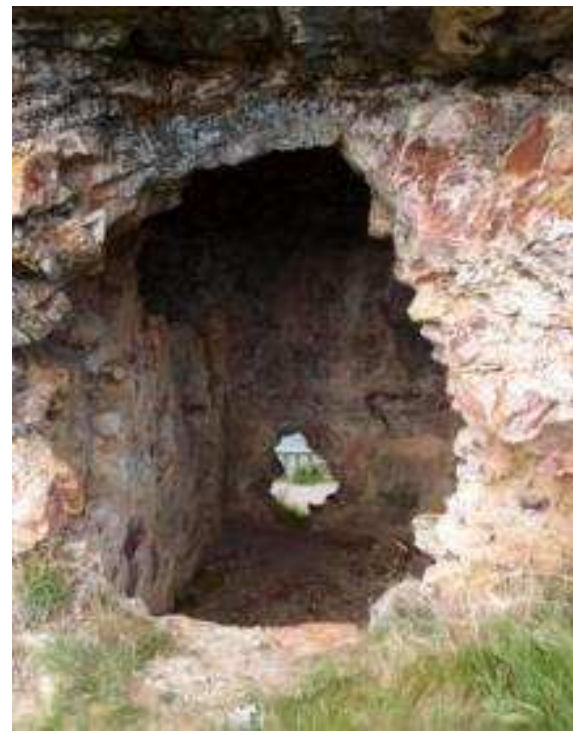

Ilustración 6. Estancia rectangular.

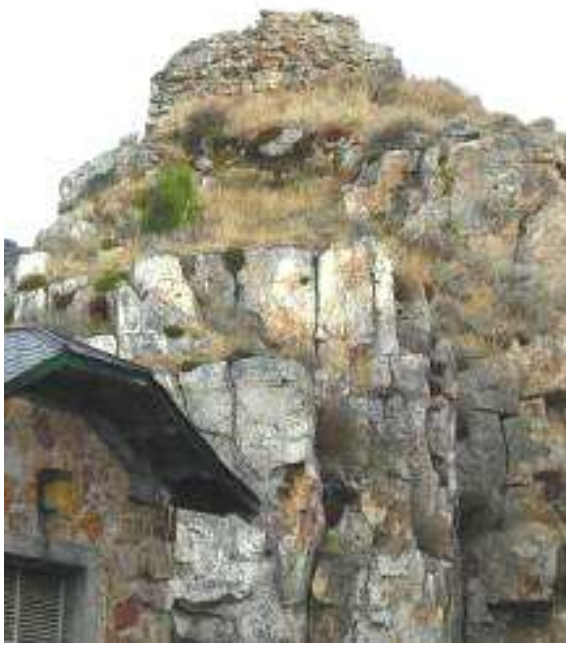

Ilustración 8. Restos del castillo junto a la torre de luz del embalse.

Bajo la torre del homenaje, y junto al camino que da acceso a este espacio, se encuentra una estancia de planta rectangular de $7.5 \times 3 \mathrm{~m}$. con una altura máxima conservada de $1.8 \mathrm{~m}$. y mínima de $1.2 \mathrm{~m}$. Se trata de una habitación excavada en la roca situada bajo el peñasco central y orientado al S. El interior está revestido con mortero de $\mathrm{cal}^{168}$. La utilización de este espacio es confusa y no poseemos datos fehacientes acerca de su uso.

A continuación se encuentra un estrecho pasillo de más de $100 \mathrm{~m}$. sobre la garganta del Luna. No se debe confundir este paso con la carretera que se observa actualmente, puesto que ésta fue construida durante las obras de la presa y destruyó gran parte de la meseta central del castillo $^{169}$.

Sobre la roca que no fue afectada por la carretera se pueden observar los restos de una estructura de planta cuadrada con muros de mampostería de menos de $1 \mathrm{~m}$. de altura y de 24 $\mathrm{m}^{2}$. que formaba parte de la muralla y que recorría toda la parte superior del barranco ${ }^{170}$.

Por último, en la parte más septentrional de la plataforma del castillo se asienta una atalaya. Esta estructura constituiría la primera defensa sobre el paso desde el puente de Trabanco situado sobre la garganta del río Luna. Mantiene un esquema de planta cuadrangular con aparejo de sillería sin escuadrar. El grosor de los muros es de $1.8 \mathrm{~m}^{171}$ con un relleno interior de cantos rodados y una altura máxima de $1.5 \mathrm{~m}$. Se conservan los contrafuertes que sujetan la pared sobre el gran escarpe occidental. A partir de esta torre se observa

\footnotetext{
168 Ídem, p. 73.

${ }^{169}$ En la actualidad podemos observar en esta zona la denominada formación de Barrios, característica por la sucesión de deposiciones marinas en forma de dunas de agua entre los que nos encontramos fósiles marinos.

${ }^{170}$ GUTIÉRREZ GONZÁLEZ. Poblamiento, p. 72.

${ }^{171}$ Ibídem.
} 


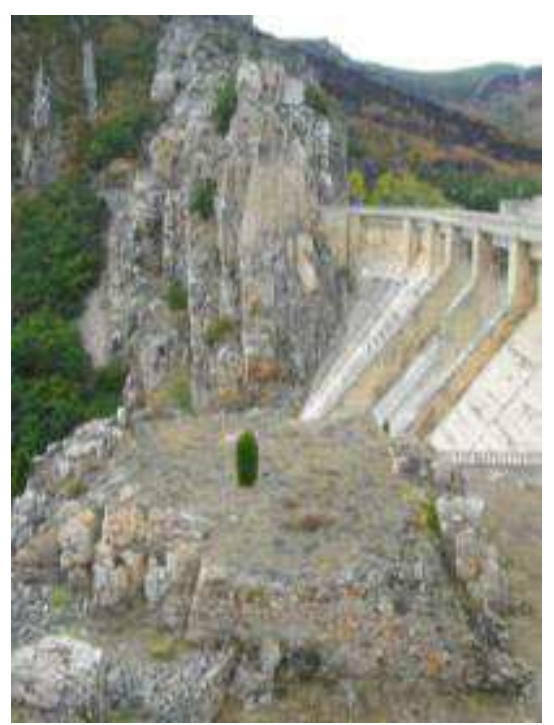

Ilustración 9. Restos de la torre septentrional del castillo.

un lienzo de muralla de unos $20 \mathrm{~m}$. de longitud en dirección E. que comunica con el resto de dependencias, creando a sus pies otro gran patio del que desconocemos sus dimensiones exactas debido a la construcción de la pared de la presa.

Al otro lado de la peña no existía ninguna estructura defensiva, puesto que las construcciones que se observan corresponden a los cables-grúas y torres de luz realizados para transportar los materiales durante la construcción de la presa.

El castillo ha proporcionado numerosos materiales arqueológicos de diversas épocas hoy recogidos en el Museo de León y en colecciones particulares.

El cerro ya fue desde la Edad del Bronce un lugar de ocupación donde los grupos ejercían un poder sobre el territorio jerarquizado. Los restos cerámicos como los vasos de superficies pulidas y cerámica carenada encontrados en la base del castillo de Luna por Celis Sánchez, verifican la existencia de una zona habitada antes de la llegada del Imperio Romano. Un objeto de interés es el gancho para carne conservado en la colección Fontaneda que, según Celis Sánchez, pone de manifiesto las vinculaciones con las producciones británicas y francesas ${ }^{172}$. Otros objetos metálicos del Bronce encontrados en el castillo son dos puñales de filos arqueados con mango y varios punzones denominados de aguja de brújula datados de entre los años 1600.1400 a. C y relacionados con el mundo de Europa Central ${ }^{173}$.

Pertenecientes a la Edad del Hierro destacan varias piezas de metalistería como puntas de lanza o fíbulas de tipo Golfo de León y de pie vuelto o torrecilla, agujas y varillas de bronce. Dentro de la industria lítica aparecieron algunas placas pétreas bien recortadas, pulidas y horadadas en su extremo. También se encontraron dos pequeñas cuentas de esteatita marrón ${ }^{174}$.

$\mathrm{Al}$ inicio de la guerra contra los astures las tropas de Publio Carisio recorrieron la zona N. llegando a romanizar los territorios del Luna. Una prueba de ello lo constatan

\footnotetext{
172 CÉLIS SÁNCHEZ. “Origen”, p. 43.

173 GOMEZ MORENO. Catálogo, p.83. Gómez moreno describe la aparición de unas fíbulas prerromanas en el castillo de Luna ya en su catálogo monumental de la provincia de León.

${ }^{174}$ CELIS SANCHEZ. "El castillo", p. 86.
} 
las monedas aparecidas en el castillo de Barrios con la efigie de Carisio por un lado y las armas de los enemigos por el lado opuesto, conservadas por un $\operatorname{particular}^{175}$.

El castillo fue uno de los centros político-militares más relevantes durante la Edad Media convirtiéndose en eje vertebrador de los inicios de la Reconquista. Si hacemos referencia a romances legendarios como el de Bernardo del Carpio, el castillo de Luna ya se encontraba en funcionamiento durante el reinado de Alfonso II. En él, según la tradición, sería encarcelado el Conde de Saldaña quien tuvo relaciones con la hermana del rey, doña Jimena, de cuya unión nació el héroe de Roncesvalles Bernardo del Carpio $^{176}$.

Durante el reinado de Alfonso III (866-910) el castillo de Luna formó parte del sistema defensivo que recorría gran parte de la Cordillera Cantábrica para proteger la calzada de Asturias a León a través del puerto de la Mesa ${ }^{177}$. La crónica de Sampiro se refiere a la edificación de Alfonso III in territorio legionensi Lunam, Gordon em et Albam...en torno al año $899^{178}$.

El ataque árabe de Almanzor durante el reinado de Vermudo II entre el 986 y el $991^{179}$ convirtió al castillo de Luna en una fortaleza inexpugnable en la cual se refugiaron los bienes del sagrado tesoro de Oviedo. La guardia y custodia del tesoro recayó sobre Gonzalo Bermúdez, quien se alzó contra el rey en el 991 desde el castillo de Luna, quien obligó al rey Vermudo II a abandonar León y refugiarse en Galicia. La pena para tal abuso fue la confiscación de todos los bienes de Gonzalo ${ }^{180}$.

El castillo sirvió muchas veces de centro de reunión para esclarecer los litigios territoriales que se originaron con la creación del Reino de León en el siglo XI y la nueva ocupación territorial por parte de los reyes don Fernando y doña Sancha ${ }^{181}$. A finales del siglo XI el castillo volvió a cobrar protagonismo al ser telón de las disputas

\footnotetext{
${ }^{175}$ RODRIGUEZ MORAN Ángel. http://www.xente.mundo-r.com/luna/penaCSS.htm.

176 GARCÍA DE LA FOZ, José. Crónica general de España. Historia ilustrada y descriptiva de sus provincias, sus poblaciones más importantes de la península y ultramar. Provincia de León. Madrid 1867, p. 21. PUYOL, Julio. Orígenes del Reino de León y de sus instituciones políticas. León, 1979, p. 104. El Chronicon Mundi de Lucas de Tuy afirma que después de la muerte de Bernardo, la reina Jimena...edificó en los confines de León los castillos de Alba, Gordón, Arbolio y Luna y llevó allí a escondidas a su hijo García, sugiriéndole que se rebelase contra su padre.

${ }^{177}$ SANCHEZ BADIOLA. El territorio, p.158 Hacia el año 876, Alfonso III se elige el asentamiento en el borde de la cordillera cantábrica como apoyo de avance feudal astur-leonés hacia el valle del Duero.

178 PÉREZ DE URBEL, Fray Justo. Sampiro. Su crónica y la monarquía leonesa en el siglo X. Madrid, 1952 , p. 22.

${ }^{179}$ GUTIERREZ GONZÁLEZ. Fortificaciones, p. 199. El castillo resistió los envites de Almanzor, convirtiéndose desde ese momento en símbolo de resistencia y denominándose a este enclave como "Peña Almanzor"

${ }^{180}$ PÉREZ DE URBEL. Sampiro, p. 23.

${ }^{181}$ MORÁN BARDÓN. Excursiones, p. 67.
} 
de los herederos de los reyes. El rey de Galicia, don García, fue encarcelado en este castillo en 1073 al haberse opuesto a la subida al trono de su hermano Alfonso VI ${ }^{182}$.

Durante el siglo XII el castillo interviene ocasionalmente en los conflictos fronterizos castellano-leoneses pasando a diferentes manos por premio o por traición al poder regio ${ }^{183}$ como la donación y posterior destierro de Alfonso VII al conde Gonzalo Peláez ${ }^{184}$. En 1399 Enrique III dona definitivamente los derechos sobre el castillo a Pedro Suárez de Quiñones ${ }^{185}$. La fortaleza se convierte entonces en estandarte del condado que se afianzó con la titulación de Juan II en 1466 a D. Diego Fernández de Quiñones, padre del Cardenal Francisco de Quiñones, mediador entre Carlos $V$ y el Papa Clemente VII como Conde de Luna ${ }^{186}$. De esta manera el castillo acaba transformándose en uno de los centros desde donde los Quiñones ejercieron su poderío feudal sobre los vecinos de los concejos de Luna y Babia ${ }^{187}$.

En esta etapa señorial es cuando se reconstruyen la mayor parte de las estructuras arquitectónicas del castillo con formas más regulares de murallas en aparejo ordinario y mortero de cal $^{188}$. Las torres de flanqueo, aunque comunes en la época, no se levantaron debido a las defensas naturales que propiciaba el terreno. A consecuencia de todas estas remodelaciones hubo pleitos con los concejos de los pueblos cercanos por los abusos cometidos al obligarles a reconstruir el castillo y levantar nuevas torres ${ }^{189}$.

De entre los objetos hallados datados durante la Edad Media destaca la cantidad de puntas de lanza con aletas o cuadradas en hierro de largas hojas con orificios para

\footnotetext{
${ }^{182}$ AGUADO BLEYE, Pedro. Manual de Historia de España. T. I, Prehistoria; Edades antigua y media. Madrid, 1971, p. 599. Arrepentido por las malas condiciones de vida de su hermano durante los 17 años que pasó en los calabozos del castillo de Luna, Alfonso VI lo mandó sacar aunque murió en el traslado a la corte. Su cuerpo fue enterrado en S. Isidoro con todos los honores de un rey junto con las cadenas de su encierro en 1090.

${ }^{183}$ GUTIERREZ GONZÁLEZ. Fortificaciones, p.199. A pesar de no ser un puesto fronterizo, su intervención se origina al haber sido concedido en tenencia por Fernando II, junto a los castillos de Argüello y Siero, a los López de Haro, hermanos de su mujer Urraca López al tomar éstos el bando castellano por no heredar el hijo de Urraca el reino leonés a la muerte del rey.

${ }^{184}$ GARCÍA GARCÍA, María Elida. "El conde asturiano Gonzalo Peláez" en Asturiensia medievalia, No 2, 1975, pp. 39-64, p 60.

${ }^{185}$ ALVAREZ ALVAREZ. Condado, p. 28.

${ }^{186}$ MORÁN BARDÓN. Excursiones, p. 65.

${ }^{187}$ SUAREZ DIEZ Luis Carlos. Memoria heráldica del Excelentísimo ayuntamiento de Barrios de Luna. León, 1996, p. 5.

${ }^{188}$ MORÁN BARDÓN. Excursiones, p. 68.

${ }^{189}$ CASADO LOBATO, Concha. Colección diplomática del monasterio de Carrizo. León, 1983. Doc. 196. El estado del castillo debía ser ruinosos en el momento de la donación y los Quiñones se ven obligados a restaurar y modernizar sus arcaicas defensas.
} 
introducir el mango ${ }^{190}$. También han aparecido clavos de sección cuadrada y circular que pudieron ser remaches de muebles o puertas y dardos de punta doble de saeta ${ }^{191}$. Otros materiales que han sido localizados en el castillo son: un anillo de hierro cuadrangular, una hebilla con pasador, un broche de cinturón y dos láminas de cobre con un grabado estrellado en forma rectangular con remate en las esquinas formando estrías que pudieron servir como adorno de mobiliario o cuero ${ }^{192}$. Es común la presencia de cerámica medieval hecha a torno con pastas muy gruesas y con decoración de incisiones o estrías con decoración típica de la Plena Edad Media ${ }^{193}$. Ángel Suárez, vecino de Barrios, habla de más objetos encontrados como una aguja con estrías rematada con la figura de un ave de menos de $1 \mathrm{~cm}$. que pudiera ser un adorno femenino para el cabello.

La vida política del castillo a finales de la Edad Media será tan solo evocadora de un pasado más glorioso. El castillo continuó formando parte de la familia de los Quiñones durante la Edad Moderna y hasta 1850 con el último de los Quiñones, el duque de Frías D. Bernardino Fernández Velasco ${ }^{194}$. En este período la utilización del castillo se reducía a un centro penitenciario y de represión. Así en $1692^{195}$ aún se nombran alcaldes para la prisión por mandato del Conde-duque de Benavente y Conde de Luna. Convertido ya en cárcel, las últimas modificaciones que se hacen en el castillo no serán defensivas, sino más bien reparaciones o de cambio de uso.

Pertenecientes a la Edad Moderna se han encontrado varios maravedís del siglo XVII, acuñados entre el reinado de Felipe III y Felipe IV y resellados años más tarde ${ }^{196}$.

En la invasión napoleónica el castillo sufrió graves ataques quedando en un estado de ruina y abandono del que no volvería a recuperarse jamás. Su función defensiva sería aprovechada como trinchera y puesto defensivo por el Frente Nacional durante la Guerra Civil española ${ }^{197}$.

\footnotetext{
${ }^{190}$ Estas piezas fueron expuestas en la exposición Regnum: Corona y Cortes en Benavente (1202-2002) y citadas en el texto de SOLER DEL CAMPO, Álvaro. "La guerra y el armamento en Castilla y León durante los siglos XII-XIV" en Regnum: Corona y Cortes en Benavente (1202-2002). Benavente 2002.

${ }^{191}$ GUTIÉRREZ GONZÁLEZ. Poblamiento, p. 72.

192 Ídem, p. 71.

193 Museo Provincial de León. 1994-1 Caja 50 Barrios de Luna. En la caja tan solo se conservan los restos de cerámica.

${ }^{194}$ MORÁN BARDÓN. Excursiones, p. 68.

${ }_{195}$ ALVAREZ-MARTÍN FUERTES. Catálogo, Doc. 845.

${ }^{196}$ GUTIERREZ CONZÁLEZ. Poblamiento, p. 263. Este tipo de moneda fue creado por Felipe II en el cambio del siglo XVI al XVII. Sin embargo se observa que continúa la edición de maravedís que incluía al león y el castillo con la leyenda de PHILIPPUS III. D(ei) G(ratia) / HISPANIARUM REX.

${ }^{197}$ SALAS LARRAZABAL. León, p. 431.
} 
Durante la construcción del embalse los pocos restos conservados fueron deteriorados en profundidad, especialmente los dos cubos que aún permanecían en la entrada este del castillo ${ }^{198}$. La edificación de las grúas para trasladar los materiales se levantó sobre los propios cimientos del castillo, lo que supuso la pérdida final de muchas de sus estructuras. La carretera de acceso a la coronación de la presa destruyó el espacio central transformando su orografía por completo y dejando al castillo en un estado total de ruina.

${ }^{198}$ GÓMEZ MORENO. Catálogo, p. 141. 


\subsection{LA ARQUITECTURA POPULAR}

La importancia de este apartado deriva de la necesidad de rescatar del olvido los edificios tradicionales de una zona que no ha sido tratada anteriormente. Debido a la dificultad de estudiar un panorama arquitectónico inundado se ha tenido que extraer la información de los planos levantados por la Confederación Hidrográfica del Duero, los fondos fotográficos y la comparación con los edificios tradicionales que aún quedan en pie. Es así como se ha podido reconstruir de manera genérica la tipología de las casas y otros edificios de los que se componían las poblaciones inundadas. En el estudio de la denominada arquitectura popular se han incluido no solo los edificios de viviendas, sino también los auxiliares que formaban parte del entramado urbano de la ZACEL.

\subsubsection{LOS ESTUDIOS SOBRE ARQUITECTURA POPULAR}

La arquitectura popular se ha convertido en las últimas décadas en un patrimonio revalorizado a medida que ha ido desapareciendo. El espacio rural se ha vaciado a causa de la industrialización, las nuevas técnicas de producción y la emigración hacia la ciudad. La mecanización suplió las actividades tradicionales lo que supuso una merma paulatina de las arquitecturas realizadas para esas funciones. Esta merma ha ocasionado que se estimen de una forma especial estas edificaciones y toda la cultura material e inmaterial que les rodea.

A partir de los años sesenta del siglo XX comienza a darse una señal de alarma sobre la pérdida de identidad de muchas poblaciones rurales. Durante las siguientes décadas aumentaron los estudios que analizaban este problema creando bases de datos, fotografías y publicaciones sobre las diferentes tipologías de edificios populares de cada zona. Los principales problemas surgieron con la nomenclatura asignada. Se barajaron diferentes posibilidades como el término vernácula, referente a un determinado territorio; el término autóctona, relativo al lugar de origen; el término rural, relacionado con las labores del campo; el término arquitectura típica, que evoca un cierto sentido romántico; o el término tradicional, que se enmarca en las costumbres y tradiciones. ${ }^{199}$ Pero el término que ha acabado estableciéndose como el más correcto y utilizado ha

199 ALONSO GONZÁLEZ, Joaquín-Miguel. Arquitectura tradicional de la comarca de Omaña y Valle de Samario. León, 2003, p. 11. 
sido el de arquitectura popular, que describe a aquellos edificios destinados a vivienda realizados de manera artesanal y asentados en un territorio rural principalmente antes de la industrialización. Existen otro tipo de construcciones que no conforman la vivienda y que servían de apoyo para las labores tradicionales denominadas como arquitectura auxiliar o complementaria.

Ante la agravante pérdida de las poblaciones rurales y su modo de vida, se ha retomado un nuevo concepto, el de patrimonio etnográfico ${ }^{200}$ que engloba no sólo a la arquitectura, sino también el modo de vida, las costumbres y los bienes muebles.

El primer texto español referente a este tipo de edificios arquitectónicos surgió en 1922 de la mano de Vicente Lampérez y Romea ${ }^{201}$. Tras este primer libro no tardaron en iniciarse otros estudios en la década de los años veinte encabezados por Leopoldo Torres Balbás ${ }^{202}$, discípulo del anterior, que diferenciaba entre dos tipos de edificios, los de montaña y los del páramo. La importancia de estos trabajos y otros, como el texto de Fernando García Mercadal de $1930^{203}$, trajo consigo la publicación de numerosos textos posteriores. A partir de los años setenta surgieron monografías sobre este tipo de arquitectura abanderadas por los trabajos de Carlos Flores sobre La arquitectura popular española o el proyecto de varios volúmenes de Luis Feduchi titulado Itinerarios de arquitectura popular en España ${ }^{204}$.

Los estudios acerca de la arquitectura popular leonesa fueron precoces, iniciándose en 1922 con la obra de Gustavo Fernández Balbuena dedicada al pueblo de Ardoncino. Posteriormente, el texto de Medina Bravo publicado en 1927 y titulado Tierra leonesa, fue otro de los escritos básicos que por primera vez recogieron una tipología general de la provincia. En los años ochenta José Luis Alonso Ponga y en los noventa Joaquín Alonso González escribieron un buen número de obras relacionadas con la arquitectura del barro y arquitectura popular. Sin embargo, el gran estudioso en torno a los edificios tradicionales en el territorio leonés, será José Luis García Grinda ${ }^{205}$, que desde 1986 lleva realizando una labor de recuperación de las tipologías de la

\footnotetext{
${ }^{200}$ ALONSO GONZÁLEZ. Arquitectura, p. 13.

${ }^{201}$ LAMPÉREZ ROMEA, Vicente. Arquitectura civil española de los siglos I al XVIII. Madrid, 1922.

${ }^{202}$ TORRES BALBÁS, Leopoldo. La vivienda popular en España. Folklore y costumbre en España. Barcelona, 1946.

${ }^{203}$ GARCÍA MERCADAL, Fernando. La casa popular en España. Madrid, 1930.

${ }^{204}$ FLORES, Carlos. La arquitectura popular español. Madrid 1974. FEDUCHI, Luis. Itinerarios de arquitectura popular en España Vol. III. Barcelona, 1986.

${ }^{205}$ GARCÍA GRINDA, José Luis. Arquitectura popular. Tomo I y II. León, 2008, p. 7.
} 
provincia de León ${ }^{206}$. Las obras de estos tres últimos autores han sido un exponente claro en los cuales se ha basado el estudio arquitectónico de la ZACEL.

En las últimas décadas del siglo $\mathrm{XX}$ y principios del siglo $\mathrm{XXI}$, las administraciones públicas como Ayuntamientos y Diputaciones, han sido las encargadas de promocionar estudios monográficos sobre la arquitectura local y provincial lo que ha favorecido la concienciación de conservar estas estructuras tradicionales.

\subsubsection{LA CASA TRADICIONAL}

La arquitectura popular en la ZACEL va unida a las actividades productivas de la zona y a las condiciones físicas del medio montañoso en el que se ubica. Los modelos arquitectónicos corresponden con las formas constructivas tradicionales de la montaña occidental leonesa que engloba los territorios de Laciana, Babia, Luna y Omaña. Sus peculiaridades también son herederas de los contactos entre las tipologías norteñas, asemejándose en muchas ocasiones a las astures o cántabras, aunque cada subcomarca plantea unas particularidades propias.

Las principales características de estas edificaciones son la presencia una serie de unidades independientes y autosuficientes con edificaciones auxiliares que se despliegan en torno a un corral ${ }^{207}$. No hay autoría ni arquitecto y su construcción se hace de una manera artesanal y anónima. Los edificios se levantan para varias generaciones, por lo que son definitivos, no provisionales ${ }^{208}$. El espacio no resulta un obstáculo a la hora de introducir patios, corrales o huertas dentro de la propia estructura de la casa. La superficie media ronda los 300-500 $\mathrm{m}^{2}$ repartidos entre el piso inferior, el superior y el corral o patio. Los asentamientos se dedican casi exclusivamente a las labores agropecuarias, organizándose a una doble altura. La planta baja está destinada a los trabajos tradicionales y la planta superior a la vivienda y pajar ${ }^{209}$. Otras estancias secundarias acogen las funciones de almacén, leñera, portal, cochiquera, bodega, gallinero, etc.

\footnotetext{
${ }^{206}$ ALONSO GONZÁLEZ. Arquitectura, p. 17.

${ }^{207}$ BENITO MARTÍN, Félix. La arquitectura tradicional de la provincia de León. León, 2005, p. 112.

${ }^{208}$ PONGA MAYO, Juan Carlos y RODRÍGUEZ RODRÍGUEZ, María Araceli. Arquitectura popular en las comarcas de Castilla y León. Valladolid, 2000, p.12.

209 Ídem, p. 645.
} 


\subsubsection{La configuración espacial}

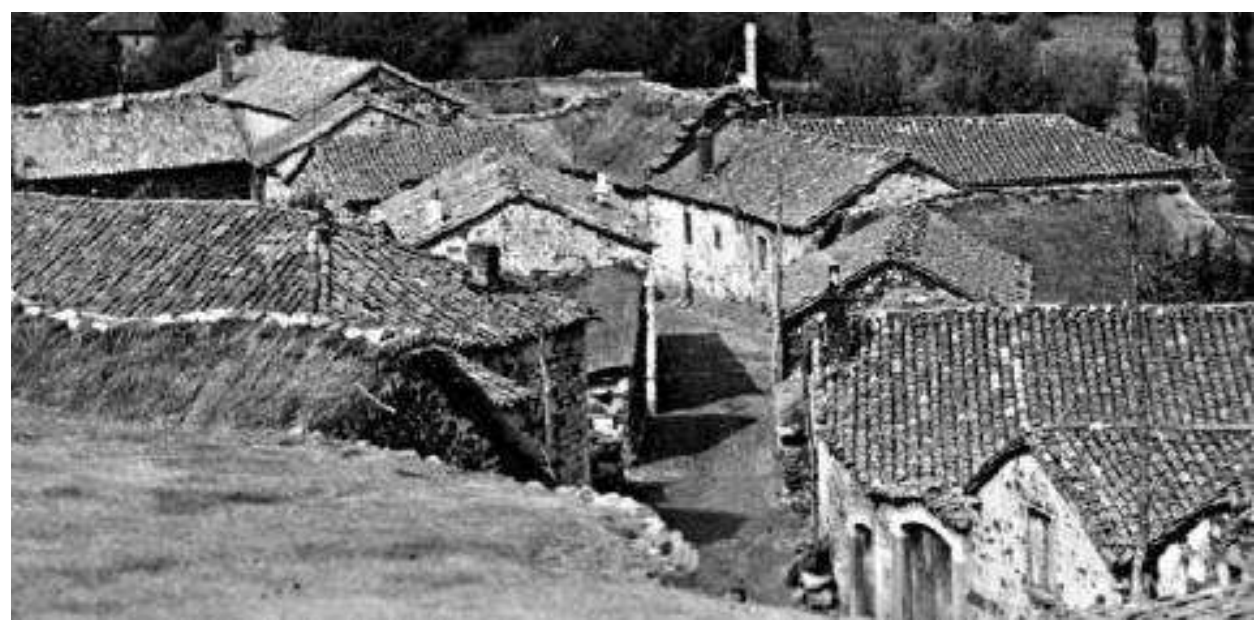

Ilustración 10. Lagüelles. Fondo fotográfico ILC.

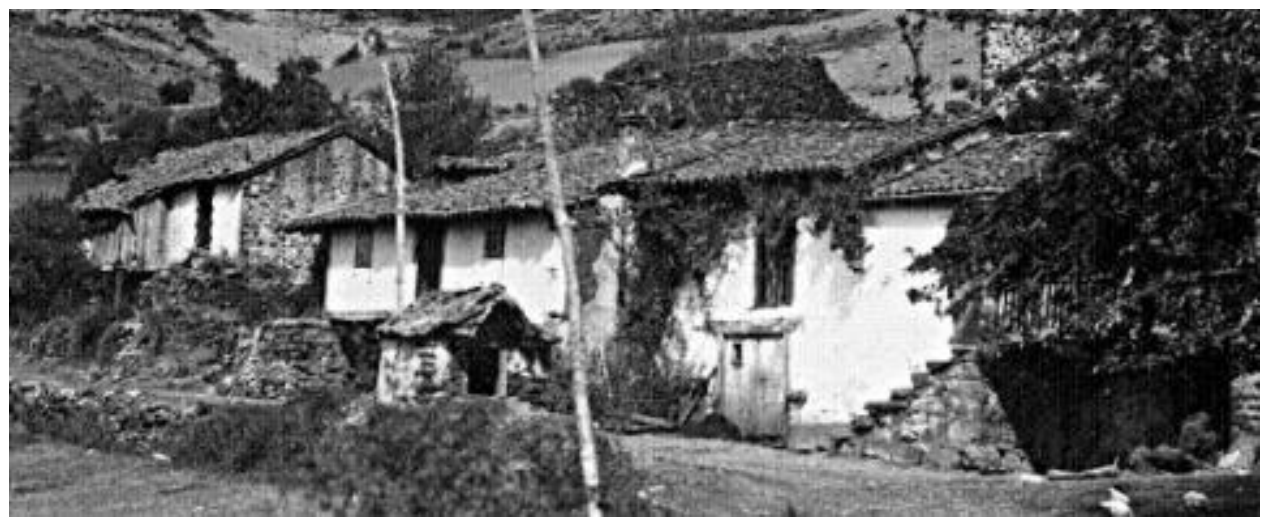

Ilustración 11. Campo de Luna. Fondo fotográfico ILC.

La planificación espacial en el Valle del Luna se caracterizó por una cierta independencia de los edificios entre si $^{210}$. Benito Martín describe su morfología con una estructura común basada en un asentamiento aislado dividido en parcelas rectangulares de grandes dimensiones en las que existe un corral cerrado donde se dispone el edificio ${ }^{211}$. La organización urbanística más común giraba en torno a las principales vías de comunicación y no alrededor de la iglesia o plaza central. La iglesia no formaba el núcleo central de la población a pesar de que a su alrededor se situaban los edificios más importantes como el ayuntamiento o la casa parroquial.

\footnotetext{
${ }^{210}$ Ídem, p. 66.

${ }^{211}$ BENITO MARTÍN, Félix. La arquitectura tradicional de Castilla y León. Vol. II. Salamanca 1998, p. 646.
} 
Los edificios se ubicaban siguiendo un esquema longitudinal adecuándose a las condiciones del terreno y al aprovechamiento de las huertas y terrenos más fértiles. Lo principal en estas poblaciones no era el abigarramiento de los edificios, sino la funcionalidad de los mismos con amplios espacios dedicados a la cría de ganado o a la explotación agrícola. Intercalando cada edificio se encontraban las huertas y pequeños pastos que formaban un entramado irregular que se adaptaba al terreno y a la forma de la finca, por lo que en muchas ocasiones esto daba lugar a callejones y estrechas callejuelas. Cada una de las unidades se organizaba de forma independiente, originando una trama discontinua en la que el espacio público no aparecía configurado ${ }^{212}$. La casa formaba en sí misma la propia manzana y en su interior podía integrar un amplio espacio destinado a corrales o patios.

Los edificios eran autosuficientes, constituyendo cada uno de ellos un módulo independiente con un edifico principal destinado a vivienda y diversas estancias auxiliares. En ocasiones los edificios secundarios como pajares o cuadras se disponían cercanos a las eras e independientes de la casa.

La presencia de cauces ocasionaba la división en barrios enclavados a las orillas de los ríos destinados en ocasiones a actividades industriales como los molinos.

\subsubsection{Los constructores}

El desarrollo de la cantería se vio favorecido por una demanda local debido a la inexistencia de una red de gremios de esta profesión. Es por ello que este oficio se organizaba en torno a grupos familiares o vecinales que se iban trasladando de unas zonas a otras. Los trabajos consistían en la construcción de edificios tanto particulares como públicos y religiosos, lo que ocasionó la especialización de alguno de estos constructores en técnicas más depuradas que las utilizadas para la arquitectura popular. Los principales oficios referentes a la construcción eran los de canteros, carpinteros, techadores y herreros.

Los canteros se encargaban de casi la totalidad de la construcción, exceptuando las labores de carpintería y la cubrición de paja, ejecutada por los techadores. En el Valle de Luna los Guisuraga eran la familia de canteros por excelencia que se 
encargaban de más del $90 \%$ de los trabajos de la zona. A su vez, éstos contaban con obreros contratados para las épocas de mayor labor. La familia Guisuraga también se encargaba de las obras religiosas, como la nueva iglesia de Sena de Luna. En ocasiones, la maña y conocimiento de estos canteros hacía que fuesen llamados a otras obras fuera de la comarca ${ }^{213}$.

Además de los canteros existían otros oficios esenciales relacionados con la construcción de edificios. Los carpinteros se dedicaban exclusivamente al trabajo en madera tanto para las grandes armaduras del tejado, forjados, puertas, corredores, ventanas como para trabajos más especializados de ebanistería. Las sierras llegaron en fechas tardías, por lo que los carpinteros hacían sus labores a mano. Utilizaban grandes sierras alargadas que recortaban los troncos, devastados previamente con la azuela. Una vez preparada la madera, el carpintero se encargaba de darle la forma adecuada ${ }^{214}$. Existían carpinteros en Oblanca, Miñera, la Truva y Mirantes. El oficio, al igual que los canteros, se enseñaba de padres a hijos por lo que la organización y distribución de estos trabajos se desarrollaba en torno a los clanes familiares.

Los techadores se contrataban aparte y provenían en su mayoría de la zona de Boñar, ya que estaban especializados en temas de cubrición vegetal, fundamentalmente de paja de centeno.

El trabajo de herrero consistía en las labores relacionadas con el hierro como cerraduras, balaustres, llamadores, herrajes, elementos de fijación e incluso utensilios cotidianos. Cada uno de los herreros trabajaba en fraguas propias o cumunales y creaba unas formas decorativas propias que acababan siendo marca de la casa. Existían herreros en San Pedro de Luna, Oblanca, Lagüelles, Miñera, Láncara y Mallo.

\subsubsection{Materiales}

Los materiales utilizados tienen relación con el asentamiento de los pueblos en un espacio montañoso. De este modo los componentes más utilizados son aquellos que se encuentran en abundancia como la piedra caliza y la madera. La roca caliza-dolomía apenas se usaba debido a la dificultad de su extracción.

\footnotetext{
${ }^{213}$ Es el caso de Petronilo Guisuraga, oriundo de Miñera de Luna, quien se encargó como jefe de obra de la colocación de la piedra del santuario de la Virgen del Camino realizado por Fray Pablo Cuello.

${ }^{214}$ Información dada por Petronilo Guisuraga. Cantero de Miñera de Luna.
} 
La piedra se empleaba

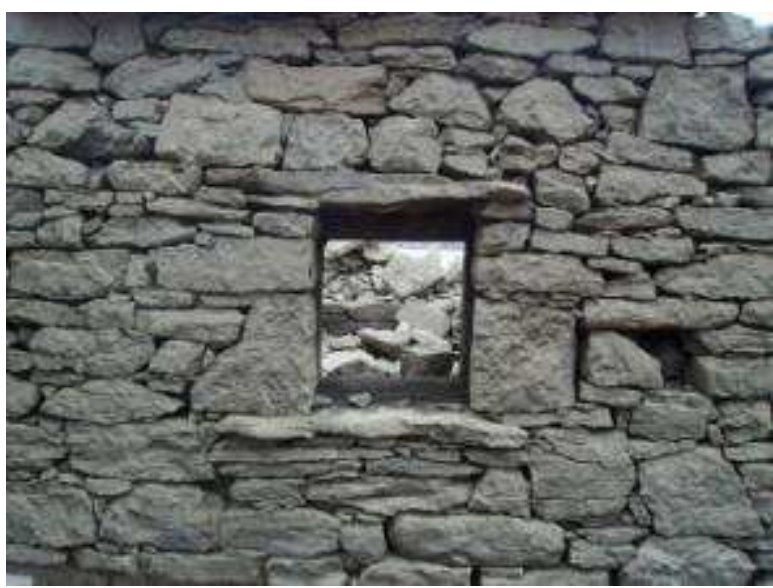

Ilustración 12. Pared de sillarejo. Miñera.

principalmente para la construcción de los muros en mampostería no concertada o sillarejo con una superficie rugosa que favorecía la unión de la argamasa. Para el refuerzo de aquellas zonas más débiles, como los vanos o las esquinas, se utilizaban adarajas o grandes bloques de piedra. La caliza se extraía de las canteras comunales mediante técnicas manuales y otros métodos como la dinamita o pólvora. Su uso estaba supeditado a las necesidades del momento ${ }^{215}$. Una vez extraída la piedra se trasladaba con carros de varas de caballos de gran alzada. El cantero debía pagar un dinero y pedir permiso a las Juntas Vecinales para poder explotar las canteras. Esto no ocurría con la madera, puesto que la mayoría de los propietarios poseían árboles especialmente destinados para el uso de la construcción o comunales de los bosques.

\begin{tabular}{|l|l|}
\hline \multicolumn{2}{|c|}{ CANTERAS } \\
\hline Puente de Orugo & Caliza gris del país \\
\hline Láncara & Caliza rosa \\
\hline Caldas de Luna (debajo del Negrón) & Caliza gris \\
\hline La Canela & Caliza blanca \\
\hline Mirantes(desfiladero de los molinos) & Caliza gris \\
\hline
\end{tabular}

A pesar de que cada población contaba con un lugar de extracción de piedra, como es el caso de las explotaciones de la Viesca y la Sierra del Agua de Miñera, las mejores canteras eran las de Caldas de Luna y la Venta de la Canela de Mirantes ${ }^{216}$.

La madera era el material más común después de la piedra. Se utilizaba principalmente para las cubiertas de las casas, forjados, armaduras, corredores, pies derechos, puertas y ventanas.

${ }^{215}$ En cada lugar existía además al menos un cantero y un carpintero dedicado a la construcción de las viviendas. Se descarta la idea que, exceptuando las construcciones menores, fueran los propios vecinos los que realizasen sus casas. Existía un amplio número de oficios relacionados con la construcción que serán los responsables de extender la tipología de sus trabajos a lo largo del valle.

${ }^{216}$ Información dada por Petronilo GUISURAGA, vecino de Miñera. 


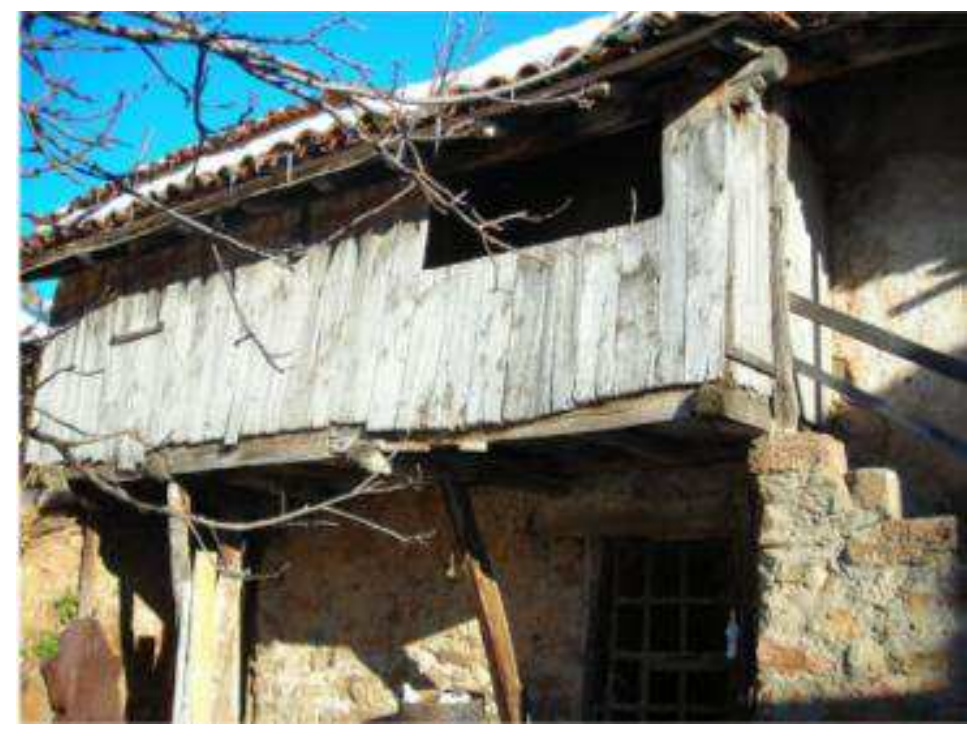

Ilustración 13. Corredor de madera. Barrios de Luna.

Las maderas más usadas eran el chopo, el roble, el fresno y el negrillo. El roble y negrillo se empleaban para las techumbres y puertas y el chopo y fresno para el resto. La sabina no se utilizaba debido a su fibrosidad y escasa resistencia, aunque era muy apreciada por sus facultades aromáticas.

El panizo servía para la cubrición de edificios secundarios, como pajares y establos. Los techadores recurrían al centeno como uno de los materiales más adecuados para conservar la temperatura interior del edificio y evitar la acumulación de la nieve gracias a su superficie resbaladiza. La paja se ataba en haces bien apretados sobre un entramado de palos y un entretejido de varas ${ }^{217}$. Según Alonso González ${ }^{218}$, este tipo de material tenía una duración de hasta veinte años, tiempo en el que debía ser rehecho.

El ladrillo se utilizó de manera escasa en la arquitectura popular de la zona dejándose para aspectos secundarios como ventanas y hornos. El tipo utilizado era el ladrillo macizo reflectante recubierto posteriormente con piedra.

El hierro tan solo se empleaba para cerraduras de puertas y enrejados de balconadas. El herrero se encargaba de dar las formas decorativas vegetales y geométricas que aún podemos observar en algunos edificios fuera del embalse.

\subsubsection{Técnicas constructivas}

Las técnicas constructivas eran muy similares a las de otras zonas próximas de Luna, Babia y Omaña ${ }^{219}$.

${ }^{217}$ COBO, Florentino. CORES, Miguel. ZARACINA, Matilde. Arquitectura popular asturiana. Conocer Asturias. Principado de Asturias, 1987, p.7.

${ }^{218}$ ALONSO GONZÁLEZ. Arquitectura, p. 52.

${ }^{219}$ BENITO MARTÍN. La arquitectura Castilla y León. Vol. I. p. 162. 
El primer paso era la cimentación. Para asentar los cimientos se hacía una zanja de al menos un metro de profundidad y se construía un mampuesto realizado con paramentos de sillarejo rellenos de piedra y barro $^{220}$.

A medida que el muro tomaba altura, se hacían unas oquedades o mechinales denominados piedras pasantes que sujetaban los andamios. Para las esquinas se usaban adarajas o piedras de grandes dimensiones que facilitaban el cerramiento de los muros. En la parte inferior se colocaba una piedra de gran tamaño y de superficies redondeadas

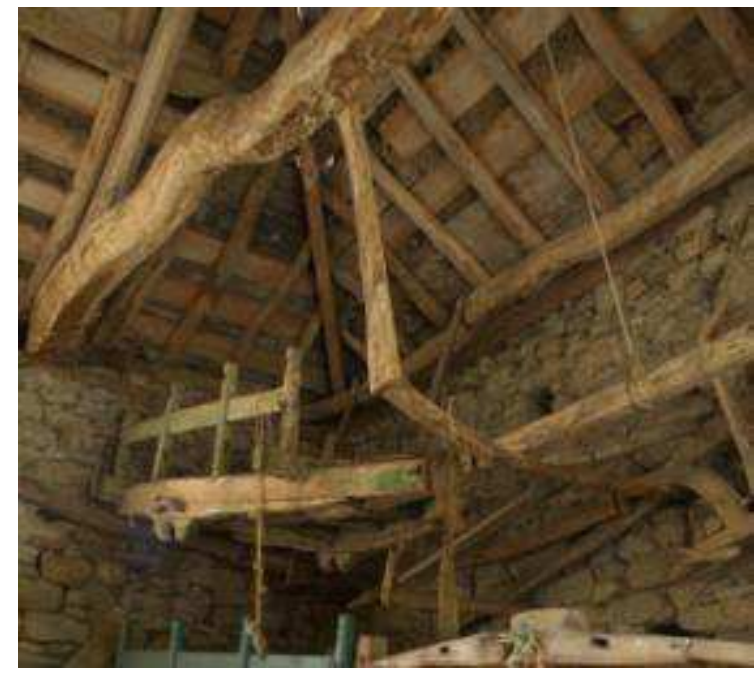

Ilustración 14 Techumbre de madera. Pobladura.

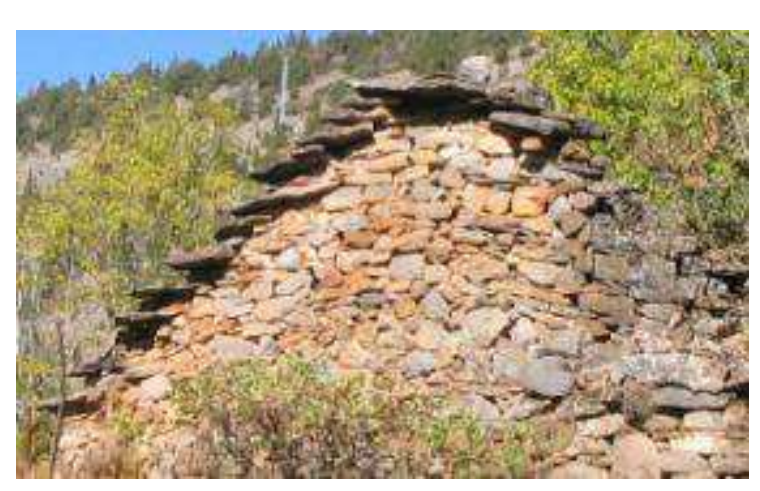

Ilustración 15. Grindalla. Mirantes de Luna que protegía los muros de ser dañados por el paso de los carruajes. Las casas de cubierta vegetal estaban construidas con muros de mampostería asentada en seco o con barro $^{221}$.

Los tabiques internos divisorios de las habitaciones eran de entramado de tabla de madera, adobes, encestados, entablillados, tablazón o mimbre, especialmente los que dividían la alcoba de la cocina ${ }^{222}$. Los pavimentos eran de madera para el piso superior o tierra apisonada para el piso inferior. Sólo en los edificios más modernos se utilizaba losas de cerámica.

En las cubiertas se apreciaban cuatro calidades dependiendo de los materiales. La que la C.H.D. ${ }^{223}$ consideró de mejor calidad era la de pizarra sobre entablado. Una segunda calidad sería la teja bien asentada sobre tabla. De tercera calidad estaría la teja sobre listones y por último los edificios cubiertos de paja.

El tipo de cubierta más común en las casas tradicionales era la parhilera a dos aguas con teja o paja sobre listones de madera. Los tejados se hacían mayoritariamente

${ }^{220}$ ALONSO GONZÁLEZ. Arquitectura, p. 49.

${ }^{221}$ COBO-CORES-ZARACINA. Arquitectura, p. 7.

${ }^{222}$ GARCÍA GRINDA. Arquitectura popular... Tomo I, p. 69.

${ }^{223}$ A.G.C.H.D. Nº 4485 . Año 1953. 
de teja árabe, dejando el panizo para las cuadras, pajares y construcciones secundarias. A partir de los años 30 y 40 se hizo común en uso de losas de pizarra en los edificios de nueva construcción. La teja se unía con una gruesa capa de barro y arcilla que servía como aislante.

Las cubiertas estaban formadas por cerchas o tijeras de madera que se ajustaban a las vigas portantes en forma de vértice. Sobre estas vigas se colocaban las ripias o tablas de poco grosor sobre los que se apoyaban el cuelmo o la teja que cubría la estancia $^{224}$. En los edificios más antiguos, y como vestigio de la cubrición de paja, los muros terminaban de manera escalonada con una losa de piedra horizontal denominada grindalla $^{225}$ que en su origen servía como fijador del panizo. Como colofón aparecía un geijo que consistía en una piedra caliza que se colocaba como remate y adorno en los hastiales $^{226}$.

\subsubsection{Distribución interior}

La estructura de la casa tradicional de la ZACEL seguía un esquema común en la montaña noroccidental cuya planta poseía la forma de L o U, diferenciándose la hornera al exterior que normalmente tenía forma cuadrada o semicircular ${ }^{227}$. La superficie de las plantas variaba de unos vecinos a otros dependiendo de las necesidades y riqueza de los mismos.

El tamaño de los edificios oscilaba en unos $300-500 \mathrm{~m}^{2}$ en total de planta baja y planta principal que podía llegar hasta los casi $1000 \mathrm{~m}^{2}$ si incluimos los corrales y cobertizos.

Los ejemplos más antiguos eran los edificios cubiertos con panizo que poseían una estructura interior muy sencilla. El espacio estaba dividido en dos partes, una estaba destinada a la vivienda y la otra a la cuadra y refugio del ganado. En la zona de la vivienda se solía disponer de un desván que servía como almacén de alimentos ${ }^{228}$. La cocina se ubicaba en el centro del edificio y se componía de un hogar con una trébede de adobe.

${ }^{224}$ GARCÍA GRINDA. Arquitectura. Tomo I, p. 83.

${ }^{225}$ ALONSO GONZÁLEZ. Arquitectura, p. 49.

${ }^{226}$ Ídem, p. 209.

${ }^{227}$ GARCÍA GRINDA. Arquitectura. Tomo I, p. 84.

${ }^{228}$ COBO-CORES-ZARACINA. Arquitectura, p. 8. 


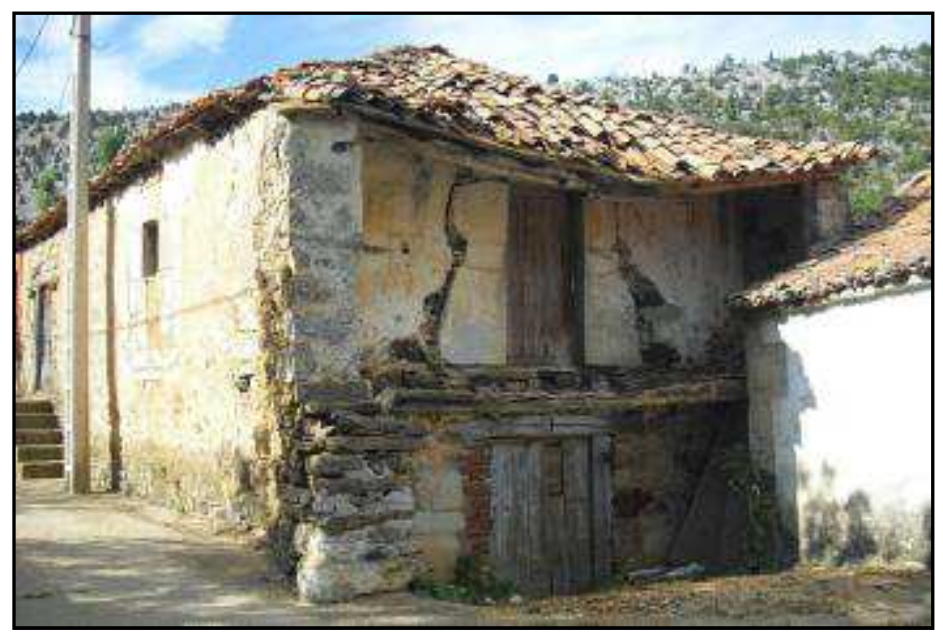

Ilustración 16. Casa tradicional con corredor semiderruido. Mallo de Luna
La casa se abría en torno a un patio o corral que distribuía las estancias que estaban compuestas por dos bloques claramente específicos, uno destinado a la vivienda y otro para albergar las labores agropecuarias. En ocasiones la dispersión de los edificios originaba un espacio entre viviendas que podía servir

como corral comunitario o como huerta. Los cerramientos de las huertas y pastos se hacían de sebe o vegetación arbustiva ${ }^{229}$.

La estructura de la casa giraba en torno un corral interior. El suelo de los patios y corrales era de tierra apisonada o enllabanada y en menor medida de empedrado. En Mirantes de Luna o San Pedro se encontraban patios empedrados con dibujos geométricos. El corral solía poseer un canal de evacuación de las aguas sucias denominado albañal. Este se conformaba a partir de dos piezas pétreas alargadas en la parte baja de los muros y estaba cubierto con una losa continua que comunicaba las cuadras dando salida a las aguas residuales ${ }^{230}$.

En la planta baja se situaba la cuadra, el pajar, las bodegas, el horno y otras habitaciones destinadas a almacén. En algunos edificios también podemos encontrar la cocina en el piso inferior, aunque esto no era lo habitual. Las estancias más grandes eran la cuadra y el pajar.

La cuadra servía no sólo como elemento de guarda del ganado, sino también como sistema calefactor que se disponía debajo de los dormitorios. En los tipos más primitivos la cuadra estaba integrada en el bloque de la vivienda y en ocasiones comunicaba con un agujero o coladera que servía para controlar el ganado y verter los despojos $^{231}$. Las cuadras raramente se encontraban en lugares alejados de la casa. Se

\footnotetext{
${ }^{229}$ Ídem, p. 95. Estas cercas naturales poseían una entrada con troncos de madera atados entre sí que formaban una tosca puerta.

${ }^{230}$ ALONSO GONZÁLEZ. Arquitectura, p. 49.

${ }^{231}$ Ídem, p. 89.
} 
emplazaban siempre en la planta baja y su superficie rondaba los 20-40 $\mathrm{m}^{2}$. A su lado aparecía el pajar, ya que su cercanía facilitaba las labores de alimentación del ganado.

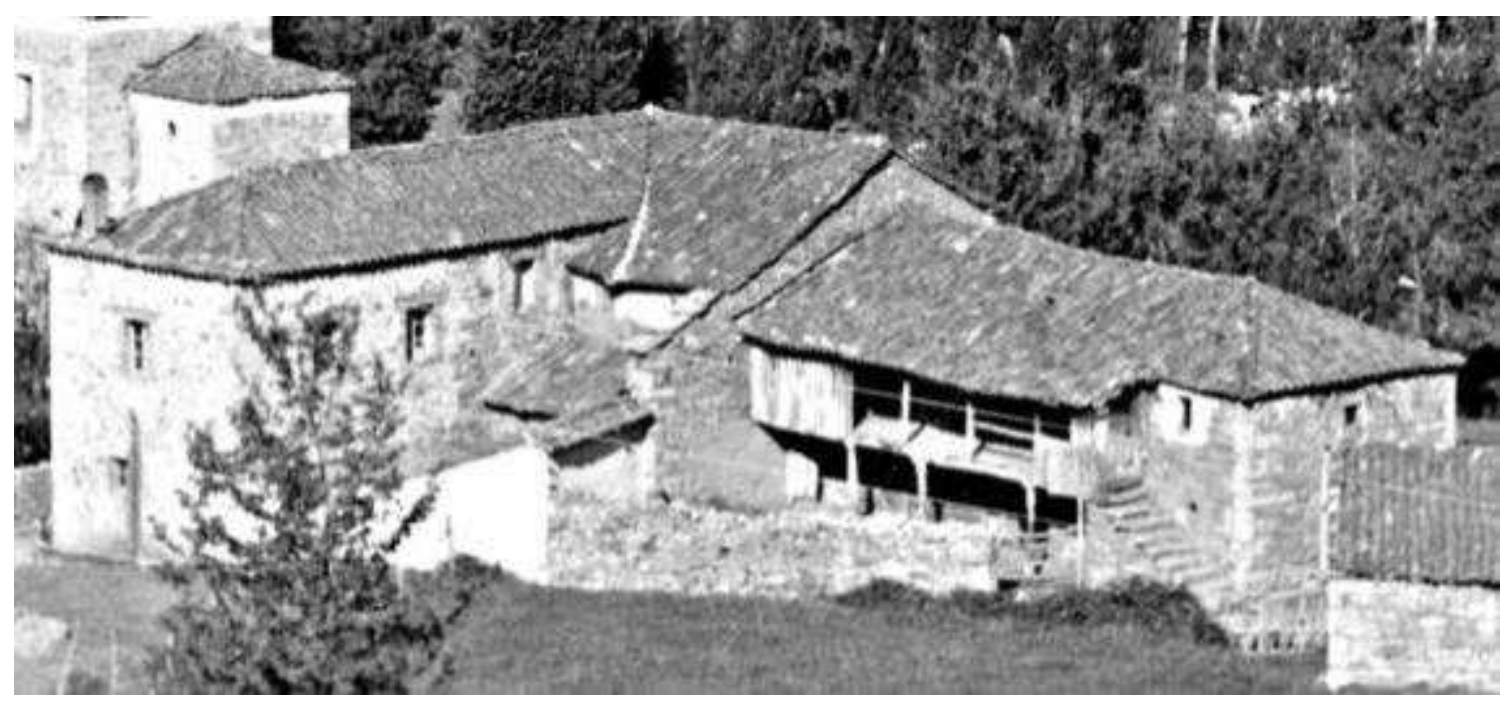

Ilustración 17. Miñera de Luna. Fondo fotográfico I.L.C.

Los pajares se adosaban a la vivienda y poseían unas dimensiones en altura superiores a las cuadras llegando a ocupar dos pisos. Su cubrición se diferenciaba de la casa ya que en muchas ocasiones la techumbre era de panizo. Cuando el pajar se situaba en el piso superior se abría un vano o boquerón para poder introducir la hierba desde el carro sin necesidad de escaleras ${ }^{232}$.

La bodega estaba compuesta por una simple estancia cuadrada excavada en la roca a un nivel inferior que el resto de la casa, aunque su profundidad no superaba el metro. Tan sólo en algunos ejemplos de Lagüelles o Arévalo se hacían un par de escalones de acceso para salvar el pequeño desnivel. Su función consistía en el almacenamiento de alimentos ya que conservaba una temperatura similar a lo largo del año.

El horno era uno de los componentes más importantes dentro de la estructura de la casa tradicional. Su localización dependía de la cocina, ya que podía estar en la planta baja y protegido por una pared de mampostería vista al exterior, o en la plata superior, siguiendo la estructura de la casa aunque en ocasiones sobresalía al exterior en forma semicircular. Normalmente ocupaba una esquina o un lateral de la estancia y en algunos ejemplos el horno invadía toda la habitación. Estaba compuesto por una bóveda

${ }^{232}$ COBO-CORES-ZARACINA. Arquitectura, p. 10. 
semiesférica de ladrillo refractario o piedra toba o toya unida con barro. La boca del horno la formaban los cantales de piedra monolítica sobre la que se colocaban la lumbre. En la base de la boca del horno se distinguían las losas de piedra planas o lloriegas $^{233}$, donde se colocaba el pan. Los hornos tradicionales también poseían una fornigüela u oquedad situada en la parte inferior de la boca del horno que funcionaba como depósito de las brasas ${ }^{234}$. Sobre la boca se ponía una vara de hierro con forma circular que servía como cimbra y refuerzo del arco. La parte superior tenía una oquedad a modo de tiro para avivar el fuego.

Junto al horno, y separada por una pared de tablones de madera, se encontraba la panera. Esta habitación estaba dedicada a los oficios del pan, albergando en su interior los instrumentos como la masera, la pala o la escoba para recoger la cernada.

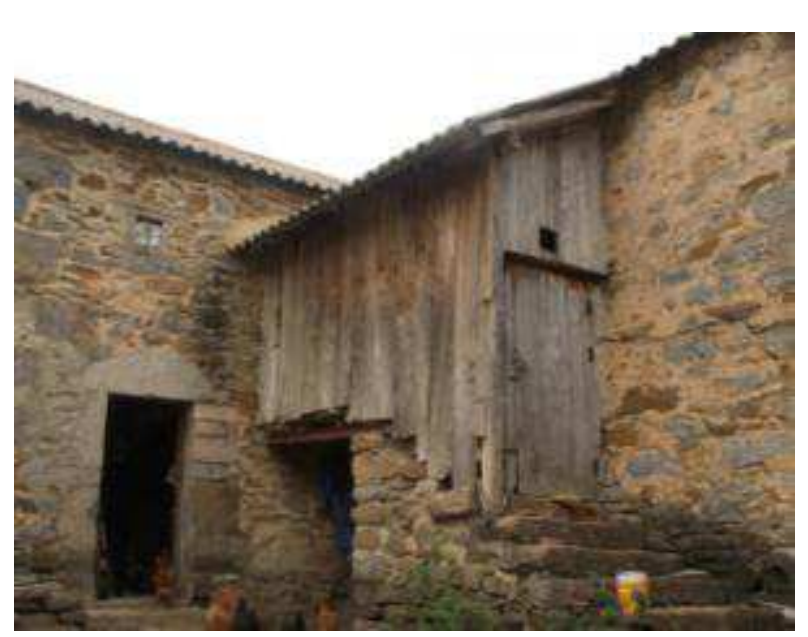

Ilustración 18. Pobladura. Escalera y corredor.

La pocilga, gallinero o leñera se solían ubicar aprovechando el espacio que se abría bajo el corredor aunque en ocasiones se hacía a propósito una pequeña estancia aprovechando los esquinales de la casa.

En algunos casos la vivienda poseía un pozo interior para el abastecimiento familiar y de labores tradicionales.

Al piso superior se accedía a través del corral o directamente desde la calle por una escalera de piedra o madera que daba paso a un corredor. Generalmente los corredores se abrían a los patios y corrales interiores y era escaso el número de ellos que daban directamente a la calle, pues no sólo servían como tránsito, sino también como almacén de productos agrícolas.

El corredor se localizaba en la fachada más soleada del edificio y estaba resguardado por los muros piñones o cortafuegos $^{235}$ de la casa. Se sujetaba sobre pies derechos con basas de piedra poco devastadas de alrededor de $0.50 \mathrm{~m}$. de altura y capiteles zapatas con molduras sencillas. Se cubría con un voladizo que sobresalía del 
propio forjado del tejado de la casa que resguardaba el corredor de las inclemencias del tiempo creando otro espacio por debajo a modo de zaguán que también estaba protegido tanto del frío como de la lluvia. Este espacio se aprovechaba como leñera, cochiquera o gallinero.

Los cerramientos más comunes eran los de tablas de madera, aunque también era frecuente el cerramiento con un armazón de mimbre revestido con mortero que dejaba un hueco para abrir un pequeño vano ${ }^{236}$. Otra opción era la utilización de una balaustrada de tablas irregulares de madera que raramente aparecía decorada o creando formas ornamentales ${ }^{237}$.

La planta alta estaba destinada a la vivienda donde se encontraba la cocina y los dormitorios. El número de habitaciones era escaso y en algunas ocasiones se reducía a un

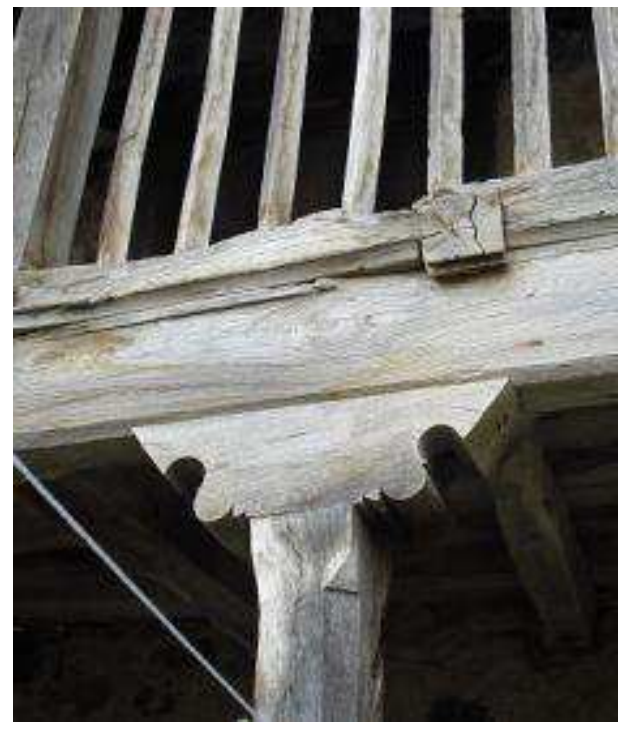

Ilustración 19. Capitel zapata. Mallo solo cuarto. A medida que se iban modernizando los edificios, el número de habitáculos era mayor, añadiéndose salas de estar, comedores y alcobas con acceso independiente. Los dormitorios se ubicaban junto a la cocina y sobre las cuadras, pues éstos eran los dos únicos sistemas de calefacción de la casa.

La estancia de mayor importancia dentro de la vivienda era la cocina. Esta podía aparecer en la planta baja asociada al horno, aunque lo más común era su situación en el piso superior. Ocupaba un espacio único dividido por paredes de tabla o cañizo en donde se situaba la alcoba y los dormitorios ${ }^{238}$. La cocina económica era el sistema calefactor más repetido en la comarca. Se colocaba pegada a la pared o en collero (espaciada). Estaba constituida por el hogar y la gloria. Este sistema se denominaba cocina de trébede y constaba de un cuerpo ligeramente elevado bajo el cual se colocaba una hornilla donde se introducía la leña o carbón.

Encima de esta estructura se disponía una chapa metálica sobre la que se $\operatorname{cocinaba}^{239}$. En muchos casos se le anexaba una pequeña escalera de fábrica que daba

\footnotetext{
${ }^{236}$ COBO-CORES-ZARACINA. Arquitectura, p. 21.

${ }^{237}$ MARTÍN CRIADO, La ornamentación, p. 279.

${ }^{238}$ ALONSO GONZÁLEZ. Arquitectura, p. 83.

${ }^{239}$ Ídem, p. 84
} 
acceso a la parte superior del hogar donde se colocaba una bancada o pollero en la que se sentaba la familia para recibir el mayor calor posible. Una oquedad en la pared lateral servía de chimenea o salida de humos.

En la casa primigenia no existía la chimenea, ya que la extracción de humos se realizaba a través de las rendijas del tejado. El llar se colocaba en el centro de la estancia adosado a la pared sobre unas losas de piedra. En medio del hogar se disponían los trespiés en los que se apoyaban los utensilios de cocina ${ }^{240}$.

La cocina se acompañaba de un escaño y una masera entre otros muebles además de la pila pétrea. Esta pila servía de fregadero y se empotraba en el muro de manera sobresaliente para dar salida al agua sucia hacia la calle. También podía contener una pila rebajada o coladera con un pequeño canalillo en donde se colocaba la arnilla para blanquear la ropa.

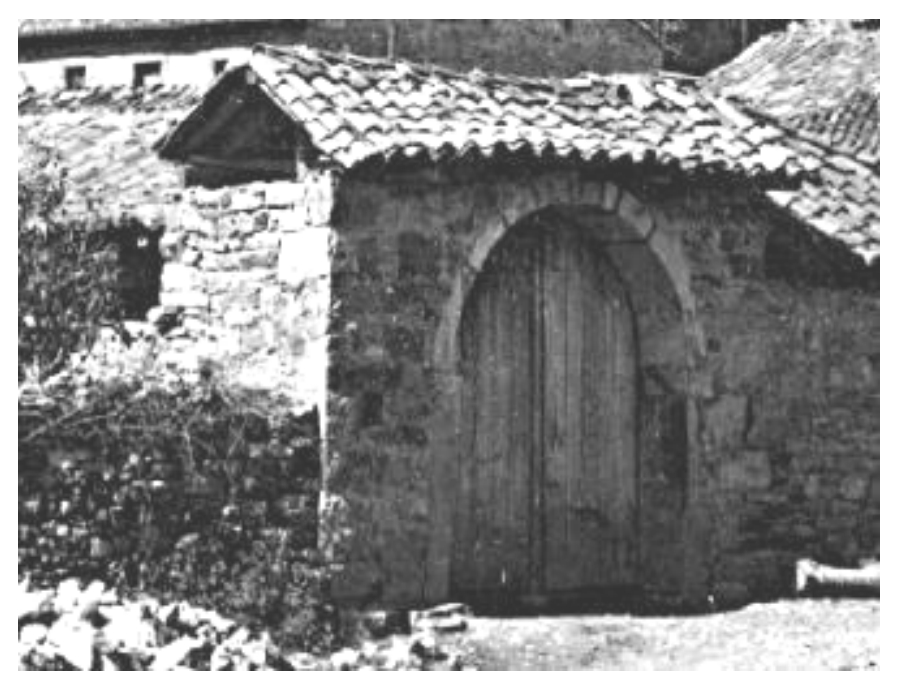

Ilustración 20. Cosera. Fondos del I.L.C.

Los accesos a la casa tradicional dependían de su situación y destino, pues no era lo mismo la entrada de la vivienda que la entrada del patio o corral. Las dimensiones de las puertas variaban de unas casas a otras y dependían de su función y rango.

Las puertas de mano eran las que daban paso a la vivienda principal. Estaban realizadas con una sola hoja en madera de roble o negrillo. Las puertas de servicio o secundarias poseían unas dimensiones inferiores y estaban hechas con materiales de menor calidad que las principales. Al corral se accedía a través de la puerta carral o portalina destinada a la entrada de carros y ganado que se abría a un cobertizo que servía como almacén de carruajes y aperos ${ }^{241}$. En algunas ocasiones aparecía un tejadillo a dos aguas como en la imagen de Cosera.

\footnotetext{
${ }^{240}$ Ídem, p.65.

241 Ibídem.
} 


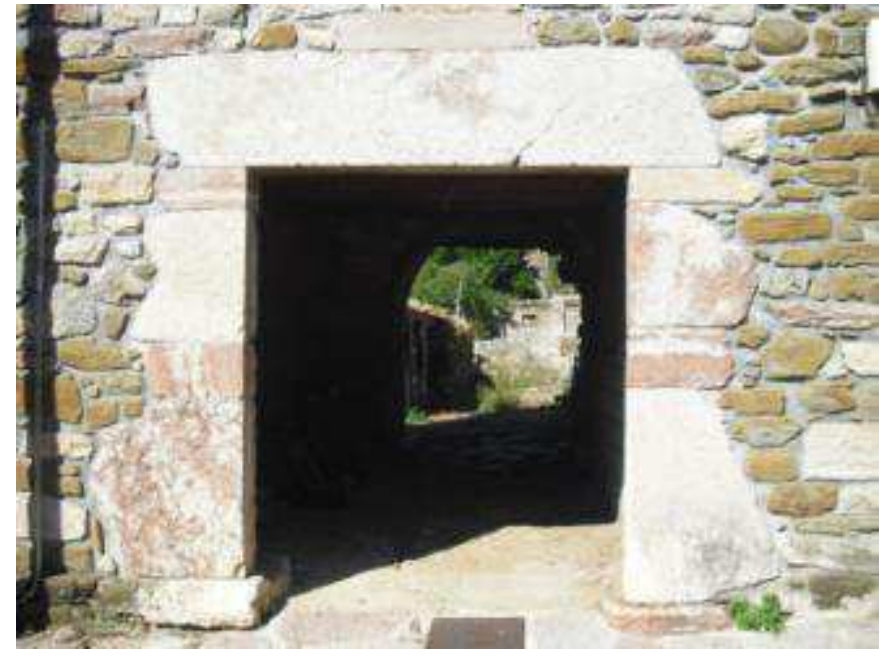

Ilustración 21 Sena de Luna. Puerta de acceso al corral.

El arco de medio punto se utilizaba sobre todo en las entradas a las cuadras, puesto que la altura de los carros hacía aconsejable el uso de este tipo de estructuras ${ }^{242}$, aunque la gran mayoría contenían dinteles rectos $^{243}$. En varias ocasiones estos dinteles poseían inscripciones con un grabado a buril poco profundo que hacían referencia al año de construcción de la casa “AÑO DE 1788،244. A los extremos de la inscripción se podía dibujar algún elemento decorativo como unas llaves, una cruz o un jarrón con tres flores de connotaciones religiosas $^{245}$.

Las puertas, por lo general, poseían decoraciones muy sobrias que se reducían a formas molduradas ${ }^{246}$. El dintel y las jambas formaban almohadillados rústicos apoyados en ménsulas como vemos en la imagen de la Venta de la Canela. Las puertas adinteladas se remarcan con grandes bloques de piedra denominados llumbrales.

Unidos inseparablemente a las puertas se encuentran las aldabas y cerraduras o bocallaves. Estaban confeccionadas con hierro forjado y poseían una forma alargada cuya decoración dependía de la maestría de los herreros ${ }^{247}$. Entre las formas más comunes se encontraban las líneas curvas geométricas y vegetales con simetría vertical.

\footnotetext{
${ }^{242}$ MARTÍN CRIADO. La ornamentación, p. 58. La moda de datar la finalización de los edificios se encuentra, según Martín Criado, en la segunda mitad del siglo XVIII, cuando la actividad constructora se incrementó mejorando sensiblemente las condiciones de los edificios tradicionales.

${ }^{243}$ ALONSO GONZÁLEZ. Arquitectura, p. 65.

${ }^{244}$ GARCÍA SUÁREZ, Una historia, p. 6. Agustín García describe su casa con un cargadero de piedra caliza de grandes dimensiones que llevaba una inscripción grabada que decía: AÑO DE 1788.

${ }^{245}$ MARTín CRIADO, La ornamentación, p. 107. Según Martín, el emblema de las tres flores en un jarrón pertenece a la Virgen, mientras que la cruz hace referencia al crucificado cuyo origen puedo estar en una casa de propiedad eclesiástica.

${ }^{246}$ Ídem, p. 243.

${ }^{247}$ Ídem, p. 254.
} 


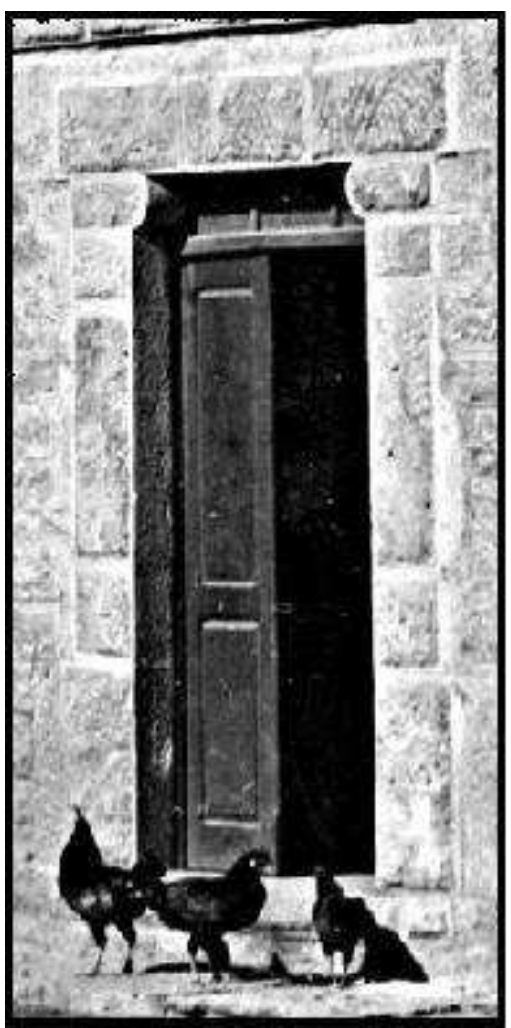

Ilustración 22 La Venta de la Canela.

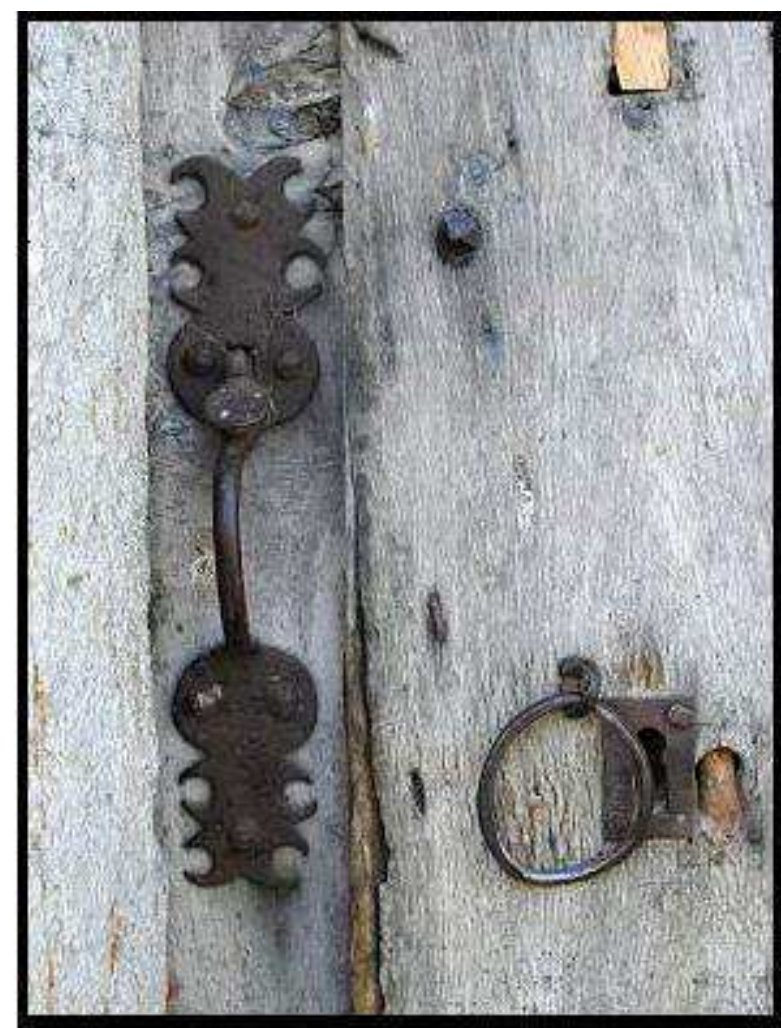

Cerradura. Mallo de Luna.

Fondo fotográfico I.L.C.

Los vanos se convirtieron muchas veces en el único elemento ornamental de los edificios. La decoración se basaba en la utilización de diferentes materiales como los ladrillos o sillares de diferentes colores y en las balconadas de enrejado de hierro.

Las ventanas solían ser de pequeñas dimensiones, especialmente en los edificios más antiguos, pues su apertura dificultaba la construcción del muro y suponía un problema a la hora de mantener el calor interior. No existía una solución única para la apertura de los vanos, aunque lo más común era la utilización de un par de grandes losas laterales cubiertas por otra superior ${ }^{248}$.

Las formas más sencillas estaban dispuestas a partir de cuatro sillares monolíticos bastantes anchos. Solían tener un derrame abocinado especialmente en aquellos bloques de mayor grosor.

${ }^{248}$ ALONSO GONZÁLEZ. Arquitectura, p. 75. 


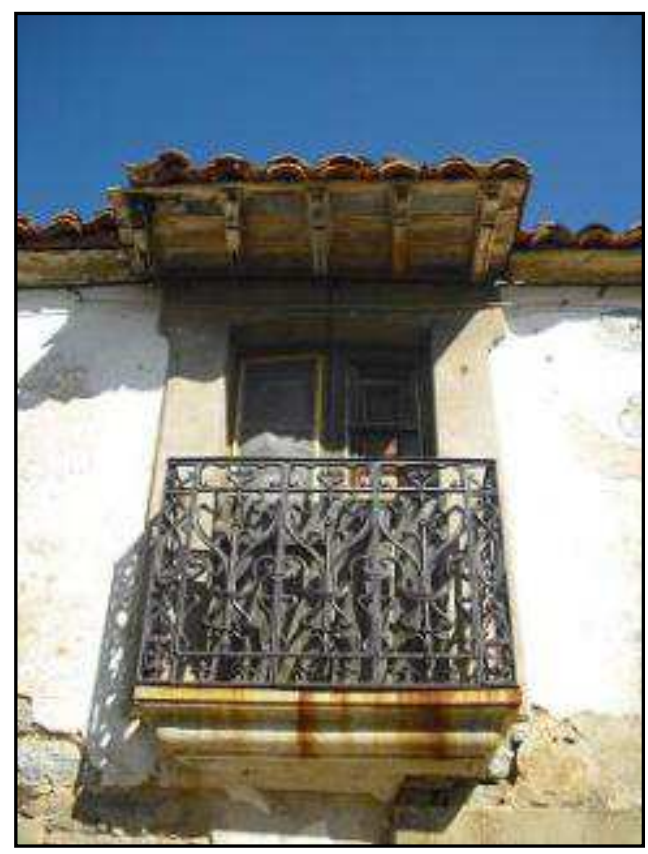

Ilustración 24. Balcón de Mallo

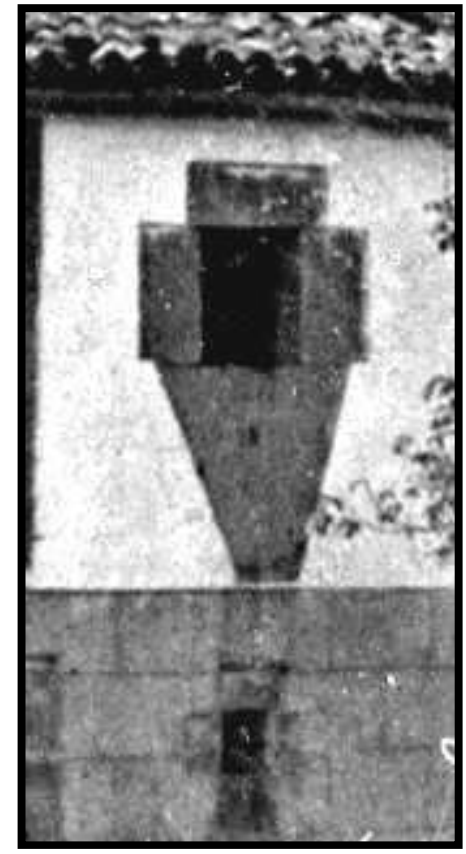

Ilustración 23 Oblanca.

Fondo fotográfico I.L.C. poseían una función decoraba en con formas molduradas que poseían normalmente la estructura del corte de la piedra, aunque en otros casos los propios sillares podían cortarse a modo de orejeras.

Los vanos de la planta baja

El pretil se de ventilación para cuadras y bodegas. Estas solían tener un barrote de hierro a modo de parteluz o un cierre de madera. En los casos más modernos se cerraba con cristal.

El piso superior contenía un número mayor de vanos cuyas dimensiones eran superiores al resto. Lo más característico era la aparición de balcones apenas sobresalientes. Su función era estérica y daban prestigio a las zonas más nobles de la casa, como las salas de estar o las habitaciones principales. Se sujetaban sobre unas ménsulas con formas molduradas sin decoraciones estridentes. El empleo de la forja era común $^{249}$. El enrejado contenía sencillas varas rectas o torneados que formaban figuras geométricas y vegetales.

La fachada principal de la casa es el contenedor de gran parte de los elementos decorativos. En ella podemos destacar la aparición de escudos, inscripciones y molduras ornamentales. Los escudos constituyen la dignificación de la casa que la diferencia del resto como observamos en el escudo de los Águila que se conservaba en una casona de Lagüelles.

Otro aspecto decorativo era el enlucido de las fachadas con cal. La diferencia de pisos se enmarcaba por una moldura de piedra. En el piso bajo se dejaba el material visto o se enlucía de colores diferentes al del piso superior, que se encalaba de blanco 
dejando libres los sillares de vanos y esquinas. Los aleros apenas sobresalían por lo que su decoración se reducía a pequeños voladizos.

\subsubsection{Tipología}

La casa predominante se dividía en dos tipologías bien diferenciadas:

- La casa con corredor.

- La casa compacta sin corredor.

Las dos tipologías convivieron perfectamente, siendo la casa compacta la que acabó imponiéndose hasta nuestros días.

\section{La casa con corredor}

La casa con corredor es el tipo más básico y más arcaico en la ZACEL. Representaba en 1950 menos del $40 \%$ de la totalidad de los edificios y su número iba disminuyendo debido a la pérdida de las labores tradicionales.

La tipología de casa con corredor se dividía en dos alturas. En la planta baja se situaban las zonas dedicadas a cuadras y pajares distribuidas en torno a un corral. En el piso superior se ubicaba la vivienda y la cocina. Las habitaciones eran de pequeñas dimensiones y se disponían al lado del hogar, la zona más caliente de la casa. En su interior contenían una cama y una pequeña arca para guardar la ropa. La separación de las estancias se hacía a través de muros de tabla o mimbre.

Los tipos de corredores se diferenciaban según el cerramiento: abierto, semiabierto o cerrado.

El abierto estaba protegido con tablas de madera con balaustres sencillos, torneados o decorados ${ }^{250}$. Esta tipología se utilizaba en las zonas más soleadas y abrigadas de los vientos.

El corredor semiabierto se componía de un entramado de tablas que dejaban parte de la estructura sin cerrar. La parte cerrada servía como almacén y el resto como zona de tránsito hacia las habitaciones. Esta estructura era la más común en el Valle.

\footnotetext{
${ }^{250}$ ALONSO PONGA. Arquitectura, p. 15.
} 
Por último, el corredor podía estar completamente cerrado con tablas de madera creando una galería mayor para el almacenamiento de los alimentos. Esta tipología era utilizada en los edificios situados en las zonas más altas y sombrías.

A partir del siglo $\mathrm{XX}$ algunos corredores se cerraron con galerías acristaladas. En ocasiones las necesidades funcionales obligaban a cerrar los corredores con mampostería para que sirviera de alcoba o almacén.

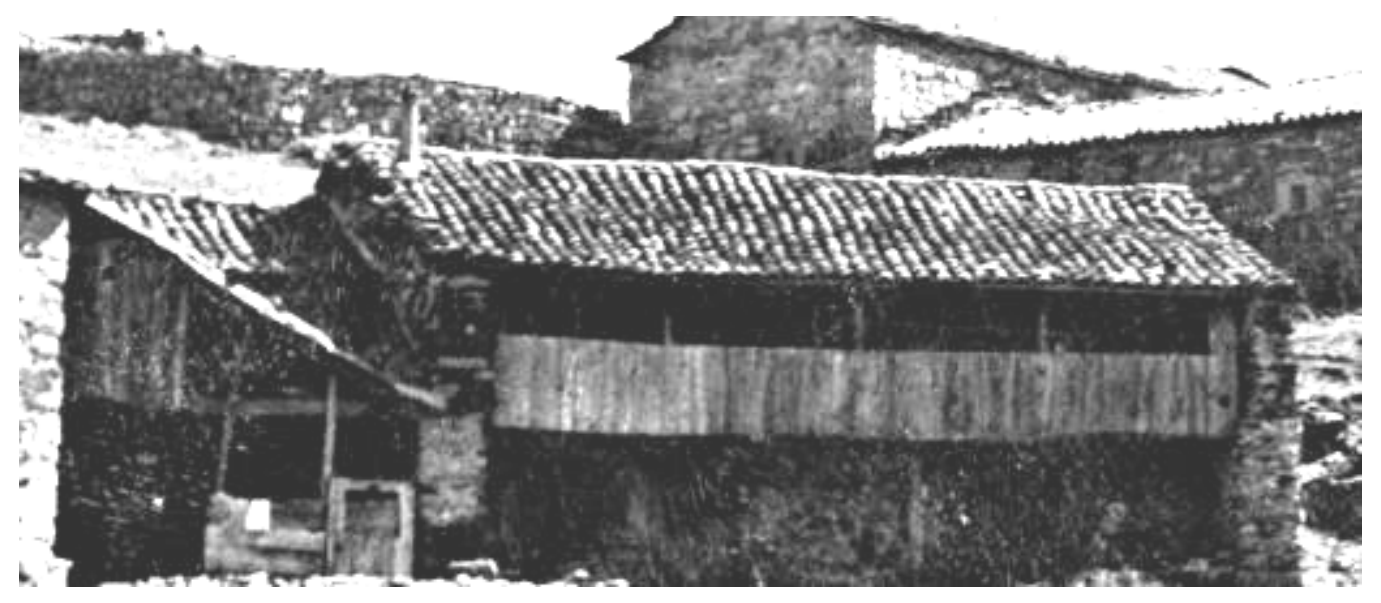

Ilustración 25. Corredor de San Pedro de Luna. Fondo fotográfico I.L.C.

Otra característica de la tipología de casa con corredor es la aparición de una escalera pétrea adosada a la pared que daba acceso al corredor y a su vez servía como apoyo del mismo ${ }^{251}$. La escalera exterior estaba confeccionada con peldaños pétreos monolíticos, aunque a veces se construía el primer tramo de piedra mientras que la zona más resguardada era de madera ${ }^{252}$. Dependiendo de las dimensiones de la fachada, la escalera podía poseer un esquema acodado, de cuarto de vuelta, de ida y vuelta, que aprovechaba mejor el espacio, o simplemente de tramo recto adosado al muro de la casa. En algunas ocasiones el último peldaño poseía una inscripción con el año de construcción de la casa.

${ }^{251}$ GARCÍA GRINDA. Arquitectura, Tomo I, p. 14.

${ }^{252}$ Ídem, p. 85 

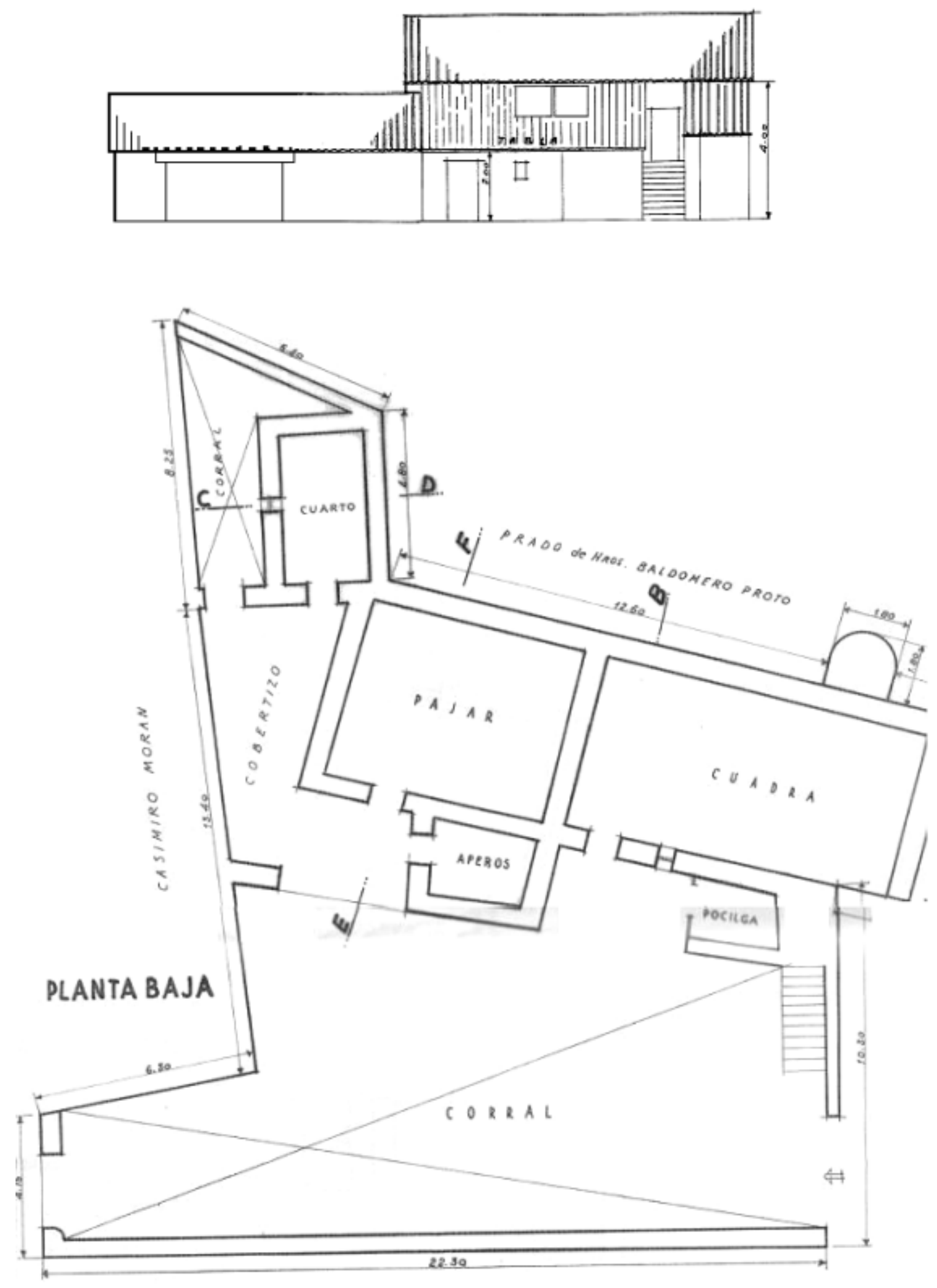

Ilustración 26. A.G.C.H.D. Mallo de Luna. C/05435. N 4461. Parcela 2100. 
Esta tipología debe su influencia a los contactos con las tierras bajas de la provincia y era la más común en la mayoría de las poblaciones, llegando a alcanzar más del $70 \%$ de los edificios en Barrios o Mallo.

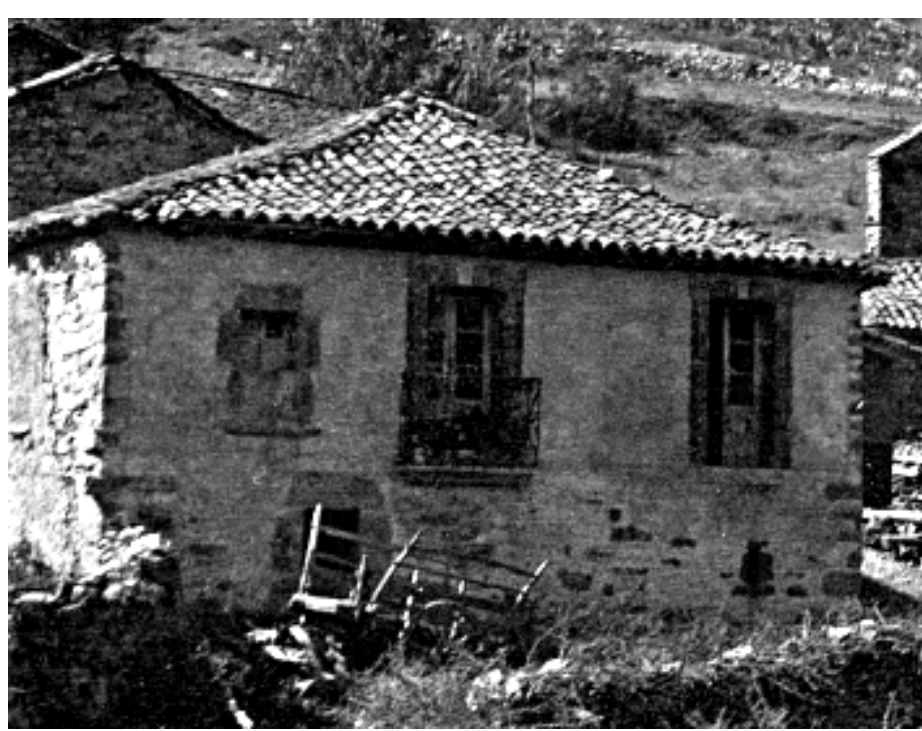

Ilustración 27. Casa sin corredor. Cosera. Fondo C.H.D.

La casa sin corredor se caracteriza principalmente por su forma compacta y la ausencia de escalera exterior. El corredor es sustituido por un balcón abierto a la calle y decorado con un enrejado. Los materiales también son diferentes. Mientras que en la casa con corredor predominaba el sillarejo, en la compacta destaca el uso de sillares de piedra bien escuadrados destinados fundamentalmente a la fachada.

El acceso principal se hace desde la calle o desde un patio y no desde el corral como en el ejemplo anterior. En el piso inferior se disponen las cuadras, pajares y almacenes. Un portalón da acceso a un cobertizo utilizado para cobijar los carros y facilitar las labores de descarga, ya que comunica con el pajar.

El espacio para la vivienda cobra cada vez más importancia en detrimento de otras estancias como los hornos o paneras. Las habitaciones se multiplican con la introducción de salas de estar, alcobas, salones e incluso los baños en los edificios más modernos. También existen habitaciones en la planta baja, pues las condiciones de habitabilidad eran mayores que en la tipología anterior.

La cubierta es siempre de teja, utilizándose la pizarra en algunos casos. 

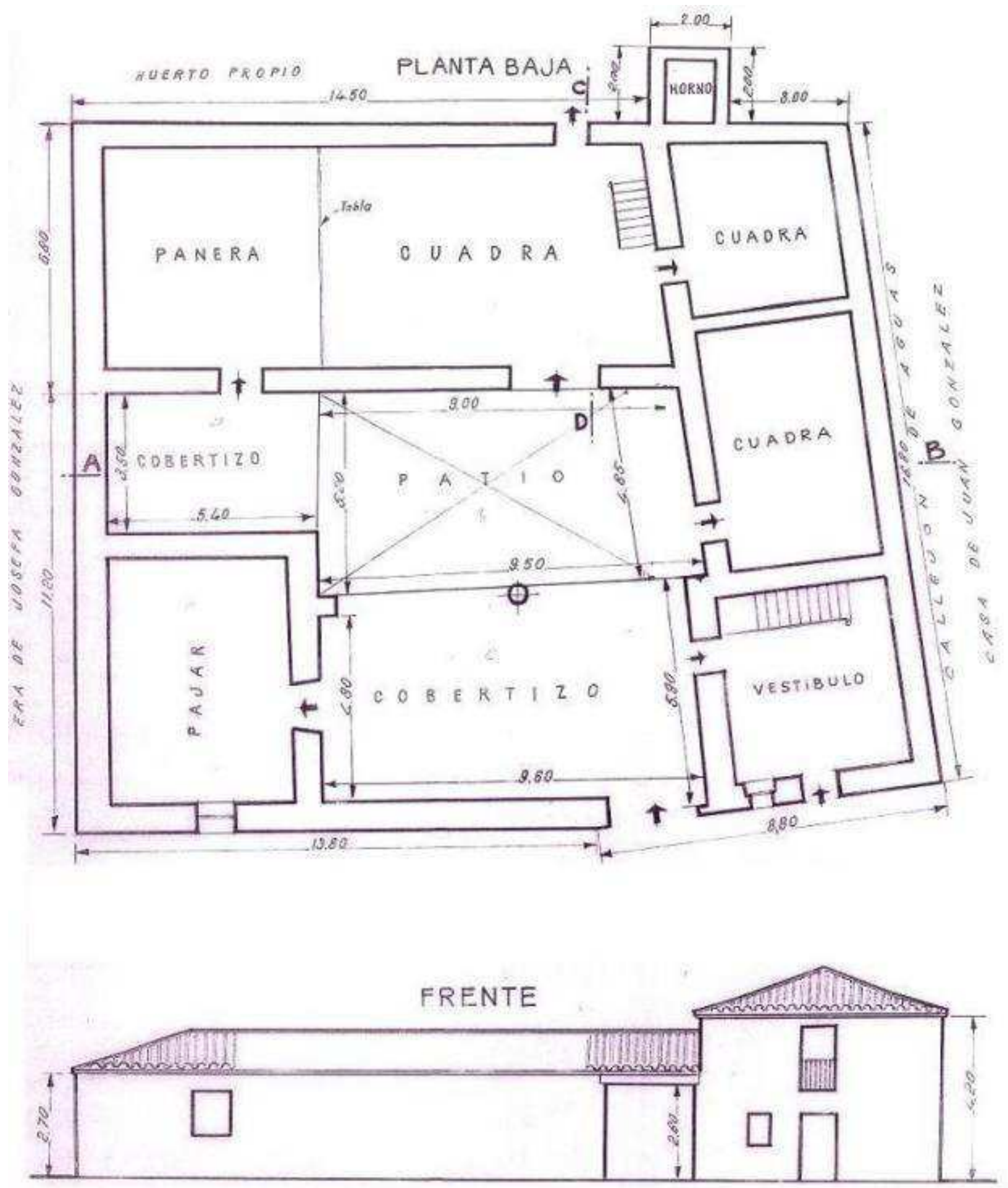

Ilustración 28 A.G.C.H.D. Barrios de Luna. C/05435. Doc. 4461. Parcela 30 


\subsubsection{ARQUITECTURA AUXILIAR}

Las construcciones auxiliares servían de apoyo a las labores tradicionales destinadas al resguardo de la ganadería, al almacenamiento y al trabajo cotidiano. En un momento de fuerte industrialización y mecanización del campo, estas estructuras dejaron de ser necesarias por lo que se fueron abandonando y apenas hoy quedan ejemplos.

Las principales construcciones auxiliares son los pajares y cuadras, las majadas y casas de vaqueiros, las fuentes, lavaderos y pozos, los hornos, las paneras, los palomares y las lecherías. Algunos de estos edificios eran de propiedad comunal, especialmente los lavaderos y fuentes, siendo la Junta Vecinal la encargada de su mantenimiento. De su forma se pueden extraer una serie de tipologías que también van a formar parte del entramado arquitectónico del Valle.

Cada uno de estos espacios se configuró a partir de las premisas de la arquitectura popular siguiendo sus técnicas constructivas y materiales tradicionales. Al ser edificios secundarios, no destinados para la vivienda, los materiales de construcción son de peor calidad como el sillarejo, la madera y la paja.

\subsubsection{Pajares y cuadras}

Tanto las cuadras como los pajares fueron los espacios más significativos en la configuración de la casa popular, ocupando más del 75\% de la superficie edificada. La importancia de estas estructuras se debía fundamentalmente al pilar económico que la ganadería suponía para estas poblaciones de montaña. El pajar y la cuadra se disponían normalmente dentro del entramado de la propia vivienda, pero en ocasiones se encontraban de manera independiente a la casa. Cuando estas estructuras estaban individualizadas pasaban a tener una morfología común y propia.

Se cubrían con materiales de características inferiores como era la paja o panizo. Los muros eran de sillarejo y se remataban en unas losas de piedra que se colocaban horizontalmente de manera escalonada denominadas grindallas y finalizados por una piedra perpendicular a modo decorativo denominada piñón o geijo. Esta forma facilitaba el asentamiento de los niveles de paja hasta la parte superior. 
El pajar, construido como una parte diferenciada de la casa, solía estar ligado al espacio de la era cercano a un lugar comunal donde se pudiera trillar y separar el grano de la paja ${ }^{253}$. Estaba constituido por una sola planta rectangular de entre $60-100 \mathrm{~m}^{2}$. con una altura de los muros de hasta $7 \mathrm{~m}$. El espacio interior era diáfano sin apenas separaciones internas y su función servía exclusivamente para el almacenamiento de la hierba para el consumo animal ${ }^{254}$. La estancia se iluminaba a través de unas pequeñas ventanas que no superaban los $0.50 \mathrm{~m}$. de altura. En algunas ocasiones poseía unas escaleras en piedra adosadas al muro exterior que servían para introducir la paja por el boquerón, una pequeña puerta en la parte superior.

La entrada a estos edificios era de grandes dimensiones para poder acceder desde el carro hasta el interior. Algunas de estas estructuras, como en Santa Eulalia, poseían un portal cerrado por un murete que servía como espacio para la carga y $\operatorname{descarga~}^{255}$.

La cuadra se ubicaba en una zona cercana al pajar, pues ello facilitaba las labores de alimentación del ganado. La principal razón por la que las cuadras se construían alejadas de la vivienda era el tamaño de la ganadería en zonas donde la disposición urbanística y el terreno no permitían la creación de grandes estructuras. Además, su situación dependía de la cercanía de los pastos con los que alimentar a los animales.

El pavimento de la cuadra era de tierra apisonada, aunque podía contener un empedrado, siempre inclinado para facilitar la salida de los líquidos hacia un canal de desagüe situado en el centro o en los laterales del edificio. Adosado al muro se encontraban los pesebres fabricados a partir de unos tablones divididos por varas de hierro o madera para separar las reses. En la parte superior se situaba la pesebrera donde se arrojaba la hierba directamente desde el pajar a través de las cebaderas ${ }^{256}$. En las esquinas se levantaba un cerramiento de varas entretejidas destinado a recoger los terneros.

\footnotetext{
${ }^{253}$ GARCÍA GRINDA, José Luis. "Función y forma: La arquitectura auxiliar agropecuaria leonesa” en La arquitectura tradicional en tierras de León, León 2005, pp. 9-68, p. 28.

${ }^{254}$ COBO-CORES-ZARACINA. Arquitectura, p. 7.

${ }^{255}$ A.G.C.H.D. Santa Eulalia. No ${ }^{\circ} 4479$.

${ }^{256}$ COBO-CORES-ZARACINA. Arquitectura, p. 30.
} 


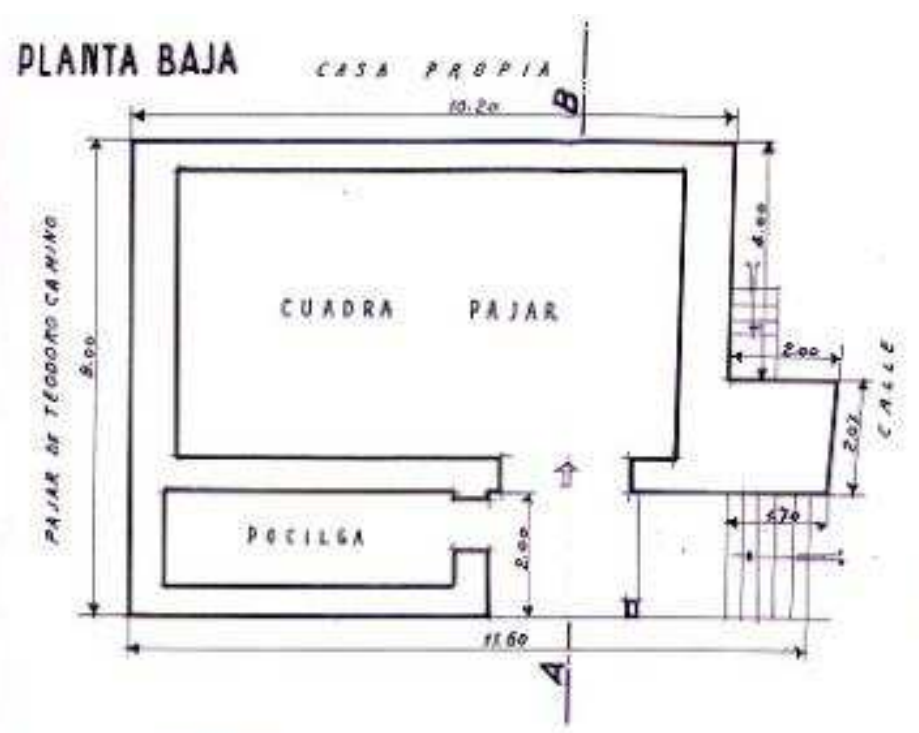

PLANTA DRAL.

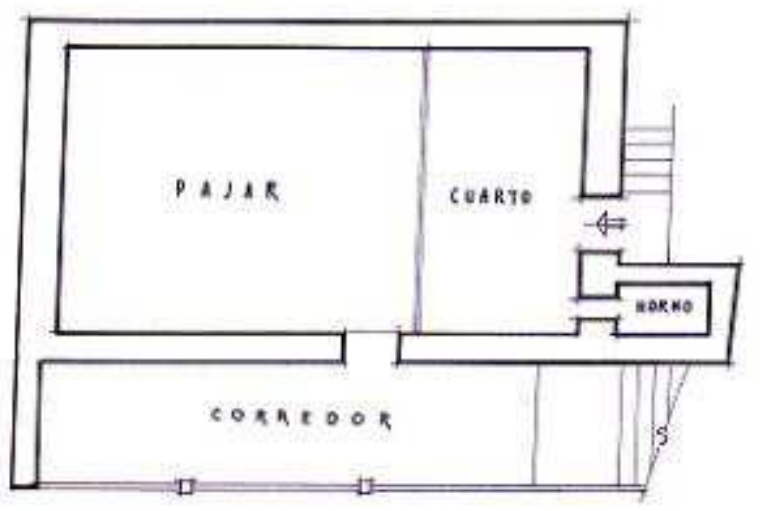

SECCION A.B

FRENTE
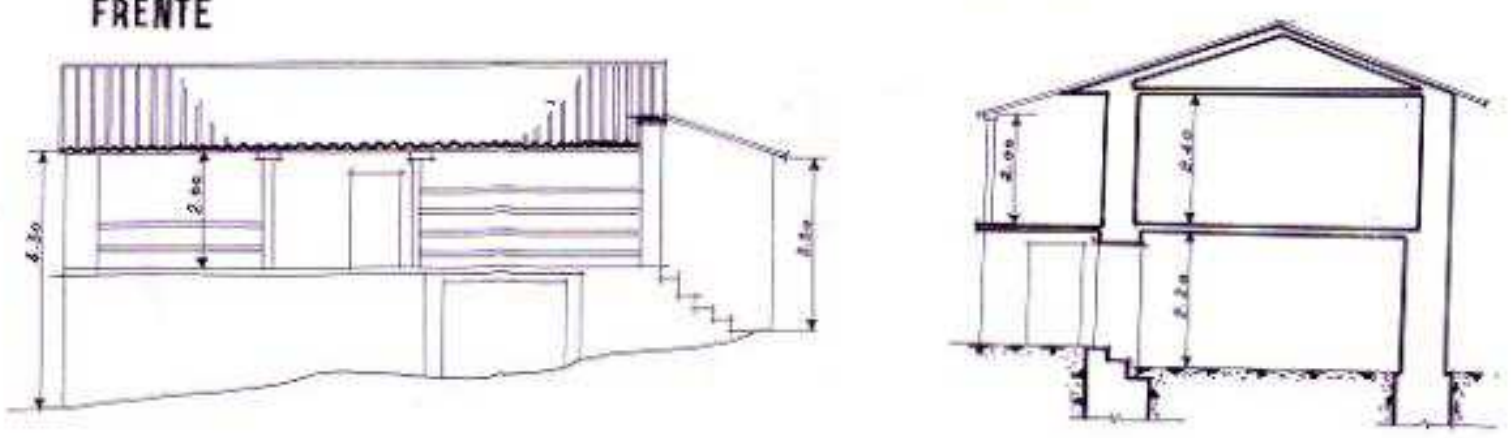

Ilustración 29. A.G.C.H.D. Cosera. C/05435. No 4461. Año 1949. Finca 3115

\subsubsection{Majadas y casas de los vaqueiros}

Las majadas y casas de vaqueiros fueron una de las estructuras arquitectónicas más comunes en los valles ganaderos. Su ubicación, alejada de la población y el desuso de la ganadería trashumante y transterminante, ocasionó su paulatina desaparición. La importancia de la trashumancia se vio favorecida por el impulso de familias nobiliarias como los Quiñones y por los monasterios como el de Guadalupe de Cáceres. A partir del siglo XVI, tomará el relevo de las grandes cabañas ganaderas los propios concejos de Luna.

Las majadas y casas de vaqueiros nacieron con un fin muy determinado, dar cobijo durante el período de estío a la ganadería de pastos de alta montaña. En Luna los refugios de los pastores se hacían en abrigos naturales o cuadras que servían de 
dormidero o guarda de aperos ${ }^{257}$. Estaban constituidos por una sola planta cuadrada o circular con muros de mampostería y cubierta de paja o teja.

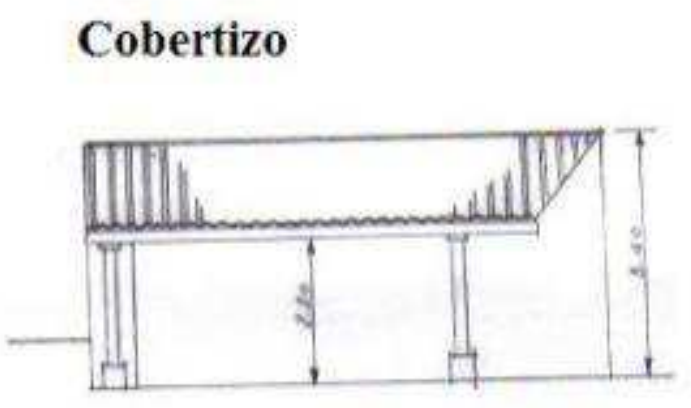

ALLADO

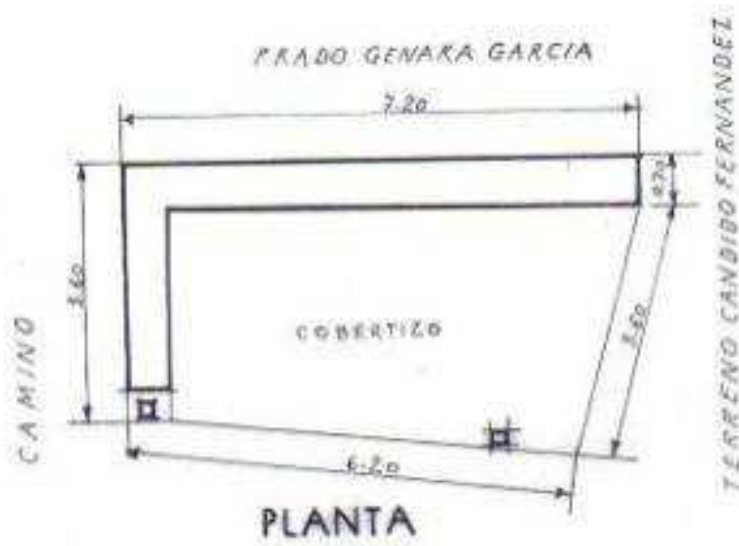

Ilustración 30. A.G.C.H.D. Santa Eulalia de las Manzanas. Nº 4479.

Las majadas podían localizarse a distancia de la población, en los collados y puertos, o dentro del propio entramado urbanístico del pueblo. Su situación también dependía de la existencia de una fuente o abrevadero para el ganado. En Miñera de Luna y Cosera aún se conserva la toponimia destinada a estas labores en lugares como el Chozo. Otras majadas mantienen su uso como la majada del Reguerón en Oblanca, la de Mallo, la de Portilla de Luna y la de Sagüera.

La tipología de las casas de vaqueiros o refugios temporales fue evolucionando con el tiempo. Su estructura dependía de las condiciones del terreno, pero solía presentar una planta cuadrada. Alrededor del edificio se construía un muro de mampostería o sillarejo que albergaba los patios interiores en donde se cobijaba el ganado. También poseía un cobertizo cubierto con tapín y teja sobre tabla para el resguardo de los terneros o corderos. En la parte exterior del recito se adecuaba un espacio porticado para el ganado que se asentaba normalmente sobre unos pilares de madera o piedra.

Las cubiertas podían ser de paja o teja. Los remates de los muros testeros solían estar resaltados de forma escalonada ${ }^{258}$. En ocasiones poseía un piso superior al que se accedía mediante unas escaleras y donde se almacenaba el alimento para el ganado.

${ }^{257}$ GARCÍA GRINDA. "Función”, p. 166.

258 Ídem, p. 19. 

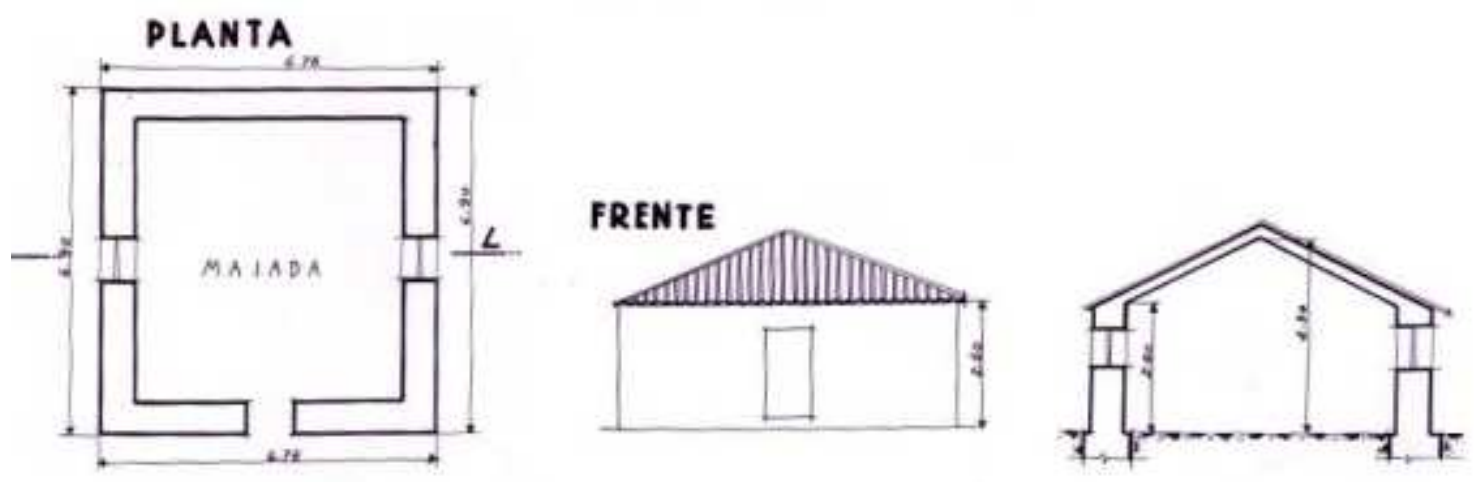

Ilustración 31. A.G.C.H.D. Mallo de Luna. C/05432. No 4461. Finca 2083

3.2.3.3.Fuentes, lavaderos, abrevaderos y pozos

La mayoría de fuentes, lavaderos, abrevaderos y pozos eran de propiedad comunal y su uso estaba destinado al abastecimiento de agua potable. La tipología de todos ellos estaba supeditada a la funcionalidad.

Las fuentes solían ubicarse en

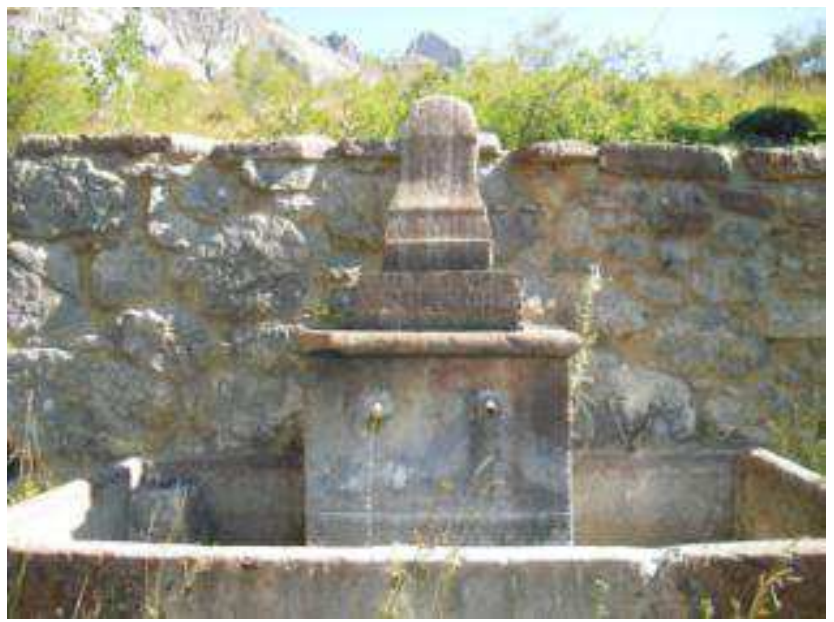
las plazas del pueblo o en espacios abiertos y podían contener algún tipo de inscripción, como la fecha de inauguración. Se abastecían del agua de fuentes y arroyos a través de una tubería de gres que daba acceso a un pilón de ladrillo o piedra. Sus formas eran variadas y podían contener uno

Ilustración 32. Fuente pública. Sena de Luna o diversos caños. Lo más común era la estructura horizontal con un pilón de piedra alargado sobre el que caía el agua del manantial ${ }^{259}$. En otros casos reutilizaban materiales como hitos o basas de piedra. Su uso era exclusivamente humano pues el ganado iba a los lavaderos y abrevaderos. El material más común era la piedra aunque encontramos ejemplos en ladrillo como el de Lagüelles. En San Pedro, Láncara y

${ }^{259}$ A.G.C.H.D. Láncara de Luna. C/05468-2. № 4498. Año 1956. 
Oblanca existía una fuente pública confeccionada con un pilón de piedra que abastecía a todo el pueblo hasta la llegada del agua corriente ${ }^{260}$.

En las poblaciones que no han quedado inundadas, las fuentes se han remodelado con materiales de los pueblos abandonados. La fuente de la iglesia de Barrios de Luna fue traída desde Láncara, las de Miñera y Pobladura reutilizan fregaderos en recuerdo de las antiguas construcciones. Se conservan algunos ejemplos de la tipología tradicional de las fuentes en Mallo y Sena de Luna, en las que podemos observar algunos elementos ornamentales como monolitos de piedra que llevan inscritas la fecha de su construcción.

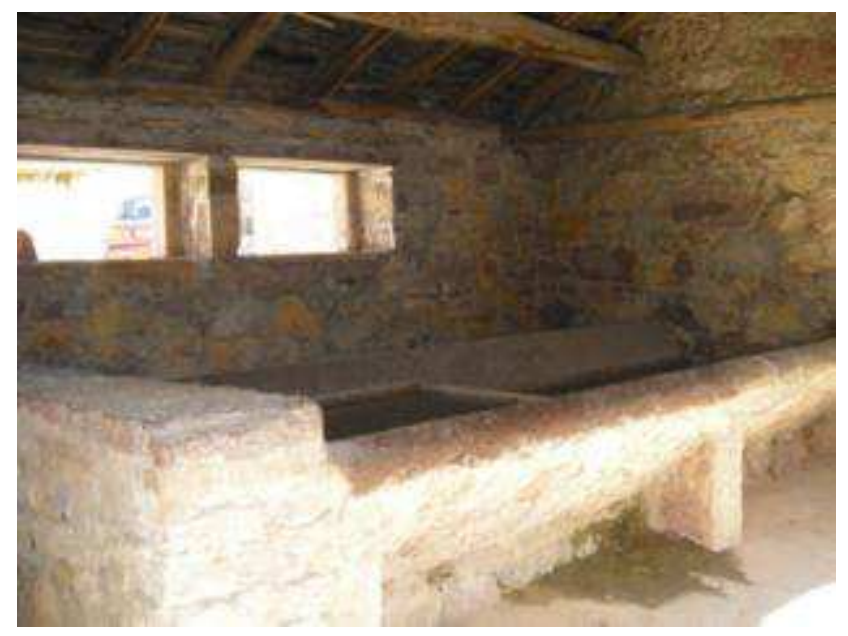

Ilustración 33. Lavadero. Sena de Luna
Los lavaderos también pertenecían a la Junta Vecinal de cada población. Consistían en una estructura rectangular de muros de piedra en forma de L cubierta con madera a una o dos aguas y sujeta sobre dos vigas de madera con base de piedra y capitel de madera. Ocupaban una superficie de unos 20 a $30 \mathrm{~m}^{2}$. En la parte central se situaba un estanque de agua dividido en varios compartimentos. El primer pilón sobre el que caía el agua se destinada como abrevadero para el ganado, el siguiente compartimento se usaba como lavadero y tenía a los laterales unas estructuras elevadas que servían para golpear la ropa y mejorar la limpieza ${ }^{261}$. Al final se abría un canal de desagüe. $^{262}$

Los abrevaderos formaban parte de la estructura de los lavaderos, pero en ocasiones aparecían individualizados, especialmente en las zonas alejadas de la población. Consistían en un depósito de agua en piedra que podía acompañarse de un pesebre en madera.

Los pozos solían localizarse dentro de las viviendas o en las huertas destinadas a cultivos y eran de propiedad particular. La abundancia de fuentes y arroyos cercanos

\footnotetext{
${ }^{260}$ A.G.C.H.D. San Pedro de Luna. C/05462. No 4485. Año 1953-54.

${ }^{261}$ A.G.C.H.D. Santa Eulalia. No ${ }^{\circ} 4479$.

${ }^{262}$ Ibídem.
} 
hacía que la construcción de los pozos en las viviendas sólo se hiciese en aquellas que tenían unas necesidades especiales como los hornos eléctricos.

Los pozos que se situaban dentro de las viviendas y se disponían en un lateral del patio. Contenían un brocal en piedra de sillarejo con una altura de aproximadamente 1 a 2 m. de diámetro.

\subsubsection{Paneras}

Las paneras eran edificios exentos destinados al almacén de cereales. Su estructura se diferencia de las paneras asturianas, puesto que no se elevaban sobre pilares de madera. Estaban realizadas con muros de mampostería y techumbre de paja, como era habitual entre los edificios secundarios. Al interior las distintas estancias se separaban con muros de tabla. La superficie media era de unos $60 \mathrm{~m}^{2}$ con un espacio diáfano para poder contener el mayor número de productos alimenticios. La entrada estaba separada del almacén propiamente dicho y a través de ella se accedía a la panera y a una sala donde se recogían los aperos. Al contrario que otros en edificios, la iluminación se hacía a través de dos vanos que favorecían la ventilación para la conservación del cereal. En Casasola existían algunos ejemplos en los cuales se aprecian estas características.

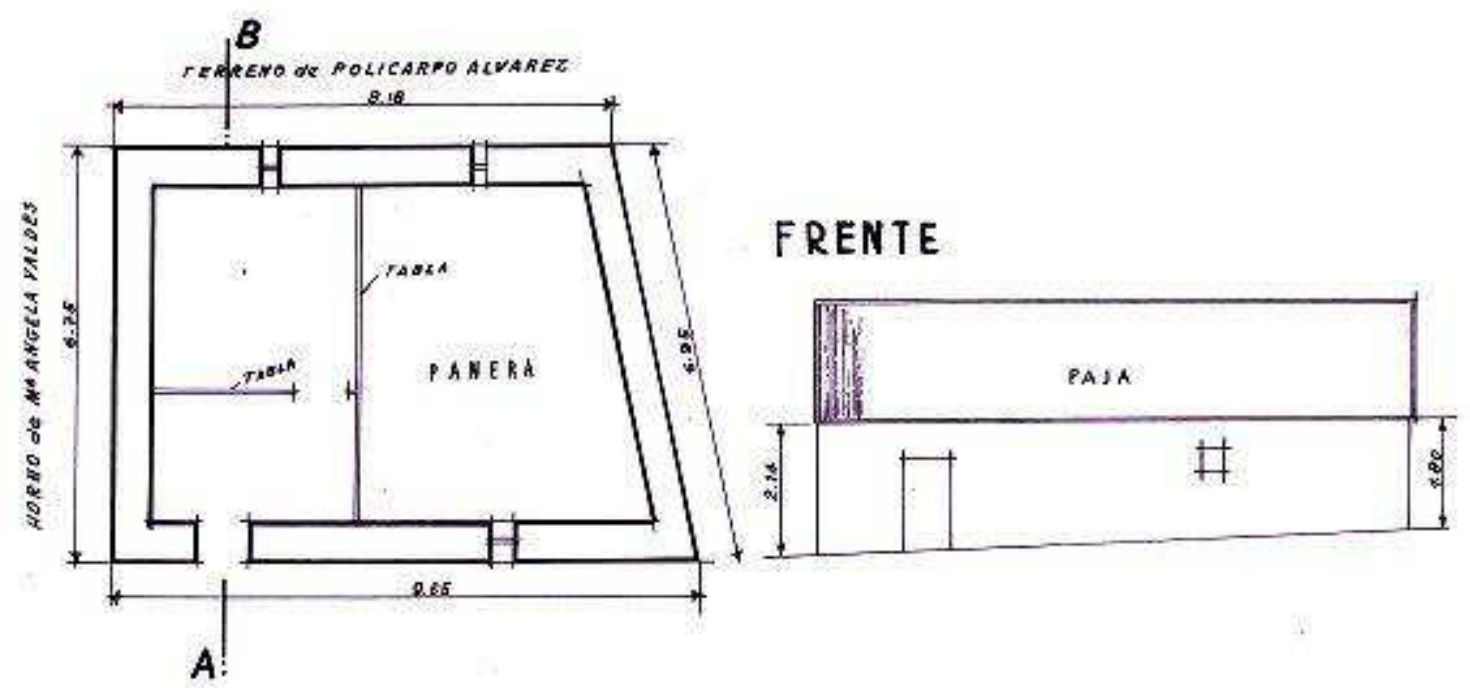

Ilustración 34. A.G.C.H.D. Casasola. C/05432. Nº 4461. Año 1949. Finca 2989. 


\subsubsection{Palomares}

Los palomares se encontraban en zonas muy concretas de Luna, no siendo frecuentes. El hecho de que apenas existan palomares en la zona de Luna se debe principalmente a las duras condiciones meteorológicas y a la escasez de actividades agrícolas, fundamentales para la manutención de las aves.

Se trata de construcciones muy herméticas, pues la única abertura al exterior, si exceptuamos las pequeñas troneras que permiten las idas y venidas de las palomas, solía ser la puerta de entrada.

Los ejemplares de Luna eran de fábrica pétrea, de planta circular, con cubierta a un agua sin linternilla y orientados a mediodía. El vuelo del alero de piedra protegía la entrada de las palomas ${ }^{263}$. La parte superior de los palomares estaba coronada con teja árabe de barro cocido que se sujetaba sobre un entramado de vigas de madera. La madera era usada también para confeccionar la puerta de entrada y el cargadero de la misma.

En el interior del palomar se situaban los nidales destinados a recibir la puesta de las palomas. La cantidad de nidales en el interior del muro se debía a que las palomas no criaban dos años seguidos en el mismo lugar, por lo que había que multiplicar las oquedades para no perder la producción.

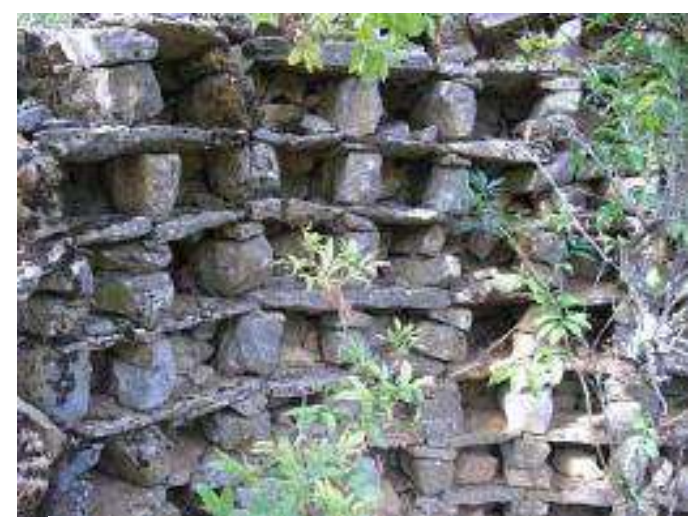

Ilustración35. Palomar de Mallo.

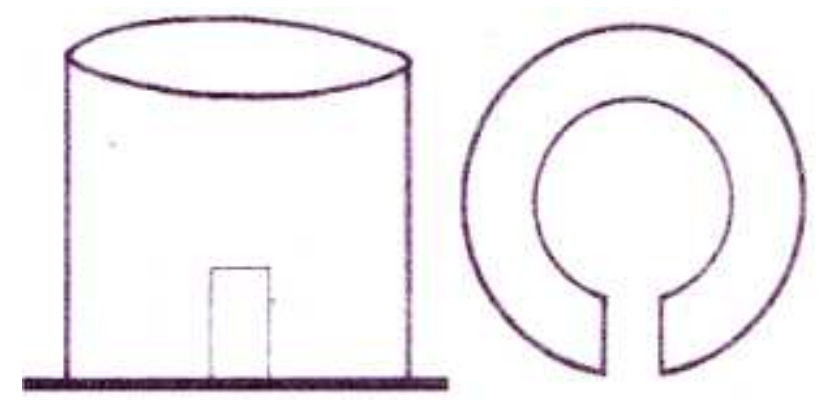

Ilustración 36. A.G.C.H.D. Mallo de Luna. Doc. 6114.

El único ejemplo que se ha encontrado dentro de los terrenos expropiados de la ZACEL ha sido el palomar de Mallo. Éste tenía una planta de sección circular con un 
mortero de barro y muros de tapial con una sola puerta de entrada ${ }^{264}$. Al exterior se recubría con una gruesa capa de cal blanca. Dentro de la estructura se encontraban los nidales colocados con piedra longitudinales a modo de pequeños dinteles y unas vigas de madera para facilitar que las palomas se posasen en el interior.

\subsubsection{Potros}

Los potros fueron construcciones abundantes en una zona dedicada casi en exclusiva a la ganadería. Algunos de ellos se encontraban dentro de la propia estructura de la casa, aunque también era común que ocupasen un espacio independiente. Otros se disponían en lugares públicos dentro del entramado urbanístico, ya que eran de propiedad comunal.

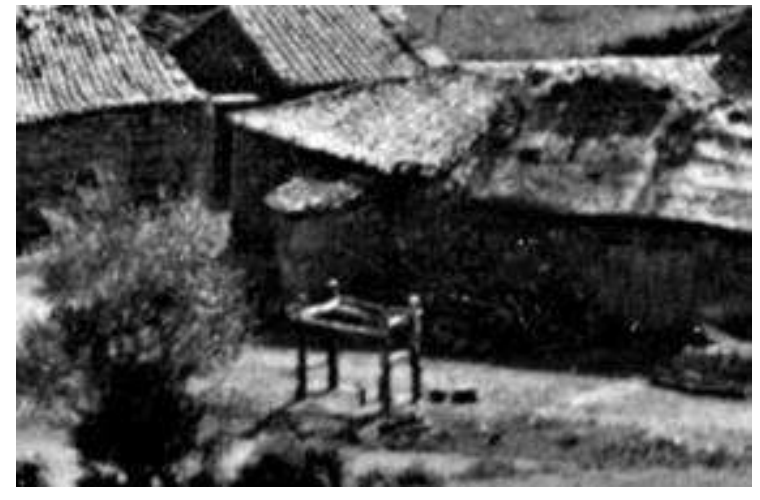

Ilustración 37. Mallo de Luna. Potro.

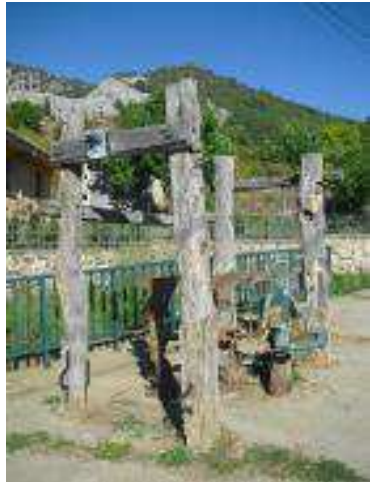

Potro en la actualidad

Fondo fotográfico del I.L.C.

Para la fabricación de los potros se utilizaban troncos de madera devastados que se situaban en ocasiones bajo un cobertizo sujeto sobre postes de madera. En otros casos, como ocurre en Mallo de Luna, el potro no poseía ningún tipo de cubrición.

En uno de los extremos se colocaba el cabezal que tenía forma de yugo y que servía para sujetar la cabeza del animal gracias a unas correas de cuero o cuerda. Las patas se apoyaban en unos pequeños troncos verticales que facilitaban la labor del herraje $\mathrm{e}^{265}$.

\footnotetext{
${ }^{264}$ A.G.C.H.D. Mallo de Luna. C/05435- № 6114. Año 1950.

${ }^{265}$ GARCÍA GRINDA. Arquitectura. Tomo I, p. 301.
} 


\subsubsection{ARQUITECTURA CIVIL}

Dentro del entramado urbano de las poblaciones del Valle se encontraban una serie de edificios civiles de uso comunitario de entre los que destacan las escuelas y los lugares de reunión de las Juntas Vecinales como los concejos, salones y ayuntamientos.

\subsubsection{Escuelas}

Las escuelas fueron uno de los edificios más significativos de la ZACEL, cuya construcción corría generalmente a cargo de las Juntas Vecinales aunque también era común la presencia de cátedras religiosas como las de Láncara, Pobladura y Otero de las Dueñas.

A principios del siglo XX existió un promotor privado, Paulino García Gago, al cual se deben la creación de gran parte de las escuelas de la zona tal y como Cosera, Lagüelles, Láncara, Mallo, Miñera, Mirantes, Oblanca y San Pedro. También costeó otras obras como la reforma de la iglesia y la donación de imágenes en Sena de Luna.

Las escuelas construidas gracias a las donaciones de Paulino García Gago seguían un esquema muy similar compuesto por un edifico de dos plantas y un patio. Es destacable la importancia que se le daba a la iluminación con grandes ventanales abiertos siempre en el muro S. del edifico, el más soleado. En la planta baja se disponía la escuela mixta, sin separación entre niños y niñas. En la planta superior se encontraba la vivienda del maestro. Se accedía a ella a través de una escalera interior realizada en madera. En el piso superior se disponía la cocina, dormitorio y salón o despacho del profesor.

Los materiales principales eran el ladrillo y la teja para la techumbre. La piedra no se usaba debido a la modernidad de los edificios y la utilización de nuevos materiales como el cemento. Cabe destacar la escuela de Oblanca, que tenía una estructura particular diferenciada con un patio que rodeaba el edificio y un gran porche descubierto sujeto sobre pies derechos. Lo más significativo de esta escuela eran los materiales utilizados para su construcción, como los sillares bien labrados en las esquinas y la pizarra para la cubrición de la techumbre, algo inusual en las construcciones tradicionales. 


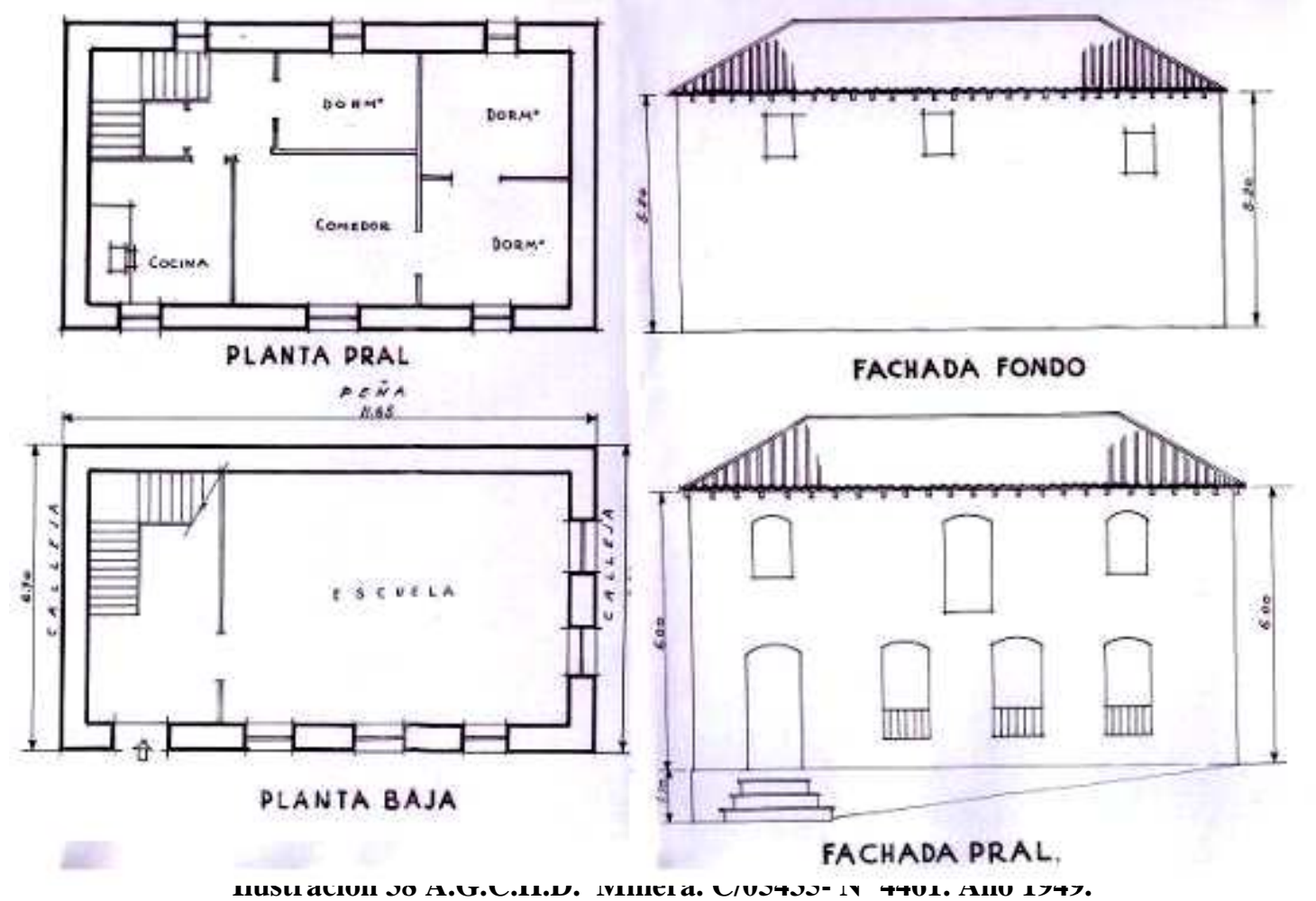

La tipología de escuelas costeada por la Junta Vecinal era bastante más sencilla. La estructura consistía en un edificio de una sola planta rectangular cubierto con una techumbre a dos aguas e iluminado por unos amplios ventanales situados por lo general en la zona S. En ocasiones la estancia se dividía en dos partes diferenciadas, una para los niños y otra para las niñas, como ocurre en la escuela de Mallo de Luna.

En Santa Eulalia se daba una circunstancia especial. La escuela estaba situada en un edificio privado dividido por varios propietarios, entre ellos la Junta Vecinal. Una de las estancias estaba destinada a escuela con cocina. El acceso se hacía a través de un corral ya que el colegio estaba rodeado de otras dependencias anexas de propiedad privada destinadas a cuadras y pajares. Es por ello que la escuela de Santa Eulalia era la única que se cubría con paja en lugar de la habitual teja.

\subsubsection{Salones y salas de junta}

Uno de los edificios más comunes de carácter civil eran los salones y salas de juntas. En ocasiones estos espacios aprovechaban otro tipo de edificios como las escuelas. En Oblanca el salón de juntas y la escuela estaban situados en el mismo 
edificio. En el piso superior se ubicaba la escuela a la que se accedía a través de unas escaleras exteriores mientras que el piso inferior era el salón de reuniones de la asamblea.

La tipología más común de los salones del concejo era sencilla. Un edifico de planta rectangular con una sola estancia interior diáfana para permitir un mayor aforo. La cubierta era a dos aguas con listones de madera y teja. La iluminación también era importante, al igual que en las escuelas, y las ventanas se abrían en la parte más soleada del edificio como en los casos de Láncara, Mirantes y Oblanca.

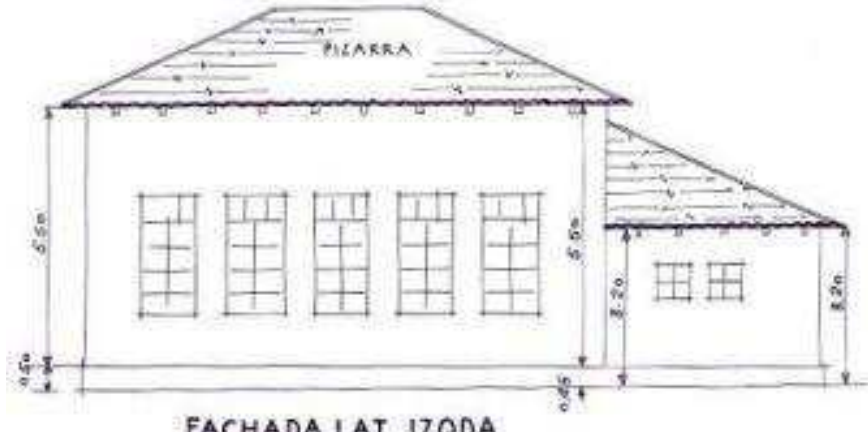

FACHADA LAT. IZQDA.

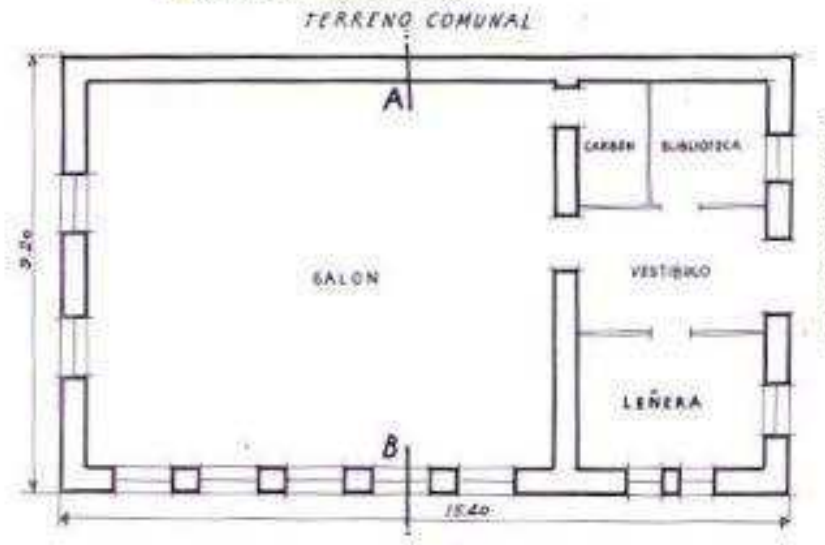

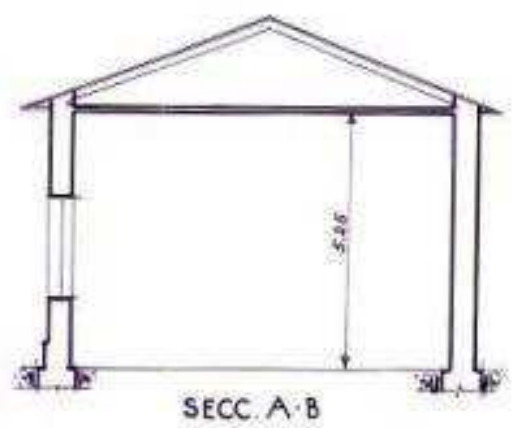

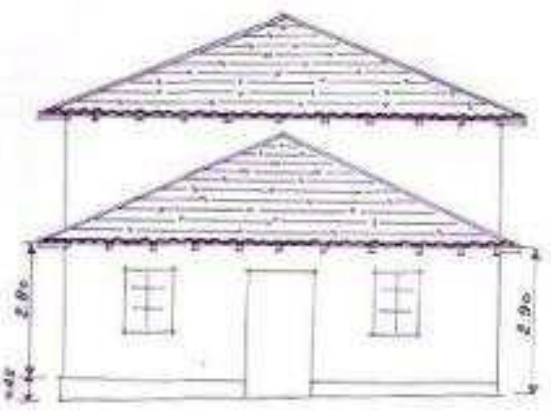

Ilustración 39. A.G.C.H.D. Lagüelles. C/05468-2. Nº 4498. Año 1956.

En Lagüelles cabe destacar un edificio moderno para la época no solo por la novedad de sus materiales, sino también por las estancias interiores de las que constaba. Era un edificio muy luminoso con cinco grandes ventanales. Al interior se abría un gran salón de reuniones en los cuales destaca una habitación destinada a leñera para la calefacción y una biblioteca, algo de lo que carecían el resto de poblaciones. 

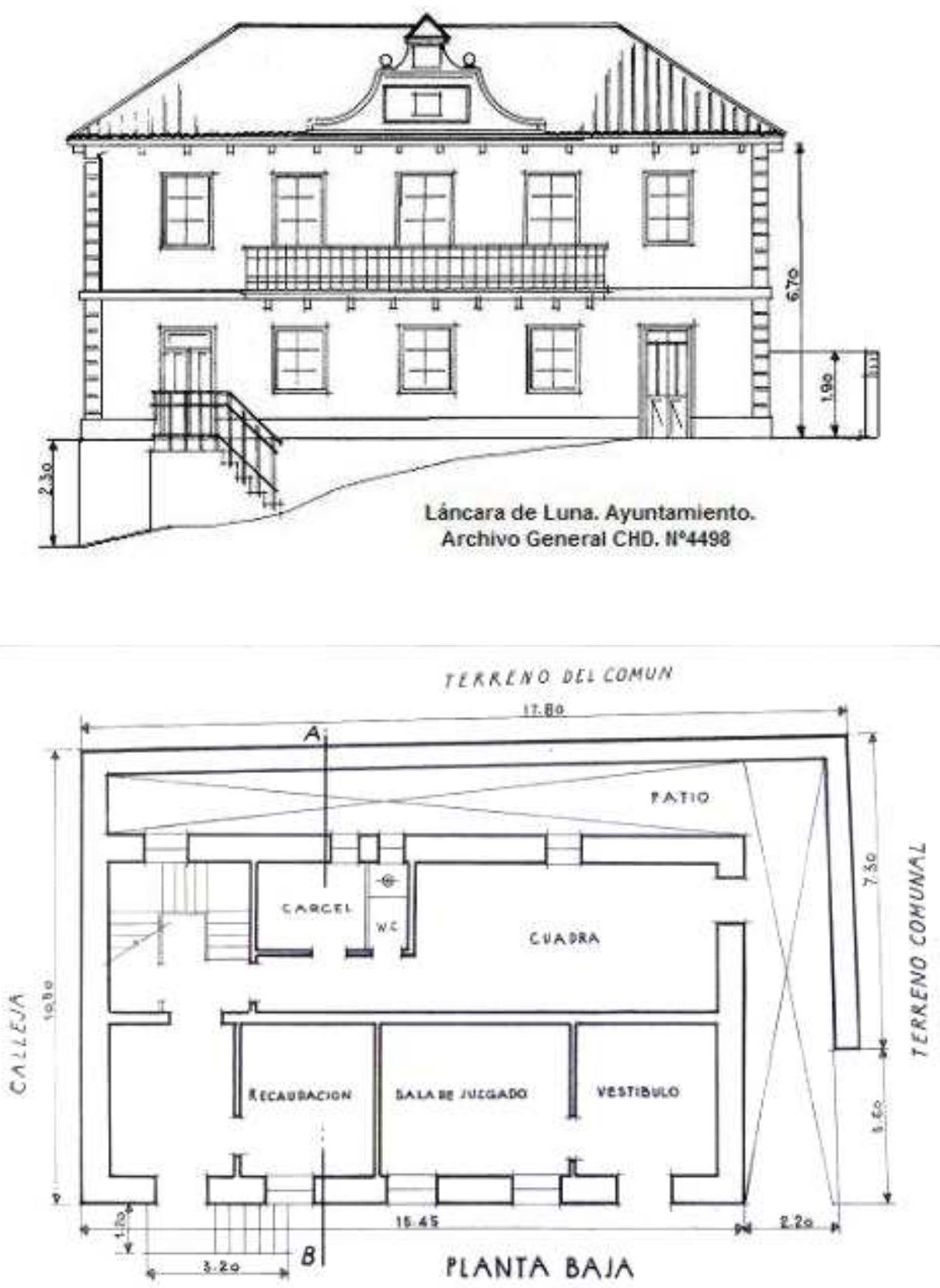

Ilustración 40. A.G.C.H.D. Láncara de Luna. C/05468-2. № 4498. Año 1956.

Las divisiones impuestas durante el reinado de Isabel II, tras la Restauración Borbónica $^{266}$, ocasionaron la creación de nuevos municipios y la modificación de los pequeños concejos que se englobaron en distritos más grandes. Es en este momento cuando Barrios de Luna y Láncara pasaron a ser la cabeza de ayuntamiento dentro del partido judicial de Murias de Paredes.

${ }^{266}$ FERRERAS CHASCO. El norte, p.156. 
El ayuntamiento se convirtió en el edificio más importante y representativo de estas localidades, especialmente en Láncara. El inmueble ocupaba una superficie de $131 \mathrm{~m}^{2}$ dividido en dos plantas rectangulares. Para acceder al edificio había una escalera lateral y una puerta principal que daban a un vestíbulo de entrada. En esta planta baja se encontraba la sala de juzgado, la de recaudaciones, una cuadra, la cárcel y un baño con agua corriente.

El acceso a la planta superior se hacía a través de una escalera interior que daba paso a las diferentes estancias como la secretaría, el archivo, sanidad y el salón de sesiones. El salón de sesiones se abría al exterior con un gran balcón corrido que ocupaba gran parte de la fachada decorado con rejería sencilla.

Los materiales utilizados eran sillares bien labrados para las esquinas, vanos y adornos en la fachada. Rematando la portada existía un frontón rodeado de dos bolas de piedra decorativas. Sobre este frontón existían unas placas posiblemente con inscripciones de la fecha de inauguración y el nombre del pueblo o del edificio.

Finalmente se cubría con una techumbre a cuatro aguas de teja sobre madera. Rodeando el edifico existía un pequeño patio alargado utilizado como cochera para los vehículos y carruajes. 


\subsection{ARQUITECTURA INDUSTRIAL TRADICIONAL}

La arquitectura industrial tradicional sirvió como apoyo para las labores económicas de la población desde la Antigüedad hasta la llegada de la Industrialización. Su uso estaba destinado a la transformación y comercialización de los productos. Las primeras maquinarias de las que se tiene constancia en la ZACEL eran muy sencillas y se basaban en el aprovechamiento de la fuerza de la mano del hombre, de los animales de tiro y fundamentalmente de la energía hidráulica.

\subsubsection{LOS ESTUDIOS SOBRE ARQUITECTURA INDUSTRIAL}

La importancia económica de la arquitectura industrial tradicional ha contribuido a su documentación en diversos archivos desde períodos medievales hasta registros posteriores como el Censo de Floridablanca, el Catastro del Marqués de la Ensenada o los Libros de Fábricas Industriales del siglo XIX y XX como la Guía fabril e industrial de España de Giménez y Guited de 1862 o el Registro de Establecimientos Industriales del año 1985. También en el Diccionario de $\operatorname{Madoz}^{267}$ se pueden encontrar informaciones puntuales sobre la cantidad de molinos de las poblaciones, la propiedad de los mismos, sus características y el beneficio que producían.

Las primeras monografías destinadas al estudio patrimonial de la arquitectura industrial y su documentación fueron parejas a las relacionadas con la casa tradicional como las publicaciones de Vicente Lampérez y Romea, Leopoldo Torres Balbás o Fernando García Mercadal ${ }^{268}$.

A partir de los años sesenta la proliferación de narraciones referidas a la arquitectura industrial tradicional se dispara gracias a la publicación de algunas obras como la de Bloch, White o la de Terry y William ${ }^{269}$. Todas estas obras estaban destinadas al estudio de las técnicas históricas utilizadas desde la Antigüedad hasta la industrialización.

\footnotetext{
${ }^{267}$ MADOZ. Diccionario.

268 LAMPÉREZ ROMEA. Arquitectura; GARCÍA MERCADAL. La casa; TORRES BALBÁS. La vivienda.

${ }^{269}$ BLOCH, Marc. Avengement et coquettes du Moulin á eau. Melanges Historiques. Tomo I y II. París, 1963; WHITE, Lynn. Tecnología medieval y cambio social. Buenos Aires, 1973; TERRY, H. y WILLIAM, T. Historia de la tecnología. 3 vol. Madrid, 1977.
} 
En los años ochenta aparece la publicación de Julio Caro Baroja ${ }^{270}$ que se convierte en referente de los estudios actuales acerca de las técnicas industriales tradicionales creando tipologías y describiendo cada uno de los componentes de las mismas. A partir de esta publicación comienzan otras muchas de carácter divulgativo especializadas en temas particulares como las obras de González Tascón ${ }^{271}$ y más recientemente las obras de Alonso González, García Tapia, García Castellón y Carlos Junquera $^{272}$. Todas ellas describen las diferentes construcciones tradicionales industriales creando tipologías diferenciadas.

Gran parte de este estudio se ha basado en la documentación extraída del archivo de la Confederación del Duero. Destacan los croquis y esbozos de las estructuras maquinarias con una profusa descripción de las mismas cuya información servía para incrementar las indemnizaciones posteriores. Gracias a ello se conoce el número de instalaciones industriales que contenía cada población y algunos datos acerca de sus particularidades como el número de piedras de los molinos y batanes o la producción de las serrerías y fábricas de paños.

\subsubsection{LOS EDIFICIOS INDUSTRIALES}

Las formas constructivas de estos primeros edificios preindustriales no diferían del resto de inmuebles. El sillarejo seguía siendo el material más utilizado para la construcción de los muros y la cubierta era de listones de madera y teja árabe aunque en algunos molinos todavía se utilizaba la paja. Lo único que variaba era el destino de las fábricas y la maquinaria interior que contenían.

En la mayoría de los casos la planta era rectangular o se adscribía al terreno en el que se asentaba y difería en dimensiones dependiendo del trabajo que se realizase en su interior. De este modo existen edificios destinados a la molienda de pequeñas

\footnotetext{
${ }^{270}$ CARO BAROJA, Julio. Tecnología popular española. Madrid, 1986.

${ }^{271}$ GONZÁLEZ TASCÓN, Ignacio. Fábricas hidráulicas españolas, y Molinos y ferrerías en el valle del Duero. Estudios sobre historia de la ciencia y de la técnica. Valladolid, 1987-88; Molinos y ferrerías en el valle del Duero. Estudios sobre historia de la ciencia y de la técnica. Tomo I. IV Congreso de la Sociedad Española de Historia de las Ciencias y de las Técnicas. Valladolid 22-27 de septiembre de 1986. Valladolid, 1988.

272 ALONSO GONZÁLEZ, Joaquín-Miguel. Los molinos tradicionales en la provincia de León. León 1993, GARCÍA TAPIA, Nicolás. Molinos tradicionales. Valladolid, 1997; GARCÍA CASTELLÓN, Fernando. Los molinos y fábricas de harina en Castilla y León. Salamanca, 1997; JUNQUERA, Carlos. Molinos tradicionales. León, 2005.
} 
dimensiones y talleres de serrería o grandes complejos molinares que rondaban los 200 $\mathrm{m}^{2}$.

La introducción de las turbinas hidráulicas en el siglo XIX no supuso una transformación en el panorama industrial tradicional. La principal fuente de energía en la ZACEL era la fuerza motriz del agua utilizada para el movimiento de los molinos, batanes y serrerías. También se usaba la energía calorífica para las herrerías, hornos y caleros. Las labores destinas a molienda siguieron realizándose con los mecanismos tradicionales, pues el elevado coste de estas turbinas no hacía rentable su uso y éstas solo se introdujeron en los grandes talleres de serrerías y pequeñas centrales eléctricas. Su principal función fue la creación de energía eléctrica a partir de la sustitución de los rodeznos tradicionales por transformadores. Los edificios no variaron en estructura, pero sí lo que contenían en su interior. De este modo, un edificio que había sido utilizado como molino, podía albergar una fábrica de luz sin apenas cambios formales.

La propiedad de los edificios industriales podía ser comunal o particular y en ocasiones, especialmente en los molinos, estaban supeditados al pago por su uso en especie o en dinero, el denominado impuesto de la maquila. Gran parte de los edificios industriales eran de propiedad comunal y su utilización se regulaba asignando días a cada usuario como ocurre especialmente en los hornos, molinos y batanes. Monasterios como la abadía de Arbas y parroquias y ermitas como la de S. Ramón de Mallo, poseían molinos propios con cargas impositivas por su uso ${ }^{273}$. No se han encontrado noticias de la pertenencia al poder señorial de ninguno de estos talleres o fábricas, lo que no supone que en diversos períodos los grandes señores pudieran tener un impuesto sobre labores concretas. La propiedad particular de estos primeros edificios industriales fue muy común especialmente en diversos oficios como los herreros, carpinteros o panaderos. Los propietarios ejercían un monopolio no sólo sobre la molienda, sino también sobre el transporte de harinas.

\subsubsection{Molinos}

La palabra molino se define por la RAE como máquina para moler, compuesta de una muela, una solera y los mecanismos necesarios para transmitir y regularizar el

\footnotetext{
${ }^{273}$ A.D.L. Fondo parroquial de Mallo de Luna. Apeo de bienes de la Capellanía de la Portería de Mallo. Barrios de Luna, año 1772. Doc. n ${ }^{\circ} 1704$.
} 
movimiento producido por una fuerza motriz, como el agua, el viento, el vapor u otro agente mecánico. También se atribuye la palabra al artefacto con que, por un procedimiento determinado, se quebranta, machaca, lamina o estruja algo y específicamente a la casa o edificio en que hay un molino. Los trabajos de molienda en la zona que nos ocupa abarcaban principalmente la trasformación del cereal en harina, ya fuera para consumo humano o para la producción de piensos de animales.

La cantidad de molinos que en el siglo XVIII ${ }^{274}$ se contabilizan en la ZACEL da una idea de la importancia de la industria molinera en esta zona de montaña, aunque su número no se debía tanto a la producción de cereal, sino más bien al aprovechamiento hidráulico de los riachuelos en pequeños molinos de escorrentía que agilizaban las labores de molienda.

\begin{tabular}{|l|l|l|l|l|}
\hline POBLACIÓN & MOLINOS & TIPOLOGÍA & $N^{\circ}$ PIEDRAS & APROVECHAMIENTO \\
\hline Arévalo & 7 & Harinero & 1 & Agua del arroyo \\
\hline Barrios & 10 & Harinero & 1 & Agua del arroyo \\
\cline { 2 - 5 } & 8 & Pisones & 1 & Fuerza humana \\
\hline Campo & 1 & Harinero & 1 & Agua del arroyo \\
\hline Casasola & 1 & Harinero & 1 & Agua del arroyo \\
\cline { 2 - 6 } & 1 & Molinón & 2 & Río Luna y electricidad \\
\hline Lagüelles & 8 & Harinero & 1 & Agua del arroyo \\
\hline Mallo & 3 & Harinero & 1 & Agua del arroyo \\
\hline Miñera & 8 & Harinero & 1 & Agua del arroyo \\
\hline Mirantes & 6 & Harinero & 1 & Agua del arroyo \\
\hline Oblanca & 2 & Harinero & 1 y & Agua del arroyo \\
\hline Sta. Eulalia & 2 & Harinero & 1 & Agua del arroyo \\
\hline
\end{tabular}

El molino contenía una serie de infraestructuras necesarias para su funcionamiento que englobaban no solo al edificio en sí sino también la zona circundante del mismo.

\footnotetext{
${ }^{274}$ A.H.P.L. Marqués de la ENSENADA. Catastro. Barrios de Luna. 1752. Rollo 23-24. Miñera de Luna.
} 1752. Rollo 3. Santa Eulalia de las Manzanas. 1752. Rollo 224. 


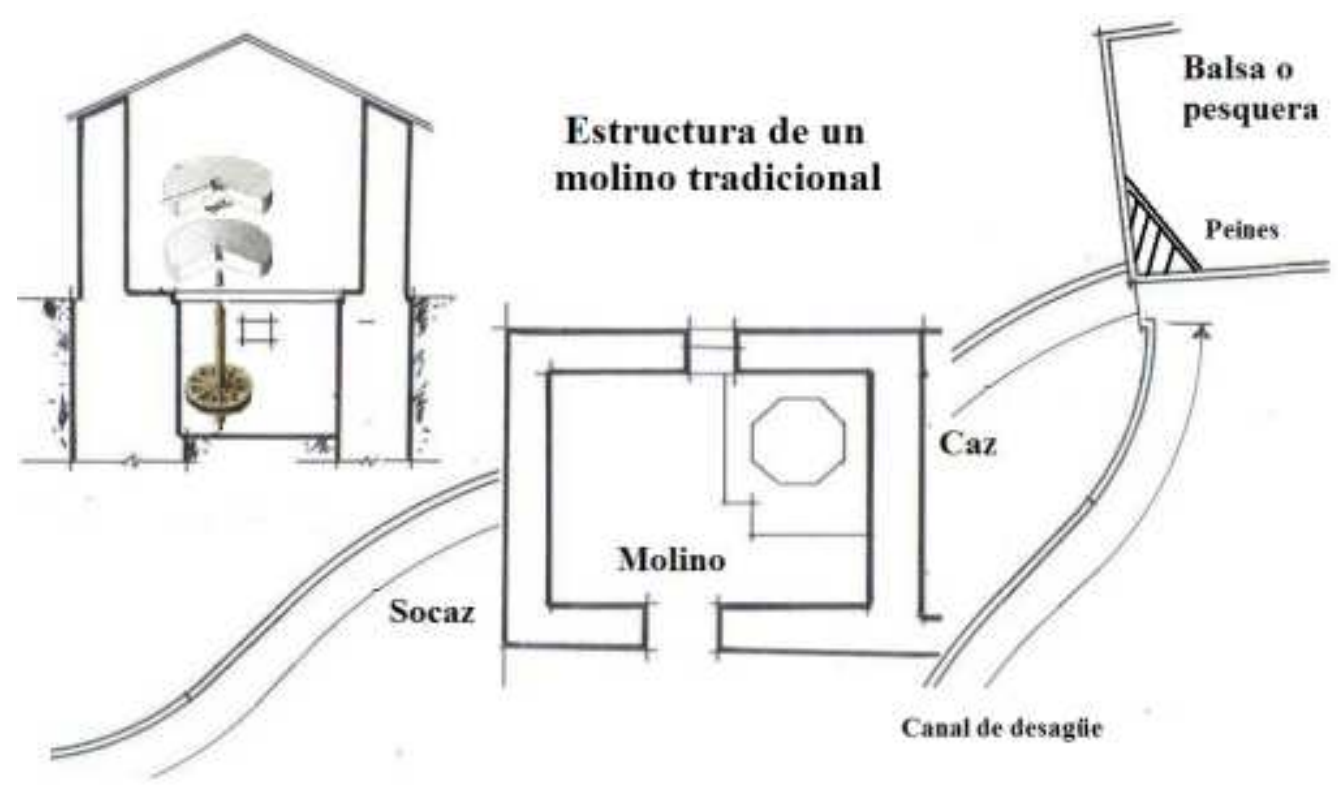

Ilustración 41. Esquema de la estructura de un molino tradicional.

La envergadura de los edificios dependía de la función del molino y el número de muelas y máquinas complementarias que contuviese además de otras construcciones subsidiarias. Los más primitivos poseían unas dimensiones reducidas, en torno a los 16 $\mathrm{m}^{2}$ de superficie, pues en su interior solo contenían una muela, mientras que otros complejos podían llegar hasta los $90 \mathrm{~m}^{2}$ incluyendo almacenes y otras dependencias.

La planta era cuadrangular con muros de piedra de mampostería y una cubierta a dos aguas con teja o cuelmo sobre listones de madera. Tenían una única entrada y se iluminaba a través de una ventana de reducidas dimensiones ${ }^{275}$.

En los molinos más tradicionales la maquinaria se sujetaba por un forjado de madera sobre cargaderos de pilastras de piedra labrada que formaban un arco de medio punto. En los molinos más modernos y de mayores dimensiones los materiales utilizados distaban de los tradicionales empleando aquellos que poseían una mayor resistencia a la humedad como el cemento, el ladrillo y el mortero hidráulico. La cubierta era de pizarra o teja curva. El tejado estaba compuesto por una armadura de madera y pizarra de buena calidad. Estos materiales se introdujeron de manera tardía en 
la zona debido a su novedad y especialmente a su carestía, lo que ocasionó que sólo se utilizasen en los grandes complejos molinares como el Molinón de Casasola ${ }^{276}$.

\section{Captación de aguas}

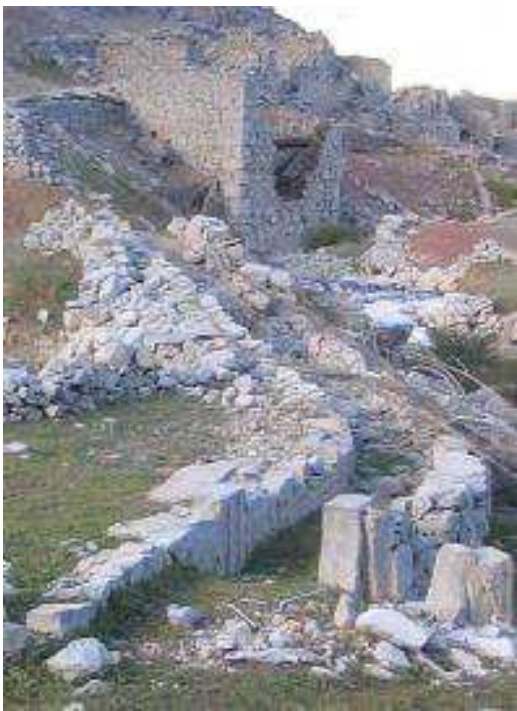

Ilustración 42. Canal de captación de las aguas. Lagüelles

Para conseguir el agua necesaria para las labores de molienda, el río o arroyo debía ser modificado en embalses y canalizaciones. El sistema de captación de las aguas podía hacerse mediante tres formas diferenciadas: una presa de escollera, una balsa o pesquera, o un depósito circular a modo de cubo.

La presa era uno de los componentes principales para el funcionamiento de los molinos en aquellas zonas donde la corriente de agua no era suficiente. La presa se construía en un lugar cercano al molino y normalmente se usaba también para el riego de los terrenos cercanos, como prados y pastizales, para regular en cierta medida el nivel de las aguas y en algunas zonas para la pesca de truchas. En la ZACEL predominaba la tipología de presa de escollera, con forma piramidal, levantada con mampuestos y sillería hidráulica o con materiales pobres como cantos rodados o ramajes muy pisados para que aguantasen el empuje de la corriente y no filtrasen demasiada agua al cauce. La parte superior se cubría con un murete que soportaba el peso del agua.

El segundo tipo de captación de aguas consistía en una balsa o pesquera anexa al molino que contenía unos peines metálicos con varios dientes verticales que servían para interceptar materiales arrastrados por la corriente de agua y evitar su paso hacia el rodezno. Este depósito se situaba en altura con respecto al molino para dar mayor fuerza y presión al agua. Tan solo existía un ejemplo de este tipo en Lagüelles en el que el agua del arroyo se recogía en un depósito circular o cubo adosado al edificio. Este sistema se debía principalmente a la irregularidad de los riachuelos y a la insuficiente potencia de los mismos. Se componía de un canal que desviaba el agua a una estructura cilíndrica o pozo que servía de almacén de la misma. Cuando el agua acumulada

${ }^{276}$ A.G.C.H.D. Casasola. C/05432. No 4462. Año 1950. 
adquiría cierta presión, se soltaba para dar fuerza al rodezno. Esta edificación se asentaba sobre la roca y aprovechaba el caudal de una presa cercana a través de un pequeño canal de $1.80 \mathrm{~m}$. de largo y $0.40 \mathrm{~m}$. de ancho excavado en la roca. El canal estaba cubierto con losas de piedra y abastecía a un pozo o cubo de $5 \mathrm{~m}$. de profundidad realizado con mampostería hidráulica. Lo más característico era la construcción de un sifón a presión por el que se obtenía la fuerza suficiente para mover la maquinaria.

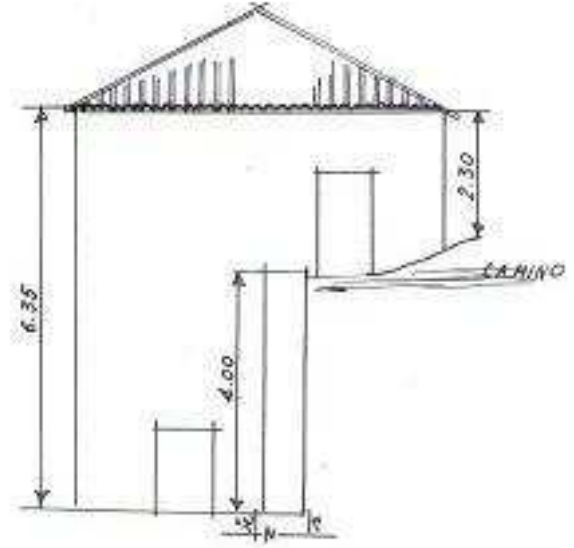

FRENTE

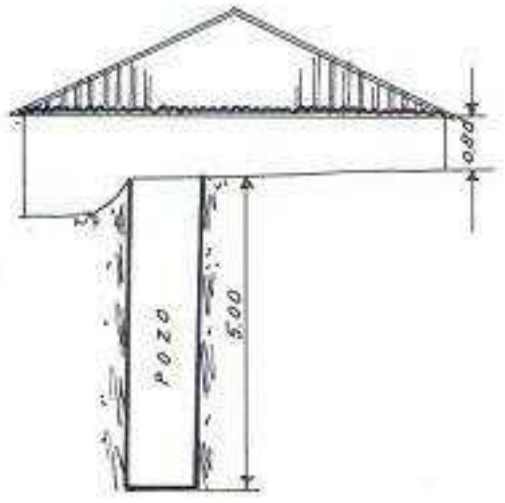

LATERAL DCHA

Ilustración 43. A.G.C.H.D. Lagüelles. C/05465. Nº 4487. Año 1954-1955. Finca 2097.

El sistema de captación de las aguas de los molinos se hacía gracias a un canal denominado caz que estaba construido con mortero hidráulico y cerrado con unos pasos de losa. El canal daba acceso al molino y se abría o cerraba dependiendo de las necesidades por una pequeña compuerta manual. El caz aprovechaba la caída natural del agua cuyo chorro ejercía la fuerza necesaria para mover el rodezno ${ }^{277}$.

El canal de entrada de agua era único, mientras que el de salida era doble, uno para el uso del molino y otro para aliviar la corriente que no era necesaria para la molienda. El agua sobrante de la presa se desviaba a un aliviadero denominado socaz. Al exterior se diferenciaba claramente por la utilización de un vano adintelado con una viga de madera o una piedra monolítica o con arcos de medio punto de lajas verticales, sillares o ladrillo. 


\section{Maquinaria}

La clasificación típica de los molinos depende de las formas del eje de la rueda del molino y del uso y aprovechamiento hidráulico del mismo. Aunque esta clasificación se basa en las formas derivadas de la localización de la rueda, como molinos de eje vertical y de eje horizontal, en la ZACEL todas las arquitecturas utilizaron el eje vertical por lo tanto esta clasificación no sería la acertada.

Lo más apropiado en este caso es basarse en una clasificación dependiendo de la estructura del edificio en sí. Sin ánimo de crear un estudio en profundidad acerca de los elementos que componían la maquinaria molinar típica, a continuación se describe de manera resumida aquellos más importantes y característicos en los molinos de la ZACEL.

La maquinaria molinar correspondía a la tipología de molino de rodezno. Estaba distribuida en dos o más plantas claramente diferenciadas: la inferior, donde iba instalado el rodezno con una abertura por donde se le daba salida al agua, y la superior o sala de moler, donde se encuentra el mecanismo de molturación propiamente dicho.

El piso inferior se conoce como la sala de rodeznos, cárcavos o arcos. En este espacio se localiza el rodezno, una rueda hidráulica horizontal con palas o álabes que giran gracias a la fuerza de la corriente del agua que cae desde un salto de más de metro y medio a través de un canal ${ }^{278}$. La velocidad de giro de la muela depende del caudal de agua y de las variaciones estacionales.

En el piso superior se encuentra el mecanismo de molturación. La tolva es una caja de madera en forma de tronco de pirámide abierta por debajo. En ella se introduce el grano a través de una canaleja hacia el ojo de la muela. Se sujeta a la estructura por medio de un castillete asentado sobre el guardapolvo que cierra el par de muelas para evitar que la harina saliente se dispersase.

La muela es la piedra que, al girar sobre otra fija, muele el grano. El rodezno transfiere el movimiento mediante un eje vertical o árbol a la muela superior llamada volandera que gira sobre otra muela inferior fija denominada solera ${ }^{279}$.

\footnotetext{
${ }^{278}$ GARCÍA TAPIA. Molinos, p. 22.

${ }^{279}$ GARCÍA CASTELLÓN. Los molinos, p. 96,
} 

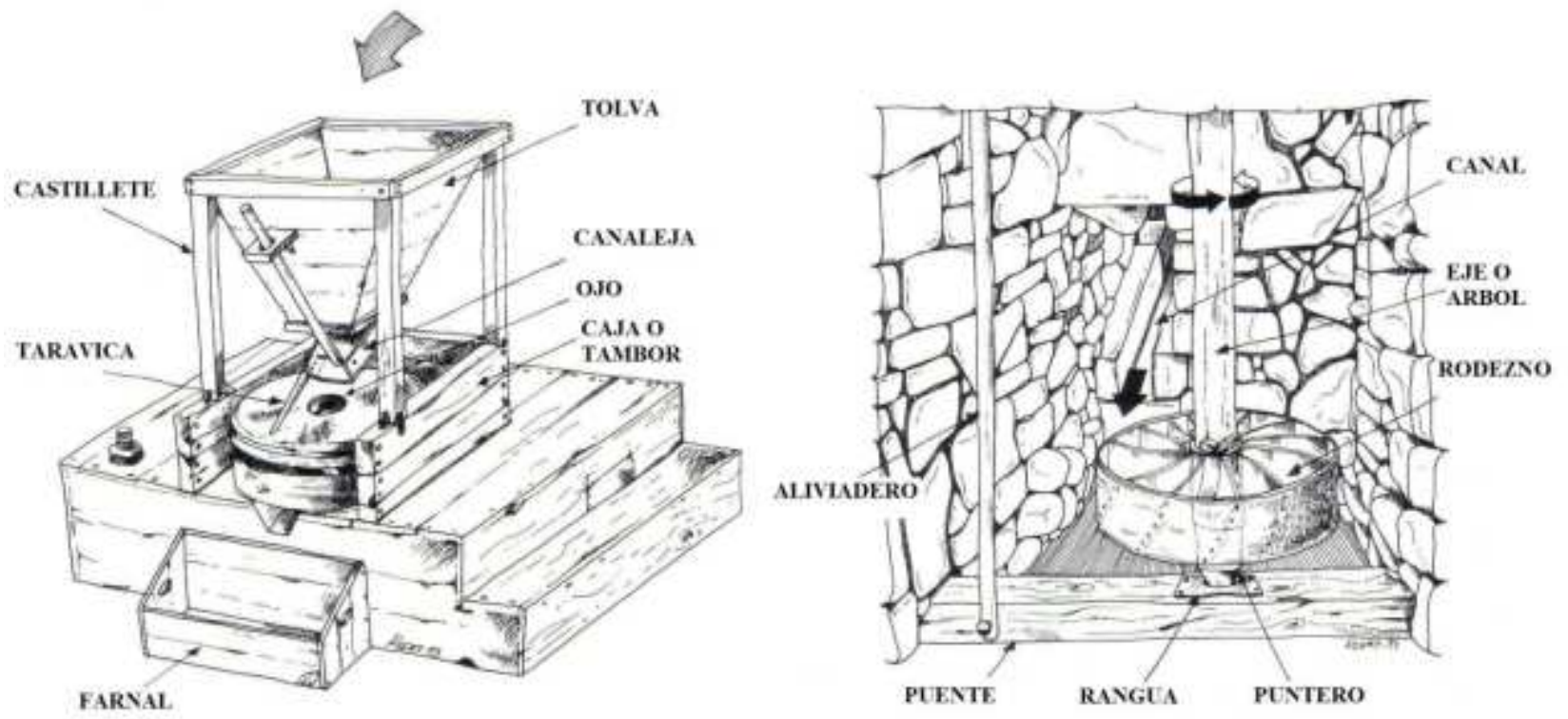

Ilustración 44. ALONSO GONZÁLEZ. Los molinos, p. 44-45.

Los molinos que primaban en el Valle del Luna eran los de la casa Dámaso Perera Román. Este tipo de molino contenía una sola pareja de piedras que se clasificaban en dos grupos:

- El grupo bancada MOLINOS PARA PIEDRAS

- El grupo herrajes

El grupo bancada consistía en cuatro columnas de hierro fundido para la base del molino y una armadura construida con vigueta de doble T. Esta bancada llevaba además cuatro escuadras de hierro fundido para centrar y nivelar las piedras y un bastidor de madera con su cubierta de $1.10 \mathrm{~m}$. de grosor para colocar el guardapolvos, banquillo y tolva.

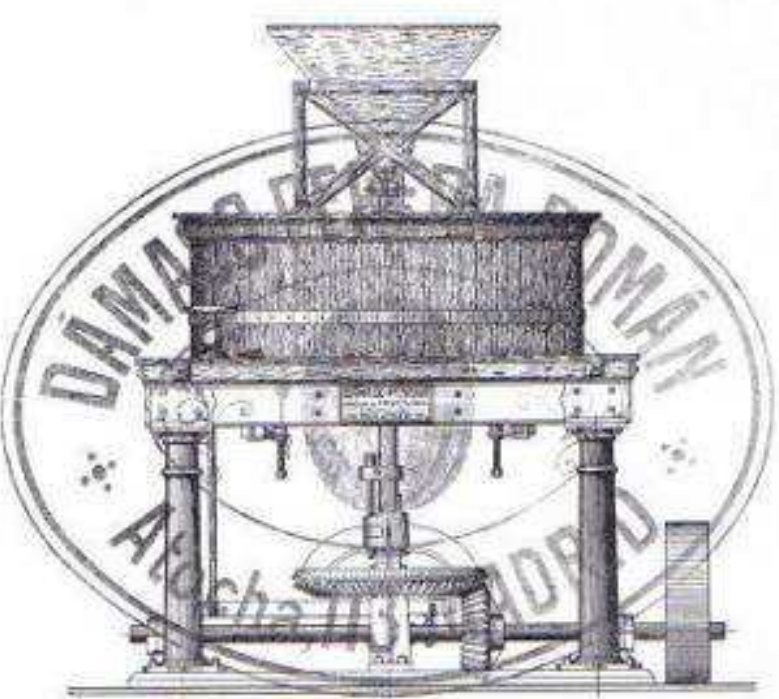

El grupo herrajes ${ }^{280}$ comprendía un juego de engrane de ángulo torneado y dividido, con diente de madera en la corona y de hierro en el piñón. La corona iba provista de un tornillo que permitía desencajar la 
estructura para poder trabajar sólo con la pareja de piedras que se precisase en un momento determinado, sin necesidad de que funcionasen todas.

Tipología

Dependiendo de la estructura del edifico se pueden clasificar los molinos de la ZACEL en tres tipologías:

- Molino de escorrentía.

- Molino vivienda.

- Molino industrial.

El molino de escorrentía, también conocido como molino rastrero, es aquel edificio de una sola planta y una sola muela que se encuentra situado en las laderas, junto a los $\operatorname{arroyos}^{281}$. Suelen ubicarse cercanos a otros molinos de similares características, pues su funcionamiento es grupal. Estos edificios están realizados en mampostería y sus dimensiones son reducidas, apenas sobrepasan los $16 \mathrm{~m}^{2}$ de superficie. Los materiales más comunes son el sillarejo y la teja árabe o cuelmo para la techumbre a dos aguas. Normalmente tiene un solo acceso que además sirve para iluminar la pequeña estancia y si existen vanos, son de pequeñas dimensiones. Contiene una balsa o presa que almacena el agua necesaria para conseguir la potencia adecuada para mover la rueda de los álabes. Esta balsa es muy común en este tipo de molinos rastreros ya que el cauce de los riachuelos a menudo no tiene la fuerza suficiente para hacer mover las muelas. Los molinos de escorrentía poseen una sola piedra y su uso queda establecido de manera comunal por turnos entre los vecinos ${ }^{282}$.

El funcionamiento de estos molinos era sencillo. Una vez que se abrían las presas comenzaba a funcionar el primer molino, el situado en la parte más elevada de la ladera. Al pasar el agua ésta se volvía a embalsar en el siguiente molino que comenzaba a funcionar y así sucesivamente. De esa manera se aceleraba considerablemente el trabajo de la molienda.

Un ejemplo muy claro de este tipo de molino de rodezno se encuentra aún en funcionamiento en Mallo de Luna.

\footnotetext{
${ }^{281}$ ALONSO GONZÁLEZ. Los molinos, p. 23.
}

${ }^{282}$ GARCÍA GRINDA. Arquitectura. Tomo I, p.85. 

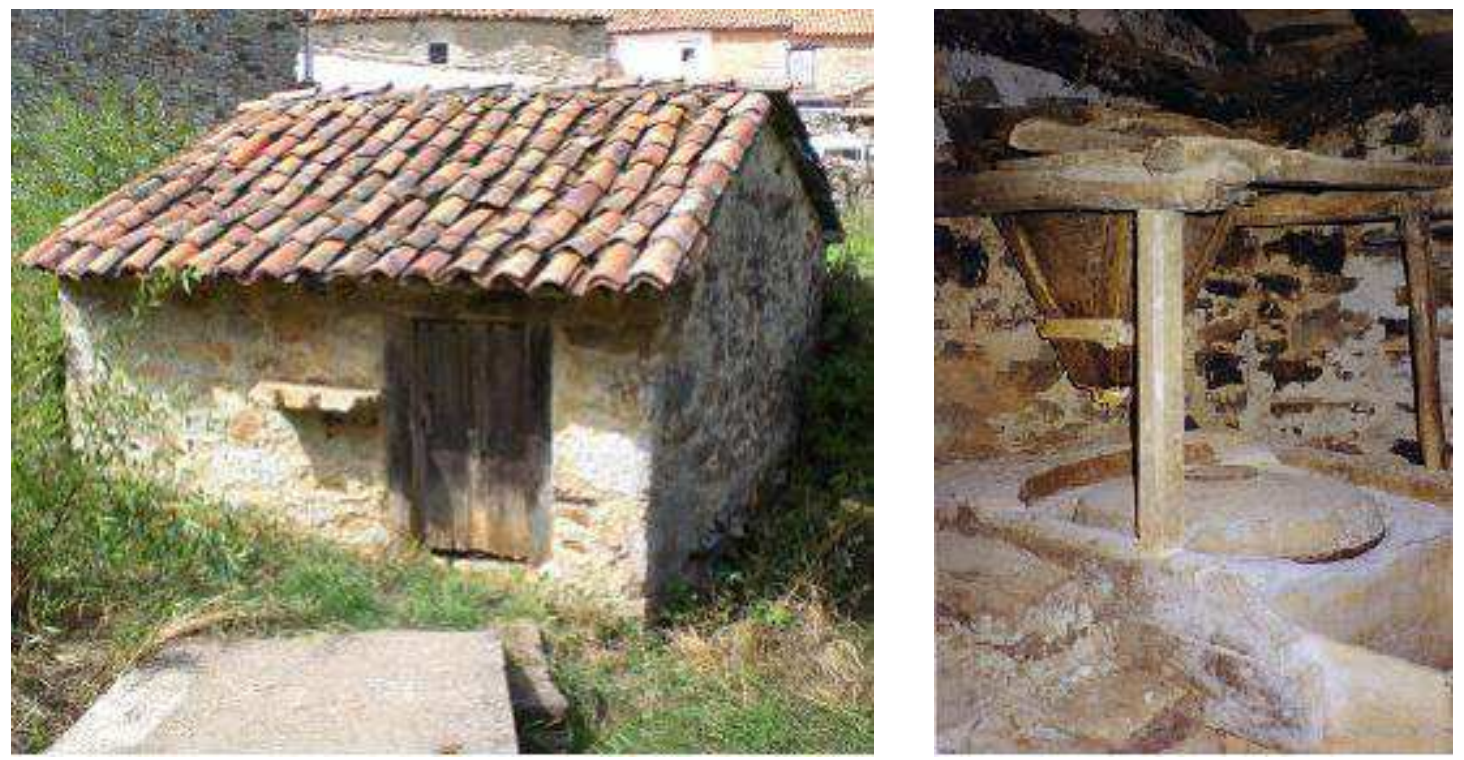

Ilustración 46. Molino de Mallo de Luna.

Este molino data del siglo XVIII ${ }^{283}$ y formaba parte de uno de los seis molinos harineros de uso vecinal que se citan en el Catastro del Marqués de la Ensenada. La planta tiene forma cuadrada con unas dimensiones de $16 \mathrm{~m}^{2}$. una altura máxima de 2,70 m. y una anchura de $4 \mathrm{~m}$. en todas sus caras. El edificio se cubre a dos aguas con teja árabe sujeta sobre listones de madera. Conserva el canal de captación y el de desagüe. A través de una compuerta de hierro se desvía el agua necesaria para el funcionamiento. La sala de la molienda se ilumina sólo por el vano de la puerta. Este vano posee una piedra sobresaliente sobre la que se posa el saco de harina para así facilitar su maniobrabilidad.

En el piso inferior se conserva el rodezno con las palas de hierro que son movidas por la fuerza del arroyo. El rodezno lleva el movimiento a la parte superior por medio de una viga de hierro llamada árbol. En el piso superior se conserva íntegramente el castillete con la tolva de madera y la única piedra muy desgastada por el uso. También se puede observar el cajón de depósito de la harina que cierra el conjunto estructural. Al ser un molino comunal la manutención del mismo es bastante aceptable ya que la maquinaria funciona perfectamente y en ocasiones puntuales sigue siendo utilizado por los vecinos para la molturación del grano en harina.

${ }^{283}$ A.H.P.L. Marqués de la ENSENADA. Catastro. 1752. Mallo de Luna. 
El segundo tipo de molino

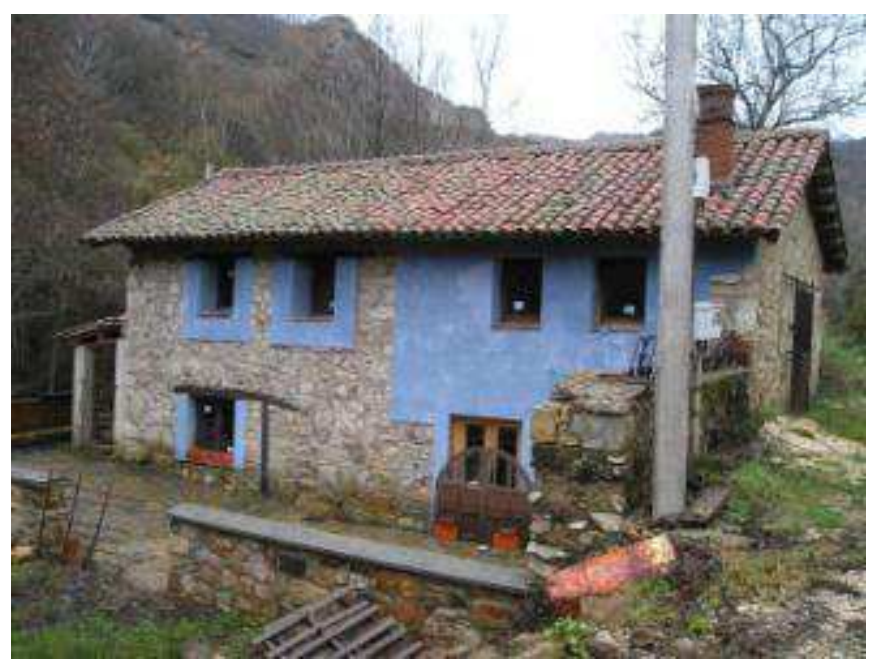

Ilustración 47. Molino particular. Barrios de Luna. es el denominado molino vivienda cuya diferencia fundamental es su división en dos pisos, la superior destinada a la vivienda del molinero y la inferior dedicada a la instalación de la maquinaria. El edificio también contaba con una serie de dependencias anexas como corrales, gallinero, cuadras y hornos ${ }^{284}$.

Destacamos el ejemplo del molino sobre el arroyo Oreo de Barrios de Luna debido a su estado de conservación. El edificio ya estaba documentado el Catastro del Marqués de la Ensenada en el siglo XVIII $^{285}$. Originariamente la planta poseía unas medidas de $13 \mathrm{~m}$. x $6.20 \mathrm{~m}$. sin contar el añadido lateral de la caseta. El material utilizado es la piedra cuarcita de Barrios y la madera, aunque actualmente se ha incorporado el cemento para la llanería. El edificio se divide en dos partes, la superior dedicada a la vivienda para los propietarios y la inferior en la que se ejercían las labores de molienda. Se cubre con un tejadillo a dos aguas. La maquinaria interior contiene una sola piedra de moler actualmente en desuso.

El tercer tipo es el molino industrial, también denominado como molino maquilero $^{286}$. Este se disponía en las zonas de continuo tránsito de agua y su funcionamiento estaba destinado a la molienda industrial introduciendo, en algunos casos, la producción de energía eléctrica. Se cimentaba con hormigón hidráulico de buena calidad para aguantar la humedad. Los soportes de los cargaderos estaban sujetos con pilastras de medio punto de piedra labrada, así como las esquinas y la fachada principal. Los muros eran de mampostería en seco con mortero de cal. Las dependencias estaban construidas con mampostería de mortero enfoscado. Los pisos se dividían a través de vigas de madera con baldosines sobre las bóvedas de ladrillo. La cubierta se realizaba en pizarra y teja curva sobre una armadura de madera ${ }^{287}$. Dentro de esta

\footnotetext{
${ }^{284}$ A.G.C.H.D. C/05439-2. No 4461 Año 1948-52.

285 A.H.P.L. Marqués de la ENSENADA. Catastro. 1752. Barrios de Luna. Rollo 23-24.

${ }^{286}$ ALONSO GONZÁLEZ. Los molinos, p. 20.

${ }^{287}$ A.G.C.H.D. C/ 05434. No 4461. Año 1942-51.
} 
tipología encontramos algunos ejemplos en el Valle del Luna, como el Molinón de Casasola.
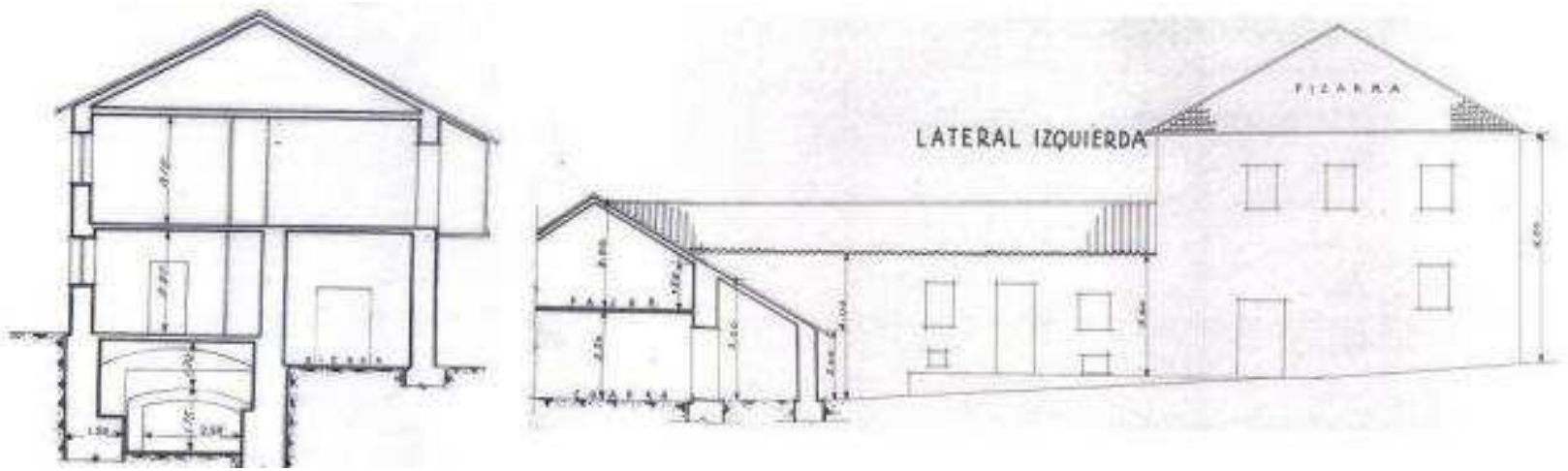

Ilustración 48. A.G.C.H.D. Casasola. El Molinón. C/05439. № 4462 . Finca 3054.

El Molinón de Casasola ocupaba una superficie total $245.61 \mathrm{~m}^{2}$ y estaba dividido en dos niveles. En el piso superior se encontraban las dependencias destinadas para la vivienda con gran cantidad de dormitorios para albergar a los trabajadores. La planta baja estaba dedicada a la instalación de la maquinaria de moler y a otras estancias como un taller, horno y serrería. Este molino de harinas y piensos anteriormente era una antigua vivienda de dos plantas que fue rebajada en la segunda planta para la instalación de los aparatos de molinería, quedando por lo tanto la primera planta convertida en sótano.

El edificio tenía dos molinos. Uno de ellos poseía una piedra de $1,40 \mathrm{~m}$. de diámetro destinada para piensos y harina que se accionaba mediante una turbina ${ }^{288}$. En esta planta se instalaron las transmisiones, correas y demás instrumentos necesarios.

El otro molino se utilizaba para moler el grano de consumo humano destinado a la venta en las poblaciones cercanas. La altura total de los muros era de 4,5 m. con una superficie de $87.43 \mathrm{~m}^{2}$. La sala de la maquinaria tenía una turbina con un sifón de hormigón, una máquina limpiadora de grano, un carril con vagonetas para llevar el grano a los distintos departamentos, instrumentos de cernido y limpieza y elevadores de harina. La fuerza continua de la corriente era usada para otras labores que se ejercían dentro del edificio como la serrería o el horno eléctrico ${ }^{289}$.

El edificio contaba con unos canales de captación y desagüe para proporcionar agua al molino. Éstos recogían el agua de la presa de escollera que tenía una compuerta

${ }_{289}^{288}$ A.G.C.H.D. C/05439-2. No 4461. Año 1948-52. 
de desagüe y alcantarillas situadas debajo del cauce de entrada ${ }^{290}$. Mantenía también un muro de defensa situado en la parte N. del molino para evitar las inundaciones. Además poseía dos puentes, uno de fábrica sobre el canal de desagüe y otro de madera ubicado en el cauce de entrada.

\subsubsection{Serrerías}

Las carpinterías fueron muy comunes a lo largo del Valle puesto que la madera era uno de los materiales imprescindibles para la construcción de viviendas y muebles. Los carpinteros acabaron siendo los oficios más desarrollados dentro de la ZACEL y su importancia es destacable por la calidad de los talleres y la introducción de turbinas eléctricas en los últimos años. Hay que destacar que estos oficios se seguían haciendo a mano hasta bien entrado el siglo XX, por lo que los talleres de carpintería no dependían exclusivamente del material aportado por las serrerías hidráulicas.

El edifico que contenía los talleres de carpintería no difería del resto. En ocasiones los carpinteros utilizaban espacios dentro de sus viviendas aunque lo más habitual era un edificio exento de una sola planta cuadrada que contenía en su interior los utensilios necesarios para el trabajo. Cabe destacar la población de Mirantes en la cual se concentraban la mayor parte de los talleres de carpintería de la ZACEL.

En las serrerías se cortaban y preparaba la madera para el trabajo de carpintería. Existían dos grandes serrerías en la ZACEL que abastecían de forma casi continuada las necesidades de todo el Valle y zonas colindantes. Estas son las de la Truva y Casasola.

\begin{tabular}{|l|c|l|l|l|}
\hline POBLACIÓN & SERRERÍA & DATACIÓN & $\begin{array}{l}\text { TALLER DE } \\
\text { CARPINTERÍA }\end{array}$ & DATACIÓN \\
\hline Casasola & 1 & S. XX & & \\
\hline La Truva & 1 & S. XVIII & & S. XIX \\
\hline Miñera & & & 1 & S. XIX-XX \\
\hline Mirantes & & & 3 & \\
\hline
\end{tabular}

${ }^{290}$ Ibídem. 


\section{El edificio}

El edificio que contenía las sierras poseía algunas diferencias con respecto al resto de edificaciones. Estaba elaborado con muros de mampostería con una cubierta de teja a dos aguas sobre listones de madera. Su planta era rectangular y sus dimensiones variaban de unos edificios a otros. Al igual que los molinos, las serrerías hidráulicas poseían una balsa o pesquera que derivaba el caudal del arroyo a través de un caz o canal hacia el molino. El agua sobrante se separaba hacia los aliviaderos construidos en mortero hidráulico que solían contener un puentecillo de madera para favorecer el tránsito.

A diferencia de los molinos, las sierras necesitaban un caudal continuo de agua para poder acometer las labores durante todo el año, por lo que los talleres se ubicaban junto al río Luna y no en pequeños arroyos de escorrentía.

El interior del edificio se dividía en dos espacios, uno destinado a la maquinaria hidráulica y otro para la serrería en sí. Destaca la proliferación de ventanales en comparación con otros edificios cuya función principal era la de iluminar lo más posible la estancia de trabajo. A la entrada del edificio existía un porticado anexo donde se apilaban los troncos que iban a ser utilizados. Este espacio se comunicaba al interior por unos raíles que transportaban los materiales a la sierra.

\section{Maquinaria}

La maquinaria de las serrerías era similar a la de los molinos y tan sólo difería la parte destinada a la sierra que sustituía a las típicas muelas. El desplazamiento de las sierras se producía mediante la fuerza hidráulica sobre un rodezno, al igual que se ha descrito anteriormente en los molinos harineros. El movimiento del rodezno se transfería por el eje o árbol hacia unos engranajes de hierro y un sistema de poleas cilíndricas denominadas volantes, se pasaban el movimiento a la sierra. La sierra podía tener forma de disco o de tira metálica, dentada, larga, estrecha y flexible que se desplazaba sobre dos ruedas que se encontraban en el mismo plano vertical con un espacio entre ellas. Es en este espacio se situaban los maderos que iban a ser cortados.

Para transportar los maderos hasta la sierra se utilizaba un carro sobre raíles con dos garras que sujetaban el tronco. El carro se movía a través de un sistema de 
engranajes accionados por una manivela móvil que facilitaba el deslizamiento. A partir de una cremallera se determinaba el grosor del tablón a cortar ${ }^{291}$.

Tipología

Existen dos tipologías de edificios destinadas a serrerías dentro de la ZACEL:

- Serrería vivienda.

- Serrería industrial.

El primer tipo se diferencia por el hecho de que al taller se le adosa la casa y otros espacios destinados a labores tradicionales que no tenían que ver con las labores de sierra en sí. Es el ejemplo de la serrería de la Truva, en Mirantes, que ya aparece en el Catastro del Marqués de la Ensenada en el siglo XVIII ${ }^{292}$.

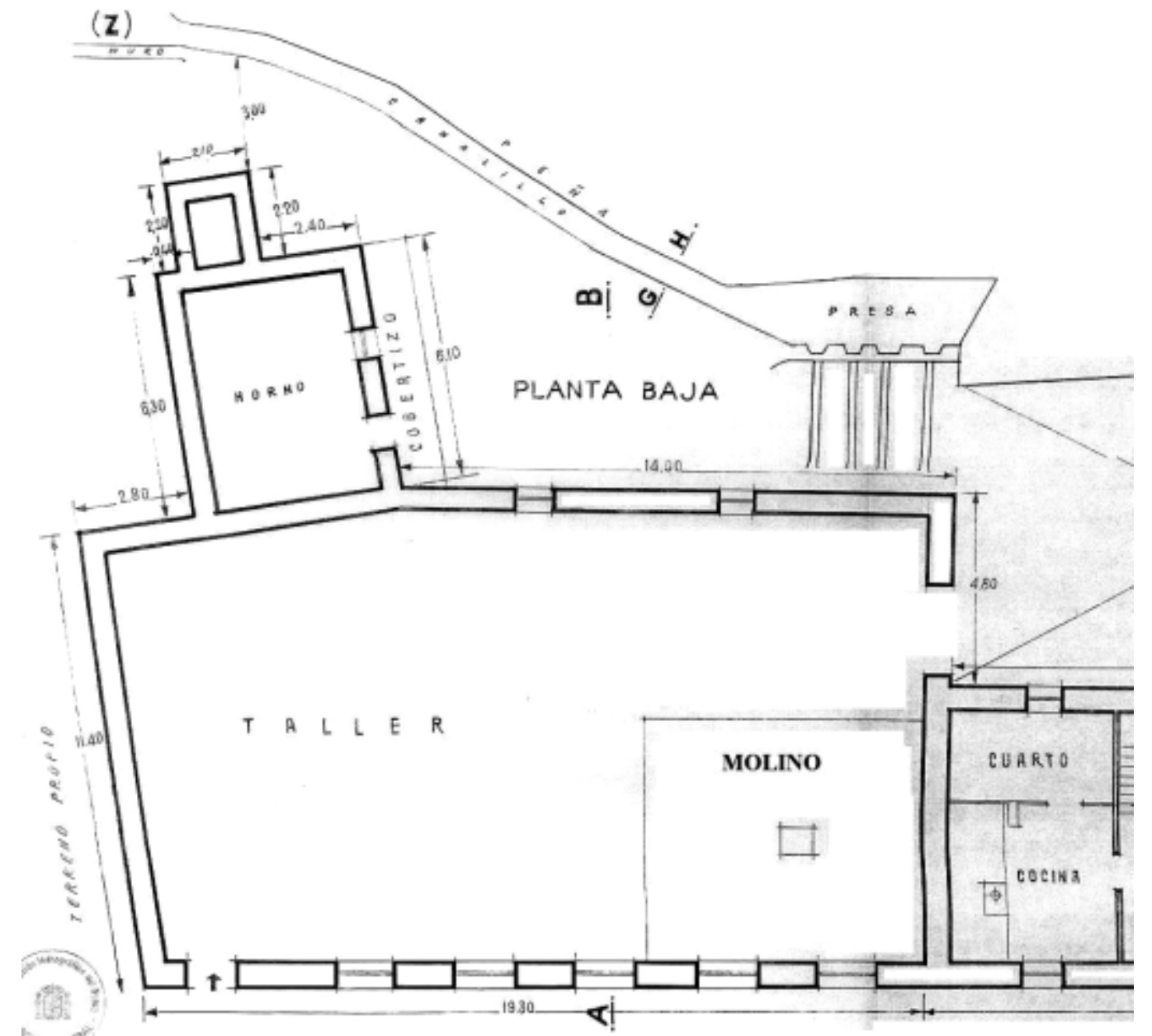

Ilustración 49. A.C.H.D. La Truva. C/05435- N 4461. Año 1950. Finca 193.

${ }^{291}$ FERNÁNDEZ DÍEZ, Alicia. Patrimonio leonés. La arquitectura industrial hidráulica. León, 2005, p. 101.

${ }^{292}$ A.H.P.L. Marqués de la ENSENADA. Catastro. 1752. Barrios de Luna. Rollo 23-24. 
Esta serrería era de propiedad privada y estaba compuesta por un edificio destinado a vivienda de dos plantas y un taller de una sola planta para la sierra. La estructura de la casa se abría en torno a un patio o corral y desde ahí se distribuían las diferentes estancias ${ }^{293}$. Poseía unas dimensiones de superficie total de $993 \mathrm{~m}^{2}$ y sus muros estaban realizados en piedra labrada con paramento liso. Este edificio se situaba en las orillas del río Luna y poseía una presa con un canal de abastecimiento de aguas. La presa tenía $2 \mathrm{~m}$. de altura y estaba sujeta con contrafuertes de hormigón. El canal de captación que suministraba agua al molino estaba excavado en la peña. El edificio contenía dos piedras que otorgaban el movimiento a través de la fuerza del chorro de agua sobre los álabes del rodezno. La maquinaria de moler se sustituía por una serie de poleas que ejercían el movimiento de la sierra. Adosado al taller, y sobresaliendo en planta, había un horno bajo un cobertizo de unos $6 \mathrm{~m}^{2}$.

El segundo tipo es la serrería industrial, destinada exclusivamente al taller y cuya datación suele ser posterior. En Casasola existía un ejemplo de un edificio de una sola planta que poseía una fragua y dos sierras, una de cinta y otra circular.

El edificio era de ladrillo, piedra y tablas de madera para el cerramiento del muro en la zona del río ${ }^{294}$. Tenía una nave rectangular de $69.31 \mathrm{~m}^{2}$. que contenía una sierra de disco de $0.80 \mathrm{~m}$. de diámetro accionada por la turbina de cinta puesta en marcha en $1945^{295}$. Esta sierra poseía una ménsula circular para el montaje de la misma. Para el movimiento de las sierras se utilizaba la energía hidráulica del río Luna contenida en una presa de escollera con excavación en el cauce. El agua se hacía pasar por unos rodillos hasta llegar a un pozo donde la presión movía la maquinaria gracias a una sencilla línea de poleas.

El cauce estaba excavado y contenía una presa de escollera para recoger el agua. Sobre el cauce artificial se elevó un puente de madera para el tránsito. También tenía una piedra para afilar las sierras.

\footnotetext{
${ }^{293}$ A.G.C.H.D. La Truva. C/05435- Nº 4461. Año 1950. Finca 193.

${ }^{294}$ A.G.C.H.D. Casasola. C/05432. N No 4461. Año 1950.

${ }^{295}$ Ibídem.
} 

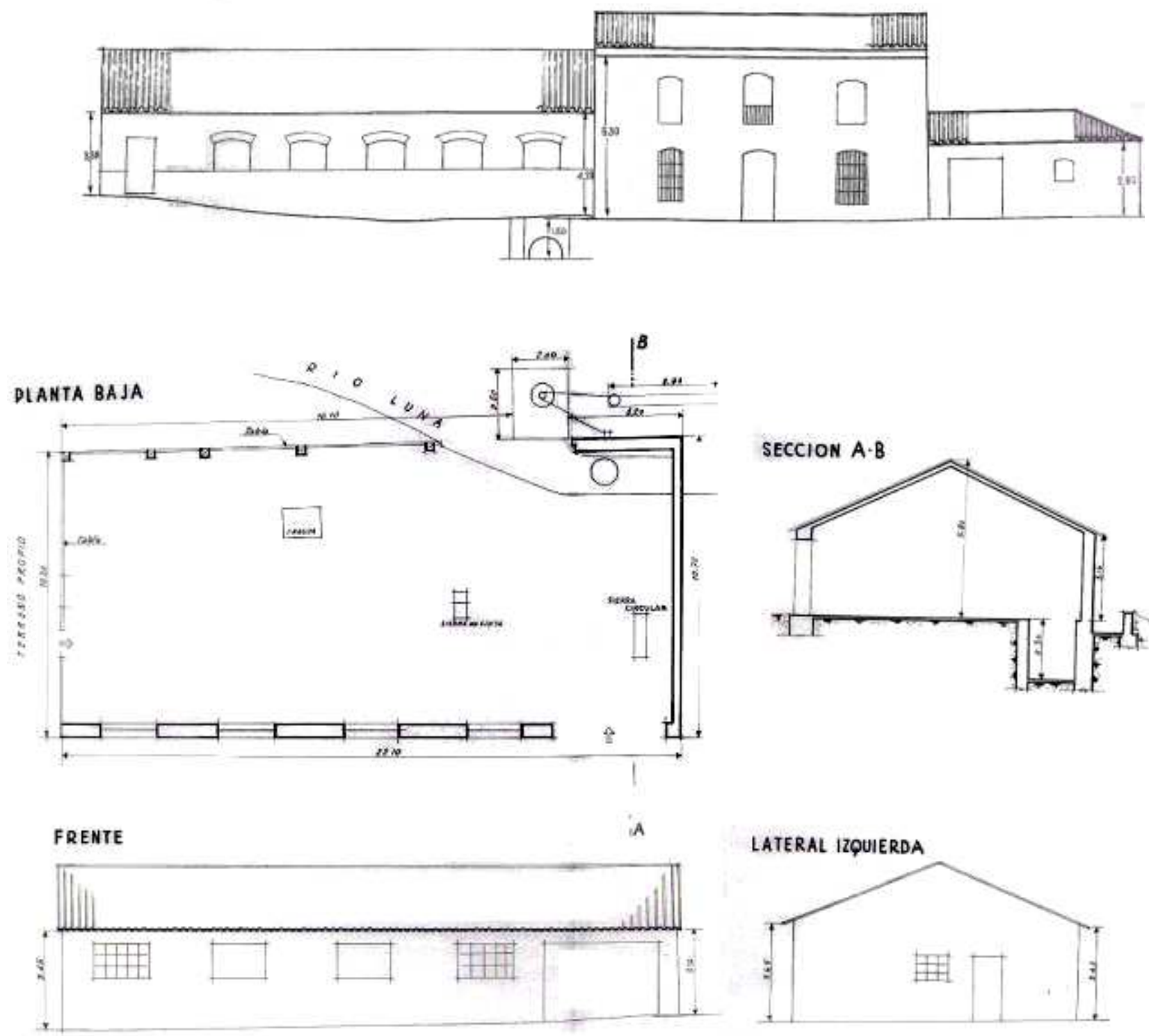

Ilustración 50. A.G.C.H.D. Casasola. C/05432. Nº 4462. Año 1950. Finca 2837.

\subsubsection{Batanes}

El batán se define por la RAE como máquina generalmente hidráulica, compuesta de gruesos mazos de madera, movidos por un eje, para golpear, desengrasar y enfurtir los paños. Dentro de la definición se incluye el edifico que la contiene.

Los batanes se usaban principalmente para tupir aquellos tejidos más holgados. Algunos de ellos eran de propiedad comunal y se usaban por turnos. El mantenimiento y reparaciones eran en régimen de sestaferia, de manera que cada uno de los vecinos 
aportaba una jornada de trabajo. Otros pertenecían a un particular o a una familia que los explotaban cobrando una cantidad en metálico o por el sistema de maquila.

En el Valle del Luna la utilización de batanes era muy común, especialmente para la elaboración de un tipo de paño denominado de Caldas. A mediados del siglo XVIII $^{296}$ la fabricación de paños de Caldas supuso un impulso dentro de la economía de la zona lo que conllevó a la proliferación de diversos batanes y pisones ${ }^{297}$. Oblanca tenía un pisón manejado en $1620^{298}$ por un vecino de Lagüelles. Casasola, Cosera, Barrios de Luna o Lagüelles también poseían batanes de propiedad comunal. En Miñera el molino hidráulico servía como batán en momentos puntuales.

\begin{tabular}{|l|c|l|l|l|}
\hline POBLACIÓN & BATÁN & DATACIÓN & PISÓN & DATACIÓN \\
\hline Barrios & 1 & S. XVIII- XIX & & \\
\hline Casasola & 1 & S. XVIII- XIX & & \\
\hline Cosera & 1 & S. XVIII- XIX & & \\
\hline Lagüelles & 1 & S. XVIII-XIX & & \\
\hline Mallo & 1 & S. XVIII & & \\
\hline Miñera & 1 & S. XVIII- XIX & & \\
\hline Oblanca & 1 & S. XVIII- XIX & 1 & 1620 \\
\hline
\end{tabular}

El edificio

El edificio de batán apenas se diferenciaba del molino excepto por su maquinaria interior. Normalmente poseía una planta rectangular y se situaba cercano al arroyo o río principal. Contenía un canal de captación con presa y un canal de desagüe por donde se evacuaba el agua sobrante. Los muros eran de mampostería o tabla con tejado a dos aguas. Al interior se abría una sola estancia destinada al almacenamiento y transformación de los paños. Destaca la gran rueda hidráulica con los mazos típicos que golpeaban la lana hasta apelmazarla y convertirla en un material muy resistente similar al fieltro.

\footnotetext{
${ }^{296}$ MADOZ. Diccionario, p. 205.

${ }^{297}$ MORÁN BARDÓN. Por tierras, p. 183-186.

${ }^{298}$ MARTÍN FUERTES. Los Quiñones, p.147. Doc. 224.
} 


\section{Maquinaria}

La maquinaria de la que consta un batán se compone de una rueda, el árbol, el armazón o "potro", el recipiente donde se coloca la tela o "imina" y los mazos o "porros". El sistema hidráulico es similar al de los molinos. La rueda impulsada por el agua hace girar el eje o árbol que en su centro lleva incrustadas unas levas que levantan y dejan caer los mazos alternativamente. Estos mazos golpean los tejidos hasta compactarlos. La rueda está compuesta por un gran tronco central que suele medir unos $2 \mathrm{~m}$. de diámetro y más de una docena de palas de madera que se van moviendo a través de la fuerza del agua. Cada uno de los mazos pesa cerca de $100 \mathrm{~kg}$ que golpean una y otra vez sobre un potro de madera con un bastidor. A los lados tiene un par de canales por los que va pasando el agua para refrigerar las piezas y evitar su deterioro.

El batán de Barrios de Luna se localizaba en el barrio de Trabanco y era de uso comunitario. El molino de batán tenía planta cuadrangular con una estructura a dos alturas, siendo la parte inferior la que contenía la rueda y la superior la que mantenía el batán. Poseía un canal de conducción de las aguas del río cerrado por una compuerta. El canal tenía una profundidad de $0.60 \mathrm{~m}$. y una anchura de $2.10 \mathrm{~m}$. por donde pasaba el cauce en sus más de $78 \mathrm{~m}$. de longitud ${ }^{299}$. El canal se bifurcaba en dos ramales, uno para mover la rueda de los mazos y el otro para el desagüe del agua sobrante.
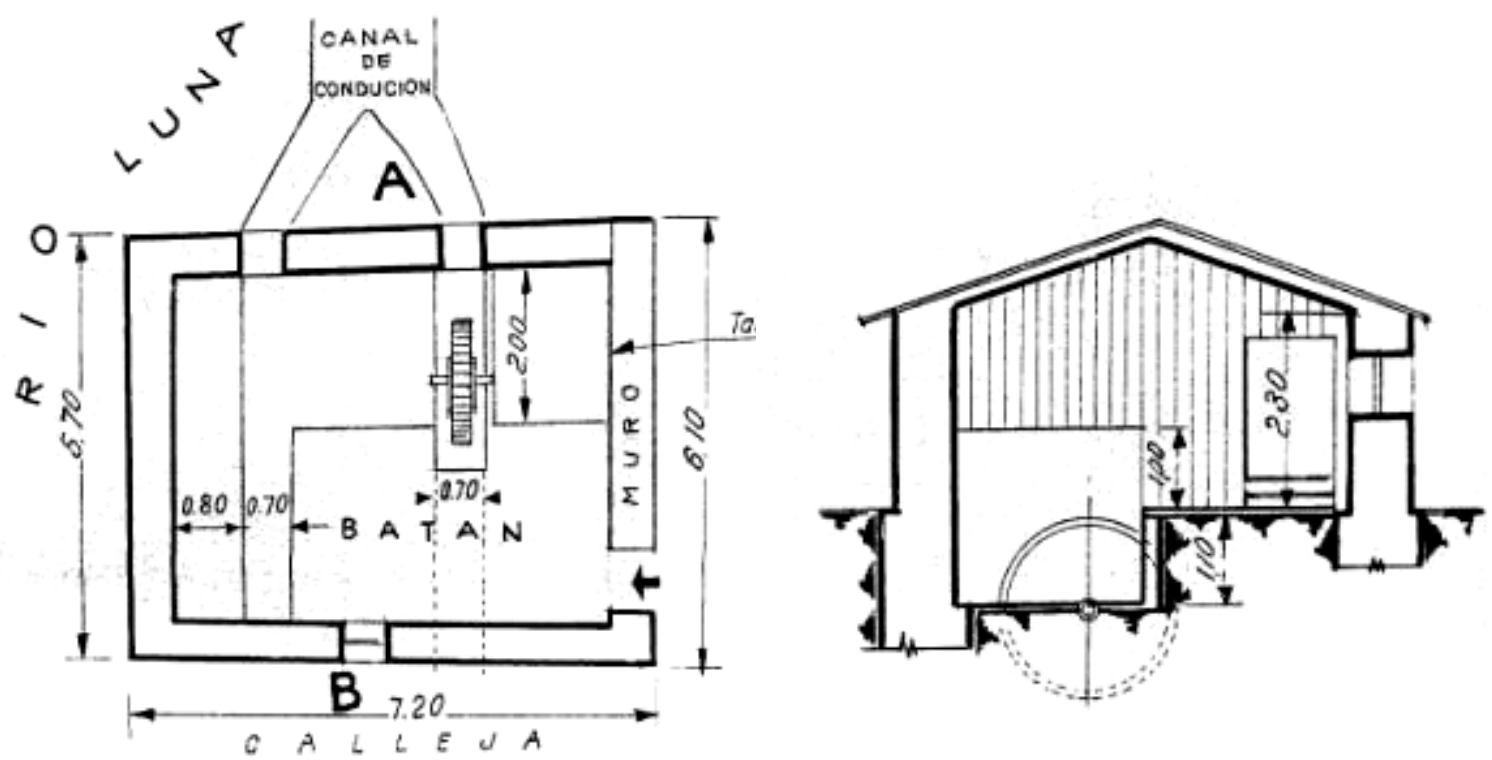

Ilustración 51. Molino de Batán. A.G.C.H.D. Barrios de Luna. C/05435- No 4461. Año 1950. Parcela $n^{\circ} 55$.

${ }^{299}$ A.G.C.H.D. Barrios de Luna. C/05435- Nº 4461. Año 1950. Parcela no 55. 


\subsubsection{Centrales hidroeléctricas}

Continuando con el uso del agua y el aprovechamiento hidráulico, a partir de $1930^{300}$ se comenzaron a realizar en la ZACEL una serie de mejoras en la maquinaria molinar. Las centrales hidroeléctricas aprovechaban el agua embalsada para dar energía a las ruedas de una turbina y así abastecer de luz eléctrica a las poblaciones cercanas.

El uso de estas pequeñas centrales fue una gran innovación a mediados del siglo $\mathrm{XX}$, ya que no sólo se obtenía la luz eléctrica para el consumo humano, sino que además se obtenía energía para otros trabajos más especializados como los hornos eléctricos, lecherías y algunas serrerías. Este avance no supuso por el contrario una revolución tecnológica, ya que la situación del valle y el uso continuado de las labores tradicionales siguió vigente.

\begin{tabular}{|l|c|l|l|}
\hline POBLACIÓN & C. HIDROELÉCTRICA. & DATACIÓN & POTENCIA \\
\hline Láncara & 1 & S. XX & $31 \mathrm{CV}$ \\
\hline Mirantes & 1 & S. XX & $3 \mathrm{Kw}$ \\
\hline San Pedro & 1 & S. XX & 1 y $2 \mathrm{Kw}$ \\
\hline
\end{tabular}

El edificio

La central hidroeléctrica constaba de una serie de edificios repartidos en varias zonas. En primer lugar se encontraba un depósito que servía para el almacenamiento del agua. Solía situarse en una ladera de fuerte pendiente para aprovechar mejor la caída del agua. Para aumentar el potencial del salto se construía una presa con una compuerta que llevaba el agua hacia la turbina eléctrica a través de un canal.

La instalación eléctrica de la central se situaba en un edificio aparte que contaba con todos los elementos necesarios para su funcionamiento, como la turbina, el alternador, cuadro de mandos, trasformador y pararrayos. Otro de los edificios más característicos era la torrecilla de planta cuadrada que en su interior albergaba un pequeño trasformador que convertía la fuerza hidráulica en corriente eléctrica gracias a

${ }^{300}$ ALONSO GONZÁLEZ. Los molinos, p. 43. 
una turbina. La luz se distribuía a través de un cableado de cobre y hierro sobre postes de madera.

Los materiales constructivos eran la mampostería hidráulica con muretes para el depósito, mientras que para el resto de edificios se utilizaba sillarejo y ladrillo. Como en el resto, su tipología no se diferenciaba del resto excepto por los trabajos que se hacían en su interior.

\section{Maquinaria}

Todas las centrales poseían una turbina, un alternador monofásico, transformador, un cuadro de maniobras, un trasformador elevador, una salida de línea con aisladores de muro y un pararrayos. Los trasformadores tenían una potencia similar de $3 \mathrm{Kw}$. con interruptores $\mathrm{y}$ fusibles y solían estar ubicados en una torre apartados del resto.

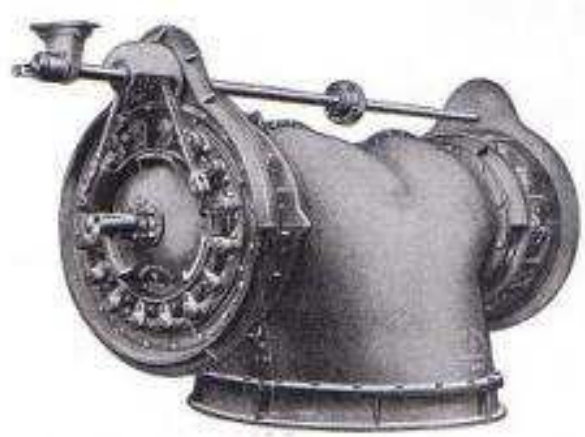

San Pedro de Luna tenía una pequeña presa con cauce y líneas de trasporte de energía para los pueblos de Oblanca, Vega de Robledo, Miñera, Mallo, Ventas de Mallo, Casasola, Caldas, Robledo y Cosera. El muro de la presa tenía $200 \mathrm{~m}$. de longitud y estaba cerrado con una compuerta. La central recogía el agua del río Caldas y lo encauzaba a través de un canal hacia la turbina eléctrica.

El edificio se asentaba en un desnivel que era aprovechado para embalsar el agua $^{301}$. La central poseía una rejilla de entrada del agua, una turbina, un alternador, un transformador, un cuadro de maniobras y una correa de transmisión. También tenía cuatro subestaciones de $1 \mathrm{Kw}$ con caseta sobre postes y tres subestaciones de $2 \mathrm{Kw}$ con caseta de fábrica, cada uno de ellos con sus transformadores correspondientes.

${ }^{301}$ A.G.C.H.D. San Pedro de Luna. C/05462. No 4485. Año 1953-54. 


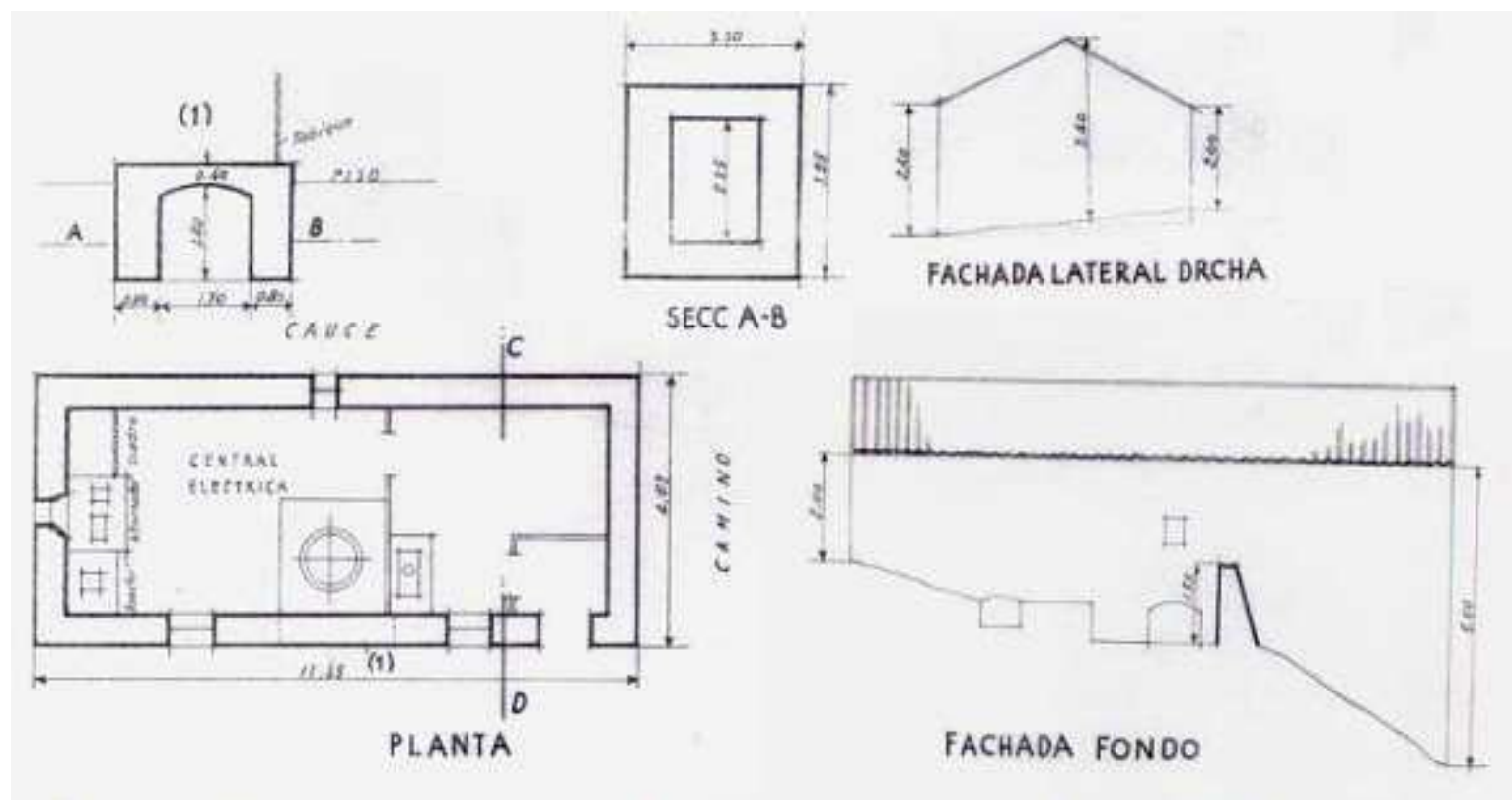

Ilustración 53. A.G.C.H.D. San Pedro de Luna. C/05462. Nº 4485. Año 1953-54. Finca 249.

Mirantes también contaba con una central hidroeléctrica distribuida en varios edificios que pertenecía a la Junta Vecinal. Se componía de una caseta bajo la cual circulaba un canal de salida de agua. El depósito tenía una estructura circular de $36 \mathrm{~m}^{2}$. La fuerza de la caída del agua desde un depósito era trasladada a un pequeño trasformador que distribuía luz al resto del pueblo a través de postes de madera con una potencia de $3 \mathrm{kw}^{302}$.

En Láncara existía otra central de aprovechamiento hidráulico que suministraba electricidad a varios pueblos e industrias particulares. El edificio estaba destinado a usos múltiples: la producción de energía eléctrica, un horno para panadería y una serrería repartidos en una sola planta de $542 \mathrm{~m}^{2}$. El conjunto estaba compuesto por una presa de toma de agua con un canal y compuertas, un molino y una estructura con raíles, además de otras dependencias como cuartos o gallinero. El embalse se adosaba al muro de la propia. La turbina era del tipo Francis de 31 C.V. de eje vertical, un regulador de admisión, un rodillo tensor sobre cojinetes de bronce, un alternador trifásico, un transformador y un cuadro de maniobra. Además contaba con una línea de red de distribución a los pueblos y pequeñas fábricas y una subestación en Sena, Rabanal, Arévalo, Santa Eulalia, Pobladura y Lagüelles con unas torres de ladrillo que a lo largo de más de ocho mil metros de cable y doscientos postes daban potencia lumínica a estas

${ }^{302}$ A.G.C.H.D. Mirantes. C/05490-1. No 5468. Año 1952-1964. 
poblaciones. También daba electricidad para la panadería del pueblo que poseía un horno eléctrico y línea de cableado eléctrico para el teléfono.
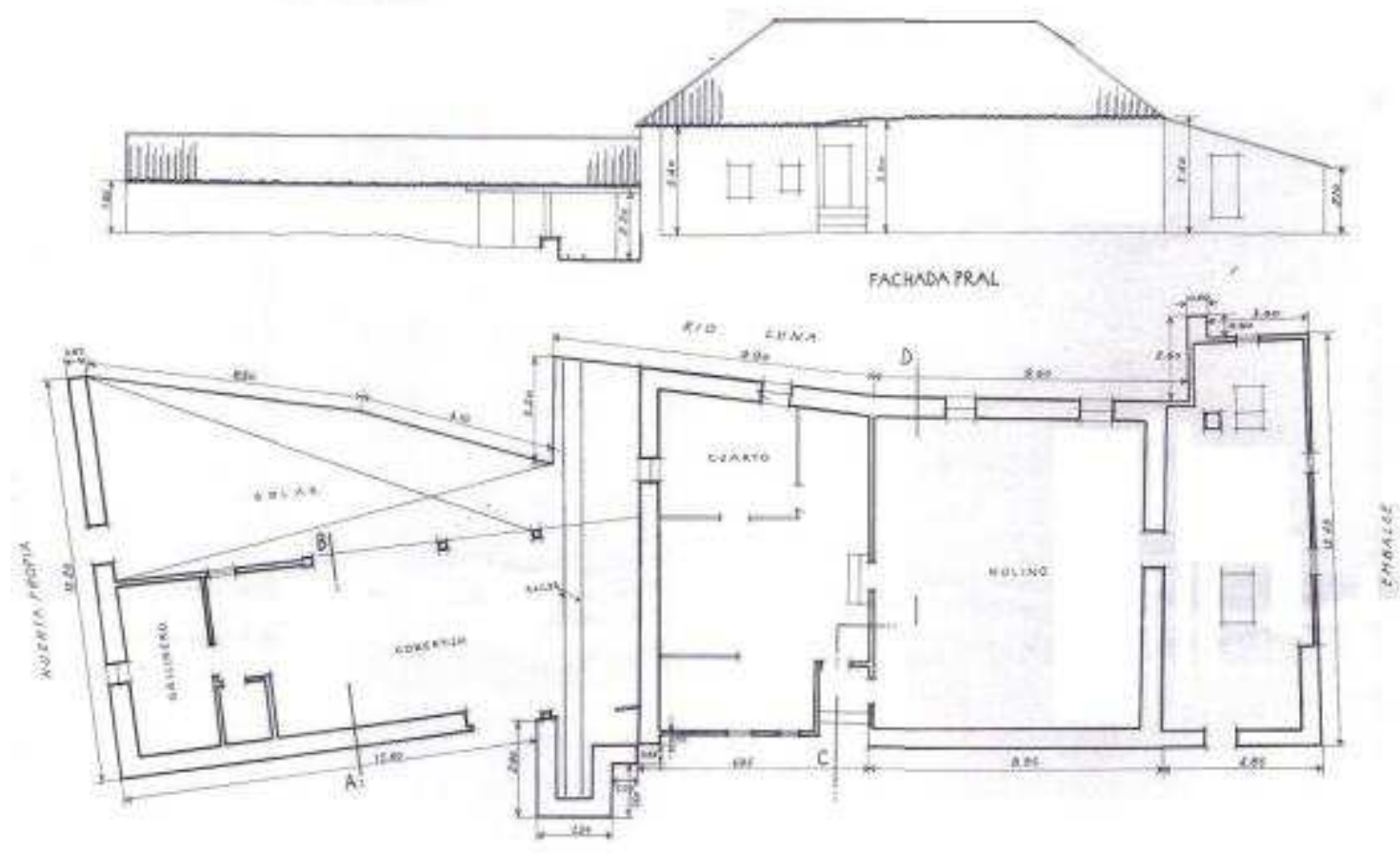

Ilustración 54 A.G.C.H.D. Láncara de Luna. C/05490-1. № 5468.

\subsubsection{Panaderías}

Un elemento significativo dentro de la arquitectura auxiliar de algunos lugares del Luna era el horno comunal empleado en turnos por vecinos. Con la llegada de la electricidad se hicieron relativamente frecuentes los hornos industriales de cocción eléctrica. Estos abastecían diariamente el consumo de varias poblaciones, por lo que la cocción en los hornos tradicionales fue abandonándose paulatinamente quedando en muchas ocasiones relegados o transformados en almacén.

\section{El edificio}

En poblaciones como San Pedro, Lagüelles o Santa Eulalia existían edificaciones realizadas expresamente para este tipo de trabajo. La estructura interior de los hornos era circular y solo en algunas ocasiones sobresalía en planta. El interior estaba fabricado con ladrillo refractario y suelo en piedra de cantería labrada. Al 
exterior se forraba con sillarejo de mampostería. El tipo de horno era de una sola boca que constaba de una campana con una oquedad por la que se introducía la leña ${ }^{303}$. Delante del horno existía una habitación destinada al amasado y fermentación del pan. La cubrición de estos edificios se hacía con teja, pues la paja no era un material seguro para las labores relacionadas con el fuego.

\begin{tabular}{|l|c|l|}
\hline POBLACIÓN & PANDERÍA INDUSTRIAL & DATACIÓN \\
\hline Lagüelles & 1 & S. XX \\
\hline Santa Eulalia & 1 & S. XIX- XX \\
\hline San Pedro & 1 & S. XIX- XX \\
\hline La Truva & 1 & S. XIX- XX \\
\hline
\end{tabular}

Característico es el ejemplo de Santa Eulalia que poseía una estructura de una sola planta cubierta con teja. El espacio colindante se acotaba con una cerca de mampostería que albergaba un pequeño portal. Dentro se ubicaba la estancia de la cocina y el horno. El horno sobresalía en planta en forma circular y se protegía mediante una pared de mampostería cubierta con el propio tejado de la casa. Tenía una superficie totalmente circular de $5 \mathrm{~m}^{2}$. Al frente del horno se encontraba la cocina que servía como almacén del pan o de piezas de carne.

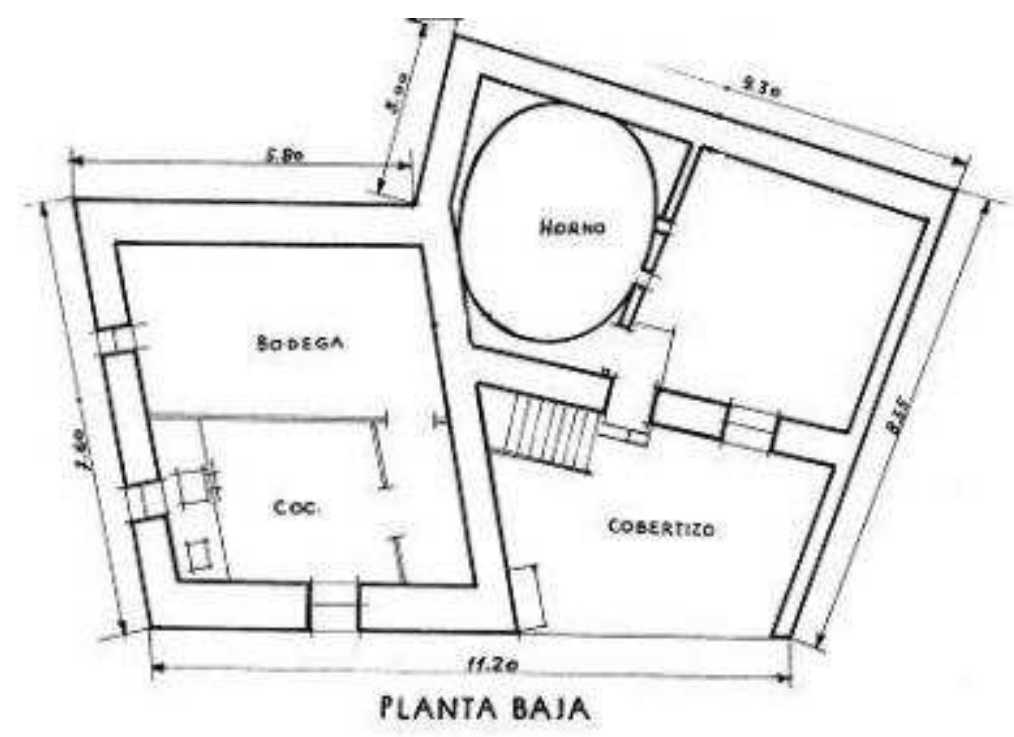

Ilustración55 A.G.C.H.D. San Pedro de Luna. C/05462. N 4485. Año 1953-54. Parcela 165'

${ }^{303}$ ALONSO PONGA, José Luis. La arquitectura del barro. Madrid, 1989, p. 40. Cuando la leña se había consumido, se amontonaban las cenizas en los laterales y en la propia base del horno se colocaba el pan. 
En San Pedro de Luna existían dos hornos industriales que seguían las mismas características constructivas. Ambos ocupaban una de las dependencias de la casa particular y constaban de una superficie total de unos $50 \mathrm{~m}^{2}$ cuya forma circular no sobresalía en planta. Se componían de un recubrimiento refractario y una bóveda térmica con cierres mecánicos ${ }^{304}$. Delante del horno se encontraba otra habitación utilizada como panera para realizar las labores del amasado. Ambos hornos poseían una instalación de agua corriente, algo poco común en la época.

\subsubsection{Lecherías}

La aparición de las lecherías fue tardía siendo habituales a partir del primer tercio del siglo XX. Su uso comienza a extenderse con la llegada del transporte del automóvil y a las nuevas técnicas de conservación de los productos perecederos. Su uso fundamental era la recogida de la leche para su posterior transformación y venta, pues el ordeño de los animales solía hacerse por los dueños de las ganaderías que se reunían en cooperativas para sacar un mayor beneficio de sus productos.

\begin{tabular}{|l|c|l|}
\hline POBLACIÓN & LECHERÍA & DATACIÓN \\
\hline Lagüelles & 1 & S. XX \\
\hline Láncara & 1 & S. XX \\
\hline Miñera & 2 & S. XX \\
\hline Oblanca & 1 & S. XX \\
\hline
\end{tabular}

Tradicionalmente la trasformación de los productos lácteos era un trabajo manual, que se hacía en las casas, y cuyos productos no se comercializaban, sino que servían para el abastecimiento familiar. Es a partir de la creación de cooperativas, que ofrecían una salida comercial a la leche, cuando comienzan a multiplicarse las lecherías.

La transformación de la leche en manteca, el producto más demandado, requería de un trabajo duro y especializado que consistía en el continuo movimiento del producto hasta la separación de la materia grasa. Antiguamente este trabajo se hacía en casa

${ }^{304}$ A.G.C.H.D. San Pedro de Luna. C/05462. No 4485. Año 1953-54. 
agitando un pellejo. Este laborioso trabajo requirió pronto de una mecanización para satisfacer las crecientes necesidades de la zona.

Lo más habitual era que los propios ganaderos llevasen en carros la leche fresca del día a la lechería, lugar donde se transformaba en una serie de productos lácteos menos perecederos. La leche de oveja apenas se utilizaba, pues los rebaños eran de carácter trashumante y su función era la cría de corderos. La leche de vaca era la más común y con ella se hacían quesos, mantequillas y sueros. El producto final, fundamentalmente leche fresca y mantequilla, se transportaba en camiones para su posterior comercialización.

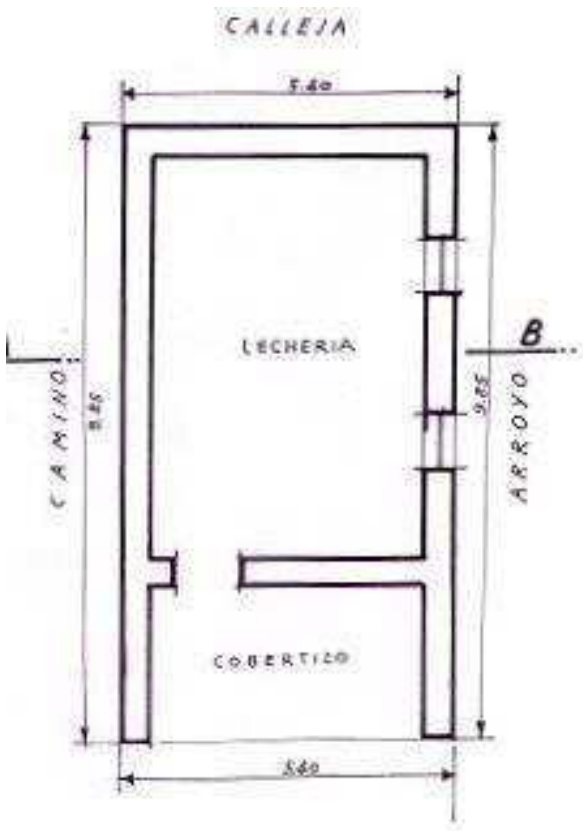

PLANTA

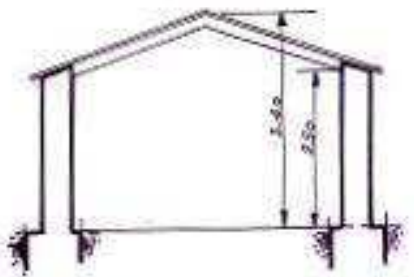

SECCIONA.B

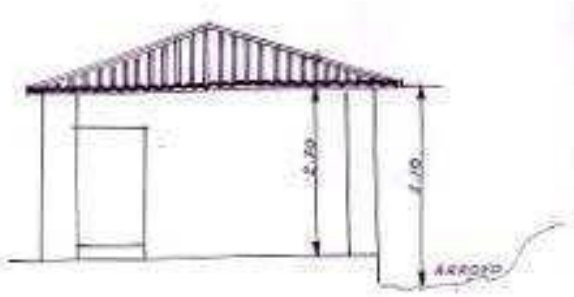

FACHADA PRAL.

\section{Ilustración 56. A.G.C.H.D. Miñera de Luna C/05435- No 4461. Año 1949. Finca 2649}

La lechería estaba compuesta por un edificio de una sola planta de muros de mampostería y tejado a dos aguas con un cobertizo al exterior. El espacio interior era diáfano para poder realizar las labores de recogida y transformación de la leche, mientras que el cobertizo servía como almacén.

El interior solía estar mejor iluminado para poder llevar a cabo las labores industriales. Dentro se calentaba la leche y se pasaba a una desnatadora. La nata extraída se fería en una feridora o recipiente en forma de tambor del cual se sacaba el suero. La nata se convertía en mantequilla y su comercialización era muy apreciada por la calidades de la leche de las vacas montañesas. 
En algunas cooperativas como en Oblanca, la lechería tenía un pozo propio del que se extraía el agua con una bomba para abastecer las necesidades de la empresa.

Cabe destacar el molino de la finca 2057 de Lagüelles, que pertenecía a la cooperativa llamada El Porvenir, dedicado a la producción industrial de manteca con maquinaria accionada por la energía eléctrica aportada por la fuerza hidráulica.

\subsubsection{Fraguas}

La fragua era uno de los pilares de la actividad agrícola, pues se ocupaba del herraje de los animales y la fabricación de los aperos de labranza necesarios para los trabajos de campo. El trabajo de los herreros solía ejecutarse en la propia casa, siendo escasos los edificios individuales que se dedicaban exclusivamente a fraguas.

\begin{tabular}{|l|c|c|}
\hline \multicolumn{1}{|c|}{ POBLACIÓN } & FRAGUA & DATACIÓN \\
\hline Láncara & 1 & S. XIX-XX \\
\hline Miñera & 1 & S. XIX-XX \\
\hline Oblanca & 1 & S. XIX-XX \\
\hline San Pedro & 1 & S. XIX-XX \\
\hline
\end{tabular}

Las fraguas estaban compuestas por un cobertizo que servía de almacén y una estancia diáfana en el interior en la cual se disponía el fogón. Junto a él existía un espacio destinado a leñera y carbonera. Los elementos imprescindibles de los que se componían las fraguas eran el fuelle y el yunque ${ }^{305}$. El fuelle era de cuero y se movía de forma manual para dar el "aire" a las brasas tanto de carbón vegetal como mineral. En el yunque se daban forma a los materiales golpeándolos manualmente con una maza cuando el hierro aún se mantenía caliente. Una vez dada la forma y enfriada en agua se remataba con los afiladores. Los oficios más comunes consistían en la fabricación de herraduras y herrajes, puesto que las balconadas y otros elementos de hierro se importaban de otras zonas cercanas como la Magdalena.

${ }^{305}$ GARCÍA GRINDA. Arquitectura. Tomo I, p. 301. 
El espacio para el almacén del combustible era igualmente importante y ocupaba muchas veces la mayor parte del edificio, pues era necesario que se encontrase perfectamente seco para mejorar las labores del herrero.

La fragua estaba realizada con muros de mampostería no concertada y se cubría con una techumbre a dos aguas de teja sobre listones de madera. El número de fraguas hace pensar en la escasa demanda de este tipo de productos y en su posible compra a poblaciones cercanas. El uso de alguna de estas fraguas era temporal dependiendo de las necesidades del momento. Cuando el edificio no era utilizado podría servir como almacén o establo para el ganado menor.

En Lagüelles encontramos un ejemplo de fragua bastante característico. Se trata de una estructura rectangular de una sola planta de unos $148 \mathrm{~m}^{2}$ que se utilizaba también como cuadra o cobertizo para resguardo de los animales.
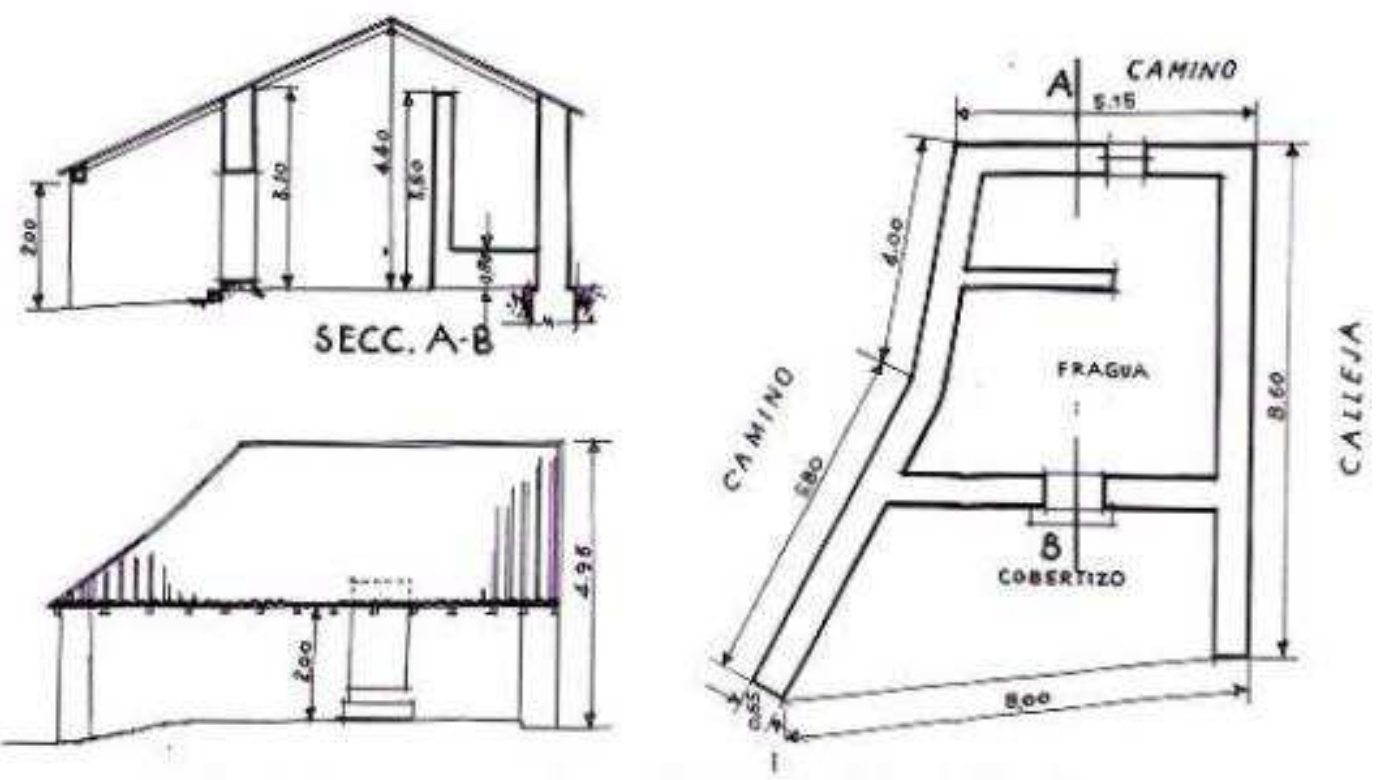

Ilustración 57. A.G.C.H.D. Lagüelles. C/ 05468-2. № 4468. Finca 2946.

\subsubsection{Caleros}

Los caleros no fueron muy comunes en la zona de estudio, pues la comercialización de la cal era mucho más barata que el coste de su producción artesanal. El uso de cal se reducía a la cubrición de los muros tanto interiores como 
exteriores. El barro sustituía las posibles carencias estructurales en la arquitectura. Las únicas construcciones que utilizaban cal eran los grandes edificios como iglesias y ayuntamientos y su exigua demanda hacía que fuese más rentable su compra a otras poblaciones cercanas como la Magdalena.

El calero.

Los caleros se disponían en lugares de fuerte pendiente para facilitar el trabajo de descarga. La materia prima era la piedra caliza, por lo que solían estar cercanos a las canteras. El calero se componía de una oquedad cilíndrica en forma de chimenea situada en terreno de fuerte pendiente y ahorrarse la construcción de gruesos muros de protección. Sobre esta oquedad se erigía una bóveda que formaba la cubierta del horno. En el calero se introducían las piedras calizas y se calentaba a $1.000^{\circ}$ centígrados para obtener la cal viva. Después la cal viva se mezclaba con agua, diluyéndose así las piedras y obteniendo cal apagada. Posteriormente se dejaba secar la pasta y así se obtenía cal en polvo.

En la ZACEL tan solo tenemos noticias de un antiguo horno de cal situado en Cosera, en la ladera O. de la colina del camino que iba desde la capilla de San Lorenzo de Miñera hasta el pueblo. Se componía de un gran pozo de unos $5 \mathrm{~m}$. de profundidad que ya se encontraba abandonado a principios del siglo $\mathrm{XX}^{306}$.

En el Cuartero de Mallo de Luna se documenta la existencia de un horno para hacer ladrillos y del que hoy tan solo quedan ruinas que hacen imposible su descripción formal.

${ }^{306}$ Información dada por Petronilo GUISURGA. 


\subsection{PUENTES}

El puente, según la RAE, es una construcción de piedra, ladrillo, madera, hierro, hormigón, etc., que se construye y forma sobre los ríos, fosos y otros sitios, para facilitar su tránsito.

El río Luna suponía un obstáculo en la circulación de uno de los principales valles de comunicación entre la meseta y la Cordillera Cantábrica, lo que conllevó a la construcción de una gran cantidad de pasarelas de diversos materiales y formas para salvar los diferentes caudales del Luna.

\subsubsection{LOS ESTUDIOS SOBRE PUENTES}

Los grandes puentes han sido considerados, dentro del mundo patrimonial, como obras propias de la ingeniería y los estudios estilísticos sobre ellos no cobraron tanta importancia como los referentes a otro tipo de construcciones inmuebles.

La consideración de los puentes como algo patrimonial será tardía y las primeras monografías se centraron en aspectos técnicos de carácter industrial. A finales de los años ochenta se abrió una nueva corriente de investigación centrada en los puentes y ahondando en su historia, características y tipología como es la obra de Leonhardt Fritz $^{307}$ en la cual se manifiesta el sentido estético referido a la construcción de puentes.

La obra de José Antonio Fernández Ordóñez, Tomás Abad Balboa y Pilar Chías Navarro ${ }^{308}$ es el primer estudio patrimonial relacionado con este tipo de construcciones haciendo referencia a los más representativos. Sus descripciones de carácter científico han aportado interesante información para el trabajo de esta tesis. Siguiendo esta corriente destaca la obra de Miguel Ángel Aramburu-Zabala Higiera ${ }^{309}$ en la que se hace un repaso por todos los puentes de Castilla y León construidos durante los siglos XVI y XVII. Este libro ha contribuido a la comprensión de algunos aspectos relevantes en torno a la construcción de los principales puentes de la ZACEL. La obra de

${ }^{307}$ FRITZ Leonhardt. Puentes: estética y diseño. Lausanne, 1986.

${ }^{308}$ FERNÁNDEZ ORDÓÑEZ, José Antonio; ABAD BALBOA, Tomás y CHÍAS NAVARRO, Pilar. Catálogo de puentes anteriores a 1936. León, 1988.

${ }^{309}$ ARAMBURU-ZABALA HIGIERA, Miguel Ángel. La arquitectura de puentes en Castilla y León 1575-1650. Valladolid, 1992. 
Inocencio Cadiñas Bardeci ${ }^{310}$ extrae información documental acerca de los ingenieros que contribuyeron a la restauración y transformación de diversos puentes de la provincia de León entre los que se incluyen los de la ZACEL. Posteriormente surgen otro tipo de obras como la de Antonio Valbuena González ${ }^{311}$ que hace un estudio acerca de los puentes medievales que daban acceso a la ciudad de León.

Las últimas obras publicadas centran su atención en la creación de los puentes y sus constructores como es la obra de David B. Steinman y Sara Ruth Watson ${ }^{312}$ en la que se da importancia no solo a la ingeniería sino también al momento y circunstancias en las que se construye, que acabarán formando parte de un testimonio patrimonial futuro.

En relación a la propia ZACEL, las primeras noticias documentales se han extraído de los diversos archivos religiosos y civiles como el del monasterio de Otero de las Dueñas ${ }^{313}$, donde se cita la restauración del puente de Miñera, o el archivo de los Condes de Luna ${ }^{314}$, donde se describen los diferentes pleitos y cargas impositivas que conllevaba el tránsito de mercancías por los puentes del Valle.

Durante la Edad Moderna y hasta el siglo XX, los documentos conservados tratan sobre las continuas restauraciones de los mismos. En el Archivo Municipal del Ayuntamiento de Barrios de Luna $^{315}$ (A.M.B.L.) existe un documento en el cual el concejo de Luna se reúne para llamar a los canteros expertos en caminos y puentes para que arreglasen las vías de comunicación y sobre todo para que se restaurase el puente de San Lorenzo de Miñera, ya que el río se había salido de su curso y en las crecidas se inundaba hacia la parte de la ermita, impidiendo el paso a la otra orilla.

Las primeras publicaciones acerca de la arquitectura de puentes en la ZACEL parten de inventarios del patrimonio provincial como el Diccionario de Pascual Madoz $^{316}$, que describe el puente de Miñera dando datos acerca del número de arcos, y

\footnotetext{
${ }^{310}$ CADIÑAS BARDECI, Inocencio. Puentes de León. (I y II) Tierras de León. № 111-112. Año XXXIX. Agosto 2000- Mayo 2001.

${ }^{311}$ VALBUENA GONZÁLEZ, Antonio. "Los puentes de acceso a la ciudad de León en la Edad Media" en El tributo de las cien doncellas y otros estudios, León, 2012. p. 278-279.

${ }^{312}$ STEINMAN, David B. WATSON Sara Ruth. Puentes y sus constructores Madrid: Colegio de Ingenieros de Caminos, Canales y Puertos, D.L. 2001.

${ }^{313}$ FERNÁNDEZ FLOREZ-HERRERO DE LA FUENTE, Otero. Vol. II.

314 ÁLVAREZ, ÁLVAREZ, César. MARTÍN FUERTES, José A. Catálogo del archivo de los condes de Luna. León, 1977.

315 A.M.B.L. La villa de Caldas, los regidores del concejo de luna durante los siglos XII al XVI y la repoblación forestal, doc. $\mathrm{n}^{\mathrm{o}} 260$ de 1556.

${ }^{316}$ MADOZ. Diccionario.
} 
el Catálogo de Manuel Gómez Moreno ${ }^{317}$ que cita brevemente las características y antigüedad del mismo. En los estudios de César Morán ${ }^{318}$ se vuelve a describir el número de arcos y algunas indicaciones acerca de su trazado irregular.

Durante las obras de construcción del embalse la más extensa fuente documental se extrajo de los planos y justiprecios de las expropiaciones conservadas en el Archivo General de la Confederación Hidrográfica del Duero ${ }^{319}$ (A.G.C.H.D.) Es curioso observar cómo se detallan y miden los puentes pertenecientes a las Juntas Vecinales, pero no se hace mención alguna a aquellos otros que estaban en manos del Estado, como el de Lagüelles. La pertenencia a esta entidad pública ocasionó que no se hiciese necesario el levantamiento de planos ni la descripción de sus características, pues no se iba a proceder al pago de las indemnizaciones. Lo que sí se especificó fue la construcción de los nuevos viaductos y los problemas de estabilidad y mala calidad de los materiales que llevaron a su destrucción y reemplazo por otros más modernos.

Tras la construcción del embalse, las siguientes publicaciones parten de nuevo de la T.D. de José Avelino Gutiérrez González ${ }^{320}$ que repasa de manera arqueológica algunos de los puentes más importantes que contenía la ZACEL como el de Miñera y el de Trabanco.

Finalmente, la web se ha convertido en otra fuente de información relacionada con las arquitecturas más contemporáneas como es el puente atirantado de Fernández Casado. En su web: http://www.cfcsl.com/ podemos encontrar todos los aspectos constructivos referentes al mismo.

\subsubsection{LOS PUENTES EN LA ZACEL}

La importancia de los puentes en la ZACEL es comprensible pues la comunicación para el tránsito de personas y mercancías sobre el río Luna dependía de la calidad, cantidad y el estado de los mismos.

\footnotetext{
317 GÓMEZ MORENO. Catálogo.

${ }^{318}$ MORÁN BARDÓN. Por tierras.

${ }^{319}$ A.G.C.H.D. Embalse de Barrios de Luna. Documentos técnicos.

${ }^{320}$ GUTIÉRREZ GONZÁLEZ. Poblamiento.
} 
Desde la Edad Media la reconstrucción y mantenimiento de las calzadas y puentes recaía sobre la población que, a base de impuestos, donaciones ${ }^{321}$ o hacenderas, debían conservar en buen estado las vías ${ }^{322}$.

Los primeros puentes estaban fabricados con materiales efímeros, como la madera, lo que ocasionaba su reconstrucción anual. A pesar de que esta tipología siguió utilizándose hasta la actualidad, a partir del mundo romano y medieval comienzan a emplearse materiales más duraderos como la piedra. Algunos ejemplos de estos periodos son el puente de S. Lorenzo de Miñera y el de Trabanco de Barrios así como otros cuya datación inicial no ha sido posible identificar como el puente de San Pedro.

La importancia económica de estas estructuras pasó a tener un nuevo componente estilístico a partir del siglo $\mathrm{XVI}^{323}$ en el que su restauración y construcción derivó de un modelo medieval a otro modelo basado en la técnica a lo romano. Ejemplo de esta transformación se muestra en un documento de $1556^{324}$ en la que el concejo de Luna reúne a los canteros expertos en caminos y puentes para acondicionar las vías de comunicación. El veedor real le encarga a Bustamante de Herrera y posteriormente a Juan Bautista de Toledo y Juan de Herrera la reparación de vías y puentes que mejorasen el camino de León a Oviedo, pudiendo encontrarse entre ellos los puentes de S. Lorenzo de Miñera y el de San Pedro de Luna ${ }^{325}$.

Durante los años posteriores la casi totalidad de los puentes de la ZACEL fueron restaurados según sus necesidades variando en ocasiones su forma y haciéndose más robustos no sólo para aguantar la fuerza de las riadas, sino también para adecuarlos al trasporte rodado más pesado.

En 1799 se creó el Cuerpo de Ingenieros de Caminos y Canales del Reino ${ }^{326}$ que optó por una renovación total de las vías y denunció el estado de conservación de los puentes, sin embargo la Guerra de la Independencia frustró esta iniciativa.

En el reinado de Isabel II se favoreció la mejora de caminos y carreteras en la ZACEL al iniciarse el trazado de la carretera de la Magdalena-Belmonte que contenía un total de siete puentes y que fue el eje de comunicación más importante para el

${ }^{321}$ FERNÁNDEZ FLOREZ-HERRERO DE LA FUENTE, Otero. Doc. 801. En un documento de 1297 Elvira de Canales, hermana de María, Monja del monasterio de Otero, dona un maravedí para el puente de Miñera.

${ }^{322}$ SACHEZ BADIOLA. La configuración, p. 303.

${ }^{323}$ ARAMBURU-ZABALA. La arquitectura, p. 63.

${ }^{324}$ A.M.B.L La villa de Caldas, los regidores del concejo de luna durante los siglos XII al XVI y la repoblación forestal .Barrios de Luna, León. 1955, Doc. 260. Año 1556.

${ }^{325}$ ARAMBURU-ZABALA. La arquitectura, p. 64.

${ }^{326}$ FERNÁNDEZ FLOREZ-HERRERO DE LA FUENTE, Otero, p. 33. 
Valle $^{327}$. El estado de conservación de algunos de ellos, como el de Trabanco en Barrios, ocasionó que se desestimase su restauración y se crease una nueva vía atravesando la roca del castillo por un túnel ${ }^{328}$.

En el siglo XX se incorporan nuevos materiales constructivos como el hormigón armado y vigas metálicas en forma de $\mathrm{T}$ como se puede observar en el caso de Lagüelles. Sin embargo, a pesar de los avances técnicos, en las zonas rurales se continuó con el uso de puentes rústicos de madera como el gran pontón de Barrios de Luna o el de Cosera.

La Guerra Civil supuso un nuevo receso debido a la destrucción de las vías para evitar el paso de las tropas. Su reconstrucción fue tardía ya que el Estado no podía hacerse cargo de las obras hasta bien entrados los años cincuenta. En este momento comienza a materializarse la idea del embalse, por lo que las obras de mejora de comunicaciones del Valle se centraron en la proyección de una nueva carretera con viaductos en la zona superior al nivel de inundación. Las Juntas Vecinales seguían siendo las encargadas del mantenimiento de los puentes, pero la falta de medios económicos y la inminente llegada de las aguas del embalse hizo que alguno de ellos, como el puente de S. Lorenzo de Miñera, se restaurase con materiales efímeros como la madera.

El embalse del Luna trajo consigo la construcción de grandes puentes que pretendían salvar el desnivel ocasionado por las aguas del pantano. Para ello se ejecutaron entre 1950 y $1953^{329}$ dos obras similares consistentes en viaductos de doce arcos sobre grandes pilastras de $24 \mathrm{~m}$. de altura. La mala calidad de los materiales empleados ocasionó el derrumbe de uno de ellos, el de Oblanca y el cierre al público del de Aralla. En 1973 se sustituyó el derruido viaducto de Oblanca por uno nuevo tal y como puede observar en la actualidad.

El último gran puente de la ZACEL se construyó en 1983 y fue el proyectado por el equipo de Fernández Casado. Este puente supuso un récord de longitud de luz en la historia del momento y puso el colofón a una larga historia de puentes que atravesaron el Valle y que facilitaron la travesía de los pasos hacia los puertos asturianos o viceversa.

\footnotetext{
327 Ídem p. 315.

${ }^{328}$ GÓMEZ MORENO. Catálogo, p. 141.

329 A.G.C.H.D. C/01289-4. No 5784. Año 1973. Embalse de Barrios de Luna. Documentos técnicos. Proyecto de restablecimiento definitivo de las comunicaciones... Antonio LÓPEZ PELÁEZ.
} 


\section{TIPOLOGÍA}

Desde los puentes más rudimentarios hasta los últimos puentes de hormigón construidos antes del embalse, se extiende un abanico de formas que pueden clasificarse en:

- Puentes sobre rollizos de madera ${ }^{330}$

- Puentes de piedra

- Puentes de cemento y hormigón

\begin{tabular}{|c|c|c|c|}
\hline \multicolumn{5}{|c|}{ PUENTES DE LA ZACEL } \\
\hline Población & Madera & Piedra & Cemento \\
\hline Arévalo & 4 & 1 & \\
\hline Barrios & 2 & & \\
\hline Campo & 3 & & 1 \\
\hline Casasola & 1 & 1 & 1 \\
\hline Cosera & 4 & 1 & \\
\hline Laguielles & & & \\
\hline Láncara & 3 & 1 & \\
\hline Mallo & 5 & 1 & \\
\hline Miñera & & & \\
\hline Mirantes & & & \\
\hline Oblanca & & & \\
\hline San Pedro & & & \\
\hline Santa Eulalia & & & \\
\hline
\end{tabular}

${ }^{330}$ Cabe destacar que no se han registrado todos los pontones, sino sólo aquellos de mayores dimensiones o de los que se tienen noticias, pues su número seguramente sería más elevado del que se muestra en la tabla. 


\subsubsection{Puentes sobre rollizos}

Los puentes sobre rollizos fueron muy comunes en todos los pueblos de la zona. Su fácil y barata construcción los hacía perfectos para salvar pequeños riachuelos. Las escasas dimensiones de estas estructuras ocasionaban que los puentes sólo se utilizasen para el paso a huertas o barriadas aunque existen ejemplos en Barrios y en Cosera que atestiguan la utilización de grandes pontones. Su uso fue continuado hasta el momento de la expropiación del embalse.

La problemática era su fragilidad ante las riadas y la reconstrucción anual cada primavera. El mantenimiento de los pontones se repartía entre los vecinos del pueblo lo que ocasionaba un abaratamiento de los costes en comparación con la construcción de un puente de piedra. La manutención de este tipo de estructuras ya aparece en un documento de $1736^{331}$ en el que el concejo de Luna se quejaba de la continua reparación que los vecinos de los pueblos debían de hacer de los numerosos puentes de madera en la zona.

\section{№4- PUENTE RÚSTICO TIPO}

ESCALA $=1: 100$
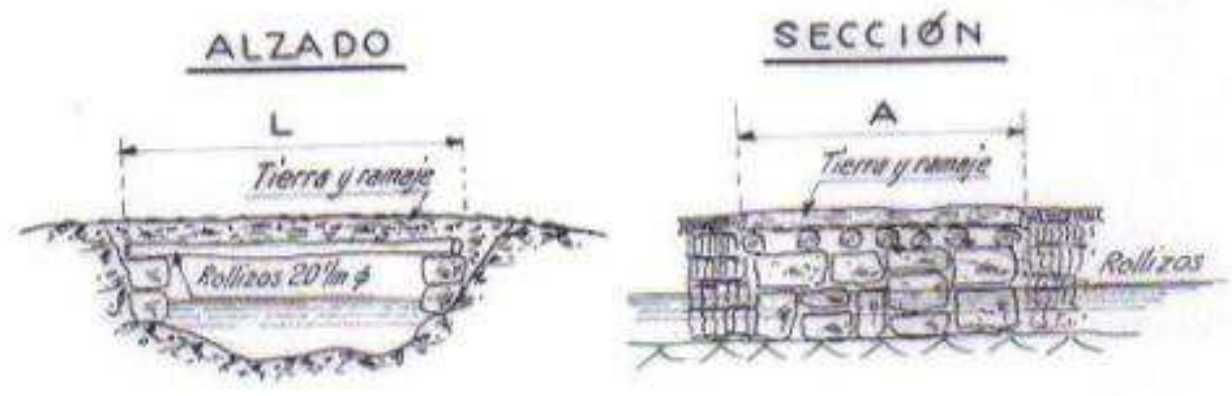

\begin{tabular}{|c|c|c|}
\hline SITUACION & L & $\Delta$ \\
\hline Paso en el camino de S. Larenzo. & 4.10 & 3.60 \\
\hline B $\rightarrow$ sobre al Aio de las Algades. & 4.50 & 2.60 \\
\hline$c$, id id, id & 4,70 & 3.00 \\
\hline 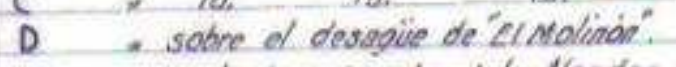 & 5.00 & 3.00 \\
\hline E $\quad x$ en la dessembociotine de lar Norados. & 4.70 & 3.00 \\
\hline
\end{tabular}

Ilustración 58. A.G.C.H.D. Cosera. C/05439-2 Doc. 4462

${ }^{331}$ CARDIÑNAS BARDECI. Puentes, p. 3 
Los materiales de los que están confeccionados los puentes rústicos son principalmente de origen vegetal. La estructura está compuesta por dos troncos de madera de unos $0.20 \mathrm{~m}$. de diámetro que se disponen atravesando el cauce del río. Encima de los mismos se asienta un enmarañado de ramas y tierra pisada entrelazadas sobre el que se colocan musgos o tapines de césped que aseguren el paso. Para evitar la erosión en las orillas del cauce se levantan unos muros de piedra sobre los márgenes del río en los que se apoyan los troncos que sustentan la base del puente.

En la ZACEL existen dos tipos de puentes sobre rollizos. La tipología más sencilla es aquella compuesta por uno o dos trocos de madera con tapines y cuya funcionalidad era la de salvar pequeños riachuelos. La altura de los mismos no superaba los 1,5 a $2 \mathrm{~m}$. y la longitud podía llegar a los 3 o $4 \mathrm{~m} .{ }^{332}$.

El otro tipo de puente se caracteriza por sus mayores dimensiones y la utilización de vigas que daban robustez y seguridad a la armadura. Su longitud era mucho mayor, pudiendo llegar a los $20 \mathrm{~m}$. La forma de los entibos variaba de unos puentes a otros, así por ejemplo en algunos casos, como en Barrios, se usaban vigas en forma de $\mathrm{V}$ invertida a modo de caballete y en otros casos, como Cosera, se hacía con pies derechos. La elección de ambos dependía de la longitud del puente y de la corriente del cauce. Debido al tamaño de los maderos y a la complicación para colocarlos, este tipo de puentes de grandes dimensiones fueron muy escasos. Además, el riesgo de desplome a causa de las riadas hacía que apenas se ejecutasen puentes sobre rollizos de grandes dimensiones.

Puente de rollizos de Barrios de Luna

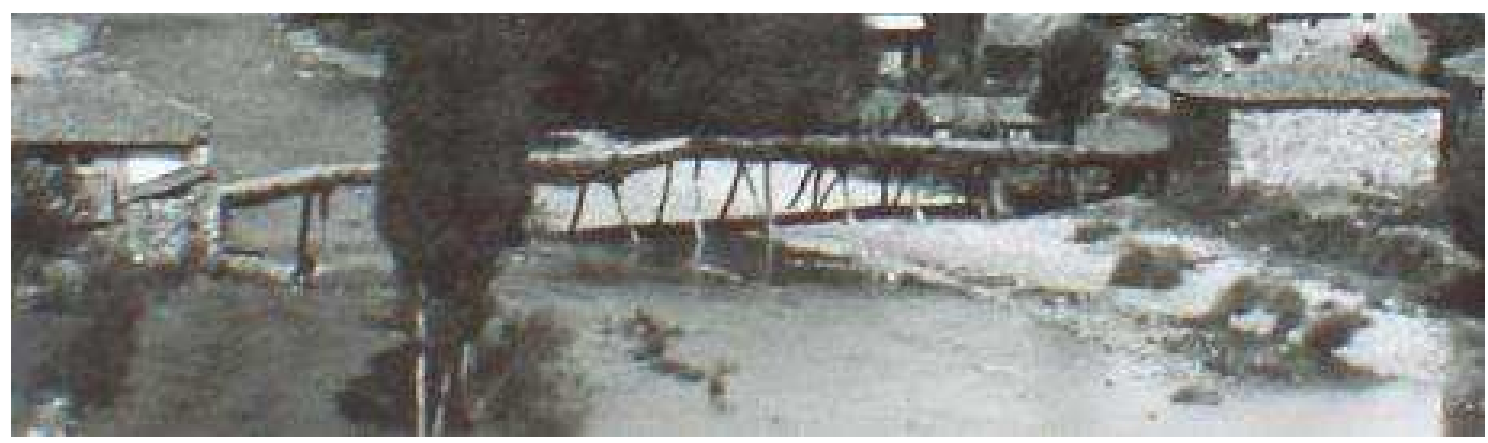

Ilustración 59. Barrios de Luna. Imagen cedida por Manuel Quiñones.

${ }^{332}$ A.G.C.H.D. Oblanca. C/05461-1. N No 448. Año 1954-1955. 
El puente sobre rollizos de Barrios ya se documenta en el siglo XVIII ${ }^{333}$ como un puente de madera sobre el río Luna. Estaba realizado íntegramente con materiales vegetales siguiendo el esquema tradicional que se ha explicado con anterioridad. Poseía una longitud de más de $22 \mathrm{~m}$. y una altura máxima que llegaba a los $4 \mathrm{~m}$. Al tener mayores dimensiones se le añadieron una serie de pivotes de madera en forma de $\mathrm{V}$ sobre los que se asentaban los troncos, que solían ser de chopo.

Puente de rollizos de Cosera

El puente de Cosera es otro de los ejemplos de grandes pontones. Se situaba sobre el río Luna y daba acceso desde Cosera al resto de los pueblos. Tenía unas dimensiones de $27 \mathrm{~m}$. de longitud, $3.10 \mathrm{~m}$. de ancho y una luz máxima de entre 1.50 y 2 m. Estaba conformado por cinco vanos rectos sujetos sobre un caballete de madera de troncos a pares de unos $0.25 \mathrm{~m}$. de diámetro cada uno. La escasa altura del puente hacía posible la utilización de pies derechos sencillos. La parte superior estaba compuesta por un tablero de tierra y ramaje sobre el que se colocaban unos tapines de hierba que le daban consistencia. A los laterales se reforzaba con un muro de mampostería sobre el que descansaban los troncos. Este muro de contención protegía el terreno anegado para evitar el arrastre en las avenidas del río Luna.

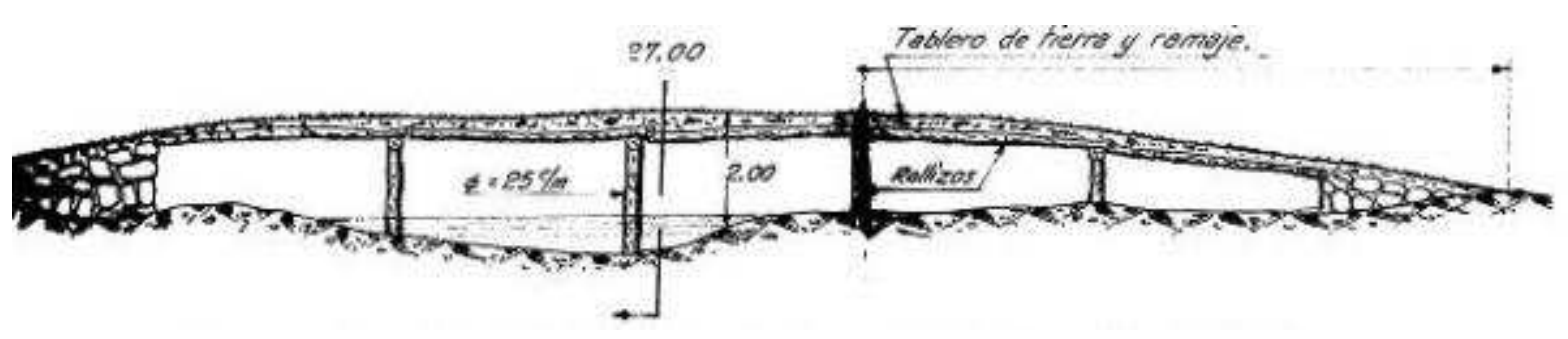

Ilustración 60. A.G.C.H.D. Cosera de Luna. N 4462. Puente rústico.

${ }^{333}$ A.H.P.L. Marqués de la ENSENADA. Interrogatorio.1756. Barrios de Luna. 


\subsubsection{Puentes de piedra}

No tan abundantes como los puentes sobre rollizos, pero sí numerosos en el Valle, fueron los puentes de sillares en piedra. Los puentes de piedra se utilizaron para salvar obstáculos naturales como el paso del río Luna en aquellos caminos oficiales transitados por carromatos o coches que necesitaban un firme más duradero que los troncos con ramaje.

El material por excelencia para la creación de estos puentes era la piedra extraída de las canteras próximas. Lo más común era la elaboración de bóvedas de cañón a base de sillería o mampostería de forma perpendicular al cauce y de diferentes dimensiones para acomodarse a la pluviometría del río ${ }^{334}$. Se empleaban en la construcción grandes bloques escuadrados que formaban los paramentos externos. El interior se rellenaba con mortero de barro y cantos rodados.

La construcción del puente empezaba por las ataguías, unas empalizadas de troncos, firmemente clavados en el suelo, e impermeabilizadas mediante pez y arcilla de cuyo interior estanco se extraía el agua. En el interior de las ataguías se procedía a la construcción de los pilares. Para asentar el muro se levantaban unos castilletes de madera de roble sobre el lecho del río, como es el caso del puente de Miñera de Luna, que según nos cuenta Petronilo Guisuraga, estaba colmado con un entramado compacto de piedras y opus caementitium.

Los canteros construían los pilares hasta el nivel de las impostas, que marcaban el comienzo de los arcos, dejando entonces paso a los carpinteros que colocaban las cimbras para los arcos y que se retiraban una vez terminados. Los arcos se apoyaban sobre machones prismáticos. Adosados a éstos se colocan los tajamares de planta triangular orientados hacia la corriente para aliviar la presión ejercida ${ }^{335}$. Una vez finalizados los arcos se rellenaba el interior del puente con cantos rodados unidos con argamasa. Finalmente se disponía la calzada.

Se desconoce el origen de los puentes de piedra de la ZACEL y si pudieron estar relacionados con la salida de las producciones minerales y el control del territorio dentro del entramado de vías de comunicación del Imperio Romano.

La Edad Media fue el período de grandes construcciones de puentes en la zona. Se continuó con la técnica romana de tablero horizontal favoreciendo no sólo la

\footnotetext{
${ }^{334}$ FERNÁNDEZ-ABAD-CHÍAS. Catálogo, p. 26.
}

${ }^{335}$ ARAMBURU-ZABALA. La arquitectura, p. 14. 
restauración de los pasos sino también creando una nueva tipología a doble vertiente. Es por ello que originalmente la rasante era mucho más larga que el tablero horizontal, disminuyendo poco a poco a consecuencia de la adición de arcos a causa de la erosión de los cauces como ocurre en el puente de Miñera de Luna. Aunque el uso de bóveda de cañón siguió vigente, a partir del XII ${ }^{336}$ se fue incorporando el arco apuntado, cuyo único ejemplo era el puente de Trabanco. Otro aspecto propio del mundo medieval era la creación de unos apartaderos sobre los tajamares para favorecer el tránsito de viajeros y el cobro de mercancías.

Durante el período moderno se van introduciendo cambios en la estructura de los puentes, haciéndolos más robustos para mejorar el tránsito de los carruajes. Sin embargo los materiales continuaban siendo los mismos, la piedra, pues la zona montañosa en la que se encuentra la ZACEL favorecía esta técnica. La utilización de bóvedas de medio cañón será la característica predominante en todas estas construcciones. En los siglos XVI-XVII se iniciaron unos pequeños intentos por reconstruir los puentes antiguos que sólo parchearon los anteriores, sin la introducción de nuevas tipologías. En las zonas montañosas como en Luna no se cumplieron las expectativas barrocas y se prefirió continuar con una técnica rústica con mampostería $\operatorname{tosca}^{337}$. Lo único que se regulaba era el ancho de los puentes dependiendo de su función y del paso de carreteras, por lo que apenas se observan diferencias con los puentes anteriores. Un ejemplo de esta tipología lo encontramos en el puente de San Pedro sobre el río Caldas.

Los puentes construidos a partir de las reformas de Isabel II estaban confeccionados con bóvedas de cañón de sillarejo o sillería que apoyaban sobre pilas con estribos de mampostería y rasante siempre horizontal ${ }^{338}$. La utilización de dovelas de piedra talladas de forma rústica será la nota dominante en la creación de las nuevas pasarelas. Comienzan a utilizarse los arcos rebajados sobre pilares rectos y sus dimensiones apenas sobrepasaban los $4 \mathrm{~m}$. La carretera de La Magdalena-Belmonte reformó el trazado de numerosos puentes que se adaptaron a las necesidades del nuevo tráfico rodado como los de Oblanca, Láncara, y los dos pequeños de San Pedro.

\footnotetext{
336 Ibídem.

${ }^{337}$ FERNÁNDEZ-ABAD-CHÍAS. Catálogo, p. 30

${ }^{338}$ Ídem, p. 35
} 
Puente de San Lorenzo en Miñera

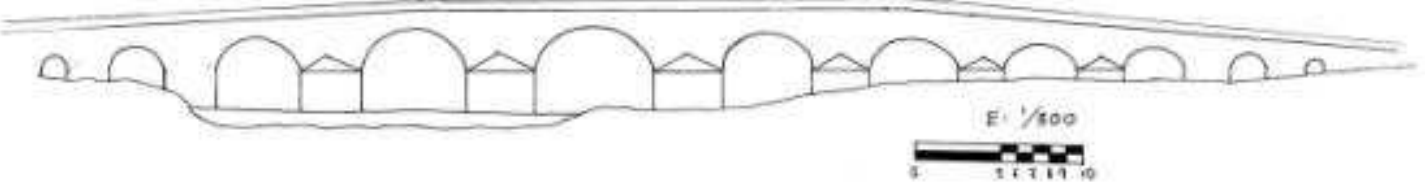

Ilustración 61. Puente de S. Lorenzo de Miñera. FERNÁNDEZ-ABAD-CHÍAS. Catálogo, p. 318

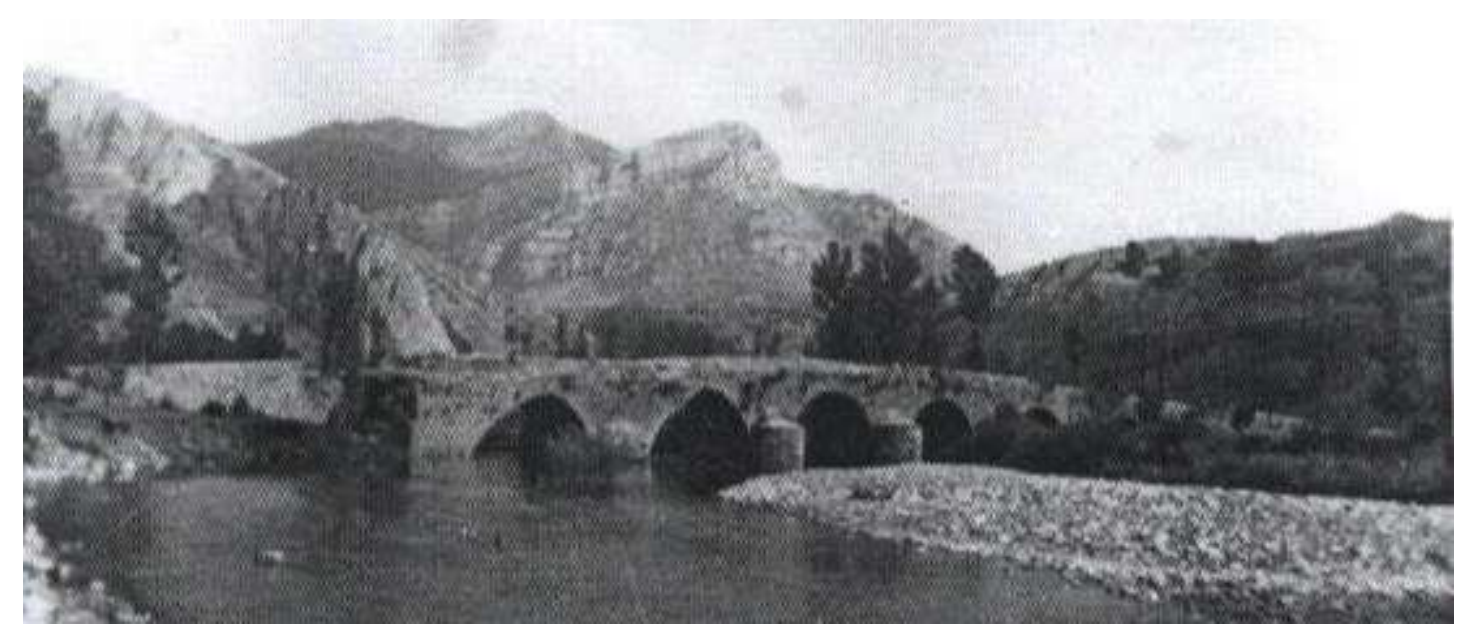

Ilustración 62.Puente de S. Lorenzo de Miñera. Fondo fotográfico I.L.C.

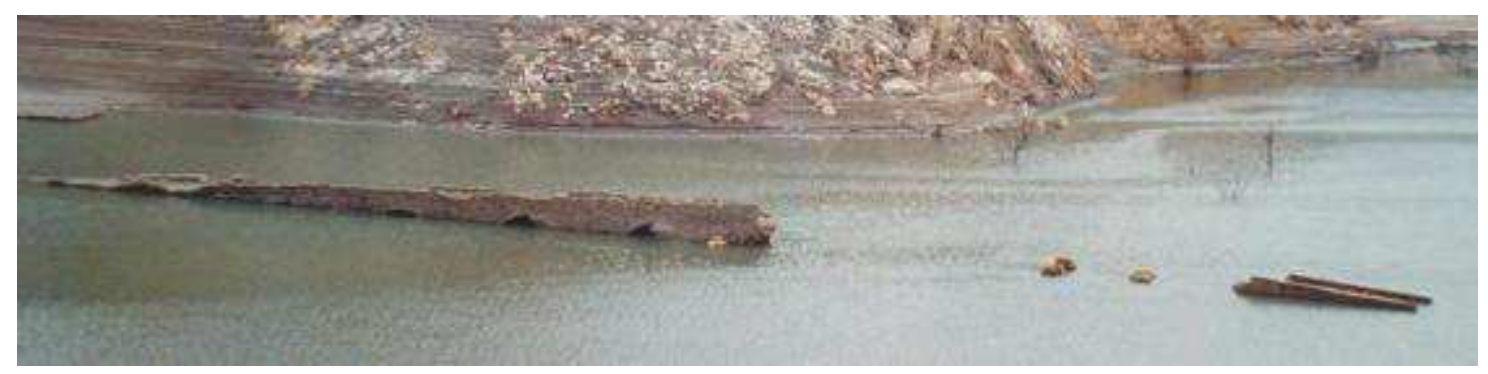

Ilustración 63. Estado actual del puente de S. Lorenzo. Foto cedida por Manuel Quiñones.

La denominación del puente de San Lorenzo viene dada por la pequeña ermita que se encontraba a uno de los extremos. La primera noticia documental data de 1297 cuando Elvira de Canales, hermana de María, Monja del monasterio de Otero, dona cierta cantidad de dinero para el puente de Miñera ${ }^{339}$.

En el momento de la inundación, el puente de San Lorenzo tenía una longitud de 90 m. aproximadamente y una luz de los arcos máxima de 7 m. y mínima de $1 \mathrm{~m}$. De los nueve arcos que describió Madoz se habían añadido otros hasta llegar a once, tres de los cuales eran los útiles del caudal. Este cambio se debió a la erosión del cauce y a las continuas crecidas del río que impedían el paso del agua por los estrechos huecos, por lo

${ }^{339}$ FERNÁNDEZ FLOREZ-HERRERO DE LA FUENTE, Otero. Vol. II. Doc. 801 E mando a la ponte de Trascastro I marauedi; e a la de Canales, otro; e a la de Minnera, otro... 
que el puente fue remodelado varias veces añadiéndole los nuevos arcos. Los propios arcos sufrieron diversas deformaciones, como se observa en la fotografía, ocasionadas por el desplazamiento del firme.

En un documento de $1556^{340}$, el concejo de Luna se reúne para restaurar el puente de San Lorenzo, ya que el río se había salido de su curso y en las crecidas se inundaba hacia la parte de la ermita, impidiendo el paso a la otra orilla. Se dan incluso las medidas de un paredón que han de ampliarse con unas dimensiones de trescientos pies de largo, seis de ancho y diez de alto, bien fabricado en tierra firme y con buena piedra $^{341}$. Parece ser que esta restauración no fue suficiente pues en 1579 se acomete la reconstrucción del puente por Baltasar Gutiérrez con la incorporación de cinco nuevos $\operatorname{arcos}^{342}$.

En 1738 el puente se encontraba en un estado ruinoso, fecha en la que se ejecutó otra reforma a cargo del arquitecto Félix de la Fuente. Su reconstrucción duró muy poco, ya que en 1744 el puente fue arruinado por otra riada. Finalmente el arquitecto Diego Martínez se hizo cargo de la obra gracias a la aportación económica de las poblaciones situadas hasta treinta leguas y de los herederos del anterior constructor Félix de la Fuente ${ }^{343}$. En 1776 tuvo que ser reparado de nuevo por los canteros Simón Barquinero y Benito Alba ${ }^{344}$ siguiendo el proyecto del arquitecto Diego Martínez. Sin embargo, estas reformas no debieron ser suficientes porque las obras no terminaron hasta bien entrado el siglo XIX.

En 1845, Madoz ${ }^{345}$ describe el puente con nueve arcos de medio punto y con grandes pilastras que se apoyaban en el lecho del río. Unos años más tarde, el puente debió sufrir una profunda remodelación, pues César Morán ${ }^{346}$ lo describe con once arcos, de trazado irregular, siendo el central más ancho. Todas estas ampliaciones eran ocasionadas por la situación del puente sobre un meandro del río Luna, por lo que los desbordamientos eran continuos. La deposición de limos anegaba la profundidad del caudal e inundaba la estructura en períodos de lluvias.

\footnotetext{
340 A.M.B. La villa de Caldas, los regidores del concejo de luna durante los siglos XII al XVI y la repoblación forestal. Barrios de Luna. León. 1955. Documento n ${ }^{\circ} 260$. Fecha 1556.

${ }^{341}$ Ibídem.

342 CARDIÑNAS BARDECI. Puentes, p. 6.

${ }^{343}$ FERNÁNDEZ-ABAD-CHÍAS. Catálogo, p. 317.

${ }^{344}$ CARDIÑAS BARDECI. Puentes, p. 6.

${ }^{345}$ MADOZ. Diccionario, p. 213.

${ }^{346}$ MORÁN BARDÓN. Por tierras, p. 184.
} 
En los años de la Guerra Civil uno de los pilares exteriores se derrumbó y fue reconstruido con pilastras de madera de roble verde ${ }^{347}$. A mediados de la década de los cincuenta, los arcos del lado N. se derrumbaron por lo que se optó, ante la inminente anegación del Valle, por no reconstruirlos y dejar una rampa de madera para el tránsito de vehículos.

Puente de Trabanco de Barrios de Luna.

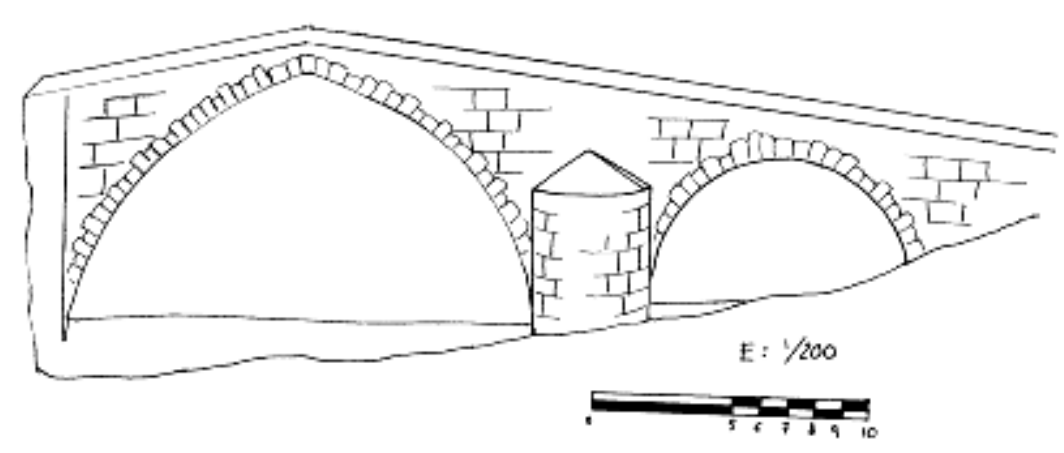

Ilustración 65. Reconstrucción del puente de Trabanco. FERNÁNDEZABAD-CHÍAS. Catálogo, p. 317

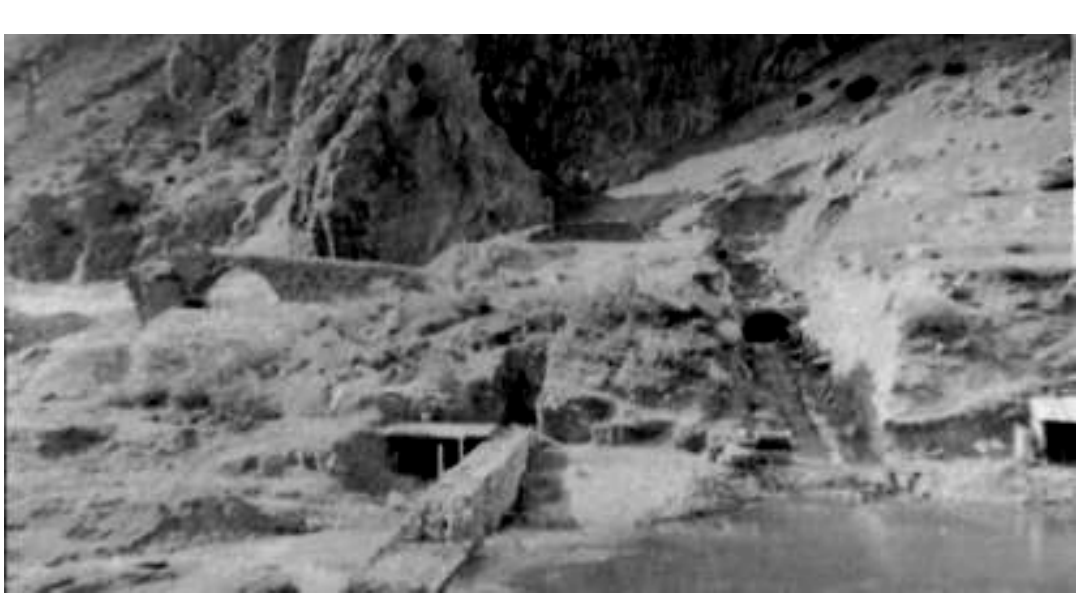

En

el diccionario de Pascual Madoz $^{348}$ se describe un puente de dos arcos en el desfiladero del barrio de Trabanco bajo el castillo de Luna. La estructura comunicaba la ruta de la Cañada Real de la Vizcaína $^{349}$ a través de una senda excavada en las rocas por la que circulaban especialmente las merinas. Según Pascual Madoz su origen pudo ser romano ${ }^{350}$, aunque su tipología, con un

Ilustración 64. Puente de Trabanco. Fondo fotográfico I.L.C. Año 1956 arco apuntado, lo acerca definitivamente al mundo medieval.

\footnotetext{
${ }^{347}$ Información dada por Petronilo GUISURAGA, vecino de Miñera. ${ }^{348}$ MADOZ. Diccionario, p. 66.

${ }^{349}$ VVAA. Los pueblos de León. Barrios de Luna. Vol. I. León, 1995, p. 40. ${ }^{350}$ MADOZ. Diccionario, p. 66.
} 
El puente poseía dos arcos y una longitud total de $35 \mathrm{~m}$. sobre el río Luna. La luz máxima era $12 \mathrm{~m}$. el arco mayor y $8 \mathrm{~m}$. en el arco de menor tamaño ${ }^{351}$. Lo más característico era la forma de sus arcos, el de mayor tamaño era apuntado, mientras que el otro era de medio punto. El puente se cimentaba con un castillete de piedra sobre pilotes de roble en el lecho del río ${ }^{352}$.

Su uso dejó de ser importante tras la reforma de Isabel $\mathrm{II}^{353}$ y la apertura de un túnel que traspasaba la Peña del Castillo y que mejoraba la comunicación. Aunque en $1890^{354}$ el arco más grande ya se había hundido ${ }^{355}$ y solo se conservaba el tramo más pequeño, su utilización continuaba gracias a la utilización de troncos de madera imitando las estructuras de los puentes de rollizos.

Con la construcción de la pared del embalse el puente fue usado como ataguía para desviar el cauce del río y posteriormente demolido.

Puente de Oblanca.

Se desconocen las medidas y longitud del puente de piedra de la localidad de Oblanca, del que tan solo se ha obtenido la fotografía que se muestra como documento testimonial. Se trata de un puente de

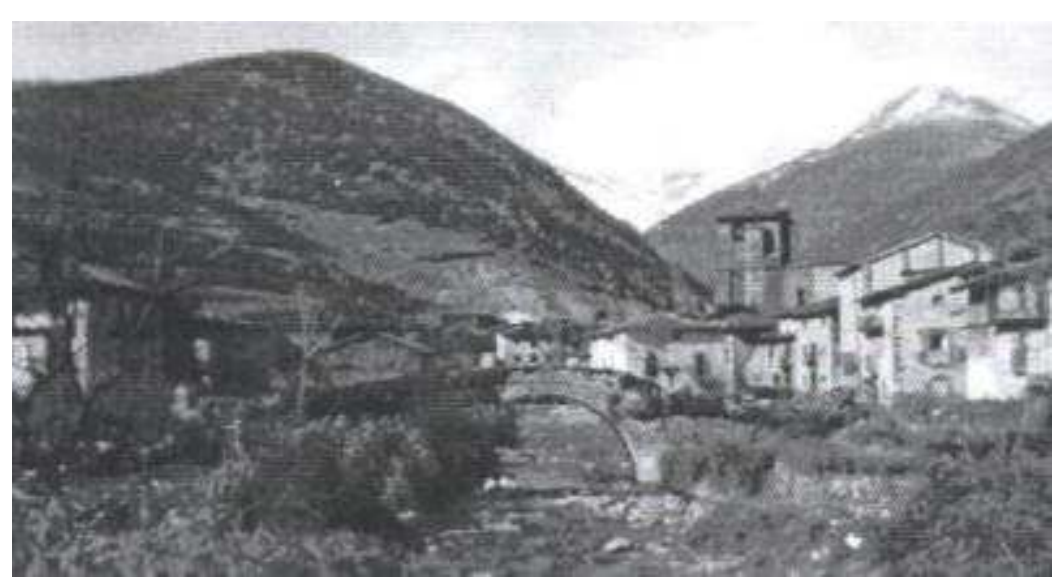

Ilustración 66. Oblanca. Fondo fotográfico I.L.C. piedra sobre el río Caldas de un solo arco de medio punto. Sus características lo aproximan a una tipología medieval, pues el trazado de la calzada es ligeramente apuntado y las pilas laterales parecen contener tajamares típicos.

${ }^{351}$ FERNÁNDEZ-ABAD-CHÍAS. Catálogo, p. 317.

${ }^{352}$ RODRIGUEZ MORAN, Ángel. http://www.xente.mundo-r.com/luna/penaCSS.htm

${ }^{353}$ GARCÍA SUÁREZ, Una historia, p. 66.

${ }^{354}$ MORÁN BARDÓN. Excursiones, p. 69.

${ }^{355}$ FERNÁNDEZ-ABAD-CHÍAS. Catálogo, p. 317. 


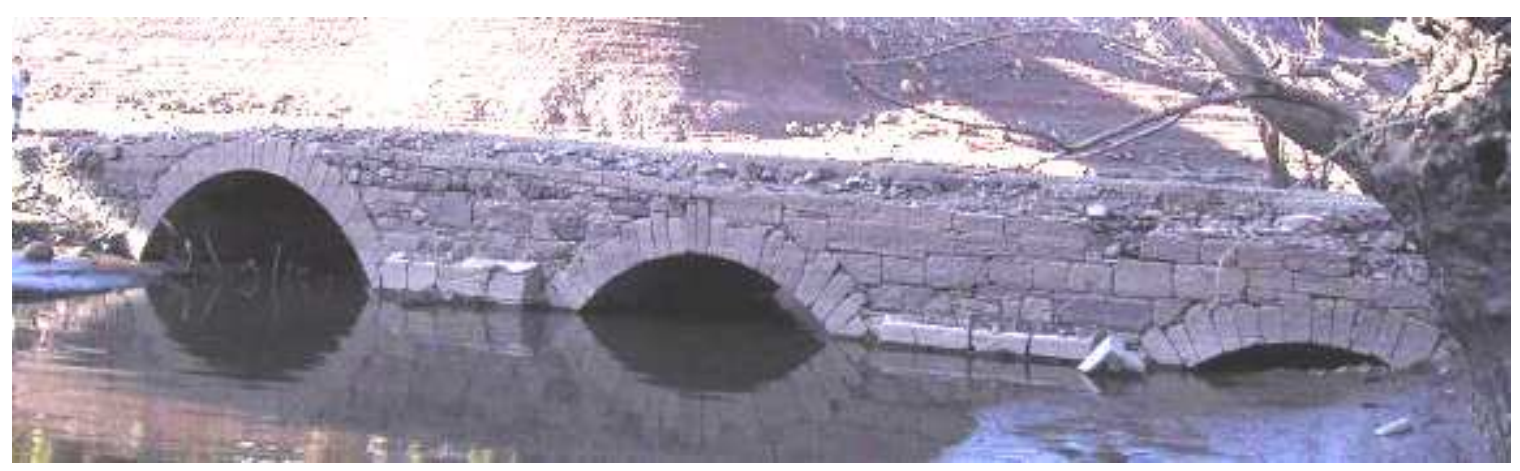

Ilustración 67. Puente de San Pedro sobre el río Caldas. Año 2005

La primera noticia documentada de este puente data de $1590^{356}$ donde se mandan reparar los puentes de San Pedro y San Lorenzo, por lo que su fecha de construcción puede ser anterior. Las numerosas reparaciones a las que fue sometido ocasionaron que su tipología final se adecuase a las formas del siglo XIX.

El puente de San Pedro contaba con una longitud de $11 \mathrm{~m}$. y tres $\operatorname{arcos}$ con bóveda de medio cañón realizados en piedra y muros de mampostería bien conservados. Los arcos utilizaban dovelas de diferentes tamaños lo que le daba un aspecto rústico. Los espacios interiores se rellenaban con materiales más pobres como cantos rodados unidos con argamasa. Para soportar la fuerza de las riadas se colocaron a contracorriente unos pequeños contrafuertes de piedra bien labrada.

Puente de San Pedro sobre el río Aralla I

A mediados del siglo XIX San Pedro de Luna se había convertido en un punto importante de cruce de caminos hacia los puertos asturianos. Durante este período se efectuó la mejora de las vías de comunicación del Valle levantándose puentes de nueva fábrica de un solo arco que sustituían a los de rollizos de madera. Los puentes de este período estaban construidos con bóvedas de cañón de sillarejo o sillería que apoyaban sobre pilas con estribos de mampostería y rasante siempre horizontal ${ }^{357}$. Todos ellos eran pasos de carretera de un solo arco de medio punto realizado con sillares de traza

\footnotetext{
${ }^{356}$ ARAMBURU-ZABALA HIGIERA. La arquitectura, p. 135.
}

${ }^{357}$ FERNÁNDEZ-ABAD-CHÍAS. Catálogo, p. 35. 
rústica sobre los que se esparcía la capa de cemento para el tránsito de vehículos. Los arcos solían tener unas dimensiones estándar de unos 3 o $4 \mathrm{~m}$. de luz y no eran excesivamente altos, ya que se elevan apenas $1.5 \mathrm{~m}$. sobre el lecho del río. La longitud de los mismos era de unos $5 \mathrm{~m}$. y se ubicaban sobre arroyos de poco caudal.

El puente de San Pedro sobre el río Aralla poseía una longitud de $4 \mathrm{~m}$. con un

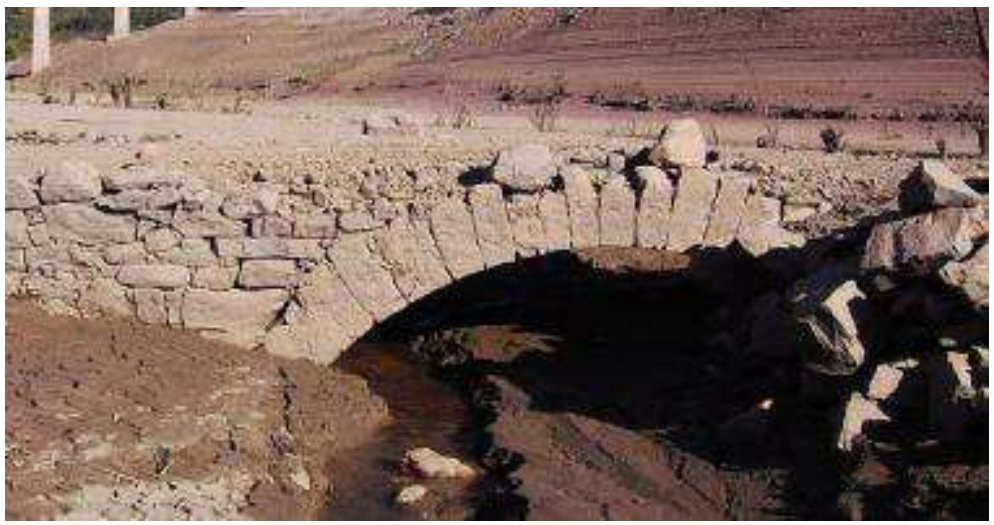

Ilustración 68. Puente de San Pedro sobre el río Aralla. 2011. solo arco de $3 \mathrm{~m}$. de luz y 1.20 m. de altura. Los materiales utilizados eran el sillarejo relleno con materiales más pobres como cantos rodados. Las dovelas del arco tenían una forma rústica utilizando piedras semilabradas.

Puente de San Pedro de Luna sobre el río Aralla II

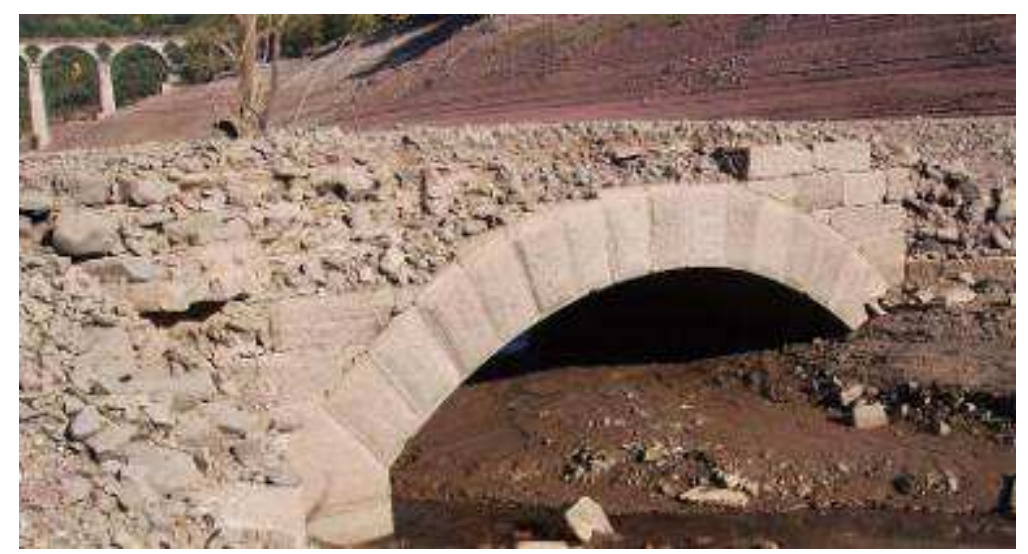

Ilustración 69. San Pedro de Luna. Puente de la antigua carretera la Magdalena-Belmonte
El siguiente puente de San Pedro se ubicaba sobre el río Aralla y daba paso al tráfico de la carretera La MagdalenaBelmonte. Data de la primera mitad del siglo $\mathrm{XX}$ y tiene una longitud de unos $5 \mathrm{~m}$. aproximadamente. Posee

un solo arco rebajado de $4 \mathrm{~m}$. de luz que descansa sobre pilares rectos de $1.50 \mathrm{~m}$. de altura. Las dovelas son de sillares labrados en forma de aparejo rústico. El interior del puente se rellena con cantos rodados unidos en argamasa. Se recubre con una capa de cemento para el tránsito de vehículos. 
Puente de Láncara sobre el arroyo

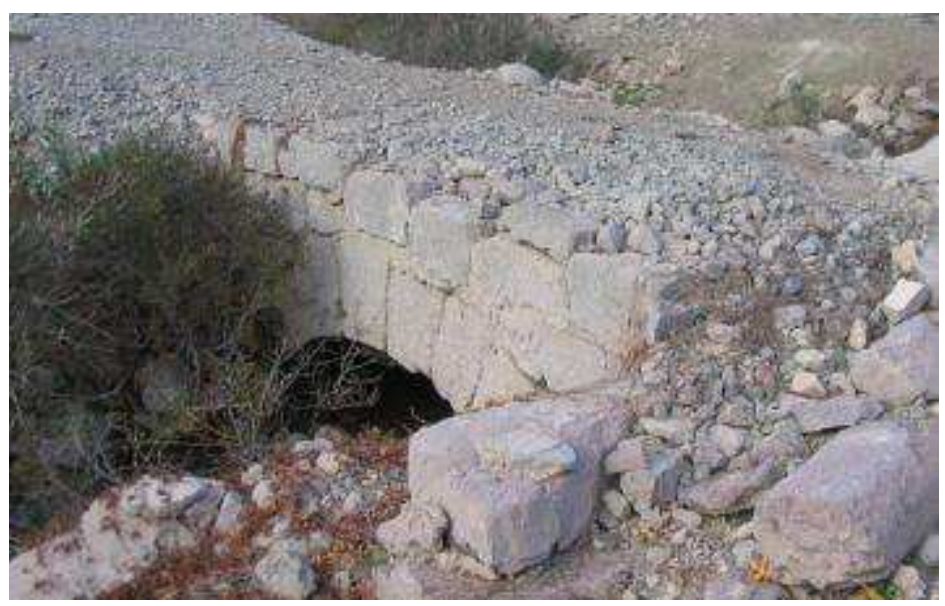

Ilustración 70. Láncara. Puente. 2008
En Láncara de Luna sólo se conserva un pequeño puente que daba acceso a carretera La MagdalenaBelmonte hacia Pobladura de Sena datado en la primera mitad del siglo XX. Este puente tenía un solo arco de $2.30 \mathrm{~m}$. de luz con dovelas de piedra en forma rústica cuya clave era de mayores dimensiones. A los extremos se colocaban unos grandes poyos de piedra labrada para proteger el puente del tránsito de vehículos. La anchura del puente es de $3.30 \mathrm{~m}$. y el arroyo estaba encauzado con un muro de aproximadamente $1 \mathrm{~m}$. de altura y una longitud total de $4 \mathrm{~m}$.

\subsubsection{Puentes de cemento y hormigón}

A pesar de que la piedra seguía siendo el material por excelencia, a partir del siglo XX se introduce el cemento y el hormigón. Esto conllevará el abaratamiento constructivo y por tanto la multiplicación de puentes de pequeñas dimensiones que sustituían a los pontones tradicionales de madera. Para dar aspecto de rusticidad al exterior, algunos puentes se revestían con piedra labrada colocándose en los extremos grandes poyos para proteger el puente del tránsito de vehículos. Para mejorar su conservación se encauzaba el riachuelo con un muro de varios metros levantado con cemento.

Continuando con las mejoras de la carretera de la Magdalena-Belmonte a comienzos del siglo XX, se proyectaron nuevos puentes para salvar los niveles más caudalosos del río Luna en Lagüelles y Láncara. Para ello se construyeron puentes de hormigón y hierro con un tablero de cemento sujeto sobre pilastras rectas. 
Puente de Oblanca sobre el río Caldas.

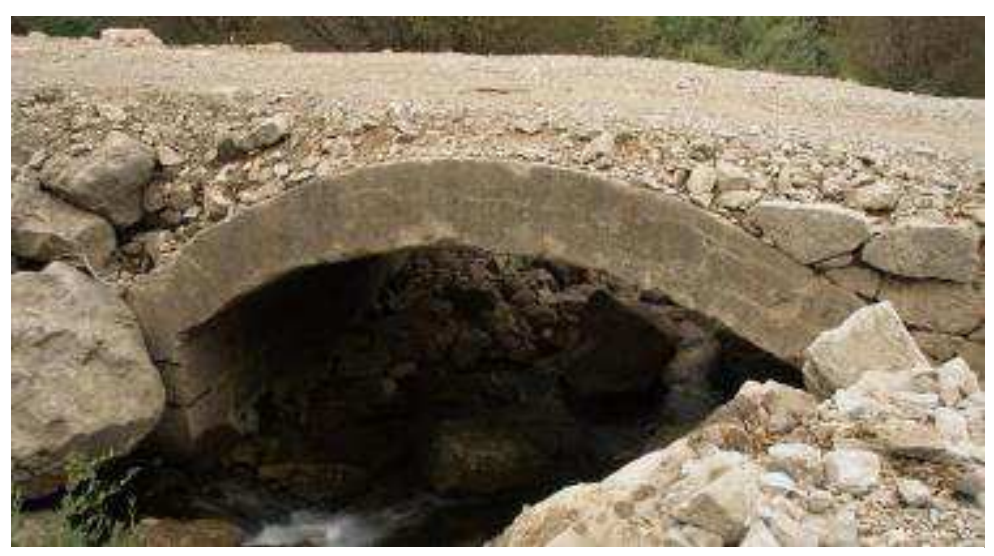

Este puente se encuentra dentro de las estructuras construidas en el siglo $\mathrm{XX}$ como mejora de las comunicaciones de la carretera La MagdalenaBelmonte. Tiene una

Ilustración 71. Puente sobre el río Caldas. Oblanca

longitud de $7.5 \mathrm{~m}$ de largo por $5 \mathrm{~m}$. de ancho y una altura de $3 \mathrm{~m}$. en un solo arco con una luz de $6 \mathrm{~m}$. El material se componía de estribos de fábrica con cemento y hormigón que sustituían los materiales rústicos de troncos, ramaje y tierra ${ }^{358}$ del puente anterior.

Puente de Lagüelles sobre el río Luna

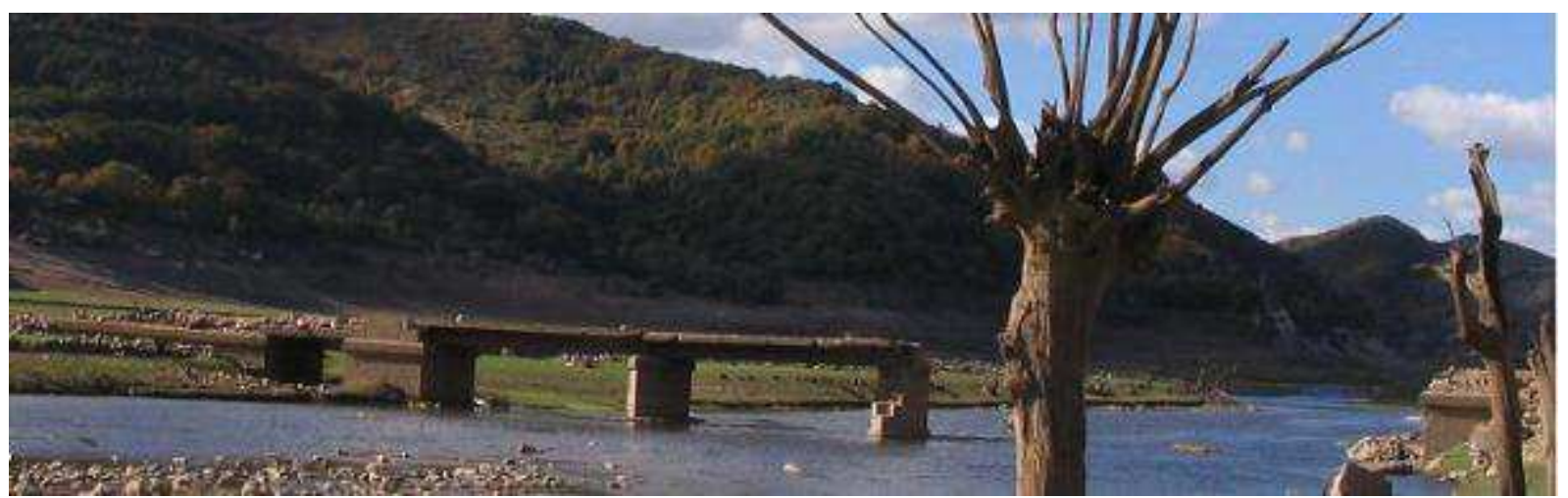

Ilustración 72 Puente de Lagüelles. Año 2008

El puente de Lagüelles data en torno a la primera mitad del siglo XX. Se situaba sobre el río Luna y comunicaba la carretera de la Magdalena-Belmonte. Tenía una longitud de unos $40 \mathrm{~m}$. aproximadamente y una altura de más de $2 \mathrm{~m}$. Estaba conformado por cuatro tramos de 7,50 m. de luz, barandillas y vigas metálicas, con piso hormigonado entre viguetas. Los estribos y pilas eran de mampostería labrada. Cada uno de los tramos estaba confeccionado en vigas de hormigón armado cubierto con una losa de $4 \mathrm{~m}$. de luz en forma de naveta. Los estribos y las pilas eran de sillería careada y

${ }^{358}$ A.G.C.H.D. Oblanca. C/05461-1. No 4484. Año. 1954-1955. Expediente original Noo 1 
sujetaban con dos vigas en forma de doble T la plataforma sobre la que se encontraba el asfalto. En los extremos del puente se disponían dos armazones de hormigón armado y de dimensiones superiores para soportar la fuerza de las avenidas.

Puente de Láncara sobre el río Luna

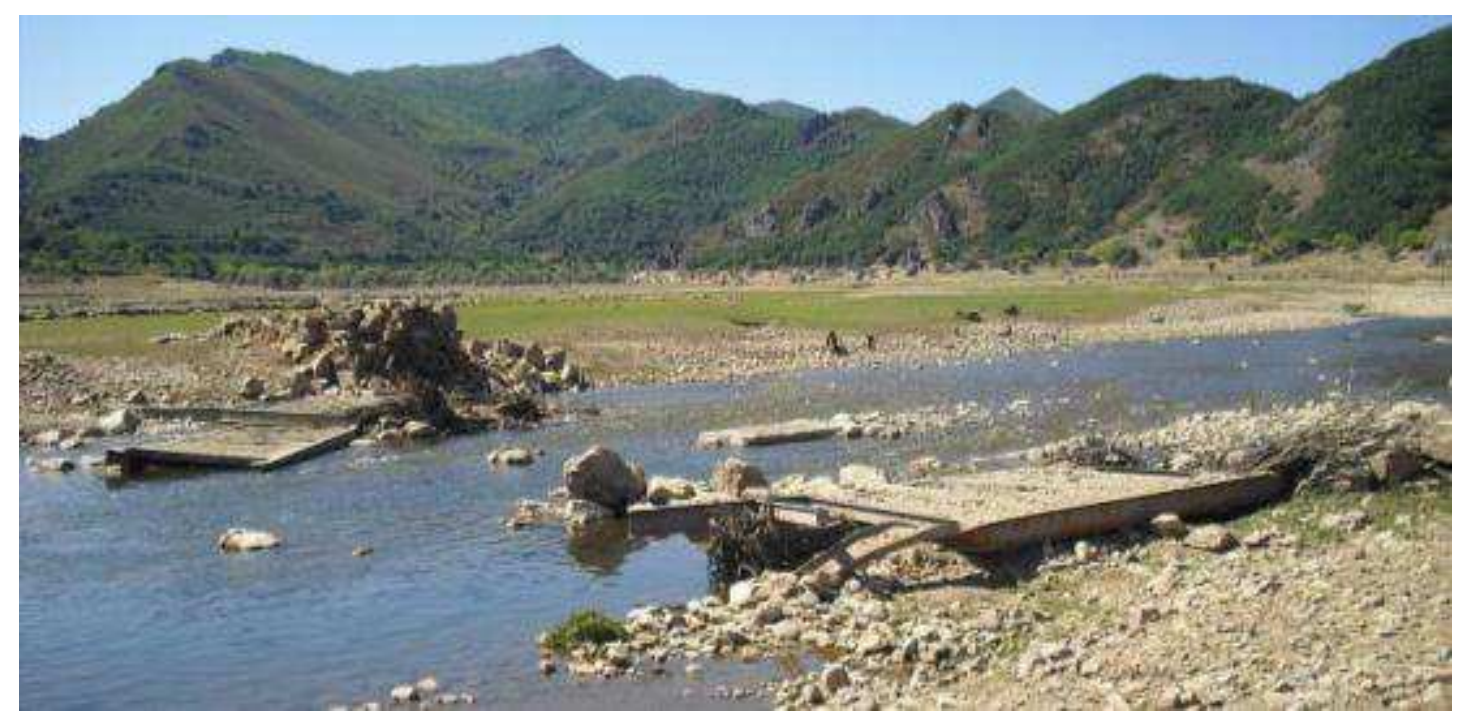

Ilustración 73. Puente de Láncara sobre el río Luna.

El puente de Láncara se relaciona con el anterior de Lagüelles en material y forma, por lo que se deriva que fueron construidos en el primer tercio del siglo XX para el tránsito de la carretera Villablino-La Magdalena sobre el río Luna.

Poseía una estructura basada en tres zapatas de hormigón con núcleo relleno rectangular de $0.80 \mathrm{~m}$. por $3 \mathrm{~m}$. con la flecha en contracorriente. El largo total del puente era de $30 \mathrm{~m}$. aproximadamente con un ancho de la vía de $6 \mathrm{~m}$. dejando $5 \mathrm{~m}$. para el tránsito de vehículos. Los asientos eran de muros de mampostería rellenos con guijarros y cantos rodados. Sobre las zapatas se colocaban cuatro estructuras de hierro de forma cuadriculada rellenas con cemento con una longitud de $5 \mathrm{~m}$. cada una.

El puente fue abandonado ante la inminente llegada de las aguas y la gran escorrentía del embalse en esta zona ha ocasionado su derrumbe y deformación de las estructuras. 


\subsection{ARQUITECTURA RELIGIOSA}

En este bloque se inventarían y se analizan las características de la arquitectura religiosa de la ZACEL, con una pequeña introducción sobre el panorama religioso de la zona así como un estudio individualizado de las peculiaridades de sus edificios. A priori, nos enfrentamos a un territorio de carácter periférico que no ofrece grandes estructuras arquitectónicas y que apenas ha sido estudiado, por lo que el trabajo de tesis se centrará en documentar las diversas construcciones religiosas que poblaban la ZACEL.

Uno de los problemas a la hora de comenzar el trabajo de investigación fue el cambio de pertenencia de estas parroquias de la diócesis de Oviedo a la de León en torno a los años cincuenta del siglo XX. Esta situación supuso cierta descoordinación y falta de rigor del momento histórico vivido que trajo como consecuencia la pérdida durante el traslado de algunos de los documentos relativos a los archivos de fábrica de las parroquias que quedaron anegadas. Por lo tanto gran parte de este capítulo se ha basado no sólo en la recuperación de estos archivos sino también en los planos levantados por la Confederación Hidrográfica del Duero, que se han convertido en la base principal para la elaboración de las tipologías y el conocimiento de estos edificios antes de la inundación.

\subsubsection{LOS ESTUDIOS SOBRE ARQUITECTURA RELIGIOSA}

Son escasas las publicaciones referentes a la arquitectura religiosa del norte de la península en los siglos XVI al XVIII y menos abundantes las que se ocupan de los edificios realizados a partir del siglo XIX en áreas periféricas a los principales circuitos artísticos. Los monasterios y grandes centros religiosos copan la atención de los estudios metodológicos quedando relegadas a un segundo plano las obras parroquiales de las diversas diócesis. Sólo aquellas fábricas rurales que tienen un especial interés, por la aportación de formas estilísticas o históricas novedosas o por estar efectuadas por arquitectos de primera categoría, son los merecedores de estudios pormenorizados.

Desde el último tercio del siglo XX y especialmente en el siglo XXI, una vez que se han finalizado la mayoría de las monografías correspondientes a las grandes 
fábricas religiosas, se ha prestado atención hacia zonas periféricas de carácter rural. En estos estudios se pone de relieve la importancia no sólo histórica y cultural de las iglesias parroquiales populares, sino también su relevancia artística. Estos trabajos utilizan una metodología más adecuada al desarrollo eclesiástico parroquial. Todos ellos poseen una estructura similar que parte de una introducción histórica sobre el momento vivido en las diversas diócesis, su contexto y el panorama económico y social de los siglos de la Edad Moderna. Posteriormente se extrae un estudio acerca de las características arquitectónicas reflejando la tipología genérica de los edificios religiosos, sus comitentes y arquitectos. Por último se procede a la catalogación de las distintas obras con un estudio formal y estilístico de cada una de las iglesias que conforman las diócesis.

Destacan algunos trabajos acerca de la arquitectura de las diócesis de diversas zonas de la península como la obra de Felipe Heras García sobre arquitectura en la primitiva diócesis de Valladolid, la de $\mathrm{M}^{\mathrm{a}}$ Pilar Corella Suarez, acerca de la provincia de Madrid, la de José Gabriel Moya Valgañón, sobre la Rioja, la de Enrique Martínez Glera, en el valle del Iregua, la de Isabel Cofiño Fernández en Cantabria, la de Ana María Pereira Morales en Galicia, la de Francisco Javier Cortés Borroy en Aragón o la de Nestor de Sousa en Portugal ${ }^{359}$. En la provincia de León sobresale la publicación de Vicente Fernández Vázquez ${ }^{360}$ sobre la arquitectura del Bierzo. Estos trabajos comienzan a tomar conciencia de la importancia de la arquitectura religiosa popular de la que se extraen una serie de características propias que no se encuentran en los grandes complejos urbanos. De esta manera se ha observado que estas obras religiosas conllevan cierto carácter regional en el que se siguen utilizando elementos tradicionales que acaban convirtiéndose en señas de identidad de un determinado territorio.

\footnotetext{
${ }^{359}$ HERAS GARCÍA, Felipe. Arquitectura religiosa del siglo XVI en la primitiva diócesis de Valladolid. Valladolid, 1975; CORELLA SUAREZ, M Pilar. Arquitectura religiosa de los siglos XVII y XVIII en la provincia de Madrid, Madrid, 1979; MOYA VALGAÑÓN, José Gabriel. Arquitectura religiosa del siglo XVI en la Rioja Alta. Logroño, 1980; MARTÍNEZ GLERA, Enrique. La arquitectura religiosa barroca en el valle del Iregua. Logroño, 1982; FERNÁNDEZ VÁZQUEZ, Vicente. Arquitectura religiosa en el Bierzo. Siglos XVI-XVIII. Ponferrada, 2001; COFIÑO FERNÁNDEZ, Isabel. Arquitectura religiosa en Cantabria. (1685-1754) Santander, 2004; PEREIRA MORALES, Ana María. Arquitectura y arquitectos en la diócesis de Tui. Siglos XVII y XVIII. Pontevedra, 2006; CORTÉS BORROY, Francisco Javier. La arquitectura religiosa de los siglos XVII y XVIII en el Bajo Aragón zaragozano y en la Ribera Baja del Ebro. Zaragoza, 2007; SOUSA, Nestor de. A arquitectura religiosa de Ponta Delgada nos séculos XVI a XVIII. Universidade dos Açores, 1986.

${ }^{360}$ FERNÁNDEZ VÁZQUEZ, Vicente. Arquitectura religiosa en el Bierzo. Siglos XVI-XVIII. Tomo I y II. Ed: Fundación Ana Torres Villarino. Ponferrada, 2001.
} 


\subsubsection{LA IGLESIA EN EL VALLE}

La repoblación durante los primeros siglos de Reconquista fue el factor fundamental para la creación de una serie de estructuras regidas principalmente a través de las parroquias y monasterios. El desarrollo de los obispados y la creación de una red de edificios religiosos, que favoreciesen la repoblación e impulsasen el avance cristiano, fueron los primeros síntomas de configuración de lo que hoy en día podemos observar en la ZACEL.

En un principio la monarquía asturiana propició una restauro ecclesiae basada en las antiguas estructuras visigodas ${ }^{361}$. En el año 812 Alfonso II el Casto traslada su corte a Oviedo, transformando la ciudad en cabecera de una nueva diócesis ${ }^{362}$. La sede ovetense se fijó en el 876 por el Papa Juan VIII incluyendo entre sus territorios los de Alba, Gordón, Argüello, Paredes, Valle de Ordás, Amío, Luna, Babia, Laciana y Coyanza $^{363}$.

Junto con la creación de las diócesis, lo reyes fundaron monasterios y los dotaron de cuantiosas tierras, a veces muy alejadas como es el caso de San Adriano de Tuñón que, en el 891, ya extendía sus dominios por el Valle ${ }^{364}$. A principios de la Edad Media el monasterio de San Millán, en Asturias, el de San Adriano de Tuñón y el de Arbas, en el puerto de Pajares en León, eran los grandes propietarios de las tierras de Luna.

La expansión de la diócesis sufrió un parón tras la muerte de Alfonso III y el traslado de la corte de Oviedo a León ${ }^{365}$. Los amplios territorios bajo jurisdicción de la diócesis de Oviedo se convirtieron entonces en foco de disputas por otras diócesis como la de Toledo, Braga y Burgos ${ }^{366}$. En 1101 el obispo Pelayo, bajo mandato de Alfonso VI, consolidará los distritos territoriales ovetenses que perdurarán hasta 1954, año en el que parte de su territorio pasa al obispado de León ${ }^{367}$ para crear una demarcación más parecida a la realidad administrativa civil.

\footnotetext{
${ }^{361}$ LERA MAÍlLO, José Carlos de. "Las iglesias del Reino de León en el siglo XII" en Regnum: Corona y Cortes en Benavente (1202-2002). Benavente, 2002, p. 70.

${ }^{362}$ GARCÍA LARRAGUETA, Colección. Oviedo, Doc. 2. 812, noviembre 16.

363 SACHEZ BADIOLA. La configuración, p. 229.

${ }^{364}$ GARCÍA LARRAGUETA, Colección. Oviedo, Doc. 13. Sucesivamente las donaciones reales irán aumentando su patrimonio, no sólo en este caso, sino en el resto de los monasterios fundados.

${ }^{365}$ GIL FERNÁNDEZ, Juan. MORALEJO, José L. RUIZ DE LA PEÑA. Juan Ignacio. Crónica de Alfonso III. Gijón, 1985, p. 42.

${ }^{366}$ Idem, p. 19

${ }^{367}$ GARCÍA LARRAGUETA, Colección. Oviedo, Doc. 117.
} 
En toda la Edad Media se fomentó el camino de peregrinación hacia los tesoros de la Cámara Santa de Oviedo por las montañas de la Cordillera Cantábrica. Esta ruta se convirtió en introductora de corrientes culturales, económicas y artísticas que ocasionaron un cierto desarrollo por todas aquellas poblaciones de tránsito. Los nuevos centros religiosos se organizaron en torno a zonas de importantes pasos cuya función principal no era sólo el resguardo de los peregrinos sino también el control del espacio conquistado $^{368}$. Las continuas donaciones hicieron que estos monasterios, como el de Sta. María de Arbas y el de Oteros de las Dueñas, tuvieran jurisdicción sobre gran parte del territorio colindante. La documentación nos cita donaciones de particulares de Cosera, Láncara, Mallo, Miñera, Mirantes y Oblanca al monasterio de Arbas hasta bien entrada la Edad Moderna ${ }^{369}$. Además de donaciones, los monasterios gozaban de otra serie de privilegios como los de la abadía de Arbas, que ejercía derechos de patronato sobre gran cantidad de iglesias de Luna ${ }^{370}$.

Entre los siglos XII al $\mathrm{XIV}^{371}$ se fundan la casi totalidad de los edificios religiosos de la ZACEL ${ }^{372}$. Es el gran momento de expansión de las parroquias en la que el territorio queda finalmente adscrito a la jurisdicción de la iglesia ovetense configurándose un edificio religioso casi para cada población. En este momento se crean diversos centros monásticos como el de S. Miguel y Sta. Doradia de Oblanca y el monasterio de Sta. Dorotea en Caldas de Luna. Posteriormente estas congregaciones, de carácter privado, pasarán a convertirse en centros parroquiales ${ }^{373}$. La primera noticia documental de estos centros se conserva en el archivo de la catedral de León, en el cual aparece una carta de donación de tierras a la abadía de Arbas en 1179 donde se cita al monasterio de Sta. Doradia de Oblanca ${ }^{374}$. En el siglo XII existe otro documento en el archivo de la catedral de León acerca de las mandas de dinero, animales, ofrendas, vestuario y varias cuarentenas hechas por Isidoro Micael a diversas iglesias, clérigos y

${ }^{368}$ BENITO MARTÍN, Félix. La formación de la ciudad medieval. La red urbana en Castilla y León. Valladolid 2000, p. 234.

${ }^{369}$ FERNÁNDEZ FLOREZ-HERRERO DE LA FUENTE, Otero. Vol II; GARCÍA LOBO, Arbas.

${ }^{370}$ A.H.P.L. Catastro del Marqués de la ENSENADA. Interrogatorio. 1752. Rollo 276. Vega de Robledo.

${ }^{371}$ BENITO MARTÍN. La formación, p. 236.

372 FERNÁNDEZ FLOREZ-HERRERO DE LA FUENTE, Otero. Vol II. Doc: 794 La iglesia de San Pedro ya se cita en un documento de compra-venta de terrenos en 1295.

${ }^{373}$ Durante los primeros años de repoblación será difícil distinguir entre una iglesia y un monasterio ya que a ambos se les puede denominar de la misma manera y las funciones de los religiosos pueden ser las mismas para una iglesia que para un monasterio.

${ }^{374}$ GARCÍA LOBO, Arbas, Doc. 111. Año 1179. Carta de donación de una tierra a favor del abad del convento de santa María de Arbas del Puerto. AHN, Consejos, leg 160022, III-5,4 cuaderno visita temporal, fol 3r. (Monasterio de santa Doradia) 
personas, entre ellas la de S. Micael de Obranca $^{375}$. La abadía de S. Miguel prontamente fue absorbida en el siglo XIV como iglesia parroquial, mientras que la de Sta. Doradia se mantuvo unos años más como espacio religioso independiente hasta su desaparición en el siglo $\mathrm{XV}^{376}$. Desgraciadamente no se conserva ningún vestigio arquitectónico de este período.

Durante los siguientes siglos la nobleza comienza una carrera por apoderarse de los territorios que muchas veces pertenecían a la iglesia por medio de compras, privilegios o concesiones reales. En otras ocasiones se impone el acto de la fundación de monasterios o el intento por controlar sus territorios a través del nombramiento de abades y abadesas de origen nobiliario, como es el caso de la abadesa Mencía de Quiñones en el monasterio Otero de las Dueñas ${ }^{377}$.

A partir del Concilio de Trento (1545-63) se inicia un nuevo modelo arquitectónico que conllevará a la creación de formas acomodadas a las nuevas directrices técnicas. La regenerada mentalidad religiosa supuso el fortalecimiento de un sentimiento místico que acabará transformando las estructuras de todos los edificios religiosos de $\mathrm{Luna}^{378}$. Surgen por tanto infinidad de capillas, capellanías, ermitas, oratorios o beneficios por misas, ordenadas por familias adineradas o por gremios y cofradías.

Es difícil establecer la datación exacta de las iglesias del Valle debido a la falta de documentación relativa a las construcciones y consagraciones. En algunas ocasiones la documentación no coincide con las inscripciones encontradas en las portadas, lo que sugiere que en realidad no se crearon edificios de nueva planta, sino que se repararon o se acomodaron a las necesidades estilísticas del momento. La gran mayoría de los edificios de la ZACEL fueron reformados, variando en ocasiones su estructura original. Los limitados recursos económicos y la escasa preocupación artística van a conformar unos edificios pequeños a los que sólo se les exigía la funcionalidad y su adecuación a

\footnotetext{
${ }^{375}$ FERNÁNDEZ CATÓN, José María. Catálogo del archivo histórico diocesano de León. Tomo I. León 1978. No 21. Doc. 784.

376 GARCÍA LOBO. Colección. León. Vol. XIII. Doc. 4112. 1482, abril, 18, jueves. Oviedo. Los canónigos y clérigos protagonizaron durante el siglo XV numerosos enfrentamientos acerca de la propiedad de los derechos de abadía, sin duda por los beneficios que aportaba. Así se observa en varios documentos de finales del siglo XV en los cuales la iglesia de Oviedo debe sentenciar en el pleito que sostenían Pedro Suárez Ferreras, canónigo de la iglesia de León y Alvar González, Clérigo de Portilla, por razón de la abadía y beneficio curado de Santa Doradia, en el arcedianato de Babia, fallando a favor de la iglesia de León, como heredera de dicha abadía, junto con otros patronato

377 ALVAREZ ALAVAREZ. El condado, p. 239.

${ }^{378}$ GARCÍA VILLOSLADA, Ricardo. La iglesia en España en los siglos XVII y XVIII. Historia de la iglesia en España. Madrid, 1979, p. 56.
} 
los postulados de la iglesia. Este hecho ocasiona una uniformidad en las estructuras arquitectónicas tanto en plantas como alzados, torres y espadañas. Entre los reinados ilustrados de Carlos III y Carlos IV se reforman la casi totalidad de los edificios religiosos de la ZACEL. En este período se llevó a cabo una gran labor de construcción y restauración de muchas de las iglesias del Valle que sufrieron una modificación en algunos de sus espacios como la creación y ampliación de sacristías, porticados, espadañas y el refuerzo de sus muros. En otras ocasiones se construyeron edificios de nueva planta como la iglesia de Mirantes de Luna. Las mismas estructuras barrocas creadas desde el siglo XVII continuaron en su lugar original hasta la reforma del Concilio Vaticano II en el cual se modificaron algunas partes que componían la liturgia cristiana.

La subida al trono de Carlos IV y la reforma ilustrada de Godoy ${ }^{379}$ traerá como consecuencia el inicio de los procesos desamortizadores que culminarán con los de Mendizábal o los de Madoz ${ }^{380}$. De esta manera los grandes centros monasteriales, que en la Edad Media habían acumulado un poder territorial sobre Luna como Arbas u Otero de las Dueñas, van a ser desposeídos de sus pertenencias acabando en el abandono total. En 1868, tras la promulgación de la Constitución de la Gloriosa, diversas comunidades como la de Otero de las Dueñas fueron definitivamente anuladas y sus religiosas trasladadas a otros conventos.

Desde mediados del siglo XIX hasta 1951, todas las parroquias y propiedades de la diócesis se encontraron bajo jurisdicción de la Archidiócesis de Compostela, debiendo pagar un tributo a la misma, acto que se recoge en los textos Madoz. En 1954 la diócesis de Oviedo se libró de la de Compostela pasando a ser ella misma Archidiócesis, recogiendo dentro de su potestad las diócesis de Astorga (erigida en 747), la de León (erigida en el siglo IV) y la de Santander (erigida en 1754) ${ }^{381}$. A consecuencia de esta nueva situación el obispado de Oviedo perdió algunos de sus territorios. En este momento Luna pasa bajo jurisdicción leonesa la cual se encargará de recoger el testigo de todo el patrimonio que quedó anegado con la llegada del embalse.

\footnotetext{
379 Ídem, p. 57.

380 Ídem, p. 70.

${ }^{381}$ ZUBIETA IRÚN, José Luis. Geografía histórica de la Diócesis de Santander. Santander 2008, p. 126.
} 


\subsubsection{Los promotores}

Las informaciones relacionadas con la autoría artística o los comitentes son muy escasas. Los libros de fábrica apenas aportan nombres concretos y cuando lo hacen se refieren a albañiles o canteros de lugares próximos o incluso de la misma localidad. Tan solo en los documentos conservados en la Catedral de Oviedo se hace referencia a familias o promotores que dedican ermitas y capillas en honor a su santo patrón. Por ello se desprende que la autoría de los edificios corresponde a un colectivo genérico de maestros artesanales que configuraron el patrimonio arquitectónico del Valle.

El concilio de Constanza de 1055 legitimaba a la iglesia la autoridad para la fundación de edificios religiosos ${ }^{382}$. De esta manera, los principales promotores eran religiosos y la fundación de monasterios, parroquias o ermitas, debía adscribirse a un tipo de reglas propuestas desde las diócesis. Diferente era el caso de las ermitas y capillas, cuya institución podía provenir de manos laicas.

Las familias con mayor poder adquisitivo vieron en la creación de ermitas o capillas una ocasión, no sólo religiosa sino también publicitaria, para asentar su poderío en la zona. La mayoría de los promotores deseaban un lugar especial, diferenciado de los cementerios comunes, para establecer en ellos un enterramiento privado. Con la fundación de ermitas o capillas aseguraban la salvación de sus almas y la celebración de misas anuales y oraciones diarias. Con el tiempo estas ermitas pasaron a los herederos que normalmente las reutilizaban o alquilaban a las cofradías para conmemorar las festividades litúrgicas. De esta manera el cambio de devoción se convirtió en algo común, reaprovechando edificios anteriores y variando tan solo su decoración y adecuación a la figura del santo patrono. Se encuentran algunos ejemplos en la ermita de S. Ramón Nonato en Mallo, anteriormente dedicada a la Virgen de la Portería; la ermita de S. Miguel de Oblanca, fundada bajo la protección de la Virgen de Nuestra Señora de la Piedad y la ermita de S. Ramón de Lagüelles, fundada como Nuestra Señora de las Angustias y posteriormente de la Vera Cruz.

\footnotetext{
382 FERNÁNDEZ VÁZQUEZ. Arquitectura, Tomo I, p. 65. Estos edificios, ya fuesen monasterios, parroquias o ermitas, debían adscribirse a un tipo de reglas concretas.
} 


\section{Promotores religiosos}

El Valle del Luna fue cuna de religiosos, algunos de ellos llegaron a ser obispos, lo que permitió diversas donaciones a las iglesias de la zona. Otros, aún siendo solo párrocos, promovieron mejoras y fundaciones de capillas en los pueblos cercanos. Un ejemplo claro lo tenemos en la iglesia de Lagüelles en la que el cura D. Pedro García funda una capilla dedicada a S. Antonio en $1715^{383}$. Sin embargo, sólo aquellos que tenían un apego especial al Valle, por haber nacido allí, promovieron el patronato de iglesias parroquiales. De entre ellos destacan tres personajes:

El primero es D. Francisco Álvarez de Quiñones, nacido en Lagüelles cuyos apellidos demuestran al menos un parentesco con la familia de los Condes de Luna ${ }^{384}$. Fue Arcediano de Medina, canónigo de la iglesia de Sigüenza, prelado de la diócesis de Oviedo y Obispo en la diócesis de Sigüenza-Guadalajara durante los años 1698-1710. Destacó por su ayuda a los monasterios que en aquellos tiempos pasaban por dificultades económicas a causa de la Guerra de Sucesión, como el monasterio de monjas de Valfermoso en Guadalajara ${ }^{385}$. Durante los años de la guerra entre el archiduque Carlos de Austria y Felipe de Anjou, el obispo se decantó por el apoyo al Borbón, lo que le ocasionó enfrentamientos con el cabildo catedralicio. Desde 1701, D. Francisco Álvarez de Quiñones se retiró a vivir alejado del obispado hasta que finalmente regresó en 1708 a Sigüenza ${ }^{386}$. Su vocación promotora puede verse en la transformación de la nave de la iglesia parroquial de Barrios de Luna adecuada a la advocación franciscana del obispo ${ }^{387}$. También mandó hacer el escudo franciscano con las cinco llagas de Cristo que se sitúa en la cúspide del retablo pétreo de Sta. Bárbara, en la llamada capilla de los Condes de Luna y que se repite en el pórtico de entrada. Este escudo parece entroncar, según Ángel Rodríguez Morán, con el culto franciscano del Cardenal D. Francisco de los Ángeles Quiñones, hijo del primer Conde de Luna, y defensor de los Comuneros, embajador y mediador entre el Emperador Carlos V y el

\footnotetext{
383 A.D.L. Fondo parroquial. Libro de cuentas de la iglesia de san Mames. Lagüelles. Año 1714. Doc. 972

${ }^{384}$ GARCÍA SUÁREZ. Una historia, p. 25. Su partida de nacimiento fue llevada por el párroco a Sena antes de la inundación, donde se conserva en el archivo parroquial.

${ }^{385}$ MOLINA PIÑEDO, Ramón. Las señoras de Valfermoso. Una historia del Monasterio de Valfermoso de las Monjas. Abadía de San Salvador de Leyre, 1996, p. 305

${ }^{386}$ GARCÍA SUÁREZ. Una historia, p. 25.

${ }^{387}$ RODRIGUEZ MORAN Ángel. http://www.xente.mundo-r.com/luna/iglesiaCSS.htm
} 
Papa, y Gobernador de la Orden Franciscana en el siglo XVI por su labor diplomática en ayuda del papado durante el denominado Sacco di Roma ${ }^{388}$.

D. Bernardo Álvarez, cura de la iglesia de S. Miguel de Trabanco y capellán de la capellanía ${ }^{389}$, es sin duda uno de los mayores promotores religiosos de la ZACEL a mediados del siglo XVIII. Fue el fundador de la ermita de S. Ramón o de la Virgen de la Portería en Mallo de Luna $^{390}$ según reza la inscripción del dintel de la entrada ${ }^{391}$. Impulsó la creación de cofradías, romerías y devociones. También dotó a la ermita de algunas de las imágenes que se conservan en la iglesia parroquial de Mallo, como la figura de Sta. Marta, la de Sta. Bárbara, S. Ramón y S. Blas en cuyas peanas se puede observar la inscripción que demuestra la donación: ESTA IMAGEN LA DONÓ BERNARDO ÁLVAREZ. La falta de documentación parroquial acerca de este personaje ofrece un vacío histórico agravado por la destrucción de la iglesia de Trabanco, en Barrios, que pudo contener más donaciones y reformas por parte de este sacerdote.

Otro de los promotores religiosos oriundos del Valle fue el Obispo Álvarez Miranda, prelado doméstico de su santidad, asistente al sagrado solio pontificio, Conde de Colle, Señor de las Arrimadas y Vegamián, ex senador del reino y un largo etcétera de títulos religiosos. A él se le debe el nombramiento de la Virgen del Camino como patrona de León ${ }^{392}$. Miranda también fue impulsor de otras grandes obras religiosas fuera del Valle, como la remodelación de la iglesias de la Virgen del Camino o la iglesia de S. José de las Ventas en León realizada por Torbado en 1928 en estilo góticomudéjar $^{393}$.

José Álvarez Miranda nació en Miñera en 1850 y fue obispo de la diócesis leonesa durante los años 1913 a 1937. En 1936, tras el estallido de la Guerra civil, apoyó al frente nacional y se enfrentó a las autoridades militares que en aquel momento gobernaban el territorio de la diócesis ovetense ${ }^{394}$. Falleció en 1937 dejando en su

\footnotetext{
${ }^{388}$ RODRIGUEZ MORAN, Ángel. http://www.xente.mundo-r.com/luna/iglesiaCSS.htm

389 A.D.L. Fondo parroquial. Capellanía de N. S. de la Portería. Mallo de Luna, año 1772, doc. 1704.

${ }^{390}$ Ibídem. El lugar fue elegido, según la tradición, por el hallazgo de unas monedas de oro, que el cura creyó en pago de Dios, por lo que aún le esperaba en el cielo.

391 MALLO Y MIRANTES. AÑO DE 1764. ESTA CAPILLA LA MANDO HACER A SU COSTA DON BERNARDO CURA DE TRABANCO.

${ }^{392}$ PRIETO SARRO Ignacio. "Luna y sus gentes”, en El siglo en León. Crónica de cien años. 19002000. León, 2000, p. 335. En octubre de 1930 se celebró la consagración de la imagen como patrona leonesa.

${ }^{393}$ GARCÍA SUÁREZ. Una historia, p. 27.

${ }^{394}$ BERRUETA. Riberas, Vid: Oblanca.
} 
testamento la repartición de bienes para los pobres ${ }^{395}$. El obispo fue el artífice de numerosas donaciones de imágenes y objetos litúrgicos de su parroquia natal. De entre ellas podemos destacar la Virgen de Fátima, el copón y patena conservados en Barrios, el manto y la corona de plata de la Virgen de las Nieves y una Virgen de marfil para el retablo de la Virgen del Rosario. En agradecimiento, el pueblo de Miñera y posteriormente el de Barrios, realizaron una inscripción en su honor que reza: $A L A$ SANTA MEMORIA DE EL EXMO. SR. DR. D. JOSÉ ALVAREZ MIRANDA HIJO ILUSTRE Y GRAN PORTECTOR DE ESTA PARROQUIA DE MIÑERA. OBISPO DE LEÓN DURANTE 24 AÑOS FALLECIÓ EL 4 DE MARZO DE 1937 RIGIENDO LA DIÓCESIS DE LEÓN. D.E.P

\section{Promotores laicos}

Los promotores laicos tuvieron gran importancia en la zona contribuyendo a la construcción de capillas y ermitas. Son pocas las noticias que se han podido recuperar sobre fundaciones y donaciones de particulares, pero sin duda, las encontradas nos acercan a lo que debió ser la realidad promotora del Valle. A partir del siglo XVII se multiplican las fundaciones, por parte de familias enriquecidas o de origen nobiliario, para la construcción de capillas o ermitas cuya finalidad era el propio enterramiento. El escudo familiar se convirtió, junto con el sepulcro, en las señas de identidad de los promotores. El coste de la construcción y los problemas de manutención ocasionaron que sólo las familias más acaudaladas acarreasen con estos gastos. El resto debía conformarse con la donación de alguna imagen u objeto litúrgico de particular devoción.

En la ZACEL encontramos ejemplos de donaciones de particulares en casi todas las poblaciones. Principalmente es el matrimonio quien lleva a cabo la labor promotora.

Una de las familias promotoras más importantes fue la Rodríguez Lorenzana que desde mediados del siglo XVII se dedicaron a fundar ermitas por diversos pueblos del Valle en honor a la Virgen. En 1644, Miguel Rodríguez Lorenzana y su mujer fundan en Oblanca la ermita de Nuestra Señora de la Piedad ${ }^{396}$ y en 1655 el matrimonio manda dar unas misas en su memoria en la ermita de su propiedad llamada Nuestra Señora de

\footnotetext{
${ }^{395}$ PRIETO SARRO. Luna, p. 335. Su cuerpo fue enterrado en la catedral de León.

${ }^{396}$ MARTÍN FUERTES. Quiñones, doc. 218, p. 145.
} 
las Angustias ${ }^{397}$ en Lagüelles. Ninguna de estas dos ermitas se mantuvo con el mismo nombre de su fundación, puesto que con el paso del tiempo las devociones fueron variando. En Oblanca la ermita de Nuestra Señora de la Piedad pasó a llamarse de S. Miguel mientras que en Lagüelles la ermita de las Angustias se denominó de la Vera Cruz y finalmente de S. Ramón. La creación de estas dos ermitas de similares características hace suponer la importancia de esta familia y el establecimiento de unos maestros canteros que van a dictar nuevas formas constructivas que se repetirán en el resto de los templos.

La familia de los Cienfuegos poseyó propiedades durante los siglos XVII-XVIII en diversas poblaciones del Valle otorgando donaciones para su sepultura a diferentes templos. En el suelo de la iglesia de Pobladura aparece una lápida sepulcral perteneciente a los Cienfuegos al igual que en la desaparecida iglesia de S. Pedro en la cual existía una lápida con su escudo de armas datada en 1599. En Barrios de Luna destaca un escudo de la misma familia que se sitúa sobre un arcosolio en el que hoy se conserva el retablo con la imagen de la Virgen de Mirantes. Puede que este espacio estuviera dedicado a la sepultura de Gonzalo Diez, hijo de Sancho Diez y de Berenguela, muerto con 19 años. César Morán ${ }^{398}$ describe que en la parte trasera de la iglesia se había depositado un sarcófago en piedra extraído del arcosolio donde se encuentra el escudo de los Cienfuegos. Morán lo atribuye a Gonzalo Díez, hijo de Sancho de los Barrios de Luna, y lo data el 4 de mayo de 1720.

La familia Quiñones también se convirtió en mecenas de las artes. Destaca la donación de la familia Álvarez Miranda, descendientes de los Quiñones, de una capilla en la iglesia de Oblanca en la que se encontraba una inscripción que Berrueta no pudo describir por encontrarse tapada ${ }^{399}$. En 1714 D. Bernardino de Quiñones y su mujer Catalina Rodríguez, pagan una cantidad de dinero por la dotación de una capilla en la iglesia parroquial de Lagüelles dedicada la arcángel S. Gabriel ${ }^{400}$. Esta capilla fue reutilizada posteriormente para enterramientos particulares.

Por último, algunos feligreses pagaban ciertas cantidades de dinero a modo de donación para la mejora de las iglesias. Así es por ejemplo que durante la reconstrucción de la iglesia en Lagüelles, en $1715^{401}$, los vecinos donaron diversas

\footnotetext{
${ }^{397}$ MARTÍN FUERTES. Quiñones, p. 147. Doc. 226.

${ }^{398}$ MORÁN BARDÓN. Por tierras, p. 183.

${ }^{399}$ BERRUETA. Riberas, Vid: Oblanca.

${ }^{400}$ A.D.L. Fondo parroquial. Libro de cuentas de la iglesia de san Mames. Lagüelles. Doc. 972. Año 1714.

401 Ídem. Año 1714.
} 
propiedades para su fundación y manutención. En otras ocasiones legaban cantidades monetarias con la finalidad de enterrarse dentro de capillas ya fundadas como es el caso de Pedro Arias y Jacinto Fernández, vecinos de Lagüelles que en 1726 se hacen sepultar en la capilla de S. Gabriel, constituida por Bernardino de Quiñones ${ }^{402}$.

\subsubsection{Las cofradías y capellanías}

Las manifestaciones sobre la piedad religiosa tienen su culmen en la creación de las cofradías. Estas surgen en el siglo XI y se desarrollan especialmente entre los siglos XIV y XVIII ${ }^{403}$. Normalmente estaban dedicadas a la Virgen o a un santo protector, aunque es muy común también la advocación a Cristo. Destacan algunas cofradías como la del Cristo de los Barrios, que protagonizaba una gran procesión en septiembre, la de la Vera Cruz de Lagüelles, la del Sto. Cristo de Arévalo y la de la Virgen de la Portería de Mallo. Normalmente era la propia parroquia quien fomentaba la creación de las cofradías, aunque también lo hacían los monasterios, familias nobiliarias y a partir de 1783 por requisito del monarca ${ }^{404}$.

Las capellanías eran otro tipo de fundaciones muy características en la zona de estudio. Cada capellanía contaba con un capellán, que solía ser el cura párroco, al que debían pagar por los servicios prestados hacia la congregación. Por lo general, cada una poseía ciertas propiedades de terreno que arrendaba y cuyos beneficios se repartían entre los cofrades. Así por ejemplo la de la Virgen de la Portería de Mallo tenía entre sus bienes la administración de un molino harinero en el arroyo, además de numerosas tierras de pastos y de cultivo que solían arrendar para el mantenimiento de la fundación ${ }^{405}$. En otras ocasiones la donación de bienes quedaba sujeta al cumplimiento de misas y otras cargas pías.

Barrios de Luna poseía diversas capellanías como la de S. Antolín y S. Claudio de Trabanco ${ }^{406}$, la de la ermita de San Juan, la de la Trinidad, la de las Ánimas del Purgatorio o Penitentes y la más popular, la del Cristo de los Barrios. En Mirantes se

\footnotetext{
402 Ídem. Año 1726.

403 ALONSO GONZALEZ Los molinos, p. 20.

${ }^{404}$ GARCÍA VILLOSLADA, La iglesia, p. 596.

405 A.D.L. Fondo parroquial de Mallo de Luna. Apeo de bienes de la Capellanía de la Portería de Mallo. Barrios de Luna, Doc. 1704, año 1772.

${ }^{406}$ A.H.P.L. Catastro del Marqués de la ENSENADA. Interrogatorio. 1752. Oblanca. Rollo 145.
} 
encontraba la hermandad de la Virgen del Rosario, en Oblanca la de Nuestra Señora ${ }^{407}$ y en Miñera la de S. Lorenzo ${ }^{408}$. ZACEL

La configuración de un espacio parroquial va a influir en la ordenación urbanística, ya que desde el propio Concilio de Coyanza $^{409}$ se establecían una serie de medidas alrededor del templo para crear un espacio tanto religioso como público, pues en los pórticos se reunían los concejos para tratar asuntos relacionados con la comunidad. Los edificios parroquiales surgen del asentamiento de una población y no al contrario. Algunas iglesias se incluían dentro del entramado urbanístico, en una zona llana y aislada del resto de edificios mientras que otras se situaban en lugares alejados y elevados.

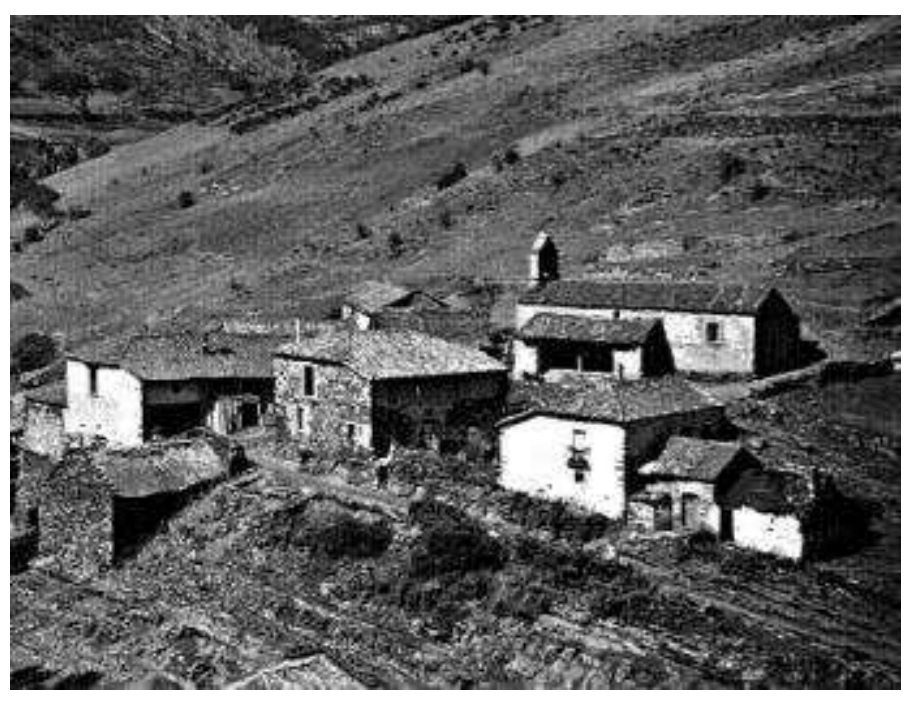

Ilustración 74. Iglesia de San Pedro. Fondo fotográfico. I.L.C.

La situación geográfica de los edificios religiosos va a depender de agentes tanto humanos como naturales, aunque el factor humano primará por encima del natural.

De entre los factores humanos serán los aspectos simbólicos y económicos los que acabarán ejerciendo una mayor influencia a la hora de construir una iglesia, ermita o monasterio. Se da la circunstancia de que en las poblaciones de Luna la iglesia no es el centro aglutinador de los diferentes espacios. Por lo general, los edificios se encuentran en zonas elevadas creando un paisaje teatral en el cual la iglesia parroquial domina la población como ocurre en Lagüelles, Mallo, Láncara o San Pedro. Se aprovecha la

407 Ídem. Miñera. Rollo 23-24.

${ }^{408}$ Esta capellanía estaba ubicada en la iglesia de Nuestra Señora del Mercado en León.

409 BENITO MARTÍN. La formación, p. 248. El Concilio de Coyanza estableció una distancia de 70 pasos alrededor de la iglesia. 
geomorfología del terreno para obtener un control visual y casi espiritual sobre el resto de edificaciones puesto que ninguna otra construcción puede sobrepasarla. En otros casos la iglesia parroquial busca un lugar privilegiado cercano a las principales vías de comunicación, como la iglesia de Miñera o la de Barrios.

En cuanto al factor natural, la orografía constituye un problema a la hora de asentar el edificio. Dependiendo de su ubicación orográfica y climática las iglesias poseerán porticados a modo de refugio para que los creyentes puedan orar $\mathrm{y}$ resguardarse de las inclemencias del tiempo. En la mayoría de los casos el pórtico se convierte en el escalón que sirve de tránsito para la entrada. Esto se debe fundamentalmente a que los edificios buscan una orientación S-E a refugio de los vientos. En algunos ejemplos como en la iglesia parroquial de Oblanca, la diferencia de terreno provocó que la nave central y el transepto estuviesen en un nivel más bajo que el resto de la estancia.

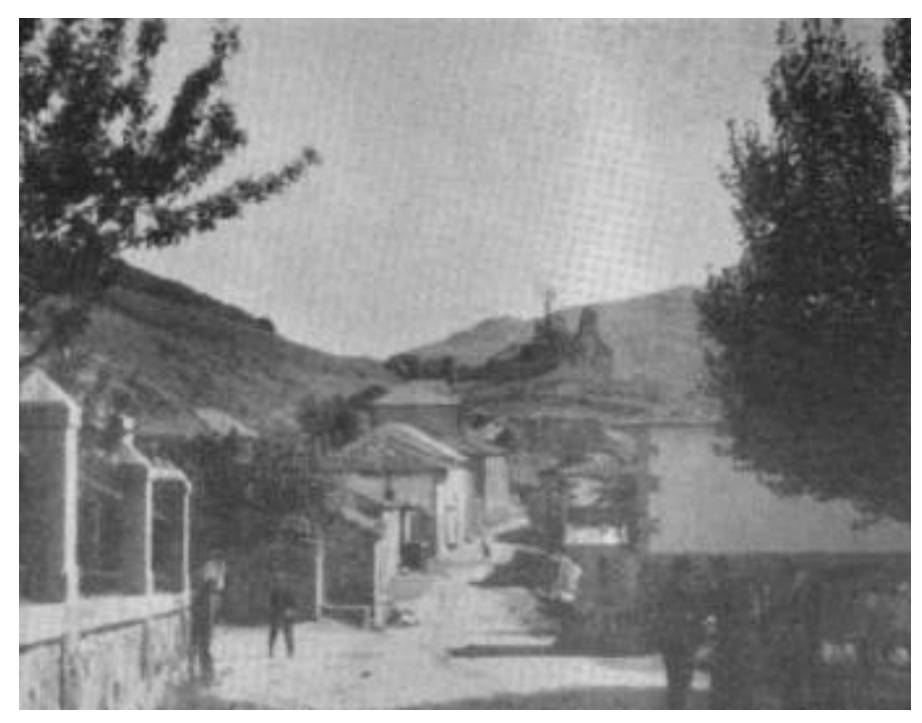

Ilustración 75. Iglesia de Láncara. Fondo fotográfico. I.L.C.

El tamaño del edificio va a configurar la ordenación urbanística, ya que aquellos edificios de mayores dimensiones son los que se sitúan en lugares llanos y amplios, como es el caso de las iglesias de Barrios y Oblanca en cuyos alrededores se acabará creando un espacio público a modo de plaza donde se asientan otros edificios importantes como el ayuntamiento o la casa del cura. Además este factor revierte en la morfología del edificio ya que en las fábricas de grandes dimensiones se utilizan torres campanarios, mientras que el resto poseen torres espadañas.

\subsubsection{Material}

Los materiales constructivos, al igual que en la arquitectura popular, son aquellos que se encuentran disponibles, en este caso la piedra caliza. Los canteros 
locales se encargaban de la extracción y transformación de la piedra bajo el mandato de la diócesis ante la inexistencia de maestros oficiales. Los edificios de la ZACEL son ejemplo de la labor popular y la sencillez de las formas tanto de las estructuras exteriores como interiores.

La piedra caliza gris o rosácea del país se extraía principalmente de las canteras de Caldas y Mirantes de Luna, pues poseía mejores calidades y menor porosidad que las del resto del Valle. La piedra labrada se destinaba para los sillares de vanos y esquinas y para formas decorativas de embellecimiento de las fachadas, vanos, torres y espadañas. Para las bóvedas se utilizada piedra toba muy porosa que se importaba de otros lugares. En el resto se usaba la mampostería o sillarejo.

Las maderas más comunes eran el chopo, castaño y roble ${ }^{410}$. El chopo se usaba para las cimbras y andamios, ya que su blanda resistencia no lo hacía propicio para la construcción $^{411}$. El castaño y roble se destinaba a las armaduras de las naves, pies derechos, zapatas, puertas y vigas de madera que tenían que soportar grandes pesos, ya que su dureza los hacía especialmente aptos para los lugares donde fuese necesario material resistente ${ }^{412}$.

Las cubiertas de los edificios eran de teja curva hasta el siglo XIX, momento en el que comienza a popularizarse la pizarra en los edificios más importantes ${ }^{413}$.

\subsubsection{Soportes}

Los muros de los edificios religiosos solían ser de mampostería de paramento doble con un grosor de 1 a 1,5 m. reservando los sillares mejor labrados para los vanos y esquinas. Al interior se utilizaba el pilar de sección rectangular o cuadrada y molduras sencillas para recoger las presiones de la cubierta, como se aprecia en la iglesia de Barrios de Luna. Para la base y el capitel se utilizaba la caliza rosácea que se diferencian de la caliza gris usada en el resto, creando de este modo un contraste cromático.

\footnotetext{
${ }^{410}$ Para la construcción de los edificios no bastaba con la madera del lugar, sino que se traían de otras zonas, ya que a veces la madera necesaria tenía que ser de una especie específica que no existía en abundancia en el valle.

${ }^{411}$ FERNÁNDEZ VÁZQUEZ. Arquitectura, Tomo I, p. 199.

412 Ibídem.

${ }^{413}$ No existían tejeras, por lo que el material debía importarse de otras zonas.
} 
Las pilastras se convirtieron, junto con el muro, en los principales elementos sustentantes de los edificios religiosos de la ZACEL. Aparecen sobre todo en aquellos que poseen una planta cruciforme o múltiples capillas. Soportan los arcos fajones de las bóvedas de cañón y el transepto aunque en algunos ejemplos, como en la iglesia de Oblanca, las bóvedas se apoyaban en dobles pilastras. En muchos edificios el muro era lo suficientemente fuerte como para soportar el empuje de las cubiertas de madera, por lo que las pilastras en el interior no poseían una función estructural sino decorativa. Es el caso de aquellos edificios de una sola nave cuyo presbiterio se separa por medio de un arco triunfal como en la iglesia de San Pedro de Luna, Láncara y Lagüelles.

Las vigas de madera se destinaban exclusivamente a soportar el tejadillo del pórtico. Se elegían maderas resistentes como el roble y se sujetaban sobre una base de piedra caliza con un capitel zapata de madera decorado con molduras como en los pórticos de San Pedro de Luna, Láncara, Lagüelles y el antiguo pórtico de Mallo.

\subsubsection{Cubiertas}

La elaboración de los edificios dependía de la capacidad económica de los feligreses a través de las primicias, donativos y demás impuestos. Una cubierta de piedra era un gasto demasiado grande para una población de pocos habitantes, por lo que en la mayoría de los casos se optaba por una cubierta de madera. Las bóvedas de crucería y de media naranja se dejaban para las zonas más importantes, como cabecera y transepto.

Los tipos de cubiertas de la ZACEL son:

Cubierta de madera: Casi todos los edificios religiosos se cubrían con estructuras de madera, especialmente aquellas zonas secundarias como la sacristía, pórticos o naves laterales. Su proliferación se debe principalmente al ahorro económico que suponía frente a las estructuras de piedra y a la abundancia de material vegetal en la zona. La cubierta más común era la armadura de parhilera ${ }^{414}$. Sobre esta estructura se colocaban las tejas o pizarras que cubrían el edificio.

${ }^{414}$ FERNÁNDEZ VÁZQUEZ. Arquitectura, Tomo I, p. 95. 
Cubierta de piedra: Estas cubiertas fueron habituales tanto en edificios parroquiales como en ermitas a partir del siglo $\mathrm{XVII}^{415}$.Todas ellas estaban construidas con piedra toba muy porosa y ligera. El modelo más común era la bóveda hemisférica o de naranja sobre el crucero a modo de cimborrio. La mayor parte de estas estructuras se apoyaban en pechinas sobre un muro con contrafuertes exteriores como se aprecia en las iglesias de Mirantes, Oblanca y Mallo.

La bóveda de cañón se utilizó principalmente para la cubrición de las naves centrales, aunque en ocasiones esta bóveda también fue usada para el

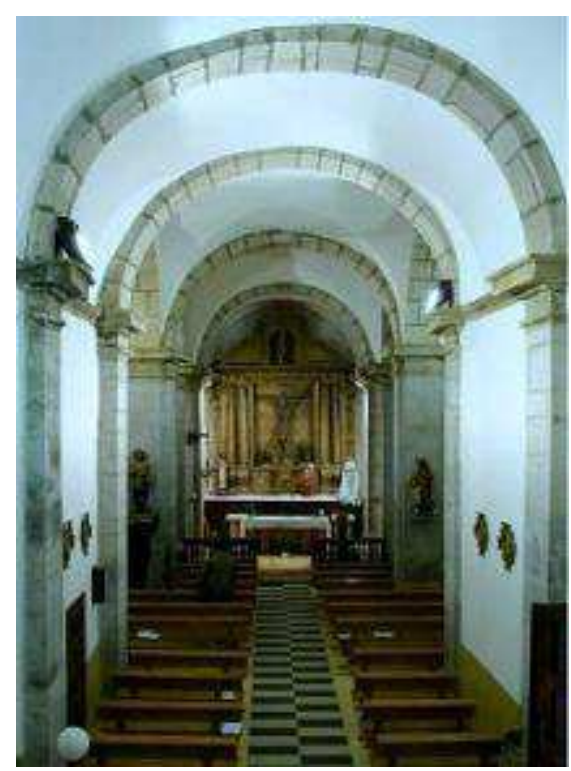

Ilustración 76. Interior de la iglesia de Barrios de Luna. presbiterio, como en la iglesia de Barrios y en la de Láncara. Ésta estaba realizada a partir de ladrillos macizos colocados a sardinel y revocados con cal para tapar las imperfecciones.

Por último, la bóveda de crucería era la menos usual. El único ejemplo de la ZACEL se encuentra en el transepto y cabecera de la iglesia de Barrios de Luna.

\subsubsection{Torres y espadañas}

Las torres y espadañas son el elemento más peculiar de los edificios religiosos. Cada torre albergaba al menos un cuerpo de campanas que era el que marcaba el ritmo de la vida de los habitantes como las horas religiosas de los trabajos del campo.

Dependiendo de las dimensiones del edificio, el templo podía contener una torre campanario o una espadaña.

\section{TORRES CAMPANARIO}

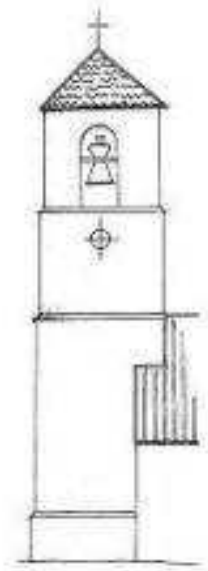

OBLANCA

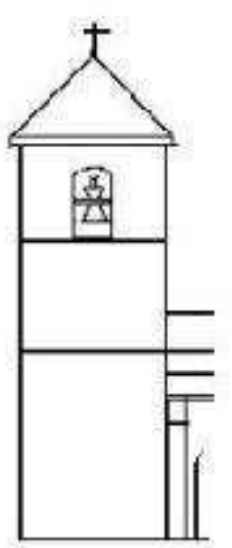

BARRIOS
Ilustración 77. Modelos de torre campanario en la ZACEL. 
Torre Campanario: Los dos ejemplos de torres campanario de la ZACEL, el de Oblanca y el de Barrios, son de sección cuadrada con un cuerpo superior de campanas. Se disponían a los pies de la iglesia para frenar los empujes de las bóvedas y asentar la fábrica. Esta tipología se originó en el siglo $\mathrm{XVI}^{416}$ respondiendo a la estética italiana clasicista y fue común a lo largo de toda la Edad Moderna ${ }^{417}$. Se compone de una base lisa que llega al cuerpo de campanas rematado por un tejado piramidal. Los vanos son de medio punto y se abren a cada lienzo del muro.

Torre Espadaña: La espadaña es la solución más económica y común en la ZACEL. El acceso al cuerpo de campanas era a partir de unas escaleras adosadas al exterior que podían ser de caracol o de sección cuadrada. Estas escaleras acababan en un descansillo de madera frente al campanario que facilitaba el trabajo de repique. Los tipos de espadañas son:

Espadañas con un solo vano: son las más sencillas y se utilizan para las ermitas y edificios pequeños. Poseen un solo arco de medio punto sin apenas decoración moldurada. El remate se realiza a través de un tejadillo a dos aguas a modo de frontón. Sobre la parte superior se coloca una cruz de hierro. Todas las ermitas del embalse poseían esta tipología que se repite de manera similar por cada uno de los edificios. En ocasiones iglesias de pequeñas dimensiones como Láncara, San Pedro, Campo y Cosera mantienen esta misma estructura, aunque las medidas del vano y de la campana son superiores a los de las ermitas.

Espadañas de dos vanos: Tienen un origen medieval y se utilizan especialmente para aquellas iglesias parroquiales rurales ${ }^{418}$. Se disponen en el muro O. y poseen una escalera interior o exterior de acceso al campanario. Estas estructuras son de mayores dimensiones ya que tienen que soportar unas campanas de mayor peso y envergadura que las espadañas que cuentan con un solo vano. El cuerpo se remata con un frontón triangular con decoración moldurada y triángulos en las esquinas. La parte superior se termina con una cruz de hierro. Son los ejemplos de Miñera y Lagüelles.

\footnotetext{
${ }^{416}$ FERNÁNDEZ VÁZQUEZ. Arquitectura, Tomo I, p. 151.

417 Ibídem

${ }^{418}$ Ídem, p. 159.
} 
Espadañas de tres vanos: Esta tipología se desarrolla entre los siglos XVII y XVIII donde las formas decorativas se multiplican con la introducción de frontones partidos, curvos y bolas en los extremos que dan al conjunto un aspecto menos pesado que las espadañas de siglos anteriores. Su estructura es similar a las de dos vanos, salvo en la parte superior en la que se abre un tercero sin campana. La decoración se multiplica y el frontón triangular rompe su forma para crear un contraste a base de remates prismáticos y formas cóncavas y convexas. Se remata con una cruz de hierro. Encontramos ejemplos en Mirantes y Mallo.

\section{TORRES ESPADAÑAS}

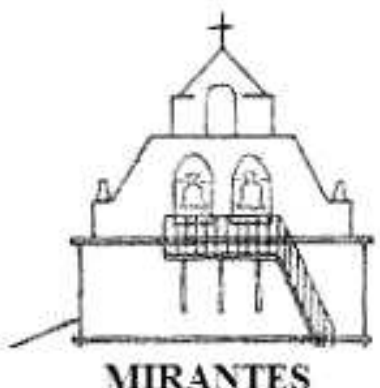

MIRANES

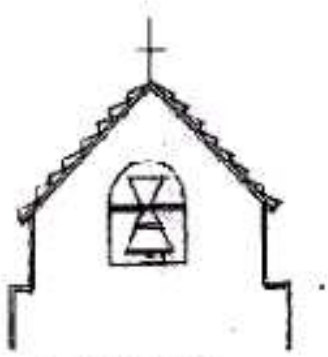

LANCARA
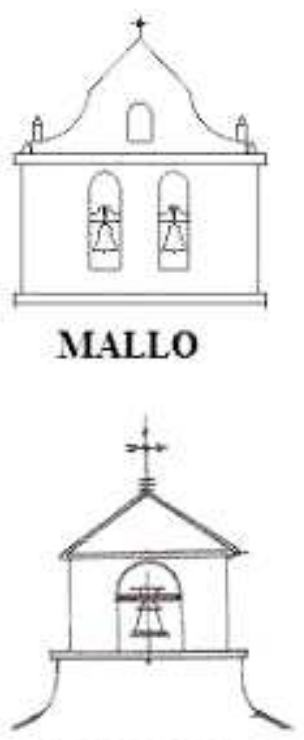

SAN PEDRO

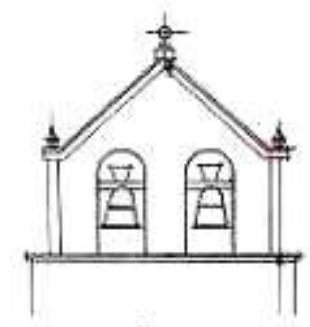

MIÑ̃EA

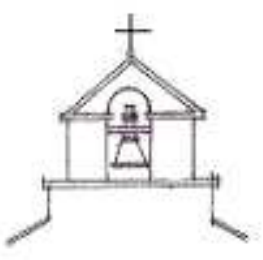

CAMPO

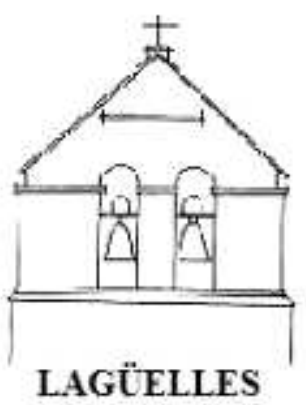

LAGÜELLES

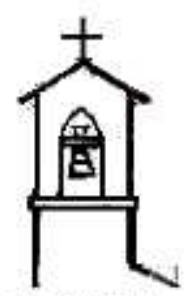

COSERA

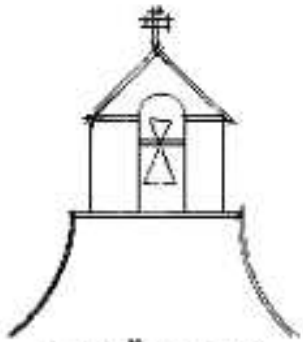

LAGÜELLES

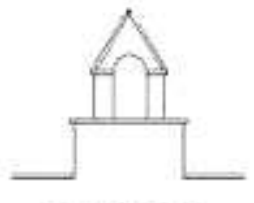

MALLO

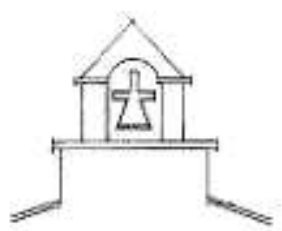

MIÑERA

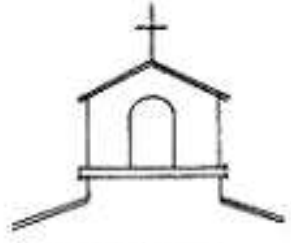

OBLANCA

Ilustración 78. Modelos de torre espadañas dentro del territorio de la ZACEL. 


\subsubsection{Vanos}

Los vanos de los edificios religiosos de la ZACEL son característicos por sus formas abocinadas o de óculos. Su función principal es iluminar el crucero y la capilla mayor, aunque en muchos casos también encontramos ventanas y óculos a los pies de la iglesia $^{419}$. Los vanos de la iglesia no poseían ningún tipo de decoración, salvo molduras lisas con grafitis a modo de rosetas. En ocasiones se cerraba con un enrejado sencillo para que los fieles pudiesen ver las imágenes devocionales.

La mayoría de las ventanas se abren en los laterales del altar, en el muro del evangelio y en el de la epístola, y especialmente en el muro S., el más soleado. En los edificios nuevos como en Mirantes cuya iglesia se reformó a finales del siglo XIX, se abrieron grandes ventanales para iluminar de forma natural el interior.

\subsubsection{Portadas}

La tipología de las portadas en las iglesias de la ZACEL es muy sencilla. No existen grandes adornos ni decoraciones excesivas más allá de las simples molduras talladas en la piedra. Las portadas se cerraban al exterior con porticados de madera, por lo que la visualización de la entrada quedaba reducida a la puerta de acceso. Es allí donde se van a desarrollar las formas decorativas que en muchos casos se reducirán a inscripciones fundacionales y escudos heráldicos o religiosos. Se pueden distinguir varias tipologías de portadas:

Portadas adinteladas: Son las estructuras más sencillas y menos numerosas. Estas portadas se trazan a partir de una gran viga de madera o piedra. Sobre ellas se colocan inscripciones conmemorativas de la fundación del edificio como observamos en la ermita de S. Ramón.

Portadas con arco: Es la tipología más común en la ZACEL que se compone de un arco de medio punto con decoración a base de molduras en las jambas y pilastras adosadas con capiteles y basas decoradas con perfiles sencillos. En algunas portadas se enmarca el alfiz como en la puerta de entrada de la iglesia parroquial de Barrios de Luna. En muchos casos la clave del arco de las puertas de entrada presentaba una

\footnotetext{
${ }^{419}$ LLAMAZARES RODRÍGUEZ, Fernando. El retablo barroco en la provincia de León. León 1991, p.
} 41. 
inscripción que hacía referencia al año de fundación, restauración de la fachada o frases dedicatorias a la casa de Dios, como es el caso de la inscripción de la puerta de la iglesia de Sta. Marta de Mallo de Luna en la que se pude leer: HAEC EST DOMUS DOMINI; la fachada de Mirantes de Luna: ISTA EST DOMUS DEI AÑO DE 1888 D.J.A.R.; y la de Barrios de Luna, que fecha el año en que se hicieron las puertas de madera: ESTAS PUERTAS HICIERONSE AÑO DE MDCCCXXXXVIII.
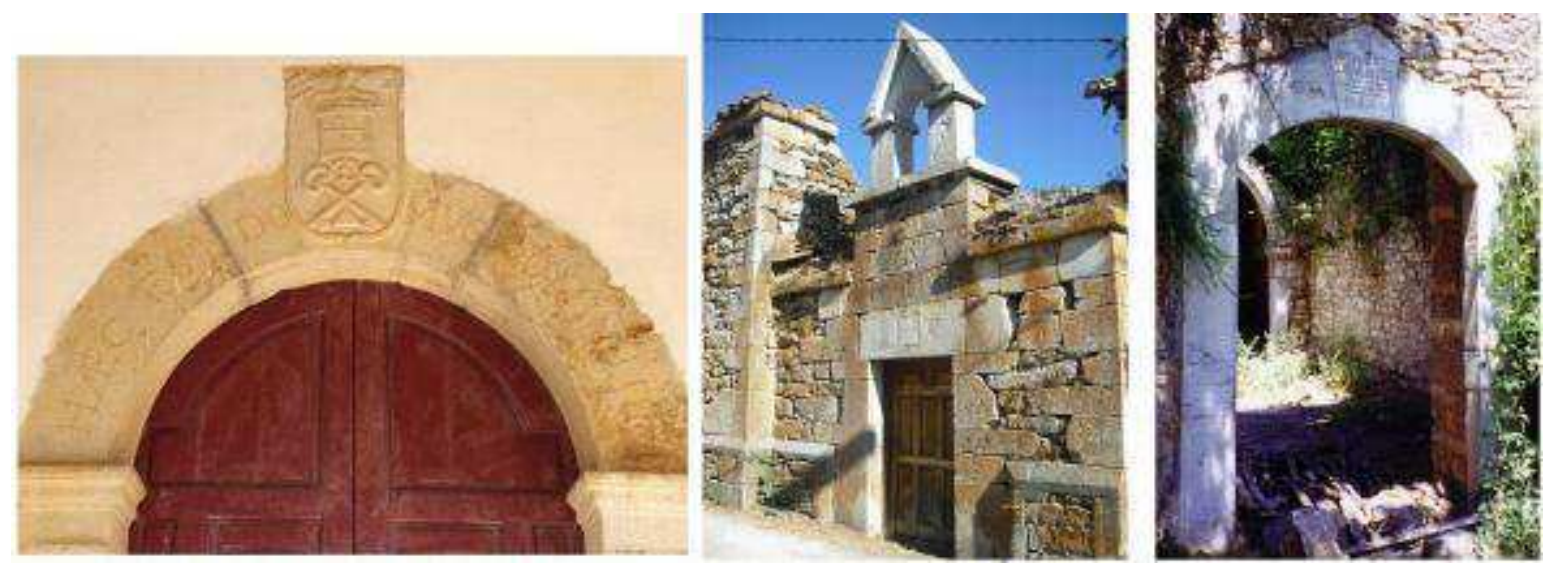

Ilustración 79. Puerta de la iglesia parroquial y la ermita de S. Ramón de Mallo. Iglesia de Mirantes.

En otros casos las inscripciones forman parte de donaciones o recordatorios como ocurre en la iglesia de Barrios de Luna, la cual posee dos placas traídas desde la anegada Miñera de Luna que recuerdan la figura del obispo Álvarez Miranda.

\subsubsection{Pórticos}

Una característica común en los lugares de montaña es la creación de un espacio porticado a la entrada de los edificios religiosos. Su finalidad principal es la de proteger la entrada de las inclemencias del tiempo y también la de crear un espacio intermedio de transición a lo sagrado. Los pórticos también eran espacios públicos donde se impartían catequesis y se reunían los concejos para tratar temas del pueblo. En ocasiones servían para albergar las carrozas procesionales, andas y demás elementos necesarios para las romerías organizadas por las cofradías. En principio los porticados se realizaban con materiales pobres, como tejadillos a un agua adosados en par hilera sujetos sobre vigas de madera como la iglesia de Mallo o la de Campo. Posteriormente, en aquellas parroquias con mayor poder adquisitivo, se levantaron porticados en piedra que llegaban 
a ocupar todo el tramo de la nave de la iglesia como es el caso de la iglesia de Barrios de Luna.

La tipología de los pórticos de la ZACEL es la siguiente:

Pórtico de vigas de madera: Este tipo fue el más común en el Valle. No es exclusivo de pequeñas fábricas puesto que lo encontramos en la iglesia parroquial de Oblanca, de grandes dimensiones. Se configura a partir de la prolongación del faldón S. de la cubierta a dos aguas que cubre el espacio destinado a pórtico. Éste se apoya sobre un muro junto a la torre que origina una habitación semicerrada sin vanos de iluminación. El peso del tejado se distribuye entre el muro de cerramiento y la viga de madera sobre una basa de piedra con capitel zapata.

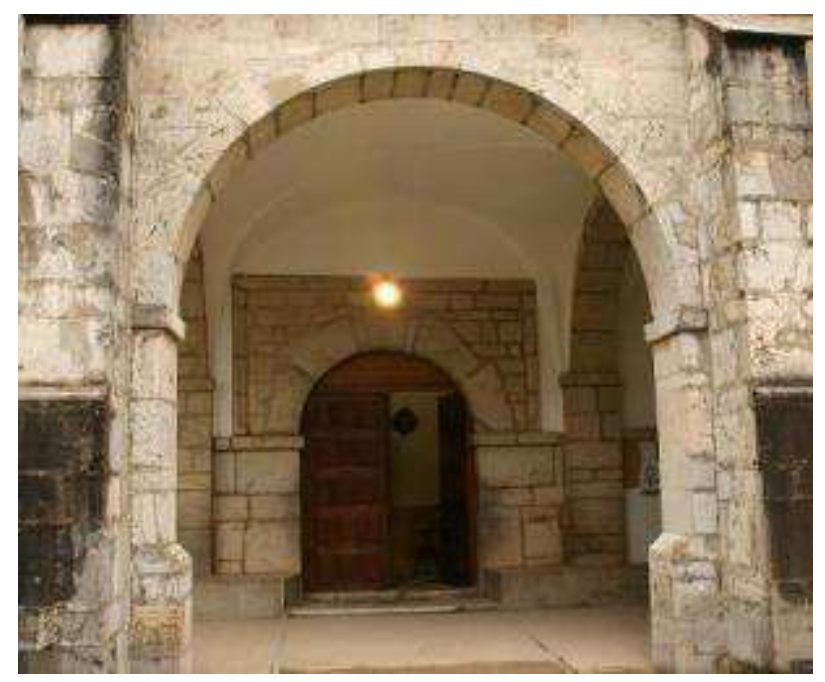

Ilustración 81. Iglesia parroquial de Barrios de Luna.

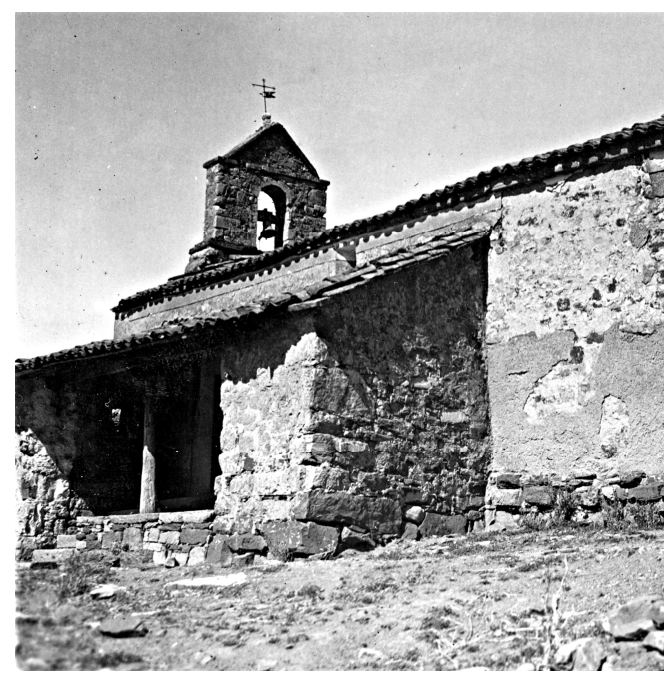

Ilustración80. Iglesia de S. Pedro. I.L.C.

Pórticos con arcos de medio punto: Los pórticos cubiertos con arcos de medio punto poseen una estructura diferenciada en la que el tejado a dos aguas de la nave central no es el mismo que cubre la estancia. Es el caso de la iglesia de Barrios de Luna, que posee un espacio adosado a la pared cerrado con dos arcos de medio punto. El pórtico se cubre con tres bóvedas de crucería separadas por arcos fajones de medio punto que descansan en pilastras con contrafuertes exteriores. Los dos primeros tramos se encuentran abiertos al exterior por dos grandes arcos de medio punto, mientras que el último tramo se cierra por el propio muro de la fábrica para ofrecer un espacio amplio que pudiese albergar las labores de preparación para la romería del Cristo de los Barrios, la mayor procesión de todo el Valle. Contorno al muro se ubica un banco corrido de piedra que servía para dar asiento a los feligreses y para la catequesis. 


\subsubsection{Sacristía}

La sacristía fue un elemento poco común durante la Edad Media y sólo las grandes fábricas parroquiales poseían una. A partir del siglo XVI al XVIII ${ }^{420}$ comienzan a multiplicarse estas habitaciones que originan una ampliación de la iglesia y una ruptura de su planta original. La liturgia se complica a partir de las disposiciones de Trento con la aportación de numerosos objetos como cálices, copas, custodias, vinajeras, palancanas, etc. Debido a este cambio se hace necesaria la construcción de un espacio destinado principalmente para la guarda y conservación de estos objetos. A veces se encontraban almacenes o trasteros que también servían para albergar mobiliario religioso como en la iglesia de Barrios de Luna, Miñera y Lagüelles. En estos almacenes se recogían las imágenes procesionales, las andas, figuras antiguas, muebles y demás objetos no litúrgicos.

En las iglesias rurales la sacristía solía estar ejecutada con materiales de inferior calidad, sobre todo en aquellos edificios en los que esta estructura se había levantado con posterioridad a la fábrica general. La mayoría de las sacristías se cubrían con un tejado a uno o dos aguas exceptuando algunos ejemplos como el de Miñera en donde se cerraba con una bóveda de naranja. En las ermitas también se acabaron creando sacristías, como en la ermita de S. Ramón de Mallo.

En la mayoría de las iglesias de la ZACEL la sacristía no conforma una unidad dentro del conjunto, sino que se adosaba a uno de los laterales del edificio. La sacristía siempre estaba cercana al presbiterio, en un lateral o en la parte trasera del testero de la iglesia. Cuando la sacristía se situaba en el lugar más soleado se aprovechaba el espacio sobresaliente para abrir un pórtico. Es el caso de las iglesias de Campo y Lagüelles. En otros ejemplos, la sacristía se situaba en el lateral N. y el espacio sobrante era aprovechado para adosar el cementerio, como ocurre en la iglesia de Láncara de Luna.

En los edificios de planta de cruz latina la sacristía ocupaba un espacio entre la cabecera y uno de los brazos, dejando al exterior un aspecto visualmente más compacto.

Finalmente, la sacristía podía encontrarse justo detrás del presbiterio, como ocurre en Oblanca o Miñera de Luna. Un caso especial es Mirantes, donde la ampliación de un lateral de la iglesia originó una ubicación extraña de la sacristía a los pies del edificio.

${ }^{420}$ FERNÁNDEZ VÁZQUEZ. Arquitectura, Tomo I, p. 176. 


\subsubsection{Atrio}

Alrededor del edificio se sitúa el atrio, un espacio acotado por una cerca que rodea el templo y que actúa como separación entre lo sagrado y lo profano ${ }^{421}$. Durante la Edad Media fue el lugar de sepultura más común para aquellos que no podía enterrarse dentro del edificio. También era el lugar de reunión de los feligreses cuando en ocasiones se celebraban festejos y procesiones. En muchos de los edificios conservados como en Barrios, Miñera o Mirantes de Luna se conservaba un tejo dispuesto en el atrio que se plantaba en el momento de la construcción del edificio.

\subsubsection{Baptisterio}

La mayoría de las pilas bautismales se encuentra en la epístola, al lado del altar y aparecen exentas. Sin embargo existe un ejemplo en el que se circunscribe un espacio diferenciado como lugar de bautismo. En la base de la torre de Barrios de Luna aparece una estructura abovedada en piedra caliza en la cual se incrusta una antigua piedra bautismal de granito. La sala tiene apenas $5 \mathrm{~m}^{2}$ a la que se accede a través de un espacio abovedado iluminado por una sola ventana lateral abocinada de forma rectangular. El lugar se utiliza hoy en día como almacén, sin embargo, su situación fuera del espacio sagrado hace pensar en la creación de un primitivo baptisterio.

\subsubsection{Cementerio}

A finales del siglo XVIII las reformas ilustradas de Carlos III variaron el modo de enterramiento dentro de la iglesia. Para ello se hizo necesaria la construcción de nuevas estructuras destinadas a cementerio, puesto que a partir de ese momento sólo los personajes religiosos que hubieran sido virtuosos o milagrosos podían inhumarse dentro del templo ${ }^{422}$. A pesar que la Real Cédula de $1787^{423}$ obligaba a construir los cementerios fuera de las poblaciones, encontramos algunos ejemplos como en Mallo,

\footnotetext{
${ }^{421}$ FERNÁNDEZ VÁZQUEZ. Arquitectura, Tomo I, p. 159

${ }^{422}$ Ídem, p. 178.

${ }^{423}$ Ídem, p. 177.
} 
Campo o el Láncara en los cuales los camposantos se ubicaron adosados o justo al lado de la iglesia y siempre en la zona más sombreada y fría, como es la N. Este aspecto se debía principalmente a la lejanía de la propia iglesia del casco urbano. En otras ocasiones se utilizaban las ermitas como capillas para los cementerios como la ermita de S. Lorenzo de Miñera, junto a la cual se planificó el cementerio.

En el cementerio, y especialmente en dependencias anexas a la iglesia, se encontraban los osarios. Su finalidad era la de almacenar los restos óseos de los cuerpos que se inhumaban pasados varios años. Habitualmente estos osarios se enterraban bajo el suelo de la iglesia, pero otras veces se destinaban espacios para éstos. Es

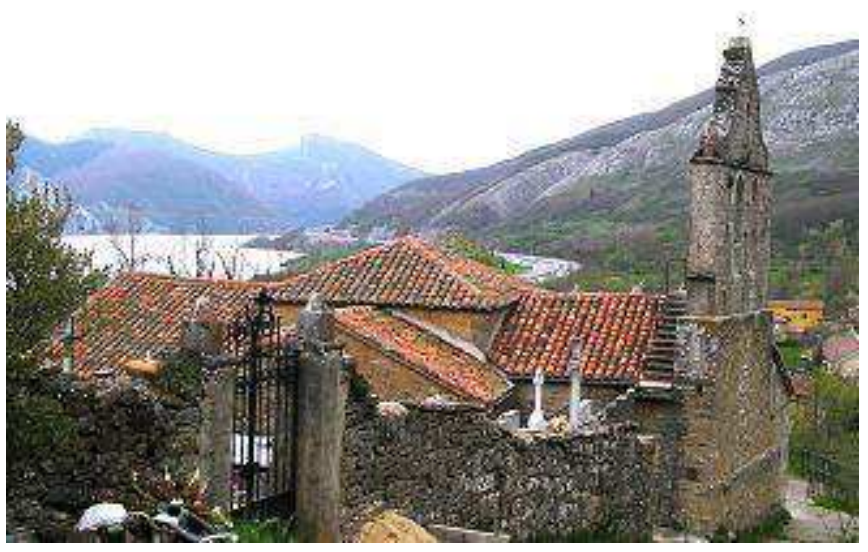

Ilustración 82. Cementerio adosado a la iglesia de Mallo de Luna. el ejemplo del osario de Miñera de Luna, abierto en el muro N. del edificio.

\subsubsection{Elementos decorativos}

A partir de los ideales de la Contrarreforma, y especialmente debido al cambio de estética del Barroco, los edificios parroquiales comienzan a decorarse tanto al exterior, con la proliferación de espadañas con diversas formas, como al interior, con la inclusión de escenas pintadas, grandes retablos y figuras devocionales que conforman un gran espacio escenográfico. La decoración se va a concentrar en vanos y fachadas, dejando el resto del edificio con formas volumétricas simples. Las más comunes son las molduras lisas sin grandes elementos sobresalientes, con un contraste cromático debido a los distintos tipos de rocas gris y rosa, y pequeños grabados con formas vegetales.

La decoración epigráfica de cruces o rosas se convirtió en un elemento ornamental muy común en las fachadas de los templos. En muchos casos sobre el dintel de la puerta se inscribía la fecha de realización del edificio o de su restauración. A ambos lados de la inscripción podían dibujarse figuras decorativas de cruces o rosetas como encontramos en la ermita de S. Ramón de Mallo. 
En otras ocasiones un alfiz enmarcaba la puerta de entrada con molduras sencillas, como en la iglesia parroquial de Barrios. Al poseer un pórtico de entrada bastante desarrollado, las iglesias eliminaban los elementos decorativos de las portadas reduciéndolos a simples perfiles.

Al interior las pilastras y los arcos fajones se disponían creando una sensación de juego de luces y sombras que rompía con la monotonía del muro. Las pilastras adosadas en el presbiterio servían para separar la nave destinada a los fieles del espacio religioso dedicado a la celebración de la eucaristía. Un arco de medio punto o apuntado cerraba el espacio recreando una especie de arco triunfal o puerta del paraíso a la que en un principio sólo podían acceder los sacerdotes. Las molduras decorativas de este espacio se basaban en elementos sencillos con el fuste liso, sin decorar y friso con perfiles geométricos.

La mayoría de los edificios se encalaban de blanco y sólo se decoraba la franja moldurada que separaba la pared del techo. Sin embargo todavía conservamos algunos restos de decoración realizada al temple sobre la pared encalada en la ermita de $\mathrm{S}$. Ramón de Mallo. En ella se puede ver la figura de un franciscano rodeado por gran cantidad de animales representados esquemáticamente. La bóveda se decoraba con pinturas estucadas que representaba unos ángeles sujetando una cruz anicónica con unas guirnaldas formando una corona. Hoy en día estas pinturas han desaparecido.

A pesar de que sólo existen datos concretos de este ejemplo, no es de extrañar que el resto de las iglesias del Valle contuvieran una decoración similar o al menos una decoración diferenciada de las simples molduras. La pintura servía de apoyo para el programa iconográfico del interior de los templos, ofreciendo un espacio teatral que se unía con la colocación estratégica de los retablos y el culto a las imágenes.

Los escudos se convirtieron en otro elemento ornamental ya que se disponían en las fachadas o en zonas visibles al interior de los templos. A partir del siglo XIV los monasterios y órdenes religiosas comienzan a utilizar los escudos como símbolo identificativo de las diferentes formaciones. ${ }^{424}$ También existen escudos pertenecientes a obispos o dignatarios eclesiásticos en las portadas de las iglesias, como en el ejemplo de la iglesia de Mallo de Luna. Este escudo posee un blasón de tipo francés en que se representan en la zona inferior las dos llaves de S. Pedro. En el cantón diestro del jefe

${ }^{424}$ CIMADEVILLA. Repertorio, p. 18 
aparece la cruz triple que porta iconográficamente el santo al haberse convertido en primer papa de la iglesia y en el cantón siniestro se encuentra un banderín deteriorada.

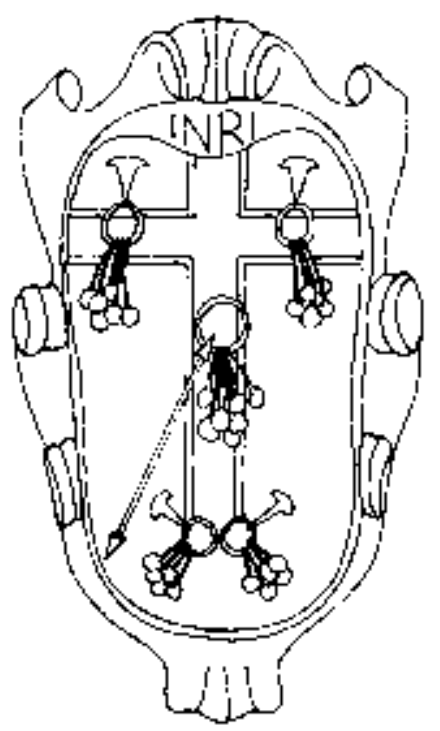

Ilustración 83. Escudo franciscano de la iglesia de Barrios de Luna.

Destaca el escudo religioso de las cinco yagas conservado por duplicado en la iglesia de Sta. Colomba de los Barrios de Luna. El escudo principal se encuentra sobre el retablo pétreo de Sta. Bárbara en el brazo N. del crucero de la iglesia. Pertenece a la orden de los Franciscanos datado en el siglo XVII. Está realizado en piedra caliza policromada de $1 \mathrm{~m}$. de alto y $0.50 \mathrm{~m}$. de ancho aproximadamente

Presenta un campo tradicional castellano con una cruz latina con las cinco yagas de Cristo de la Pasión. El color del fondo es dorado, la cruz posee tonalidades azules y la sangre que brota es de color rojizo. No lleva timbre ya que es un escudo perteneciente a una orden monástica. Se adorna con una cartela con filatelias contraídas en color añil. Este mismo escudo se repite en el pórtico de entrada y parece entroncar, según Ángel Rodríguez Morán, con el culto franciscano del Cardenal D. Francisco de los Ángeles Quiñones ${ }^{425}$.

\subsubsection{Arquitectura de interior: el retablo}

La creación de espacios arquitectónicos interiores experimentó un gran desarrollo en la ZACEL a partir de la Contrarreforma ${ }^{426}$. En este período la casi totalidad de las iglesias del Valle fueron remodeladas estructuralmente para ajustarse a los mandatos de Trento y así sus antiguos retablos fueron reemplazados por otros de tipología barroca.

El altar mayor pasó a ser la parte fundamental del templo realzando su presencia a través de una escalinata que elevaba el espacio con respecto al resto del edificio. El

\footnotetext{
${ }^{425}$ RODRIGUEZ MORAN, Ángel. http://www.xente.mundo-r.com/luna/iglesiaCSS.htm

${ }^{426}$ MARTÍN GONZÁLEZ, Juan José. El retablo barroco en España. Madrid, 1993, p. 5. 
sagrario y la exaltación de la eucaristía cobraron cada vez más importancia, convirtiéndose en el centro de la composición de los retablos de este período ${ }^{427}$.

La estructura es similar en todos los casos. En el primer cuerpo se sitúa la imagen del santo titular del retablo bajo una hornacina de gran tamaño. En los laterales del retablo, separados por columnas, aparecen las imágenes devocionales. El mayor protagonismo de los retablos se lo llevan los elementos sustentantes, es decir, las columnas y pilastras. Existe también un juego de entrantes y salientes que generan un gran dinamismo y sensación de inestabilidad en toda la obra. Así las columnas sobresalen y las hornacinas se retranquean dando formas circulares con frontones partidos. Los cuerpos van disminuyendo en altura y la decoración deja de ser tan minuciosa a medida que el retablo avanza. En el ático se suele representar la crucifixión o el patrón de la iglesia.

De entre las tipologías de retablos barrocos podemos encontrar numerosos ejemplos en el Valle de Luna:

El retablo contrarreformista: se desarrolla durante la primera mitad del siglo $\mathrm{XVII}^{428}$. Mantiene las estructuras herrerianas con trazados muy rectos tendiendo a la horizontalidad clasicista. La calle central se dedica a la figura principal, mientras que las calles laterales se cubren con relieves o pinturas. Su estructura suele ser recta, puesto que la base mantiene una forma lineal que obliga al resto del retablo a evitar la multiplicación de salientes ${ }^{429}$. Las hornacinas aún carecen de la profundidad que tendrán años más tarde. Las formas siguen siendo clásicas, ajustándose al cuadrado y al círculo. Los frontones se presentan rectos, o bien curvados y partidos mostrando las nuevas tendencias. En el ático se encuentra en muchas ocasiones el Calvario, aunque veces se sustituye por la heráldica de los clientes. Es el caso del retablo del Sto. Cristo de los Barrios de Luna.

El retablo prechurrigueresco: parte de la segunda mitad del siglo XVII ${ }^{430}$. La decoración comienza a ser uno de los factores más importantes incluso por encima de las formas estructurales. Las cartelas cobran mayor importancia y el banco se carga de elementos decorativos destacando las formas vegetales. Las columnas sufren una mayor transformación decorativa desde la base y capiteles, en donde se introducen cabezas de

\footnotetext{
${ }^{427}$ Ídem, p. 6.

${ }^{428}$ LLAMAZARES RODRÍGUEZ. El retablo, p.38.

${ }^{429}$ MARTÍN GONZÁLEZ. El retablo, p.11.

${ }^{430}$ LLAMAZARES RODRÍGUEZ. El retablo, p. 39.
} 
serafines y querubines, hasta los fustes. Comienza a utilizarse la columna salomónica, a pesar de la pervivencia de los estriados enriquecidos con cabezas de angelotes y el uso de la columna estípite. Los transparentes van a ser la gran innovación de este momento, abriéndose una ventana en la parte central del retablo donde suele ubicarse la custodia o la imagen de mayor devoción. Ejemplo de este tipo es el retablo de la Virgen del Rosario de Barrios de Luna.

El retablo churrigueresco: se data entre finales del siglo XVII y primer tercio del siglo $\mathrm{XVIII}^{431}$. Se caracteriza por una ornamentación que lo cubre todo, con numerosos entrantes y salientes que dan sensación de movimiento a la obra. La columna salomónica es el máximo exponente de este período en el que se desarrollan todo tipo de decoraciones basadas en temas eucarísticos como las hojas de parra. Las hornacinas cada vez son más profundas, rematadas por conchas veneras y encuadradas en ramajes y cabezas de angelitos. En este período pudo estar establecido un taller itinerante que se encargó de realizar la mayoría de los retablos del Valle. Forman parte de esta tipología los retablos de Sta. Bárbara y S. Roque de Barrios de Luna, el retablo principal de Lagüelles conservado en Pobladura, el destruido retablo mayor de Mallo y el de la Virgen del Cuartero de la misma localidad, y los desaparecidos retablos principales de Miñera y Cosera.

El gran esfuerzo del siglo XVIII por la decoración interior de las iglesias ocasionó que durante el siguiente siglo apenas hicieran falta remodelaciones y por ello casi no se ejecutaron nuevos retablos y los que se montaron eran de pequeñas dimensiones evitando la utilización del dorado a favor de la policromía. Las formas son cada vez más sencillas eliminando los complicados elementos decorativos del siglo anterior. La columna salomónica deja de ser protagonista en favor de una mayor pureza constructiva que sigue la línea de las directrices neoclásicas. Los frontones, decoraciones vegetales, angelotes, etc. se van eliminando paulatinamente para dejar paso a las formas estructurales que son las que competen el entramado del retablo.

Martín González ${ }^{432}$ define una serie de tipologías retablísticas a partir de la función que éstas poseían. Así algunas de ellas pueden adscribirse a desaparecidos retablos de la ZACEL:

El retablo rosario está dedicado a la figuración de la Virgen con relieves que aluden a la vida de María. Aunque su forma y exaltación comenzó en el Barroco, será

\footnotetext{
${ }^{431}$ Ídem, p. 40.

${ }^{432}$ MARTÍN GONZÁLEZ, El retablo, p. 16
} 
en el siglo XIX cuando se le dé un importante empuje a la devoción de esta imagen. Ejemplos de esta tipología son el retablo de la Virgen del Rosario de Miñera y de S. Pedro de Luna hoy desaparecidos.

El retablo camarín se caracteriza por poseer un espacio trasero para que los fieles dejen los exvotos a la imagen de devoción. Si la imagen pertenece a la Virgen se suele dejar caer el manto por detrás para ser besado por los feligreses ${ }^{433}$. Algunos ejemplos se encontraban en la iglesia de S. Miguel de Campo, el cual poseía la figura de la Purísima Concepción, y en el retablo de la Virgen de la Nieves de Miñera.

El siglo XX apenas aportó novedades y durante los primeros años continuó con los modelos tradicionales basados en tipologías barrocas. El dorado desaparece y la policromía utiliza aguadas de colores que imitan rocallas y mármoles fingidos como en el retablo de Nuestra Señora del Rosario de Mirantes conservado en la iglesia de Barrios de Luna.

Avanzado el siglo, y con la proliferación de las figuras de la tipología de Olot, los talleres catalanes comienzan a exportar una serie de retablos con una nueva concepción de estilos, especialmente el gótico, que se implantará en toda la geografía.

A finales de siglo los retablos eliminarán cualquier aspecto historicista acercándose a formas puras y definidas a través de elementos geométricos simples como el cuadrado, el círculo y el triángulo como se observa en el nuevo retablo principal de Mallo de Luna. La importancia del retablo se irá devaluando hasta tal punto que se deja la figura de culto sin ningún tipo de estructura y sujeta a la pared con una simple peana como se puede observar en las iglesias de nueva edificación fuera del embalse.

${ }^{433}$ Ibídem. 


\subsubsection{TEMPLOS PARROQUIALES}

Los templos parroquiales son aquellos edificios que están bajo el control administrativo del obispado y que se sitúan en el núcleo o cercanos a una población. Se originaron en la Edad Media durante el período de la Repoblación. Su creación va paralela a la de las aldeas y villas y su evolución irá de la mano del propio desarrollo económico del lugar en el que se asientan ${ }^{434}$.

Las parroquias se convirtieron en el brazo más directo e importante para el manejo de la población de una manera no sólo espiritual sino también económica. Las parroquias fueron las contenedoras de un gran número de impuestos que repercutía directamente en la riqueza del edificio y del obispado. Los diezmos, primicias, votos y otras cargas se convirtieron en algo común en la vida de los feligreses que con sus aportaciones monetarias ayudaron al mantenimiento del templo y del propio párroco. A cada pueblo le correspondía una parroquia y cada feligrés se veía identificado no sólo por el lugar en el que nació, sino por el lugar donde fue bautizado. De tal manera influyó la creación de las parroquias que algunas poblaciones tomaron el nombre del santo patrono de la iglesia, como es el caso de San Pedro de Luna o de Santa Eulalia de las Manzanas.

El sistema de control lo ejercían los obispos a través de las visitas sinodales. Al menos una vez en el mandato el obispo debía asistir a cada una de las parroquias. El resto del tiempo se enviaba a un visitador que realizaba inspecciones anuales ${ }^{435}$. Los visitadores se encargaban de informar sobre la buena marcha y el estado y decoro en que se encontraban los edificios religiosos. Son comunes las quejas y avisos de los visitadores a los sacerdotes sobre la necesidad de mantener en buenas condiciones las imágenes, telas y cubiertas de las iglesias.

Los templos parroquiales se financiaban gracias a la acción de sus patronos, donaciones reales, de vecinos o de herencias que, cuando no podían costear a maestros de primera fila, acudían a canteros locales que seguían las directrices de los obispados $^{436}$. El coste de su fábrica corría a cargo de la propia población, por lo que su grandeza dependía de las posibilidades económicas de los vecinos y del número de

\footnotetext{
${ }^{434}$ FERNÁNDEZ VÁZQUEZ. Arquitectura, Tomo I, p. 45.

435 Ídem, p. 65.

${ }^{436}$ Los modelos usados fueron clasicistas, sin grandes ornamentaciones y con unas estructuras diáfanas y sencillas.
} 
habitantes entre los cuales se podía repartir la deuda. Es por ello que los edificios de las poblaciones más pequeñas presentan unas dimensiones reducidas, lo mismo que el número de retablos e imágenes del interior ${ }^{437}$. Otra característica es su lejanía de los grandes centros artísticos por lo que las novedades arquitectónicas llegaban tarde, perpetuándose las formas estilísticas de una época más allá de los límites cronológicos establecidos.

La gran mayoría de los edificios parroquiales de la ZACEL datan de entre los siglos XVII al XIX. En este momento se desarrollan en España dos aspectos que conllevarán a la creación de una gran cantidad de edificios religiosos. Por un lado estaría el desarrollo económico que el descubrimiento de América trajo y por otro la Contrarreforma y el nuevo esfuerzo eclesiástico por mantener viva la religiosidad católica.

Las iglesias se construyeron de nueva planta o se renovaron las existentes variando aquellas partes más significativas. Lo más importante era que los edificios se acomodasen a las nuevas necesidades religiosas. Las cabeceras semicirculares dan paso a un testero recto mucho más amplio y desarrollado que dará mayor importancia a la liturgia.

El edificio se configura a partir de dos espacios, la cabecera o presbiterio, destinado los oficios litúrgicos y la nave, el lugar donde se reúnen los feligreses. A partir de estos dos módulos se articula el resto de los espacios templarios.

Lo más habitual es la planta longitudinal, de una sola nave, con el presbiterio destacado. La adopción de esa fórmula se debe tanto a su fácil resolución constructiva, que no comporta complicaciones estructurales, como a cuestiones religiosas que favorecen la visión del ritual. La capilla central, casi siempre resaltada por un arco triunfal, contiene un gran retablo. En muchas ocasiones el presbiterio se eleva en altura y se cubre con bóveda de cañón ${ }^{438}$. El transepto podía contener una techumbre diferenciada con una bóveda de media naranja o semiesférica como en Miñera de Luna u Oblanca, o con una bóveda de crucería como en la iglesia parroquial de Barrios ${ }^{439}$.

\footnotetext{
${ }^{437}$ FERNÁNDEZ VÁZQUEZ. Arquitectura, Tomo I, p. 83.

${ }^{438}$ COFIÑO FERNÁNDEZ. Arquitectura, p. 33.

${ }^{439}$ Ibídem.
} 


\subsubsection{Tipología}

1. Iglesias de planta rectangular.

Las iglesias de planta rectangular eran la tipología más común de la ZACEL. Su forma variaba dependiendo del número de naves que poseyesen y de las capillas adosadas entre los contrafuertes. Cuatro son los ejemplos en las poblaciones estudiadas con este tipo de planta: San Pedro de Luna, Láncara, Mirantes y Campo de Luna. Son edificios de una sola nave sin capillas laterales cubiertas con una techumbre a dos aguas excepto en el presbiterio, que se cierra con una bóveda de cañón. En algunas ocasiones, como en la iglesia de Mirantes, existía una bóveda semiesférica cerrando el espacio del presbiterio con un arco que tenía una doble abertura hacia la nave central y la lateral debido a las obras de ampliación que tuvieron lugar a comienzos del siglo XX.

Generalmente el altar contenía un solo retablo elevado a veces en altura por una o dos gradas. En el muro S. del presbiterio se abría en todos los casos una ventana abocinada. En la parte posterior de la nave se encontraba el coro elevado en altura al cual se acedía mediante una escalera de madera.

El pórtico se adosaba siempre en el muro S. del templo, excepto en la iglesia de Mirantes, que carecía de porticado. Todos ellos poseían un banco corrido que servía como lugar de reuniones. Esta estructura se cubría a un agua y aprovechaba la caída del tejado. En la iglesia de Láncara el pórtico se sujetaba por medio de cinco columnas de madera sobre basas de piedra y capitel moldurado. La iglesia de San Pedro poseía un pórtico con una escalera que salvaba el desnivel del terreno. En la iglesia de Campo de Luna el pórtico se sujetaba sobre las paredes laterales.

Otro elemento común en todas las iglesias de planta rectangular sin capillas es el remate de una torre espadaña en el muro O. Esta espadaña estaba constituida por un cuerpo de campanas que albergaba un único arco. En Mirantes la espadaña poseía tres vanos con dos campanas a la cual se accedía mediante una escalera metálica. Todas ellas se remaran con una cruz o veleta.

A partir de los modelos más sencillos de plantas de una sola nave se irán ampliando diferentes espacios dependiendo de las necesidades de la iglesia, como la sacristía, almacenes y osarios. La sacristía se adosaba al muro del presbiterio en dirección N. o S. pero con un acceso directo al altar y una ventana abocinada como 
método de iluminación. Este espacio era de sección cuadrada y a veces, como en el caso de Mirantes, se incluía dentro de la estructura del propio edificio, aunque lo más normal era que estuviese adosada.

Dentro de las iglesias de planta rectangular podemos encontrar iglesias de una o dos naves.

Las iglesias de una sola nave son el tipo más sencillo y económico. Se ejecutan comúnmente sobre una estructura anterior de origen medieval ${ }^{440}$. Están conformadas por dos espacios claramente diferenciados, la capilla mayor y el cuerpo de la iglesia. Al carecer de espacios destinados a capillas, se crean unas oquedades en la pared a modo de hornacinas bajo arcosolio en los que se incrustan los pequeños retablos devocionales. Tanto la cabecera de la iglesia como la nave tienen el mismo tamaño y sólo se dividen por medio de un arco apuntado o de medio punto que separa los dos espacios. Son los ejemplos de San Pedro, Láncara y Campo.

Las iglesias de dos naves surgen ante la necesidad de ampliar el espacio dedicado a los fieles. Comúnmente se crean con la eliminación de uno de sus muros a partir del cual se amplía el edificio. El problema de este tipo de planta es la descentralización del altar mayor que ha de ser compensada con la creación de otro pequeño altar en el muro testero. Es el caso de la iglesia de Mirantes de Luna que fue ampliada por uno de sus lados dejando el altar desviado y creando un muro nuevo con amplios ventanales.

2. Iglesias de planta de cruz latina.

Es la tipología que se implantará a partir del siglo XVI en la mayoría de los edificios de nueva construcción. Se crea para favorecer las nuevas necesidades litúrgicas que se dictan desde la Contrarreforma.

Los edificios de planta de cruz latina poseen una sola nave de similares dimensiones que el presbiterio. Es común observar un cimborrio o bóveda de media naranja en el transepto como en la iglesia de Miñera y Oblanca. En estos edificios el transepto se cubría con una bóveda semiesférica cubierta con una techumbre a cuatro aguas.

${ }^{440}$ FERNÁNDEZ VÁZQUEZ. Arquitectura, p. 123. 
El transepto puede estar formado por capillas y no necesariamente se levanta en el momento de su construcción, sino que pueden ser añadidos posteriores. Observamos cómo en la iglesia de Miñera la capilla lateral se empequeñece debido a la ampliación del pórtico. En Lagüelles la planta interior nada tiene que ver con la forma compacta exterior, puesto que la separación de los muros conforman el número de capillas.

La división de las capillas laterales se realiza a través de arcos de medio punto, lo mismo que el presbiterio del resto de la nave. Los brazos del transepto son más estrechos y cortos que los de la nave. Generalmente siguen una simetría casi exacta dejando el cruce de las naves como eje axial. En esta zona se eleva un pequeño cimborrio sin ventanas que cubre una bóveda semiesférica como se observa en Mallo y Oblanca. En el caso de Cosera todo el edificio se cubre con madera exceptuando el presbiterio, que siempre utiliza bóveda de cañón. La iglesia de Barrios de Luna posee dos naves separadas por pilastras a modo de transepto. En este caso el espacio lateral es más ancho y elevado que la nave central. El templo se cubre con bóvedas de arista desapareciendo la bóveda semiesférica común en el resto de iglesias. La sacristía puede acomodarse al espacio dejado por uno de los brazos del transepto o adecuarse a la parte trasera del presbiterio creando una simetría con la nave principal. Cabe destacar que la torre campanario sólo aparece en las iglesias que poseen una planta de cruz latina, como es Barrios y Oblanca con un transepto bastante desarrollado.

En los ejemplos conservados podemos estableces varias tipologías:

Iglesias de cruz latina con torre campanario. La principal diferencia entre los edificios con torre campanario y espadaña son las dimensiones. Los dos ejemplos de iglesias con torre campanario son la de Oblanca y la de Barrios de Luna. Poseen una estructura cruciforme muy desarrollada. En Barrios el crucero es doble, separado por pilastras que sustentan bóvedas de crucería. En Oblanca, el crucero se eleva en altura dejando un espacio central para la bóveda. Ambas iglesias tienen una nave central más larga que el presbiterio aunque en Oblanca esta diferencia se subsana con la construcción de un espacio detrás del presbiterio que se utiliza como sacristía. Las torres superan los $15 \mathrm{~m}$. de altura y poseen un cuerpo de campanas rematado con un tejadillo piramidal. Otro elemento diferenciador es el desarrollo del pórtico. Barrios contiene un espacio cubierto con bóveda de crucería sobre pilares de piedra mientras que en Oblanca este espacio se cierra con el propio muro sujeto con una viga de madera. 
Iglesias de cruz latina con torre espadaña. Los ejemplos de iglesias de planta de cruz latina y torres espadaña son los de Cosera, Mallo y Mirantes de Luna. Estas se configuran a través de un espacio central en el cual se abren el resto de estancias. En algunos casos, como en Mallo, las dimensiones entre el presbiterio y la nave central son similares ocasionando un esquema cercano al centralizado. El espacio de unión del crucero se marca con una bóveda de naranja como ocurre en Mallo y Miñera. Las espadañas son muy variadas, desde la de un solo cuerpo de campanas, como la de Cosera, o la de Miñera, hasta la espadaña de Mallo, con un doble cuerpo de vanos desarrollados en dos alturas.

Iglesias con capillas a modo de transepto. El único ejemplo de esta tipología es la iglesia de Lagüelles. Al interior se abren una serie de capillas que conforman una estructura de doble cruz mientras que al exterior esta distribución no se observa. 


\section{IGLESIA DE SAN PELAYO DE CAMPO DE LUNA}
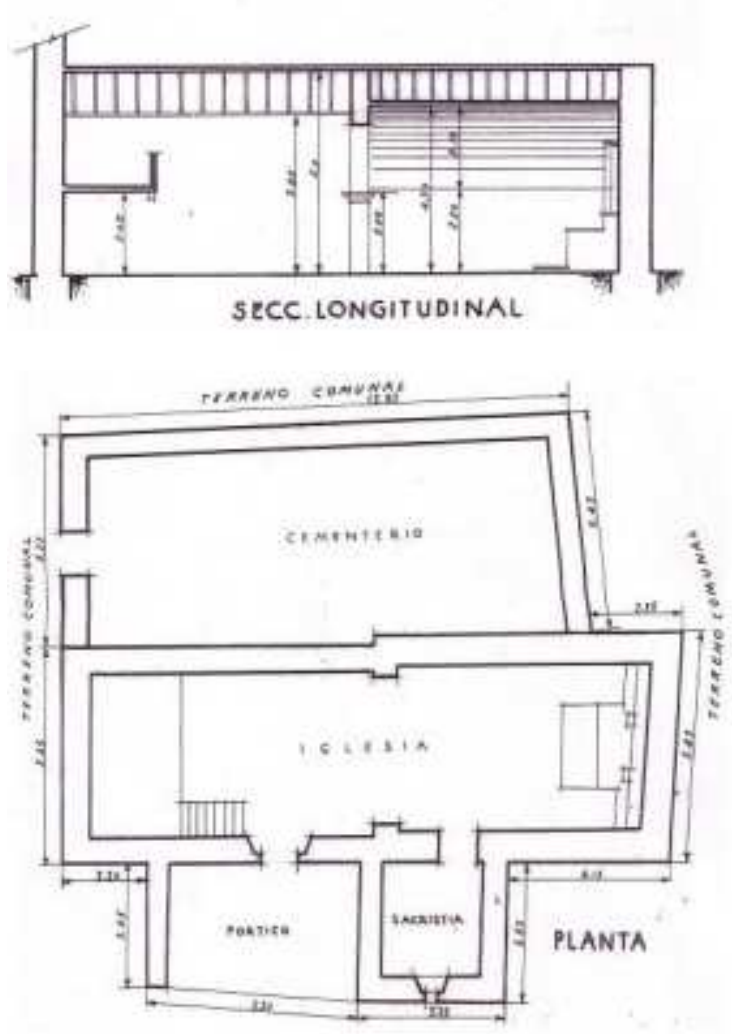
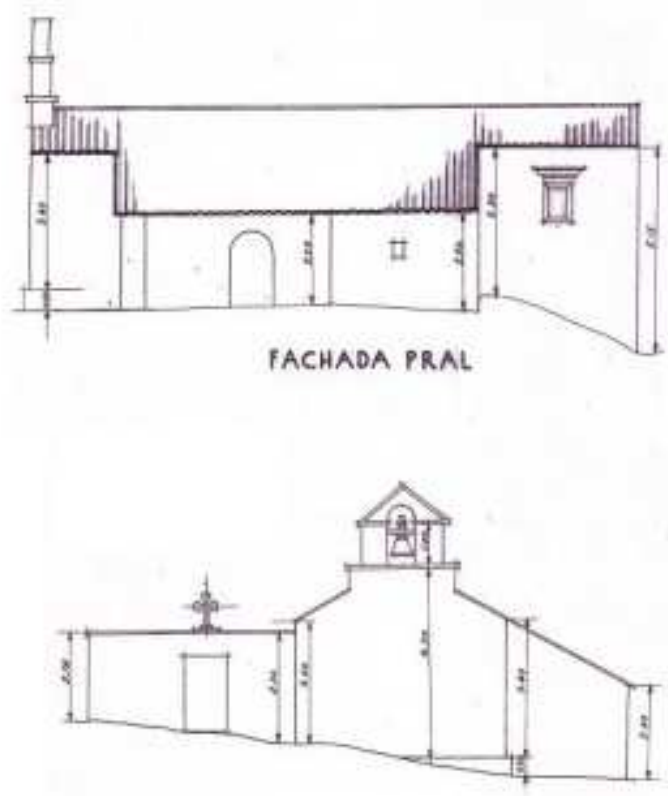

FACHADA LATERAL IZQDA

Ilustración 84. A.G.C.H.D. Campo de Luna. No 4486. Finca 1486-1487.

Localidad: Campo de Luna

Santo Patronal: S. Pelayo

Obra: Reformada en $1845^{441}$.

Superficie: $120 \mathrm{~m}^{2}$.

Análisis: La iglesia de Campo se inscribe dentro de la tipología rectangular con cabecera cuadrada sin capillas adosadas.

El acceso al edificio se hacía a

través de un pórtico situado en el lado S. Unida al templo se encontraba la

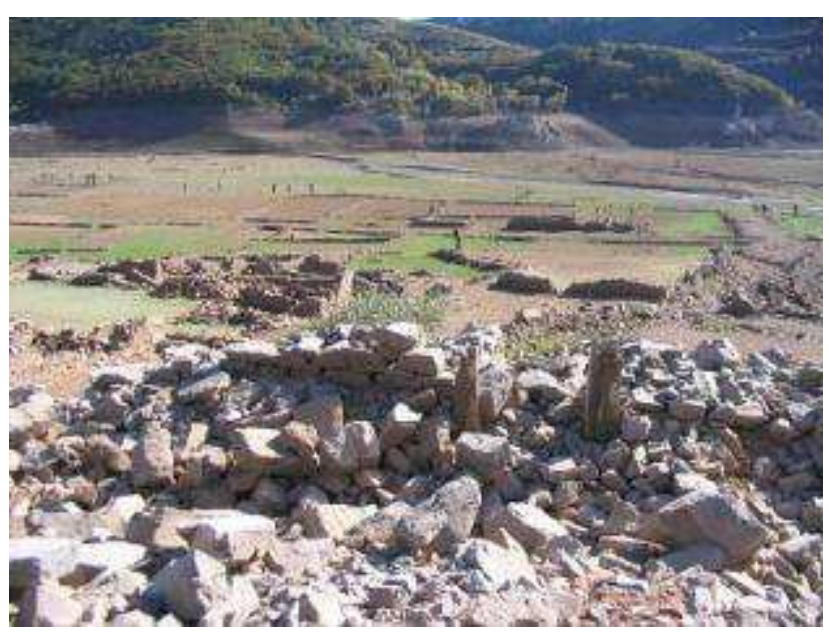

Ilustración 85. Estado actual de la iglesia de Campo. Año 2012. sacristía de planta cuadrada con un 
vano de iluminación abocinado.

El presbiterio no estaba elevado en altura y se diferenciaba del resto de la nave a través de unas pilastras adosadas con molduras bajo un gran arco de medio punto. La cubierta de la iglesia era de madera a dos aguas, excepto en el presbiterio, en el que se alzaba una pequeña bóveda realizada con piedra toba. La luz se filtraba a través de la puerta de entrada y de una pequeña ventana abocinada en el muro S. del presbiterio. En la parte posterior del templo se encontraba el coro en madera al cual se accedía a través de una escalera adosada.

La torre estaba constituida por una pequeña espadaña achaparrada con un solo cuerpo de campanas y una altura máxima de $7 \mathrm{~m}$. La única campana que contenía está datada en $1861^{442}$. En la parte N. del templo se le adosaba el cementerio parroquial cerrado con un muro de mampostería similar al ejemplo de Láncara de Luna.

${ }^{442}$ A.D.L. Fondo parroquial. Libro de cuentas de la iglesia de santa Bárbara. Campo de Luna. Doc. 866 


\section{IGLESIA DE SAN MAMES DE MIRANTES DE LUNA}
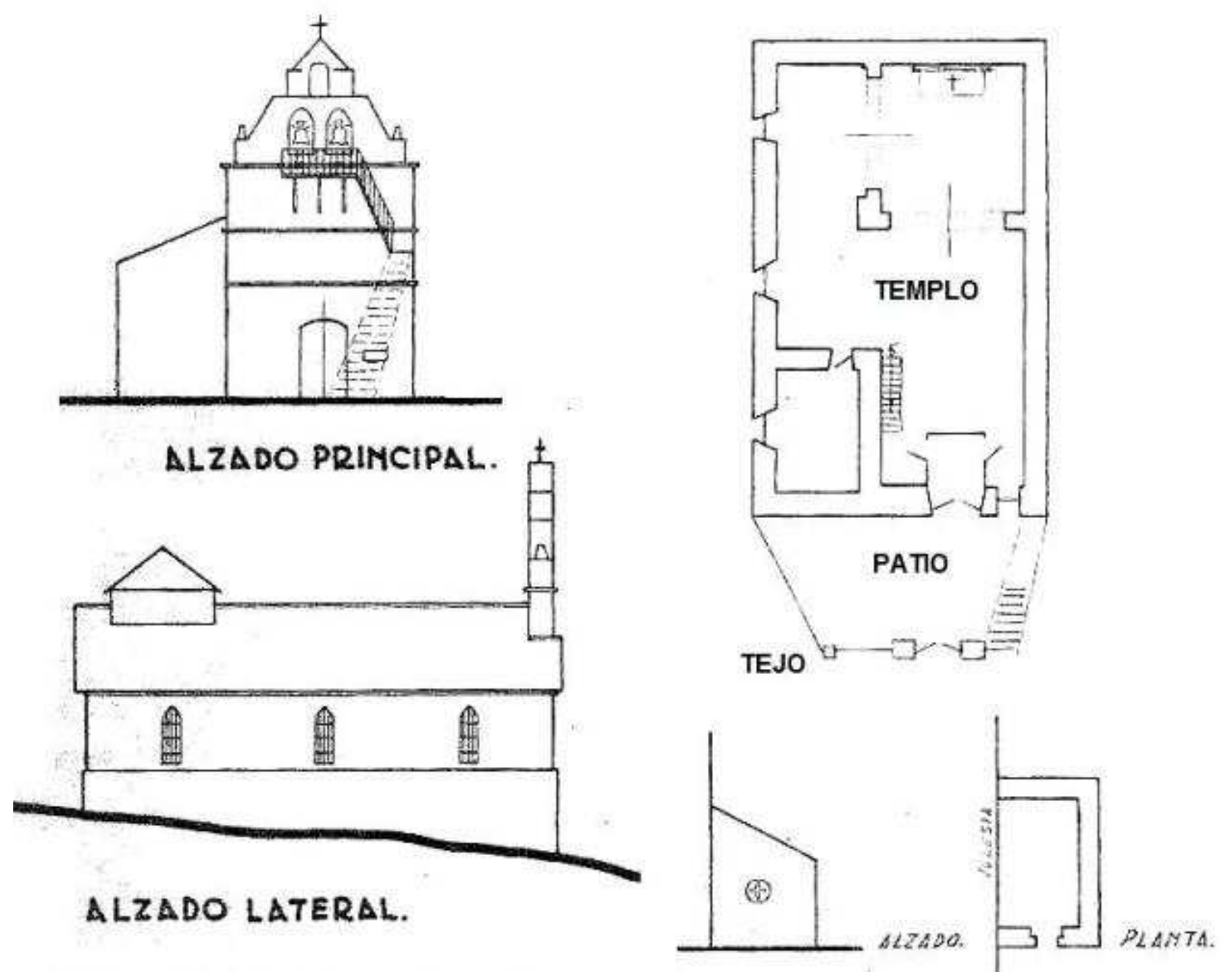

Ilustración 86. A.G.C.H.D. Mirantes de Luna. No 5468.

Localidad: Mirantes de Luna

Santo Patronal: S. Mames

Obra: Edificio fundado en 1888 , como muestra una inscripción en la puerta de entrada ${ }^{443}$, e inaugurado en 1892 con patronato compartido entre la corona y el duque de Uceda $^{444}$. En 1930 se compraron unos terrenos para ubicar el baptisterio
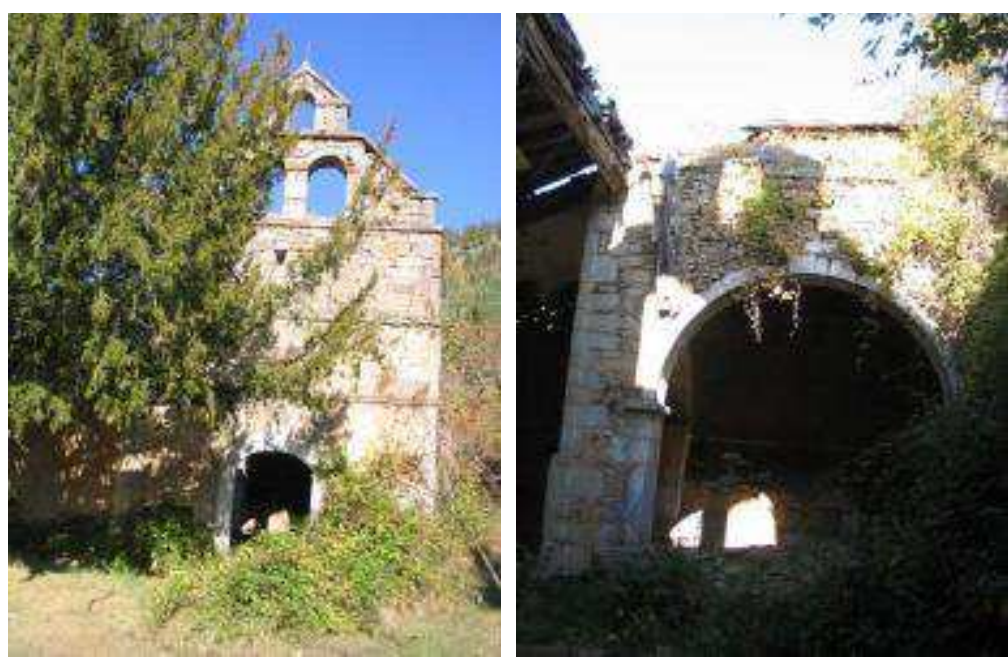

Ilustración 87. Estado actual de la iglesia de Mirantes. Año 2011

${ }^{443}$ A.D.L. Fondo Parroquial. Mirantes de Luna. Libro de fábrica. Doc. 1686c-379. Año 1888.

444 Ídem, año 1892 
y se amplió el espacio de la iglesia aprovechando el alero de la misma para cubrirlo.

Superficie: $162 \mathrm{~m}^{2}$.

Análisis: La iglesia es de planta rectangular con cabecera cuadrada desviada del eje central a causa de la ampliación del edificio en el muro S., donde se ubicaba un pequeño retablo. La sacristía se dispone a los pies del edificio. El presbiterio esta elevado en altura y remarcado con un gran arco de medio punto en cada lado sujeto sobre pilastras cuadradas con una moldura en lugar de basa y capitel. Se cubría con una bóveda de media naranja sobre pechinas. La bóveda fue pintada en $1915^{445}$ con la representación de una cúpula celeste a base de tonalidades azules y blancas para las nubes. La cubierta del resto del templo era a dos aguas con techumbre de madera.

La iluminación provenía de los grandes vanos abiertos en el muro S. En la parte superior se encontraba el coro, al cual se accedía por unas escaleras de madera adosadas a la pared de la sacristía y realizadas en $1914^{446}$. Sobre la columna central del templo existía un púlpito con escaleras de madera.

La fachada principal estaba compuesta por una puerta de medio punto en cuyo dintel se labró la fecha de la inauguración del edificio:

\section{ISTA EST DOMUS DEI AÑO DE 1888 D.J.A.R}

La torre espadaña contenía dos cuerpos con tres campanas que fueron desmontadas y trasladadas a los pueblos vecinos, una de ellas datada en $1914^{447}$.

El atrio se cerraba con unas verjas de hierro sujetos en tres columnas de piedra labrada.

\footnotetext{
445 Ídem, año 1915

446 Ídem, año 1914

${ }^{447}$ Ibídem.
} 


\section{IGLESIA DE SAN MARTÍN DE LÁNCARA DE LUNA}
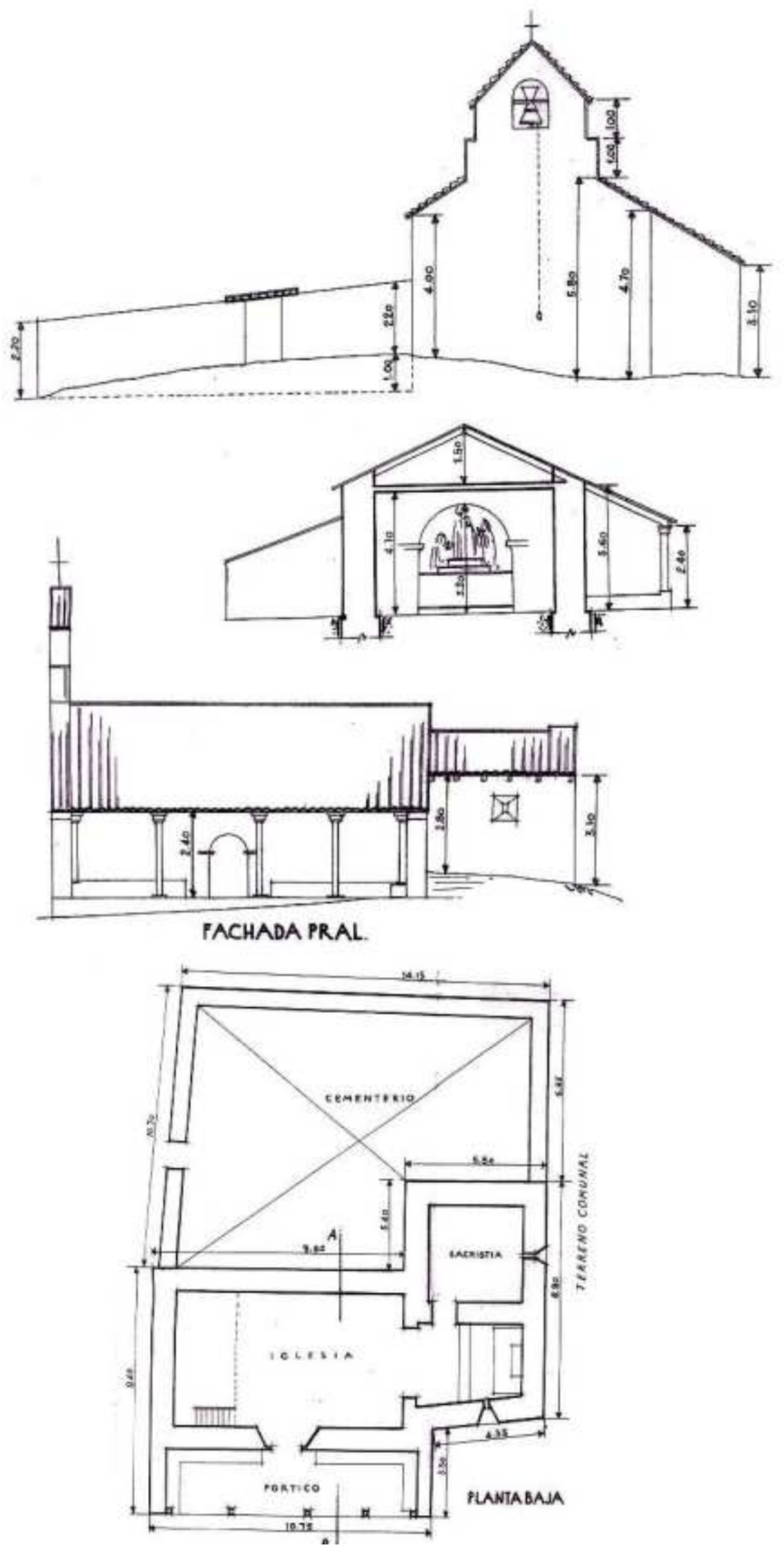

Ilustración 88. A.G.C.H.D. Láncara. C/05468-2. № 4498. Año 1956. Finca 2951. 

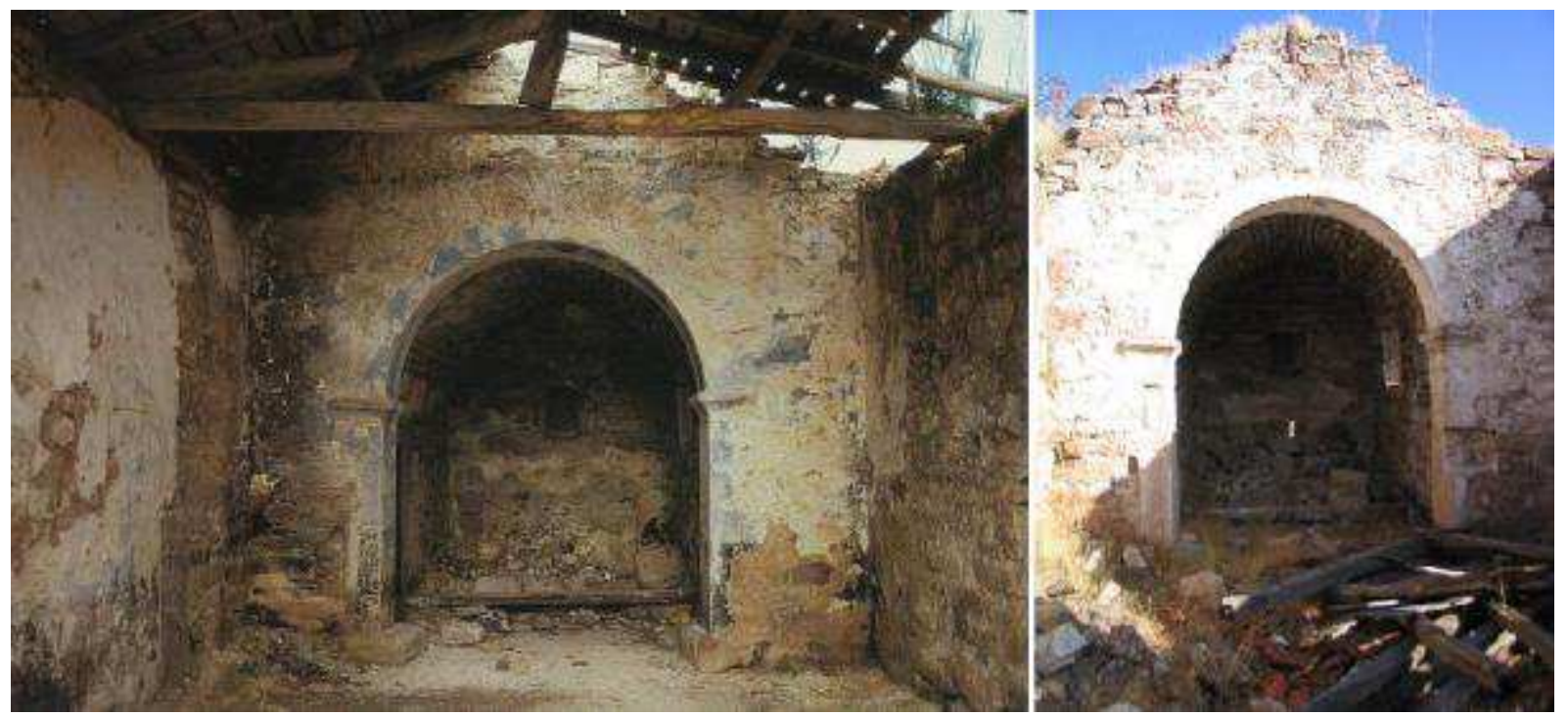

Ilustración 89. Aspecto de la iglesia de Láncara en 1997. GARCÍA-PÉREZ. Enciclopedia, p.113.

Aspecto de la iglesia en 2012.

Localidad: Láncara de Luna.

Santo Patronal: S. Martín.

Obra: Siglos XVIII-XIX.

Superficie: $143 \mathrm{~m}^{2}$.

Análisis: Los autores de la enciclopedia del románico en Castilla y León, García Guinea y Pérez González ${ }^{448}$, identifican una posible cronología románica en el ábside por su pequeño tamaño y por el alero con canecillos achaflanados que recuerdan el siglo XIII. Sin embargo, hay que discrepar de esta teoría ya que esta estructura es debida a la pobreza de materiales y la continuidad de tradiciones arquitectónicas, que pueden dar como consecuencia una arte con cierto aspecto primitivo. Además, la técnica constructiva es muy similar a la de las cercanas iglesias de Pobladura o Portilla de Luna, edificios que no han sido catalogados como del período medieval.

La planta de la iglesia tiene una forma rectangular con cabecera cuadrada de dimensiones más reducidas que la nave. No contiene capillas adosadas. Los elementos sustentantes de la iglesia eran los propios muros, ya que carecía de pilastras o columnas en el interior. La altura de la nave no sobrepasaba $\operatorname{los} 4.10 \mathrm{~m}^{449}$. En el costado

448 GARCÍA GUINEA, Ma Ángeles y PEREZ GONZALEZ, José María. Enciclopedia del románico en Castilla y León. León. ED: Fundación Santa María la Real. Centro de estudios del románico. Aguilar de Campoo. 2002, p. 113

${ }^{449}$ A.G.C.H.D. Láncara de Luna. C/05468-2. № 4498. Año 1956. 
septentrional se adosaba una sacristía de planta cuadrada. Al otro lado se encontraba un pequeño pórtico que tenía un banco corrido dedicado a las reuniones de los concejos ${ }^{450}$.

La entrada al edificio se hacía a través de un pórtico sujeto con cinco columnas de madera, dos de ellas adosadas al muro, con basa simple y capitel moldurado. El arco de entrada era de medio punto abocinado y decorado con una pequeña moldura en la base. El presbiterio se elevaba en altura gracias a dos pequeños peldaños y se enmarcaba por un arco triunfal con molduras simples. El altar principal estaba dedicado a S. Martín con la imagen del mismo presidiéndolo.

La torre era una espadaña de casi $9 \mathrm{~m}$. de altura con un solo cuerpo de campanas. La techumbre era a dos aguas con bóveda de cañón, hecha a base de lajas, sin imposta y de gran rusticidad. El mampuesto estaba revocado y decorado con motivos geométricos, lo mismo que en la nave ${ }^{451}$. Adosado al muro N. de la iglesia estaba el cementerio ${ }^{452}$, rodeado con una tapia de mampostería en seco y de una superficie de $132 \mathrm{~m}^{2}$.
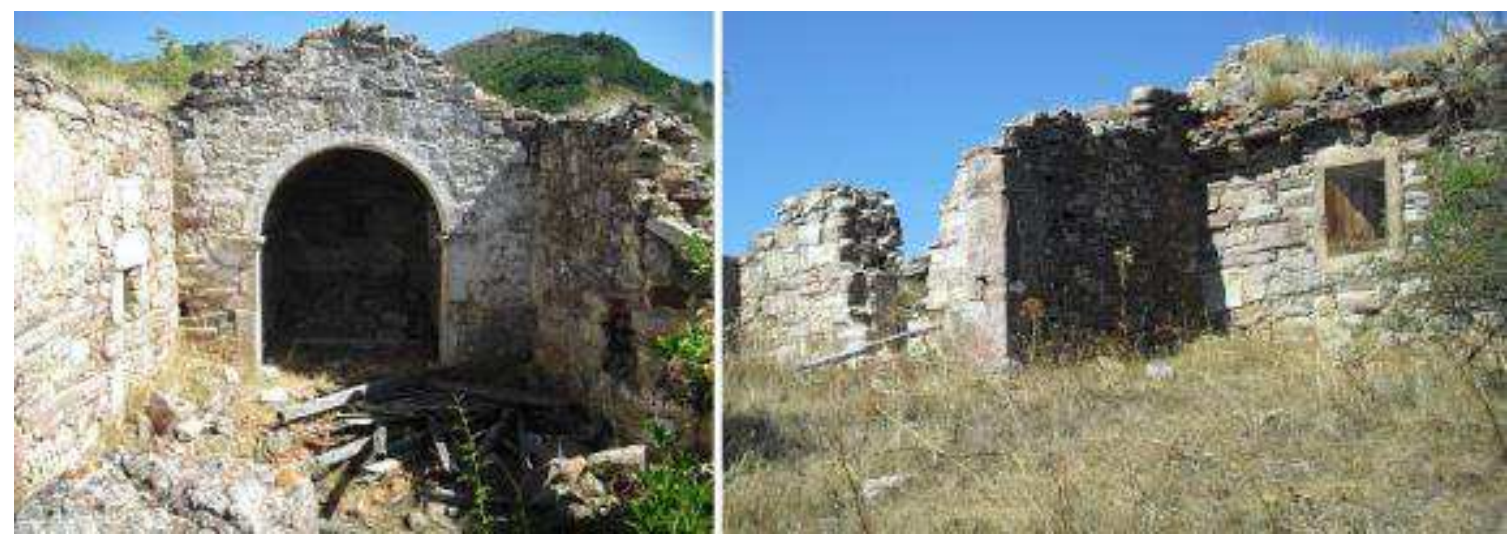

Ilustración 90. Estado actual de la iglesia de Láncara. Año 2012

${ }^{450}$ GARCÍA-PEREZ. Enciclopedia, p. 113.

${ }^{451}$ Ibídem.

${ }^{452}$ A.G.C.H.D. Láncara de Luna. C/05468-2. No 4498. Año 1956. 
IGLESIA DE SAN PEDRO DE LUNA
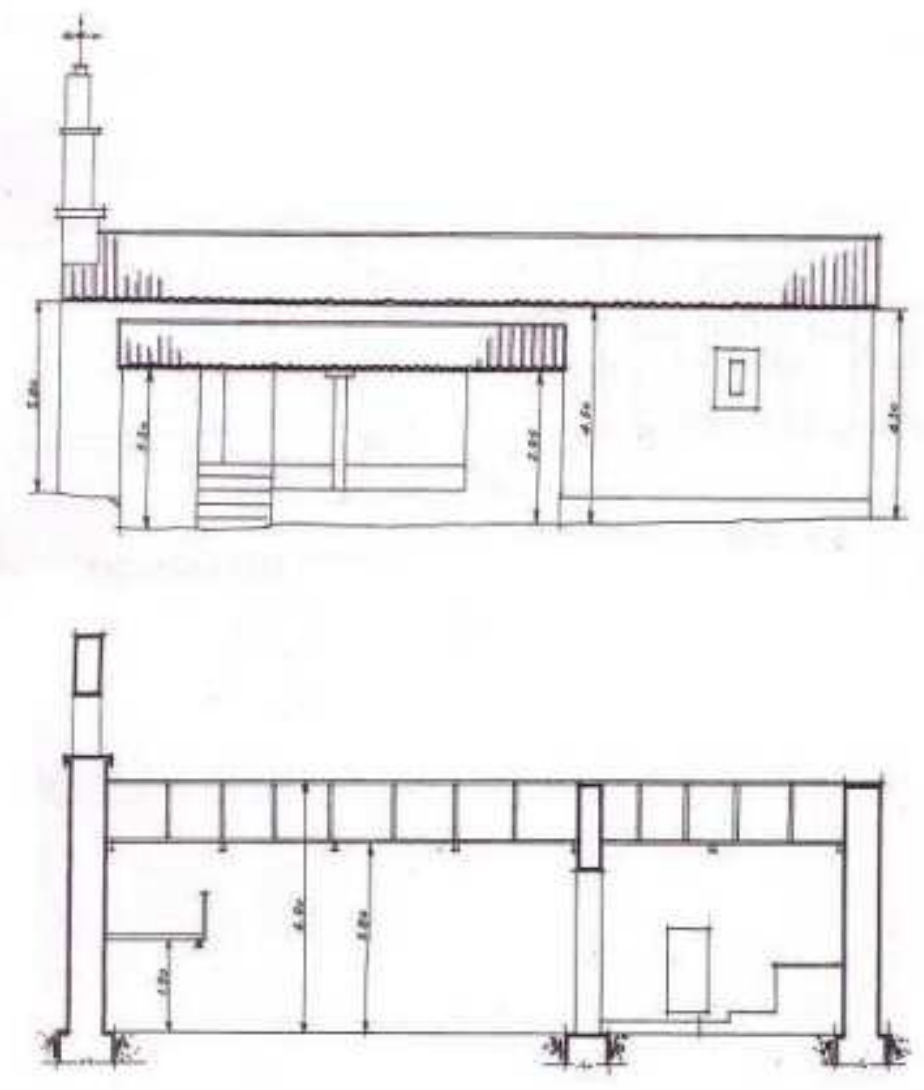

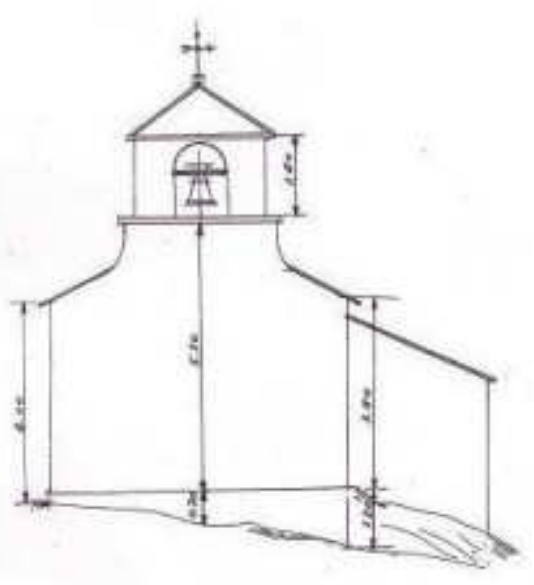

FACHADA LATERAL I2QDA.
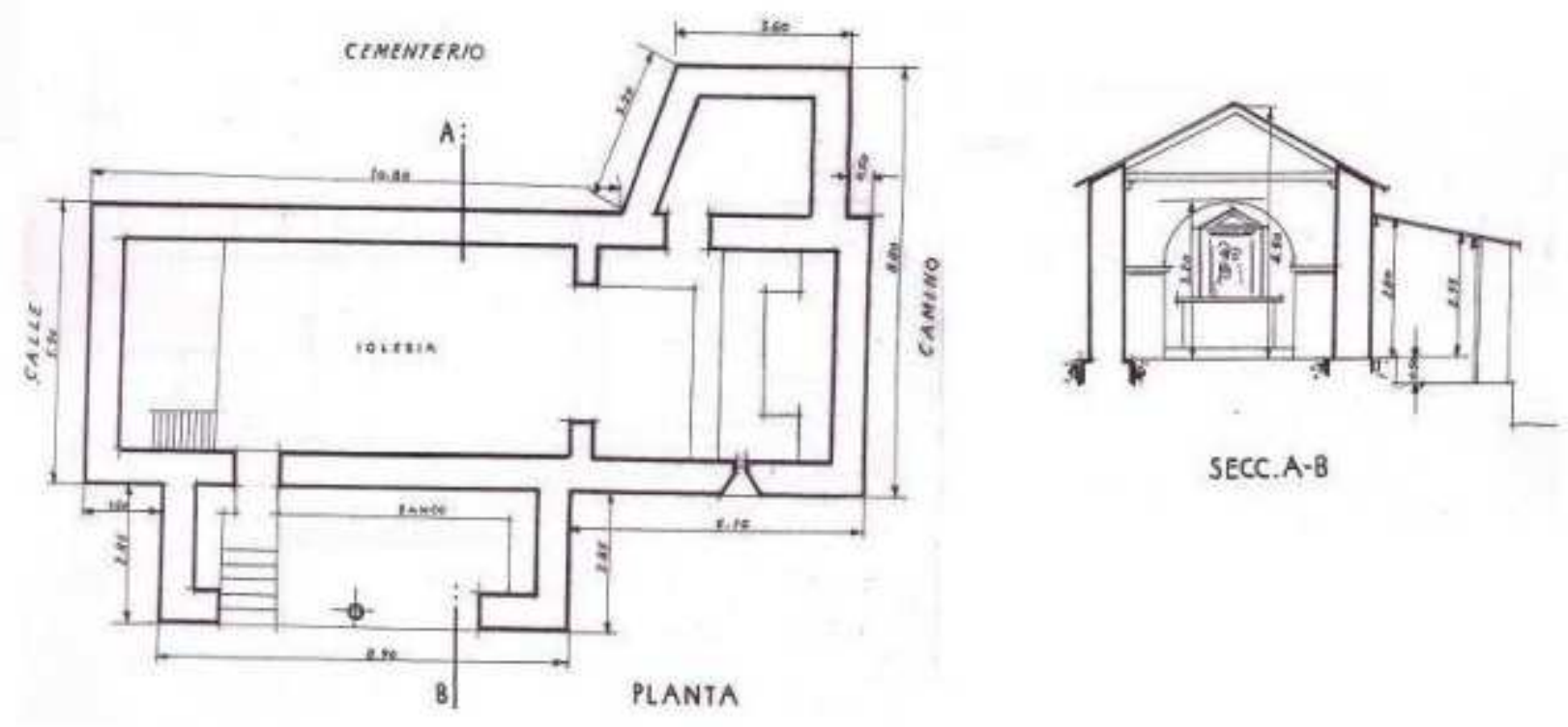

SECC. $A-B$

Ilustración 91. A.G.C.H.D. San Pedro de Luna. Nº 4485. Finca 156. 
Localidad: San Pedro de Luna.

Santo Patronal: S. Pedro.

Obra: Reformada en $1862^{453}$.

Superficie: $130,63 \mathrm{~m}^{2.454}$

Análisis: La estructura de la iglesia era de planta rectangular sin capillas adosadas y con cabecera cuadrada cuyo presbiterio estaba elevado en altura a través de unas gradas de piedra $^{455}$. La separación de la nave y el presbiterio se hacía gracias a un gran arco de $3.20 \mathrm{~m}$. de altura apoyado sobre pilastras. La altura máxima de la nave era de $4.90 \mathrm{~m}$. y la espadaña medía unos $7 \mathrm{~m}$. aproximadamente. La iglesia se cubría con una techumbre a dos aguas con listones de madera sobre los cuales se colocaban las tejas. Tenía un solo acceso y una ventana abocinada en la zona S. de la cabecera ${ }^{456}$. En la parte del O. se alzaba el coro en madera.

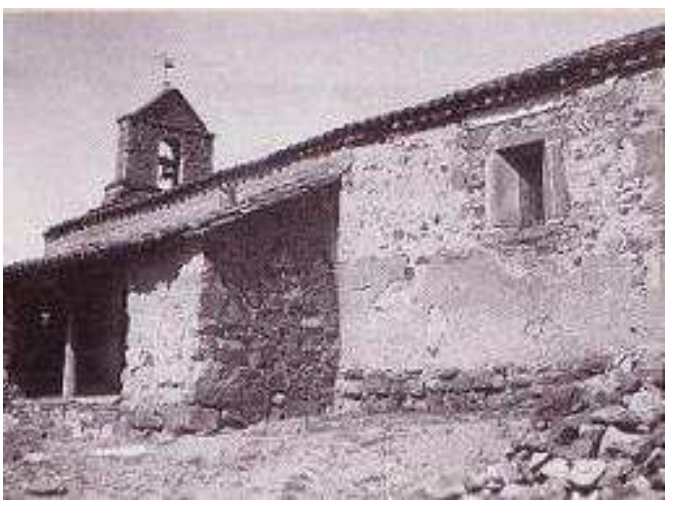

Ilustración 92. Iglesia de S. Pedro. Fondo fotográfico. I.L.C.

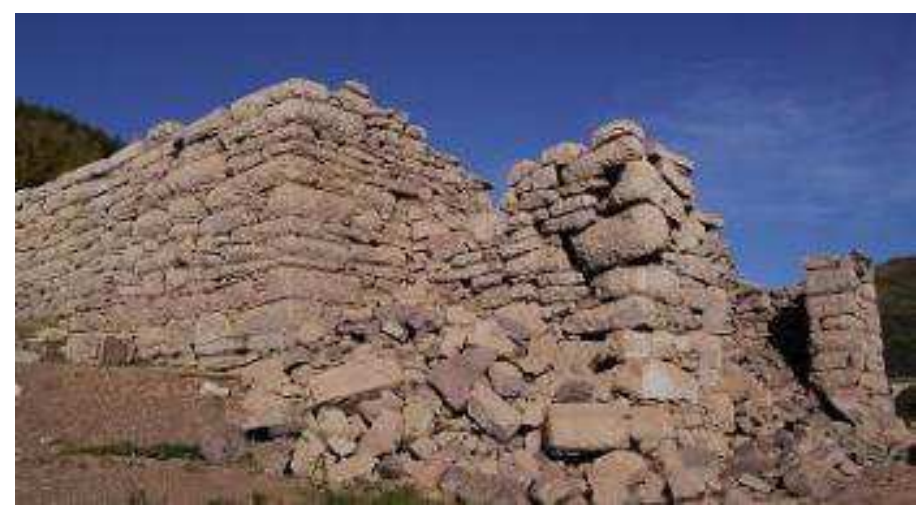

Ilustración 93. Iglesia de S. Pedro. Estado actual. Año 2010

La sacristía se ubicaba al N. con una planta trapezoidal. Fue reformada en $1845^{457}$ construyéndose una ventana con vidriera para conseguir una iluminación natural. Unos años más tarde se empedró la iglesia.

Al S. sobresalía un pequeño pórtico al que se accedía por unas escaleras pétreas. El pórtico estaba sujeto por un pilar de madera y cerrado con muros de mampostería. Tenía un banco corrido para las catequesis o reuniones del pueblo. La puerta de la iglesia esta databa en 1849 y fue construida con madera de roble ${ }^{458}$.

\footnotetext{
${ }^{453}$ A.D.L. Fondo parroquial. San Pedro de Luna. Libro de cuentas. Doc. 881. Año 1862

${ }^{454}$ A.G.C.H.D. San Pedro de Luna. C/05462. No 4485. Año 1953-54

${ }^{455}$ A.D.L. Fondo parroquial. San Pedro de Luna. Libro de cuentas. Doc. 881. Año 1852

${ }^{456}$ Ibídem.

457 Ídem. Año 1845

458 Ídem. Año 1849
} 
La iglesia se remataba con una torre espadaña de un solo cuerpo de campanas con decoración de molduras muy sencillas.

El edificio tenía unos graves problemas de conservación mucho antes de la aparición del embalse, principalmente por el tipo de material, sillarejo y tapial, con el que estaba construido. En 1862 la iglesia sufrió un derrumbe al no soportar el peso y la humedad producida por la nieve. La creciente población de San Pedro opto por construir un nuevo templo. En la carta del párroco al obispado de Oviedo se expresa claramente cómo la fábrica no admite reparos y es necesaria la construcción de un nuevo edificio, no sólo por las malas condiciones sino por ser un lugar demasiado pequeño para el pueblo y los numerosos forasteros que pernoctaban en el lugar. Ante la negativa del obispado se optó por reconstruir el muro derruido cuyo coste recayó sobre los propios feligreses que aprovecharon para crear la tribuna del templo y la sacristía ${ }^{459}$. 
IGLESIA DE CRUZ LATINA CON TORRE CAMAPANARIO DE SANTA COLOMBA DE LOS BARRIO DE LUNA

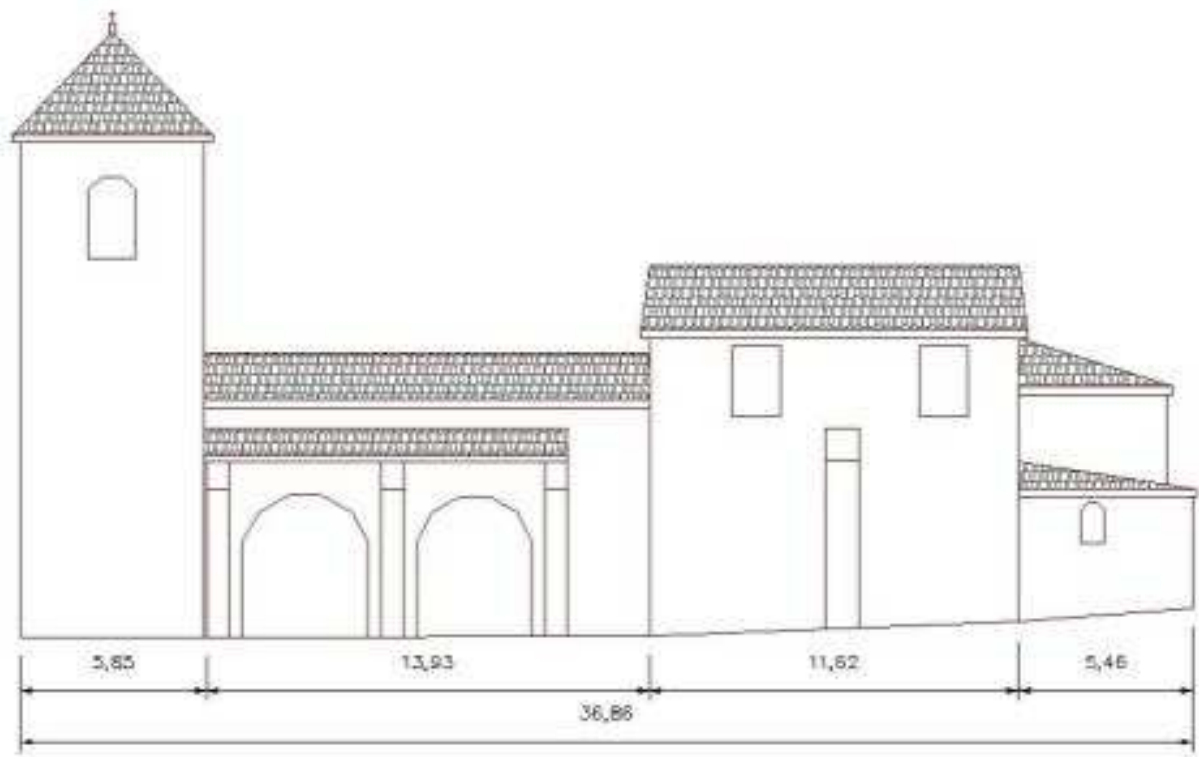

ALZADO SUR

$\cdots$

SIPFRFCIE CONSTRUIDA- $403,40 \mathrm{M}$ 
Localidad: Barrios de Luna.

Santo Patronal: Sta. Colomba y Sto. Cristo de los Barrios, cuya fiesta se celebra el 14 de septiembre.

Obra: Datada por Manuel Gómez Moreno en el siglo XIV pero con trazas del siglo $\mathrm{XVII}^{460}$.

Superficie: $463.40 \mathrm{~m}^{2}$

Análisis: La iglesia de Sta. Colomba posee una planta de cruz latina de una sola nave con transepto doble sobresaliente y cabecera cuadrada. La separación entre los espacios del transepto se realiza a través de dos pilares centrales sobre los que descansan los arcos de medio punto que sustentan las bóvedas de crucería. El presbiterio se cierra con una cabecera cuadrada que iguala la altura de la nave central. Los soportes de los muros laterales se componen de pilastras adosadas que sobresalen al exterior en forma de contrafuertes de piedra caliza-dolomía bien labrada.

La sacristía, de planta cuadrada, se ubica en el muro S. del presbiterio. Está compuesta por gruesos muros de mampostería y sin contrafuertes exteriores. En el muro N. de la nave central se adhiere una estancia rectangular que sirve de trastero y que se encuentra muy próxima al lugar donde aparece el arcosolio sobre el que asoma el escudo de los Cienfuegos.

A los pies de la iglesia se halla un recinto cuadrado cubierto con una primitiva bóveda de cañón utilizado como baptisterio, ya que en esta sala aún se conserva una antigua pila bautismal en piedra caliza desbastada sin ningún tipo de decoración. Sobre esta estancia surge la torre de la iglesia de planta cuadrangular iluminada por una pequeña ventada abocinada.

La torre es de planta cuadrada y finaliza con un cuerpo de campanas abiertas a cuatro vanos $^{461}$. Se conservan dos campanas, la más pequeña es de 1799 y lleva el nombre de José y María. La otra data de $1820^{462}$.

El único acceso de entrada al templo es a través de la puerta principal que está formada por un arco de medio punto sujeto sobre una gruesa línea de imposta y remarcado por un alfiz con decoración moldurada, aunque según la documentación parroquial, existía otro acceso denominado la puerta de Cayes y que fue tapiado en

${ }^{460}$ GÓMEZ MORENO. Catálogo, p 560.

${ }^{461}$ Ídem. Año 1855. En 1855 se realizan unas puertas para la torre y en 1861 se paga la cantero por la realización de la obra de la torre del a iglesia.

${ }_{462}$ Ídem. Año 1858. El gasto de la campana es muy alto, 765 reales para la campana, por lo que se puede dar a entender que se ha comprado una nueva, a pesar de no especificar nada mas en la documentación. 
$1877^{463}$. Cabe destacar la inscripción que se observa en la entrada que recuerda el año de la reparación de las puertas en $1848^{464}$.

\section{ESTAS PUERAS HICIERONSE AÑO DE MDCCCXXXXVIII}

El pórtico se encuentra adosado al muro S. sujeto con pilastras reforzadas con contrafuertes. En 1877 el pórtico sufrió un derrumbe y hubo de ser reconstruido ${ }^{465}$. La profundidad del pórtico y la aparición de un banco corrido por toda la estancia nos advierte de su utilización como centro de reuniones a salvo de las inclemencias del tiempo. En el pórtico se encuentran dos inscripciones que recuerdan la figura de D. José ALVAREZ MIRANDA, obispo de León y oriundo de Mirantes.

A LA SANTA MEMORIA DE EL EXMO. SR. DR. D. JOSÉ ALVAREZ MIRANDA HIJO ILUSTRE Y GRAN PORTECTOR DE ESTA PARROQUIA DE MIÑERA. OBISPO DE LEÓN DURANTE 24 AÑOS FALLECIÓ EL 4 DE MARZO DE 1937 RIGIENDO LA DIÓCESIS DE LEÓN. D.E.P

DESAPARECIDA LA IGLEISA DE MIÑERA A CAUSA DEL PANTANO, ESTA LÁPIDA QUE ALLÍ RECORDABA AL EXCMO. SR. ÁLVAREZ MIRANDA, FUE TRASLADADA A ESTA PARROQUIA POR ORDEN DE EXCMO. Y RVDMO. SR. D. LUIS ALMARCHA, OBISPO DE LEÓN A INSTANCIAS DEL EXMO. Y RVDMO. SR. D. LUIS ALONSO MUÑOYERRO, ARZOBISPO DE SIÓN, VICARIO GENERAL CASTRENSE.
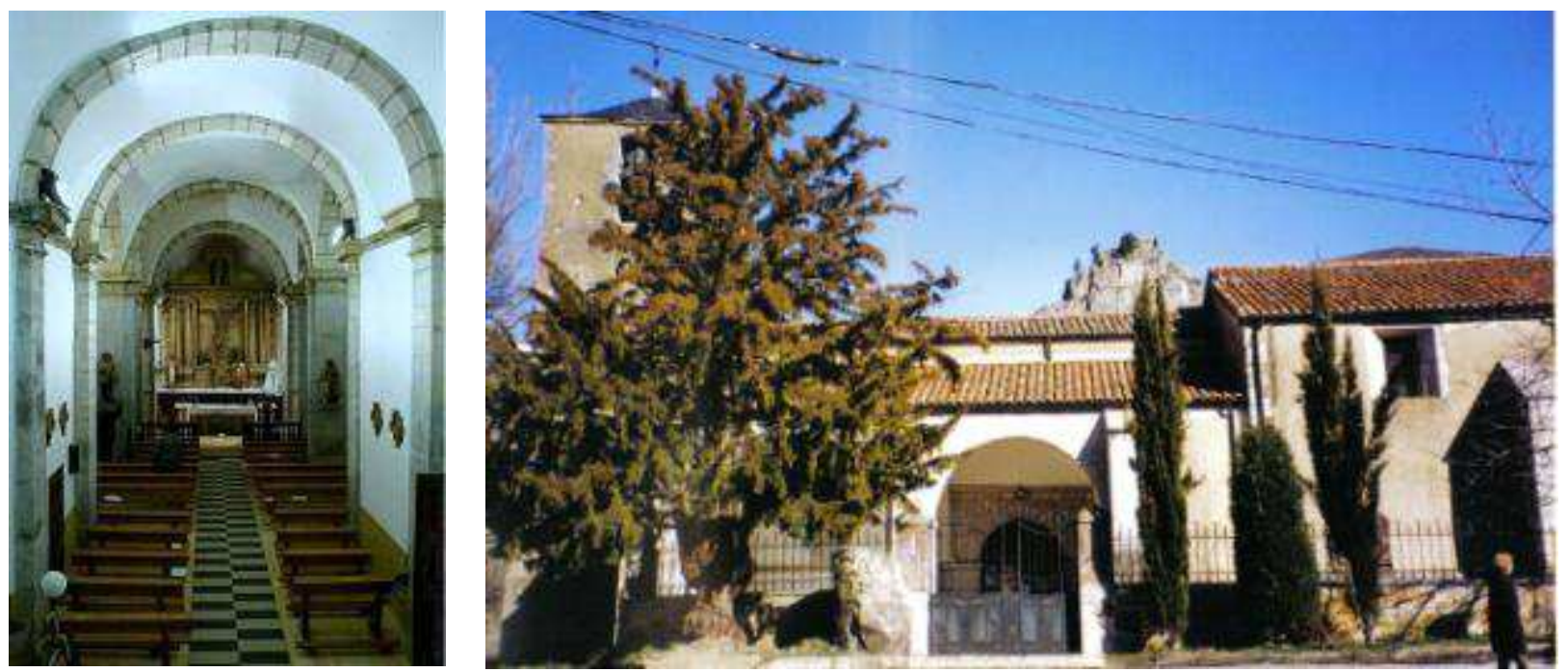

Ilustración 94. Iglesia de Sta. Colomba de los Barrios de Luna

463 A.D.L. Fondo parroquial de Barrios de Luna. Doc. 1990 435, año 1877.

464 Ídem. Año 1848. Los vecinos de Barrios son los que adeudan la cantidad de 646 reales de vellón para la labra de las puertas de la iglesia. Pero además se realizó un hachero para las velas y las puertas del baptisterio. En 1887 se compone la puerta tras el derrumbe del pórtico.

465 Ídem. Año 1877. En 1887 se compone la puerta tras el derrumbe del pórtico. 
IGLESIA DE PLANTA DE CRUZ LATINA CON TORRE CAMPANARIO DE SAN MIGUEL DE OBLANCA
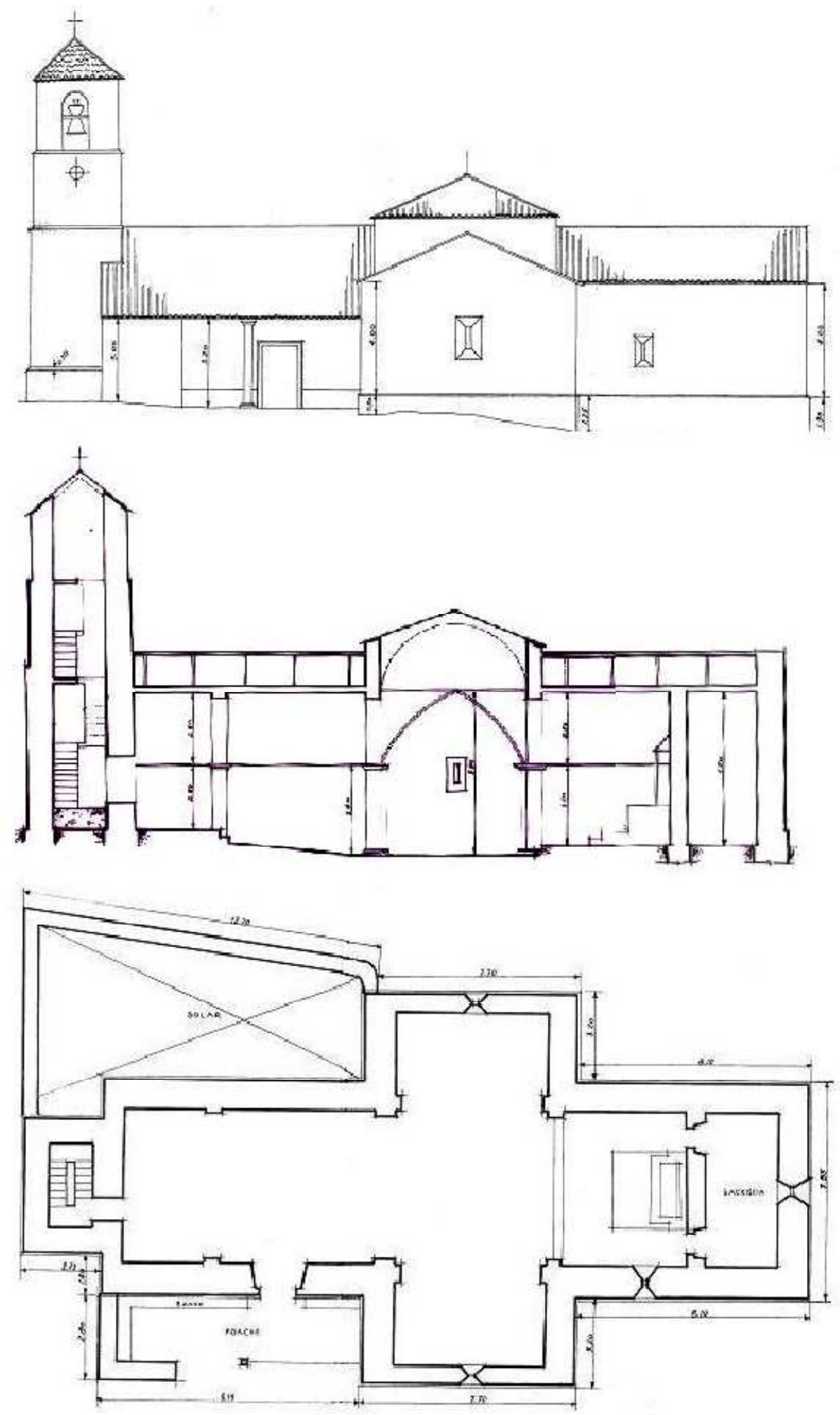

Ilustración 95. A.G.C.H.D. Oblanca. C/05461-1. N 4484. Año 1954-1955. Finca 582. 
Localidad: Oblanca.

Santo Patronal: S. Miguel.

Obra: Siglo XVIII-XIX.

Superficie: $281 \mathrm{~m}^{2}{ }^{466}$

Análisis: $\quad \mathrm{Su}$ estructura estaba configurada por una planta de cruz latina con una cabecera cuadrada muy desarrollada elevada en altura. La iglesia contaba con una sola nave con cubierta a dos aguas que en el transepto remataba con una bóveda semiesférica a modo de

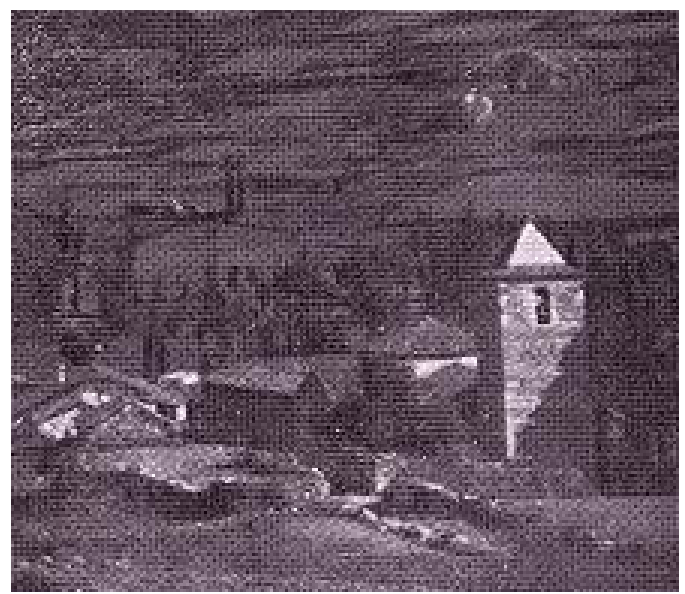

Ilustración 96. Antigua iglesia de Oblanca. Berrueta. Riberas. Vid. Oblanca. cimborrio sujeto sobre arcos apuntados.

Debido a la orografía del terreno en que se ubicaba el edificio, la parte central se encontraba más baja que el resto de la iglesia descendiendo a modo de rampa hasta el transepto. El presbiterio estaba elevado en altura gracias a una pequeña escalinata de dos peldaños. Detrás del altar se encontraba la sacristía cubierta a dos aguas con un entramado de madera. La separación de los distintos tramos de la nave se hacía a través de pilastras adosadas.

El pórtico de entrada se cerraba con un tejadillo a un agua sujeto por una viga de madera con basa y capitel de piedra moldurada. Rodeando el espacio existía un banco corrido lo que indica que se utilizaba también como lugar de reunión del pueblo en los antiguos concejos. La puerta principal era adintelada decorada con molduras simples y poseía una inscripción en relieve relativa a la fecha de construcción de la iglesia ${ }^{467}$.

En el interior de la iglesia había una capilla fundada por la familia Álvarez Miranda, descendientes de los Quiñones, de los cuales existió un virrey en las Indias. En esta capilla se conservaba una inscripción acerca de su fundación ${ }^{468}$.

En la parte O. se situaba la torre de planta rectangular, con una escalera interior de tres tramos que llegaba al campanario. La torre medía $13 \mathrm{~m}^{469}$ de altura y era de sección cuadrada. Tenía adosado al norte un pequeño solar que fue utilizado como cementerio en épocas anteriores.

\footnotetext{
${ }^{466}$ A.G.C.H.D. Oblanca. C/05461-1. No 4484. Año 1954-1955.

${ }^{467}$ BERRUETA. Riberas. Vid: Oblanca

468 Ibídem

${ }^{469}$ A.G.C.H.D. Oblanca. C/05461-1. No 4484. Año 1954-1955.
} 


\section{IGLESIA DE PLANTA DE CRUZ LATINA Y TORRE ESPADAÑA DE SAN MIGUEL DE COSERA}

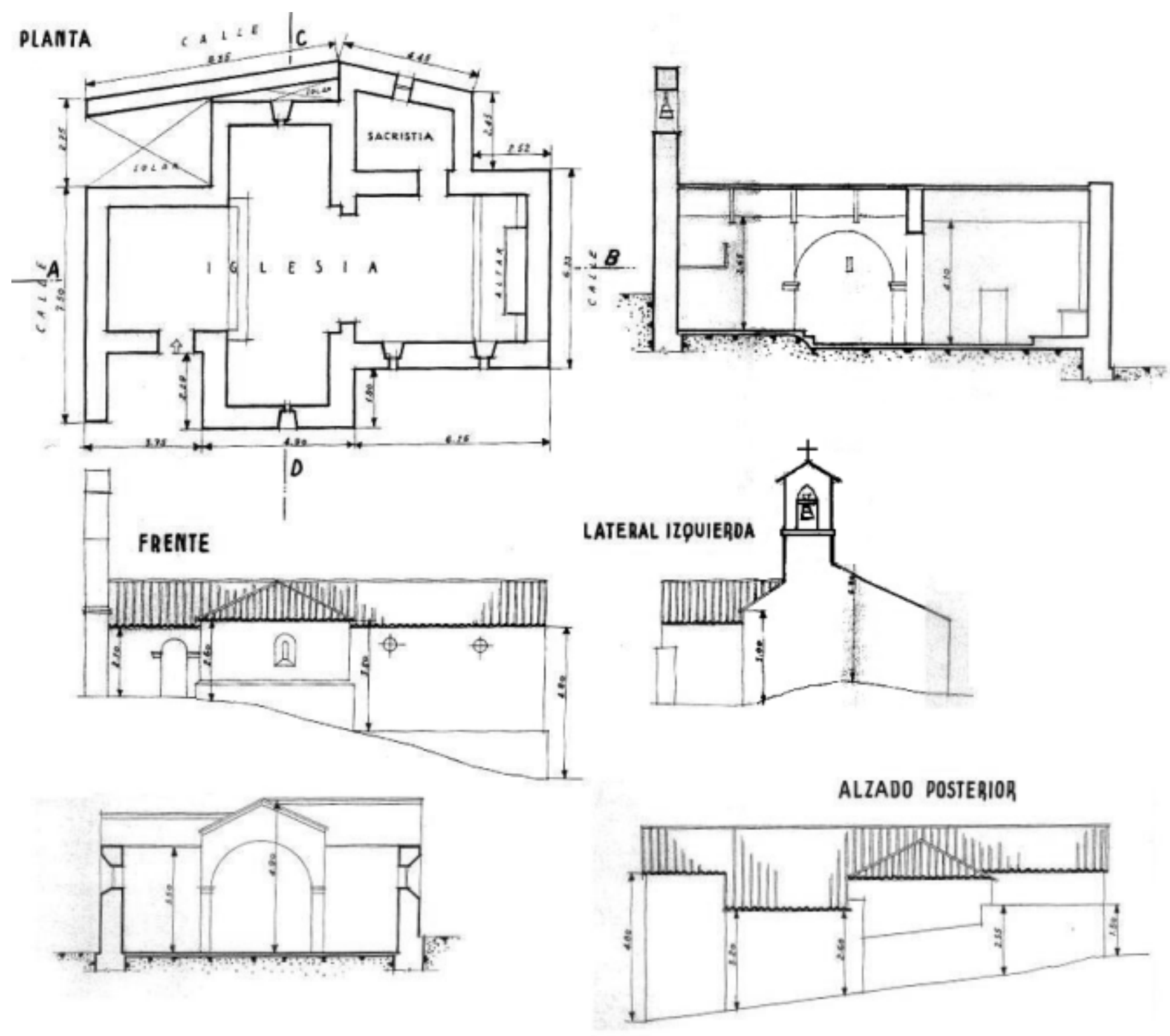

Ilustración 97. A.G.C.H.D. Cosera. C/05432. N 4461. Año 1950. 


\section{Localidad: Cosera.}

Santo Patronal: S. Miguel.

Obra: La iglesia de S. Miguel de Cosera fue remodelada entre los años 1868 a 1877, fecha en la que se traslada el retablo mayor para ejecutar las obras de mejora de la bóveda de la iglesia.

Superficie: de $137.80 \mathrm{~m}^{2} .470$

Análisis: El edificio poseía una planta de cruz latina con una cabecera cuadrada muy desarrollada con respecto al resto del edificio. La estructura de la iglesia se adecuaba a las condiciones del terreno, por lo que la parte trasera de la nave central estaba más elevada, sin embargo esto no se apreciaba en el interior. Se accedía por un lateral que estaba resguardado por una prolongación de la pared de la torre. No existía pórtico cubierto de entrada. La puerta contenía un arco de medio punto que daba acceso al coro, fabricado en madera y elevado en altura.

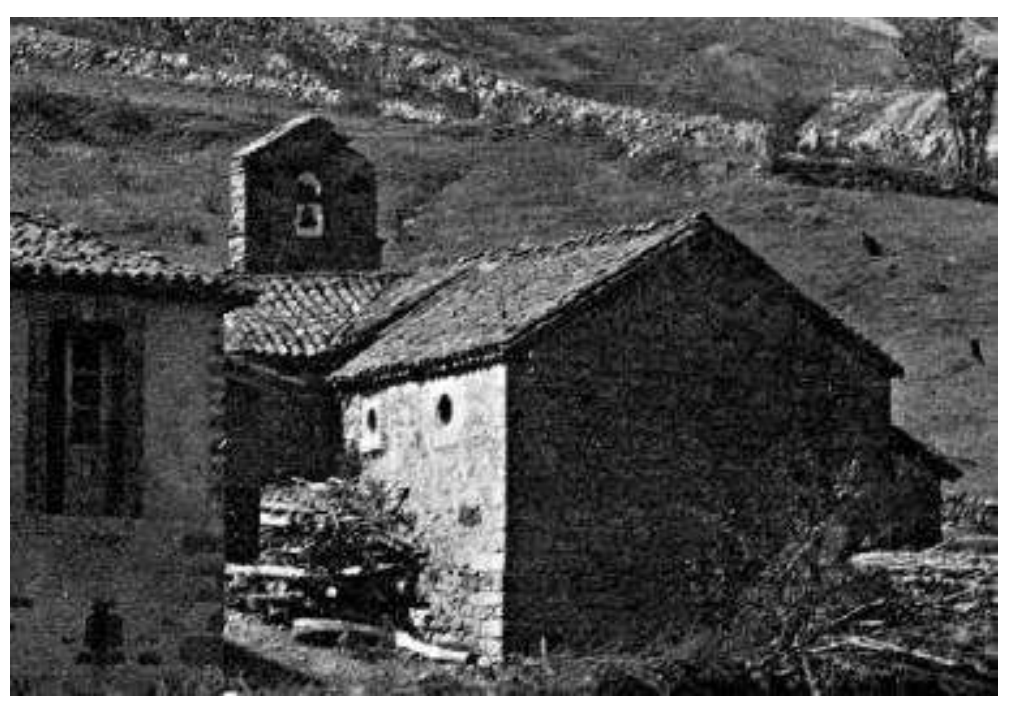

Ilustración 98. Cosera. Fondo fotográfico. I.L.C.

El transepto sobresalía en planta del edificio y estaba separado con grandes arcos de medio punto sobre pilastras adosadas. La cubierta del edificio era a dos aguas con listones de madera bajo tejas. No existía ningún tipo de bóveda. La iluminación penetraba a través de dos vanos circulares abocinados en el muro S. del presbiterio y en los extremos del transepto. En dirección N. se encontraba la sacristía de planta trapezoidal que se adecuaba al urbanismo de la calle.

La torre se componía de un muro grueso rematado con una espadaña de un solo cuerpo de campana y terminado con un tejadillo a dos aguas ${ }^{471}$.

\footnotetext{
${ }^{470}$ A.G.C.H.D. Cosera. C/05432. No 4461. Año 1950.

${ }^{471}$ Ibídem.
} 


\section{IGLESIA DE PLANTA DE CRUZ LATINA Y TORRE ESPADAÑA DE SANTA}

\section{MARTA DE MALLO DE LUNA}

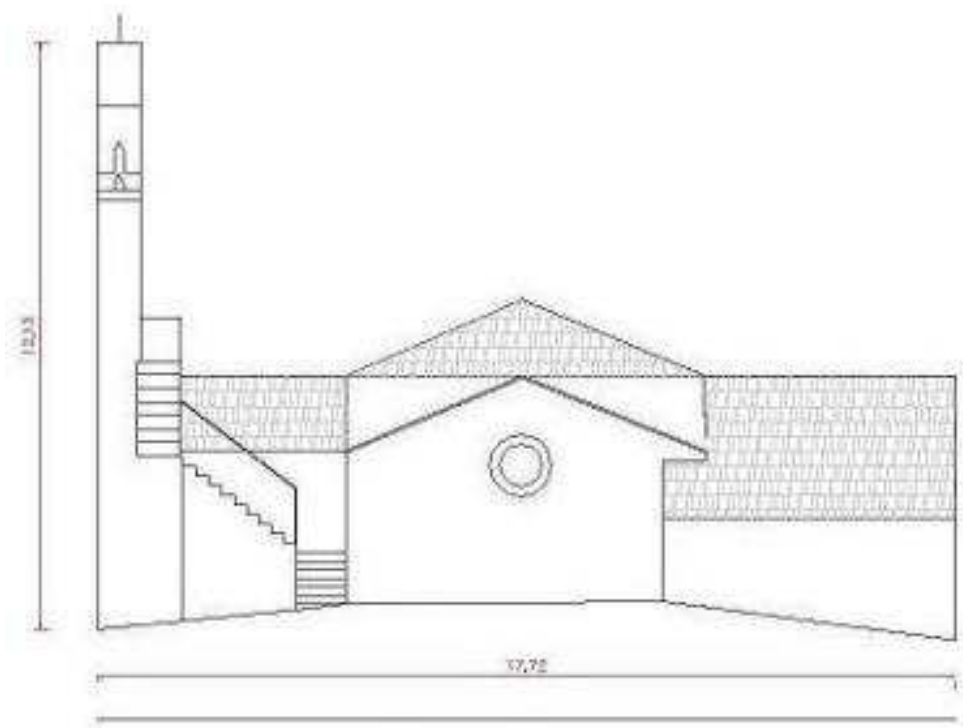

ALZADO NOR'TE

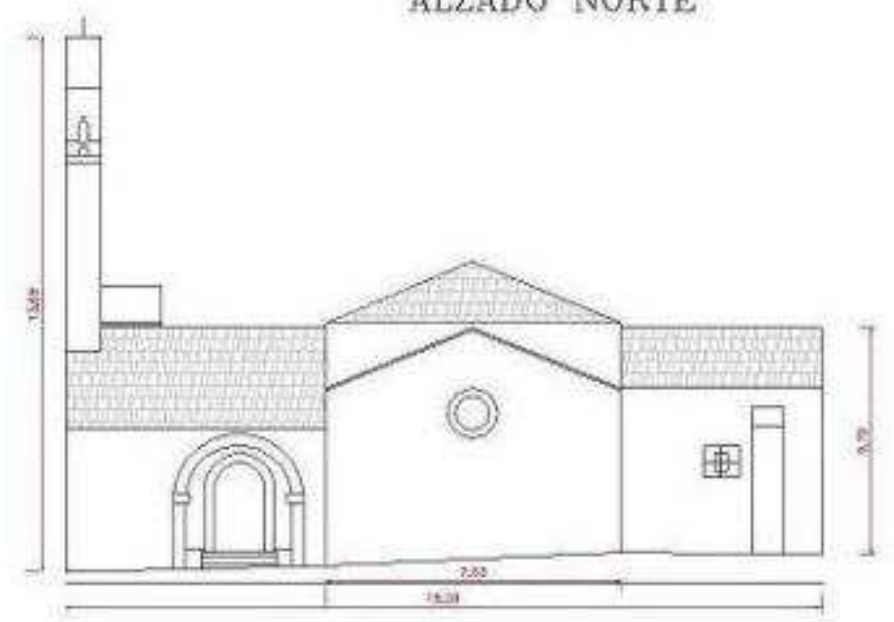

ALZADO SUR
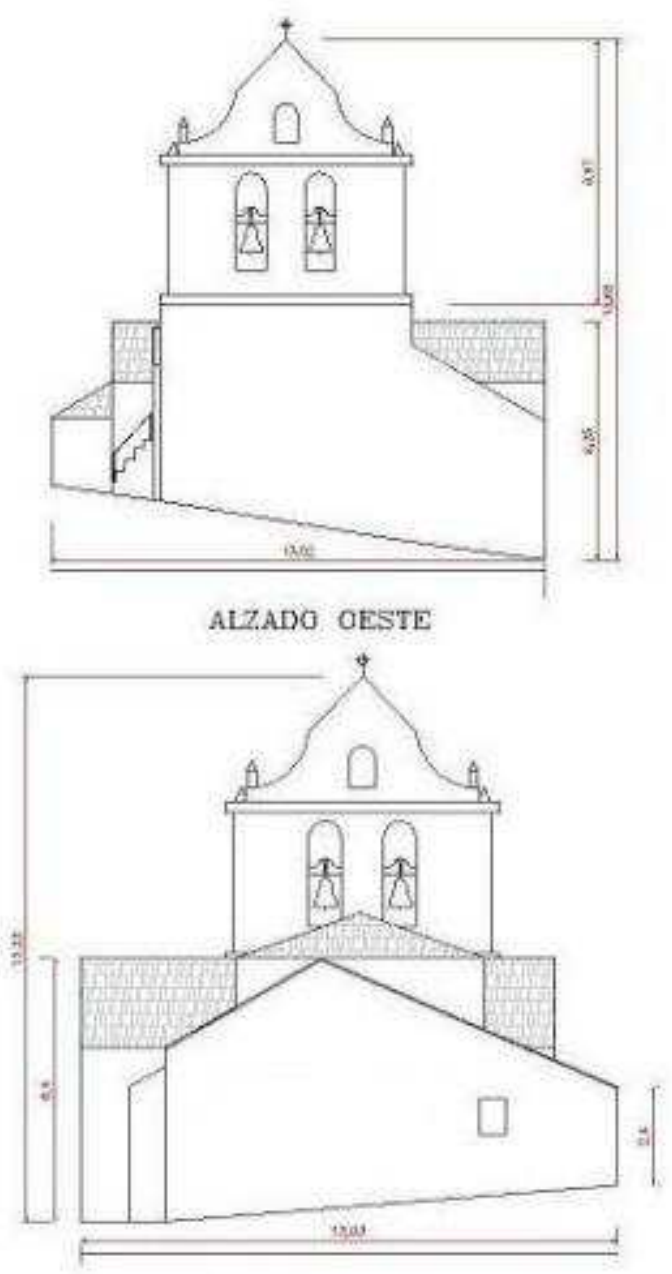

ALZADO ESTE

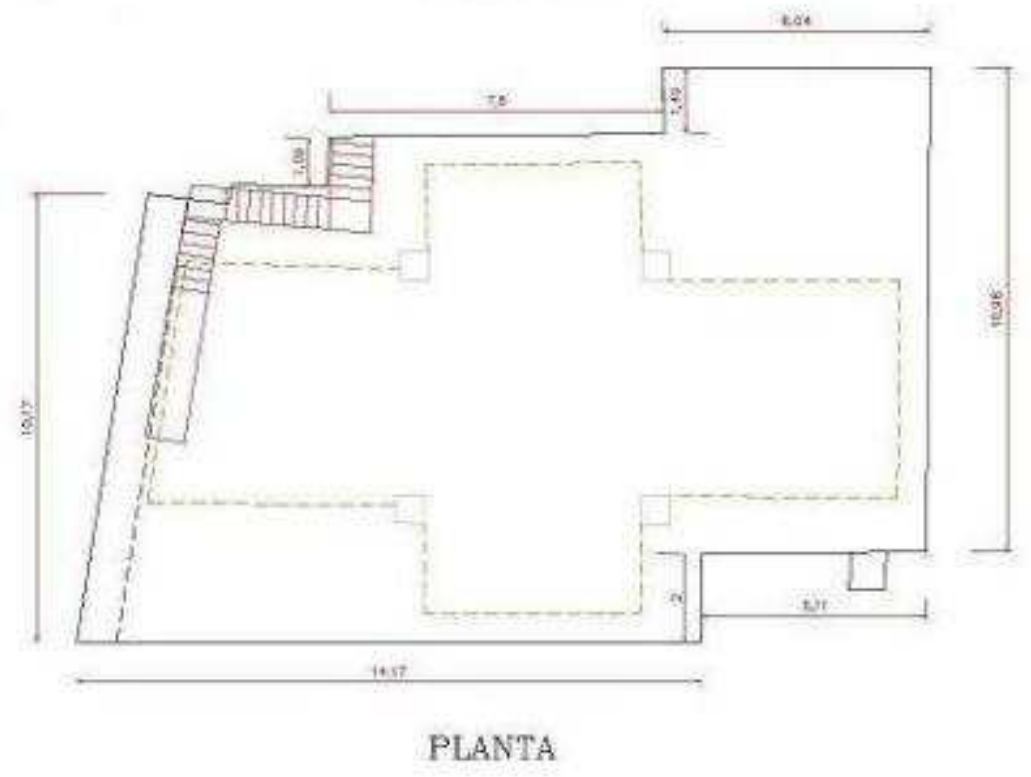


Localidad: Mallo de Luna.

Santo Patronal: Sta. Marta.

Obra: La fábrica de la iglesia de Sta. Marta posee una inscripción en la portada que data de 1800 y que dice: HAEC DOMUS DOMINII 1800. Sin embargo sufrió varias remodelaciones en 1892 cuando se inaugura la nueva parroquia de patronato real ${ }^{472}$.

Superficie: $194 \mathrm{~m}^{2}$.

Análisis: Tiene una planta de cruz latina con transepto y cabecera cuadrada elevada en altura. Cada lado del transepto se utiliza para ubicar los correspondientes retablos de S. Lorenzo y de la Virgen del Cuartero.

Las naves están sujetas por pilastras simples adosadas a la pared con arcos de medio punto y cubiertas con bóveda de cañón exceptuando la capilla, que se cubre a un agua. En el exterior se refuerza con contrafuertes de caliza gris.

La parte posterior del coro fue renovada en torno a $1927^{473}$ alargando la nave central para el campanario y para acomodarse al trazado del camino ${ }^{474}$. Esta obra fue ejecutada en cemento y aparejo regular labrado y peraltado con tres troneras.

La cubierta de la nave es de madera. En la nave central y lateral, se cubre con bóveda de cañón, mientras que el cimborrio se eleva apenas un metro en altura del resto del edificio y se cubre con bóveda de arista. Se cierra todo ello con un tejado a dos aguas y a cuatro en la unión de las naves.

En la iglesia existen tres vanos abocinados cerrados con cristaleras trasparentes que se fueron abriendo sucesivamente para dar mayor iluminación a la iglesia. Uno de ellos, el orientado al S., es circular y los otros adintelados, decorados con molduras sencillas y lisas con sillares bien labrados. Los aleros y cornisas tienen una decoración simple con molduras estucadas.

El porticado fue traído desde la inundada iglesia parroquial de Miñera para sustituir al anterior fabricado con muros de mampostería sujetos sobre una viga de madera.

La torre espadaña fue remodelada en $1927^{475}$ con sillares de caliza gris. En lo alto de la espadaña se corona con una cruz de hierro de este mismo período. En la torre

\footnotetext{
472 A.D.L. Fondo Parroquial. Libro de Fábrica. Mirantes, Doc. 1686c-379. Año 1892. Desde 1887 se están realizando las obras de remodelación de la nueva iglesia, cuya parroquia se tiene que trasladar a San Salvador de Trabanco mientras continúen las labores.

${ }^{473}$ A.D.L. Fondo Parroquial. Libro de cuentas. Mallo de Luna, Doc. 2035. Año 1927.

${ }^{474}$ Ibídem

${ }^{475}$ Ibídem
} 
sobresalen dos campanas, una de ellas data de 1848 y fue trasladada desde la iglesia parroquial de Miñera que sustituiría a otra fundida en $1911^{476}$. La otra campana pertenece a Mallo y data de 1996.
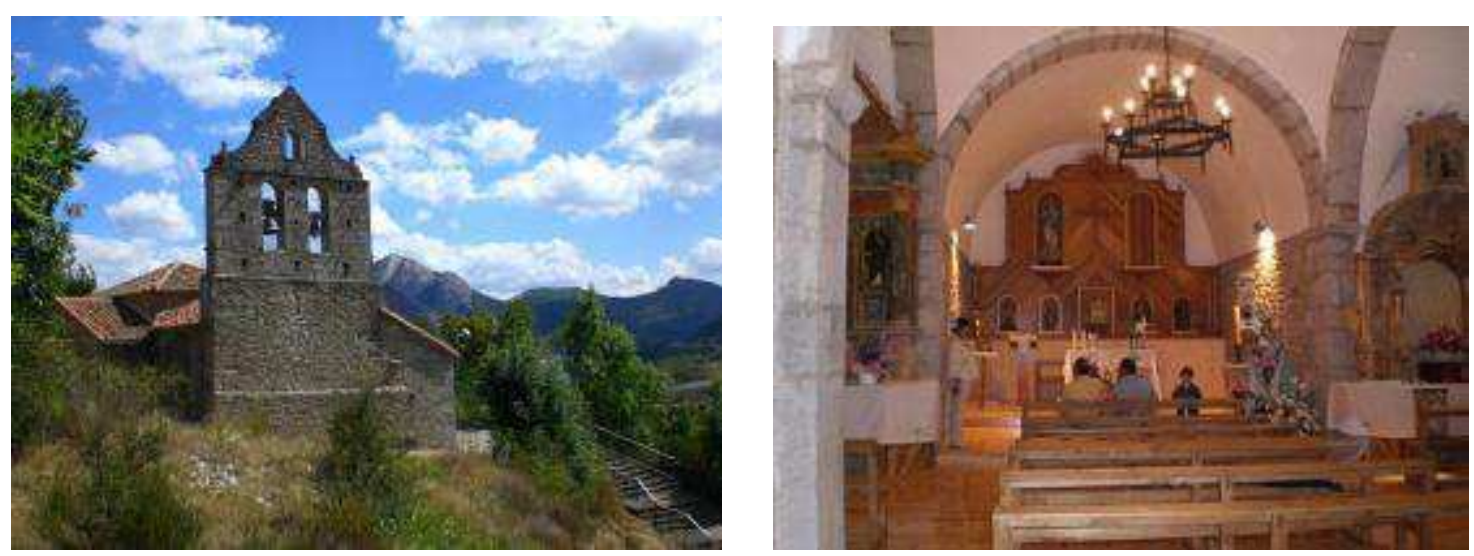

Ilustración 99. Iglesia de Sta. Marta de Mallo de Luna.

476 Ídem. Año 1911. 
IGLESIA DE PLANTA DE CRUZ LATINA Y TORRE ESPADAÑA DE LA VIRGEN DE LAS NIEVES DE MIÑERA
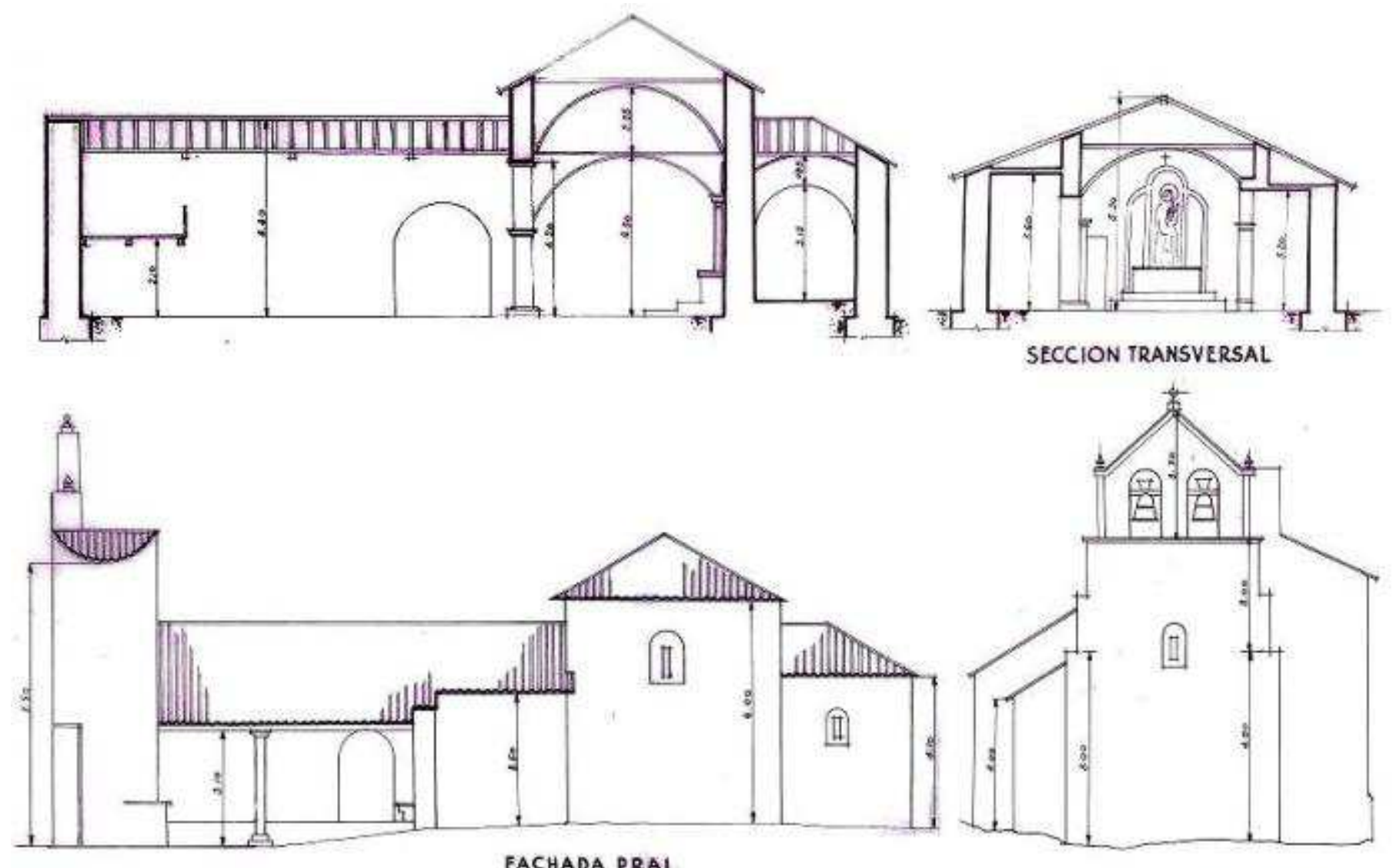

FACHADA PRAL.

FACHADA LATERAL IZQDA

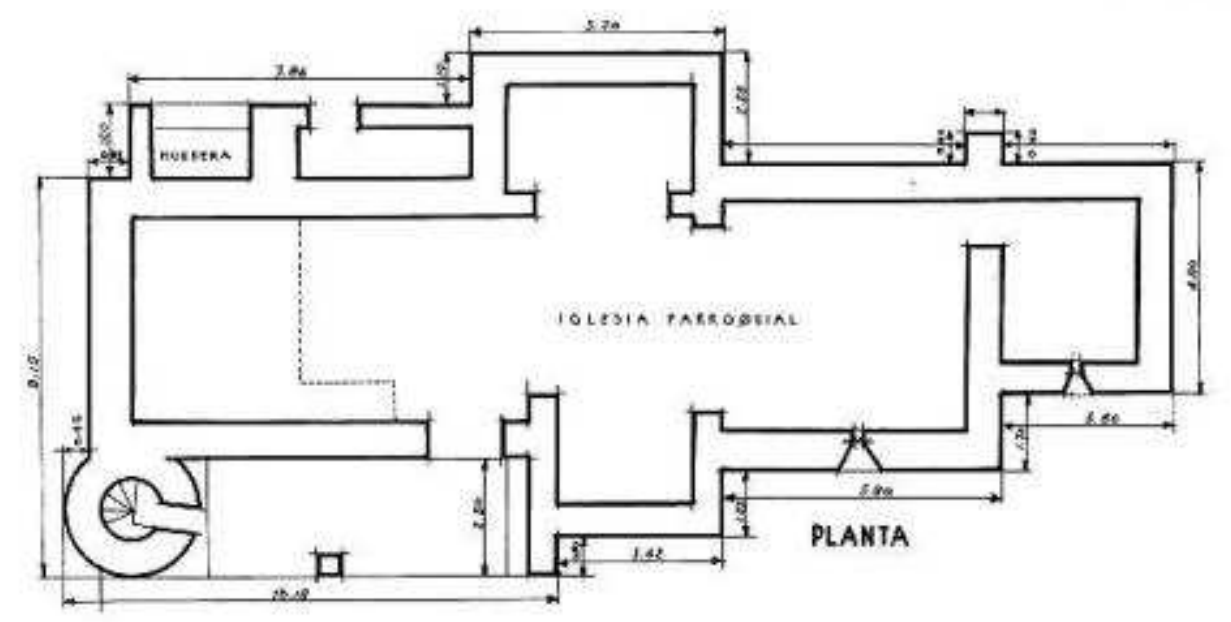

Ilustración 100. A.G.C.H.D. Miñera de Luna. C/ 05434. No 4461. Año 1942-51. Finca 2599 


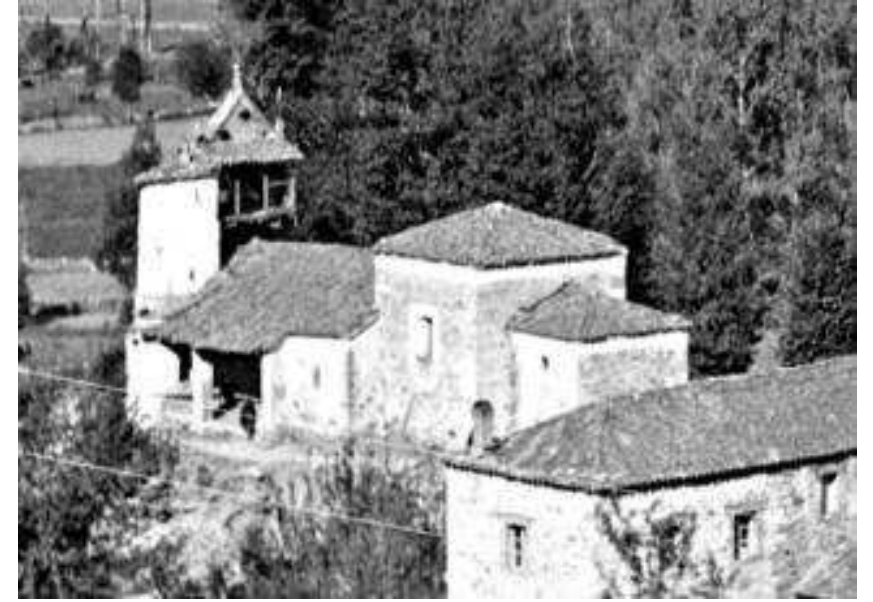

Ilustración 101. Iglesia de Miñera. Fondo fotográfico. I.L.C.

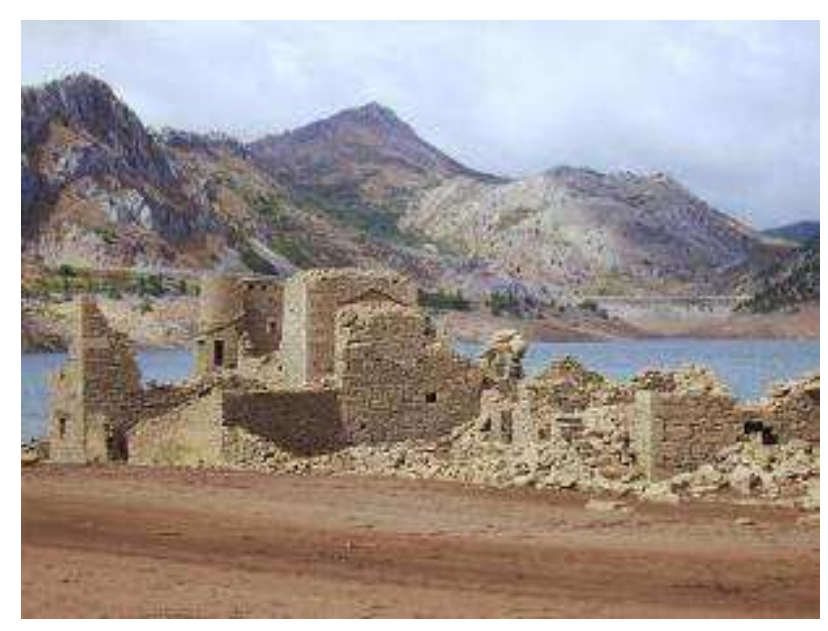

Iglesia en la actualidad. Año 2011.

Localidad: Miñera de Luna.

Santo Patronal: Ntra. Sra. de las Nieves.

Obra: La mayoría de la fábrica de la iglesia de Ntra. Sra. de las Nieves de Miñera data de $1837^{477}$, cuando se ejecutan las obras de remodelación de la iglesia con la reconstrucción de la torre, el pórtico y la tribuna. ${ }^{478}$

Superficie: $184.53 \mathrm{~m}^{2}{ }^{479}$

Análisis: Edificio de planta rectangular con cabecera cuadrada y capillas a los laterales no simétricas debido a la ampliación del pórtico y de anexos aledaños a la iglesia acomodándose a las condiciones del terreno. Estos espacios se abrían con arcos de medio punto y cubiertas con techumbre plana de madera.

El presbiterio se separaba del resto de la nave a través de un gran arco de medio punto sustentado por pilastras. En el altar mayor se encontraba el retablo dedicado a la patrona Sta. María de las Nieves. Detrás del altar se ubicaba la sacristía, de planta cuadrada. El presbiterio sobresalía en altura del resto de la nave y se marcaba por un arco de medio punto sujeto por pilastras adosadas con basa y capiteles sencillos.

La nave de la iglesia se cubría con una techumbre a dos aguas con listones de madera, mientras que el presbiterio lo hacía con una bóveda semiesférica en piedra toba muy porosa para evitar el excesivo peso hacia los muros. La sacristía también se cubría con bóveda de naranja.

\footnotetext{
477 A.D.L. Fondo parroquial. Libro de fábrica. Miñera de Luna. Doc. 1682. Año 1837.

478 A.D.L. Fondo parroquial. Libro de cuentas de la iglesia de san Mames. Lagüelles. Doc. 973. Año 1871. En 1871 la parroquia de Lagüelles ofrece dinero para la fábrica de Miñera

${ }^{479}$ A.G.C.H.D. Miñera de Luna. C/ 05434. No 4461. Año 1942-51.
} 
En la parte N. existían dos estancias rectangulares adosadas al templo. Uno de los anejos estaba destinado a osario abierto al exterior por un hueco en la pared. La otra estancia, construida en $1885^{480}$, se cerraba con una puerta fabricada con tabla y se utilizaba como trastero para guardar los objetos de la iglesia. En la parte posterior había un coro de madera, elevado en altura, al que se accedía desde el interior a través de unas escaleras.

Para la mejora de la iluminación del templo se abrieron en $1850^{481}$ una serie de ventanas con sillares abocinados bien labrados en caliza gris en la tribuna y en el altar de Ntra. Sra. del Rosario. Sobresale el vano circular bajo la torre espadaña que iluminaría la mayor parte de la estancia, cerrado con una pequeña vidriera.

Poseía un pequeño pórtico contiguo en la parte S. construido en $1837^{482}$. Esta galería de entrada estaba sujeta por un pilar de piedra con basa y capitel sencillo ${ }^{483}$. El suelo estaba empedrado con cantos rodados realizando dibujos geométricos. El pórtico fue trasladado a la iglesia de Mallo de Luna antes de la inundación.

La torre fue reconstruida casi totalmente entre $1837-49^{484}$ y tenía forma de espadaña con un cuerpo de dos campanas refundidas en 1848. La escalera de caracol con peldaños de piedra labrada que subía a la torre fue creada unos pocos años más tarde junto con el corredor del campanario.

\footnotetext{
${ }^{480}$ A.D.L. Fondo parroquial. Libro de fábrica. Miñera de Luna. Doc. 1682. Año 1885.

481 Ídem. Año 1850.

482 Ídem. Año 1837.

${ }^{483}$ Anteriormente existía una columna de madera que sujetaba el pórtico. El problema de la sujeción de la madera hace que en torno a 1850 se reforme esta parte con un nuevo pórtico de piedra cubierto con un empedrado de cantos rodados.

${ }^{484}$ A.D.L. Fondo parroquial. Libro de fábrica. Miñera de Luna. Doc. 1682. Año 1837.
} 


\section{IGLESIA CON CAPILLAS A MODO DE TRANSEPTO Y TORRE ESPADAÑA}

\section{DE SAN MAMES DE LAGÜELLES}
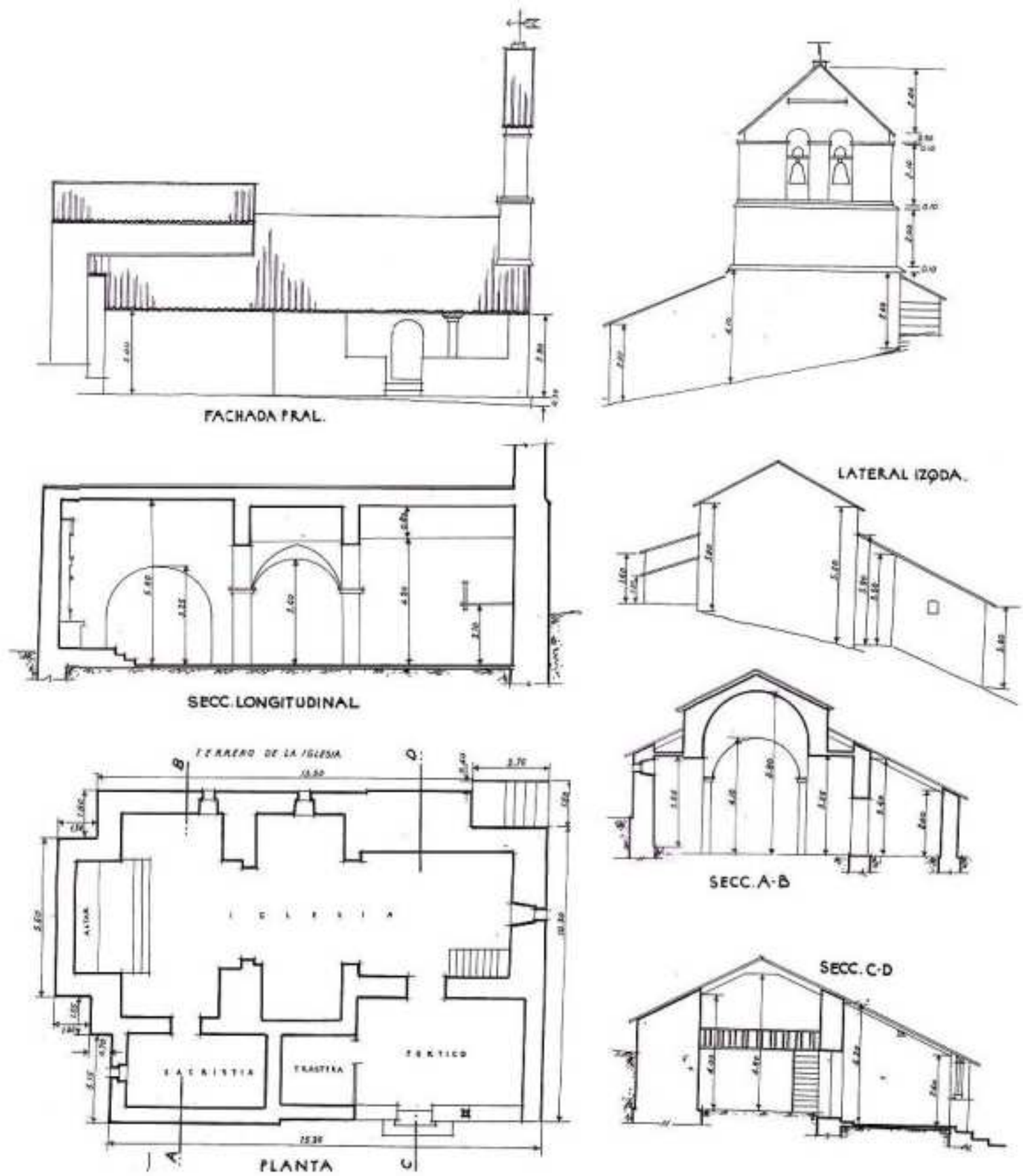

Ilustración 102. A.G.C.H.D. Lagüelles. Nº 4497. Finca 2081. 
Localidad: Lagüelles.

Santo Patronal: S. Mames.

Obra: La actual fábrica de la iglesia de S. Mames fue realizada en $1715^{485}$.

Superficie: $157.59 \mathrm{~m}^{2}$.

Análisis: La estructura exterior de la planta era rectangular mientras que al interior se distribuía como de doble cruz latina debido a la multiplicación de capillas laterales. El presbiterio estaba elevado en altura para dar paso al altar con cabecera plana. Sobre él se asentaba el retablo principal de S. Mames. En la parte N. se situaba la sacristía, por la que se accedía desde la cabecera. A los pies se encontraba el coro. La edificación estaba adaptada a las condiciones del terreno por lo que la sacristía y el pórtico tenían un considerable desnivel con respecto al resto.

La cubierta de la nave era a dos aguas, excepto en el presbiterio que se utilizó la bóveda de cañón reconstruida en $1909^{486}$. La separación de las naves se hacía con arcos
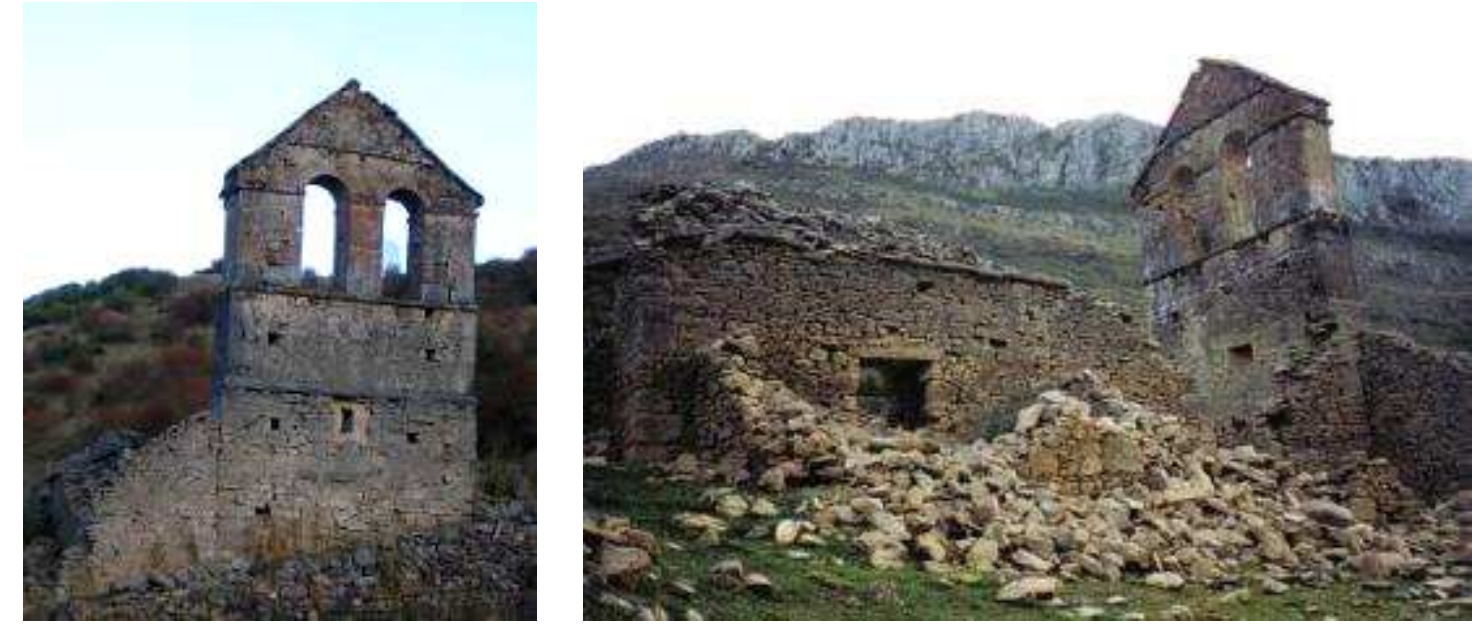

Ilustración 103. Lagüelles. Estado actual de la iglesia. Año 2012

de medio punto, siendo los de la nave central mayores que los de las laterales. El pequeño pórtico datado en 1894 con postes de madera y muros de sillarejo daba acceso al interior de la nave. La trastera de la iglesia fue reformada en 1900 a partir del espacio sobrante del pórtico ${ }^{487}$. Como iluminación se encontraba un pequeño vano rectangular en el muro norte bajo la torre y otro vano en el presbiterio con rejas de hierro realizado en $1891^{488}$.

\footnotetext{
${ }^{485}$ A.D.L. Fondo parroquial. Libro de cuentas de la iglesia de san Mames. Lagüelles. Doc. 972. Año 1714. 486 Ídem. Doc. 973. Año 1909.

487 Ídem. Doc. 973. Año 1891.

${ }^{488}$ Ibídem
} 
El acceso a la torre se hacía a través de una escalera exterior que daba paso al campanario. La torre espadaña contenía dos campanas bajo arquillos reformada entre $1849-1856^{489}$ con un corredor de madera.

489 Ídem. Doc. 972. Año 1849. 


\subsubsection{ERMITAS}

La RAE define ermita como capilla o santuario, generalmente pequeño, situado por lo común en despoblado y que no suele tener culto permanente.

Las ermitas de la ZACEL solían estar situadas cercanas a las poblaciones e incluso dentro del entramado urbanístico. Lo más habitual era su ubicación en lugares de continuo tránsito como puentes, calzadas, en la línea de demarcación de las comarcas y municipios, o en un lugar apartado como consecuencia de un milagro o hecho religioso acaecido en el lugar. Muchas de ellas fueron fundadas por laicos, por lo que su situación geográfica también dependía de los terrenos donados para su construcción.

En algunas de las ermitas se celebraba una gran romería como consecuencia de leyendas milagrosas o apariciones marianas. Un ejemplo es la ermita del Cuartero de Mallo, levantada en el collado de la peña del Cuartero debido a la aparición milagrosa de la imagen de la Virgen y en donde todavía se sigue celebrando una romería, o el ejemplo de la ermita de S. Ramón en la misma localidad, cuya fundación tuvo que ver con un saco de monedas que el párroco encontró en el lugar y que interpretó como designio divino para la construcción de una ermita.

En el siglo $\mathrm{XV}^{490}$ comienza un fervor devocional por aquellos santos y vírgenes de carácter auxiliador, como son S. Roque, S. Miguel, S. Antonio, las Ánimas, la Virgen y Cristo, por lo que se irán creando toda una serie de redes de edificios únicamente destinados al culto de estas imágenes.

A partir del siglo XVII, y como consecuencia de la Contrarreforma, se va a fomentar la exaltación popular destinada a este tipo de figuras. Para propiciar este fervor los propios párrocos instan a los feligreses a la creación de cofradías y ermitas dedicadas a curaciones y milagros de la Virgen y los santos. Este es el caso de la ermita de S. Lorenzo, cuya imagen, según cuenta la leyenda, se sacó en procesión durante un incendio ocurrido en Mallo.

Los encargados de su fundación y mantenimiento son personas tanto laicas como religiosas. Las fundaciones de ermitas por particulares fueron muy comunes en el siglo XVII. Encontramos muestras de este tipo en la capilla de Nuestra Señora de la Piedad en Oblanca fundada en 1644 por Miguel Rodríguez Lorenzana y su mujer ${ }^{491}$ o la ermita

\footnotetext{
${ }^{490}$ FERNÁNDEZ VÁZQUEZ. Arquitectura, p. 55.

${ }^{491}$ MARTÍN FUERTES. Colección, Doc. 218, p. 145.
} 
de Nuestra Señora de las Angustias de Lagüelles, en $1655^{492}$ o la ermita de las Ánimas de Casasola fundada por el licenciado Pedro Casado en 1673 quien donó unos bienes y herencias para la misma ${ }^{493}$. En el siglo XIX se siguieron realizando fundaciones de edificios religiosos, como es el caso de la ermita de la Virgen del Cuartero de Mallo, en $1882^{494}$. La fundación de ermitas por patronato religioso era menor y sólo tenemos noticias de la ermita de S. Ramón de Mallo. Las cofradías también podían ser partícipes de estas fundaciones como la de la ermita de la Vera Cruz de Lagüelles o la del Sto. Cristo de Arévalo.

La reutilización de estos edificios y el cambio de patronato fue una práctica habitual en toda la zona. Por ejemplo la ermita de Lagüelles de Ntra. Sra. de las Angustias pasó a denominarse de la Vera Cruz en $1717^{495}$ gracias a la creación de la cofradía del mismo nombre. Otro caso de reutilización del mismo edifico para imágenes devocionales diferentes lo encontramos en Mallo de Luna. La ermita de S. Ramón Nonato fundada en 1764 por don Bernardo, cura de Trabanco, fue en su origen dedicada a la Virgen de la Portería.

Los patronos eran los responsables del mantenimiento de estas capillas y ermitas cuyos gastos solían ser los de reparación del tejado, la compra de cera para la iluminación del templo y la limpieza del mismo. Además, debían recaudar los impuestos y donativos dados por lo vecinos. A pesar de que el patrono fuera el responsable del edificio, el párroco y el obispo en general eran quienes concedían los permisos de misas y festividades sagradas en el lugar. El obispado, a través de los visitadores, se encargaba de mantener el respeto cristiano es estos lugares de patronato laico.

La fábrica de todas las ermitas era sencilla. Su función se reducía a contener la imagen del patrón y a los feligreses el día de la fiesta, por lo que los materiales con los que se edificaban no eran de gran calidad. Su forma era similar ya que poseían una planta cuadrada o rectangular con una cubierta a dos aguas bajo la que podía descansar una bóveda semiesférica o rebajada. La nave estaba separada del ábside por un arco apuntado o de medio punto. Los propios muros eran los que soportaban la techumbre,

\footnotetext{
492 Ídem. Doc. 226. p.147.

${ }^{493}$ FERNÁNDEZ CATÓN. Catálogo, №. 21 Doc. 1663.

${ }^{494}$ A.D.L. Fondo parroquial. Barrios de Luna. Doc.1990-435. En el archivo parroquial de Barrios se cita la cantidad de cinco reales para el traslado de piedra para la construcción de la ermita de la Virgen del Cuartero.

${ }^{495}$ A.D.L. Fondo parroquial. Libro de cuentas de la iglesia de S. Mames. Lagüelles. Doc. 972. Año 1714. Doc. 972.
} 
ya que su peso no era excesivo, por ello no eran corrientes los contrafuertes. La fachada se remataba con una pequeña espadaña de un hueco con una sola campana.

\subsubsection{Tipología}

Vicente Fernández Vázquez distingue tres tipos de ermitas según su ubicación y su forma ${ }^{496}$.

Las ermitas vecinales son aquellas que se encuentran dentro del casco urbano de la propia población. Se dedican principalmente a los santos y vírgenes de mayor devoción y solo se abren al público el día de la fiesta del patrono mientras que el resto del año permanece cerrado. Este es el caso de las ermitas de S. Ramón de Lagüelles, S. Miguel de Oblanca y Sto. Cristo de Arévalo.

Las ermitas de despoblado se encuentran en lugares apartados donde según la tradición acaeció algún milagro o hecho particular, aunque muchas de ellas pueden tener un origen pagano de antiguos centros de culto ${ }^{497}$. El principal motivo de abandono de las ermitas de despoblado era su lejanía del centro poblacional, que en algunos casos acabaron convirtiéndose en refugio para el ganado. En estas ocasiones los propios cofrades o dueños preferían destruir el edificio colocando una cruz encima de las ruinas como recordatorio de un lugar sagrado ${ }^{498}$, como ocurrió en la ermita de la Virgen del Cuartero en Mallo, que se encontraba en mal estado debido a su lejanía de la localidad y en peligro de derrumbe $e^{499}$.

Las ermitas humilladeros habitualmente tenían como misión ser el punto final de los Vía Crucis. Estaban situadas en caminos, cruces de vías, puentes o entradas de pueblos. Este tipo de ermitas solían tener un pórtico que cubría la fachada en la que se abría una puerta con una pequeña reja por la que se podía observar el interior del templo. Además poseían un par de ventanas a cada lado de la entrada de manera abocinada que también permitían el rezo a los transeúntes. Característica de esta tipología es la ermita de S. Lorenzo de Miñera, que se encontraba en un lugar de paso

\footnotetext{
${ }^{496}$ FERNÁNDEZ VÁZQUEZ. Arquitectura, p. 56.

${ }^{497}$ Ibídem.

498 Ibídem.

${ }^{499}$ A.D.L. Fondo parroquial de Barrios de Luna. Doc. 1990 435. Año 1860. En 1860, la iglesia parroquial de Barrios de Luna, mandó trasladar una piedra para la ermita de la Virgen del Cuartero, ya que la dovela que cerraba el arco era muy inestable.
} 
principal dentro el Valle junto al puente de piedra y que acabó denominándose de la misma manera que el edificio religioso.

A pesar de la diferenciación anterior, las ermitas de la ZACEL se adecúan más a una tipología que se divide en dos grupos más sencillos, las ermitas de planta cuadrada y la de planta rectangular, pues su localización dentro o fuera del entramado urbanístico no repercutía en una diferenciación formal.

1. Ermitas de planta cuadrada.

Ermitas de planta cuadrada con techumbre a dos aguas: Estas ermitas son características de las poblaciones con menores recursos económicos. Su sencilla construcción hacía que los promotores privados, como las cofradías, eligiesen esta opción para abaratar costes. No poseían apenas decoración interior, tan sólo un pequeño altar albergaba la figura del santo patrón que era custodiada la mayor parte del año por un mayordomo o en la iglesia parroquial donde continuaba su culto hasta que era trasladada el día de la fiesta en romería a la ermita. Solían poseer unas dimensiones escasas que apenas llegaban a los $20 \mathrm{~m}^{2}$ y el único vano de iluminación era la puerta de entrada, como observamos en la ermita de las Ánimas de Casasola y el Cristo de Arévalo. La pobreza de sus materiales ocasionó la destrucción y el abandono de estas ermitas antes incluso que la llegada del embalse, como es el caso de la ermita de S. Juan de Barrios de Luna.

Ermitas de planta cuadrada con techumbre abovedada: Los edificios religiosos abovedados suponían un aumento considerable del coste de la empresa, por lo cual sólo existe un ejemplo claro en la ZACEL: la ermita de S. Ramón de Mallo. Su fundación por parte de D. Bernardo, cura de Trabanco, hizo posible la incorporación de una bóveda de naranja con decoraciones pictóricas en el interior. La iluminación venía a cargo de unos pequeños vanos abocinados tanto en la sala como en la sacristía, a través de la cual existía otro ventanal por el que se podía observar la imagen de culto. Otro edificio que en su origen pudiera estar cubierto con una bóveda es la derruida ermita de la Virgen del Cuartero de Mallo. Las últimas labores de restauración sacaron a la luz una estructura cuadrangular con muros de mampostería y sillares bien labrados para vanos, esquinas y aleros. En la parte trasera poseía unos contrafuertes esquineros que hacen pensar que la cubierta sería abovedada. 
2. Ermitas de planta rectangular

Ermitas de planta rectangular con tejado a dos aguas: La ermita de planta rectangular fue bastante común en la ZACEL, debido sin duda a su mayor capacidad para albergar feligreses. La principal diferencia con respecto a las ermitas de planta cuadrada es la multiplicación de elementos que los asemejan a una iglesia, como es el caso de una espadaña o campanario y la ubicación perpetua de la imagen de culto en un retablo. Apenas poseían ventanas de iluminación y la decoración era bastante sobria, especialmente en aquellas ermitas dotadas por cofradías. Dos son los ejemplos de estas características: la ermita de S. Lorenzo de Miñera y la de S. Miguel en Oblanca. Ambas poseen una estructura similar con una nave rectangular y un presbiterio elevado en altura y separado del resto a través de un arco apuntado en el caso de Miñera y rebajado en el de Oblanca.

Ermitas de planta rectangular con bóveda: La ermita de S. Ramón de Lagüelles es el único ejemplo de esta tipología. Fue fundada por la familia Rodríguez Lorenzana quien también promovió la construcción de la ermita de S. Miguel de Oblanca. El potencial económico de esta familia favoreció la construcción de un edificio más lujoso con piedra caliza labrada en vanos y esquinas y con un presbiterio recubierto con una bóveda. Su ubicación en el casco del pueblo podría formar parte de un programa propagandístico por parte de la familia que querría establecer cierto poderío religioso en el Valle. Se desconoce la decoración interior pero se supone que, a la vista de la ermita de S. Ramón de Mallo, poseía al menos decoración pictórica en la propia bóveda. 


\section{ERMITA DEL SANTO CRISTO. ARÉVALO}
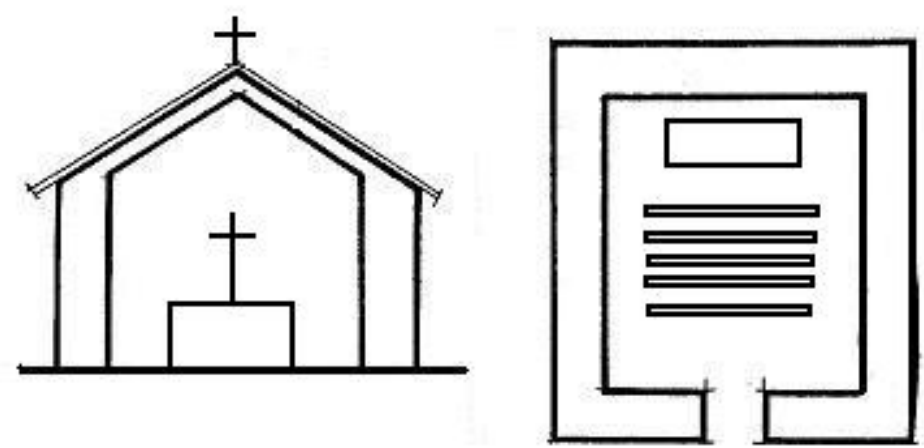

Ilustración 104. Posible reconstrucción de la ermita del Santo Cristo de Arévalo

Localidad: Arévalo.

Santo Patronal: Sto. Cristo.

Obra: Desconocida, posible siglo XVIII-XIX.

Superficie: Desconocida.

Análisis: Apenas existen noticias acerca de la desaparecida ermita del Cristo de Arévalo. Tan solo se ha podido extraer información a través de la memoria popular y de la imagen titular que se conserva en la iglesia de Sena de Luna.

La ermita era de pequeñas dimensiones, en torno a $16 \mathrm{~m}^{2}$ teniendo en cuenta las medidas comunes de otras ermitas de la zona. Seguramente estaría realizada con una techumbre a dos aguas sin torre espadaña. Los materiales más comunes serían muros de mampostería con sillares en vanos y esquinas. Se desconoce igualmente el número de accesos al edifico y vanos de iluminación.

Arévalo se había conformado como un barrio de Sena de Luna. Al igual que ocurría en otras poblaciones, como Casasola, la escasez de población determinó la inexistencia de un centro parroquial, por lo que la única opción era adscribirse al más cercano jurisdiccionalmente. Para evitar la ausencia de centros religiosos, los propios vecinos optaban por fundar una ermita que sirviese para los oficios referentes a funerales y festividades como fue la ermita del Sto. Cristo. 


\section{ERMITA DE SAN JUAN. BARRIOS DE LUNA}
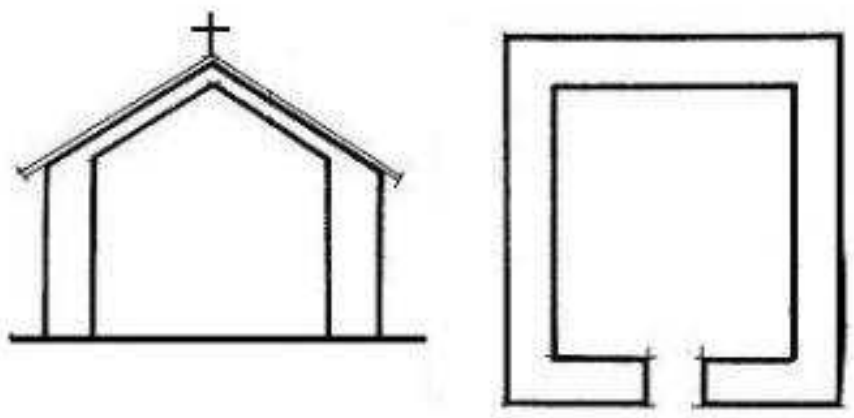

Ilustración 105. Posible reconstrucción de la ermita de S. Juan.

Localidad: Barrios de Luna.

Santo Patronal: S. Juan.

Obra: En $1752^{500}$ se cita la capilla de S. Juan, llevada por un capellán llamado D. Pedro Álvarez, que recibía diezmos de Barrios de Luna.

Superficie: Desconocida.

Análisis: La ermita de S. Juan fue descrita en el Diccionario de Pascual Madoz como una ermita de aspecto ya ruinoso ubicada en el casco de la localidad y en cuyo interior se encontraba un sepulcro de identificación desconocida ${ }^{501}$. Al igual que ocurre con la iglesia de S. Salvador de Trabanco, no se conocen las causas de su desaparición, aunque probablemente, al ser de carácter privado, pasase a abandonarse por sus propietarios al dejar de ser rentable por no percibir los diezmos de los cofrades que la componían. Con las obras de construcción del embalse los restos de la ermita de S. Juan que aún permanecían en pie fueron demolidos para levantar el Cuartel de la Guardia Civil, junto al campamento Obrero.

500 A.H.P.L. Catastro del Marqués de la ENSENADA. Interrogatorio. Barrios de Luna. Rollo 23-24. 1752. En el libro de eclesiásticos se citan los diezmos a pagar por el pueblo y entre ellos se encuentra un pequeño diezmos para la capilla de San Juan de Barrios de Luna.

${ }^{501}$ MADOZ. Diccionario, p. 66. 

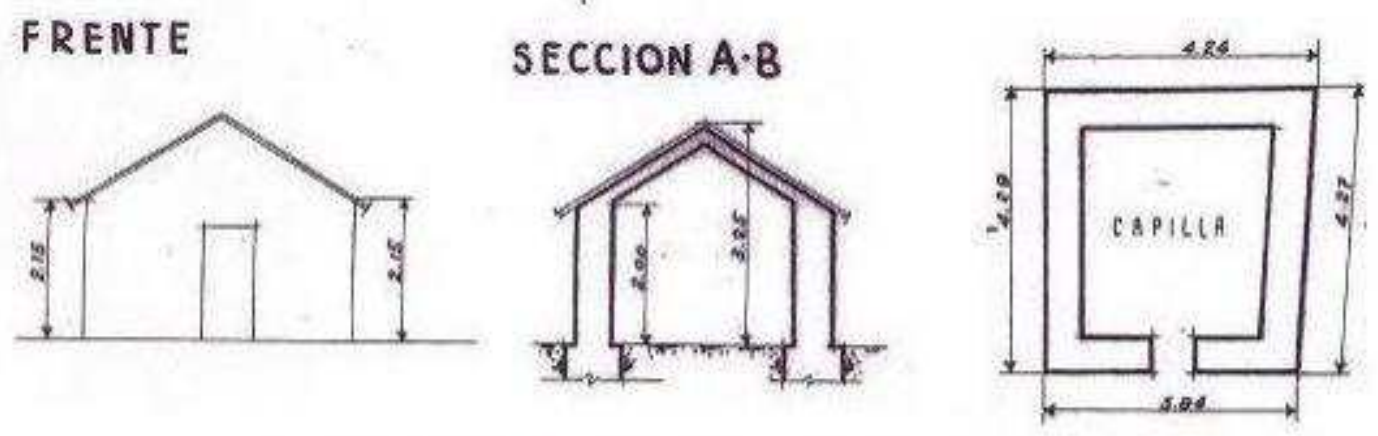

Ilustración 106. A.G.C.H.D. Casasola. Capilla de las ánimas. C/ 05434. Nº 4461. Año 1942-51. Parcela 2993

Localidad: Casasola.

Santo Patronal: Las Ánimas.

Obra: En torno a 1673 el licenciado Pedro Casado funda en Casasola una capellanía dejando unos bienes y herencias para la misma ${ }^{502}$, siendo la única capellanía existente la de las Ánimas. En el momento de la expropiación la ermita pertenecía a los herederos de José Suárez ${ }^{503}$.

Superficie: $17 \mathrm{~m}^{2}$.

Análisis: La ermita de las ánimas se encontraba en Casasola, una población que pertenecía a Barrios de Luna y que por lo tanto, lo mismo que ocurría en Arévalo, no poseía iglesia parroquial. Las dimensiones de la capilla apenas superaban los $18 \mathrm{~m}^{2}$ en una estructura cuadrada con una techumbre a dos aguas. La puerta de acceso estaba cerrada por una verja desde la cual se podía ver el interior de la ermita. Es por ello que podría tratarse de una ermita de tipología humilladero.

Los materiales usados eran muros de mampostería para las paredes y sillares en los vanos y esquinas. Al interior se cubría con listones de madera sobre los que se disponía la teja árabe. 
ERMITA DE SAN RAMÓN DE MALLO

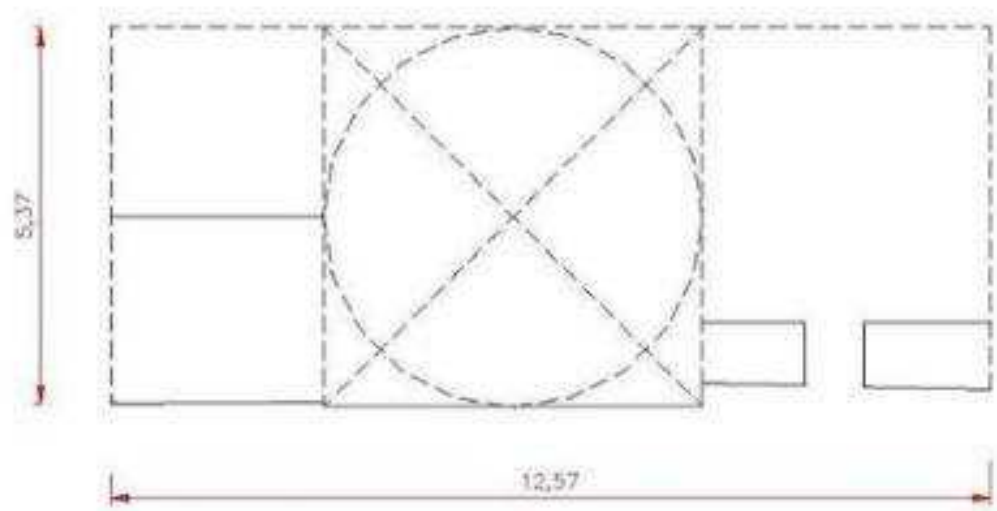

PLANTA
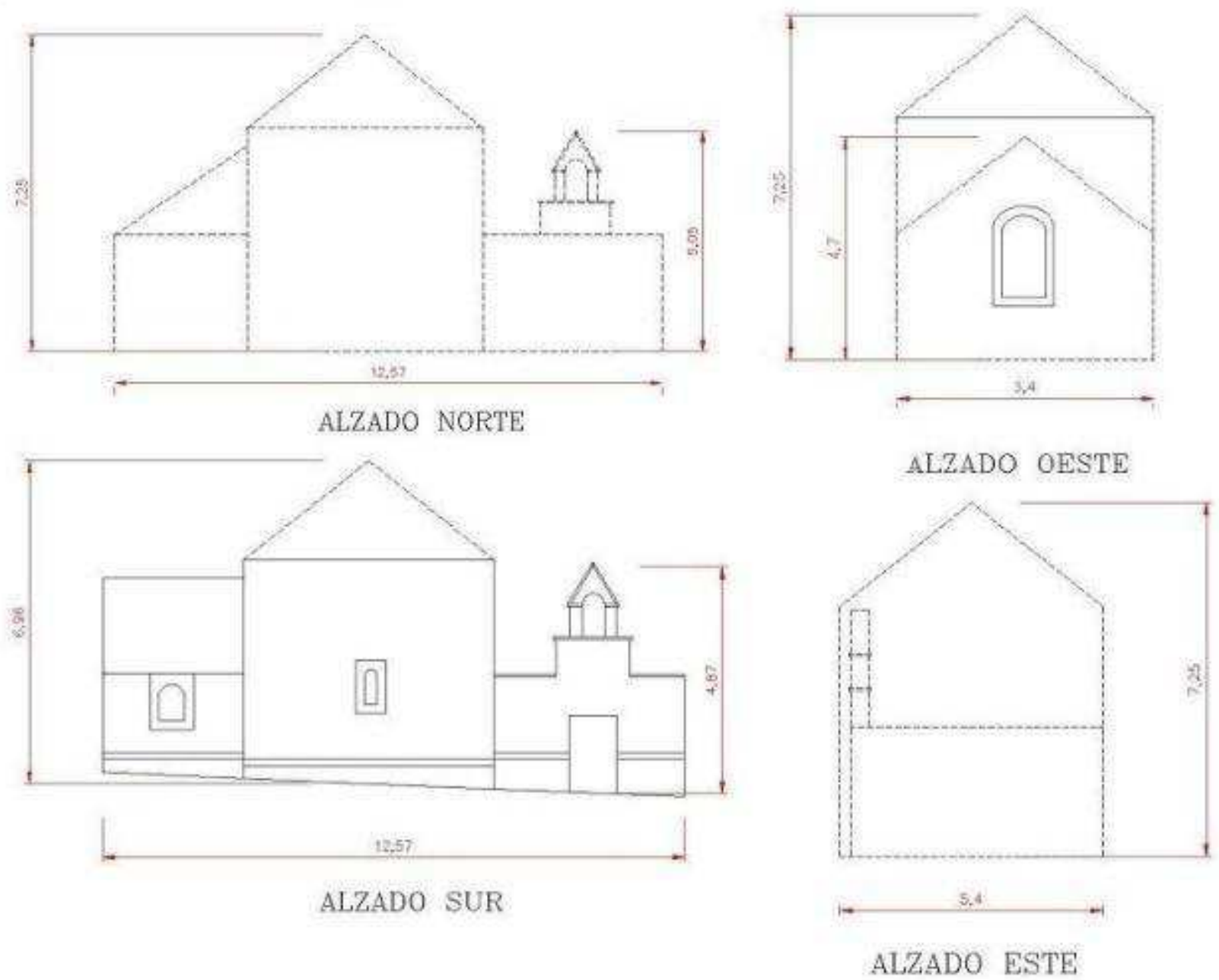

Ilustración 107. Ermita de S. Ramón de Mallo. Plano. 
Localidad: Mallo de Luna.

Santo Patronal: El primer patronazgo perteneció a la Virgen de la Portería, cuya imagen se conserva en la iglesia parroquial. Posteriormente se cambió la dedicación a S. Ramón Nonato.

Obra: Fue fundada en 1764 por don Bernardo Álvarez capellán y cura de la iglesia de S. Miguel de Trabanco, Mallo y Mirantes ${ }^{504}$ según una inscripción fundacional que aparece en la parte central de la puerta de entrada:

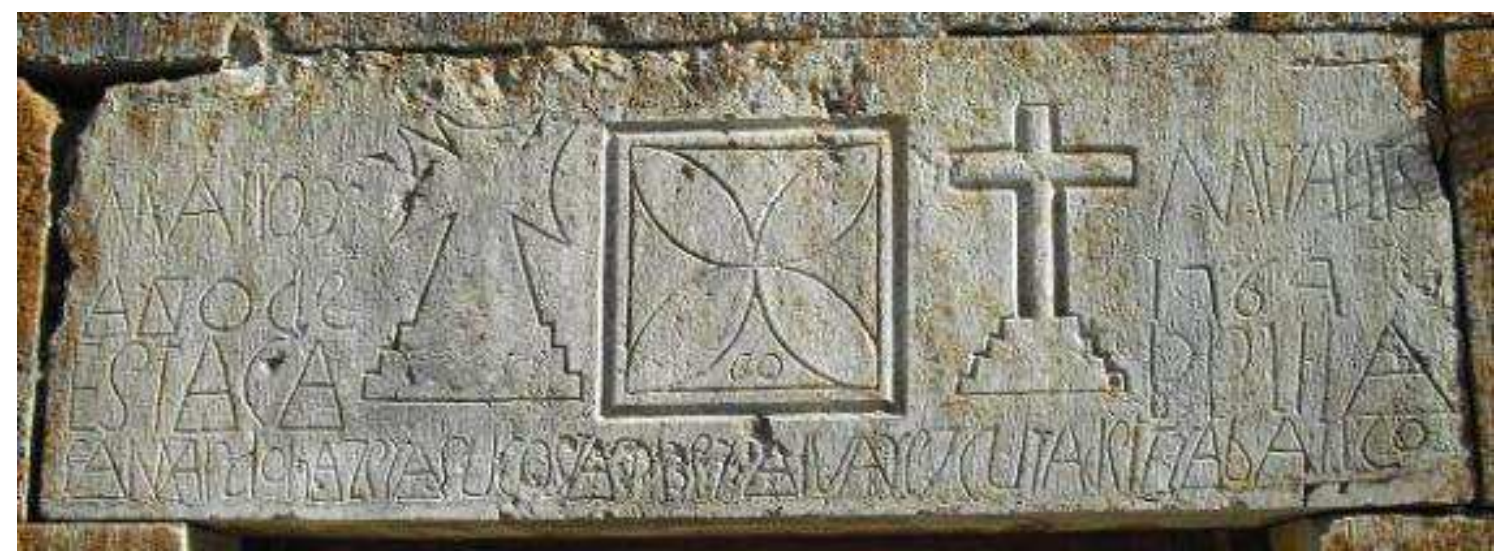

MALLO Y MIRANTES. AÑO DE 1764. ESTA CAPILLA LA MANDO HACER A SU COSTA DON BERNARDO CURA DE TRABANCO

El grabado de esta inscripción es poco profundo con una decoración basada en dos cruces anicónicas diferentes en tamaño y forma que simbolizan las dos parroquias de Mallo y Mirantes que se han unido para construir la ermita. Posee otra ornamentación central en forma de roseta de cuatro puntas enmarcada en un cuadrado. Este tipo de roseta se repite en el resto de vanos de la ermita. La caja de escritura es desordenada y se reparte por los huecos que la decoración deja libres.

Superficie: $51 \mathrm{~m}^{2}$.

Análisis: Edificio de planta cuadrada de $36 \mathrm{~m}^{2}$ de superficie. La nave principal mide $12.57 \mathrm{~m}$. largo y $5.37 \mathrm{~m}$. ancho y se cubría con una bóveda rebajada. Se le adosa al E. una pequeña sacristía de unos $15 \mathrm{~m}^{2}$ cubierta con una techumbre a dos aguas. La entrada se remata con una torre espadaña de pequeñas dimensiones con un solo cuerpo de campana.

La puerta de entrada está enmarcada con un gran arco de medio punto con decoración de molduras sencillas. Al interior se ilumina con un pequeño vano

${ }^{504}$ A.D.L. Fondo parroquial. Capellanía de nuestra señora de la portería. Mallo de Luna. Doc. 1704. Año 1772. 
abocinado con decoración esgrafiada a base de rosetas. En la zona del altar se abre una ventana desde la que se podía ver el interior de la sacristía donde se guardaba la imagen del santo patrón.

La bóveda estaba decorada con pinturas estucadas que representaban unos ángeles sujetando una cruz anicónica con unas guirnaldas formando una corona. En las paredes se localizaba la imagen de S. Francisco de Asís bendiciendo el ganado y la de S. Ramón, el último patrón de la ermita. La imagen del franciscano es la única de la que tenemos testimonio gráfico. En ella aparece rodeado por gran cantidad de animales representados esquemáticamente y en menor tamaño que el de la figura humana. Este motivo se inscribe en una orla ovalada rematada con hojas de acanto que podía formar parte de un programa iconográfico mayor. Mariano Berrueta describe cómo sobre las credencias existían dos calaveras que podían

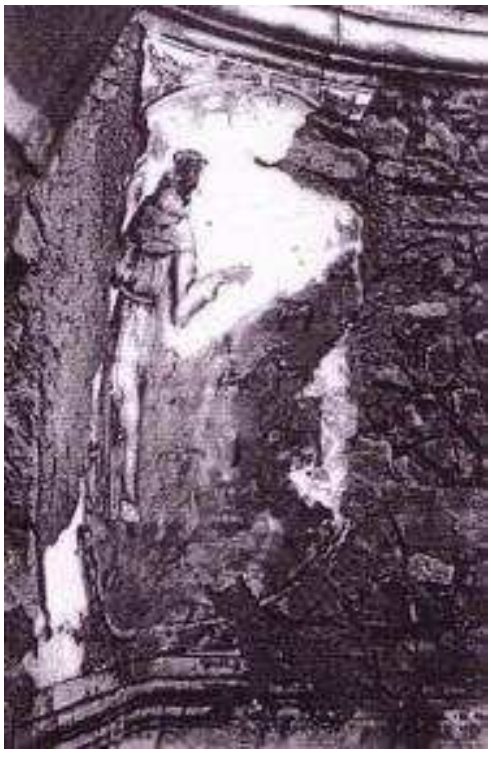

Ilustración 108. GARCÍA SUÁREZ. Una historia, p.121. ser de los fundadores ${ }^{505}$.
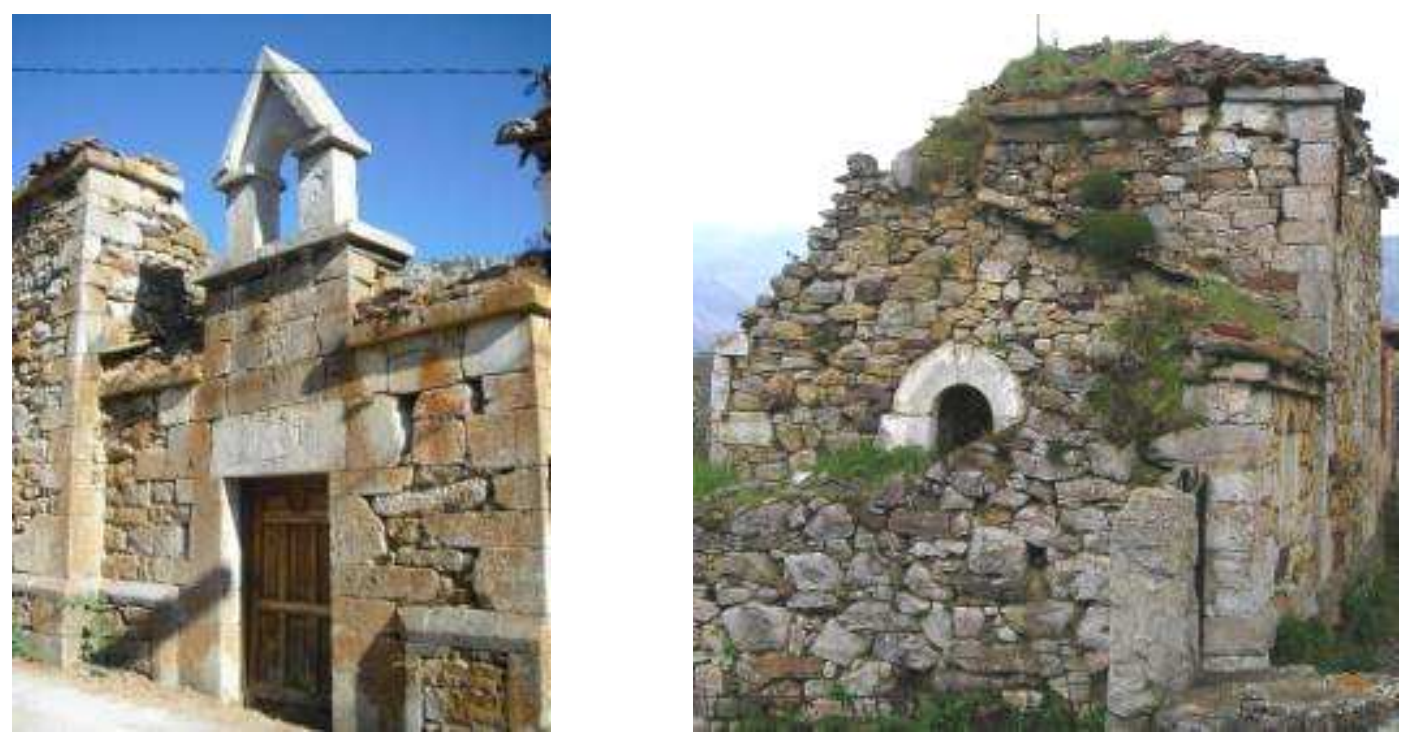

Ilustración 109. Ermita de S. Ramón de Mallo. Estado actual. Año 2011.

${ }^{505}$ BERRUETA. Riberas, Vid: Mallo de Luna. 

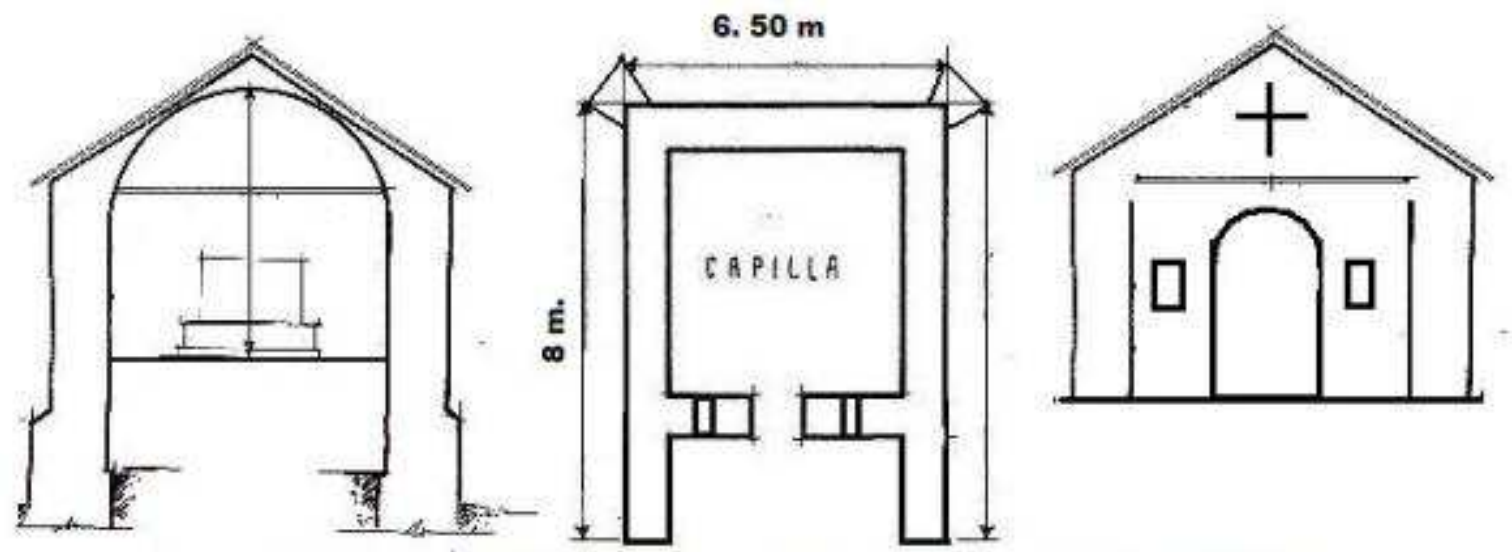

Ilustración 110. Posible reconstrucción de la ermita del Cuartero.
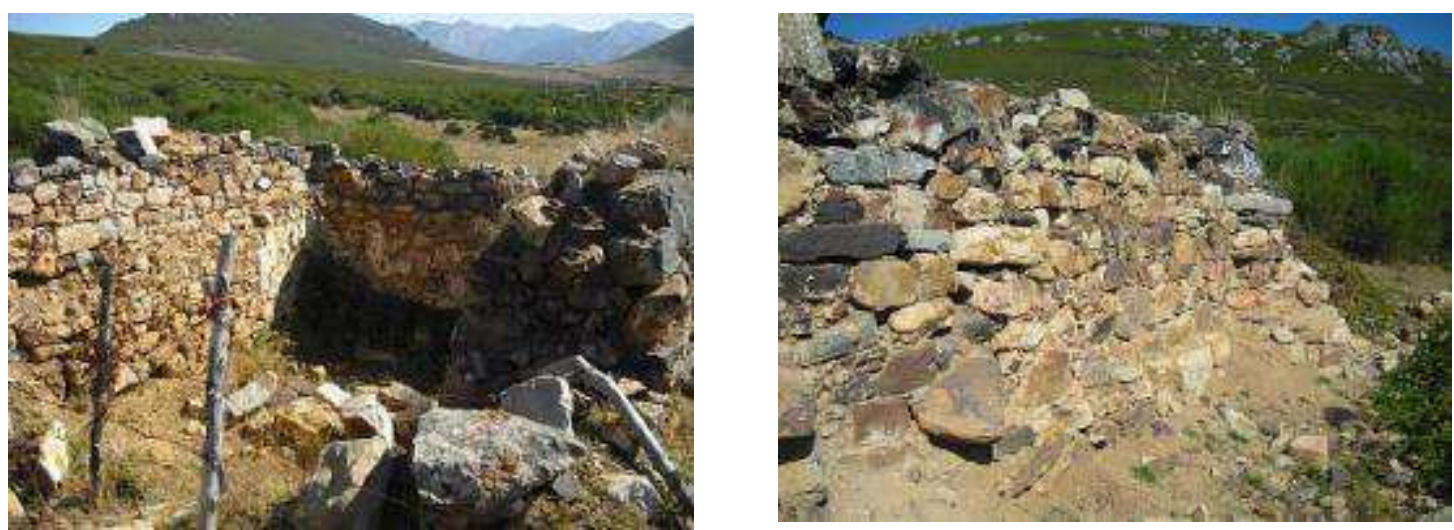

Ilustración 111. Restos de la ermita del Cuartero. Mallo. Año 2011.

Localidad: Mallo de Luna, collado del Cuartero.

Santo Patronal: Virgen del Cuartero.

Obra: $1882^{506}$.

Superficie: $51 \mathrm{~m}^{2}$.

Análisis: La ermita se encuentra en la zona del Cuartero, sobre un collado a más de $4 \mathrm{~km}$. del pueblo. Su ubicación coincide con una amplia zona que ya estuvo poblada desde la Edad Media por otras ermitas como la de la Canal de Irede o el perdido monasterio del Monte de los Frailes ${ }^{507}$. La primera vez que se nombra el Cuartero es en

${ }^{506}$ A.D.L. Fondo parroquial. Barrios de Luna. Doc.1990-435. En el archivo parroquial de Barrios se cita la cantidad de 5 reales para el traslado de piedra para la realización de la ermita de la Virgen del Cuartero. ${ }^{507}$ La ermita del Cuartero se construyó en un lugar tan apartado según la leyenda común entre los pastores de la aparición de la imagen de la Virgen enterrada en aquel lugar. 
un documento de $1195^{508}$ en el que la catedral de León enumera los territorios que posee en la zona. La abundancia de ermitas determina la importancia del lugar, paso obligado de la cañada real.

En el Cuartero, amplio collado de separación entre los pueblos de Mallo, Irede y Aralla, existían además otras construcciones de carácter civil, como un horno para hacer ladrillos, una majada y abundantes fuentes. También se observan las ruinas de otra estructura que servía de protección para los pastores.

Hoy en día la ermita del Cuartero, junto con las otras construcciones, se encuentra derruida y solo se conservan los cimientos. Las últimas labores de restauración por parte del pueblo sacaron a la luz una estructura cuadrangular de muros de mampostería y sillares bien labrados para vanos, esquinas y aleros. En la parte trasera poseía unos contrafuertes esquineros de mampostería en forma piramidal que sobresalían metro y medio del muro. De entre los restos del derrumbe se han encontrado piedras tobas, lo que hace pensar que el edificio estaría cubierto con una bóveda. Al interior las paredes estaban encaladas. Se observa una línea de imposta en la parte media del muro a $3 \mathrm{~m}$. de altura sobre la base. Esta forma constructiva, junto con los relatos de los más ancianos del lugar, hace pensar que se trataba de una especie de cripta u osario cubierto con un suelo de madera.

La ermita tenía un cuerpo sobresaliente para el refugio de los viandantes con un gran arco de entrada ${ }^{509}$. La puerta era de madera con dos ventanas a cada lado muy angostas pero suficientes para poder observar el interior.

El edificio se utilizaba solo en períodos festivos y poseía una imagen de una Virgen de pequeñas dimensiones con el niño sentado sobre su regazo con una tipología muy cercana a la de las Theotokos. La figura fue sustituida por otra del siglo XIX identificada con la Virgen del Carmen que se conserva en la iglesia parroquial.

${ }^{508}$ FERNÁNDEZ CATÓN. Catálogo, Doc. 1721...et per illam Pennam Foratam et per illam Pennam Lazzam usque in illo Quartero...

${ }^{509}$ A.D.L. Fondo parroquial de Barrios de Luna. Doc. 1990 435. Año 1860. En 1860, la iglesia parroquial de Barrios de Luna, mandó trasladar una piedra para la ermita de la Virgen del Cuartero, ya que la dovela que cerraba el arco era muy inestable. 

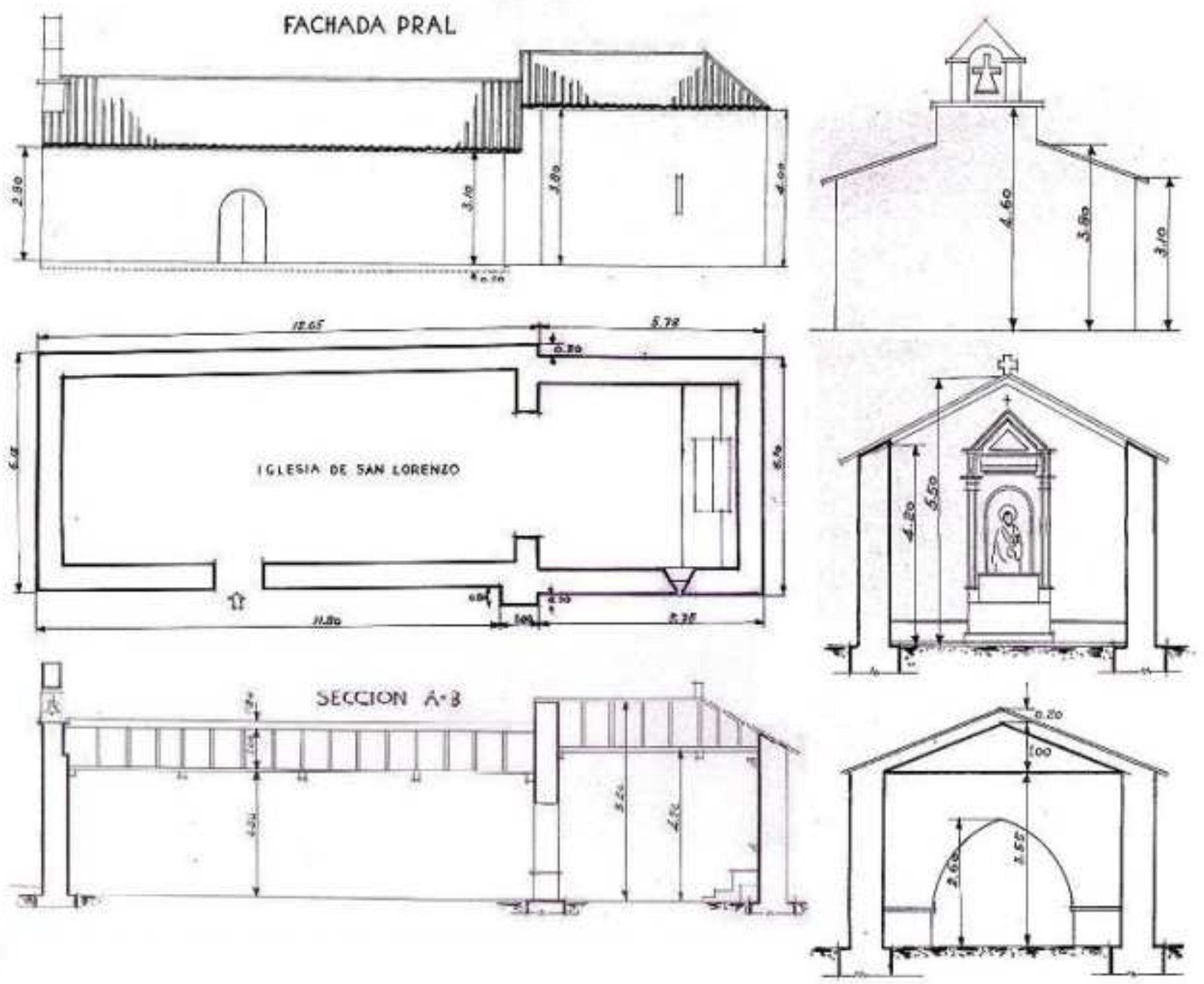

Ilustración 112. A.G.C.H.D. Miñera de Luna. C/ 05434. Nº 4461. Año 1942-51. Finca 2456.

Localidad: Miñera de Luna, junto al puente de S. Lorenzo.

Santo Patronal: S. Lorenzo.

Obra: La ermita de S. Lorenzo es datada por Mariano Berrueta ${ }^{510}$ entre los siglos XII o XIII ya que menciona la existencia de una cabeza labrada bajo el alero de la techumbre con acusado carácter de antigüedad, similar a otras presentes en la catedral de León. Sin embargo la fábrica final está más cercana a los siglos XVII o XVIII.

Superficie: $113 \mathrm{~m}^{2}{ }^{511}$

\footnotetext{
${ }^{510}$ BERRUETA. Riberas, Vid. Miñera de Luna

${ }^{511}$ A.G.C.H.D. Miñera de Luna. C/ 05434. No 4461. Año 1942-51.
} 
Análisis: Presenta una planta rectangular sin capillas adyacentes y presbiterio cuadrado. Todo el edificio se cubría con techumbre de madera a dos aguas. La separación del presbiterio se hacía a través de un arco apuntado de tan solo $2.60 \mathrm{~m}$. de altura en su clave, cuyo arranque desde el propio muro de cerramiento era excesivamente bajo $^{512}$. La entrada contenía un pequeño arco de medio punto sin decoración ni porticado. La iluminación se hacía a través de una sola ventana en el presbiterio. La torre consistía en una pequeña espadaña con un solo cuerpo de campanas de reducidas dimensiones con sillares bien labrados.

Adosado al muro norte se encontraba el cementerio.

$\mathrm{Su}$ funcionalidad era temporal, ya que sólo se utilizaba para la festividad del santo patrón y los oficios funerales del cercano cementerio.

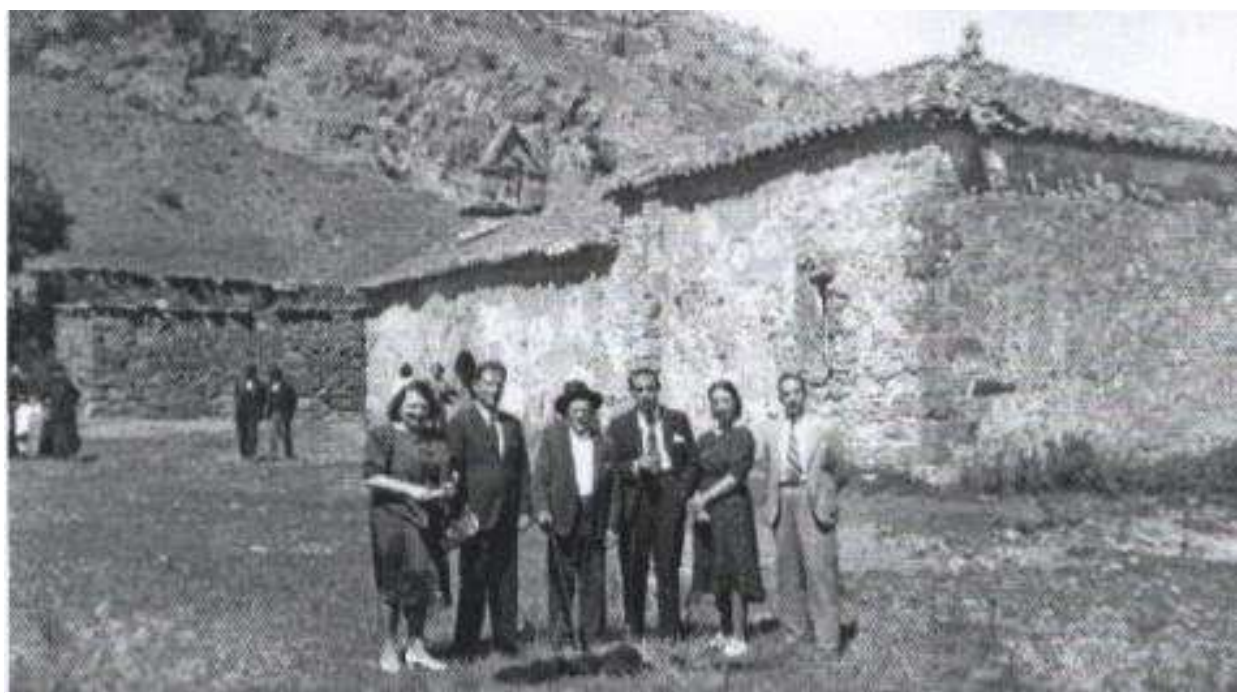

Ilustración 113 Ermita de S. Lorenzo. Fondo particular.

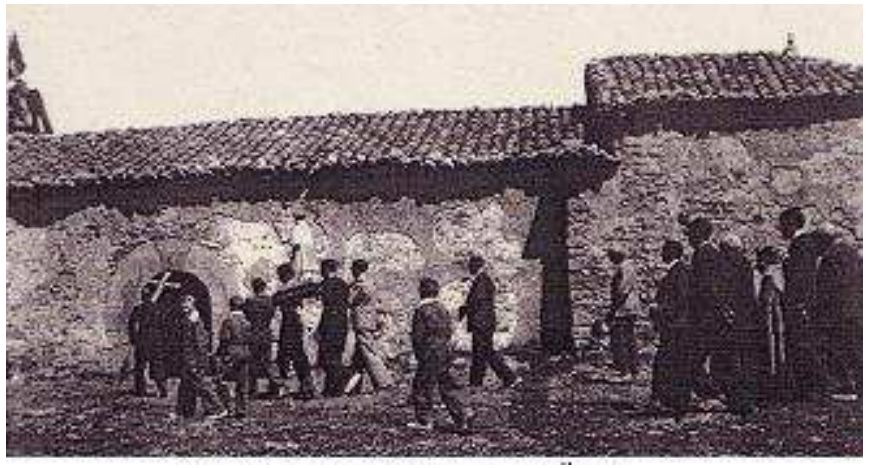

Ilustración 114. Ermita de S. Lorenzo. Miñera.

GARCÍA SUAREZ. Una historia, p. 89

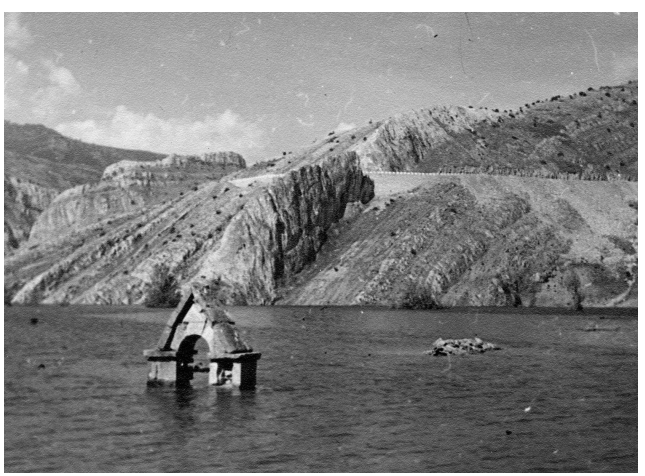

Ilustración 115. Ermita de S. Lorenzo.

Fondo fotográfico C.H.D. 6_a52.

512 A.G.C.H.D. Miñera de Luna. C/05435- No 4461. Año 1950. 


\section{ERMITA DE SAN MIGUEL DE OBLANCA}
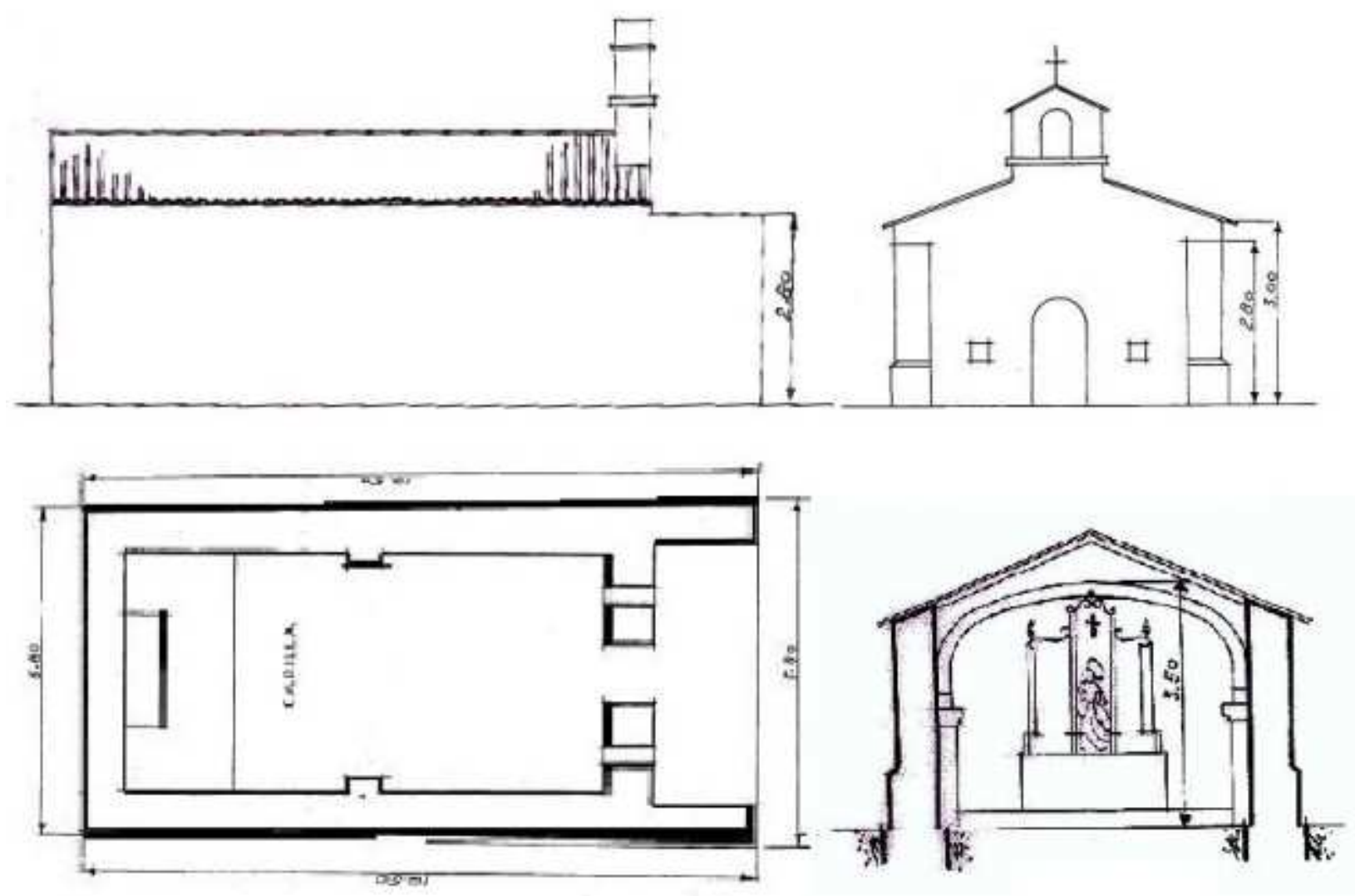

Ilustración 116. A.G.C.H.D. Oblanca. C/05461-1. N 4484. Año 1954-1955. Finca 520.

\section{Localidad: Oblanca.}

Santo Patronal: S. Miguel.

Obra: En $1644^{513}$, Miguel Rodríguez Lorenzana y su mujer fundan la ermita de Nuestra Señora de la piedad.

Superficie: $60 \mathrm{~m}^{2}$

Análisis: Esta capilla contaba con una sola nave cuadrada cubierta con una techumbre a dos aguas. El altar se elevaba del resto por medio de un escalón en fábrica. El presbiterio se abría hacia la mitad de la nave donde se observaba un arco carpanel muy rebajado. El arco estaba sujeto por dos pilastras adosadas al muro con capitel moldurado ${ }^{514}$. La fachada consistía en un muro simple protegido por dos paredes que sobresalían de la nave. La entrada estaba realizada con un arco de medio punto sencillo y la estancia se iluminaba a través de dos pequeños vanos cuadrados a los lados. La

${ }^{513}$ MARTÍN FUERTES. Catálogo. Doc. 218, p. 145.

514 A.G.C.H.D. Oblanca. C/05461-1. N 4484. Año 1954-1955. 
capilla contaba con un retablo dedicado a S. Roque. Este retablo era de estilo barroco con la imagen del patrón en el centro ${ }^{515}$.

El edificio se cubría con una techumbre de madera a dos aguas. La altura de la nave no superaba los $3 \mathrm{~m}$. Se remataba con una pequeña espadaña con un solo cuerpo para albergar una campana. 


\section{ERMITA DE SAN RAMÓN DE LAGÜELLES}
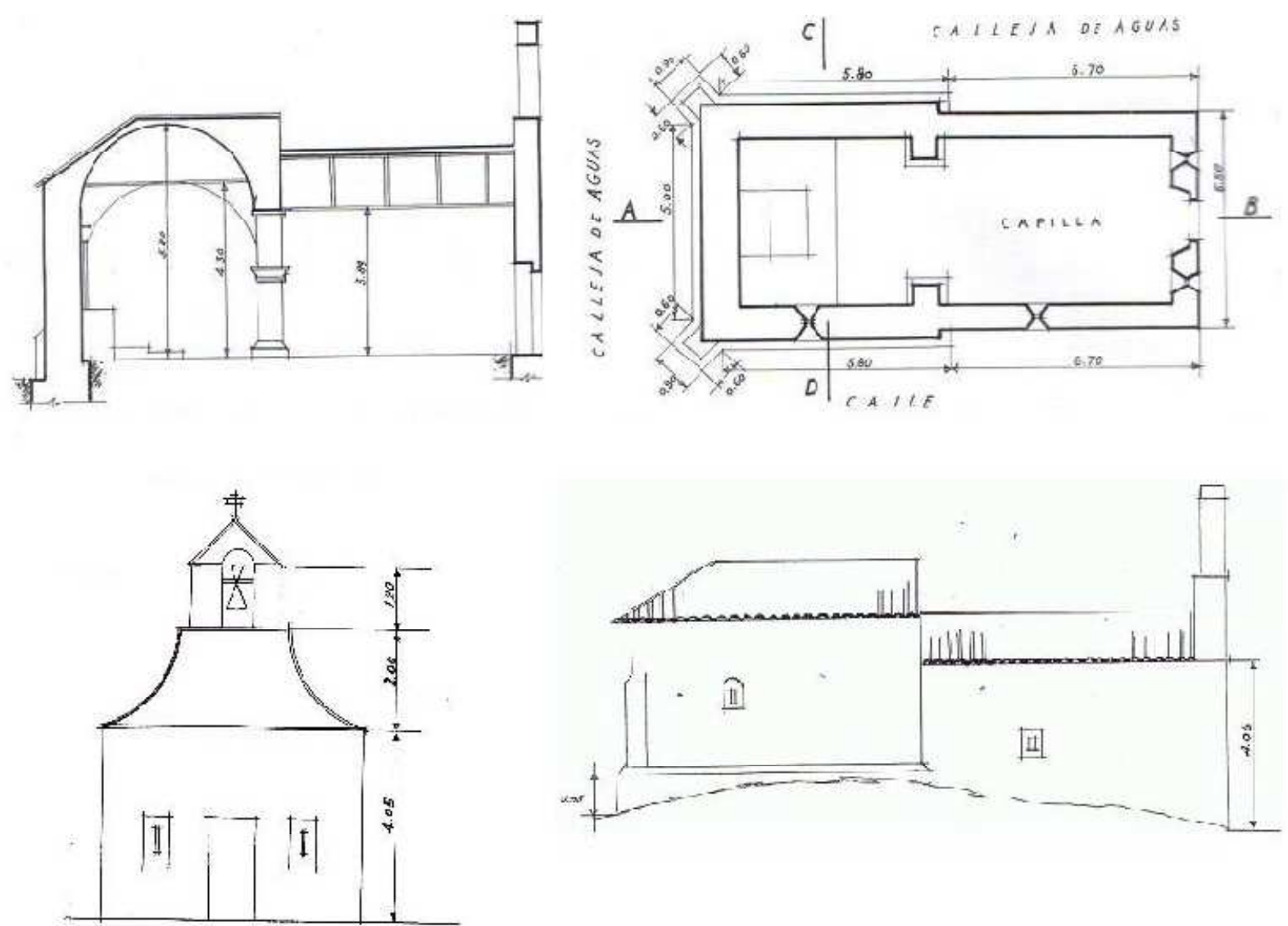

Ilustración 117. A.G.C.H.D. C/05468-2. No 4498. Año 1956

Localidad: Lagüelles, barrio del Vergel.

Santo Patronal: S. Ramón.

Obra: Las primeras noticias sobre la construcción de la capilla datan del siglo XVII, cuando Miguel Rodríguez Lorenzana y su mujer mandan en 1655 dar unas misas en su memoria en la ermita de su propiedad llamada Ntra. Sra. de las Angustias ${ }^{516}$. Posteriormente se constituyó la cofradía de la Vera Cruz en $1717^{517}$ por el corregidor Antonio Pérez quien mandó a un obrero la trasformación de la fábrica para adecuarse al nuevo culto. La cofradía de la Vera Cruz, poseía en el interior del templo un solo altar

${ }^{516}$ MARTÍN FUERTES. Quiñones, Doc. 226, p.147.

${ }^{517}$ A.D.L. Fondo parroquial. Libro de cuentas de la iglesia de S. Mames. Lagüelles. Año 1714. Doc. 972 
con la imagen del Sto. Cristo rodeado por una cortina ${ }^{518}$. Esta cofradía fue clausurada por mandato del obispo en 1817 debido a la desproporcionada ingesta de vino de los cofrades durante las celebraciones del Jueves Santo ${ }^{519}$. Tras este escándalo la cofradía se disuelve y la ermita pasa a la advocación de S. Ramón.

Superficie: $78.54 \mathrm{~m}^{2}$

Análisis: La capilla tenía una planta rectangular con cabecera cuadrada. El presbiterio se separaba del resto del templo por un arco semicircular sujeto por pilastras adosadas al muro. Elevado sobre una pequeña gradería se encontraba el único retablo que conservaba la capilla dedicada a S. Ramón.

Los materiales para la construcción eran la piedra y sillarejo para el relleno de los muros y los sillares de piedra caliza bien labrados para las puertas y ventanas. La cubierta de la capilla era a dos aguas excepto sobre el altar, que se levantaba una bóveda semiesférica de $6 \mathrm{~m}$. de altura. En la bóveda se usaba piedra toba, más porosa y para la cubrición se utilizaba teja árabe sobre tabla.

El acceso al edificio se hacía a través de una pequeña puerta situada al O. con dos ventanas adinteladas creando un abocinado en el interior.

La fachada presentaba una torre espadaña abierta en la parte superior por un vano con un arco de medio punto que sujetaba la pequeña campana del edificio.
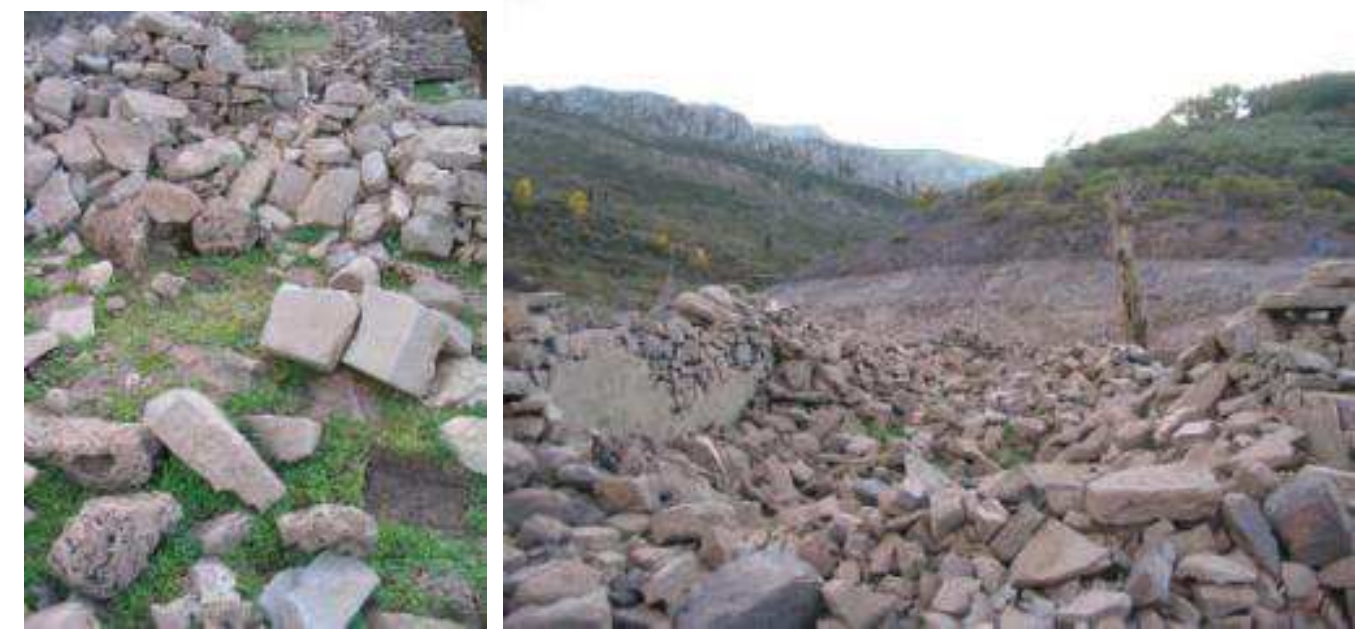

Ilustración 118. Ermita de S. Ramón de Lagüelles. Estado actual. 2012

518 A.D.L. Fondo parroquial. Libro de cuentas de la cofradía de la Vera Cruz en su capilla del lugar de Lagüelles. Doc. 971. Año 1761. La única iluminación de la estancia se hacía a través de una lámpara que alumbraba la cruz careciendo de vanos, exceptuando el de la puerta de entrada.

519 Ídem. Año 1817. 
4. LA CONSTRUCCIÓN DE LA PRESA 
En el presente capítulo se estudian, de manera cronológica, todos los aspectos relacionados con la construcción de los nuevos edificios industriales y civiles levantados en la ZACEL como consecuencia de la realización de la presa de Barrios de Luna desde 1942 hasta su inauguración en 1956. Dentro de este apartado se comenta brevemente la historia de los embalses en nuestro país así como una descripción de las características de las presas que se pueden encontrar en el territorio español.

\subsection{LOS ESTUDIOS DE ARQUITECTURA DE PRESAS}

Durante años la arquitectura industrial ha estado apartada de los estudios patrimoniales, puesto que sus fábricas han sido entendidas como edificios funcionales sin componente estético en los que primaba la operatividad y la rentabilidad. Este panorama cambia a comienzos del siglo XXI cuando se abordan monografías relativas al estudio artístico de las fábricas y los edificios industriales.

La preocupación por la puesta en valor, y en ocasiones musealización de los espacios fabriles, ha ido creciendo de manera rápida y organizada en las últimas décadas. A consecuencia de ello se ha creado una nueva corriente en la que expertos discuten acerca del presente y las perspectivas de futuro de los complejos industriales que han quedado en desuso. Esta tendencia lleva a la transformación de los grandes espacios fabriles en futuros ejes patrimoniales que enriquecen la variedad cultural de nuestro entorno ${ }^{520}$.

Los primeros estudios relativos a las fábricas como componente patrimonial se centraban en la industria tradicional. Con el avance de los tiempos las investigaciones se han ido dirigiendo hacia aspectos industriales más contemporáneos. Como ejemplo se pueden citar diversas publicaciones como son las de Inmaculada Aguilar Civera, en las que hace un repaso del concepto, método y fuentes que llevan a la nueva idea de la fábrica como componente patrimonial; la de Julián Sobrino sobre arquitectura industrial donde plantea de manera generalizada los aspectos más significativos de la industrialización desde el siglo XVIII; la de Gillian Darley en la que se diseña un modelo tipológico nuevo referente a la construcción industrial; la de Carlos Nardiz Ortiz

\footnotetext{
${ }^{520}$ Ejemplo de este movimiento lo encontramos en la misma provincia de León con el museo de la Siderurgia de Sabero o el reciente complejo de la Ciudad de la Energía de Ponferrada.
} 
sobre la estética del paisaje industrial; y la obra de Alzola y Minondo sobre la historia de las obras públicas en la península ${ }^{521}$.

En cuanto a las publicaciones sobre embalses destaca la impecable obra de Eugenio Vallardino sobre los tratados de presas españolas, el texto de Nicholas J. Schnitter acerca de la historia de las presas y su estudio individualizado de los hechos históricos que conllevaron a la creación de los embalses; la publicación de Miguel Alonso Aguiló sobre la problemática de las presas españolas; la obra de Fernández Ordóñez, sobre las presas y azures, y el libro de Joaquín Díez-Cascón Sagrado y Francisco Bueno Hernández sobre las presas españolas desde el siglo I hasta $1900^{522}$.

La bibliografía referente a los aspectos técnicos es variada y abundante no sólo en publicaciones sino también en páginas web que describen las fases y tipologías de construcción de las presas como la página oficial de la Confederación Hidrográfica del Duero: www.chd.es.

En lo referente al espacio de estudio destaca la guía de Federico Sanz Rubiales y Óscar Domínguez Cortés en la que se hace un repaso patrimonial no sólo arquitectónico, sino también natural y etnográfico de las zonas inundadas por las grandes presas del Duero ${ }^{523}$. Junto a todas estas fuentes de información se deben mencionar otras referentes a la situación política del momento de construcción de las presas como la obra de Oscar Médel, que estudia los aspectos económicos de la dictadura de Franco, y otras monografías relacionadas con la problemática de los embalses en la provincia como la obra de Íñigo Domínguez Calatayud en referencia al embalse de Riaño ${ }^{524}$.

\footnotetext{
${ }^{521}$ AGUILAR CIVERA, Inmaculada. Arquitectura Industrial. Concepto, método y fuentes. Valencia, 1998; SOBRINO Julián. Arquitectura industrial en España, Madrid, 1996; DARLEY, Gillian. La fábrica como arquitectura: facetas de la construcción industrial. Barcelona, 2010; NÁRDIZ ORTIZ, Carlos. "El paisaje de la ingeniería, la estética, la historia, el análisis y el proyecto", OP Ingeniería y Territorio, $\mathrm{n}^{\circ} 54$, 2001, pp. 28-35; ALZOLA y MINONDO, Pablo. Historia de las Obras Públicas en España, (1899), Madrid, Colegio de Ingenieros de Caminos, Canales y Puertos, 1979

522 VALLARDINO, Eugenio. Tratado básico de presas. Madrid, 1991; J. SCHNITTER, Nicholas. Historia de las presas. Las pirámides útiles. Madrid ,2000; AGUILÓ, Miguel Alonso, La Enjundia de las Presas Españolas, Madrid, ACS, Actividades de Construcción y Servicios, S.A., 2002. FERNÁNDEZ ORDÓÑEZ, José Antonio y otros. Catálogo de noventa presas y azures españoles anteriores a 1900. Madrid, 1984; DÍEZ-CASCÓN SAGRADO, Joaquín y BUENO HERNÁNDEZ, Francisco. Las presas y embalses en España. Historia de una necesidad. I Hasta 1900. Madrid, 2003.

${ }^{523}$ SANZ RUBIALES Federico y DOMÍNGUEZ CORTÉS, Óscar. Guías para recorrer y conocer. Embalses de la cuenca del Duero. Palencia, 1999.

${ }^{524}$ MÉDEL, Oscar "Pantanos contra la pertinaz sequía" en El franquismo año a año. Lo que se contaba y se ocultaba durante la dictadura. Tomo12. "Queda inaugurado este pantano. 1952" Madrid, 2006; DOMÍNGUEZ CALATAYUD, Íñigo. "Riaño, historia de una agonía: hablan los hombres de Riaño" en Tierras de León, Vol. 16, № 24, 1976.
} 


\subsection{LA OBRAS HIDRÁULICAS EN EL TERRITORIO ESPAÑOL}

La RAE define la palabra embalse como un gran depósito que se forma artificialmente, por lo común cerrando la boca de un valle mediante un dique o presa, y en el que se almacenan las aguas de un río o arroyo, a fin de utilizarlas en el riego de terrenos, en el abastecimiento de poblaciones, en la producción de energía eléctrica, etc.

La creación de los embalses, por parte del hombre, se originó para satisfacer las necesidades tanto agrícolas como poblacionales y para regular los cauces hidrológicos ${ }^{525}$. La presa más antigua de la que se tiene constancia en el mundo es la de Narmer, situada en Egipto, y datada hacia el 3100 a.C. ${ }^{526}$ de tipología de presa de gravedad.

Las primeras grandes presas documentadas en el territorio hispano pertenecen al período romano y su construcción fue consecuencia del crecimiento urbano y de la necesidad de abastecimiento de agua potable. La agricultura y la minería ${ }^{527}$ se vieron favorecidos por la creación de redes de canales y embalses ${ }^{528}$. En Mérida se conservan los ejemplos del embalse de Proserpina y el de Cornalbo, de 19 m. y 24 m. de altura respectivamente ${ }^{529}$.

El mundo árabe reutilizó las antiguas conducciones romanas y creó otras nuevas, destinadas al regadío, que se extendieron por todo el territorio conquistado. En la Edad Media se fue perdiendo la destreza de las grandes obras públicas romanas y la altura de las presas disminuyó debido a la falta de tecnología. Su uso se hizo específico de la industria hidráulica de molinos, batanes y azudes, así como a las destinadas a satisfacer las necesidades agrícolas ${ }^{530}$. Cabe destacar la presa de Almansa en Albacete, terminada en $1384^{531}$ con una altura de $21 \mathrm{~m}$. que aún se encuentra en servicio ${ }^{532}$. En la zona que

\footnotetext{
${ }^{525}$ SCHNITTER. Historia, p. 69.

${ }^{526}$ VALLARDINO. Tratado, p. 26.

${ }^{527}$ PÉREZ GARCÍA Luis Carlos y SÁNCEZ-PALENNCIA F. Javier. El yacimiento aurífero de Las Médulas: situación y geología, en Las Médulas (León) Un paisaje cultural en la "Astúrica Augustana" León, 2000, p. 174.

${ }^{528}$ FERNÁNDEZ ORDÓÑEZ, Catálogo, p. 32.

${ }^{529}$ SANZ-DOMÍNGUEZ, Guía, p. 22.

${ }^{530}$ VALLARDINO. Tratado, p .27.

${ }^{531}$ DÍEZ-CASCÓN-BUENO. Las presas, p. 185.

${ }^{532}$ FERNÁNDEZ ORDÓÑEZ, Catálogo, p. 155.
} 
nos ocupa señalamos la Presa Cerrajera en el río Órbigo cuyo origen se remonta a $1315^{533}$.

La gestión del agua, desde el mundo romano y especialmente a partir de la redacción de las Partidas de Alfonso X, estaba supeditada a la pertenencia de concejos, derechos señoriales, eclesiásticos y reales ${ }^{534}$. Los conflictos derivados de su uso, destinados principalmente al aprovechamiento agrícola y energético de los molinos, se resolvían a través de pactos previamente fijados.

Durante el siglo XVI España experimentó una leve mejora de las canalizaciones del agua gracias a la multiplicación de azudes y a los nuevos descubrimientos técnicos. Las primeras presas no poseían gran capacidad y su uso estaba destinado fundamentalmente al regadío y la regulación de los cauces. Sobresale la presa de La Albuhera de San Jorge en Cáceres, realizada con un tipo mixto de gravedad y contrafuertes con una altura máxima cercana a los $11 \mathrm{~m}^{535}$.

En el reinado de Felipe II se retomó la técnica de construcción romana del muro de retención con un espadón aguas abajo como se observa en la presa de Grajilla, de 1560 , cerca del Escorial ${ }^{536}$. Su finalidad era doble: el riego de los jardines del monasterio y el uso lúdico, pues en este espacio se llevaban a cabo festivales acuáticos. Otro de los grandes ejemplos de este período es la presa de Tibi, en Alicante, con $46 \mathrm{~m}$. de altura construida en 1594 en forma de arco-gravedad y recubierta con sillares ${ }^{537}$.

Tras la subida al trono de Carlos III se da un gran impulso a la modernización del país extendiendo los embalses a todas las provincias y promoviendo la construcción del gran proyecto hidráulico que supuso el Canal de Castilla. En este periodo se finaliza la presa de Relleu sobre el río Amadorio en Alicante ${ }^{538}$.

Con el fin del Absolutismo se produce un cambio en la mentalidad del Estado y con él una serie de reformas basadas en la planificación hidrológica de los usos del agua y la creación de un sistema administrativo a nivel general de las diferentes necesidades hidráulicas del país. Uno de los mayores problemas a la hora de llevar a cabo el proyecto era la propiedad de las aguas pues, según los postulados redactados en las

\footnotetext{
${ }^{533}$ http://www.valdefuentesdelparamo.com/paginas/pueblo/presaIntro.html

${ }^{534}$ MELGAREJO MORENO, Joaquín. "De la política hidráulica a la planificación hidrológica. Un siglo de intervención del Estado" en El agua en la historia de España. Alicante, 2000. p. 276.

${ }^{535}$ FERNÁNDEZ ORDÓÑEZ, Catálogo, p. 219.

${ }^{536}$ SCHNITTER. Historia, p. 43.

${ }^{537}$ SANZ-DOMÍNGUEZ, Guía, p. 22.

${ }^{538}$ FERNÁNDEZ ORDÓÑ̃Z, Catálogo, p. 251.
} 
Partidas de Alfonso $X$ basados en el Derecho Romano ${ }^{539}$, éstas pertenecían a los diversos estamentos.

En 1864 se elabora un estudio de las cuencas españolas dirigido por la Junta Consultora de Caminos, Canales y Puertos. Un año más tarde se crean las Diez Divisiones Hidrológicas administradas por las Jefaturas Provinciales ${ }^{540}$.

La legislación referente al uso y control del agua fue regulada durante el gobierno de los Moderados gracias a la primera Ley General del 3 de agosto de 1866 en la cual todo aprovechamiento de aguas debía tener la autorización del Estado ${ }^{541}$. Unos años más tarde, tras la revolución de la Gloriosa y el Sexenio Revolucionario, se crea la Ley de Canales y Pantanos en 1870 por la que se fija la concesión perpetua y la libertad de modificar rentas a las empresas encargadas de explotar los recursos. La legislación fue variando dependiendo de los diferentes gobiernos. En 1879 se aprobó la Ley de Aguas que sería sustituida seis años después por la Ley de Grandes Regadíos ${ }^{542}$. La acción del Estado pretendía la creación de canales, pantanos y otros recursos hidrológicos para modernizar la obsoleta economía del país.

Los avances de la Revolución Industrial favorecieron la construcción de presas de manera rápida y continua como la de Valdeinfierno en Murcia ${ }^{543}$, o la de Villar, proyectada para abastecer de agua a la ciudad de Madrid $^{544}$.

Tras la crisis de 1898, el Estado verá en los recursos hidrológicos la salida del retraso agrícola que llevaba arrastrando la España del XIX. En 1902 se aprueba el Plan Nacional de Aprovechamientos Hidráulicos ${ }^{545}$ que proponía la creación de más de 200 presas y otros tantos canales. Este plan no tuvo los resultados esperados, puesto que las condiciones políticas (la llegada de los liberales, el reinado de Alfonso XII y la regencia de María Cristina) fueron nefastas para el desarrollo de las políticas económicas.

En el primer tercio del siglo XX hay que resaltar la figura de Manuel Lorenzo Pardo, ingeniero y director de la Confederación del Ebro durante la dictadura de Primo de Rivera, que acabará por imponer la idea de la importancia de los embalses para el crecimiento económico. En las primeras décadas se optará por restaurar gran parte de

\footnotetext{
${ }^{539}$ MELGAREJO MORENO, "De la política”, p. 276.

${ }^{540}$ www.chduero.es/ "Antecedentes históricos y la administración pública del agua” Confederación hidrográfica del Duero.

${ }^{541}$ MELGAREJO MORENO, "De la política", p. 278.

${ }^{542}$ MÉDEL, "Pantanos", p. 19.

${ }^{543}$ FERNÁNDEZ ORDÓÑEZ, Catálogo, p. 359.

${ }^{544}$ DÍEZ-CASCÓN-BUENO. Las presas, p. 293.

${ }^{545}$ MÉDEL, "Pantanos", p. 18.
} 
los embalses anteriores elevando los muros de la presa y aumentando así su capacidad $^{546}$. La gestión del agua permaneció en manos de las Jefaturas Provinciales hasta que en 1926 Rafael Benjumea, Ministro de Fomento, creó el germen de las futuras Confederaciones Hidrográficas, las denominadas Confederaciones Sindicales, en el río Ebro $^{547}$.

La Confederación Sindical Hidrográfica del Duero se instituyó por Real Decreto el 22 de junio de 1927 bajo la dictadura de Primo de Rivera ${ }^{548}$ siguiendo las bases de las tradicionales gestiones de regantes de las diversas poblaciones. Su principal función era la planificación hidrográfica y la regulación y aprovechamiento del agua.

En tiempos de la República se creó el ministerio de Obras Públicas, basado en los postulados de Lorenzo Pardo, con un apartado especial encargado de crear un plan Nacional de Obras Hidráulicas ${ }^{549}$. Destaca dentro de la comunidad de Castilla y León la construcción del embalse de Águeda, en Salamanca, finalizado en 1931 con la tipología de presa de gravedad y el embalse del Arlanzón en Burgos, finalizado en $1933^{550}$.

Continuando con las ideas de Pardo, desde el inicio del período franquista la política económica autárquica obligó a la creación de numerosas infraestructuras que permitiesen el suministro energético del país. A partir de 1940 se comienzan a ejecutar una serie de trabajos de canalización de las aguas y retención en presas como las de Madrigal de la Vera, Cijara, Almendralejo, Yesa, Ejea de los Caballeros, San Bartolomé, Villalcampo o Barrios de Luna entre otros muchos saltos y abastecimientos de agua potable ${ }^{551}$ que Franco denominaría "nuevos mares hechos por la mano del hombre" $" 552$.

Durante la dictadura franquista las Confederaciones Hidrográficas dejaron de tener autonomía para convertirse en elementos de acción nacional destinados casi exclusivamente a la creación de embalses y canales ${ }^{553}$. El sistema centrista unificó todas las cuencas dentro de un plan nacional que no distinguía sectores ni provincias y que buscaba más bien un aspecto propagandístico y económico antes que un desarrollo equilibrado de los recursos.

${ }^{546}$ DÍEZ-CASCÓN-BUENO. Las presas, p. 379.

547 "Antecedentes históricos y la administración pública del agua" Confederación hidrográfica del Duero. UTC 20-04-2009. http://www.chduero.es

${ }_{548}$ MELGAREJO MORENO, "De la política", p. 290.

${ }^{549}$ MÉDEL, "Pantanos", p. 19.

${ }^{550}$ El embalse del Águeda. http://www.chduero.es/Inicio/Infraestructuras/Losembalsesdelacuenca/

${ }^{551}$ MÉDEL, "Pantanos", p. 10.

${ }_{552}$ Ídem, p. 7.

${ }^{553}$ MELGAREJO MORENO, "De la política", p. 293. 
El pantano del Ebro, inaugurado en 1958, fue sin duda la obra más emblemática del régimen que seguía las directrices del Plan Peña ${ }^{554}$, a la que siguieron otras muchas relacionadas con la idea de crear una España verde y productiva. El Plan Peña, denominado así por su realizador Peña Boeuf, consistía en una regularización de todos los cauces de los grandes ríos para abastecer de agua a la agricultura y la población en épocas de estío.

La necesidad y urgencia con la que se llevaron a cabo algunas de estas presas contribuyó a provocar tragedias como la de Vega de Tera en Zamora ${ }^{555}$, cuya rotura hizo que por primera vez se replantease la seguridad de los embalses en España.

En total, en el período comprendido entre 1940 y 1963, se construyeron 287 embalses y 35 presas $^{556}$ lo que le supuso a Franco numerosos apelativos acerca de este hecho. La cuenca del Duero fue la que mayor número de obras hidráulicas soportó con un total de $198.600 \mathrm{ha}^{557}$ de terreno inundado.

Tras la llegada de la Democracia la política hidráulica se organizó de una manera más equilibrada y centrada no sólo en el uso agrícola, sino también en el aprovechamiento de la energía, la calidad de las aguas y el impacto sobre el paisaje natural $^{558}$. En 1985 se aprobó la Ley de Aguas $^{559}$ en la cual se reforzó el papel de las Confederaciones con un carácter mucho más autónomo y dependientes del Ministerio de Medio Ambiente ${ }^{560}$.

Cabe destacar la construcción de la gran presa de la Cuenca del Duero, la de Riaño en la provincia de León, iniciada en los años sesenta y finalizada en 1987, cuya inundación se convirtió en una de las más polémicas del momento ${ }^{561}$. Dos de los últimos embalses de la Cuenca son los del Castro de las Cogotas, construido con bóveda de doble curvatura en 1994 y el embalse de Irueña finalizado en el $2003^{562}$ con la

\footnotetext{
${ }_{554}^{55}$ MÉDEL, "Pantanos", p. 25.

${ }^{555}$ La presa fue finalizada en 1956 con la tipología de gravedad pero en 1959, debido a las continuas crecidas, no soportó los empujes y acabó rompiéndose sepultando el pueblo de Ribadelago y ocasionando un desastre humano con más de 140 víctimas.

${ }^{556}$ MÉDEL, "Pantanos", p. 15.

557 Ídem, p. 16.

${ }^{558}$ MELGAREJO MORENO, "De la política”, p. 307.

559 Ídem, p. 294.

${ }^{560}$ www.chduero.es “Antecedentes históricos y la administración pública del agua” Confederación hidrográfica del Duero.

${ }^{561}$ www.chduero.es "El embalse de Riaño". La pared tiene la tipología de arco y está realizada en hormigón con una altura de $100 \mathrm{~m}$.

562 Ídem, "El embalse de Irueña". "El embalse de Castro de las Cogotas".
} 
tipología de arco gravedad. Su principal función es la de regular el caudal de los ríos y abastecer de agua a los terrenos cultivables y a las poblaciones próximas.

En la actualidad, la pertenencia de España a la Unión Europea ha dado como consecuencia la adecuación de las normativas a nivel europeo y para ello se ha creado la Directiva Marco del Agua $^{563}$, por la que se rige la gestión de los recursos estableciendo la necesidad de crear un marco de actuación que garantice la calidad de las masas de agua y promueva un uso sostenible ${ }^{564}$.

Las polémicas acerca de la creación de embalses no han cesado. La necesidad de crear nuevas presas para regular el régimen de los ríos, mantener reservas acuáticas y para obtener energía hidráulica, continúa siendo motivo de controversia. El coste medioambiental, humano, histórico y social que supone la inundación de ciertos espacios ha dado como consecuencia una reducción de los mismos.

El consumo humano de agua se ha incrementado espectacularmente en las últimas décadas debido al desarrollo de las grandes ciudades. Los cambios climáticos a los que estamos expuestos obligan a poseer unas reservas acuáticas importantes para poder continuar con el nivel de desarrollo económico y el potencial eléctrico, pues la sociedad demanda una energía más potente y limpia que no se vea afectada por las vicisitudes de la economía mundial.

La publicación en 2009 de un nuevo Plan Hidrológico ${ }^{565}$ buscó dar soluciones a los problemas relacionados con la distribución y reserva de agua. Los principales inconvenientes del que se hace eco el plan son el abastecimiento de la población, el excesivo gasto del agua en los cultivos, el problema de la desertificación y el abusivo uso de los acuíferos. Las nuevas leyes en torno a los embalses hoy en día van dirigidas a un consumo responsable y a una explotación eficiente de los recursos acuáticos de nuestro entorno. La construcción de grandes presas queda descartada en favor de un desarrollo sostenible de los recursos naturales.

\footnotetext{
${ }^{563}$ Directiva 200/60/CE del Parlamento Europeo y del Consejo de 23 de octubre de 2000.

564 www.chduero.es "Antecedentes históricos y la administración pública del agua" Confederación hidrográfica del Duero.

565 www.chduero.es Plan hidrológico de la parte española de la demarcación hidrográfica del Duero 2009.
} 


\subsection{TIPOLOGÍA DE PRESAS}

El principal propósito de un embalse es el de disponer de agua potable para el uso agrícola y para el consumo humano, aunque en los últimos años su principal función es la explotación de la energía hidroeléctrica.

Se pueden diferenciar los tipos de presas en dos grandes bloques: según su forma y según los materiales con lo que se ha construido. La utilización de uno u otro modelo es consecuencia de una serie de factores como son las condiciones geomorfológicas y climatológicas del lugar así como las condiciones socioeconómicas del momento.

Tipos de presa según su forma: según el modo en que resisten el empuje del $\operatorname{agua}^{566}$.

Presas de gravedad: Este tipo es el más estable y el de menor mantenimiento. $\mathrm{Su}$ resistencia se debe al peso de la construcción especialmente en el fondo o parte baja del muro. La base es ancha y se va estrechando a medida que se eleva la pared creando una forma piramidal. La cara del embalse es vertical, mientras que la parte exterior forma un ángulo a modo de contrafuerte para contrarrestar el empuje del agua ${ }^{567}$.

Presas de arco: Son aquellas que trasmiten los esfuerzos hacia los laterales gracias a su forma curvada. Este tipo de presa se asienta sobre rocas firmes que han de ser vigiladas constantemente para evitar la formación de fisuras ${ }^{568}$. Suelen ubicarse en gargantas estrechas que minimizan el empuje del agua.

Presas mixtas de arco-gravedad: La presa mixta es la unión de las dos tipologías anteriores que conllevan una curvatura menor y un peso en forma de talud en la parte inferior para soportar mejor la presión.

Presa de contrafuertes ${ }^{569}$ : Consiste en una pared vertical con refuerzos a modo de pilares o bóvedas. Este tipo de presas no es muy común debido a la complicidad técnica que entraña su factura. Suele utilizarse en aquellos terrenos poco estables, ya que aguanta muy bien los empujes en zonas blandas.

\footnotetext{
${ }^{566}$ SANZ-DOMÍNGUEZ, Guías, p. 20.

${ }^{567}$ VALLARDINO, Tratado, p. 57.

${ }^{568}$ SANZ-DOMÍNGUEZ, Guías, p. 20.

${ }^{569}$ HERNÁN RAMÍREZ, Diego. Presas de Escollera. Facultad de Minas, Universidad Nacional de Colombia, 2006, p. 9.
} 
Presa de bóvedas: Son aquellas que poseen unos contrafuertes paralelos separados por bóvedas que trasmiten el empuje sobre los apoyos. Esto supone una economía material aunque requiere una mayor complicación técnica ${ }^{570}$.

Tipos de presa según el material: Dependiendo de los materiales que se utilicen en una presa, podemos tener uno u otro tipo de construcción que condicionará su forma, altura y fuerza.

Presa de escollera: son las más antiguas, económicas y frecuentes a lo largo de la historia. Se constituyen según el modelo de presa de gravedad por medio de la acumulación de materiales sueltos impermeables como la tierra pisada con ramajes o paja $^{571}$. Para evitar los deslizamientos de terreno poseen unos muros de refuerzo en los extremos o pilotes anclados en la tierra ${ }^{572}$.

Presa de fábrica: Es el tipo de presa más común en la península debido al régimen de lluvias torrenciales que hace necesario la creación de aliviaderos que trabajen regularmente a lo largo de una buena parte del año ${ }^{573}$. Normalmente son de hormigón aunque en épocas anteriores era común el uso de materiales de mampostería y ladrillo $^{574}$.

${ }^{570}$ VALLARDINO, Tratado, p. 56.

${ }^{571}$ SCHNITTER, Historia, p. 173.

${ }^{572}$ HERNÁN RAMÍREZ. Presas, p. 9.

${ }^{573}$ SANZ-DOMÍNGUEZ, Guías, p. 21.

${ }^{574}$ VALLARDINO, Tratado, p. 57. 


\subsection{EL EMBALSE DE BARRIOS DE LUNA}

Los intentos de realizar una presa en el Valle del Luna fueron numerosos y tempranos, pues algunos datan de comienzos del siglo XX.

En 1902 se efectuaron los primeros sondeos en la cuenca del río Luna para la creación de un dique que abasteciese de agua al canal del Órbigo ${ }^{575}$. El proyecto fue retomado durante la dictadura de Primo de Rivera ${ }^{576}$ en 1928, tras la creación de la Confederación Sindical Hidrográfica del Duero. Fue el Conde de Guadalhorce quien promovió un plan hidrológico que incluía los valles de Selgas y Luna. Como consecuencia de este plan se constituyó de la empresa Saltos Motrices de Valle de Luna, por parte del ingeniero Ginés Navarro, que tenía como fin el aprovechamiento energético de la central eléctrica de Abelgas para la futura presa de Barrios de Luna. Tal propósito quedó aparcado a consecuencia de los avatares económicos, políticos y sociales del momento ${ }^{577}$.

Durante el período de la República se replanteó de nuevo el proyecto a cargo del Plan Nacional de Obras Hidráulicas, redactado en 1933 y reformado en $1935^{578}$. En $1936^{579}$ Luis de Llanos se presentó como ingeniero de las obras. En tan solo un año, Llanos ya poseía todos los datos geomorfológicos correspondientes al plan de la cuenca pero de nuevo, debido a los continuos cambios políticos y la situación del país ante la inminente Guerra Civil, las obras fueron demoradas una y otra vez ${ }^{580}$.

En la Dictadura se retomó el plan hidrológico que finalmente sería llevado a cabo con la construcción de la presa de Barrios de Luna. El proyecto fue aprobado el 3 de febrero de $1941^{581}$ y el 31 de enero de $1945^{582}$ se adjudicaron las obras al ingeniero D. Luis de Llanos y Silvela. Durante este periodo intermedio el ingeniero se concentró

575 A.G.C.H.D. Proyecto del pantano de Barrios de Luna. D. Luís de Llanos y Silvela. C/00719-1 Nº 4001. Año 1936.

${ }^{576}$ VVAA. El siglo en León. Todos los pueblos y sus gentes. León, 2001, p. 340.

577 Ibídem. Finalmente sería el hijo de Ginés, José Navarro, quien prosiguió el proyecto de la central eléctrica de su padre favoreciendo la construcción de la presa de Barrios por la que obtendría los beneficios de su explotación hidráulica en la central de Mora de Luna La concesión de la construcción de la central de Mora se dio en primer lugar a la empresa Ginés Navarro, aunque finalmente pasaría a Eléctricas Leonesas S.A.

578 Ibídem.

${ }^{579}$ Ibídem.

580 "El pantano de los Barrios de Luna, por su importancia y su coste, es la obra más grande realzada en la provincia en los últimos siglos” en DIARIO DE LEÓN. B.O.E. lunes 22 -09-1956, página 3.

${ }^{581}$ A.G.C.H.D. Proyecto de almacén de cemento y vivienda para vigilante-guarda. Ingeniero: D. Luís de Llanos y Silvela. C/00470-1. No 1952. Año 1942.

582 BOE. 31 de enero de 1945. "El pantano de los Barrios de Luna" en DIARIO DE LEÓN. Jueves 15 03-1945, página 4. 
en la ejecución de la presa y de todos los edificios necesarios para las obras como el almacén de cemento o el campamento para los obreros. En torno a 1942 los trabajos de preparación de las obras ya habían comenzado. En este sentido se adecuaron las vías y puentes de la población de Barrios para soportar un tráfico más pesado, se acometió la construcción de unos barracones provisionales para cobijar a los obreros y se construyó el almacén de cemento para comenzar con el abastecimiento de materiales que la presa requería.

El 8 de julio de 1.952 se constituyó el Sindicato Central del Embalse de los Barrios de Luna con una Junta General presidida por Luis de Llanos y Silvela ${ }^{583}$ que en 1955 ejercerá de presidente del sindicato como ingeniero delegado en la constitución de la Comunidad de Regantes del Paramo ${ }^{584}$. La última noticia referente al ingeniero es del 1 de abril de 1969, año en el que se le concede la Gran Cruz de la Orden del Mérito Civil por sus labores realizadas en la consecución de la presa de Barrios de Luna ${ }^{585}$.

El 24 de septiembre de 1956, quince años después de su aprobación, se inaugura la presa de Barrios de Luna.

\subsubsection{FICHA TÉCNICA}
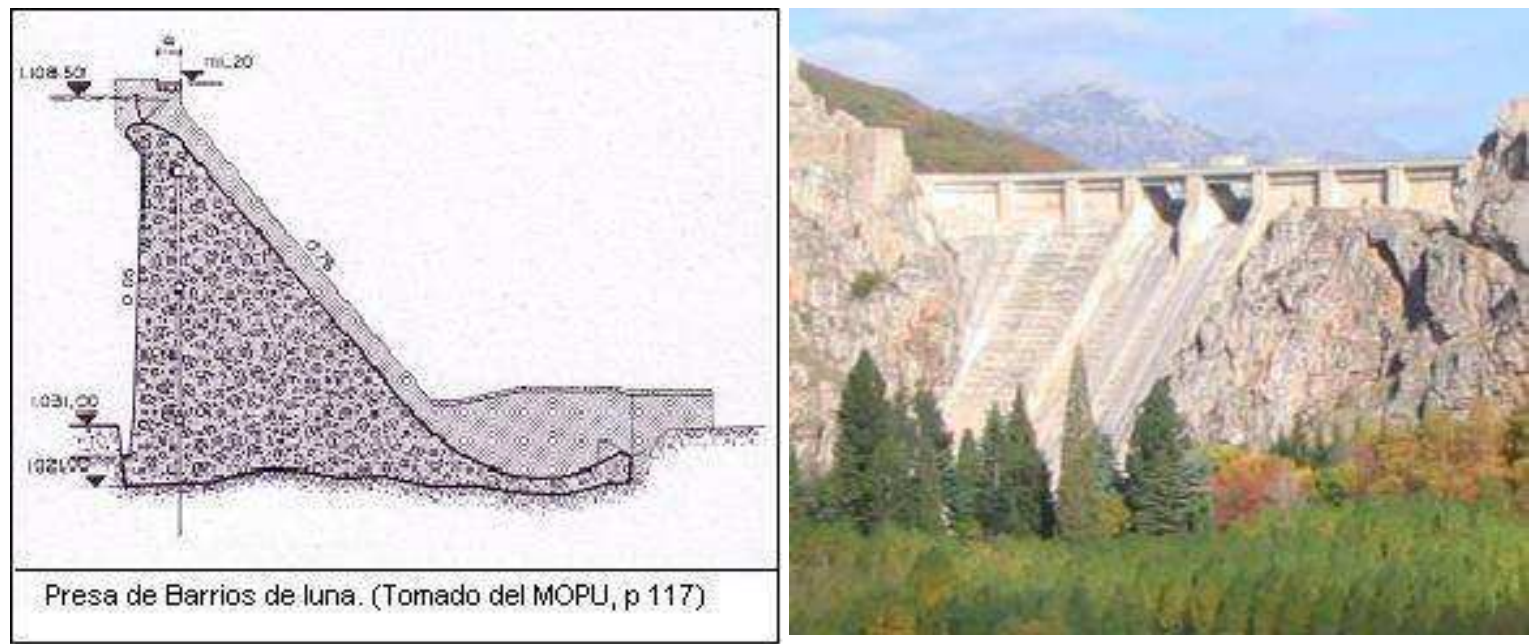

\footnotetext{
${ }^{583}$ Ibídem.

${ }^{584}$ Acta de constitución de la comunidad de regantes del páramo. Santa María del Páramo, 1955, pp.1-4 ${ }^{585}$ BOE 26 abril 1969 No 102. 6452. Decreto. 757/1969.
} 


\begin{tabular}{|c|c|c|}
\hline \multicolumn{3}{|c|}{ DATOS GENERALES DEL EMBALSE DE BARRIOS DE LUNA } \\
\hline \multirow{3}{*}{ LOCALIZACIÓN } & Término Municipal & Barrios de Luna \\
\hline & Provincia & León \\
\hline & Río & Órbigo-Luna \\
\hline DESTINO & \multicolumn{2}{|c|}{ Energía, riegos y almacenamiento. } \\
\hline \multirow{4}{*}{ PROMOTORES } & Propietario & C. H. D. \\
\hline & Constructor & G. Navarro \\
\hline & Proyectista & L. Llanos Silvela \\
\hline & Empresa & Ginés Navarro S.A. \\
\hline \multirow{6}{*}{ DATOS GENERALES } & Año de terminación & $1956^{586}$ \\
\hline & $\begin{array}{l}\text { Año de comienzo de } \\
\text { explotación }\end{array}$ & 1961 \\
\hline & Tipo de presa & Presa de gravedad en planta recta \\
\hline & Superficie del embalse & 1130 (ha) \\
\hline & Capacidad de embalse & 308 millones de $\mathrm{m}^{3}$ \\
\hline & Superficie regable & $50.000 \mathrm{Ha}$ \\
\hline \multirow{6}{*}{ DIMENSIONES } & Altura sobre cimientos & 90 metros \\
\hline & Altura sobre el cauce & $81,2 \mathrm{~m}^{587}$ \\
\hline & Longitud coronación & $163,15 \mathrm{~m}$ \\
\hline & Costa $^{588}$ & $40 \mathrm{Km}$. \\
\hline & Espesor de coronación & $4 \mathrm{~m}$ \\
\hline & $\begin{array}{l}\text { Cota de coronación } \\
\text { sobre el nivel del mar }\end{array}$ & $1.111,20 \mathrm{~m}$ \\
\hline
\end{tabular}

\footnotetext{
${ }^{586}$ Ministerio de Obras Públicas y Urbanismo: Inventario de presas españolas. Ávila, 1986, p. 117.

${ }^{587}$ www.chduero.es

${ }^{588}$ SANZ-DOMÍNGUEZ, Guías, p. 103.
} 


\begin{tabular}{|c|c|c|}
\hline \multirow[t]{2}{*}{ VOLUMEN } & Volumen de la presa & $308\left(10 \mathrm{~m}^{3}\right)$ \\
\hline & Volumen del embalse & $308\left(\mathrm{hm}^{3}\right)$ \\
\hline \multirow{5}{*}{$\begin{array}{l}\text { ALIVIADERO } \\
\text { Y DESAGÜE }\end{array}$} & Aliviadero & $\begin{array}{l}\text { Dos aliviaderos con compuertas } \\
\text { Taintor de } 15 \mathrm{~m} \text { de luz y } 6.50 \mathrm{~m}^{589}\end{array}$ \\
\hline & $\begin{array}{l}\text { Capacidad del } \\
\text { aliviadero }\end{array}$ & $1300(\mathrm{~m} 3 / \mathrm{s})$ \\
\hline & Desagüe & $\begin{array}{l}\text { Dos desagüies de fondo y otros dos } \\
\text { de tomas }\end{array}$ \\
\hline & $\begin{array}{l}\text { Capacidad máxima de } \\
\text { desagües }\end{array}$ & $90 \mathrm{~m}^{3}$ por segundo \\
\hline & Tipo de aliviadero & $\begin{array}{l}\text { Trampolín que finaliza en dos } \\
\text { dientes centrales del cuenco } \\
\text { amortiguador de energía. }\end{array}$ \\
\hline POTENCIA & Potencia instalada & 76.800 kilovatios ${ }^{590}$ \\
\hline DATOS & Precipitación anual & $956 \mathrm{Mm}$. \\
\hline HIDROGROLÓGICOS & Aportación anual & 470 millones de $\mathrm{m}^{3}$ \\
\hline HORMIGÓN USADO & $308.000 \mathrm{~m}^{3}$ & Hormigón ciclópeo \\
\hline COSTE TOTAL & \multicolumn{2}{|l|}{$34.625 .364,13 \mathrm{pts}^{591}$} \\
\hline
\end{tabular}

${ }^{589}$ A.G.C.H.D. Suministro y montaje de las compuertas del aliviadero. Pantano de Barrios de Luna. C/00675-3. No 3792. Año 1960.

${ }^{590}$ www.chduero.es

${ }^{591}$ A.G.C.H.D. C/00719-.1 No 4001. 


\subsubsection{EL PROCESO DE CONSTRUCCIÓN}

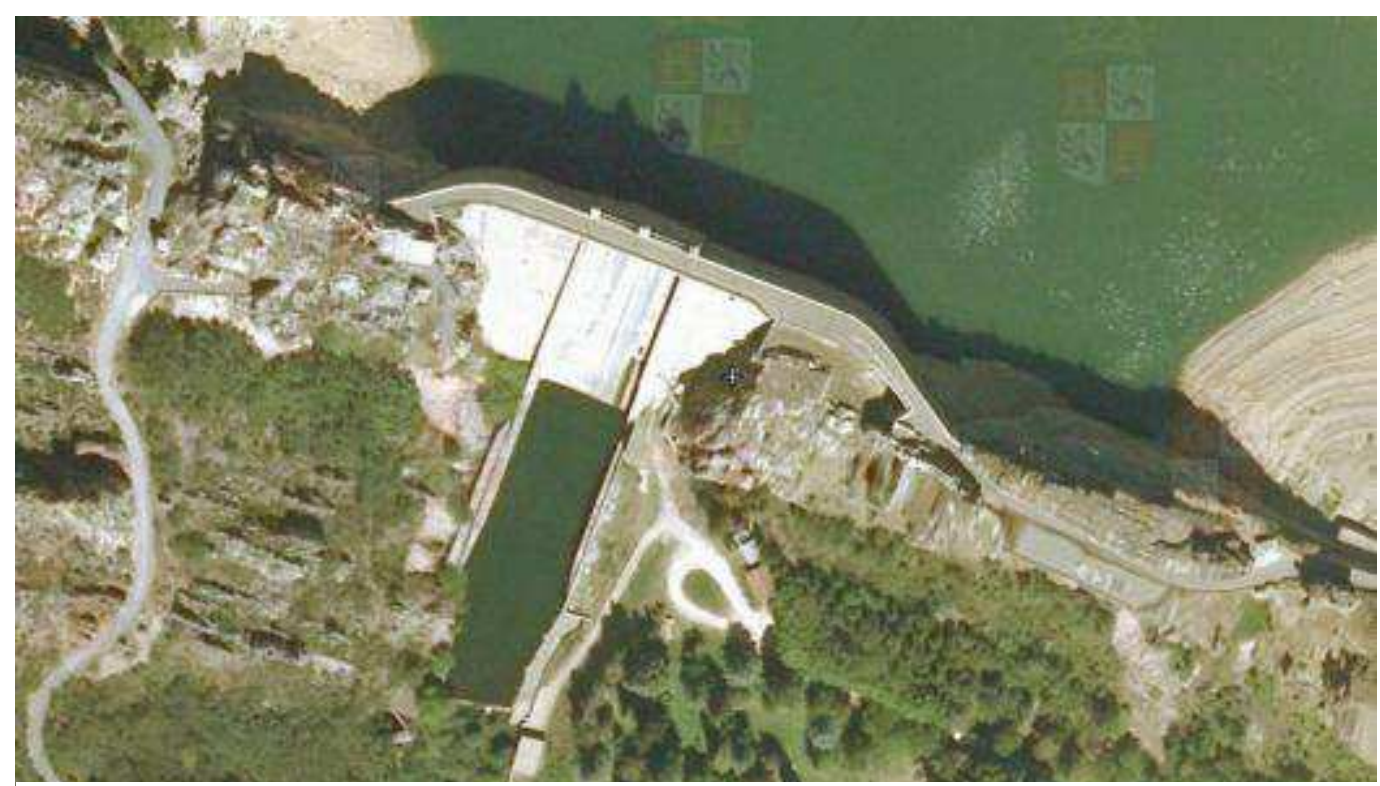

Ilustración 119. Sig-Pac. Barrios de Luna.

La finalidad principal del proyecto de la presa de Barrios de Luna era la de regular la cuenca del Órbigo y permitir el riego de unas 50.000 ha de terreno de regadío, además del aprovechamiento hidroeléctrico en la central de Mora de Luna ${ }^{592}$. Durante los primeros años las intenciones de progreso no se correspondieron con el avance económico. La tardanza del embalsado y la poca o nula política de implantación de regadíos en la región del Páramo ocasionaron numerosos malestares entre la población. Lo que anteriormente habían sido halagos y apoyos al régimen, pronto se convirtieron en críticas. Pero con la llegada del agua, la presa se convirtió en un estandarte de modernidad y crecimiento económico que ha permitido el desarrollo agrícola en zonas de secano. Hoy en día el embalse es un elemento esencial que aporta agua a una extensión de regadío de 40.586 ha distribuidas entre ambos márgenes del río Órbigo ${ }^{593}$.

La construcción del embalse supuso no sólo la inundación de los pueblos de la ZACEL y la desaparición de su patrimonio, sino también la creación de nuevos edificios que marcarían un punto de modernidad en las estructuras tradicionales del Valle. Las obras de la presa también exigieron la planificación de nuevas vías de comunicación que sustituyeron a las inundadas. Se crearon nuevos accesos a

${ }^{592}$ A.G.C.H.D. Proyecto del pantano de Barrios de Luna. D. Luís de Llanos y Silvela. Año 1936. N 4001. C/00719-1.

${ }^{593}$ Ibídem. 
poblaciones que habían quedado aisladas y se elevaron viaductos para favorecer el tránsito.

Barrios de Luna se convirtió en el contenedor de las nuevas fábricas durante las décadas de los años cuarenta y cincuenta. La mayoría de estos edificios tenían un carácter funcional y efímero destinado a satisfacer las necesidades de las obras de la presa. Muchos de ellos fueron abandonados una vez finalizado el uso para el que habían sido creados, otros sufrieron una transformación para adecuarse a nuevas funciones y otros fueron finalmente demolidos.

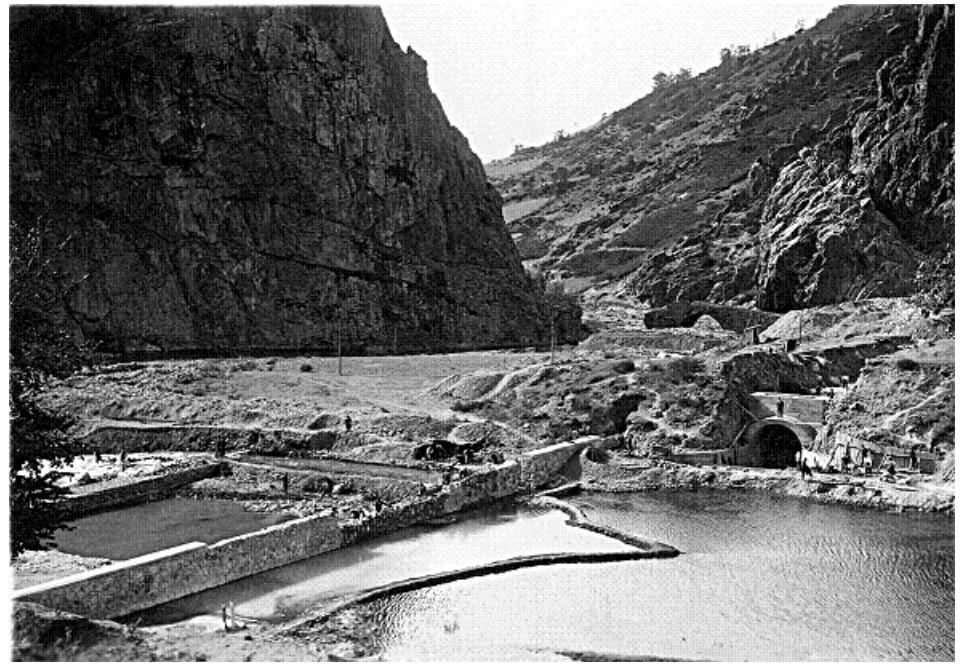

Ilustración 120 Construcción de la ataguía. Barrios de Luna-02 Fondo fotográfico. I.L.C.

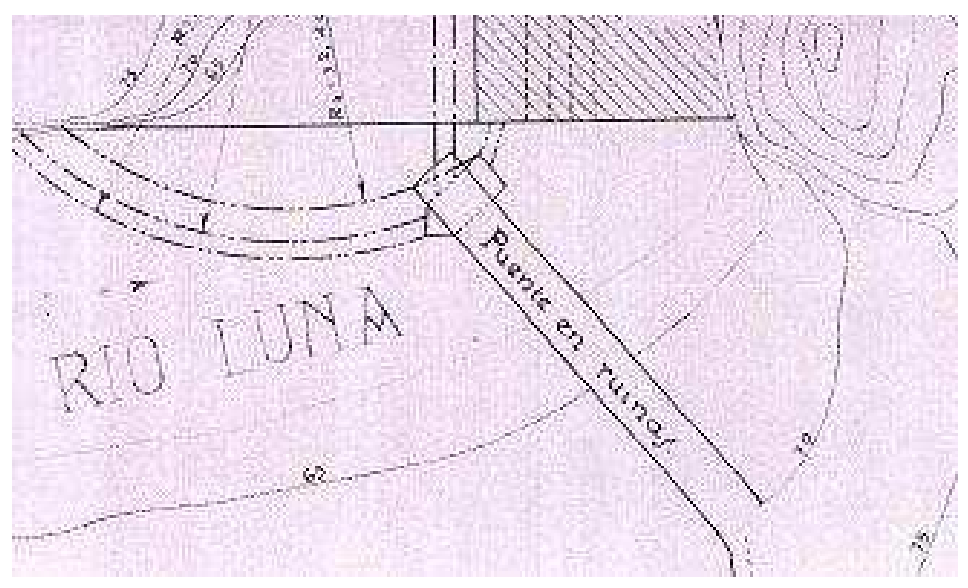

Ilustración 121. A.G.C.H.D. Proyecto del pantano de Barrios de Luna. Ataguías y puente en ruinas. $N^{\circ} .4001$.
En 1945 se inician los trabajos de la pared de la presa. La ubicación de la presa de Barrios de Luna, a $12 \mathrm{~km}$ de la Magdalena, se escogió debido a la configuración geomorfológica del crestón de cuarcita del castillo y el consiguiente abaratamiento de los costes de material y dimensiones de la pared que el embalse requería ${ }^{594}$.

Las primeras obras en acometerse fueron: la construcción de una galería de conducción que llevase las aguas hasta la central de Mora, la desviación del caudal del río Luna a su paso por la garganta y el cerramiento del túnel de la antigua carretera que atravesaba la peña del castillo ${ }^{595}$. 
Para llevar a cabo los trabajos se hizo necesaria la contratación de casi 1200 empleados. Los primeros trabajadores procedían de las localidades más próximas al embalse, aunque también venían de Galicia y, tras la finalización del embalse del Ebro, de Burgos y de otras provincias. Éstos se alojaban en los barracones construidos ex profeso a pie de obra y en viviendas particulares de los pueblos cercanos ${ }^{596}$.

Uno de los aspectos más característicos del Régimen fue la mano de obra de reclusos políticos. Cerca de cincuenta de ellos fueron empleados para los trabajos más duros como la apertura del canal de abastecimiento de la central hidroeléctrica de Mora de Luna $^{597}$ y la construcción del dique de retención de aguas frente a la presa. Algunos de estos presos murieron durante las labores por causas relacionadas con las condiciones de trabajo ${ }^{598}$.

El punto de partida de las obras fue la construcción de unas ataguías de desviación del caudal del río. Una vez separado el cauce, se procedió a la apertura de los desagües de fondo situados a pocos metros del nivel del suelo. Unos treinta obreros expertos en minería trabajaron en las labores de demolición de la roca cuarcítica ${ }^{599}$.

La cimentación de las

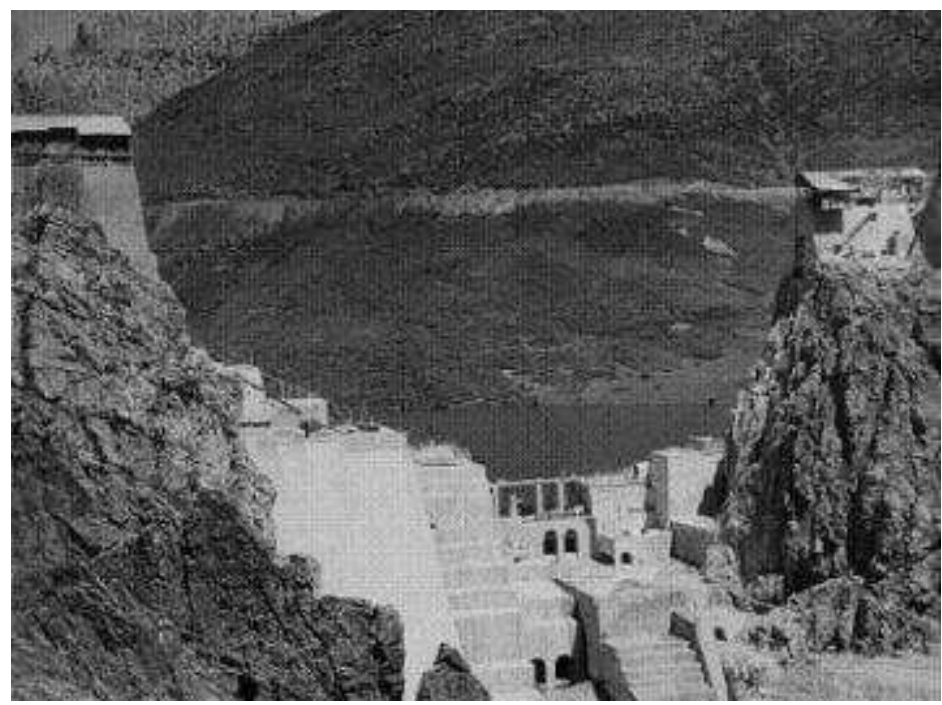
ataguías supuso el primer proceso en la destrucción del patrimonio de Luna, pues se aprovechó el antiguo puente medieval de piedra situado en el barrio de Trabanco para abaratar los costes. Los arcos fueron cegados con cemento y hormigón de manera que

Ilustración 122. Proceso de construcción de la pared del sirvieran como muro de embalse. A.G.C.H.D. Archivo fotográfico Barriosllenado_1_a52.

contención de las aguas y a la vez desvío del caudal.

\footnotetext{
596 Ibídem.

${ }^{597}$ Ídem, p. 342. Los presos dormían en barracones aislados custodiados por el cuartel de la Guardia Civil situados en el barrio de S. Juan.

${ }^{598}$ Información dada por Luis Pérez Díaz, vecino de Banalla, Lugo y trabajador de las obras del embalse de Barrios de Luna.

${ }^{599}$ Muchos de ellos murieron años más tarde de silicosis a causa del polvo de las perforaciones. Información dada por Petronilo Guisuraga, vecino de Miñera de Luna.
} 
A continuación se comenzó el cuerpo de la presa. Éste se levantó por tramos de diferentes dimensiones que se iban encofrando de manera independiente según la disposición del terreno. En la pared se utilizaron bloques de hormigón ciclópeo mientras que para la pantalla de impermeabilidad se usó hormigón en masa. En la medida en que se finalizaba un tramo se iba reteniendo el agua de la presa. Durante la construcción de la pared se efectuaron galerías interiores que comunicaban los desagües de fondo con las turbinas eléctricas que aportaban la energía hidráulica.

Además de la gran pared de la presa, los trabajos trajeron consigo la creación de otros espacios imprescindibles para la obra como fueron:
a. Edificios industriales
b. Edificios civiles
c. Nuevas vías de comunicación

\subsubsection{EDIFICIOS INDUSTRIALES}

Una vez aprobado el proyecto del pantano, el 3 de febrero de $1941^{600}$, se levantaron una serie de edificios necesarios para el comienzo de las obras. Las primeras edificaciones industriales estaban destinadas al almacenamiento y trasporte del material, así como al abastecimiento de energía. Estos edificios industriales se hicieron con una técnica muy similar aprovechando los materiales sobrantes de la presa pero procurando una estética que, además de funcional, se integrase en el engranado de la arquitectura de la zona.

Los materiales fundamentales fueron el sillarejo y el hormigón. Los cimientos estaban hechos con un tipo de basamento continuo y los zócalos en aparejo mixto. Se empleó la técnica de mampostería en muros de carga ya que gran parte de la piedra utilizada se obtenía al efectuar las explanaciones. Los tabiques interiores de ladrillo estaban revestidos de yeso y la cubierta era de pizarra o teja sobre listones de madera. Para las esquinas, arcos de la puerta y ventanas se utilizó sillarejo de labra tosca.

Aunque la construcción de estas fábricas se entendía como algo perecedero, que desaparecería una vez terminadas las obras, la estética utilizada y el cuidado con el que

\footnotetext{
${ }^{600}$ A.G.C.H.D. Proyecto de almacén de cemento y vivienda para vigilante-guarda. Ingeniero: D. Luis de Llanos y Silvela. C/00470-1. No 1952. Año 1942.
} 
se eligieron los materiales de cada uno de los edificios industriales es destacable. Cabe señalar que algunos de estos edificios, como las torres-grúas, fueron remodelados para un uso turístico. Otro ejemplo es la utilización de la cuarcita de Barrios para las torres eléctricas, cuya fábrica aún confunde a algunos paseantes con antiguos vestigios del castillo de Luna.

\subsubsection{Almacén de cemento}
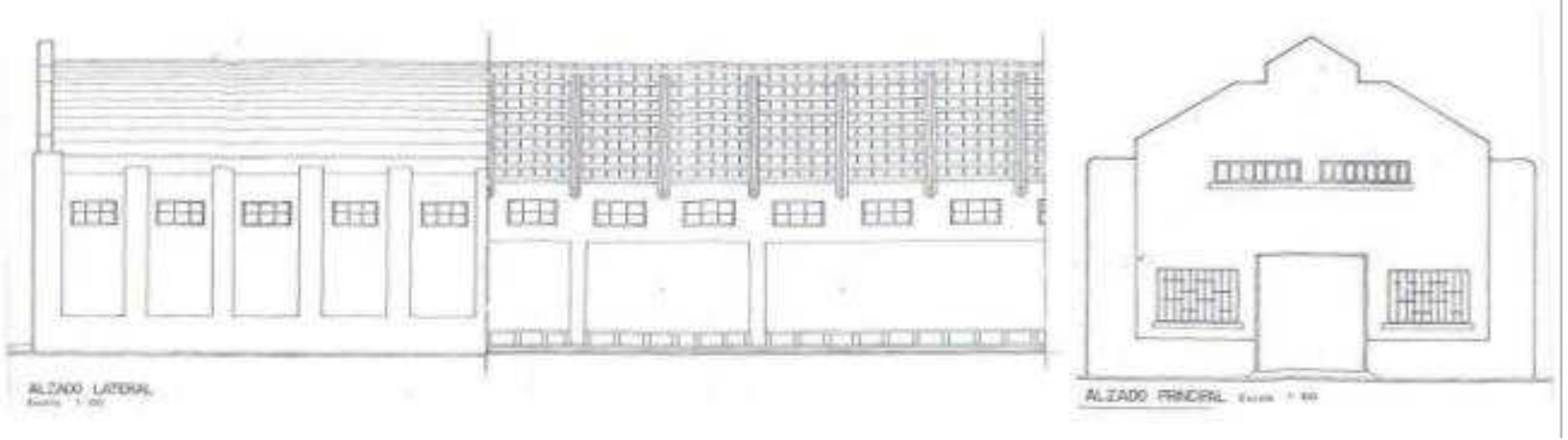

Ilustración 123. A.G.C.H.D. Proyecto de almacén de cemento y vivienda para vigilante-guarda. Ingeniero: D. Luís de Llanos y Silvela. C/00470-. Nº 1952. Año 1942.

El primer edificio industrial que se levantó fue el almacén de cemento. Su construcción se debió principalmente a la necesidad de abastecer de material a las obras. La piedra extraída de las canteras próximas suponía un ahorro significativo de los costes. Debido a las malas condiciones meteorológicas del lugar no era posible la extracción durante el invierno, por lo que el almacén debía tener una capacidad superior para poder albergar el material preciso para toda la temporada. Así en $1942^{601}$ D. Luis de Llanos y Silvela proyectó el plano de un almacén situado sobre una cota superior a la de la coronación de la presa para facilitar el transporte de material en pendiente y no en rampa $^{602}$. La altitud elegida para el almacén fue $1142 \mathrm{~m}$., mientras que la cota de coronación se hallaba en $1110 \mathrm{~m}$.

El almacén se levantó con una planta rectangular de $13 \mathrm{~m}$. de ancho y $90 \mathrm{~m}$. de longitud dividida por un pasillo central de $4 \mathrm{~m}$. en el que se efectuaba la descarga de los camiones que transportaban el cemento desde la estación de la Robla. El pasillo

${ }^{601}$ A.G.C.H.D. Proyecto de almacén de cemento y vivienda para vigilante-guarda. Ingeniero: D. Luis de Llanos y Silvela. C/00470-1. No 1952. Año 1942.

${ }^{602}$ Ibídem. 
contenía dos vías de raíles de $0.60 \mathrm{~m}$. para la utilización de vagonetas que trasladaban el cemento a la obra. Contenía catorce cargaderos de diferentes dimensiones para guardar los sacos de cemento ${ }^{603}$. Junto con el almacén se edificó una casa para el guarda que se componía de una cocina comedor de 4 x $5 \mathrm{~m}$. y de tres dormitorios con servicios ${ }^{604}$.

Dentro de este proyecto se trazó un pequeño camino hasta la presa que después sería aprovechado como vía de comunicación hacia la localidad de Mallo. Una vez finalizadas las obras el edificio fue destinado a taller de reparaciones y almacén general.

En 1985 se aconsejó la restauración del almacén, consolidando su estructura y aspecto original $^{605}$. La carestía de la obra y la falta de inversión ocasionaron que finalmente, a comienzos del siglo XXI, fuese totalmente demolido y en su lugar se encuentra hoy un solar vacío.

\subsubsection{Cable grúa}

Para favorecer las labores de trabajo de la presa se estimó útil la creación de un cable grúa de bloques encofrados sobre los crestones rocosos ${ }^{606}$. Este blondín o grúa teleférico constaba de dos torres de cemento situadas a ambos lados de la garganta. Poseían unas guías que soportaban dos vagonetas aéreas que llevaban material desde el almacén de cemento hasta la otra parte del desfiladero ${ }^{607}$. El puente poseía una capacidad de $5000 \mathrm{~kg}$, con elementos de accionamiento eléctrico y manual de las compuertas, un cuadro de maniobra, indicadores de apertura y cierre, tuberías, llaves de by-pass y conducción de aire y accesorios.

Una vez finalizadas las obras del embalse se desmontó el entramado de cable y la maquinaria, pero se mantuvo el contrafuerte sobre el que se sujetaba el puente guía. Se cegaron los arcos de acceso y se colocó una escalera para que sirviera de mirador directo sobre la compuerta del embalse.

\footnotetext{
603 Ibídem.

${ }^{604}$ Ibídem.

${ }^{605}$ A.G.C.H.D. Reparación y rehabilitación de los edificios del la C.H.D. Eustrogio Briso. C/01842-1. No 7925. Año 1985.

${ }^{606}$ A.G.C.H.D. C/00719-1. No 4001. Año 1936.

607 "El pantano de los Barrios de Luna, por su importancia y su coste, es la obra más grande realzada en la provincia en los últimos siglos" en DIARIO DE LEÓN. Lunes 22 -09-1956, p. 3. 

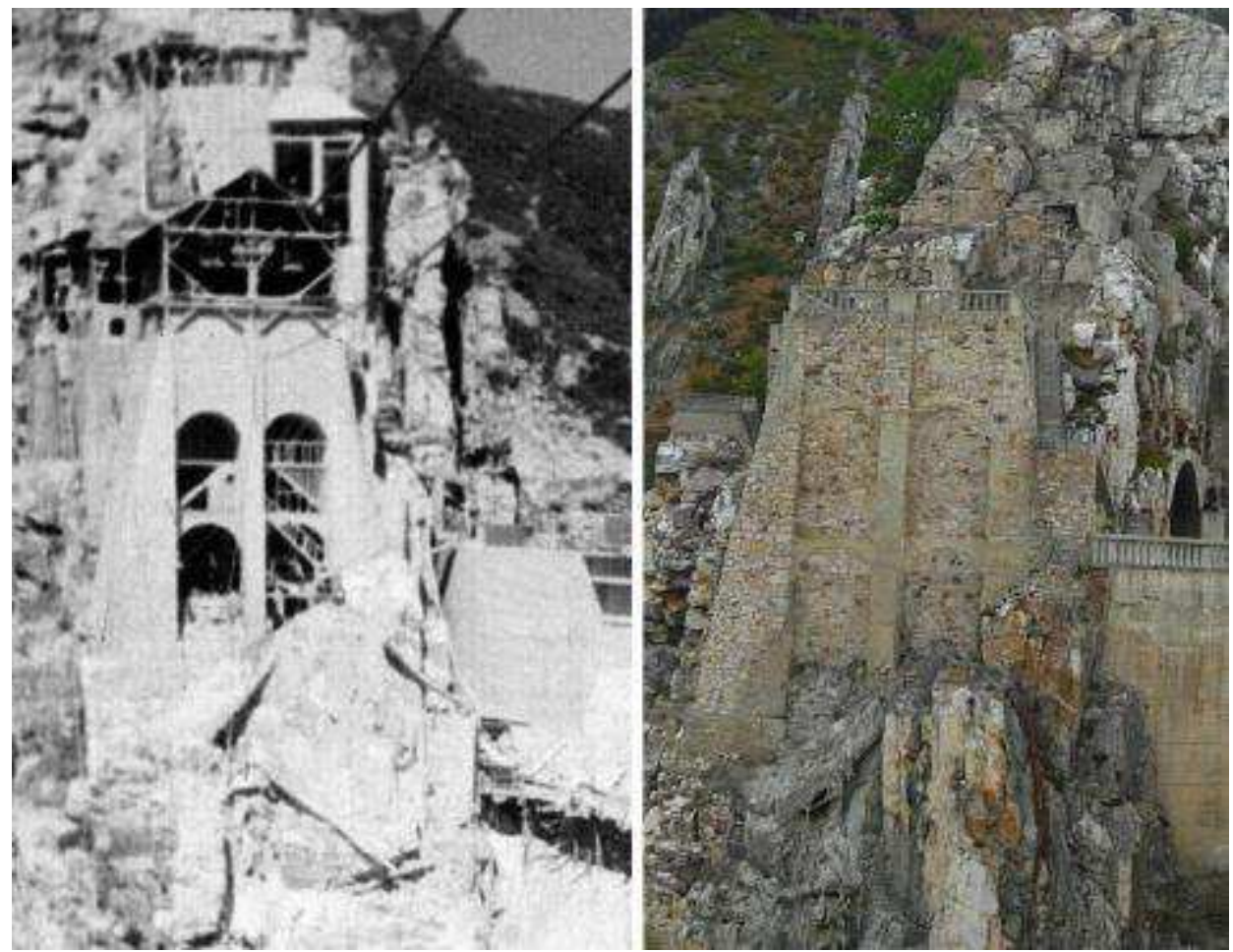

Ilustración 124. Aspecto original y actual de la torre de cable-grúa. A.G.C.H.D. Fondo fotográfico. Barrios_Deta_Const_3_52.

\subsubsection{Ferrocarril}

Para favorecer el trasporte de los materiales, desde el almacén hasta la base de la presa, se planificó un pequeño tramo de ferrocarril de vagonetas con una longitud de $1100 \mathrm{~m}$. elevado del suelo en el último recorrido por arquillos de cemento y hormigón ${ }^{608}$. Su uso principal fue el transporte de material y para ello se usaron vagonetas movidas por dos turbinas eléctricas conservadas hoy en día in situ.

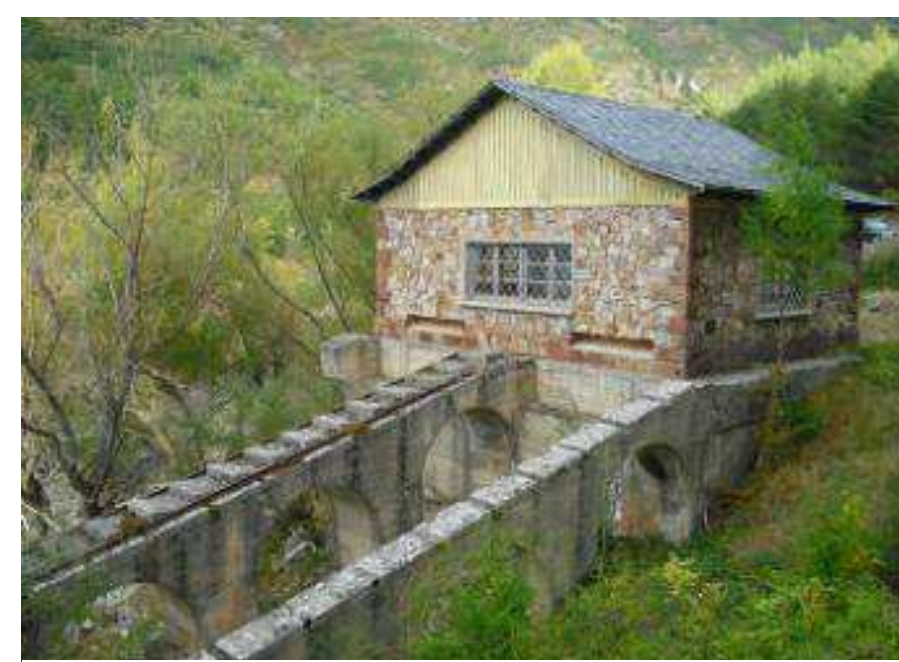

Ilustración 125. Caseta del ferrocarril. Barrios. Año 2010.

${ }^{608}$ A.G.C.H.D. C/00719-1. No 4001. Año 1936 y "El pantano de los Barrios de Luna, por su importancia y su coste, es la obra más grande realzada en la provincia en los últimos siglos" en Diario de León. Lunes 22 -09-1956. Página 3. 
El edificio se sitúa en la entrada del castillo y se eleva del suelo un par de metros en la zona de mayor desnivel. Tiene una sola planta de unos $20 \mathrm{~m}^{2}$ aproximadamente con tejado a dos aguas y paredes recubiertas de sillarejo de cuarcita extraída de la propia roca del castillo. En el interior se conserva en perfecto estado la maquinaria utilizada para el trasporte de las vagonetas.

En la actualidad existe un proyecto de reforma y recuperación de este espacio para convertirlo en un centro de interpretación de la presa de Barrios.

\subsubsection{Cementera}

La cementera era una construcción auxiliar utilizada con el propósito de abaratar costes y evitar los continuos transportes de material desde la Robla. Se sitúa a 1090 m. de altitud en el km 69 de la carretera de Barrios. Su estado es ruinoso. Posee una estructura rectangular de $120 \mathrm{~m}^{2}$ dividida en dos tramos de 5.50 y $6.50 \mathrm{~m}$. separados por un muro de argamasa con sillarejo. La altura máxima de los muros conservada es de $3.50 \mathrm{~m}$. En los muros interiores se observan un par de oquedades recubiertas que servían para colocar el poste de madera que sujetaba las vigas de amarre. Entre los tubos de desagüe donde se hacía la mezcla de la cal había un espacio de $2 \mathrm{~m}$. Además de éstos contenía otros tres canales de evacuación de la cal en el primer tramo y dos en el segundo de $0.50 \mathrm{~m}$. de diámetro inclinados a $45^{\circ}$ sobre una ladera de gran pendiente.
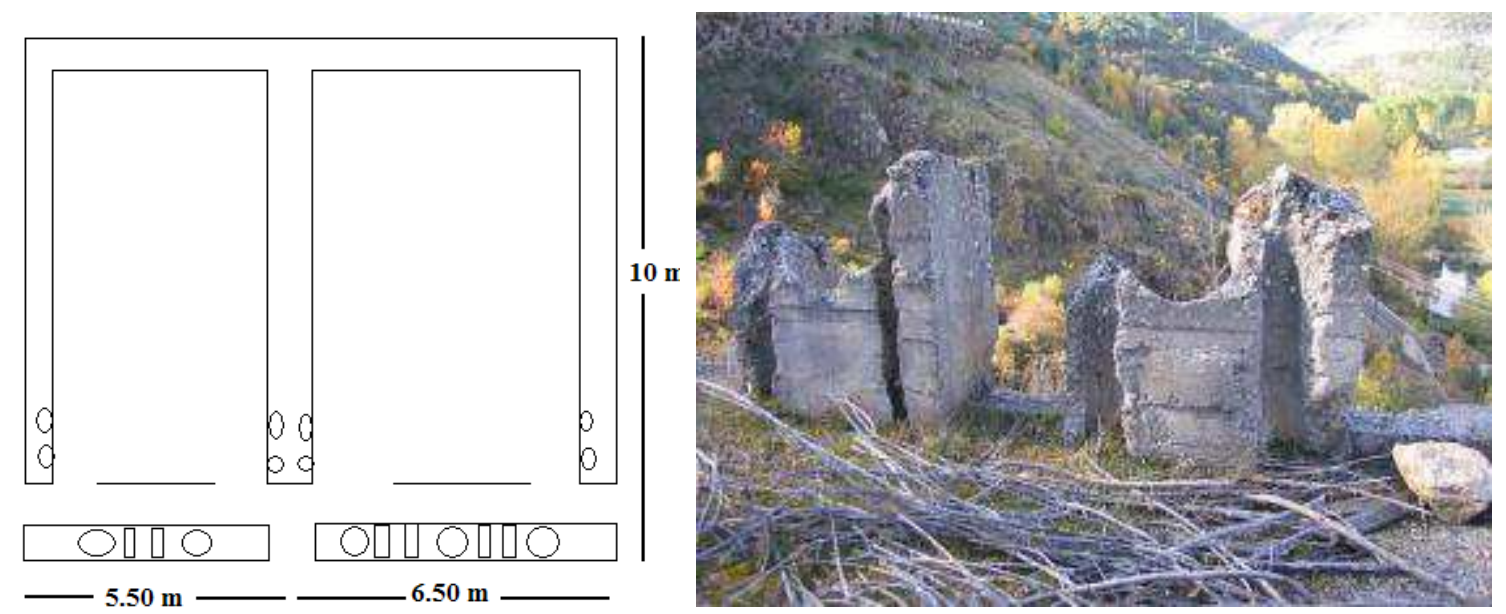

Ilustración 126. Plano y estado actual de la cementera de Barrios. 


\subsubsection{Torres eléctricas}

En las décadas de 1920-30 el ingeniero Ginés Navarro, que había construido la central eléctrica de Abelgas, consiguió la concesión de los permisos de suministro para la construcción de la presa al igual que para la creación de la central de Mora de Luna. Los primeros trabajos se abastecieron con la energía de la central de Abelgas que pronto se vio desbordada, por lo que a partir de 1951 se construyeron dos instalaciones eléctricas o torres de distribución provisionales para las obras del embalse ${ }^{609}$. Una de ellas se sitúa sobre un crestón al que se accede por unas escalerillas, ubicado en la carretera dirección a Mallo, a la salida

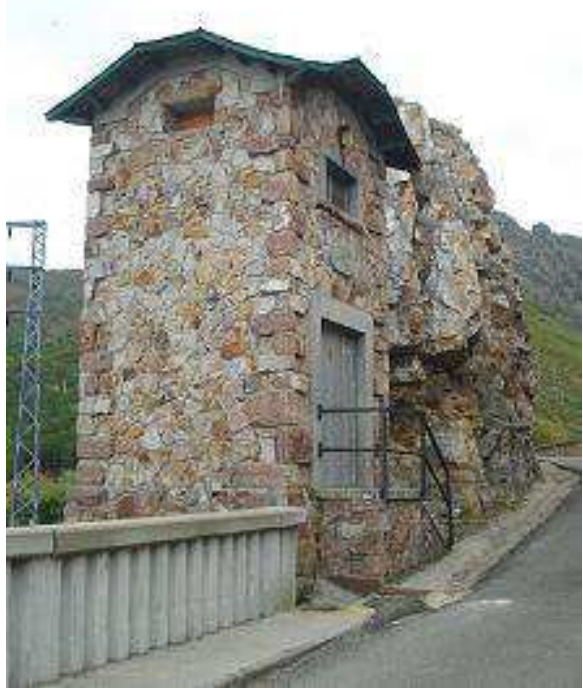

Ilustración 127. Torre de distribución del túnel ${ }^{610}$. Esta se encargaba de dar energía al cable-grúa y fue desmantelada una vez finalizadas las obras. La otra torre se encuentra en el margen derecho de la pared de la presa y aún mantiene su función, pues es la que suministra la energía a las compuertas de la presa.

$\mathrm{Su}$ tipología corresponde con la estructura típica de una torre rectangular en ladrillo y revestida con placas de sillarejo de cuarcita. Ambas poseen una altura aproximada de $4 \mathrm{~m}$. y una planta de $4 \mathrm{~m}^{2}$.

Es necesario advertir que tanto la estructura de las torres de distribución como los contrafuertes de las dos torres que sustentaban los cables-grúas, han sido confundidos en varias ocasiones como restos de la estructura torreada del castillo. Ello se ha debido a la utilización de sillarejo extraído del propio crestón rocoso que da una visión rústica a los edificios.

\footnotetext{
${ }^{609}$ PRIETO SARRO. “Luna”, p. 340.

${ }^{610}$ A.G.C.H.D. Proyecto de campamento obrero. Pantano de Barrios de Luna. Memoria. C/00272-4. N No. 4597.
} 
Como punto final en la construcción de edificios industriales se creó la central hidroeléctrica de Mora de Luna $^{611}$. El modelo fue diseñado por el propio ingeniero D. Luis de Llanos. Es un edificio de una única planta con mampostería revestida.

Posee una sala en la que se integran las turbinas y la

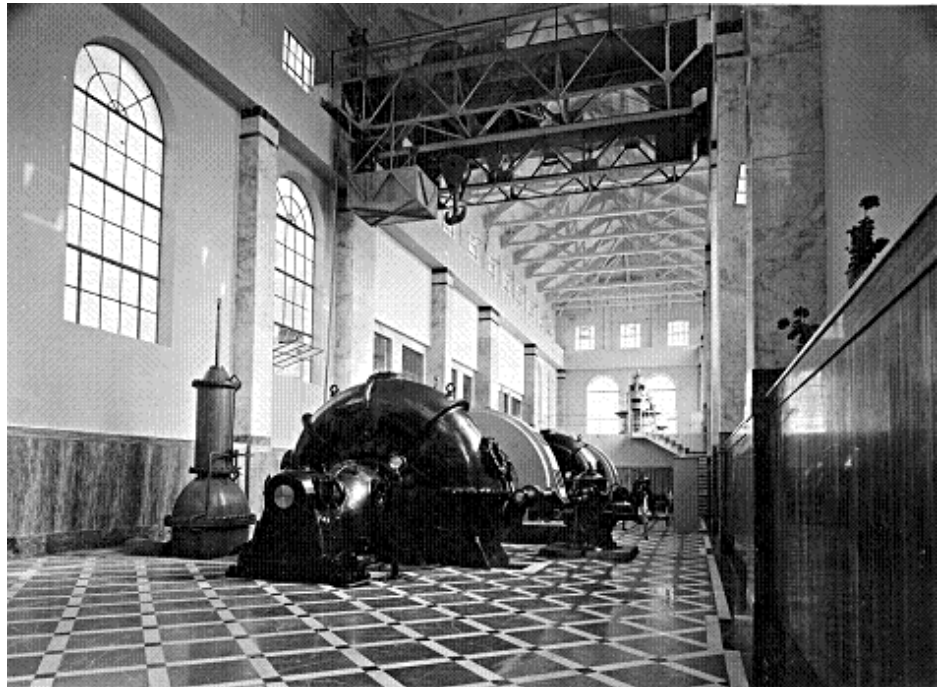

Ilustración 128 Central de Mora de Luna. A.G.C.H.D. Archivo fotográfico. Año 1956 maquinaria correspondiente. La sala se constituyó desde un principio como un espacio iluminado por dos tramos de vanos. El primero en forma de medio punto y el segundo en forma rectangular, otorgando de esta manera un aspecto más proporcionado al conjunto. El tejado está confeccionado con listones de madera bajo una techumbre a dos aguas en pizarra.

La central posee una potencia instalada de $76.800 \mathrm{Kw}$ y aunque en un principio se adjudicó su explotación a Ginés Navarro S.A., finalmente la empresa concesionaria fue la Unión Fenosa. Hoy en día produce una energía media anual de $128 \mathrm{GWh}^{612}$.

\subsubsection{Contra embalse de Selgas}

En 1961 se hace el contra-embalse en Selgas ${ }^{613}$, a 19 km. de Barrios de Luna. Su construcción se concibió como obra complementaria del embalse de Barrios para el riego del Páramo y el abastecimiento de agua potable a la ciudad de León. Se encuentra en el término municipal de Rioseco de Tapia y su propietario es C.H.D. Fue proyectado por el mismo ingeniero Luis de Llanos como una presa del tipo de gravedad con una altura sobre cimientos de $14.14 \mathrm{~m}$. sobre una superficie de 48 ha.

\footnotetext{
${ }^{611}$ A.G.C.H.D. C/01480-2. No. 3497.

${ }^{612}$ http://www.chduero.es/ Embalse de Barrios de Luna.

${ }^{613}$ SANZ-DOMÍNGUEZ, Guías, p. 103.
} 
La presa está emplazada aprovechando la escotadura que forman el ramal de la Friera y la Peñosa. El embalse de Selgas anegó las tierras fértiles y molinos de escorrentía del Valle de la Barca.

En 2010, la Fundación Patrimonio Natural finalizó las obras para la adecuación del embalse al uso de discapacitados y la iniciación infantil en actividades de pesca dentro del programa NINFA de promoción del uso sostenible de la pesca como recurso para el desarrollo rural ${ }^{614}$.

\subsubsection{EDIFICIOS CIVILES}

Junto con los edificios de carácter industrial se construyeron otros para albergar a los trabajadores e ingenieros que participaban en las obras del embalse. El ingeniero D. Luis de Llanos y Silvela proyectó la gran mayoría de los edificios civiles de viviendas para los empleados que trabajaban en el embalse. Algunos de estos se planificaron para un uso temporal, sin embargo otros, como la Casa Administración, supusieron un hito en la nueva construcción de la ZACEL. Además de los edificios para viviendas, también se planeó la creación de un cementerio nuevo que contuviese los restos mortales de los fallecimientos acaecidos durante los años de construcción de la presa.

Los materiales utilizados para los edificios de uso civil eran similares a los industriales. El sillarejo, hormigón y la pizarra para las cubiertas fueron los más comunes. La piedra empleada en el sillarejo rústico se extraía del material sobrante de las canteras de la presa. En ocasiones aparece un juego cromático entre la caliza gris y la rosa que será característico en otras obras como la central de Mora y que ya se encontraba patente en la arquitectura típica de la zona.

La preocupación del ingeniero D. Luis de Llanos por diseñar edificios acordes con las técnicas tradicionales llegó hasta los detalles más insospechados, pues como método de calefacción en las casas se integró la gloria. A pesar del respeto por las técnicas populares los nuevos edificios se completaron con mejoras como los servicios, el agua corriente y la luz eléctrica.

${ }^{614}$ http://www.patrimonionatural.org/ver_noticia.php?id_not=219 
A la hora de crear el proyecto de las nuevas viviendas se establecieron tres tipologías dependientes de la clase de trabajadores que iban a disfrutarlas: la vivienda destinada a la administración y los ingenieros, la de los empleados y la de los obreros.

El edificio más importante y con mejores comodidades fue la Casa Administración, que se convirtió en un emblema de la modernidad y prosperidad de la anegada comarca.

Los edificios destinados para los empleados estaban construidos con materiales más baratos como el ladrillo y su estructura era principalmente funcional con una sola planta en la cual se dividían las distintas estancias de la vivienda y almacenes, pues debían albergar no sólo al personal, sino también a sus familias.

Por último las viviendas para los obreros se planificaron como barracones temporales con habitaciones dobles que posteriormente sufrieron mejoras significativas de habitabilidad. El número de obreros que participaron en las labores de la presa se incrementó tanto que se optó por no levantar más edificios y reubicar al resto en casas particulares de las poblaciones cercanas.

Los presos políticos que participaron en las obras, consecuencia de la "ley de vagos y maleantes", eran alojados en barracones diferenciados cercanos a las obras y custodiados por la Guardia Civil ${ }^{615}$. Apenas tenían contacto con el resto de obreros, pues los trabajos que realizaban eran los más penosos y siempre separados del resto.

\subsubsection{Casa Administración.}

La Casa Administración es sin duda la mejor obra de carácter civil de las obras del embalse. Fue planificada por el ingeniero D. Luis de Llanos y Silvela en $1941^{616}$. Su función principal era la de vivienda y oficina personal de los facultativos encargados de la dirección de las obras. Se sitúa a 300 m. aguas abajo del emplazamiento de la presa, en el margen izquierdo del río Luna a $1072 \mathrm{~m}$. de altitud sobre una explanada artificial.

\footnotetext{
615 VVAA. El siglo, p. 341. Eran conocidos como los de la Colonia y recibían una pequeña remuneración además de redimir la pena.

${ }^{616}$ A.G.C.H.D. Proyecto de casa administración para el pantano de Luna. Barrios de Luna. № 917- Año 1941.
} 

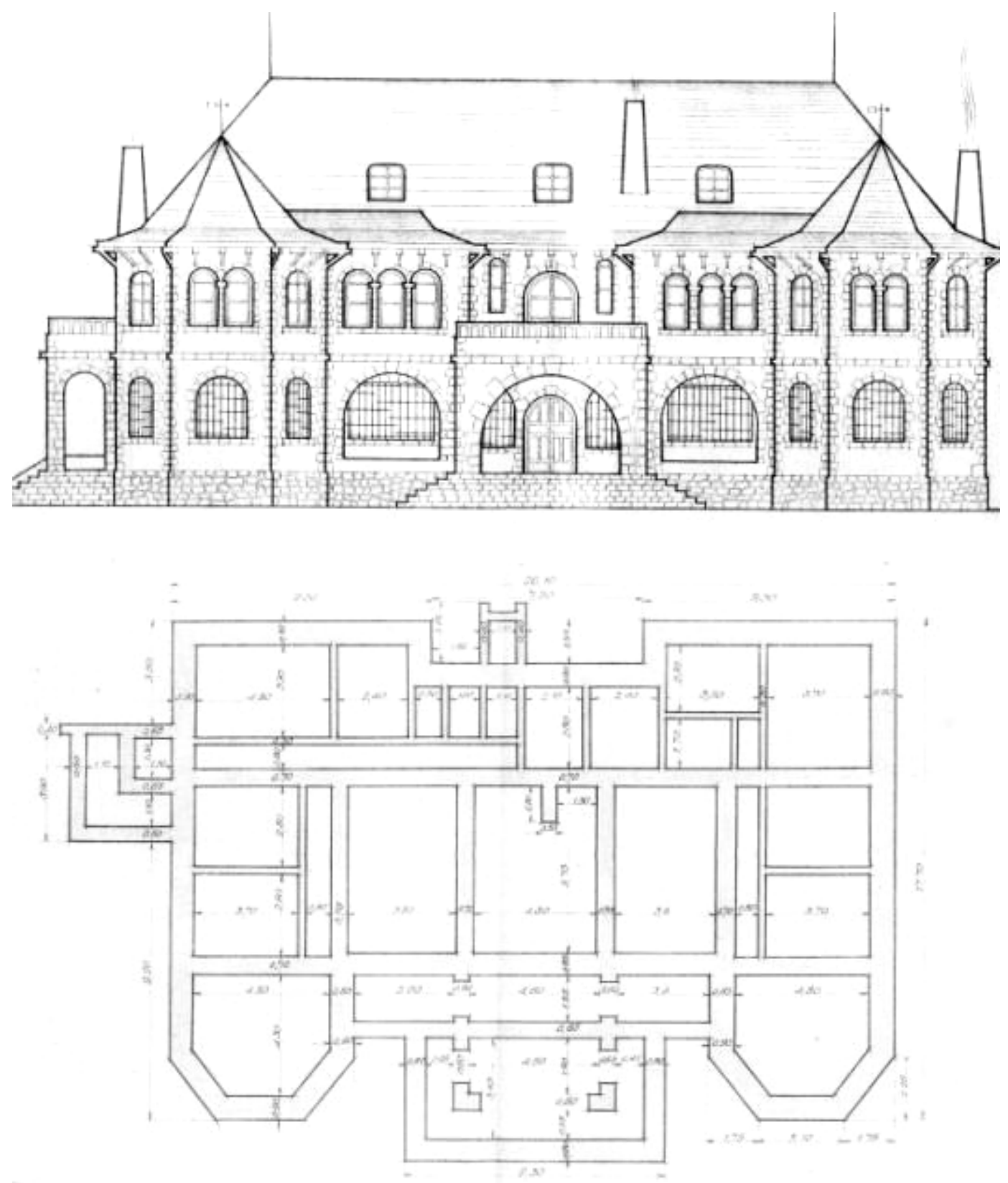

Ilustración 129 . A.G.C.H.D. Proyecto de casa administración para el pantano de Luna. Barrios de Luna. No 917- Año 1941.
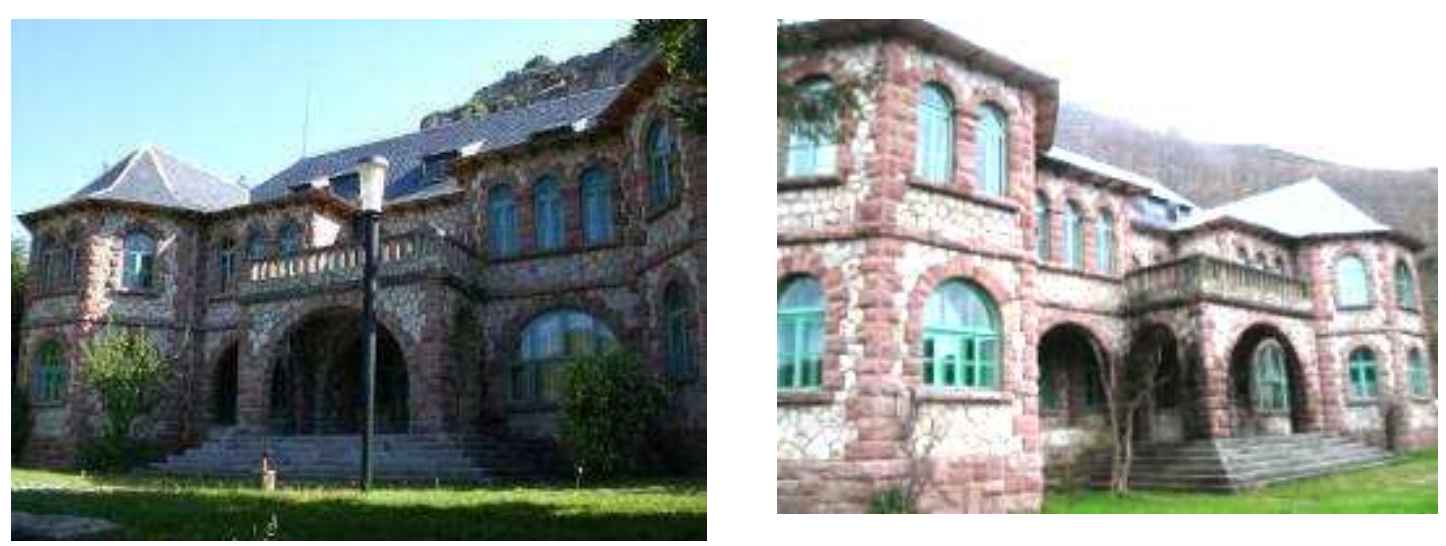
La Casa Administración se compone de una serie de viviendas y servicios con habitaciones individuales, laboratorio de ensayos de materiales, garaje y vivienda para el guarda. El zaguán de entrada divide las dos alas de la planta: la derecha destinada a oficinas y despachos y la izquierda destinada a la vivienda del personal con servicios de calefacción y baño.

Se aprovecharon las técnicas calefactoras propias de la zona, como la gloria y se añadieron aseos en todas las plantas cuyo abastecimiento de agua procedía de una pequeña fuente situada en las cercanías de la ladera. El techo de pizarra se construyó muy inclinado teniendo en cuenta el nivel de precipitaciones de nieve.

En general, el edificio pretendió ser un compendio de la arquitectura tradicional de la zona que mezclaba lo rústico con la modernidad del momento. Para su construcción se utilizó un paramento ordinario extraído de las propias canteras del embalse. El juego cromático de las diferentes piedras gris y rosa le otorgaba un aspecto decorativo significativo.

Durante la inspección técnica de 1985 se hicieron mejoras en la cimentación de la casa con hormigón armado anclado a la roca. Se restauró la cubierta original que constaba de pórticos de madera laminada sobre los que se colocan las piezas de pizarra y se mantuvieron igualmente los cerramientos originales. En 2010 se acometió otra restauración que consistió en la consolidación de sus soportes. El mayor cambio fue el interior, reestructurando las habitaciones e incorporando una nueva instalación eléctrica, mejorando de la canalización de aguas residuales y suministro de agua potable.

El estado de conservación actual es bueno, ya que aún se mantiene como oficina de la C.H.D. En el interior se conserva la estructura original y todo el mobiliario realizado para su fábrica.

\subsubsection{Garaje}

En las inmediaciones de la Casa Administración se encuentra otro edificio destinado a garaje para tres vehículos y casa del chófer. También fue proyectado por D. Luis de Llanos y Silvela en $1949^{617}$. Fue construido con mampostería ordinaria hidráulica asentada sobre cimientos de hormigón.

\footnotetext{
${ }^{617}$ A.G.C.H.D. Proyecto de garaje habitación. Ingeniero: D. Luis de Llanos y Silvela. C/00370-2. N ${ }^{\circ}$
} 1924. Año 1949. 
Cuenta con dos plantas unidas a través de una escalera exterior adosada a la fachada. La planta principal contiene tres dormitorios, un cuarto de estar con chimenea de campana, cocina-comedor, un pequeño cuarto a modo de despensa y servicios sanitarios. La planta inferior estaba destinada a garaje.

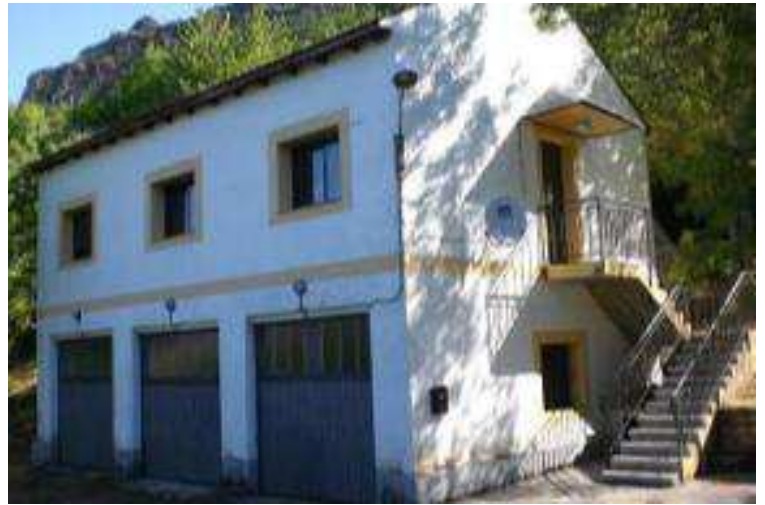

Ilustración 130. Garaje.

4.4.4.3.Viviendas para los empleados

Este tipo de edificios estaban destinados a viviendas de empleados cualificados. A pesar de que se proyectaron varios, tan solo se finalizaron cuatro de ellos, que en la actualidad son de propiedad particular. Su finalidad no era solo la de cobijar a los ingenieros de segunda categoría, sino también a sus familias, que se veían desplazadas al lugar debido a la dilación de las obras a lo largo de los años. Todos ellos fueron planificados en 1942 por el ingeniero Llanos y Silvela.

El primer par de viviendas están situadas en la ladera S. cercana al campamento obrero. Las viviendas siguen el esquema rectangular de los barracones para los obreros pero con una mejor distribución interior y una superficie de $100 \mathrm{~m}^{2}$ cada una.

En su interior están distribuidas en dos partes con entradas independientes, una dedicada a la vivienda y otra destinada a almacén. El espacio habitable consta de un salón-cocina, baño y tres dormitorios. También posee una bodega subterránea para la conservación de alimentos.

El otro par de edificios planificados por Luis de Llanos en 1942 se encuentran a 1142 m. de altitud sobre la ladera a pocos metros de la Casa Administración. Posee una superficie de $49.20 \mathrm{~m}^{2}$. Los cimientos son de hormigón forjado con cubierta de tabicones palomeros y tejas cerámicas planas ${ }^{618}$. El cerramiento de las viviendas se realizó mediante ladrillo perforado revestido con mampostería careada en piedra caliza del país.

En la actualidad estos edificios son propiedad particular. 


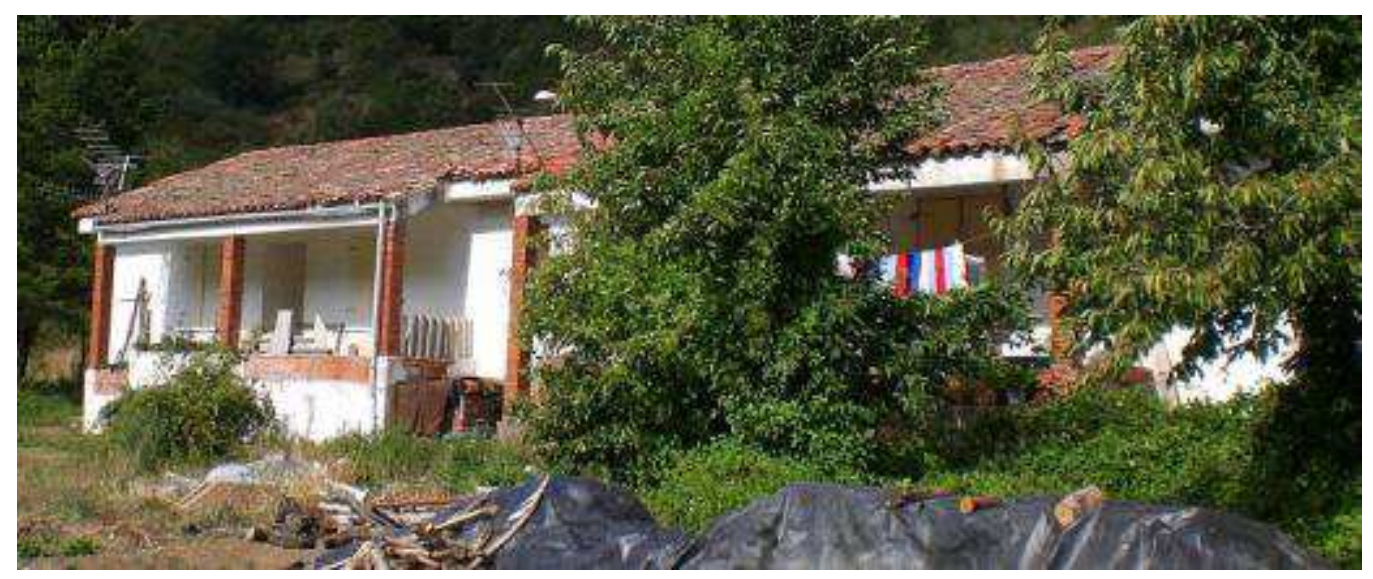

Ilustración 131. Modelo de vivienda para los empleados en la actualidad.
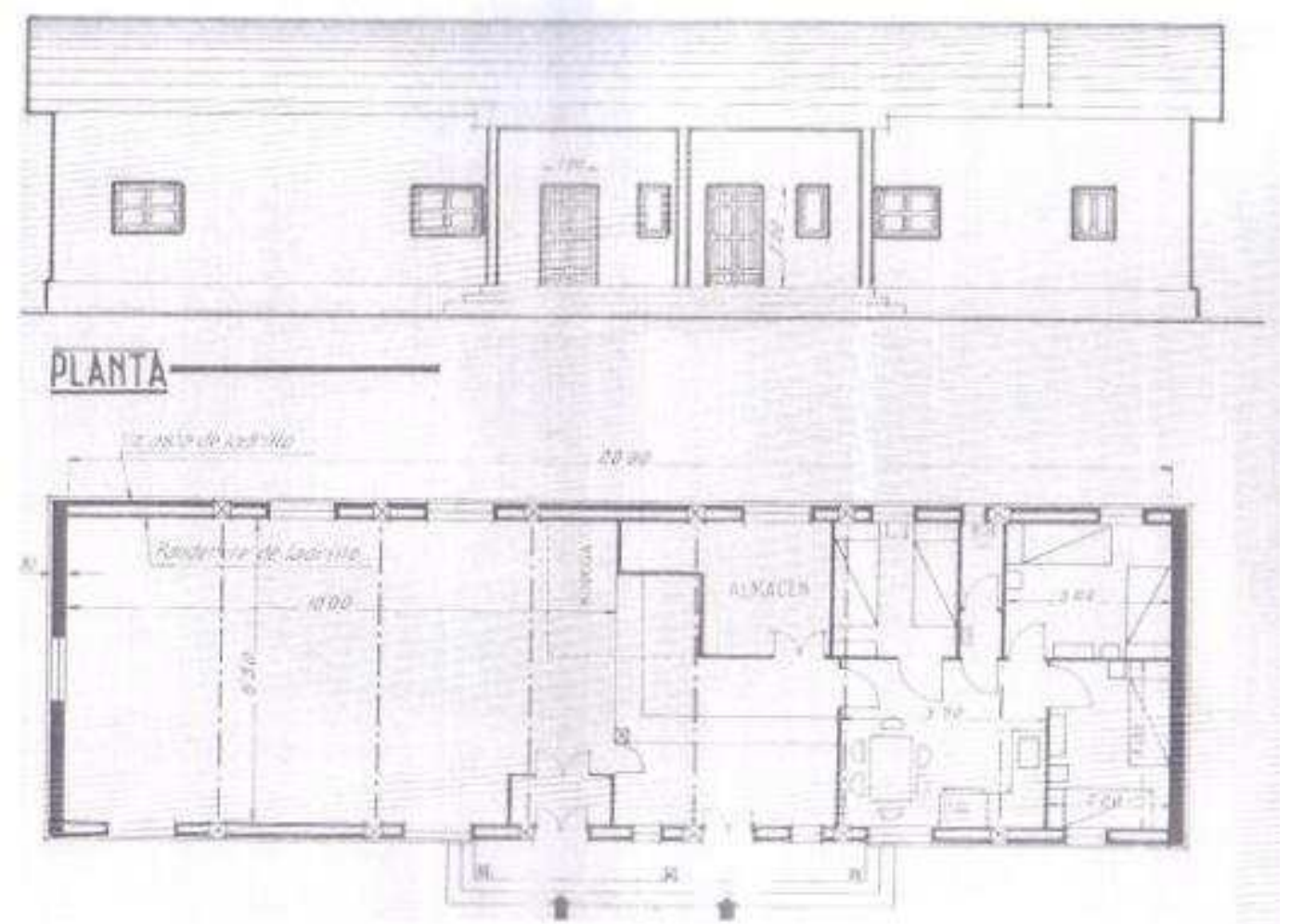

Ilustración 132 A.G.C.H.D. Proyecto para viviendas de los empleados. C/00272-5. No 1110 

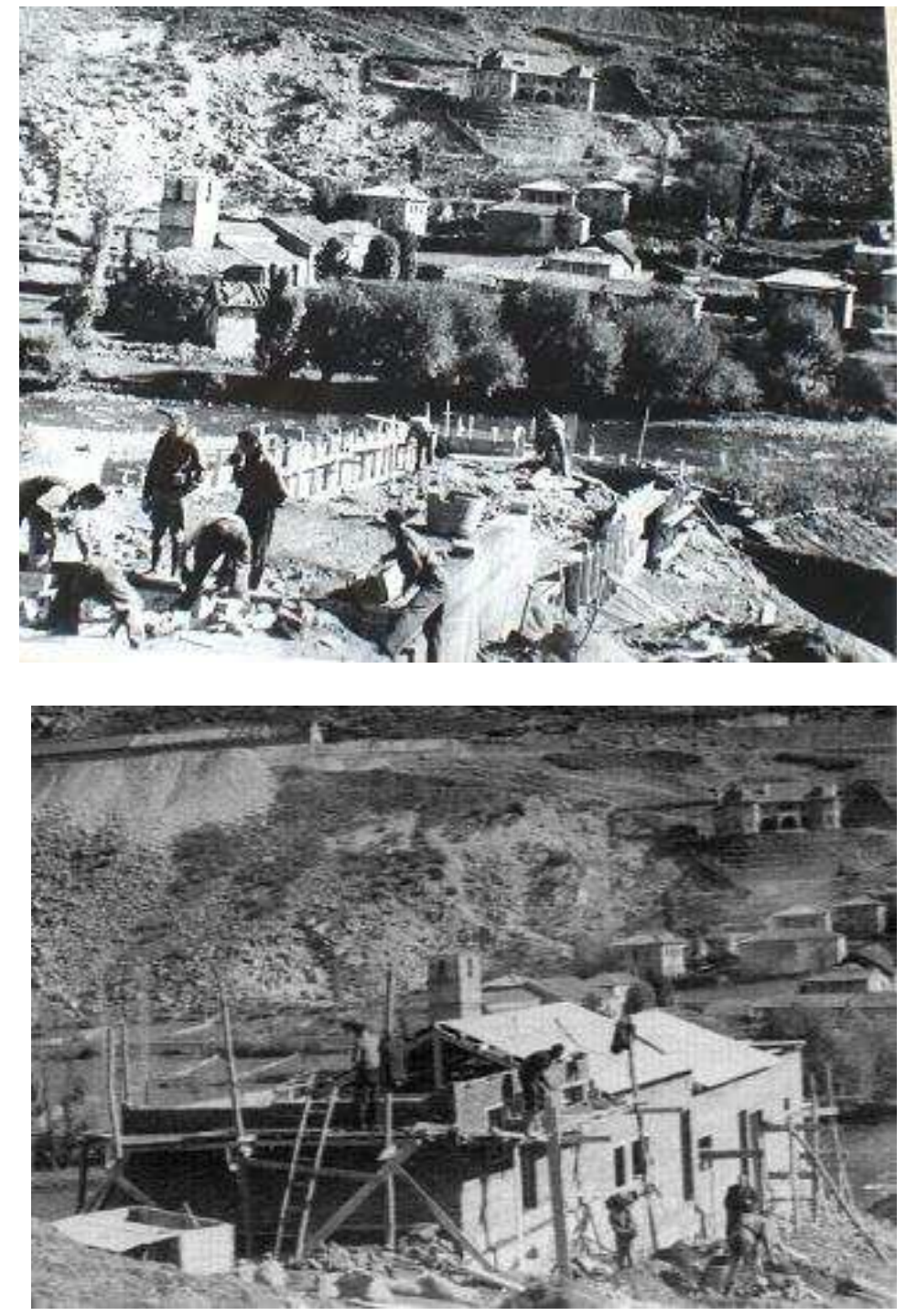

Ilustración 133. Obras de ejecución del campamento. A.G.C.H.D. Fondo fotográfico. Barrios-barracones-presa.
En el margen derecho del río Luna, junto a una alargada explanada, se ubicó el edificio destinado para vivienda de los obreros que participaban en las labores de la presa. En 1942 el ingeniero D. Luis de Llanos y Silvela creó un proyecto de barracones para albergar a cincuenta hombres en camas o literas. En un principio se pensó en barracones de madera desmontables, los cuales se utilizarían posteriormente en la construcción de la desviación de las carreteras gracias a su movilidad, pero la duración de las obras del embalse hizo necesaria la realización de un edificio más duradero. Este consistió en una estructura rectangular de $33.60 \mathrm{~m}$. de longitud por $5.60 \mathrm{~m}$. de ancho sobre pilares de ladrillo macizo. Cada barracón quedaba dividido en dos compartimentos de 15 x 5 m. con entrada independiente. El espacio central servía para alojar los servicios sanitarios de retretes.

En 1943 trabajaban en la obra cien obreros, pero las necesidades de la presa hicieron que su número llegase a quintuplicarse. Se hizo entonces preciso un nuevo proyecto con un edificio de dos plantas y con mejoras sanitarias que, por problemas presupuestarios, nunca llegó a ejecutarse. En vez de construir otros edificios los obreros 
tuvieron que ser alojados en casas particulares de Barrios o pueblos aledaños en régimen de alquiler todo incluido.

En total se construyeron tres barracones, dos de ellos destinados a los obreros y el tercero como cantina y almacén. Parte de uno de los barracones destinados a los obreros fue usado como enfermería. Esta ocupaba un espacio de 18 x $6.10 \mathrm{~m}$. y poseía tres salas para curas. Además contenía una habitación destinada a vivienda para el practicante con un comedor, cocina y dormitorio.

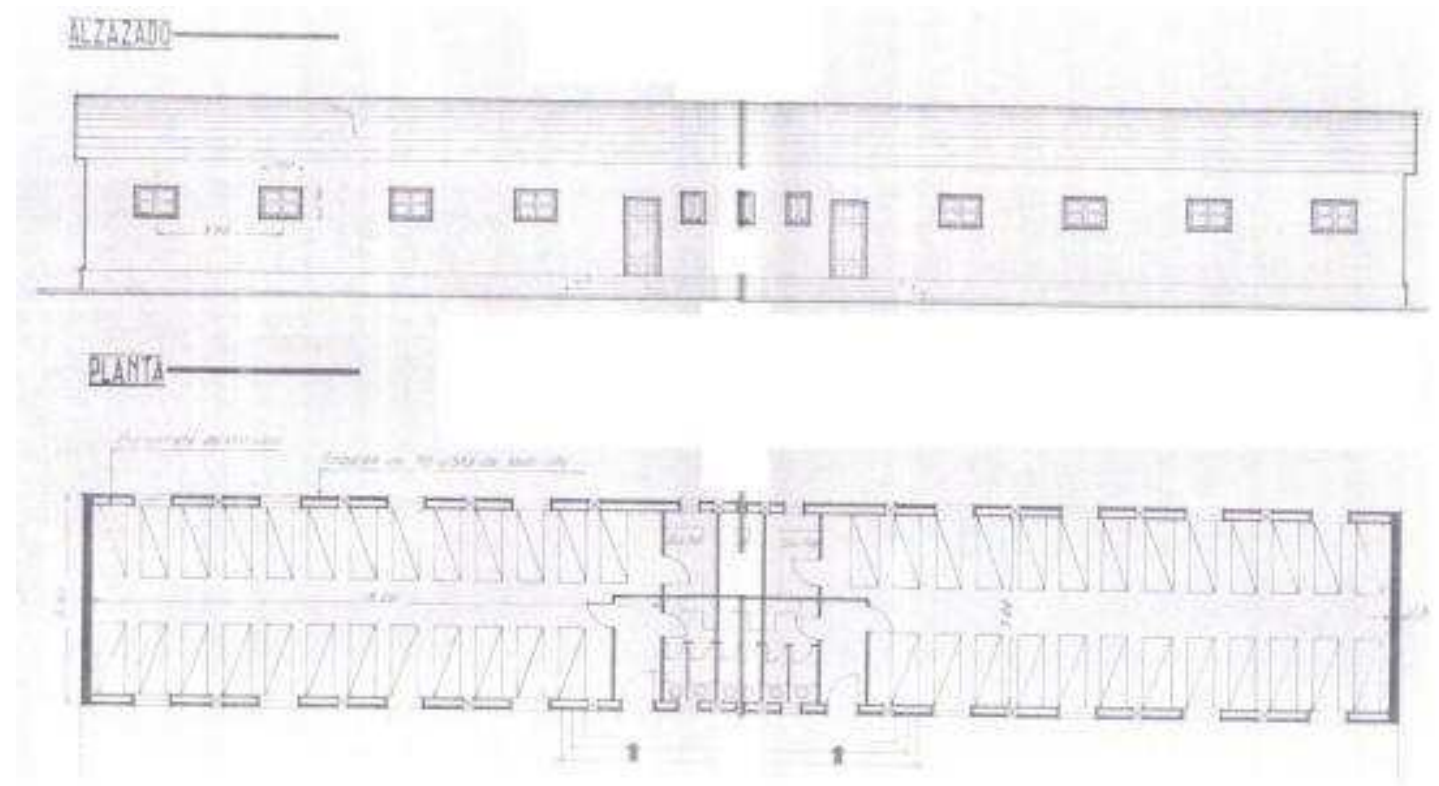

Ilustración 134 .A.G.C.H.D. Proyecto de construcción del campamento obrero. C/00272-5. No 1110.

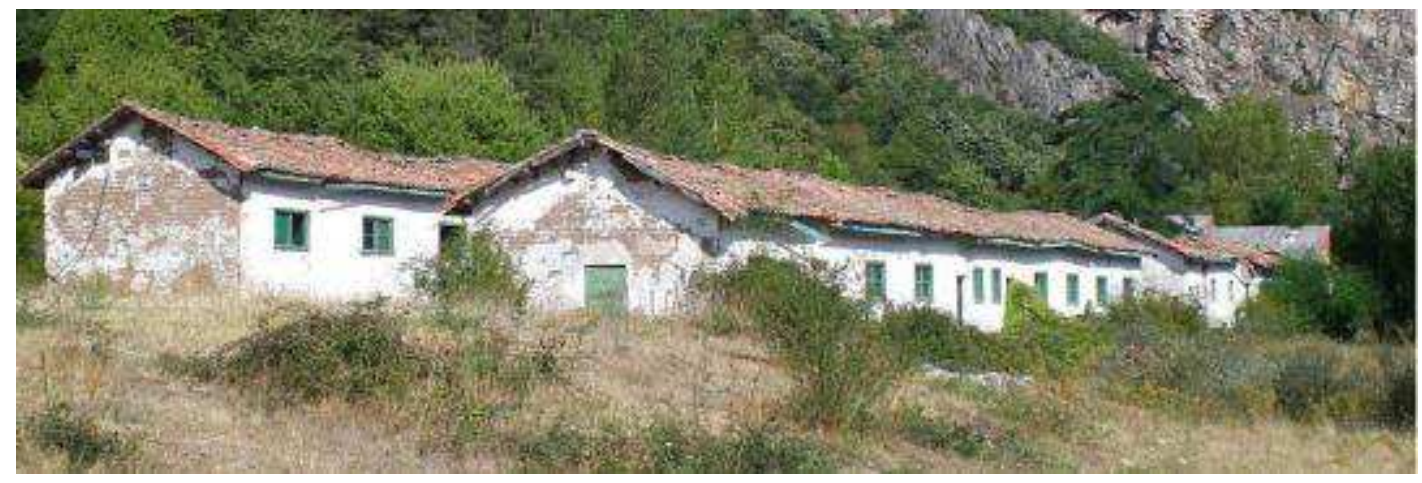

Ilustración 135. Vista del campamento en 2008, un año antes de su destrucción. 
Junto a los barracones se proyectó la edificación de un cuartel de la Guardia Civil, ya que en un primer momento se llevaron presos de guerra para realizar los trabajos más penosos de la presa. El cuartel de la Guardia Civil se levantó en el lugar que ocupaban los restos de la antigua ermita de S. Juan. Se proyectó con una saladormitorio para cuatro guardias solteros y tres viviendas para guardias con familia, siendo la de mayores dimensiones destinada al comandante del puesto. En una sala anexa se encontraba el despacho y un cuarto destinado al armero.

El Cuartel de la Guardia Civil fue destruido una vez finalizadas las obras del embalse. Hoy en día tan solo queda en pie el muro de contención de la ladera y la pequeña escalera por la que se accedía. La vegetación y el expolio acabaron con el resto.

Dentro del recinto del campamento obrero también se construyeron otros anexos destinados a satisfacer las necesidades de los obreros. Uno de ellos era la cantina que tenía un mostrador, almacén y bodega para el uso y disfrute de los trabajadores y sus familias ${ }^{619}$. También se encontraba la vivienda del encargado compuesta por cocinacomedor, tres dormitorios y servicios. Hoy en día este espacio se utiliza como refugio de ganado aunque aún se conserva el mobiliario interior.

Una vez finalizadas las obras de la presa los obreros abandonaron el campamento. En $1960^{620}$ se concedió el arrendamiento del campamento obrero al patronato de S. José de la Felguera (Asturias) regido por el párroco don José Arenas, quien trasformó los barracones en campamentos de verano. Durante varios años la C.H.D. cedió este espacio para el aprovechamiento de dicho patronato quien lo restauró y acondicionó para el alojamiento de los hijos de los mineros asturianos.

En el año 2001 se abandonó definitivamente debido a las malas condiciones de su estructura y así quedó a la espera de nuevas inversiones para su rehabilitación ${ }^{621}$. En el verano de 2009 el ayuntamiento de Barrios de Luna derrumbó los dos barracones y la enfermería dejando la cantina para reuniones y festividades del pueblo.

\footnotetext{
${ }^{619}$ A.G.C.H.D. Proyecto de acondicionamiento y mejora de las viviendas...Embalse de Barrios de Luna. D. Luis López de Sosoaga. C/00272-4. Nº.4597. Año 1966.

${ }^{620}$ Ibídem.

${ }^{621}$ PRIETO SARRO. "Luna”, p. 341.
} 


\subsubsection{Cementerio}

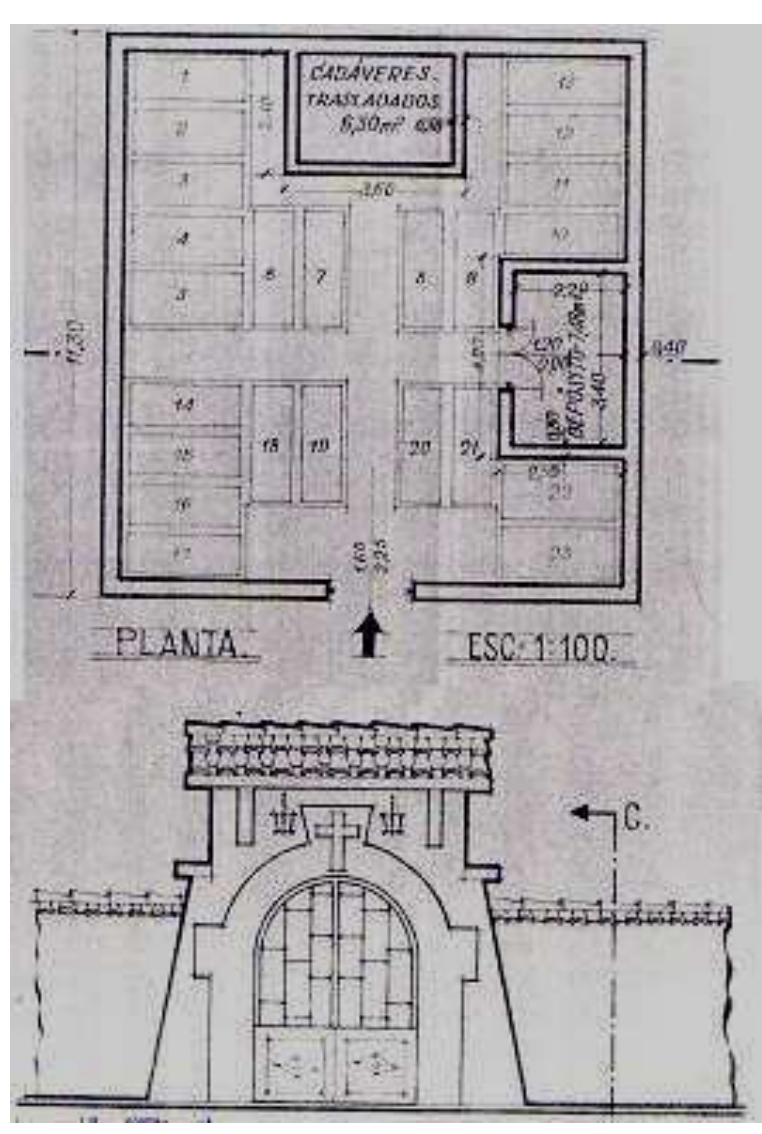

Ilustración 136. A.G.C.H.D. Proyecto de cementerio. C/00414-3. No 1725. Año 1952
El traslado de los restos mortales de los cementerios se convirtió en una problemática, pues su coste debía ser pagado por los propios familiares y muy pocos fueron los que optaron por exhumar los cuerpos.

Durante los años de construcción de la presa se prohibió expresamente el enterramiento en las poblaciones que iban a quedar anegadas. De esta manera se proyectó la construcción nuevos camposantos fuera del embalse.

El propio arquitecto D. Luis de Llanos planeó en 1949 tres cementerios con capacidad para veintitrés panteones más un espacio para los restos exhumados. Debido al alza de los precios el presupuesto se quedó corto en tres años y solo se pudo ejecutar uno de los cementerios, el de Miñera, que fue posible gracias al esfuerzo económico del pueblo ${ }^{622}$. El cementerio tenía una estructura cuadrada de 10.70 x $11.30 \mathrm{~m}$. con un recinto de 2.20 x $3.40 \mathrm{~m}$. para depósito de cadáveres y práctica de autopsias.

El nuevo cementerio no acogió más que un cadáver, pues los vecinos optaron por llevar los restos a otras poblaciones cercanas a sus nuevas residencias o al cementerio de León ${ }^{623}$.

El director general de Obras Hidráulicas acordó la cubrición de los cementerios inundados con grandes losas de hormigón de un metro de espesor para evitar que los huesos emergiesen a la superficie. Así se hizo en Campo, San Pedro, Oblanca, Lagüelles, Láncara y Santa Eulalia.

\footnotetext{
${ }^{622}$ A.G.C.H.D. Proyecto reformado de sustitución de los cementerios embalsados. Ingeniero: D. Luís de Llanos y Silvela. C/00414-3. No 1725. Año 1952.

${ }^{623}$ Información dada por Petronilo GUISURAGA, vecino de Miñera de Luna.
} 


\subsubsection{NUEVAS VÍAS DE COMUNICACIÓN}

La construcción de los puentes se proyectó como mejora de las comunicaciones del Valle dentro del plan de infraestructuras de la presa. Al quedar anegadas las carreteras anteriores se diseñó un nuevo trazado para la vía de la Magdalena- Belmonte en la cual se incluían puentes y viaductos que facilitaron la comunicación por encima del nivel de inundación de las aguas. Su construcción se inició a la vez que las obras de la pared del embalse y no finalizó hasta los años ochenta, debido a los sucesivos derrumbes y restauraciones de los viaductos de Oblanca y Aralla.

Dentro del proyecto de la presa también se llevaron a cabo otra serie de infraestructuras creadas como compensación de los daños sufridos por las obras del embalse. Así en Barrios se levantaron dos puentes de hormigón que mejoraron la comunicación del pueblo, uno en dirección a Irede y otro de acceso al campamento obrero. De la misma manera se renovaron las carreteras con nuevos tramos de vía hacia Mallo e Irede.

En la construcción de los puentes se utilizó el cemento y el hormigón. Estos dos componentes permitían la creación de grandes estructuras debido a su maleabilidad en fresco y al abaratamiento de los costes. Aún así, el propósito de los ingenieros no era tanto crear formas modernas como mantener cierto aire de rusticidad, por lo que también se utilizaron sillares de piedra o incluso dibujos en cemento que pretendían imitar las formas tradicionales.

Dentro del espacio de la ZACEL se encuentran tres tipologías bien definidas: los puentes de hormigón, viaductos y puentes atirantados.

\subsubsection{Puentes de hormigón}

En el proyecto de mejora de las comunicaciones de la presa se programaron varios puentes cuya característica general fue la utilización del hormigón. La tipología estructural seguía los modelos industriales. Tanto es así que los diseñadores eran ingenieros que buscaban la mayor funcionalidad en detrimento de la estética. Sin embargo se dan ciertas pautas estilísticas de carácter tradicional dentro de los puentes ubicados en centros urbanos. 
Para salvar pequeños riachuelos, en el trazado general de la nueva carretera que bordea el embalse, se crearon puentes de un solo ojo con una luz aproximada de $5 \mathrm{~m}$. Los materiales utilizados eran el hormigón para las pilas y contrafuertes y la piedra para la línea de imposta. Algunos ejemplos son los dos pequeños puentes de un arco sobre el río de Aralla y sobre el río Caldas.

Los puentes más característicos de esta tipología se encuentran en Barrios de Luna.

\section{Puente de acceso al campamento obrero. Barrios de Luna.}

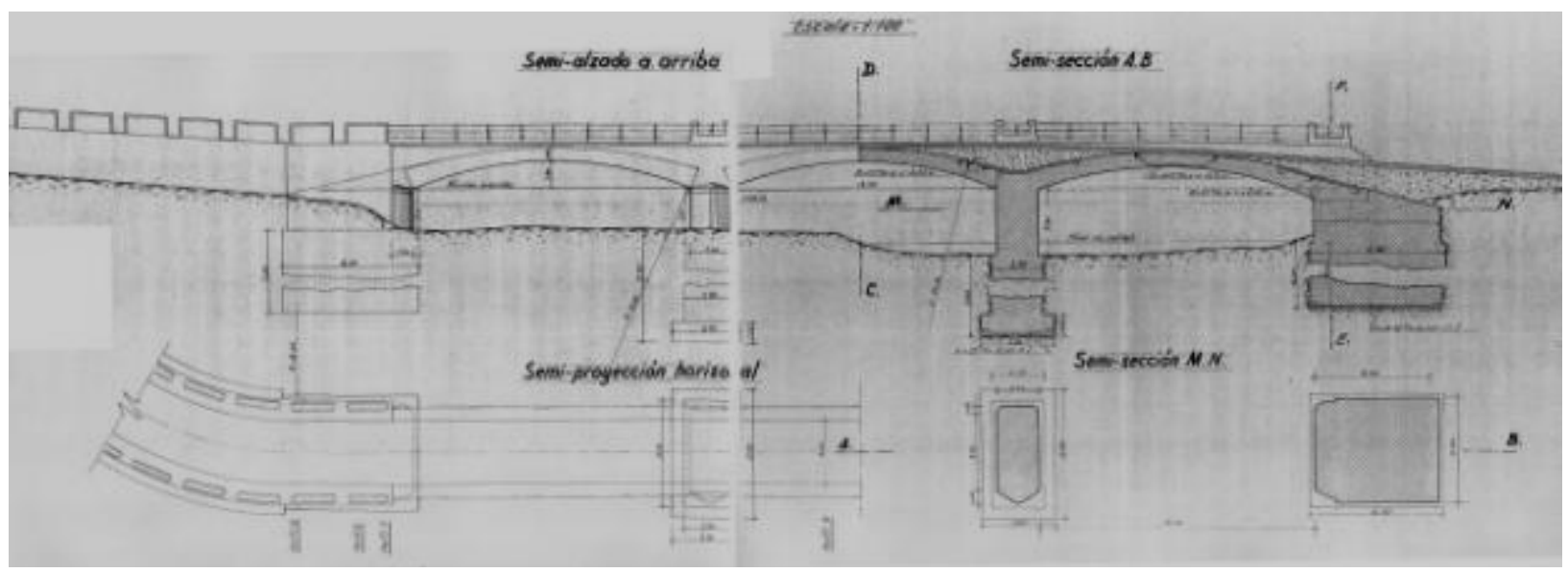

Ilustración 138 A.G.C.H.D. C/00589-4. No 3404. Año 1957.

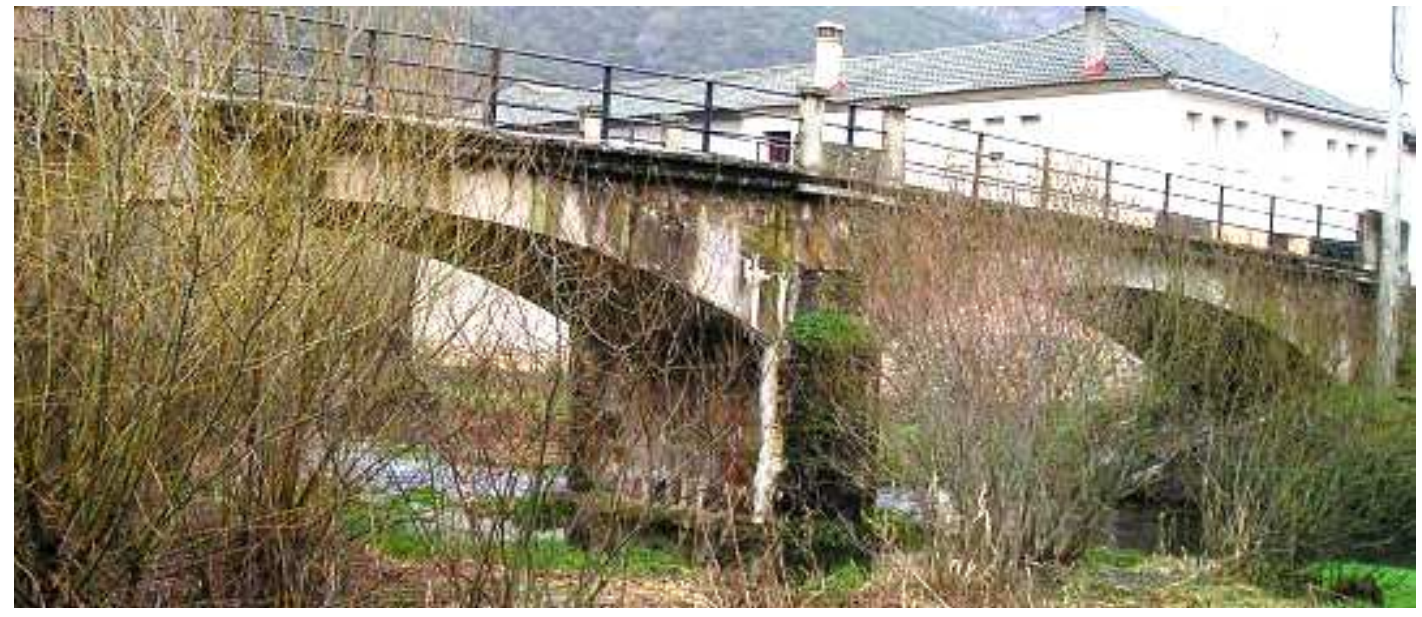

Ilustración 137. Estado actual del puente diseñado por Baltasar Ríos.

El puente que daba acceso al campamento obrero se encuentra situado sobre el río Luna, en la calle de los Molinos de Barrios. El proyecto inicial data de 1942 y fue ejecutado por el ingeniero D. Luis de Llanos y Silvela para dar salida al campamento. 
Este puente sustituía a otro anterior realizado con rollizos de madera y que se ha descrito anteriormente en el apartado de los puentes.

Las malas condiciones del firme y la escasa calidad de los materiales empleados en el puente de Llanos y Silvela motivaron su desmantelamiento y reparación posterior.

En 1957 el Ingeniero D. Baltasar Ríos proyectó otro puente en sustitución del anterior. Se optó por una fábrica de mejor calidad y el aumento de profundidad de la cimentación de las pilas y estribos con respecto al plan anterior llegando a los $7.5 \mathrm{~m}$. de profundidad $^{624}$. La longitud total del puente actual es de $65 \mathrm{~m}$. con una altura de $5 \mathrm{~m}$. hasta la barandilla y de $2.80 \mathrm{~m}$. hasta el cierre de los arcos. Posee tres $\operatorname{arcos}$ de $13 \mathrm{~m}$. de luz realizados en hormigón encofrado con dovelas en los estribos de piedra devastada. Los materiales utilizados son el hormigón armado para los soportes, piedra para las dovelas de los arcos y hierro para la balconada y la balaustrada.

\section{$\underline{\text { Puente de Barrios de Luna hacia Irede }}$}

El puente se sitúa en el tramo de la CV-102-26 dando acceso a la población de Irede. Fue proyectado en $1945-55$ por el ingeniero D. Luis de Llanos y Silvela ${ }^{625}$ dentro del plan de mejora de las vías de comunicación de Barrios de Luna. Posee una longitud total de $70 \mathrm{~m}$. con una altitud máxima de $15 \mathrm{~m}$. y una anchura de $5 \mathrm{~m}$. Tiene cinco arcos de medio punto con una luz similar de todos ellos de $9.50 \mathrm{~m}$. La línea de imposta de los arcos y los tajamares son de aparejo hexagonal de piedra extraída de las canteras próximas y cuyo cromatismo rosáceo contrasta con el hormigón gris. El resto de la estructura es de hormigón armado. Para la barandilla se utilizó el hierro.

Sus características formales se adecúan a una tipología rústica basada en modelos similares a los realizados en la ingeniería de puentes para ferrocarriles. Su forma pretende adecuarse al espacio rural en el que se inserta y que predomina en otros puentes cercanos como el de Vega de los Caballeros.

\footnotetext{
${ }^{624}$ A.G.C.H.D. C/00589-4. No 3404. Año 1957.

${ }^{625}$ Ibídem.
} 


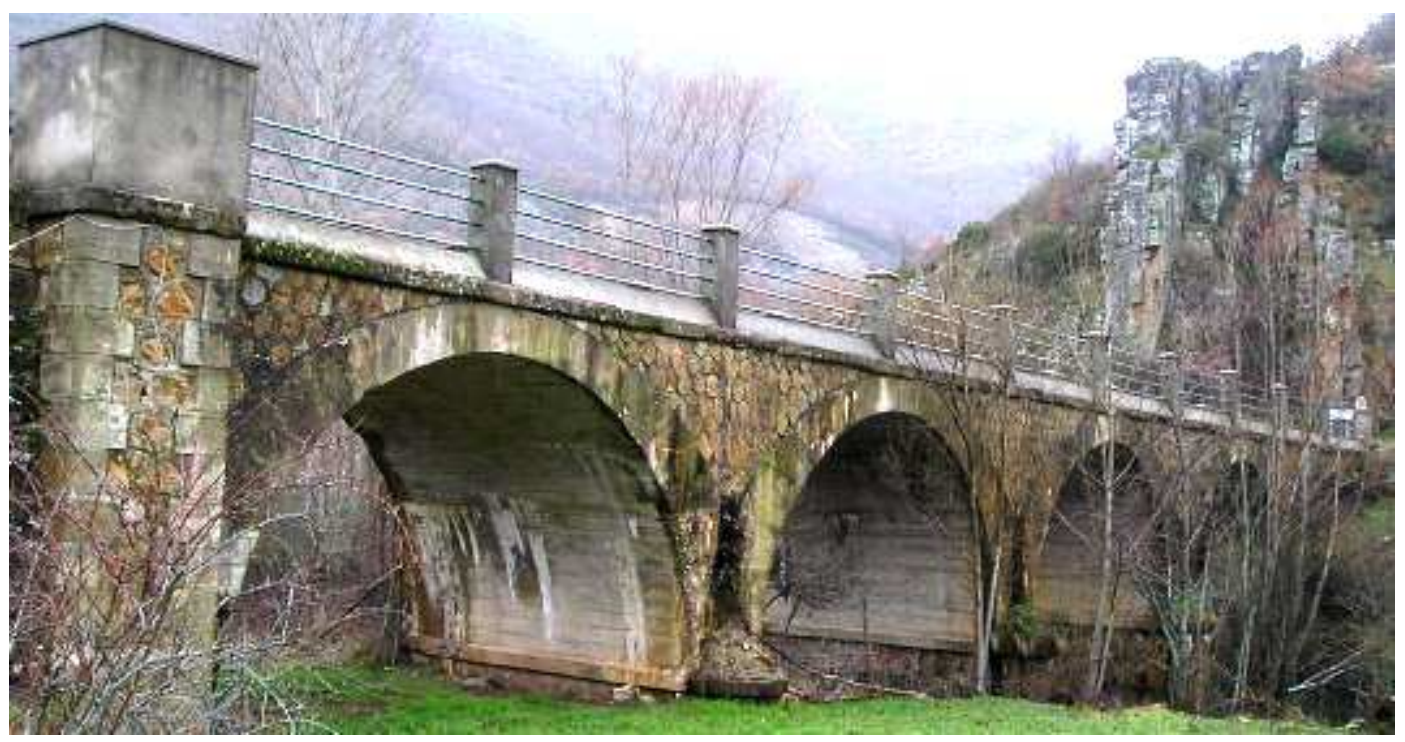

Ilustración 139. Puente hacia Irede. Barrios de Luna.

\subsubsection{Viaductos}

Los viaductos comenzaron a erigirse de forma masiva a principios del siglo $\mathrm{XX}$, aunque ya existían algunos modelos en el siglo XIX especialmente relacionados con la arquitectura del hierro. Estas construcciones se efectuaban principalmente para el paso de grandes valles o barrancos. Con el cerramiento del embalse la carretera de la Magdalena-Belmonte quedó anegada, por lo que se hizo necesaria la construcción de un nuevo trazado con dos tramos de viaductos. Ambos puentes se levantaron a la vez y con similares características para rentabilizar los gastos. Sin embargo el ahorro presupuestario también repercutió en la calidad del material, lo que ocasionó a la larga su destrucción.

En el proyecto inicial de las obras comenzadas en 1950 los viaductos constaban de siete vanos de medio punto de $17 \mathrm{~m}$. de luz, en alineación recta y dos accesos en curva de dos y tres vanos respectivamente de medio punto y $6 \mathrm{~m}$. de luz ${ }^{626}$. Debido a los fallos mecánicos de ambos viaductos éstos tuvieron que ser reparados y transformados con posterioridad.

\footnotetext{
${ }^{626}$ A.G.C.H.D. Informe de la comisión técnica del derrumbamiento del viaducto de Oblanca. Embalse de Barrios de Luna. C/01301-2. Nº 5834. Año 1973.
} 


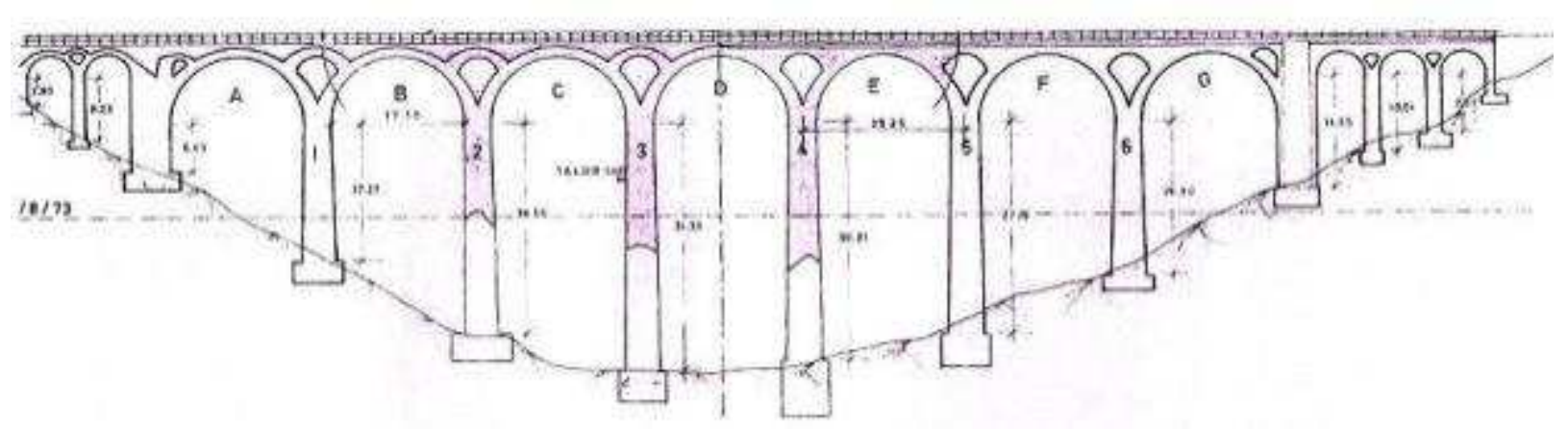

Ilustración 140. A.G.C.H.D. N$^{\circ}$. 5834. Viaducto de Oblanca según su plano original.

Las obras para la construcción del viaducto de Oblanca comenzaron en 1950 y finalizaron tres años más tarde. El viaducto estaba proyectado con una longitud de cerca de los $160 \mathrm{~m}$. y un total de siete arcos de medio punto, en alineación recta, con una luz de $17 \mathrm{~m}$. y dos arcos a los extremos en curva de $6 \mathrm{~m}$. La altura máxima era de $24.10 \mathrm{~m}$. en el arco central. Los materiales utilizados fueron el hormigón en masa y la mampostería para las pilas. Debido a los problemas de asiento los cimientos se profundizaron y los pilares, que en un principio eran de piedra, se reforzaron con hormigón.

Los continuados problemas de inestabilidad del firme del viaducto aconsejaron la restricción en la circulación por el puente a vehículos de más de cinco toneladas. La inestabilidad del puente era tal que la línea de transporte de Martiniano Fernández tuvo que obligar a sus pasajeros a atravesar el viaducto a pie.

Según el informe se había empleado hormigón de mala calidad, lo que provocó el despido del encargado de la contrata, hecho que ya había ocurrido con el anterior ${ }^{627}$.

En la madrugada del 14 de agosto de 1973, se desplomó una de las bóvedas del viaducto de $24.10 \mathrm{~m}$. de altura ${ }^{628}$.

Para restituir el tráfico sobre Oblanca, se proyectó un nuevo viaducto en 1973 por el ingeniero D. Antonio López Peláez ${ }^{629}$. El nuevo plan se concibió con tramos rectos de hormigón prefabricado, soportados por seis pilas prismáticas de $21 \mathrm{~m}^{2}$ cada

\footnotetext{
${ }^{627}$ A.G.C.H.D. C/01301-2. №. 5834. Año 1973.

${ }^{628}$ ABC Madrid. "Se inician los trabajos de construcción del viaducto de Oblanca". 3/10/1973, p.45

629 A.G.C.H.D. C/01301-2. No 5834.
} 
una. La altura máxima de cada pila es de $40 \mathrm{~m}$. y la mínima de $15 \mathrm{~m}$. Consta de ocho vanos, el central más grande, con una luz de $29 \mathrm{~m}$. y $22 \mathrm{~m}$. para los vanos laterales ${ }^{630}$.

El tablero está formado por vigas en $U$ de acero pretensado y prefabricado que se van acoplando unas a otras. La longitud total del viaducto es de $225 \mathrm{~m}$.

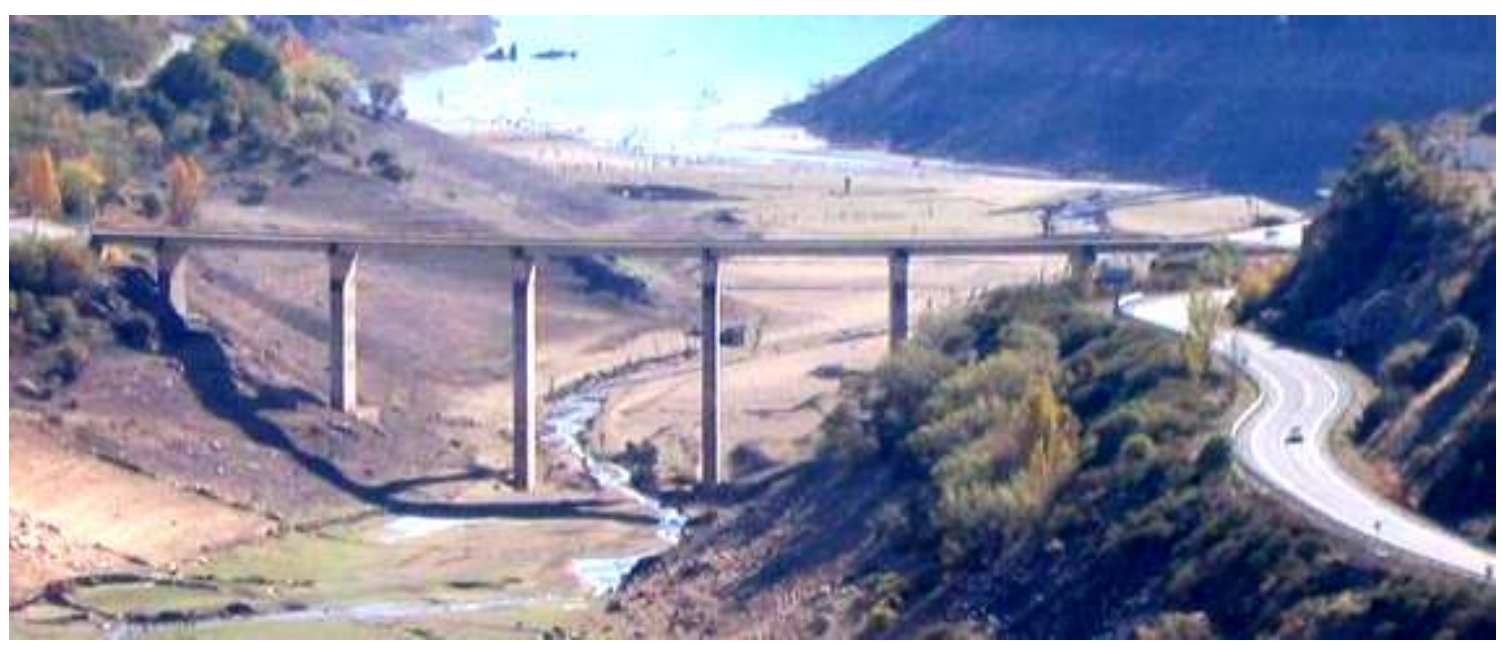

Ilustración 141. Vista general del nuevo viaducto de Oblanca. Año 2012.

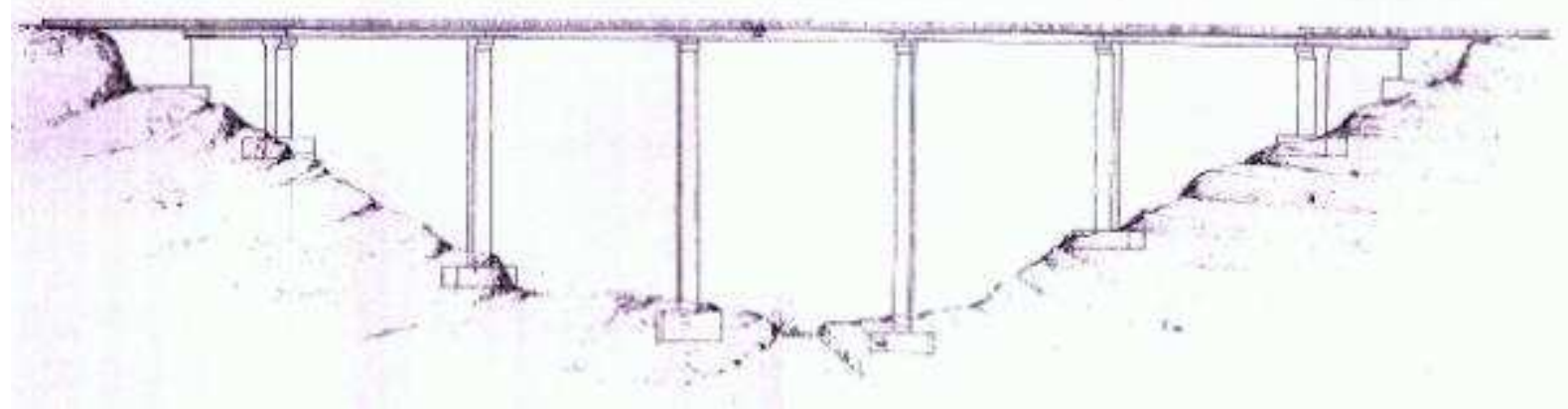

Ilustración 142. A.G.C.H.D. C/01301-2. Nº . 5834. Año 1973.

\section{$\underline{\text { Viaducto de Aralla }}$}

El viaducto de Aralla, situado en las proximidades de San Pedro de Luna, comenzó a construirse en 1953 tras haberse finalizado el de Oblanca. Sus características eran similares al anterior, conteniendo un total de nueve arcos de medio punto de $17 \mathrm{~m}$. de luz en el arco central y una longitud de cerca de los $170 \mathrm{~m}$. Los arcos tienen un vano interior para aligerar el peso de la estructura.

630 A.G.C.H.D. C/01289-4. No 5784. 


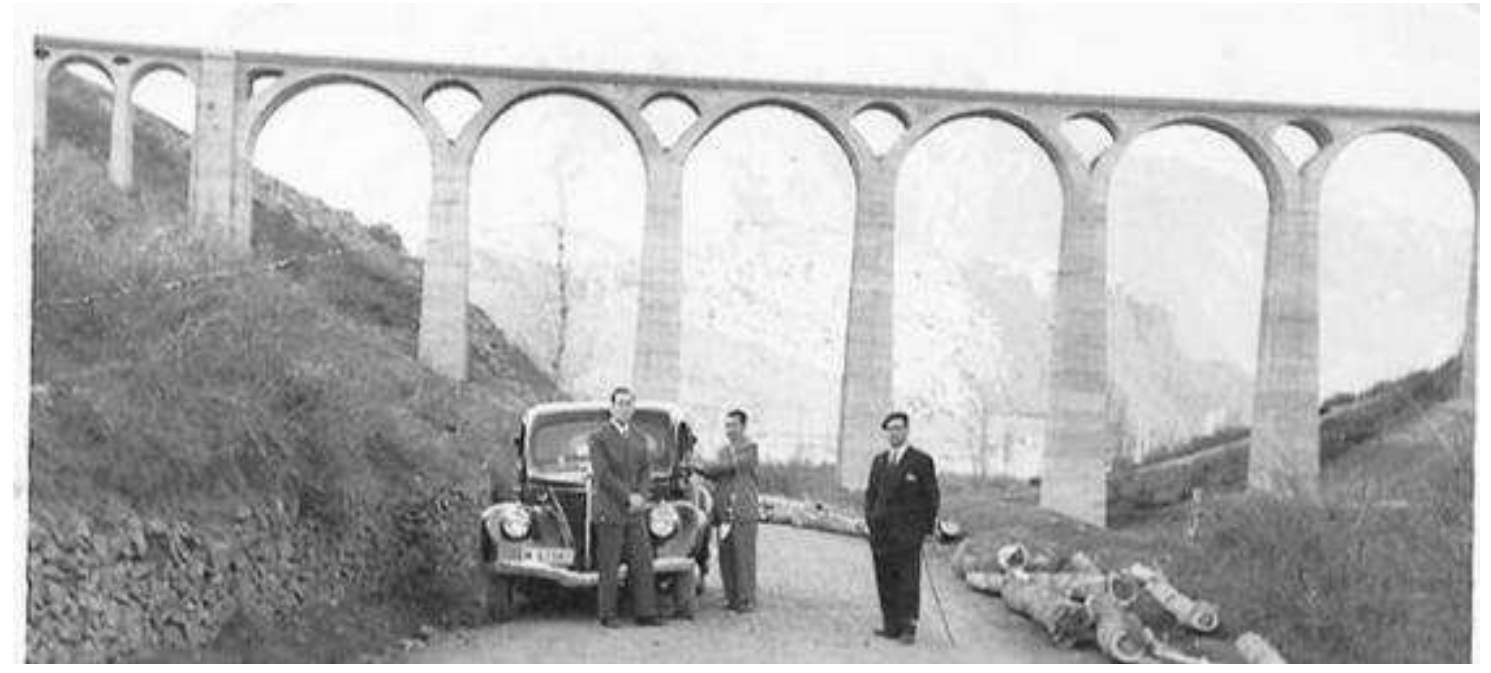

Ilustración 143. Viaducto de Aralla. Fondo fotográfico I.L.C.

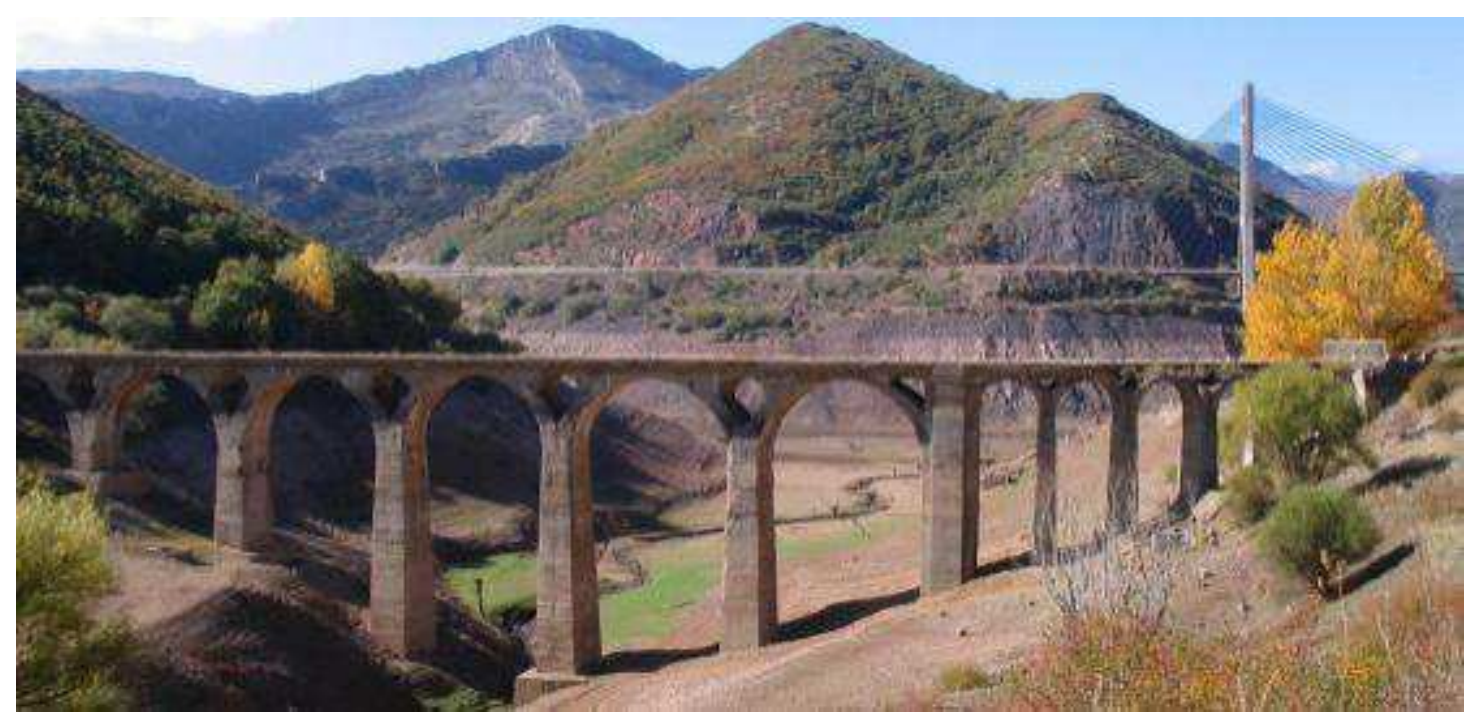

Ilustración 144 A.G.C.H.D. Nº 5834. Viaducto de Aralla en el año 2009.

Tras el derrumbe del viaducto de Oblanca se cierra el tráfico en el de Aralla. Para restituir la circulación lo más rápidamente posible, y así volver a comunicar los pueblos que quedaron aislados, se proyectó un tramo de carretera que bordeaba el Valle y aumentaba la longitud de la vía. Esta opción se escogió por ser mucho más barata y presentar menores riesgos que la reparación del puente. 
5. CAUSAS DE DEGRADACIÓN 
En este último capítulo se reúnen, de manera general, todos los condicionantes que han ocasionado la pérdida del patrimonio inmueble de la ZACEL debido, directa o indirectamente, a la construcción del embalse de Luna. A partir del conocimiento de los bienes de los que constaba y lo que hoy en día se conserva se podrán sacar las conclusiones para descifrar el origen de su desaparición y los procesos degradantes a los que estuvieron y siguen estando sometidos.

Cronológicamente el punto de partida de la degradación del Valle de Luna es la aprobación definitiva del proyecto de construcción de la presa de Barrios en 1945. A partir de este momento se produce un cambio gradual en el paisaje cultural y social de la ZACEL cuyas consecuencias seguirán afectando al patrimonio hasta nuestros días.

\subsection{LOS ESTUDIOS SOBRE LA DEGRADACIÓN.}

El primer paso para esclarecer las causas de degradación ha sido el estudio acerca de todos los agentes que han intervenido en la desaparición de los bienes de la ZACEL, aislando aquellos aspectos que tienen que ver de manera particular con la construcción del embalse. El conocimiento y el tratamiento metodológico adecuado referente a los hechos resultan fundamentales a la hora de sentar las bases de este trabajo. Por ello es necesario analizar las publicaciones relacionadas con los procesos de degradación de los bienes inmuebles ${ }^{631}$.

De las fuentes consultadas en relación a los agentes de destrucción que afectan al patrimonio de la ZACEL, cabe destacar aquellas que describen de manera genérica estas circunstancias. La obra de José Coscollano ${ }^{632}$ ha sido una de las más completas e importantes a la hora de elaborar las pautas, pues en ella se han identificado de manera clara y precisa los aspectos que integran la degradación de los edificios. Su repaso por los procesos de restauración, unido a cada una de las acciones que dañan los diferentes tipos de construcción, ha sido una guía muy útil para conocer las causas generales que intervinieron en la evolución degenerativa de los bienes inmuebles. Igualmente interesante ha sido la extensa publicación de Juan Monjo Carrio ${ }^{633}$ referida a las

\footnotetext{
${ }^{631}$ Hay que señalar que la casi totalidad de las obras están relacionadas con los métodos de restauración dejando tan sólo los capítulos introductorios a las causas de destrucción.

${ }^{632}$ COSCOLLANO RODRÍGUEZ, José. Restauración y rehabilitación de edificios. Madrid, 2003.

633 MONJO CARRIO, Juan. Patologías y técnicas de intervención en estructuras arquitectónicas. Madrid, 2001.
} 
patologías arquitectónicas. Su obra profundiza en los aspectos tradicionales de agresión estableciendo una serie de agentes de carácter humano que afectan no al edifico unitario sino al conjunto arquitectónico en sí. El texto incide en la importancia de partir de un punto inicial del cual se desprenden el resto de agresiones.

La obra de Salvador Vicenc García Fortes y Nuria Flos ${ }^{634}$, se ajusta a aspectos arqueológicos abriendo el campo hacia los bienes muebles. Su publicación retoma un elemento clave tal y como es la pérdida de unos bienes materiales y su correspondiente traslado hacia otros lugares donde desaparece su significación y sentido inicial, como es el caso de la zona que nos ocupa.

Junto a estas obras de carácter general encontramos otras muchas que indagan en los males que afectan particularmente a algunos materiales. Tal es el caso de la obra de Alejandro López de Roma ${ }^{635}$. Dicho estudio está dedicado a la conservación de los diferentes tipos de maderas que han sufrido un deterioro causado por el medio subacuático. A pesar de que la mayoría de los ejemplos analizados se basan en los problemas relacionados con el mar, sin embargo existe un apartado destinado a la madera sumergida en agua dulce que ha aportado datos relevantes a la hora de esclarecer las consecuencias de la inundación al respecto.

En la bibliografía existen otras obras relacionadas con los diversos procesos de restauración. Referente al estudio destacamos la obra de Ángel Fernández Muñoz y Demetrio Gaspar Tebar ${ }^{636}$ pues en sus investigaciones trata de las afecciones de las estructuras hormigonadas que también se detectan en el inundado Valle. En otras obras como la de Vicenc Gibert y Joseph López ${ }^{637}$ se presentan las causas degradantes de la madera y sus interacciones con el medio.

En conjunto, todas estas publicaciones tienen en común que el origen de la degradación del patrimonio es causado por múltiples factores que a veces son consecuencia unos de otros y que unidos desencadenan una pérdida sustantiva que se agrava aún más con el abandono por parte del hombre.

\footnotetext{
${ }^{634}$ GARCÍA FORTES Salvador y FLOS TRAVIESO Nuria. Conservación y restauración de los bienes arqueológicos. Madrid, 2008.

${ }^{635}$ LÓPEZ DE ROMA, Alejandro. "Conservación y tratamientos de maderas extraídas en un medio subacuático" en La madera en la conservación y restauración del patrimonio cultural. Madrid, 1985.

${ }^{636}$ FERNÁNDEZ MUÑOZ, Ángel. Restauración Arquitectónica. Valladolid, 1992. GASPAR TEBAR, Demetrio. "Durabilidad del hormigón y los materiales pétreos" en Seminario 51 del CEMCO. Madrid 1988.

${ }^{637}$ GIBERT, Vicenç y LÓPEZ, Joseph. Aula de madera. Restauración. Barcelona, 1999.
} 


\subsection{LA LEGISLACIÓN ESPAÑOLA Y LA PROTECCIÓN DEL PATRIMONIO EN EL EMBALSE DE LUNA}

La ley de protección de los bienes, vigente durante las labores de construcción de la presa (1942-1956), era la ley de Patrimonio Artístico Nacional de $1933^{638}$ con algunas normas y disposiciones posteriores, como las leyes y decretos de 1953, 1955, 1958,1963 y $1972^{639}$.

En el período de la Dictadura de Franco las políticas de protección de los bienes se vieron reducidas a la restauración de los monumentos más representativos del bando vencedor destruidos durante la contienda. Se despreciaba el entorno urbano y especialmente las arquitecturas tradicionales ${ }^{640}$ que se suponían subordinadas a las grandes construcciones ${ }^{641}$. Uno de los puntos más importantes era la defensa de los bienes inmuebles con más de un siglo de antigüedad del comercio exterior y la protección de los mismos frente a destrucciones o reformas perjudiciales ${ }^{642}$.

El régimen jurídico de los bienes inmuebles estaba fundamentado en la denominación de Monumentos Histórico-Artísticos. Según el artículo 19.1 de la ley de $1933^{643}$, su venta o traspaso había de notificarse en el Registro de la Propiedad en el cual se declaraba el precio de su venta. La administración poseía un mes para estimar el derecho de tanteo y su posible actuación de conservación. La declaración de edificios tutelados por el Estado debía iniciarse como demanda de particulares o agrupaciones e ir acompañada de un informe previo favorable de las Academias de Bellas Artes e

\footnotetext{
638 Ley del Patrimonio Artístico Nacional, de 13 de mayo de 1933. (L.P.A.N.) Anteriormente la Constitución de 1931 ya había planteado, en su art. 45, la necesidad de protección del tesoro Cultural de la Nación y la creación de un registro de los bienes considerados más importantes.

${ }^{639}$ La disposición del 25-12-1955 desarrolla algunos aspectos ya citados por la ley de 1933 como la prohibición del traslado de monumentos y todo intento de reconstitución, procurando los medios para su conservación y limitándose a restaurar lo imprescindible.

${ }^{640}$ Habrá que esperar hasta la Ley de Patrimonio de 1985 y a algunas recomendaciones internacionales de salvaguarda del patrimonio arquitectónico rural para que los bienes tradicionales sean considerados y protegidos. Recomendación (89) 6 la protección y puesta en valor del patrimonio arquitectónico rural consejo de Europa del Comité de Ministros a los Estados miembros. Adoptada por el Comité de Ministros el 13 de Abril de 1989 en la 425 a reunión de los Delegados de Ministros.

${ }^{641}$ CALDERÓN ROCA, Belén. "La tutela jurídica de los centros históricos: diserciones sobre la antítesis entre teoría y práctica en base a la preservación del valor cultural" en BA artículos, Revista del Departamento de Historia del Arte. Universidad de Málaga, no 25, 2004, pp. 519-553, p. 547.

642 L.P.A.N. Art. 2.

643 Idem. Art. 19.
} 
Historia $^{644}$. La Junta Superior del Tesoro Artístico era el organismo competente para estimar la protección de los monumentos ${ }^{645}$.

La insuficiente legislación, junto con la lentitud de las administraciones a la hora de tomar parte en las decisiones patrimoniales, ocasionó una libre disposición en cuanto a la conservación o destrucción de los bienes de la ZACEL. A pesar de que existían diferentes reglamentaciones como el decreto-ley, de 12 de junio de 1953, que ampliaba, por primera vez, el inventario de bienes patrimoniales: inmuebles u objetos muebles de interés artístico, arqueológico, histórico y etnológico o folclórico, la necesidad de crear una "España verde", para un futuro progreso agrícola, legitimó la desaparición de los edificios por fuerza mayor.

Los diversos vacíos legales de la ley abrieron una serie de dudas acerca de su interpretación y aplicación. Por un lado se prohibía el derribo de inmuebles aun cuando no estuviesen declarados, mientras que por otro lado sólo se intervenían aquellos incluidos en los catálogos monumentales ${ }^{646}$.

En el caso de la ZACEL, el único edificio que estaba catalogado como monumento por Gómez Moreno era el castillo de Barrios de Luna ${ }^{647}$. Sin embargo, durante los procesos de expropiación de los terrenos ocupados para la construcción de la presa no se declaró el desmantelamiento del castillo, por lo que administrativamente éste no iba ser afectado por las obras. La realidad fue muy diferente, ya que los restos de la fortaleza fueron una de las primeras estructuras derribadas para la adecuación de la carretera de acceso a la presa y la construcción de los edificios industriales. El estado de ruina del conjunto y la imposibilidad de su conservación favorecieron el silencio administrativo a la hora de plantear un sistema de protección de un bien que se encontraba declarado dentro de los inventarios monumentales.

La primacía de la ejecución de un proyecto de especial relevancia en el Régimen, como eran los planes de aprovechamientos hidroeléctricos del Estado, justificó la destrucción de los bienes de la ZACEL. A ello se le sumó la inexistencia de un sistema presupuestario que llevase a cabo un estudio e inventariado del patrimonio

\footnotetext{
${ }^{644}$ L.P.A.N. Disposición del 25-12-1955 sobre defensa, conservación y acrecentamiento del patrimonio histórico-artístico nacional, art. 20, art. 27.

${ }^{645}$ CALDERÓN ROCA. "La tutela", p. 541.

${ }^{646}$ GARCÍA FERNÁNDEZ, Javier. "La regulación y la gestión del Patrimonio Histórico-Artístico durante la Segunda República (1931-1939)” en Revista de Patrimonio Histórico. № 1 2007.pp 1-15, P 5

${ }^{647}$ GÓMEZ MORENO. Catálogo, Vid. Barrios de Luna.
} 
que iba a ser anegado ${ }^{648}$. Esta situación no se debió tanto a las dificultades económicas y políticas del momento, sino más bien a la dejadez y falta de conciencia cultural de aquellas personas encargadas de la elaboración de todos los procesos que un proyecto de presa requería. Ello ocasionó que no se promoviese el traslado de los bienes inmuebles más importantes y que ningún edificio del embalse de Luna fuese salvado de las aguas.

La ley de 1933 no era partidaria del traslado de los edificios ${ }^{649}$, salvo en ocasiones extremas como las que se dieron durante los procesos de expropiación de algunos embalses como el caso de San Pedro de la Nave en Zamora u otros en la cuenca del río Miño ${ }^{650}$. Esta práctica no se popularizaría hasta la Conferencia General de París de 1968 a consecuencia de la construcción de la gran presa de Asuán ${ }^{651}$. La mayor crítica del momento hacia el traslado y reconstrucción de los bienes inmuebles afectados por un embalse se basaba en la manera de rehacer los edificios y en la posible variación o cambio estético por parte de arquitectos pertenecientes a una corriente historicista poco respetuosa con el original ${ }^{652}$. El coste económico del traslado suponía el primer obstáculo a la hora de conservar el patrimonio, por lo que apenas se acometieron esfuerzos en este sentido. De los tres grandes embalses que se crearon en la provincia de León durante el Régimen de Franco, el de Villameca en 1947, el de Barrios en 1956 y el del Porma en 1968, ninguno contó con un sistema propio de conservación.

Otra de las cuestiones patentes en la ley de 1933 era la de la propiedad de los bienes. La consideración del patrimonio religioso como privado estipulaba su libre venta, permuta o donación sin necesidad de autorización alguna. Los responsables eclesiásticos poseían libertad absoluta para decidir sobre el futuro de los mismos siempre y cuando no se trasladasen fuera del territorio español ${ }^{653}$.

\footnotetext{
${ }^{648}$ ALVAREZ ALVAREZ, José Luis. "La ley de 1933 y la transmisión de obras de arte "en $B$. ANABAD XXXIII 1983, n 2, pp. 227-234, p. 229

${ }^{649}$ L.P.A.N. Art 19.

${ }^{650}$ PONS SOROLLA Francisco. "Traslado de monumentos en España: Puertomarín” en Arquitectura. $\mathrm{N}^{\circ}$ 36, Madrid, 1961, pp. 17-25, p.18.

${ }^{651}$ MORÁIS VALLEJO, Emilio. "Traslado de edificios históricos, el caso de León durante la etapa franquista” en De Arte, 1, 2002, pp. 113-137, p. 119. A raíz de este hecho ese mismo año se creó la Recomendación sobre la Conservación de los Bienes Culturales que la Ejecución de Obras Públicas o Privadas pueda poner en Peligro del 19 de noviembre de 1968 que dejaba en manos de las administraciones estatales las pautas para una correcta conservación del patrimonio anegado.

${ }^{652}$ GONZÁLEZ-VARAS, Ignacio. Conservación de los bines culturales. Teoría, Historia, principios y normas. Madrid , 2003, p. 514

${ }^{653}$ HERNÁNDEZ HERNÁNDEZ, Francisca. El patrimonio cultural: la memoria recuperada. Gijón, 2002, p. 159.
} 
En relación a la legislación propia de la iglesia católica cabe mencionar la Comisión de Arte Sacro de $1948^{654}$ y el Concordato de 1953 en cuyo artículo XXI ${ }^{655}$ establece que cada diócesis ha de configurar una serie de normas de consolidación y conservación de todo aquel patrimonio que poseyese valor siempre que no estuviese ya incluido en la declaración de Monumento Nacional. Cabe decir que los bienes inmuebles religiosos del Valle de Luna fueron considerados como faltos de ese valor necesario para su conservación por lo que no existió ningún control canónigo que evitase tanto la profanación como la eliminación de sus templos.

El cambio de diócesis en 1954 de los territorios de Luna de la sede de Oviedo a la de León se convirtió en un problema añadido, pues la descoordinación entre ambas diócesis supuso un desorden administrativo que acabó favoreciendo el saqueo del patrimonio religioso.

La destrucción del patrimonio por parte de las instituciones estatales no se paró tras la inauguración del embalse. Entre 1979-82 se llevaron a cabo las obras para la autopista AP-66 en cuyo tramo Oblanca-Caldas de Luna se encontraba el castro de Oblanca. La importancia de este castro fue constatada por César Morán en cuyos dominios encontró importantes objetos arqueológicos. Sin embargo, la falta de rigor a la hora de hacer un estudio de la zona ocasionó que se desmontara la casi totalidad del promontorio. La pérdida del yacimiento se produjo durante el inicio del período democrático, pero en los años previos a la publicación de la Ley de Patrimonio Histórico de $1985^{656}$ (L.P.H.E.). La fecha de entrada en vigor de las políticas de protección fue posterior a la finalización de las obras de la autopista AP-66, por lo que la conservación de los bienes hasta el momento se basó en los postulados de la Constitución de 1978 y en aquellas normas de patrimonio que aún seguían vigentes.

Desde el punto de vista de la legislación actual de la ley de Patrimonio de 1985, la inundación del Valle de Luna no habría sido posible sin una catalogación, estudio de impacto y oposición pública que durante la Dictadura no existió o fue silenciada. Con la vigente legislación, según el artículo 15.5, los bienes inundados pueden ser considerados como zona arqueológica: lugar o paraje natural donde existen bienes muebles e inmuebles susceptibles de ser estudiados con metodología arqueológica,

\footnotetext{
${ }^{654}$ ALMARCHA, Luis. Instituciones diocesanas. León, 1970, pp. 191-209.

${ }^{655}$ MARTINEZ BLANCO, Antonio. "Estatuto civil y concordato del patrimonio artístico y documental de la iglesia" en Anales de la universidad de Murcia, Vol. XXX, N 1-2. Murcia,1972, pp222-254, p. 225

${ }^{656}$ L.P.H.E. Ley 16/1985, de 25 de junio.
} 
hayan sido o no extraídos y tanto si se encuentra en la superficie, en el subsuelo o bajo las aguas territoriales españolas ${ }^{657}$.

El cambio de mentalidad con respeto al patrimonio anegado en la provincia de León se vio favorecido por la oposición de los vecinos ante la construcción de embalses como el de Riaño en 1986 y el apoyo de los medios de comunicación.

La modificación de la L.P.H.E. en 1994, supuso una mejora de aquellos aspectos que no estaban claros acerca del papel de las Comunidades Autónomas y la conservación de su propio patrimonio. A resulta de esto, cada Comunidad va a publicar una serie de leyes exclusivas de su territorio, pues éstas son valedoras y mejor conocedoras de su propio patrimonio. En el caso de Luna nos remitimos a la Ley 12/2002, de 11 de julio, de Patrimonio Cultural de Castilla y León (LPCCyL). En el art. 43.1 se establece que la declaración de zona arqueológica determinará la obligación para el Ayuntamiento en cuyo término municipal radique, de redactar un plan especial de protección del área afectada u otro instrumento de los previstos en la legislación urbanística o de ordenación del territorio que cumpla en todo caso los objetivos establecidos en esta Ley.

Los ayuntamientos y municipios de las inmediaciones no pueden ejercer un mecanismo de control sobre la protección de su patrimonio, pues el territorio colindante al embalse es propiedad de la Confederación Hidrográfica del Duero, quien no posee una política de conservación de los bienes inmuebles. El único aspecto que durante los primeros años reservó el patrimonio fue la propiedad administrativa de los territorios anexos al embalse. Sin embargo, al no poseer la C.H.D. de una guarda y custodia eficiente, esta situación ha conllevado un avance del expolio de los restos que quedan.

El Inventario de los Bienes del Patrimonio Cultural de Castilla y León es hasta ahora el único instrumento de protección, estudio y difusión de los bienes. Para conocer el estado actual de los bienes se ha consultado el Inventario de Fichas Arqueológicas de Castilla y León en referencia a las cartas arqueológicas existentes hasta la fecha (I.F.A. C y L. No 164.). La última carta arqueológica fue realizada por Terra Arqueos desde el $15 / 11 / 2004$ al 15/06/2005. Los datos recogidos se basaron fundamentalmente en las prospecciones de la Carta Arqueológica de 1983-86, los datos recogidos por José Avelino Gutiérrez González publicados en su memoria de licenciatura de 1986 y las

${ }^{657}$ L.P.H.E. Título II de los Bienes Inmuebles. Art 15.5. 
piezas halladas por César Morán Bardón. En ningún caso se hace referencia a las poblaciones anegadas como restos arqueológicos que necesiten salvaguarda.

A pesar de las diferentes políticas de protección y de las numerosas leyes que se hacen cargo del patrimonio en diversos ámbitos, ninguna de ellas ha podido adecuarse a la situación generada por el embalse, lo que ha ocasionado una perdida irremediable de todos los bienes de los que se componía la ZACEL. Aunque los avances actuales en materia de protección son grandes, el patrimonio del embalse de Luna continúa padeciendo en nuestros días un expolio y degradación sin control jurisdiccional alguno. 


\subsection{LA DESTRUCCIÓN DEL PATRIMONIO DE LA ZACEL}

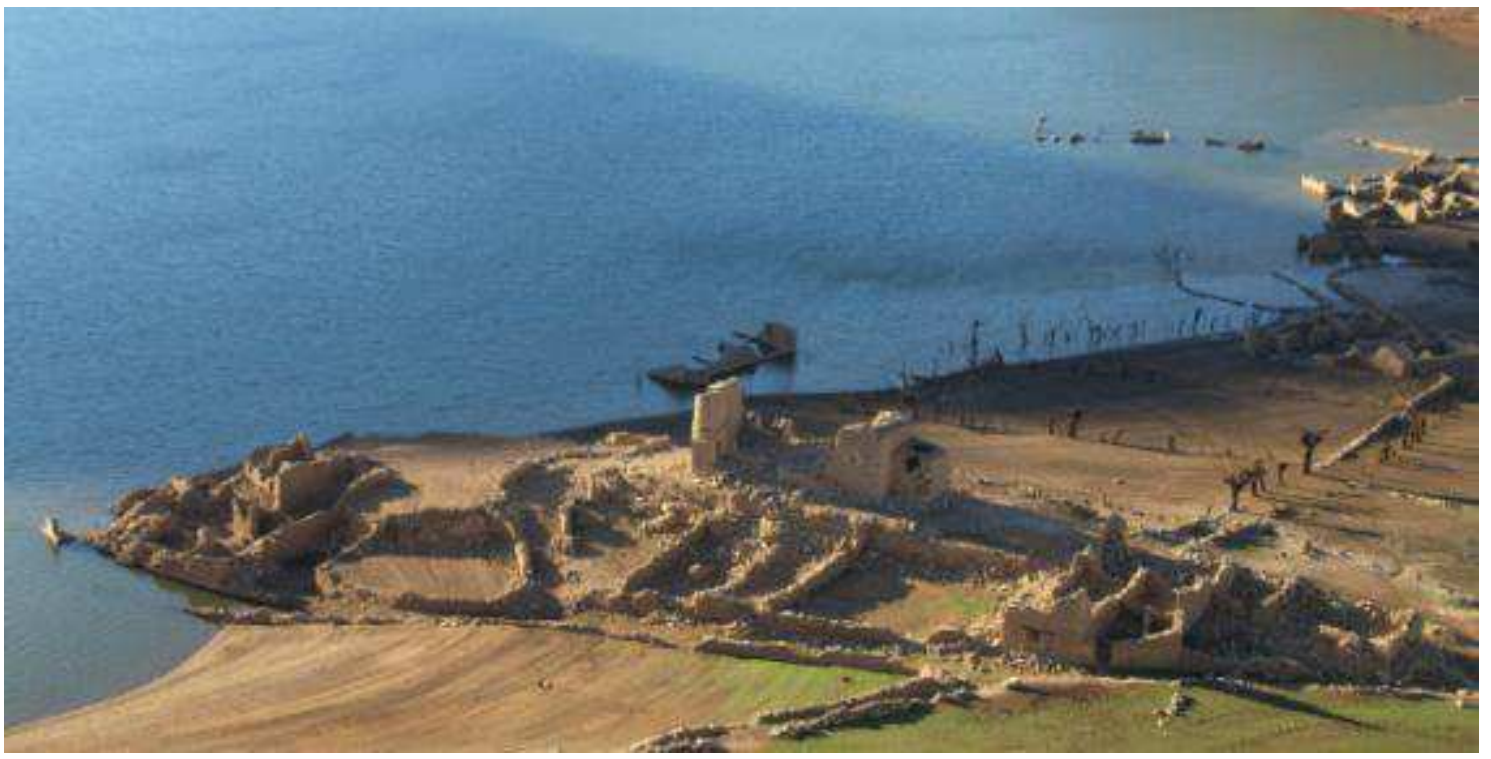

Ilustración 145. Iglesia parroquial Nuestra Señora de Miñera de Luna. Año 2009.

Las causas de degradación de la arquitectura de la ZACEL no devinieron de forma individual, sino que surgieron a partir de la acumulación de varios factores que aceleraron el proceso. El hecho de que los edificios no hayan llegado hasta nuestros días no ha sido sólo consecuencia del embalse, sino también de su mala conservación, el desuso, o los propios defectos constructivos que han ocasionado su ruina. Si se profundiza más en lo que supuso la destrucción de los bienes es fácil observar que algunas de las estructuras ya habían quedado obsoletas y habían sido abandonadas, especialmente aquellas destinadas a albergar una industria tradicional, molinos y batanes, y otras construcciones de carácter secundario como cuadras, pajares, hornos o palomares. Los edificios religiosos, especialmente las ermitas, también habían sufrido un abandono anterior a la construcción de la presa, originado fundamentalmente por su alejada situación de los centros urbanos y por la falta de fieles que las conservasen.

Los patentes beneficios que supuso la construcción del embalse, en una España empobrecida tras las penurias de la posguerra, tuvieron una serie de graves consecuencias para la ZACEL que comenzaron a partir de la adjudicación del proyecto de las obras en 1941 y a la aprobación definitiva del mismo en $1945^{658}$.

La construcción de la presa de Luna se publicitó desde un primer momento como una gran obra de ingeniería que atraería la riqueza del regadío a la provincia 658 BOE. 31 de enero de 1945 "El pantano de los Barrios de Luna" en DIARIO DE LEÓN. Jueves 15 03-1945, p. 4. 
dentro de la política autárquica de la España de los años cincuenta. Los continuos cambios de gobierno, que en el pasado habían ocasionado la renuncia de los proyectos de la presa, provocaron entre la población una cierta incredulidad hacia la consecución de dicha obra. Por ello, a pesar de que desde 1942 se procedió a la construcción de los primeros edificios necesarios para el inicio de las obras, la población continuó con sus labores tradicionales.

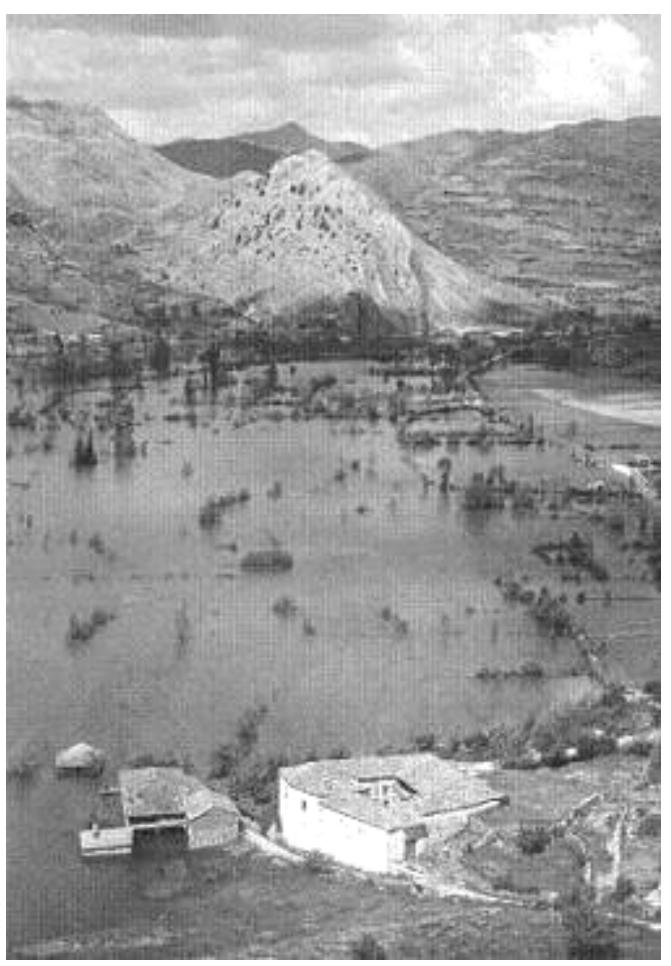

Ilustración 146. Miñera de Luna. Fondo Fotográfico C. H. D. Barrios-Miñera_3_a52

La envergadura de la obra impuso un ritmo considerablemente lento lo que creó cierta inquietud en el gobierno el cual se vio obligado a acelerar las obras. En 1951, estando la pared de la presa a mitad de su ejecución, se comienza a embalsar el agua y por lo tanto a inundar los terrenos más cercanos ${ }^{659}$. Este improvisado cambio cogió por sorpresa a los vecinos, quienes vieron cómo cada semana el nivel de agua ascendía por las calles de las poblaciones más cercanas a las obras, cubriendo poco a poco los edificios e incluso las cosechas de la última siembra, que quedaron sin recolectar. Tal fue la rapidez de la inundación que los propietarios de los inmuebles próximos a las compuertas no tuvieron tiempo de recoger sus pertenencias. C.H.D. puso a disposición de aquéllos grandes barcazas con el fin de facilitar el transporte de todos los enseres hasta la otra orilla del embalse.

El primer caserío desahuciado fue el barrio de Trabanco al que siguieron la Truva junto con las Ventas de Mallo y la Canela. Las últimas localidades desmanteladas fueron Mirantes, Santa Eulalia de las Manzanas y Arévalo ${ }^{660}$, que optaron por la expropiación voluntaria debido a la desaparición de las vegas y por lo tanto de su medio de subsistencia.

\footnotetext{
${ }^{659}$ PRIETO SARRO. “Luna”, p. 341.

${ }^{660}$ Ídem, p. 355.
} 
El 16 de diciembre de $1954^{661}$ se publicó la Ley de Expropiación Forzosa del Embalse de Luna que obligó a todos los vecinos de la ZACEL a abandonar su residencia ${ }^{662}$ a pesar de que el embalsado no se completó definitivamente hasta $1960^{663}$.

Los habitantes cerraban sus casas quizás con la esperanza de que el agua no entrase en ellas, a pesar de que la administración exigió a todos los vecinos la entrega de sus llaves en señal de que cedían su propiedad a la C.H.D. Dada la política de la época no se les dio la posibilidad de asentarse en un lugar previsto, con lo que se produjo un movimiento migratorio desordenado y disperso.

Dieciséis poblaciones se vieron afectadas total o parcialmente por la creación del embalse. Quedaron inundadas: Campo de Luna, Casasola, Cosera, Láncara, Lagüelles, Miñera de Luna, La Canela, La Truva, San Pedro de Luna, Oblanca, Ventas de Mallo. Otras fueron total o parcialmente afectadas como Barrios de Luna, Mirantes de Luna, Arévalo y Santa Eulalia de las Manzanas. Estas tres últimas poblaciones terminaron por desaparecer al ser anegadas las tierras que servían de sustento para sus moradores. En total más de 300 edificios distribuidos en trece pueblos, en los que habitaban alrededor de 750 personas ${ }^{664}$ y $666 \mathrm{~h}^{\mathrm{a}}$ de terreno cultivable, cotos de caza y pesca y diferentes yacimientos de carácter histórico y arqueológico fueron inundados.

La destrucción de los edificios de la ZACEL fue ejecutada en dos períodos bien diferentes. El primero comenzó en 1949 y finalizó en 1964, momento en que se cerraron los expedientes de expropiación de los terrenos anegados. El segundo periodo transcurre desde la anegación total de los restos hasta nuestros días. Cabe destacar el año 2000, en el que C.H.D. inicia la venta legal de los vestigios legitimando el expolio y por tanto favoreciendo su destrucción.

\subsubsection{LA DEGRADACIÓN DE LA ZACEL DESDE 1949 A 1964.}

Durante los años comprendidos entre 1949 a 1964 se llevaron a cabo los trabajos de construcción de la presa, se levantaron los planos de todos los bienes expropiados, se tasó la indemnización correspondiente a ellos y se inundó el Valle.

${ }^{661}$ B.O.E. 16, diciembre, 1954. Sobre expropiación forzosa del Embalse de Luna. León.

${ }^{662}$ GONZÁLEZ-CRISTÓBAL-NISTAL, Movimientos, p. 68.

663 Ídem, p. 22.

${ }^{664}$ CONDE GARCÉS. El pantano, p. 46 
Las primeras obras en ejecutarse se centraron en la cimentación de la presa situada en el barrio de Trabanco de Barrios de Luna. Todos los edificios fueron demolidos para vaciar el espacio en que se iba a asentar la pared de la presa. El puente medieval situado sobre la garganta del Luna fue usado como ataguía para desviar el caudal del río. Sus arcos fueron rellenados con hormigón y, una vez finalizadas las obras, el puente fue demolido.

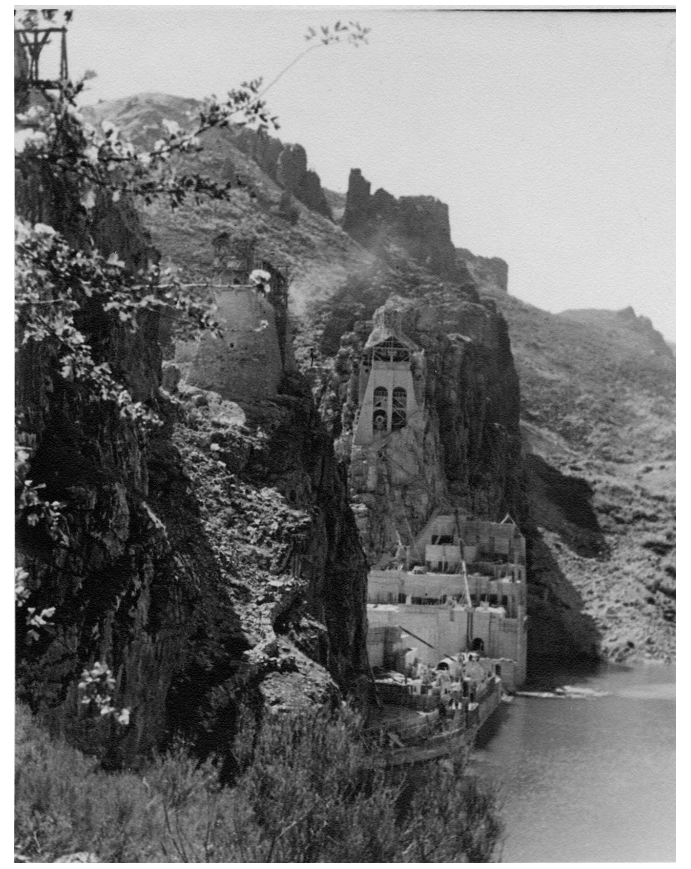

Ilustración 148. Comienzo de la inundación. Fondo fotográfico C.H.D. Barriosllenado_1_a52

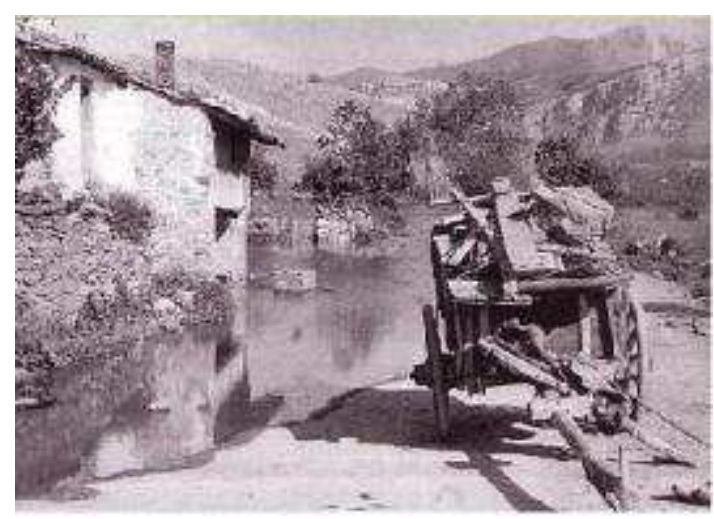

Ilustración 147. Fondo fotográfico I.L.C. La rápida inundación de los terrenos hace apresurado el acopio de los enseres.
El trazado de una nueva carretera de acceso sobre el castillo de Luna eliminó los restos de los dos cubos que se conservaban en la entrada y varió por completo el espacio central sobre el que se disponían los lienzos de las murallas y las torres de la fortaleza ${ }^{665}$. Las estructuras medievales fueron usadas como cimientos para construir los edificios industriales necesarios como las torres de distribución o las torres que soportaban los cables-grúas.

En los primeros años de trabajo de las obras de la presa la gran mayoría de los habitantes de la ZACEL continuaron en sus domicilios ejerciendo las mismas actividades. La única diferencia con respecto al pasado fue que no se acometieron arreglos en los bienes deteriorados. Este es el caso del puente de S. Lorenzo de Miñera en el que las pilas externas fueron dañadas a causa de una crecida por lo que se optó, ante la inminente anegación del embalse, por parchear el problema creando una rampa de madera para facilitar su acceso temporal.

Como se ha citado anteriormente, en 1951 se comienza a embalsar el agua a pesar de que la pared de la presa aún no estaba finalizada. Se produce entonces el mayor ${ }^{665}$ GARCÍA SUÁREZ. Una historia, p. 19. 
proceso de desmantelamiento de los bienes de la ZACEL. A pesar de que en 1949 se habían llevado a cabo los estudios de las expropiaciones, entre $1952-1964^{666}$, se abrió un segundo pliego de indemnizaciones a causa de las peticiones de los vecinos de algunas poblaciones como Santa Eulalia, Arévalo y Mirantes que solicitaron una expropiación voluntaria.

En las expropiaciones no se incluían los bienes muebles, enseres personales y ciertos materiales estructurales. Debido a esta situación, los propietarios de las casas fueron los primeros en desmantelar parte del armazón de sus hogares para reutilizarlos en la construcción de nuevos edificios en localidades próximas al embalse. Los haberes privados, como los aperos de labranza o el mobiliario, fueron recogidos por los propios dueños para continuar con las labores agrícolas tradicionales en otros lugares.

Una vez que los antiguos propietarios hubieron retirado todos los materiales que consideraban precisos, la administración envió a personas dedicadas a la venta, como anticuarios y particulares, que recopilaron las piezas de mayor valor económico. Los materiales más apreciados fueron las tejas, debido a su utilidad y carestía, las puertas, las ventanas, las vigas de madera y los dinteles, estos últimos poseían inscripciones correspondientes con el año de construcción de la casa y por lo tanto contenían un valor estético. Los siguientes materiales más valorados fueron todos aquellos realizados en metal, como rejas, balaustres, cocinas, llamadores o cerraduras. La venta de los objetos metálicos a anticuarios, chatarreros o su utilización decorativa, muy por encima del valor funcional, ocasionó que la práctica totalidad de ellos desapareciera antes de la inminente llegada de las aguas.

Los bienes de titularidad pública se dispersaron a causa de la venta, los traslados y los robos. El material de alguno de los edificios públicos fue vendido y sus beneficios repartidos entre los miembros de las Juntas Vecinales. Otras construcciones, como las fábricas tradicionales o los puentes, se desmantelaron de manera caótica. Los sillares que primero se arrancaron fueron los más accesibles, como los pretiles de los puentes, quedando el resto bajo las aguas. Se observa este fenómeno en los puentes de Miñera, San Pedro y Oblanca y en las arquitecturas industriales tradicionales del resto de poblaciones. Las pilas, fregaderos y ruedas de molino se destinaron en la decoración de embozados de corrales como en Mora o se recolocaron en las plazas públicas de los pueblos aledaños de Barrios, Pobladura y Miñera. Los bienes de los concejos se

${ }^{666}$ A.G.C.H.D. Mirantes de Luna. C/ 05490-1. № 5468. Año 1960. 
enviaron a los cercanos ayuntamientos de Barrios y Sena. Aquellos que poseían un carácter especial, como los escudos, fueron objeto de comercialización. Es el caso del escudo de los Águila en Lagüelles, que fue vendido a un vecino de Torrebarrio junto con los sillares mejor labrados de la casa que lo contenía ${ }^{667}$.

La documentación civil paso a manos de alcaldes, jueces, secretarios, etc., que la conservaron en sus casas hasta que fue depositada parcialmente en el Archivo Provincial de León. Los archivos parroquiales se enviaron al Archivo Diocesano, a otros ayuntamientos o quedaron custodiados por particulares.

El Estado no intervino en la compra-venta de ninguna propiedad, con lo que la pérdida de su patrimonio se vio favorecida por la libertad incontrolada que se dio a las autoridades civiles y religiosas para disponer de los bienes. La problemática a la hora de elaborar un inventario de los bienes expropiados, a causa de la dificultad de establecer su legitimidad, trajo como consecuencia la dispersión y en el peor de los casos la pérdida y desaparición de las obras. En los casos del patrimonio religioso éste acabó muchas veces redundando en beneficio económico de los responsables de las parroquias $^{668}$. D. Eladio, párroco de Sena y D. Mariano, de Miñera, se hicieron cargo de la reorganización de la gran mayoría de los objetos litúrgicos. Las imágenes más valiosas fueron vendidas a anticuarios o coleccionistas, mientras que las obras de menor valor se dispersaron entre el robo y el traslado a otros lugares.

El clamor popular propició que ciertas figuras y retablos, que poseían una devoción especial, se llevasen a otras parroquias aledañas como Barrios, Mallo, Sena o Caldas. En otros casos el saqueo de las iglesias era tan evidente que los propios vecinos debieron llamar a la Guardia Civil para denunciar las malas prácticas de algunos de estos párrocos. Los periódicos, en especial el Diario de León, se convirtieron en las armas usadas para poner de relieve el problema del robo continuado ${ }^{669}$. Sin embargo los propios vecinos de las poblaciones cercanas también se convirtieron en expoliadores del patrimonio religioso al esconder en sus casas muchas imágenes de devoción.

No obstante, algunos otros vecinos cumplieron una gran labor a la hora de recuperar las imágenes de culto y evitar la dispersión. Destacamos a Ernesto Tuñón y su mujer que promovieron la conservación de muchas de las figuras gracias a su traslado a

${ }^{667}$ CIMADEVILLA SANCHEZ. Repertorio, Vol. III, p. 17.

${ }^{668}$ AMOR TAPIA, Ma Luisa. El patrimonio cultural castellano expoliado. Burgos. 2008, p. 184.

${ }^{669}$ Destacamos alguna de las noticias firmadas por ALONSO PÉREZ Enrique "Los espectros del embalse de Luna" en Diario de León, publicado el 21 de diciembre de 2008. http://www.diariodeleon.es/noticias/ 
iglesias cercanas como Robledo o Caldas. Sin embargo ello conllevó a su vez otro tipo de degradación colateral pues las iglesias que se convirtieron en contenedoras de las nuevas imágenes eliminaron sus propios bienes por encontrarse en peores condiciones que las recién llegadas.

Las Juntas favorecieron la reutilización de los elementos constructivos de las iglesias como fue el caso de la iglesia de Miñera. Su pórtico pétreo fue trasladado a Mallo para sustituir el que poseía levantado en madera. Las piedras que conformaban la bóveda se trasladaron a los Barrios de Luna y Vega de los Caballeros para reutilizarlas como material para la construcción de edificios particulares.

La dificultad de trasladar los grandes retablos ocasionó la pérdida o mutilación de muchos de ellos. El precio del traslado de dichos conjuntos no entraba dentro de las indemnizaciones, por lo que su coste debía ser sufragado por las propias parroquias ${ }^{670}$. Esta situación propició el abandono de muchos de los retablos y la amputación de otros para facilitar su transporte y adecuación a los nuevos templos.

\subsubsection{Los expedientes de perjuicios}

Desde el inicio de las obras la C.H.D. intentó mantener un mecanismo de arbitraje entre los intereses justos de las tierras y de las viviendas expropiadas. Sin embargo dichos expedientes establecían unas cuantías teóricas basadas en la calidad de los materiales de los edificios y las dimensiones sin tener en cuenta el valor social de la pérdida de los terrenos inundados. Las prisas por la ejecución de un proyecto, que ya estaba replanteado desde comienzos del siglo XX, obligaron a redactar una lista muy similar basada en el justiprecio que se había utilizado en la presa del Ebro, de reciente construcción $^{671}$.

El perito de la administración estableció en el pliego de observaciones distintos conceptos de expropiación en el que se incluían las propiedades que iban a ser anegadas, aquellas que quedaban fuera del embalse pero no era posible su uso y aquellas que se veían afectadas por la ocupación de las nuevas vías y caminos ${ }^{672}$. Dentro

\footnotetext{
${ }^{670}$ A.G.C.H.D. Expediente de expropiación en el término de Láncara. C/05468-2. № 4498. Año 1956. El traslado de las imágenes y otros enseres aprovechables costó 10 pts.

${ }^{671}$ A.G.C.H.D. Expediente de expropiación del Embalse de Barrios de Luna en el término de Láncara, distrito de Lagüelles, fincas segregadas, planos y otros documentos. C/05465. № 4487. Año 1954-1955. ${ }^{672}$ Ibídem.
} 
de estos documentos se dibujaba un plano a escala 1:2000 para cada una de las fincas rústicas y a escala 1:100 para las urbanas.

Junto con la toma de datos se clasificaron las fincas dependiendo de ciertos criterios de valoración referentes a las mejoras realizadas en los dominios rústicos, como la utilización de cercas de mampostería en seco, en barro, en mortero de cal o de sebe. Además, el valor de la finca se acrecentaba dependiendo de si poseía árboles frutales y pozo.

El precio de las expropiaciones se ponderó de forma equivalente en todos los pueblos. El desglose de los precios con respecto a las fincas rústicas era el siguiente:

Prados de regadío permanente: $1.125,00$ pts. /área

Prados de regadío eventual: 725,00 pts. /área

Prados de secano: 500,00 pts. /área

Pastizales y eriales: desde los 140,00 pts. /área para los pastizales de primera calidad hasta las 4,00 pts. /área para los eriales o pedregales.

Huerta: dependiendo de si poseía riego permanente o no las indemnizaciones iban desde los 1.300,00 pts. /área hasta las 400,00 pts. /área.

Cereales: dependiendo de si poseía riego permanente o no las indemnizaciones iban desde los 900,00 pts. /área hasta las 75,00 pts. /área.

Monte: 14,00 pts. /área.

Seto: 90,00 pts. /área.

Alameda: 150,00 pts. /área.

Era. 150,00 pts. /área.

Cercados: dependiendo del material, desde los 40,00 pts, $\mathrm{m}^{2}$ de mampostería en seco hasta las 2,00 pts. $\mathrm{m}^{2}$., el alambre de espino.

Pozos: Entre las 2.500,00 pts., hasta las 1.400,00 pts.

Cauces. 16,00 pts. $/ \mathrm{m}^{3}$.

En cuanto a las fincas urbanas, éstas se tasaban según los metros cuadrados, el material y la calidad de las techumbres.

Solar: 20,00 pts. /área.

Patios o corrales: 112,50 pts. /área.

Tejados de $1^{\circ}$ clase (pizarra, entablado): 325,00 pts. /área.

Tejados de $2^{\circ}$ clase (tejas bien sentadas): 275,00 pts. /área.

Tejados de $3^{\circ}$ clase (teja sobre listones): 220,00 pts. /área. 
Tejados de $4^{\circ}$ clase (panizo): 110,00 pts. /área.

Para los edificios de viviendas se implantaba el siguiente justiprecio. En caso de que las viviendas no alcanzasen estas cifras se aplicó un mínimo de 45.000,00 pts. por cada una:

Planta de $1^{\circ}$ clase: 350,00 pts. /área.

Planta de $2^{\circ}$ clase: 275,00 pts. /área.

Planta de $3^{\circ}$ clase. 192,00 pts. /área.

Planta de $4^{\circ}$ clase: 110,00 pts. /área.

Cobertizo: desde 100,00 pts. /área., hasta 50,00 pts. /área.

Edificio en ruinas: desde 100,00 pts. /área., hasta 75 pts. /área.

Parta los edificios públicos la tasación era diferente.

Iglesia: 1000 pts. / $\mathrm{m}^{2}$ de la planta y 300 pts. $/ \mathrm{m}^{2}$ de la cubierta.

Capilla: 600 pts. $/ \mathrm{m}^{2}$ de planta y 300 pts. la cubierta.

Cementerio: a 125 pts. $/ \mathrm{m}^{2}$

Abastecimiento de aguas: la captación por 500 pts., las tuberías de gres por 20 pts. y la fuente por 100 pts.

Puentes: la calidad y el estado de conservación de los puentes variaban el precio de la expropiación que iba desde las 1.200 pts. en los más pequeños y realizados en madera, hasta las 11.000 pts. los de piedra como el puente de Miñera. ${ }^{673}$

Dentro los expedientes se describían las bases de indemnización de daños y perjuicios de las propiedades y de las actividades económicas del Valle como las lecherías, molinos, fraguas y otras actividades industriales. La maquinaria se pagó a parte dependiendo del valor de ésta. Se incluyó el criterio de abono de las indemnizaciones por los daños económicos en un $15 \%$ del valor de la producción a los propietarios vecinos del pueblo y en un $7.5 \%$ a los forasteros.

Para llevar a fin tan complejo asunto se llamó a reunión a todos los ayuntamientos afectados y se certificó el número de vecinos de cada población y sus respectivas posesiones. Con la recopilación de los datos se redactó un estudio acerca de los justiprecios que se debían pagar a los propietarios. Destacan los gastos derivados por cambio forzoso de residencia, la reducción del patrimonio familiar y la interrupción de las actividades económicas. Dentro del cambio forzoso de residencia se incluyeron los 
traslados de los enseres personales, muebles y animales. El ganado fue vendido en una gran feria común en la población de Casasola. Alrededor de 2000 cabezas de ovejas y cabras fueron comercializadas a Extremadura, mientras que otras tantas se quedaron en la Ribera del Órbigo o Camposagrado.

Las indemnizaciones de las obras comunitarias iban a parar al obispado de León y a las Juntas Vecinales.

Una vez cerrado el embalse, todos los bienes pasaron a ser propiedad de la C.H.D.

El descontento de los antiguos pobladores ante la insuficiencia de las indemnizaciones causó un cierto movimiento reivindicativo que tomó fuerza durante los años previos a la inauguración del embalse. Alguno de los vecinos insistió en entrevistarse con el alto dignatario para solventar el problema, lo que ocasionó tensión entre los encargados de la obra. El propio ingeniero Luis de Llanos tuvo que reunirse con los locales para pedir cierta mediación en el conflicto y evitar así la intervención de la Guardia Civil. El obispo Luis Almarcha, acompañado de su vicario Muñuyerro, natural de la zona, visitó la comarca para reclamar calma y compresión ${ }^{674}$. El problema finalmente se solucionó de la mano del que posteriormente sería el alcalde de Barrios, Jacinto Rodríguez con la aportación de fondos en compensación por la pérdida y el pago puntual de las indemnizaciones. ${ }^{675}$

\subsubsection{La inauguración}

El 24 de septiembre de 1956 Francisco Franco, acompañado de su mujer Carmen Polo y otros altos dignatarios como el obispo Luis Almarcha y el ingeniero Luis de Llanos, asistieron a la clausura de las obras del pantano en una brevísima ceremonia acortada a causa de la lluvia ${ }^{676}$. La noticia fue recogida por la prensa nacional e internacional gracias a la Agencia Router, quien difundió en varios periódicos londinenses el titular de "La gran Presa de Luna"677. Los periódicos locales, como el

\footnotetext{
${ }^{674}$ PRIETO SARRO. "Luna”, p. 346

${ }^{675}$ Ibídem.

676 "Franco inauguró esta mañana el Pantano del os Barrios de Luna y la Central eléctrica de pie de presa" en DIARIO DE LEÓN. Lunes 24 -09-1956. Página 1 y 8. La intensa lluvia deslució una inauguración que se había planteado con un artístico templete en el puente con los colores nacionales

677 "El pantano de los Barrios de Luna, por su importancia y su coste, es la obra más grande realzada en la provincia en los últimos siglos" en DIARIO DE LEÓN. Lunes 22 -09-1956. Página 3 
Diario de León, publicaron con gran solemnidad todo el aparato conmemorativo que incluía un discurso que no llegó a pronunciarse a causa de la intensa lluvia y que se redujo a un único "Arriba España”. Los actos previstos constaban de bailes tradicionales y la entrega de un ramo a Carmen Polo con una carta estratégicamente colocada en la cual se reivindicaba el justo pago de las indemnizaciones. Tras la visita a la presa en coche se procedió a un vino español en la casa de la Administración para posteriormente trasladarse a la central de Mora de Luna en la cual se dispuso una comida a base de consomé y suprema de ave. La comida terminó con premura y la comitiva se trasladó al Hostal de S. Marcos en León para finalmente descansar ${ }^{678}$.

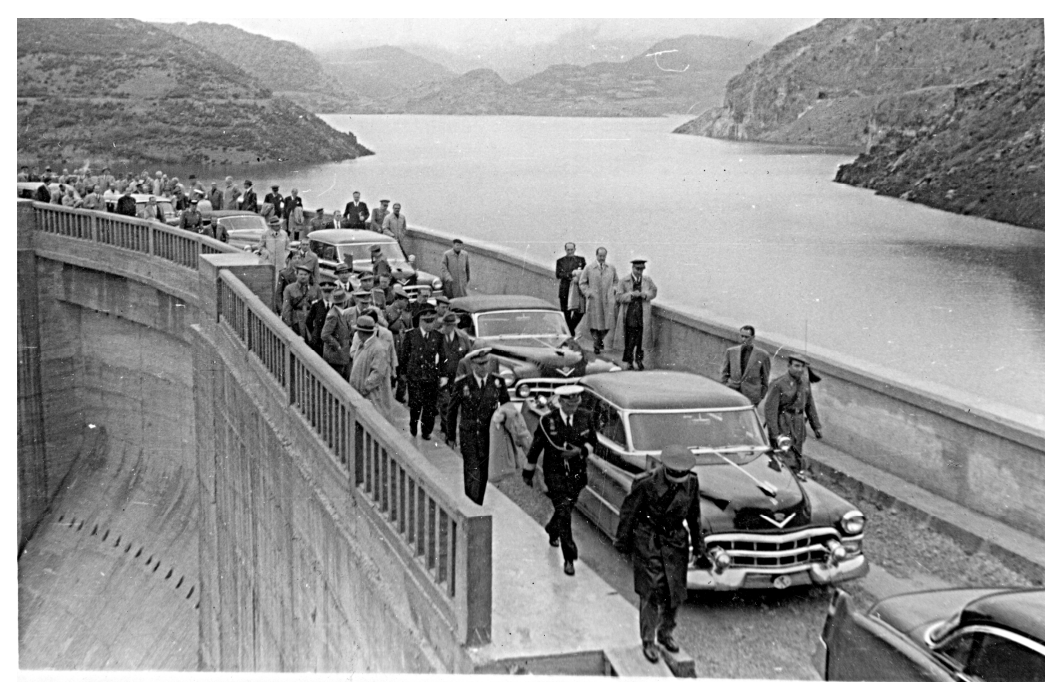

Ilustración 149. Visita oficial del General Franco para inaugurar el embalse de Luna (24-09-1956). Fondo fotográfico del I.L.C.

Es significativo destacar el artículo publicado en el Diario de León dos días antes de la inauguración del embalse en $1956^{679}$, en el que se hace un repaso detallado y casi nostálgico por las localidades y pueblos que quedaron sumergidos y el coste de las pérdidas humanas de algunos trabajadores. Al comienzo de este artículo se exalta la magnitud de una obra de importancia nacional aunque a medida que avanza el texto se muestra de manera descorazonadora la conversión de una tierra de nobleza en lo que se denomina un paisaje típico de las rías gallegas o de los Países Bajos. No duda el periodista en destacar la hidalguía de sus gentes al tener que abandonar sus tierras y sus antepasados, ahora cubiertos por las aguas. Por primera vez, y esquivando la censura, hay una cierta duda de que el esfuerzo haya merecido la pena.

\footnotetext{
678 “Franco inauguró". El obispo Almarcha bendijo las instalaciones en presencia del Caudillo.

679 "El pantano de los Barrios de Luna, por su importancia y su coste, es la obra más grande realizada en la provincia en los últimos siglos" en Diario de León 22, septiembre, 1956.
} 


\subsubsection{Movimientos migratorios}

La expropiación forzosa ocasionó una migración masiva acrecentada por el desarraigo producido por la inundación. Un $26 \%$ del total de la población del término tuvo que ser realojada. La pérdida de la casa familiar suponía el mayor perjuicio no solo económico, sino también moral. La dificultad para encontrar un lugar de similares características era impensable, puesto que las arquitecturas tradicionales habían dado paso a la construcción en ladrillo dentro del núcleo de la ciudad.

Los cambios sociales provocaron una profunda depresión en las gentes del Valle que vieron cómo desaparecían pueblos enteros y recuerdos bajo las aguas. Esta migración se dio no solo en los pueblos inundados, sino también en otros que perdieron gran parte de sus pastos y por lo tanto de su base económica tradicional ${ }^{680}$.

Aunque desde 1951 ya se venían dando los plazos para una paulatina expropiación de las diversas poblaciones, sin embargo en las indemnizaciones no se proyectó un protocolo de reubicación de la población emigrante. Las personas mayores se quedaron en las zonas cercanas, mientras que los jóvenes emigraron a las ciudades ${ }^{681}$. El Régimen ofreció destinos alternativos en aquellos territorios de nuevo cultivo intensivo como el llamado Plan Badajoz. Muchos de los vecinos eligieron lugares más cercanos como La Robla, La Magdalena o casas de protección oficial en San Andrés del Rabanedo, Pinilla, los barrios de Trobajo, Jesús Divino Obrero y el Ejido en León ${ }^{682}$. En otras ocasiones se repoblaron algunos barrios no anegados como el de las Juncarinas, en la antigua Miñera.

5.3.1.2.La actitud de las poblaciones ante la inundación.

No todas las poblaciones sufrieron la misma destrucción ni sus Juntas Vecinales ejercieron las mismas soluciones frente a la llegada de las aguas. En algunos pueblos lo que primó fue el fin económico y la necesidad de compensar las escasas indemnizaciones frente al recuerdo nostálgico de otras poblaciones que prefirieron mantener las estructuras en pie como memoria de lo ocurrido.

${ }^{680}$ SIMONET, Julio E. La arquitectura muerta. Madrid, 2001, p. 106.

${ }^{681}$ GONZÁLEZ-CRISTÓBAL-NISTAL. Movimientos, p. 68. La población se dispersó principalmente hacia los barrios de San Andrés de León.

${ }^{682}$ PRIETO SARRO. "Luna", p. 347. 
La decisión de derrumbar los inmuebles se dejó en manos de las Juntas Vecinales, aunque la mayoría de los pueblos prefirieron mantener sus edificios en pie, sin duda por falta de consenso entre los responsables. Las Juntas de Oblanca, Láncara, Santa Eulalia y Arévalo optaron por desmantelar todas sus estructuras. Otras localidades como Lagüelles, Campo, San Pedro o Mirantes, prefirieron mantener los edificios en pie como recuerdo de sus antiguos hogares. En aquellas localidades como Mirantes y Láncara en las que la inundación no llegó a la iglesia parroquial, ésta continuó abierta para la celebración de romerías.

\section{Arévalo.}

Las expropiaciones ocasionadas por la construcción del embalse de Luna tuvieron como fin la compensación económica de todos aquellos vecinos que se vieron afectados no sólo por la inundación del embalse sino también por los terrenos marginales cercanos a las aguas. Algunas de estas poblaciones como Arévalo, que se encontraba en una cota muy próxima al nivel de inundación de las aguas del embalse, no sufrieron la inundación total, pero todos sus bienes fueron expropiados. En un segundo pliego de indemnizaciones que se dio desde 1952 a 1964, la Junta Vecinal, ante la pérdida de los terrenos de cultivos, optó en 1957 por aceptar la expropiación. Sus vecinos lograron trasladarse a zonas cercanas como Sena o Pobladura ya que la escasa población en el momento de la inundación, apenas 60 habitantes, favoreció el abandono de pueblo.

De entre los edificios expropiados más destacados cabe señalar la ermita del Sto. Cristo de Arévalo cuya imagen fue llevada a Sena de Luna y el molino sobre el arroyo del pueblo por cuya maquinaria se pagó 2.500 pts. También tenía cuatro puentes, dos de ellos sobre el río Abelgas y los otros dos sobre el arroyo Pobladura ${ }^{683}$. El de mayores dimensiones, situado sobre el río Abelgas, se tasó en 8.500 pts. mientras que el resto no superó las 3.000 pts. La totalidad de las fincas fue valorada en 407.291,79 pts.

A pesar de la expropiación, la situación del pueblo en la cola del embalse facilitó que el Común continuase explotando los terrenos de pasto para el ganado la mayor parte

${ }^{683}$ A.G.C.H.D. C/ 05454. № 4479. Año 1957. 
del año en que las aguas del embalse estaban retiradas, por lo que se siguieron ejerciendo las actividades agrarias y ganaderas tradicionales.

\section{Barrios de Luna.}

Barrios de Luna también sufrió la expropiación de varios de sus terrenos. La más importante fue la del barrio de Trabanco y la destrucción de los restos del castillo de Luna.

El barrio de Trabanco se encontraba en la garganta del río Luna, el lugar elegido para levantar la presa de Barrios. Para agilizar el inicio de las obras se dinamitaron los edificios y sus escombros se utilizaron para las obras de desvío del caudal. De esta manera los restos del puente medieval de Trabanco fueron usados como ataguía y posteriormente destruidos.

Los cimientos del castillo de Luna se aprovecharon para colocar las torres de electricidad y las grúas de transporte de material. A su vez, la explanada en la que se encontraba fue desmantelada para construir la carretera de acceso a las obras.

A pesar de todo ello Barrios fue la población más favorecida por la construcción de la presa. Como compensación a los daños sufridos C.H.D. mejoró las vías de comunicación y construyó varios puentes sobre el río Luna, además de benefícios fiscales sobre la explotación de los recursos de la presa. La población también se vio beneficiada por la cantidad de obreros que llegaron de otros lugares para trabajar en las labores de la presa.

Durante los años en que duraron los trabajos, Barrios se convirtió en el centro neurálgico de la actividad económica del Valle. Se multiplicaron las casas de comida, salas de fiesta y hasta un cine. Sin embargo esta riqueza fue estacional y tras el fin de las obras gran parte de los obreros se marcharon.

La iglesia parroquial de Barrios acogió diversos objetos religiosos de otras poblaciones. De Mirantes se trajo el retablo y la Virgen del Rosario, la Virgen en Majestad, S. Blas y el estandarte de la Virgen. De Miñera se transportó el cáliz y la patena donada por el obispo Álvarez Miranda y de Láncara la rejería de la iglesia. 
En la actualidad Barrios de Luna cuenta con 317 habitantes ${ }^{684}$ dedicados al sector primario y de servicios, fundamentalmente gracias a la aportación económica de la presa de Luna.

\section{Campo de Luna}

La expropiación de Campo de Luna supuso el menor desembolso económico para la Confederación debido a su escasa población, apenas 45 habitantes, y la inexistencia de una industria productiva. Su economía se basaba en el cultivo de tierras de secano y prados de regadío para el ganado. El único molino en pie se encontraba derruido con anterioridad al embalse y las reducidas dimensiones de la iglesia parroquial, la más pequeña de la ZACEL, no originaron grandes beneficios por las indemnizaciones.

Ante esta situación la Junta Vecinal de Campo en reunión conjunta y decidió aprovechar la venta de todos los materiales posibles para aumentar el dinero de las expropiaciones, especialmente los de carácter público como la escuela y la iglesia parroquial. La decisión de la venta del resto de edificios fue opcional, a diferencia de Oblanca y Láncara, por lo que aún pueden observarse los restos estructurales de algunas casas de la antigua población.

\section{Casasola}

La población de Casasola sufrió los mismos procesos de expropiación que Miñera, puesto que era considerada como barrio del anterior. En el momento del embargo contaba con 30 habitantes y, a diferencia del resto de los pueblos, su economía se basaba fundamentalmente en la explotación de la serrería, molino y central eléctrica del gran complejo industrial del Molinón. También poseía una ermita dedicada a las Ánimas del Purgatorio, molino, horno eléctrico y fragua. La expropiación del Molinón fue uno de los mayores desembolsos para la administración, cuya maquinaria fue valorada en 253.643 pts. con una indemnización total de 1.046 .813 pts. debido fundamentalmente a la calidad de los materiales con los que estaba confeccionado y las

${ }^{684}$ Fuente. INE. Para el Municipio de Barrios de Luna. 
dimensiones del edificio. El precio pagado por el resto de los edificios de Casasola apenas fue de 676.703 pts. $^{685}$.

\section{Cosera}

Al igual que Campo, Cosera contaba con un escaso número de habitantes, unos 47 en total, lo que supuso un coste menor en las expropiaciones. Su economía estaba basada en la cría de ganado y la pesca de truchas, aunque también se cultivaban cereales como el trigo, el centeno y el lino que se transformaban en los dos molinos harineros de una sola piedra que conservaba. Su iglesia, dedicada a S. Miguel, tuvo un coste de expropiación de 700 pts $/ \mathrm{m}^{2}$ mientras que el coste por el traslado de las imágenes fue de 5000 pts. ${ }^{686}$ El cementerio ya no se utilizaba en el momento de la inundación y los enterramientos se hacían en Miñera, por lo que no se indemnizó por el traslado de los restos.

La construcción de la autopista AP-66 atravesó parte de la roca sobre la que se asentaba la población y cuyo túnel lleva el nombre de Cosera en recuerdo del pueblo

\section{Lagüielles.}

Lagüelles era una de las poblaciones más dinámicas del Valle de Luna. En el momento de la inundación llegaron a contabilizarse 112 habitantes cuya economía se basaba en el floreciente negocio de los numerosos molinos harineros que se situaban a lo largo del arroyo y cuyo estado de conservación era bastante bueno, por lo que fueron valorados por unas 4.000 pts. más otro suplemento dependiendo de la fuerza hidráulica $^{687}$. También se desarrollaron otro tipo de industrias como panaderías y lecherías. Además, Lagüelles era rico en pesca y tenía una caseta destinada a guardar nieve para conservar las truchas del río hasta su venta ${ }^{688}$. También poseía varios edificios públicos como salones y escuelas cuya indemnización repercutió en la propia Juta Vecinal.

\footnotetext{
${ }^{685}$ A.G.C.H.D. C/05439.2. N No 4462. Año 1950.

${ }^{686}$ A.G.C.H.D. C/05430. № 4461. Año 1950.

${ }^{687}$ A.G.C.H.D. C/05465. No 4487. Año. 1954-1955.

${ }^{688}$ PRIETO SARRO. “Luna y sus gentes”, p. 319.
} 
El caso del puente de cemento fue distinto. En 1955 dos tramos cayeron al río con motivo de una avenida y fueron sustituidos por madera ${ }^{689}$. Esto supuso una pérdida de valor a la hora de su tasación por lo que se estimó por separado dependiendo de los materiales de los que constaba ${ }^{690}$.

Cabe destacar el traslado de las imágenes que formaban parte de la iglesia. En Robledo se conservan las obras de Ntra. Sra. de las Angustias, el Cristo Crucificado y S. Ramón. La Magdalena tiene la figura de Ntra. Sra. del Carmen. La figura de S. Mames fue llevada por los propios vecinos a Caldas de Luna, al igual que la imagen de Sta. Bárbara, mientras que la titularidad de la parroquia pasó a pertenecer a Santa Olaja del Porma, que había experimentado un crecimiento importante de población ${ }^{691}$. El total de costos valorados en Lagüelles ascendió a 12.669.224 pts. ${ }^{692}$.

\section{Láncara}

En 1950 Láncara era la cabeza del ayuntamiento y el pueblo que más habitantes poseía, un total de 183, lo que suponía un número elevado de residentes para la época en comparación con el resto de núcleos de las poblaciones cercanas.

Durante los procesos de la expropiación la Junta Vecinal se reunió para decidir acerca del futuro de las construcciones. Para sacar un mayor beneficio de ellas se estimó la eliminación total de todas y cada una de las viviendas para la venta o reutilización de sus materiales de construcción. De entre los edificios más importantes destacaba el ayuntamiento y diversas casas destinadas a escuela y concejo.

La situación del pueblo, en la cola del embalse y la cercanía a las vías de comunicación, facilitó este desmonte y el aprovechamiento continuado de los restos hasta hoy en día. Tan sólo se dejó en pie la iglesia dedicada a S. Martín, pues ésta se encontraba sobre un altozano al cual no llegaba el nivel de inundación de las aguas del embalse. En un primer momento quiso convertirse en abanderada del recuerdo de los pueblos del Valle, sin embargo, tras la desaparición de la población, el edificio se convirtió más bien en un recuerdo olvidado del pasado que en un estandarte de resistencia. Finalmente en 1956 C.H.D. expropió la iglesia con una cantidad de 700 pts.

\footnotetext{
${ }^{689}$ A.G.C.H.D. C/05465. № 4487. Año. 1954-1955.

${ }^{690}$ Ibídem.

${ }^{691}$ Información dada por Elsa y Albito, vecinos de Lagüelles.

${ }^{692}$ A.G.C.H.D. C/05465. No 4487. Año. 1954-1955.
} 
el $\mathrm{m}^{2}$ de planta y $300 \mathrm{pts}$ el $\mathrm{m}^{2}$ de cubierta, las mismas cantidades que se había pagado en el resto de las iglesias. En la expropiación de la iglesia se hace referencia a una indemnización al pueblo por el traslado de las imágenes y otros enseres aprovechables cuyo coste fue de 10 pts. más el traslado de los restos mortales a otras poblaciones cercanas $^{693}$. Los bienes religiosos sufrieron una dispersión grande. El retablo principal de Láncara fue llevado a Pobladura de Luna y como no cabía en el presbiterio, hubo que recortarlo y acomodarlo a su nueva ubicación. A Barrios de Luna fue a parar la rejería de la iglesia.

En total, el valor de la expropiación de todos los conceptos de la población de Láncara ascendió a 21.277.086 pts ${ }^{694}$.

\section{Mallo.}

Durante toda la primera mitad del siglo XX la población en Mallo se mantuvo a la espera de las consecuencias de la construcción del embalse. Una vez finalizada la obra, Mallo pierde el barrio de Las Ventas que constituía un centro poblacional dentro del término con 25 habitantes en el momento de su inundación. Este barrio tuvo un gran despliegue económico debido a la llegada de los inmigrantes a principios del siglo XX que provenían de América y que, enriquecidos por la prosperidad suramericana, construyeron un caserío dedicado especialmente al comercio.

La inundación del barrio de las Ventas supuso la desaparición de las mejores tierras de cultivo de Mallo y la pérdida de uno de sus motores vitales, el comercio. Sin embargo también se vio beneficiado al recibir algunos bienes de las poblaciones anegadas como el retablo de la ermita de S. Lorenzo, la Virgen de Fátima, la campana y el antiguo pórtico de Miñera.

El pueblo quedó aislado no solo por la inundación, sino también, aún después, por la construcción de la autopista AP-66 León-Campomanes. La creación de esta vía rápida podría haber supuesto un aliciente para la población, pero al no crearse ningún acceso, la comunicación sólo pudo realizarse a través de una carretera comarcal. Este aislamiento va a perjudicar a los habitantes, especialmente por la dificultad de su tránsito sinuoso y por la pérdida de población joven, ya que la mayoría de los vecinos son personas de avanzada edad.

\footnotetext{
${ }^{693}$ A.G.C.H.D. C/05468-2. No 4498 . Año 1956.

${ }^{694}$ Ibídem.
} 
Hoy en día Mallo de Luna subsiste gracias al creciente negocio de la ganadería vacuna de alta montaña y la vuelta de algunos de los habitantes especialmente en el verano.

\section{Miñera}

Miñera era una de las poblaciones más grandes del anegado Valle. En el momento de la expropiación contaba con 178 habitantes. La economía se basaba fundamentalmente en la explotación de los prados para el ganado y la agricultura de subsistencia. La industria estaba asentada sobre la proliferación de pequeños molinos harineros y lecherías de la cabaña ganadera.

En $1953^{695}$ se abandona definitivamente el pueblo y comienza la inundación. El coste total de la expropiación fue de 20.594 .992 pts $^{696}$. La Junta Vecinal se reunió ese mismo año para decidir su futuro y seguir el modelo de algunas de las otras poblaciones anegadas. El alcalde de Miñera mandó derruir todos los edificios, pero los propios vecinos del pueblo se negaron a que esto ocurriera, lo que dio libertad para que cada uno escogiera el destino. Se disolvió la Junta Vecinal para que no hubiese escándalos ni motines y gran parte de la documentación del ayuntamiento e iglesia fueron llevaros a Barrios de Luna ${ }^{697}$. Los edificios comunes como la iglesia no se demolieron. Las imágenes más significativas fueron llevadas a poblaciones cercanas, mientras que otras se repartieron entre vecinos devotos del pueblo como la Virgen de las Nieves. A la localidad de Mallo se trasladó el retablo de la ermita de S. Lorenzo, la Virgen de Fátima, la campana y el antiguo pórtico de la iglesia parroquial. En Caldas se encuentra la cajonería de la sacristía y en Robledo la imagen de la Purísima Inmaculada. Otros objetos litúrgicos como el cáliz del obispo Miranda fueron llevados a Barrios de Luna.

A partir del cierre de la presa se anegó el núcleo más importante de Miñera, quedando unas pequeñas tierras en la zona alta que fueron aprovechadas años más tarde para refundar el nuevo pueblo de Miñera por la iniciativa de D. Petronilo Guisuraga. El nuevo asentamiento se ubica en el margen derecha de la carretera la MagdalenaBelmonte con un total de siete viviendas.

\footnotetext{
${ }^{695}$ A.D.L. Cosera de Luna. Libro de fábrica Doc. 1701.

${ }^{696}$ A.G.C.H.D. C/05430. $\mathrm{N}^{\circ} 4461$.

${ }^{697}$ Información dada por Petronilo Guisuraga, natural de Miñera de Luna.
} 


\section{Mirantes.}

La economía de Mirantes se basaba fundamentalmente en la explotación de las vegas y en los recursos ganaderos, especialmente por la producción de leche. La cantidad de lecherías de Mirantes es significativa si se compara con el resto de poblaciones. Las labores de carpintería tradicional también fueron numerosas hasta la aparición de las serrerías eléctricas. Destaca la Venta de la Canela, una agrupación de casas destinadas al comercio que tuvo su origen en un edificio construido por Raimundo Fernández a comienzos de 1900.

En el primer pliego de razonamientos tan solo se expropió la Venta de la Canela y no el grueso de la localidad de Mirantes, pues las aguas no llegaban a inundar la población. Sin embargo, tras ser anegadas las vegas y por lo tanto el medio de vida de los habitantes, la Junta Vecinal decidió la venta posterior de la población en 1960. A pesar de que la iglesia también fue expropiada por un valor de 756.554 pts. ${ }^{698}$, ésta siguió manteniendo su función litúrgica unos años más hasta que se cerró definitivamente en 1971. Entonces sus imágenes principales fueron trasladadas a otras localidades como Barrios de Luna, que conserva el retablo y la Virgen del Rosario, la Virgen en Majestad, S. Blas y el estandarte de la Virgen. El resto de materiales fueron reutilizados en otras obras como la madera del suelo en la escuela de Vega de Robledo.

\section{Oblanca.}

En el momento de la expropiación ${ }^{699}$ Oblanca se había convertido en uno de los centros más importantes del Valle debido a su floreciente industria comercial basada en la explotación de productos lácteos como la leche desnatada y la manteca. Existía además una carnicería, dos talleres de carpintería, herrería y dos fraguas, una sastrería y un comercio de comestibles que a su vez era estanco oficial. César Morán ${ }^{700}$ también relata la existencia de una fábrica de paños de Caldas. La población en 1950 ascendía a más de 138 habitantes $^{701}$.

\footnotetext{
${ }^{698}$ A.G.C.H.D. C/5468. Año 1960.

${ }^{699}$ A.G.C.H.D. C/05461-1. No 4484. Año 1954-55.

${ }^{700}$ MORÁN BARDÓN. Por tierras, p. 183-186.

${ }^{701}$ Dirección General de Estadística del 31 de diciembre de 1940.
} 
Ante la inundación y la pérdida de todas las propiedades la Junta Vecinal de Oblanca se reunió para tomar una decisión. Se resolvió, en una votación conjunta, derribar todos los edificios y vender los escombros para sacar un mayor beneficio por las indemnizaciones. La tierra vegetal de los prados fue aprovechada para abonar los terrenos próximos. El escombro de los edificios, de los que previamente se había extraído la piedra, madera y tejas, se utilizó como relleno de carreteras y firme de los desniveles $^{702}$.

Los bienes eclesiásticos se llevaron a otras parroquias. Sena de Luna obtuvo imágenes de la Virgen del Perpetuo Socorro de Oblanca y Vega de Robledo posee la figura de S. Roque.

Hoy en día apenas se pueden reconocer los barrios que conformaban el pueblo de Oblanca, puesto que tan solo se perciben acumulaciones de los restos de escombros que quedaron.

\section{San Pedro de Luna.}

San Pedro de Luna contaba con una población de 111 habitantes dedicada al cultivo de las tierras y al ganado, con algunos oficios tradicionales como el de tejedor $^{703}$. Durante el siglo XX se produjo un desarrollo económico basado en la proliferación de una serie de comercios que le dieron cierta prosperidad y le convirtieron en centro comercial de la comarca. Entre los comercios cabe destacar un chocolatero, una droguería, un herrero, un cantero, una carnicería, una fábrica de gaseosas, dos panaderías y una venta de vino. También poseía una central eléctrica que daba luz a las poblaciones cercanas y a los hornos eléctricos de pan.

Tras las expropiaciones del embalse la Junta Vecinal se reunió para decidir el futuro de las edificaciones que iban a quedar anegadas. Se dio libertad a cada vecino para que recogiese todo material reutilizable por lo que algunas edificaciones aún mantienen sus muros. En total, la expropiación de San Pedro costó 7.548-610 pts ${ }^{704}$.

El coste de la expropiación de la iglesia fue similar al resto, 700 pts $\mathrm{m}^{2}$ de planta y 300 pts. $\mathrm{m}^{2}$ de cubierta, a pesar de que el edificio contaba con algunos fallos

\footnotetext{
${ }^{702}$ Información dad a por Petronilo GUISURAGA, vecino de Miñera.

703 A.H.P.L. Marqués de la ENSENADA. Catastro. 1752. San Pedro de Luna. Rollo 217.

${ }^{704}$ A.G.C.H.D. C/05462. No 4485. Año 1953-54.
} 
estructurales $^{705}$. El cobro por el traslado de las imágenes y otras partes aprovechables fue de 10.000 pts. $^{706}$, una cantidad mucho mayor que en otras poblaciones. La única imagen cuya pista ha podido seguirse es la del titular S. Pedro que se encuentra en la iglesia parroquial de Sena de Luna.

\section{Santa Eulalia de las Manzanas.}

A pesar de que el grueso de la población de Santa Eulalia no se inundó, la eliminación de sus tierras fértiles destruyó el único modo de supervivencia de sus habitantes. Ello ocasionó que la Junta Vecinal decidiera la venta de la población en una segunda expropiación en $1960^{707}$. 67 habitantes desmantelaron sus casas y se trasladaron a poblaciones cercanas como Pobladura, Sena o Abelgas entre otros. El coste total de la expropiación fue de 13.875 .091 pts. $^{708}$

El paisaje que se muestra hoy en día en Santa Eulalia es bien diferente. Los edificios se confunden entre la vegetación y tan solo las calles parecen conservar su tránsito debido al paso del ganado. La reutilización de casi todo el poblado como cabaña ganadera ha supuesto la conservación de algunas zonas cerradas al público que evitan su expolio.

\footnotetext{
${ }^{705}$ A.D.L. Campo de Luna. Doc.: 886. desde 1892 a 1928. Las continuas nevadas sobre la zona provocaron el hundimiento de parte de la techumbre en 1862.

${ }_{706}$ A.G.C.H.D. C/05462. No 4485. Año 1953-54.

${ }^{707}$ A.G.C.H.D. C/ 05490-1. No 5468. Año 1960.

${ }^{708}$ A.G.C.H.D. Año 1957. No 4479. C/ 05454.
} 


\subsubsection{LA DEGRADACIÓN DE LA ZACEL DESDE 1964 A LA ACTUALIDAD}

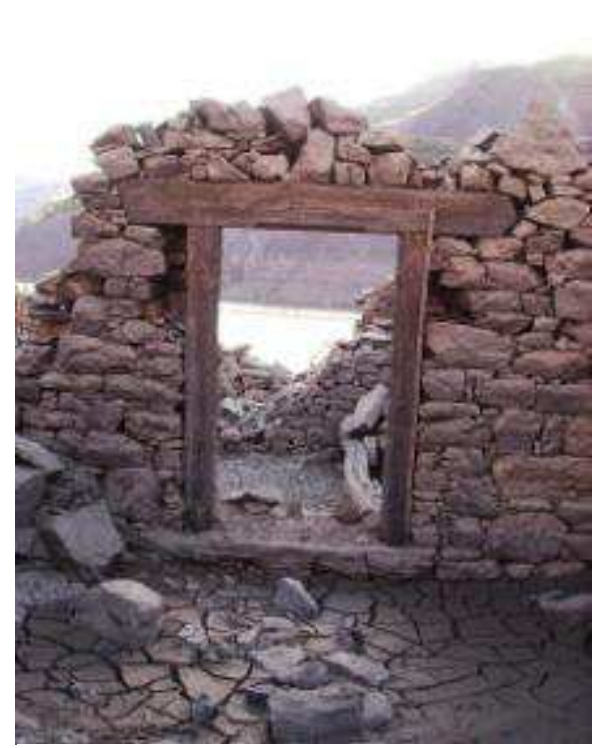

Ilustración 150. San Pedro de Luna 2009

El período que transcurre desde la década de los sesenta hasta la entrada del siglo XXI se caracteriza por la inundación de los bienes y el desmantelamiento de las estructuras que habían sido utilizadas para las obras de la presa.

Los procesos de expropiación llevados a cabo tras la ejecución del proyecto habían traído como consecuencia la ruina de los edificios. Una vez cerradas las compuertas y anegados los territorios, los bienes inmuebles de la ZACEL pasaron a sufrir una degradación específica derivada del embalse ${ }^{709}$.

Durante este segundo período el recuerdo del antiguo paraje se va paulatinamente olvidando y la amenaza de ruina de los edificios que habían quedado en pie acabará por facilitar el desmantelamiento de los mismos. En los primeros años las edificaciones fueron respetadas en su integridad pero, con el olvido de la tragedia y la revalorización de los materiales, como la piedra, los antiguos pueblos se convirtieron en canteras para los nuevos. Este hecho ocasionó la eliminación de los elementos sustentantes de los muros y cubiertas del edificio lo que aceleró su destrucción.

Tras la finalización de las obras de la presa, las fábricas construidas ex profeso fueron destruidas o reformadas. Las primeras que se desmontaron fueron las destinadas al transporte y depósito de materiales como el almacén de cemento, el pequeño tramo de ferrocarril y las torres grúas. En algunas ocasiones se aprovecharon las estructuras ya realizadas para darles unos fines bien distintos. Por ejemplo, las bases sobre las que se apoyaban los cables-grúas fueron acondicionadas como miradores sobre la pared del embalse. En otros casos los problemas de mantenimiento acabaron en el derribo controlado del edificio. Es el ejemplo del almacén de cemento de Barrios, el cuartel de la Guardia Civil y el campamento obrero. El primero formó parte de un proyecto de

${ }^{709}$ COSCOLLANO RODRÍGUEZ. Restauración, p. 10. 
remodelación en $1985^{710}$ en el que se incluía la construcción de nuevos edificios de la Confederación, pero su mal estado y la carestía que suponía su restauración acabaron finalmente con su demolición.

El cuartel de la Guardia Civil fue destruido una vez acabadas las obras del embalse, ya que la función de control de los obreros había terminado, y hoy en día tan sólo queda en pie el muro de contención de la ladera. En cuanto a los barracones de los obreros, en $1960^{711}$ la C.H.D. cedió el espacio para el aprovechamiento de un campamento de verano que continuó su uso hasta que en 2001 se abandonó definitivamente debido a las malas condiciones de su estructura ${ }^{712}$. En el verano de 2009 el ayuntamiento de Barrios de Luna decidió derrumbar los barracones dejando en pie tan solo la cocina para reuniones y festividades del pueblo.

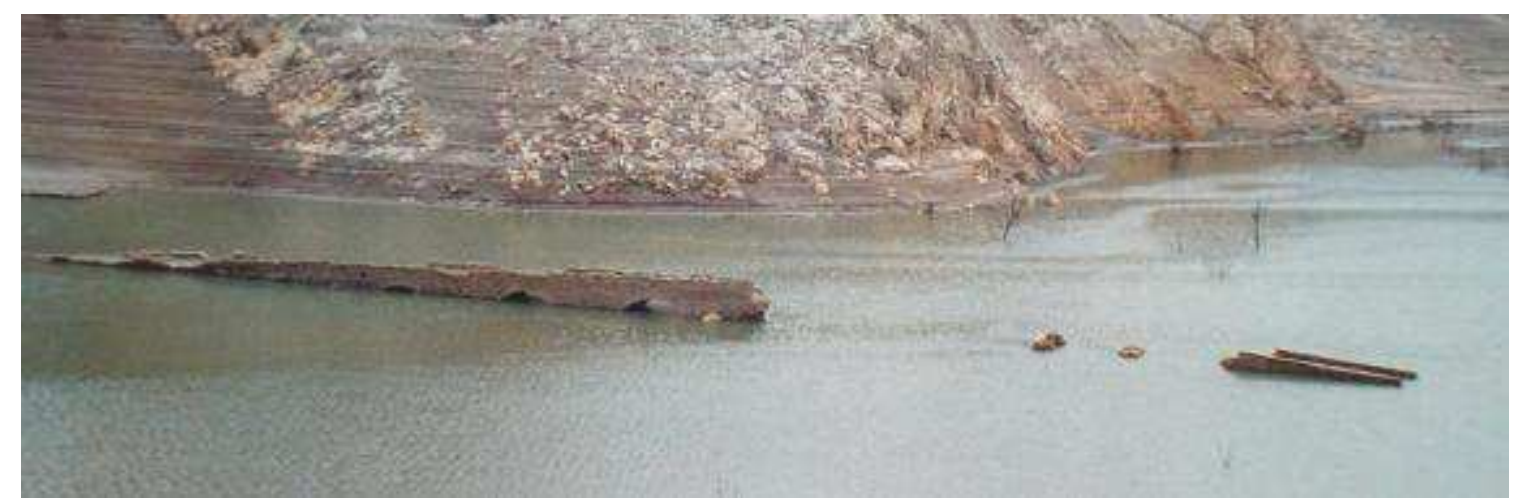

Ilustración 151. Puente de S. Lorenzo de Miñera. Foto cedida por Manuel QUIÑONES.

Todos los edificios que conformaban los restos arquitectónicos de la ZACEL quedaron sujetos al proceso de degradación impuesto por las condiciones derivadas del embalse. Dicho proceso no se comportó de la misma manera en todos los espacios, pues ha sido sometido a una serie de condicionantes dependiendo principalmente del lugar en el que se localizan los restos arquitectónicos. De esta manera se pueden diferenciar entre tres tipos de agresión: aquellas arquitecturas que han quedado totalmente sumergidas, las que emergen en períodos estivales y las que quedaron fuera de las aguas del embalse. Los grados de destrucción o conservación serán diferentes según la

\footnotetext{
${ }^{710}$ A.G.C.H.D. Reparación y rehabilitación de los edificios del la C.H.D. Eustrogio Briso. C/01842-1. No 7925. Año 1985.

${ }^{711}$ A.G.C.H.D. Proyecto de acondicionamiento y mejora de las viviendas...Embalse de Barrios de Luna. D. Luís López de Sosoaga. C/00869-3. No 4597. Año 1966.

712 PRIETO SARRO. "Luna", p. 341.
} 
localización de los inmuebles con respecto al nivel del agua embalsada, pues cuantos más factores de degradación se le unan, mayor será su destrucción.

\subsubsection{El patrimonio constantemente sumergido}

Es aquel que se encuentra sumergido durante todo el año. En esta situación se hallan las poblaciones de La Truva, el barrio de Trabanco, Cosera, Casasola, Las Ventas de Mallo, La Venta de la Canela y parte de Miñera. En estas zonas totalmente anegadas la acción humana es imperceptible, pues el hombre no puede llegar a ellas salvo en contadas ocasiones durante las cuales se produce el vaciado técnico del embalse. Es por ello que el deterioro vendrá determinado por causas físico-químicas relacionadas con el agua y por las deposiciones de sustancias aportadas por las corrientes del embalse.

La capacidad erosiva de los embalses conlleva una carga de sedimentos en suspensión lenta pero continua. La acumulación de depósitos en las zonas bajas implica la protección de las estructuras. Los lodos salvaguardan los restos de otros ataques y los mantienen en unas condiciones permanentes de temperatura y de luz apenas alteradas. En estas circunstancias los materiales más endebles, como la madera, soportan mejor el paso del tiempo, pues la humedad hace que aumente de volumen y que mejore su comportamiento mecánico.

A medida que se asciende a la superficie se añaden otros agentes como el aporte calorífico y el aumento de luminosidad, que beneficia el crecimiento de algas y microorganismos ${ }^{713}$. Las algas pertenecen a los ecosistemas acuáticos y su presencia en los edificios se asocia con el ataque a los carbonatos presentes en la composición de las rocas, especialmente las calizas. La principal agresión de estos seres vivos es la aparición de pequeños agujeros ${ }^{714}$ por lo que los daños son solo superficiales y no afectan a la estructura del edificio.

El proceso de la disolución de los componentes de unión de los muros, denominado hidrólisis, es la principal causa de destrucción no antrópica de los edificios anegados. El agua hidrata las sales solubles contenidas los componentes de cal. Los elementos de cohesión de las juntas, en particular las formadas por cales, se disuelven

\footnotetext{
713 GARCÍA-FLOS. Conservación, p. 89.

${ }^{714}$ MINGARRO MARTIN, Francisco. Degradación y conservación del patrimonio arquitectónico. Madrid. 1996, p. 400.
} 
dejando sin unión los mampuestos. Este fenómeno conlleva una disolución paulatina dependiendo de las características de los minerales de los que están compuestos ${ }^{715}$. Los materiales más sensibles a este tipo de ataque son los porosos, como las rocas areniscas, la madera, el adobe, el tapial, el ladrillo y especialmente los estucados ${ }^{716}$. Los encalados murales son los primeros en deteriorarse puesto que el agua penetra por los poros empapando la superficie y ocasionado un aumento de volumen con la consiguiente desintegración y disolución ${ }^{717}$.

La presión del agua estancada es otro de los problemas a los que tienen que enfrentarse los bienes permanentemente sumergidos. El agua ejerce un empuje sobre las construcciones cuya fuerza no había sido prevista, aplastando las estructuras. Las lesiones mecánicas se agravan por las condiciones del suelo empapado del embalse que provoca un debilitamiento del terreno sobre el que se asienta el edificio. La falta de asiento del muro ocasiona que la superficie de contacto con el suelo sea inferior a la necesaria y que por lo tanto el muro no se contenga llevando a una deformación o un desplome $^{718}$. A este factor hay que añadir la presión a la que están sometidas las estructuras anegadas.

La propia pujanza que ejerce una masa liquida tan importante puede conllevar a la aparición de los seísmos inducidos, es decir, movimientos o arrastres de terreno y grietas causadas por la presión hidrostática que empuja el agua contra los muros de contención $^{719}$. En el caso que nos ocupa, el ingeniero de la presa Luis de Llanos y Silvela observó algunos problemas referentes al tipo de roca que iba tener que soportar el empuje del agua. Las cuarcitas del cierre se habían agrietado y hendido por defecto del pliegue que presentaban. Consecuencia de ello se observaba un continuo goteo en el túnel que atravesaba la roca del castillo. Este goteo resultó un problema para los estudios de permeabilidad de la zona, por ello se tomó en cuenta que el cierre de la presa debía de estar continuamente revisado para evitar las posibles filtraciones ${ }^{720}$. Llanos y Silvela se percató de otro inconveniente añadido: la reducida extensión del frente vertical de la roca de cuarcita que estaba asentada sobre una base de pizarra. Para

\footnotetext{
715 Ídem, p. 388.

${ }^{716}$ Ibídem.

${ }^{717}$ GARCÍA-FLOS. Conservación, p. 120.

${ }^{718}$ MONJO CARRIO. Patologías, p. 102.

${ }^{719}$ VALLARDINO. Tratado, p. 79.

${ }^{720}$ A.G.C.H.D. Comisión de estudios geológicos para la construcción de obras hidráulicas. Barrios de Luna. No 2121. Año 1929.
} 
solventar el problema se recomendó el uso de hormigón inyectado en las zonas más débiles.

\subsubsection{El patrimonio estacionalmente sumergido}

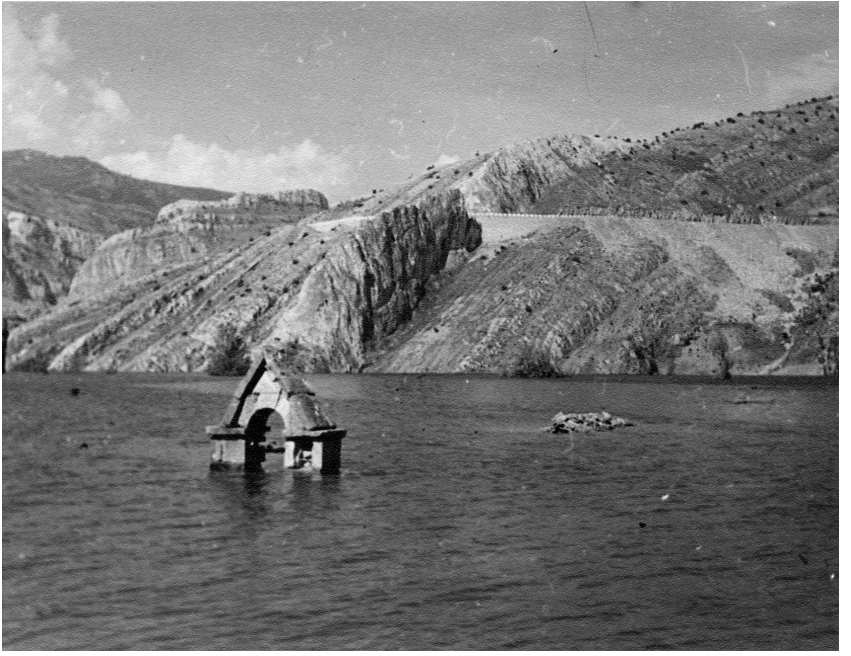

Ilustración 153. Ermita de S. Lorenzo de Miñera. Fondo fotográfico C.H.D. 6_a52.

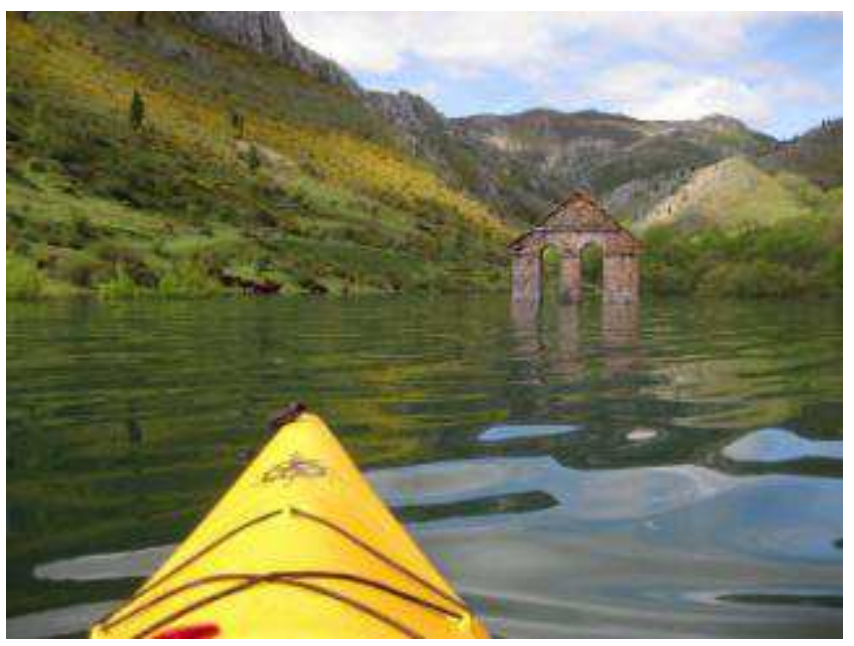

Ilustración 152. Iglesia de Lagüelles. 2010.

www.eltiempo.es/fotos/en-provincia-leon/espadana-dela-iglesia-de-languelles.

Es aquel que permanece bajo las aguas y emerge en períodos de estío como ocurre en las poblaciones de Miñera, Campo, Lagüelles, Láncara, San Pedro y Oblanca. A los factores presentados anteriormente se añaden otros como son los continuos vaciados estacionales del embalse que modifican las condiciones constantes en las que se encuentran los materiales sumergidos y el expolio de los restos por la mano del hombre.

El principio de termoplasticidad surge cuando un material, como la madera o la piedra, se ha adaptado a las condiciones de humedad y temperatura constante del agua del embalse y estas varían a otras de radiación solar y pérdida de humedad debido al vaciado estacional. Esta situación no ocurre de manera precipitada, pues la gran capacidad del embalse permite una disminución lenta y paulatina del nivel de las aguas. Debido a ello, la desecación de los materiales o su inundación no se produce de un día para otro, sino que sigue un proceso de semanas. Durante este tiempo los materiales pueden adaptarse a 
las nuevas condiciones. Sin embargo, dependiendo de la composición de los mismos podemos encontrar una serie de fallos diferenciados.

Las rocas que emergen sufren una insolación en la parte superior. Esta insolación trae como consecuencia un aumento de la temperatura exterior, lo que acaba originando tensiones y grietas internas. Los minerales de cuarzo y calcita experimentan una mayor dilatación por causas térmicas y un enfriamiento demasiado brusco puede producir fisuras como se ve en los restos de edificaciones de las antiguas poblaciones. Cuando las rocas vuelven a estar inmersas, el calcio reacciona con el agua convirtiéndose en hidróxido de calcio. Esta reacción conlleva un aumento de la temperatura y el volumen que acaban creando fisuras. La coloración de los minerales también influye en su conductividad térmica, ya que aquellos más oscuros van a absorber más rápidamente el calor.

Otro de los materiales que más se va a ver afectado por los cambios estacionales es la madera. Cuando se seca reduce su volumen, hecho que conllevará a la aparición de grietas. Los rayos UV destruyen la composición de la lignina deshaciéndola y ocasionando una falta de adherencia entre las fibras apareciendo el llamado peinado como puede observarse en las vigas de las ruinas de los edificios ${ }^{721}$.

La madera sumergida absorbe gran cantidad de agua, lo que conlleva a la desaparición de los extractos solubles. El duramen y la albura de la madera se debilitan por los factores ambientales del embalse, por lo que no pueden resistir las cargas ${ }^{722}$. Al mismo tiempo la celulosa es atacada por los microorganismos acuáticos dejando tan solo la lignina como residuo. Esta disminución de material ocasiona una pérdida de resistencia que será de vital importancia a la hora de soportar las tensiones durante el secado, puesto que se produce una contracción y deshidratación que acaba provocando fisuras. Si a esto le añadimos que esta hidratación es estacional, el contenido de humedad varía drásticamente, llegando a un punto en el que el material no puede soportar las cargas a las que está sometido ${ }^{723}$.

En las estructuras de cemento la unión del dióxido de carbono con la calcita, procedente de éste, da como resultado bicarbonato cálcico muy soluble en el agua ${ }^{724}$. De esta manera, al contacto con la humedad del embalse, se va disgregando poco a poco el

\footnotetext{
${ }^{721}$ VVAA. La madera en la conservación y restauración del Patrimonio Cultural. Madrid, 1985, p 24.

${ }^{722}$ BERGÓS, Juan. Maderas de construcción, decoración y artesanía. Barcelona. 1951, p. 61.

${ }^{723}$ GARCÍA-FLOS. Conservación, p. 97.

${ }^{724}$ MINGARRO MARTIN. Degradación, p. 392.
} 
calcio del hormigón, lo que conlleva una pérdida de masa y la consecuente disminución de consistencia. Cuando al efecto del anhídrido carbónico se une a la acción del viento se produce una carbonatación, dando lugar a la conocida aluminosis. Esta patología se agrava con los condiciones de humedad que posee el embalse. Como en los casos anteriores, el efecto se incrementa si el hormigón es de mala calidad o ha sido sometido a unos procesos de fraguado mal calculados. Este factor fue uno de los causantes de la rotura de los pilares de los viaductos de Aralla y Oblanca.

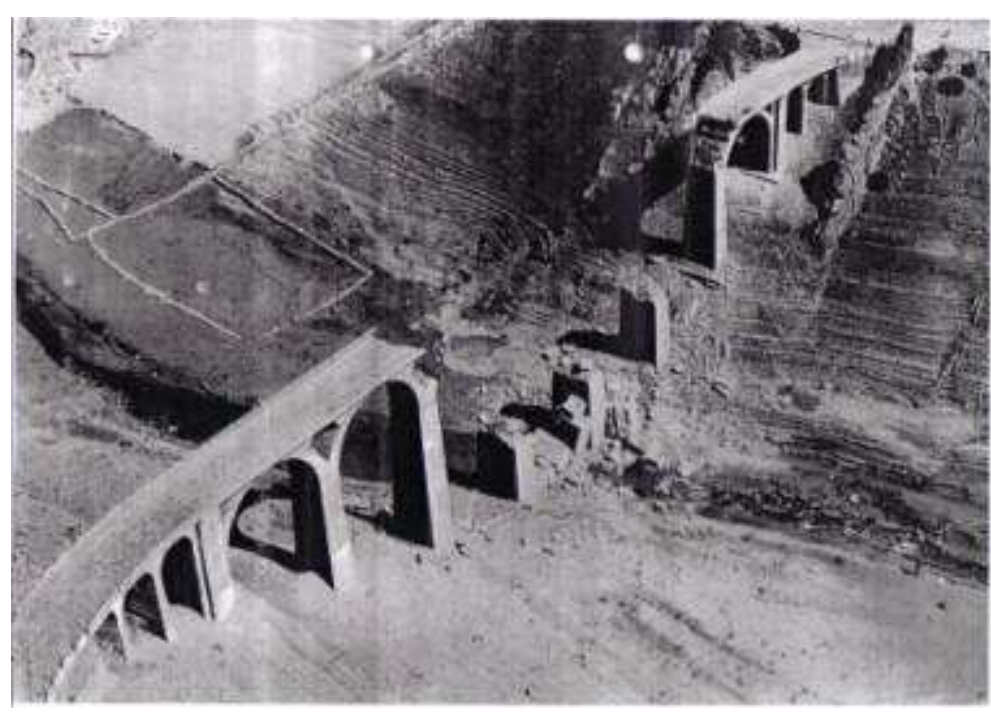

Ilustración 154 .A.G.C.H.D. Derrumbe del viaducto de Oblanca. C/01301-2. No 5834. Año 1973

Con la desecación del embalse en 1971 se observó una degradación anormal del viaducto de Oblanca consistente en la aparición de algunas coqueras en las pilas $\mathrm{y}$ desprendimientos de hormigón en los arcos. La escasa cantidad de cemento usado para el fraguado del material, unido a la falta de tiempo a la hora de su secado, ocasionó un hormigón débil expuesto a estas patologías dañinas. Para solucionarlo se proyectó una armadura en la cara inferior del arco afectado para disminuir la figuración ${ }^{725}$ mejorando la resistencia a las heladas. Se colocó una cimbra metálica desde donde se rellenaron las fisuras y los huecos de las bóvedas con un hormigón de alta calidad y se rectificaron las zonas donde se observó el descostrado. Sin embargo, la diversa granulometría del hormigón utilizado y el alto contenido en árido, en comparación con la escasez de cemento, ocasionaron finalmente el desplome del viaducto de Oblanca en $1973^{726}$.

Al comenzar los problemas mecánicos de sujeción de las pilastras en el viaducto de Oblanca se hizo conveniente sustituir el viaducto de Aralla, ya que era de similares

\footnotetext{
${ }^{725}$ A.G.C.H.D. Informe de la comisión técnica del derrumbamiento del viaducto de Oblanca. Embalse de Barrios de Luna. C/01301-2. No. 5834. Año 1973

${ }^{726}$ A.G.C.H.D. Proyecto de reparación urgente del viaducto de Oblanca. Embalse de Barrios de Luna. C/01262-3. No. 5671.
} 
características al de Oblanca y presentaba los mismos problemas. Por ello se autorizó un cambio de fábrica de las pilas de mampostería a hormigón con una mayor profundidad de cimientos debido al mal estado del firme. Para solventar los problemas de inestabilidad se multiplicaron los arcos en la sección N. así como el refuerzo de los pilares en su base. Los continuados problemas de estabilidad conllevaron a la realización de un nuevo trazado de vía cerrando al público el viaducto.

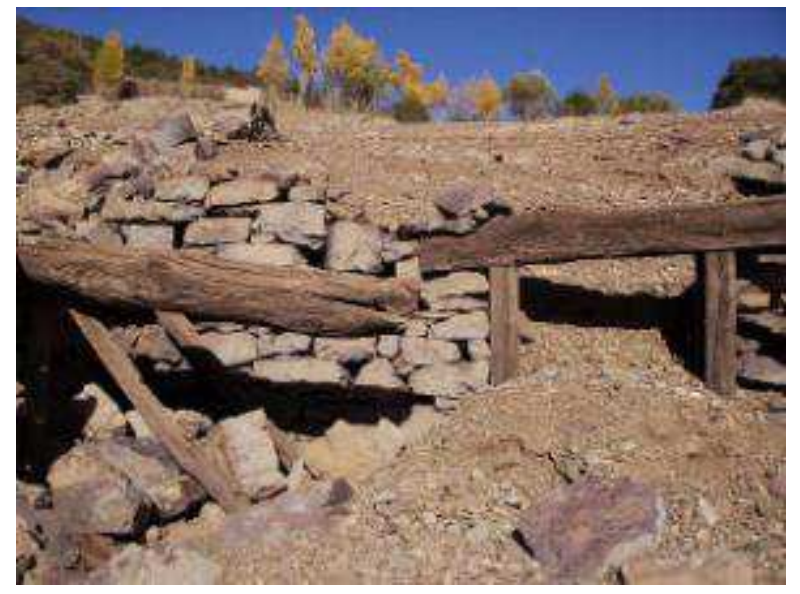

Ilustración 155. Edificio cubierto por el derrumbe de la ladera. 2010

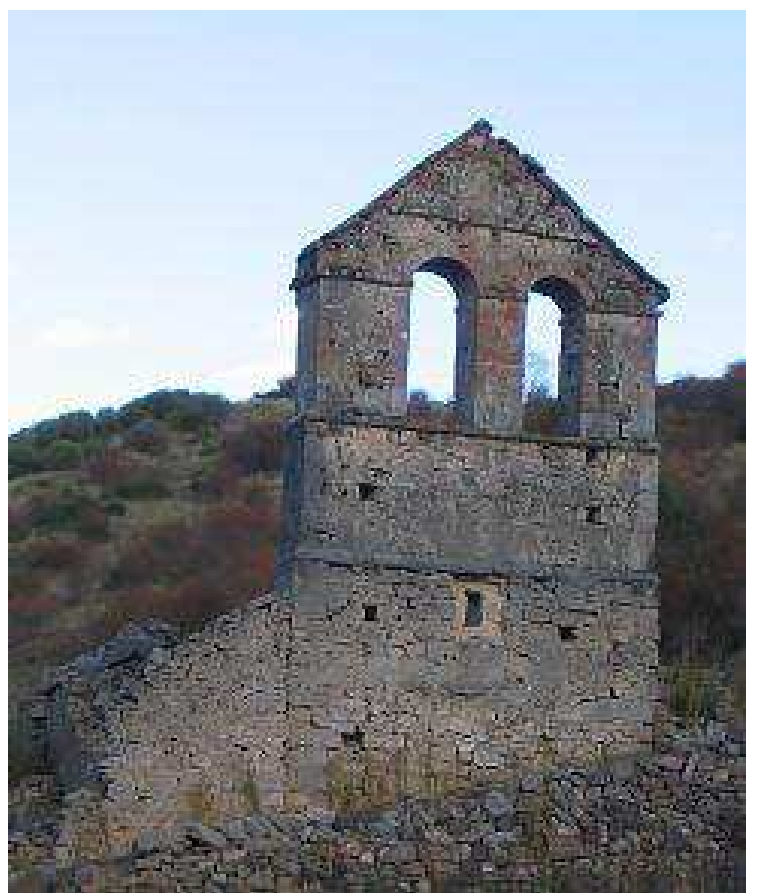

Ilustración 156. Agrietamiento del muro de la iglesia parroquial de Lagüelles en la actualidad.
Uno de los factores más comunes que afecta al patrimonio inmueble de este apartado es el arrastre y la erosión del terreno sobre el que se asienta. El mayor proceso erosivo del embalse tiene lugar durante el vaciado estacional y depende del lugar que ocupan los restos. Así por ejemplo aquellos edificios que se encuentran en zonas de corrientes o fuertes pendientes sufren una degradación mayor. Cuanto más verticales son los taludes que bordean el vaso, y dependiendo de su litología, mayor es el riesgo de erosión y por lo tanto de derrumbe. Las poblaciones de San Pedro, Campo, Casasola y Lagüelles son ejemplos de ello. Fácilmente se puede observar cómo la situación de los edificios en la ladera de una pendiente ha llevado al derrumbe de los edificios. Al haberse eliminado la vegetación que sustentaba el terreno éste se ha desplaza enterrando los restos ${ }^{727}$.

Otro problema suscitado por los movimientos de terreno es el quebranto.

${ }^{727}$ VVAA. Guías metodológicas para la elaboración de estudios de impacto ambiental. Grandes presas. MOPU. Madrid, 1989, p. 92. 
En este caso el suelo se levanta a causa de la absorción de humedad ocasionando la aparición de fisuras en la base de los muros ${ }^{728}$.

Cuando el suelo se deforma, parte de la estructura del edificio queda sin asiento originando un exceso de cargas. Es el caso de la torre espadaña de la iglesia de Lagüelles. La fuerte pendiente sobre la que se ubica y la inundación estacional de la base de los muros hace que la estructura se debilite y comience a deformarse. Al desaparecer el firme del suelo por causa de la erosión el muro tiende a sujetarse sobre el lado contrario, lo que origina tensiones que acaban por provocar grietas y posteriormente derrumbes.

Otro factor degradante es el arrastre de material en zonas de fuerte corriente ${ }^{729}$. Éstas corrientes solo están presentes durante los períodos estacionales, cuando las aguas del embalse bajan y los arroyos vuelven a encauzarse por su trazado original. La acumulación de lodo y sedimentos durante el invierno cubren las estructuras como los arcos de los puentes, lo que hace que el agua no encuentre salida y se estanque, aumentando la fuerza contra ellos. Al desaparecer el suelo firme las estructuras acaban cediendo ante los empujes de la corriente ${ }^{730}$. Se observa un ejemplo claro en el puente de San Pedro de Luna sobre el río Caldas, donde el nivel del suelo se ha elevado debido a la deposición de sedimentos y el curso del arroyo tiende a buscar la salida por los laterales.

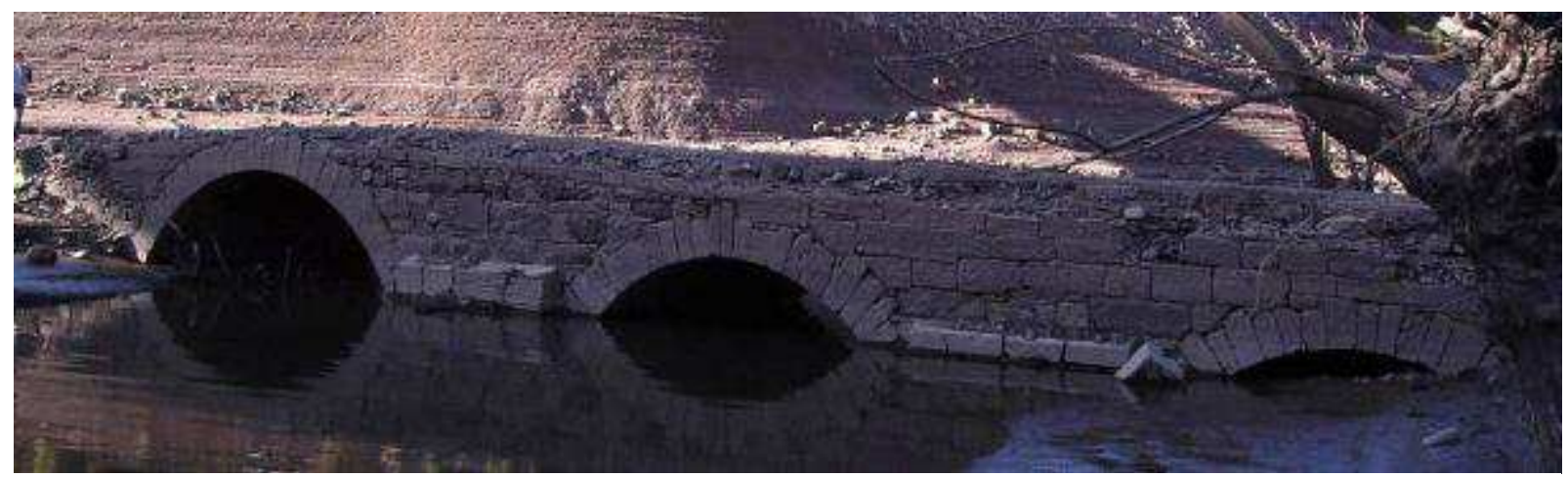

Ilustración 157. Puente de San Pedro sobre el río Caldas taponado por la deposición de sedimentos.

El arrastre de sedimentos también es un factor de riesgo especialmente para los yacimientos arqueológicos, como los castros, que tiene como consecuencia la dispersión de restos hacia zonas no catalogadas. Un caso particular aparece en Miñera de Luna

\footnotetext{
${ }^{728}$ MONJO CARRIO. Patologías, p. 239.

${ }^{729}$ ARAMBURU-ZABALA. La arquitectura, p. 9.

${ }^{730}$ VVAA. Guías metodológicas. p. 99.
} 
donde afloraron restos cerámicos, datados en período medieval, primero por arrastre y posteriormente por deposición. El origen de estos depósitos es desconocido, puesto que este fenómeno tan solo se dio durante un tiempo y no ha vuelto a repetirse.

En cuanto a las agresiones de tipo químico que se pueden observar éstas tienen que ver con la inundación y desecación de las estructuras y están atribuidas a su descomposición o cambios de humedad y temperatura ${ }^{731}$.

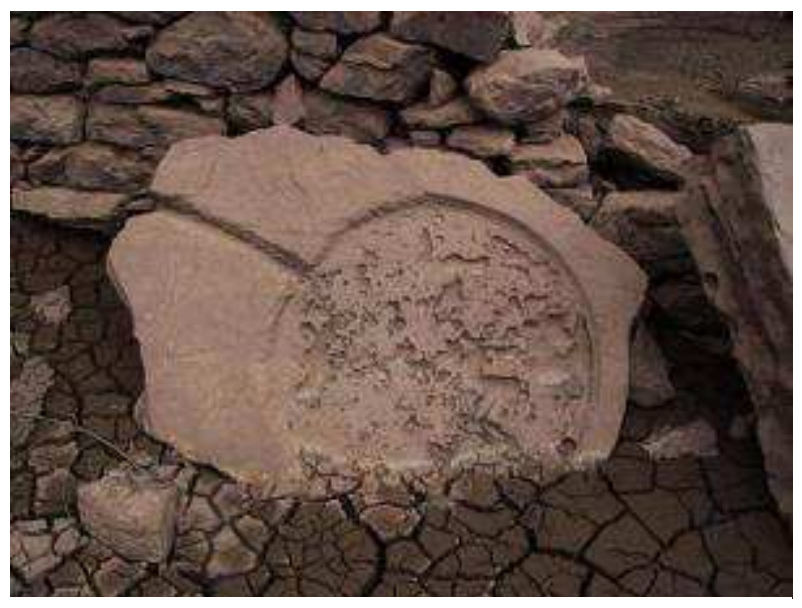

Ilustración 158. Pila de lavar afectada por eflorescencias. Miñera de Luna,

Los factores químicos no ocasionan un grave problema en sí mismos, sin embargo pueden venir acompañados de otros agentes que aceleran la destrucción de aquellos materiales más endebles. La aparición de las eflorescencias en los restos emergidos está ligada a la cristalización de determinadas sales a consecuencia de la evaporación ${ }^{732}$. Las sales contenidas en el interior del propio material son arrastradas hacia el núcleo por efecto de la humedad o de la lluvia. Tras la evaporación, como la que tiene lugar con la desecación del embalse, los minerales disueltos aumentan de tamaño taponando los poros y creando una capa cristalina llamada eflorescencia, que se puede reconocer gracias a su color blanquecino $^{733}$. Las zonas más afectadas serán aquellas partes húmedas del muro que están expuestas a los efectos de secado del viento y del sol. Se puede observar este efecto en cimentaciones de las estructuras de las casas que emergen en verano. Estas eflorescencias pueden ser beneficiosas, puesto que una vez creadas forman una capa protectora que impide que otras alteraciones penetren en el material, aunque a su vez impiden la transpiración de éste pudiendo ocasionar otras degradaciones.

La oxidación es un proceso que se acelera en ambientes de temperatura y humedad relativamente altas, como ocurre en los bienes del embalse. Los objetos metálicos en contacto con el agua se corroen debido a la interacción del oxígeno con los

\footnotetext{
${ }^{731}$ COSCOLLANO RODRÍGUEZ. Restauración, p. 18.

${ }^{732}$ MONJO CARRIO. Patologías, p. 188.

733 Ídem, p. 189.
} 
cloruros de las sales disueltas en las aguas. ${ }^{734}$ Los daños se centran la oxidación de las armaduras metálicas de los tableros y vigas de las estructuras de la ZACEL.

El último factor degradante de este apartado viene de la mano del hombre. La accesibilidad de los materiales emergentes favorece su expolio y por lo tanto la destrucción de los edificios y demás obras. Durante los períodos de desecación es fácil observar cómo las personas utilizan maquinarias para penetrar en el todavía fangoso suelo y poder así acarrear los sillares que se han desplomado durante el invierno. La fragilidad de la estructura no hace prudente la eliminación de los muros que aún permanecen en pie, por lo que el expolio se basa en la recopilación de materiales seguros, dispersos por el suelo o sin grandes cargas que sustentar.

Un ejemplo muy claro se observa en la iglesia de Miñera. Los muros se vieron debilitados por el aprovechamiento del material durante la expropiación y por las variaciones estacionales y la disolución de la argamasa de unión. La articulación ha afectado principalmente a elementos sustentantes (arcos, bóvedas, pilares) que han sido dañados a causa de la humedad o de la pérdida de unión de las juntas. Los fallos mecánicos llevaron a la rotura de los riñones de los arcos provocando el hundimiento de la clave y de las bóvedas ${ }^{735}$. El derrumbe de la bóveda ocasionó un desprendimiento de parte del muro que ha llevado a la inclinación de las paredes y su posterior ruina por lo que los materiales dispersos por el suelo pueden ser fácilmente recogidos durante los períodos de estío del embalse sin ningún peligro.

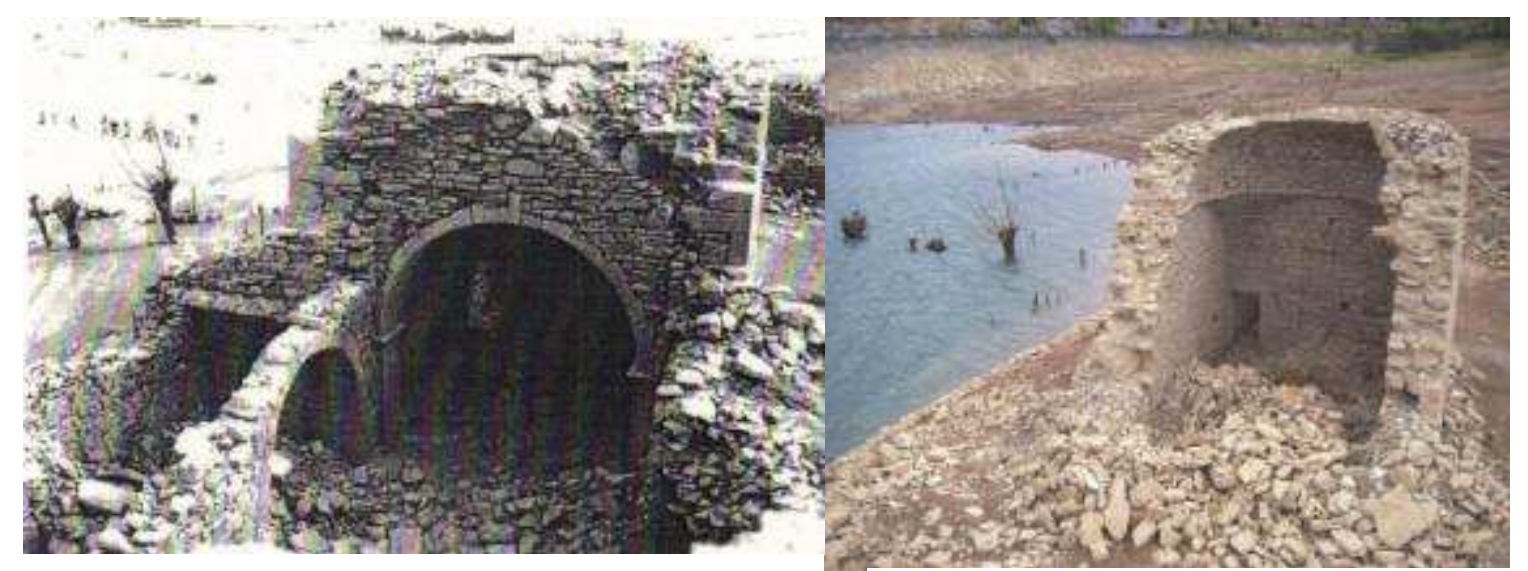

Ilustración 159. GARCÍA SUÁREZ. Una historia, p. 74. Año 1992.

Ilustración 160. Miñera de Luna, Año 2011.

\footnotetext{
${ }^{734}$ GARCÍA-FLOS. Conservación, p. 112.

735 CASTRO VILlALBA, Antonio. Historia de la construcción medieval. Aportaciones. Barcelona, 1996, p. 126.
} 
Las únicas edificaciones que se han sufrido un menor expolio son aquellas que han quedado aisladas por la inundación. Lagüelles es un caso muy significativo. Su complicado acceso ha favorecido una mejor conservación, pues el sinuoso camino no permite el robo de grandes restos. En la antigua población aún se pueden ver en pie los edificios y los sillares de mejor calidad, lo que ha conllevado a que la mayoría de las estructuras aún se mantengan en pie.

\subsubsection{El patrimonio no sumergido}

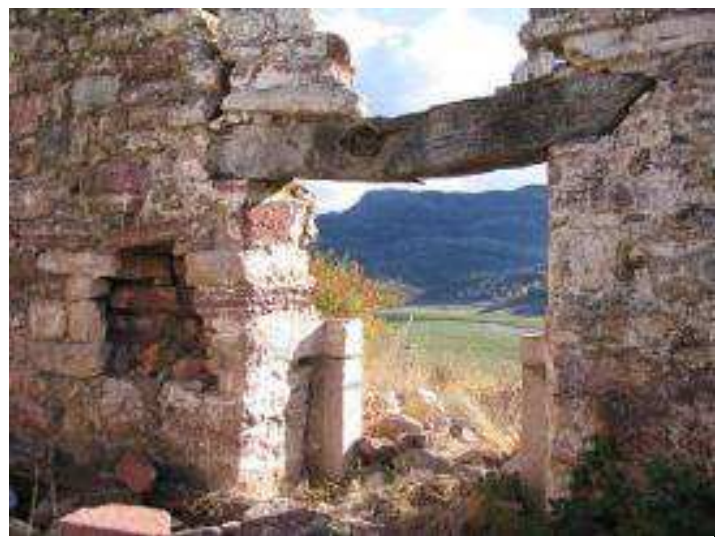

Ilustración 161. Iglesia de Láncara. Deformación de la viga de entrada.

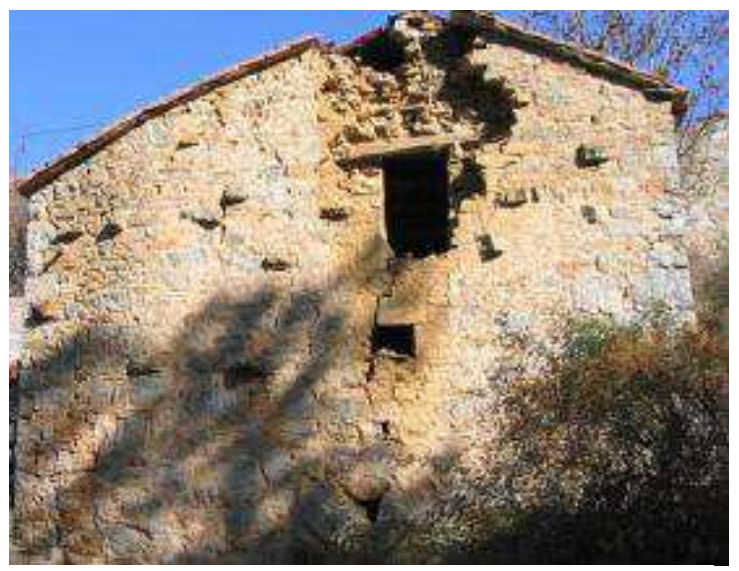

Ilustración 162. Mirantes de Luna en la actualidad.

En los bienes que quedaron fuera del nivel de inundación de las aguas del embalse las acciones destructivas vendrán de la mano de factores físicos, mecánicos, humanos y biológicos. El mayor agravante es el abandono y expolio de materiales ante una titularidad completamente desinteresada en su conservación. En esta situación se encuentran las poblaciones de Mirantes, Arévalo y Santa Eulalia de las Manzanas.

La principal causa de degradación de los edificios no sumergidos viene como consecuencia del abandono de las estructuras. El debilitamiento aparece en aquellas partes menos protegidas y donde los empujes son mayores como ocurre en las cubiertas y vanos ${ }^{736}$.

El primer paso para el derrumbe de los edificios es la aparición de deformaciones de los muros o pandeo de los mismos. El pandeo es un problema que puede dar como consecuencia una ruptura total o parcial de la pared o paredes debido a una excesiva flexión de los materiales. La

\footnotetext{
${ }^{736}$ MONJO CARRIO. Patologías, p.124.
} 
ausencia de contrafuertes agrava el problema como ocurre en la iglesia de Láncara, donde la caída de la techumbre de madera ha empujado el muro hacia el interior de la estancia. En Mirantes de Luna se observa cómo las fisuras se abren por las partes más débiles como el dintel o las jambas y se extienden por todo el muro. Las grietas y fisuras surgen cuando la deformación es tan alta que el material no puede soportar la presión y cede por la parte más frágil donde los empujes son mayores, como en aquellos muros que han de soportar cargas de bóvedas con un empuje lateral ${ }^{737}$.

El crecimiento de vegetación es uno de los síntomas más significativos del abandono de los edificios. Es especialmente agresivo en las poblaciones que han quedado fuera de la cota de inundación del embalse. Claro ejemplo de ello es Santa Eulalia. La trasformación del núcleo urbano en una explotación ganadera ha tenido como consecuencia el desarrollo de una vegetación mucho más compacta que en otros lugares. El cercado impide la entrada al interior y sólo el ganado, que se concentra en las zonas de pastizal, recorre el trazado de las antiguas calles. La vegetación ha invadido totalmente el pueblo, desapareciendo casi por completo la estructura urbana y los edificios bajo la gran masa de arbolado. En las localidades de Mirantes de Luna y Arévalo la situación es diferente. En este caso, el acceso a las ruinas está abierto y el tránsito humano y de ganadería permite que la vegetación no sea tan abundante.

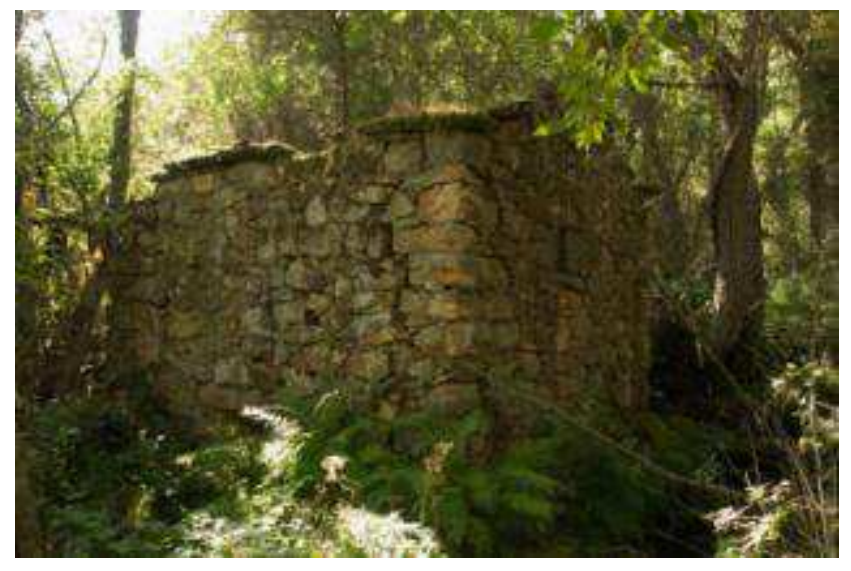

Ilustración 163. Santa Eulalia. Crecimiento descontrolado de la vegetación sobre las ruinas.

Los insectos xilófagos son otro de los agentes degradantes del patrimonio externo de la ZACEL. Éstos se alimentan de las sustancias nutritivas de la madera ocasionando graves daños si atacan en las vigas estructurales. Las especies más peligrosas pertenecen a las familias de las termitas y los escarabajos. La agresión de estos xilófagos es mayor dependiendo de las condiciones en las que se encuentre la madera, como por ejemplo el haber sido atacados por algún tipo de hongos ${ }^{738}$. Los hongos, líquenes y musgos son muy comunes en zonas de humedad y abundante sombra como es el caso de Luna. En su crecimiento estos seres eliminan sustancias ácidas que son potencialmente causantes

\footnotetext{
${ }^{737}$ CHING. Diccionario, p. 192.
}

${ }^{738}$ GIBERT- LÓPEZ. Aula, p. 14. 
de diferentes alteraciones como la lixiviación $^{739}$, un proceso mediante el cual las bacterias sintetizan el nitrógeno y el azufre mientras que los hongos segregan ácido oxálico.

La nitrificación ${ }^{740}$ es otro proceso mediante el cual el ácido nítrico producido por la descomposición de los microorganismos disuelve los materiales oxidando el amoniaco y transformándolo en ácido nitroso ${ }^{741}$.

A partir de la formación y posterior muerte de las especies vegetales se va creando un suelo propicio para la aparición de plantas superiores. Los musgos se originan gracias al exceso de humedad unido a una temperatura y luz adecuada en lugares ricos en fosfatos. Sus raíces pueden provocar pequeñas fisuras. En la iglesia de Láncara se observa este tipo de agresión ocasionada por la acumulación de sustrato en las grietas del edifico. En el presbiterio se dan las condiciones perfectas para la aparición de musgos y mohos como es la abundante humedad, la protección de la luz y el abandono. La poca luminosidad que entra en el interior lleva a la aparición de musgos y mohos favorecidos por la suciedad del entorno y los restos de alimentos dejados por el hombre. En la sacristía de la iglesia de Láncara el ataque es mucho mayor, pues esta estancia está muy deteriorada por las humedades y la falta de luminosidad, lo que ha originado la aparición de hongos y mohos.

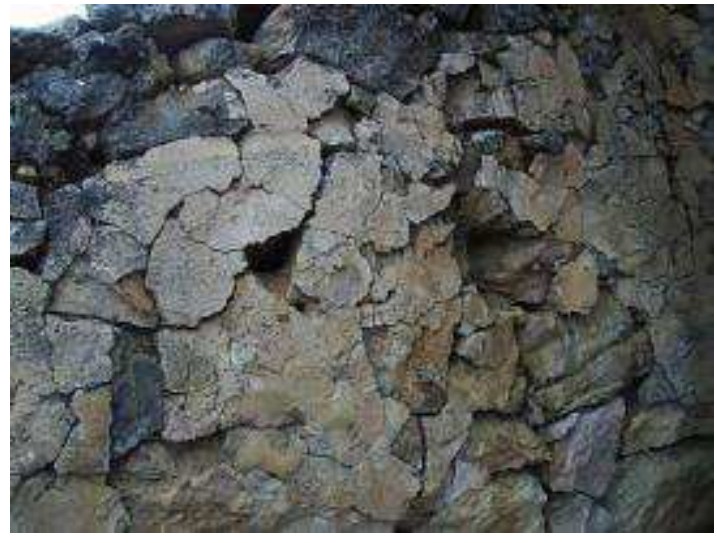

Ilustración 164. Desplacados del enfoscado que recubría la piedra. Arévalo.
A pesar de que los edificios no se encuentren anegados, las condiciones de humedad del Valle abren el paso a factores químicos igualmente degradantes. El proceso de carbonatación proviene de la alteración del anhídrido carbónico atmosférico que, al disolverse en agua, forma ácido carbónico ${ }^{742}$. La calcificación es el proceso mediante el cual los

\footnotetext{
${ }^{739}$ GARCÍA-FLOS. Conservación, p. 102.

${ }^{740}$ COSCOLLANO RODRÍGUEZ. Restauración, p. 13.

${ }^{741}$ MINGARRO MARTIN. Degradación, p. 380. La simbiosis entre el alga y el hongo crea los líquenes que van a proliferar rápidamente por las superficies pétreas. Sus hifas penetran por los poros de la roca en busca de alimento a partir de la descomposición química del material. Al morir los líquenes dejan una especie de residuo sobre la roca que es el sustento para otras especies como los musgos, especialmente en aquellas zonas más húmedas de la ZACEL.
} 
componentes cálcicos, al contacto con el agua o la humedad, sufren una serie de transformaciones que acaban por disolver el material. En los edificios anegados este paso es casi inmediato y no se conserva ningún ejemplo que haya sobrevivido a la inundación. Sin embargo, en las construcciones que han quedado fuera del embalse los revoques pueden conservarse si se encuentran protegidos. Es el caso de la ermita de $\mathrm{S}$. Ramón de Mallo que ha perdido parte de su techumbre lo que ha originado la destrucción casi total de las pinturas del interior. En ella se podía observar hasta hace unos años un programa iconográfico basado en escenas de la vida de S. Francisco y $\mathrm{S}$. Ramón.

La oxidación es también causante de la pérdida de adherencia y de la aparición de costras de óxido en los parapetos de la carretera o los propios viaductos. La porosidad del cemento que envuelve las estructuras de hormigón facilita la penetración de la humedad y con ello la oxidación de los materiales ferruginosos ${ }^{743}$.

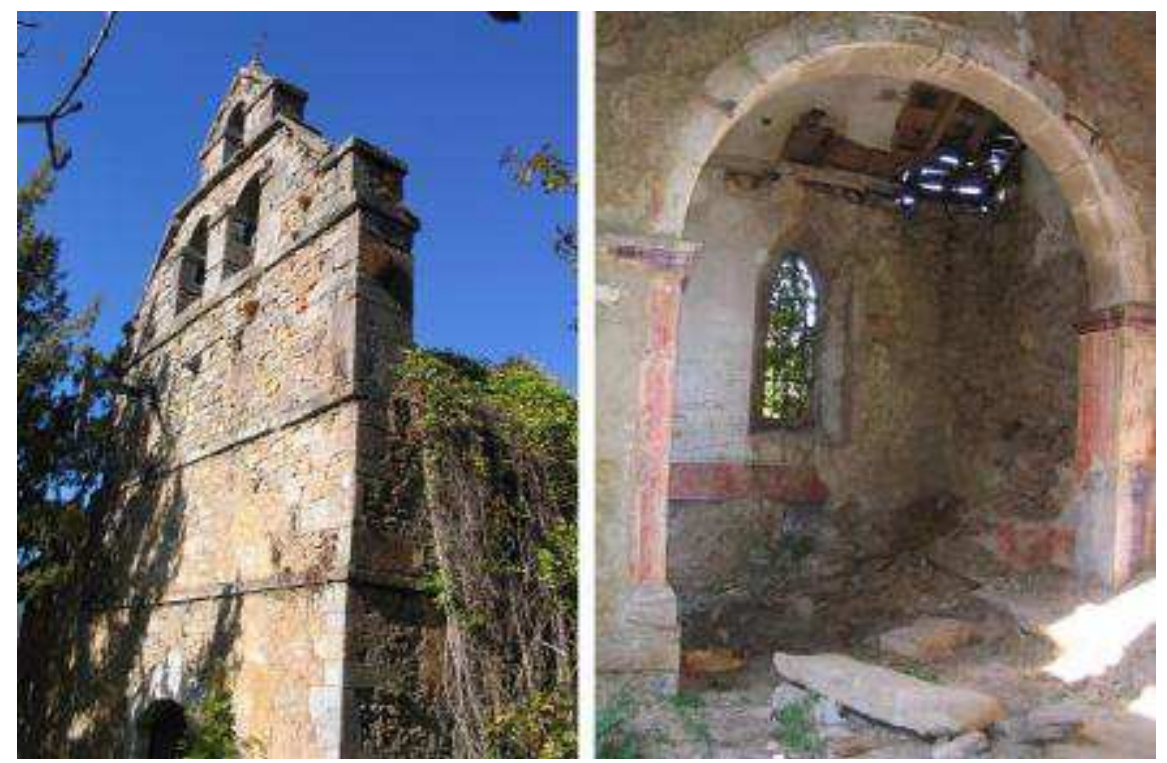

Ilustración 165. Estado actual de la iglesia de Mirantes. Año 2009

El expolio fue y es uno de los factores más virulentos que ha afectado a los bienes no anegados. La accesibilidad a los edificios que quedaron fuera de la cota de inundación ocasionó el robo de numerosos materiales. Las iglesias de Láncara y Mirantes son dos ejemplos significativos. Los templos quedaron fuera de las aguas, por

742 COSCOLLANO RODRÍGUEZ. Restauración, p. 14. Este es uno de los componentes causantes de la lluvia ácida que transforma la caliza en bicarbonato cálcico, el cual aumenta el volumen de la pieza, descompone los materiales desde el interior y disuelve los minerales alcalinos que contiene la roca.

${ }^{743}$ A.G.C.H.D. Proyecto de rehabilitación del puente sobre el aliviadero. Embalse de Barrios de Luna. C/ 02162-1. N No 9526. Año 1993. 
lo que en un principio sus estructuras fueron conservadas para seguir realizando cultos en ellas. Sin embargo, ante la falta de una población que las protegiese y conservase, se fueron abandonando paulatinamente.

La iglesia de Mirantes de Luna sufrió uno de los mayores saqueos del Valle en un breve período de tiempo. Durante los años 1960-1970, la iglesia continuó ejerciendo sus labores religiosas con un mayordomo encargado de su mantenimiento. El recuerdo de sus habitantes logró que durante un tiempo la iglesia estuviera abierta al culto gracias a la procesión de romerías. Sin embargo, con el paso de los años el edifico se fue abandonando hasta que se cerró definitivamente en $1971^{744}$. A partir de entonces comienza un desmantelamiento sucesivo de todos sus materiales. Las tejas fueron reutilizadas en la construcción de otros edificios particulares, la tarima del suelo fue trasladada a Vega de Robledo para la mejora de la casa escuela ${ }^{745}$, las puertas y ventanas se llevaron a otros edificios y los altares acabaron siendo robados y vendidos por piezas en mercadillos de anticuarios. Al ser propiedad de la C.H.D. y no del obispado, las denuncias de su expolio fueron llevadas sólo por los antiguos vecinos que apenas tuvieron repercusión judicial o mediática.

Tras el expolio el edificio quedó sin cubierta ni suelo, desprotegido frente a agresiones físicas, químicas, mecánicas y biológicas. Así el agua se introdujo en las texturas internas de los muros del edificio, aumentando la afección de otros procesos degradantes. La vegetación se ha adueñado del interior, los muros sufren un pandeo y agrietamiento considerable. Los sillares de la torre espadaña corren riesgo de caer, lo que supondrá no solo un peligro para la estructura sino también una oportunidad para su reaprovechamiento.
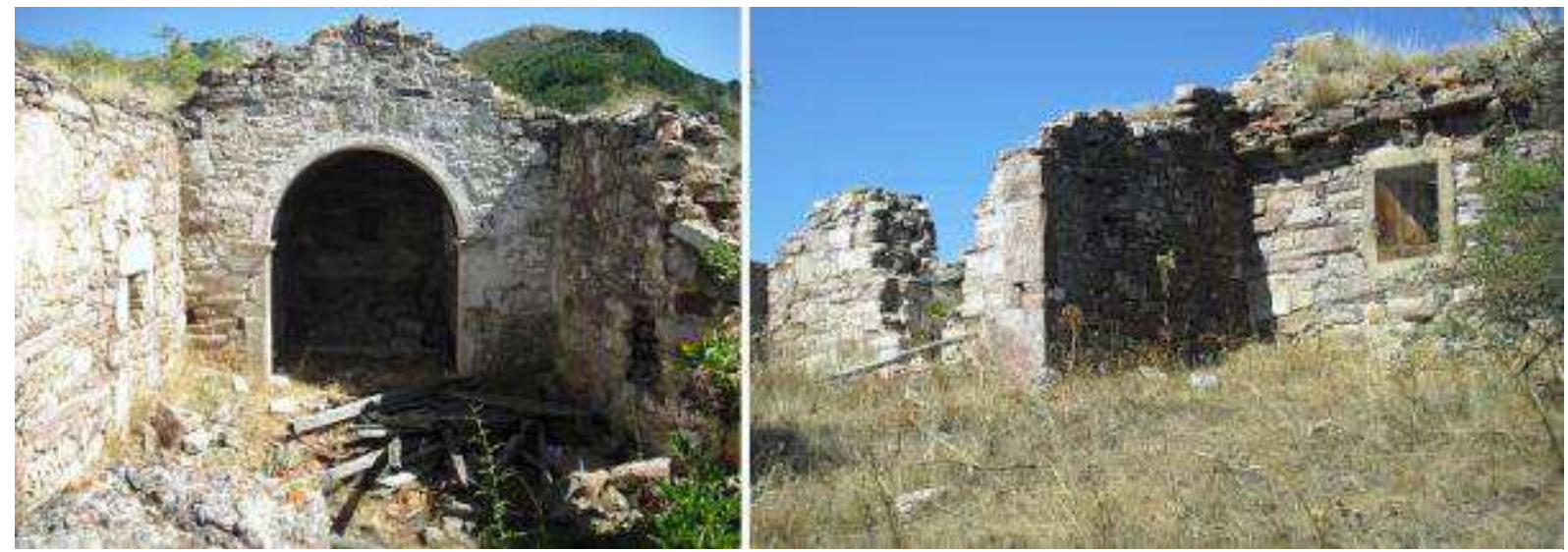

Ilustración 166. Estado actual de la iglesia de Láncara. Año 2010.

${ }^{744}$ Información dada por Petronilo Guisuraga vecino de Miñera.
${ }^{745}$ Ibídem. 
La iglesia de Láncara sufrió un expolio similar. El templo sobrevivió a la inundación por estar situado sobre un altozano junto al cual se construyó la carretera actual. Durante los primeros años la iglesia permaneció en pie como único recuerdo y testimonio del pueblo y también como romería que conmemoraba la festividad de la localidad. A pesar de encontrarse junto a la carretera no se delimitó ningún acceso hacia el edificio, lo que conllevó un cierto peligro para los viandantes que quisiesen entrar en el templo. La única vía segura pasaba por el antiguo camino de Láncara que emerge solo en los períodos de estío.

La eliminación de las tejas y materiales útiles para la construcción dejó sin protección el entramado de madera. Las lluvias ocasionaron las primeras goteras. Los muros se empaparon lo que produjo a su vez el desmoronamiento de parte del material y por lo tanto la exclusión de la base sobre la que se sujetaban los tirantes. Finalmente, a causa de los empujes, el entramado del tejado cayó arrastrando no solo la cubierta del edificio sino también otros elementos que protegía como el enlucido interior y la parte superior de los muros. 


\subsection{ARQUITECTURA POSTERIOR AL EMBALSADO}

Los avances económicos de los que disfrutaron algunas poblaciones durante la construcción del embalse desaparecieron con el fin de los trabajos. Gran parte de las estructuras creadas para la presa fueron eliminadas y la riqueza que había traído la obra, con la multiplicación de casas de comida, tiendas, y hasta un cine, se esfumaron una vez finalizada la pared y el embalsado del agua. A pesar de que algunos obreros se quedaron en las inmediaciones esto no supuso una mejora en las condiciones económicas del Valle, puesto que la mayoría se trasladaron a otras localidades o retornaron a sus lugares de origen.

La eliminación del terreno cultivable y de pastos provocó una disminución de la población en los pueblos cercanos al nivel de las aguas. Las actividades agrícolas debieron suprimirse u ocupar lugares más elevados. Muchas familias, afectadas por el embalse, solicitaron una expropiación total de todos sus terrenos al quedarse sin posibilidad de sustento. Gracias a estas nuevas expropiaciones la C.H.D. aumentó sustancialmente sus propiedades. Las nuevas tierras, consistentes en monte bajo y pastizales, fueron revendidas, lo que ocasionó una pequeña recuperación sobre todo para el desarrollo de explotaciones ganaderas ${ }^{746}$.

El embalse se convirtió en una barrera tanto física como psicológica, un obstáculo que alargó de manera evidente la comunicación entre pueblos y que aceleró la pérdida sustancial de la calidad de vida del Valle. A esto hay que sumarle que, desde la finalización de la presa, apenas se realizaron mejoras en las carreteras de acceso a los pueblos, lo que ha conllevado a un paulatino deterioro de las mismas. Al mal estado del firme y los problemas de fraguado del hormigón usado se le añadió la anteriormente mencionada caída del viaducto de Oblanca y el consecuente aislamiento del Valle durante algún tiempo. Este aislamiento se hizo más fuerte tras la construcción de la autopista AP-66, que permitió la circulación rápida dejando en segundo plano el paso por las poblaciones de la ZACEL.

${ }^{746}$ CONDE GARCÉS, Pantano, p. 51. 


\subsubsection{LA NUEVA ARQUITECTURA}

El cambio trascendental del paisaje que supuso la construcción de la presa llevó a la creación de diferentes obras en la ZACEL que no hubiesen sido posibles sin la presencia del embalse.

\subsubsection{Edificios de la C.H.D.}

Tras la finalización de la presa y el embalsado del agua apenas se volvieron a efectuar inversiones en la ZACEL salvo las correspondientes a la mejora de las carreteras financiadas por el Fondo Social Europeo, fondos MINER o la propia Diputación de León.

En 1966 el Ingeniero D. José Félix Lezcano proyectó un vivero volante ubicado en el término de Mallo para asegurar el suministro regular de la plantación de pinos que impidiesen la erosión y disminuyesen la evaporación de las aguas embalsadas haciendo a la vez el terreno lo más productivo posible ${ }^{747}$. En el lugar se levantó una caseta para las herramientas y tres pozos de depósito con un volumen acuífero suficiente para los riegos necesarios gracias al abastecimiento de una fuente natural. Este espacio ha sido desmantelado en la actualidad.

Otro aspecto relacionado con la repoblación vegetal se encuentra en el colchón de la presa en Barrios. Este espacio se configuró como un pequeño jardín botánico con varias especies arbóreas como fresnos, pinos, chopos, abetos y secuoyas. El parque se acotó con un cercado en vallas metálicas cuya estampa más característica fueron las puertas de entrada en las que se puede observar el escudo de los ingenieros de caminos, canales, puentes y puertos. Dentro del parque se levantaron varias casetas destinadas a la guarda y custodia de materiales de mantenimiento. Su estructura era muy sencilla, siendo construcciones de una sola planta rectangular con muros de mampostería irregular o encalados y con una cubierta de teja o pizarra a dos aguas.

\footnotetext{
${ }^{747}$ A.G.C.H.D. Proyecto de repoblación forestal en los términos de Barrios de Luna y Sena de Luna. Provincia de León. Embalse de Barrios de Luna. C/00862-4. № 4565. Año 1966.
} 
La intención de la C.H.D. de levantar nuevos edificios para modernizar la plantilla del personal de la presa acabó en un simple proyecto que no pasó del papel ${ }^{748}$. Así se diseñaron nuevos edificios de viviendas para los encargados, el acondicionamiento de los almacenes e incluso la ejecución de un parque de bomberos.

En 1985 el ingeniero Eustrogio Briso proyectó varios edificios destinados a viviendas y oficinas de los empleados que sustituyesen a los diseñados por Luis de Llanos en 1942. Se programaron seis viviendas dispuestas en hilera con garaje propio y patio interior $^{749}$. Ninguna de estas inversiones se llevó a cabo, por lo que se optó por la restauración de los antiguos edificios o la destrucción de otros que corrían peligro de derrumbe como el almacén de materiales o los barracones de los obreros.

\subsubsection{Edificios civiles}

La arquitectura civil que sobrevivió al embalse se vio sometida a un cambio trascendental debido a las nuevas necesidades constructivas. Los edificios tradicionales quedaron obsoletos $\mathrm{y}$ poco a poco se fueron abandonando algunos espacios representativos de los antiguos modos de vida como los hornos, cuadras y pajares. La emigración del campo a la ciudad ocasionó que en los primeros años apenas se levantasen nuevas edificaciones en la ZACEL. Tan solo se restauraron unas pocas casas con nuevos materiales ajenos a las técnicas tradicionales como el cemento, el ladrillo y el hormigón.

A finales del siglo XX comienza a desarrollarse una corriente tradicionalista en la que se pone de relieve la importancia de los antiguos materiales de construcción ${ }^{750}$. Las nuevas formas arquitectónicas supusieron edificios más modernos y con mejores comodidades. La piedra vista en los muros, que hasta entonces se había cubierto de cal, se pone de moda. Las nuevas normas de urbanismo de los ayuntamientos apoyaron el uso de parapetos pétreos lo que ocasionó una revalorización de éstos. El alto precio de los materiales hizo posar la vista sobre las poblaciones derruidas de los pueblos anegados de la ZACEL, que se convirtieron en la cantera para la creación de nuevos edificios para Barrios, Mallo, Mora, Sena o Vega de los Caballeros.

\footnotetext{
${ }^{748}$ A.G.C.H.D. Reparación y rehabilitación de los edificios de la C.H.D. Eustrogio Briso. Embalse de Barrios de Luna. C/01842-1. No 7925. Año 1985.

749 A.G.C.H.D. C/01842-1. No 7925. Año 1985.

${ }^{750}$ Ibídem.
} 
La técnica tradicional se ha perdido en favor de una estética que mezcla muchas veces sillares pertenecientes a edificios religiosos con piedras usadas como fregaderos o ruedas de molino. Esta mezcolanza prioriza lo estético tradicional por encima de lo funcional y su agrupación es considerada como una muestra de coleccionismo que se exhibe ante los viandantes. Es por ello que, a pesar de que esta nueva construcción ayude al mantenimiento del pueblo, también es un factor que ha acelerado la destrucción de las antiguas edificaciones.

\subsubsection{Vías de comunicación}

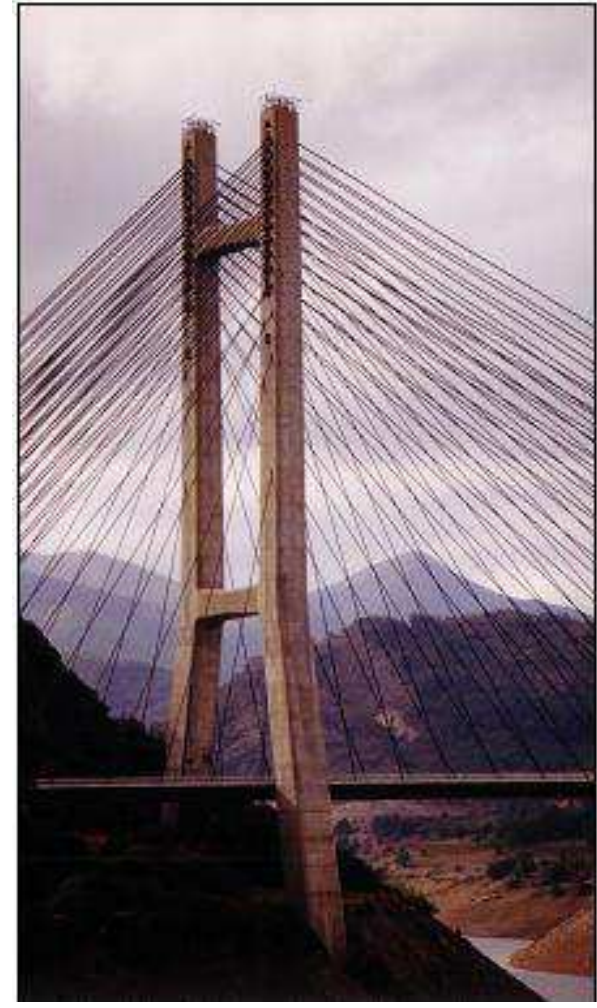

Ilustración 167. Puente atirantado de Fernández Casado.
Como se ha dicho anteriormente, el embalse obligó a la construcción de una nueva carretera con viaductos en una cota superior al nivel de inundación de las aguas. Tras la finalización de las obras se crearon dos nuevas vías de comunicación a poblaciones que habían quedado aisladas como eran Mallo e Irede. La carretera de Mallo fue pensada en primer momento para dar salida a los materiales del almacén y favorecer el tránsito de éstos hasta las obras de la presa. Una vez finalizada su función, la carretea se adaptó para comunicar la población de Mallo. La otra carretera hacia Irede fue trazada dentro de los proyectos de compensación de la presa.

Pero sin duda la vía más importante, cuyo trazado tuvo que acomodarse a los enormes cambios que había ocasionado la presa, fue la autopista AP-66, que forma parte de la denominada "Vía de la Plata". Su construcción se inició en 1975 y en agosto de 1983 se abrió al tráfico su primera fase, terminándose en su totalidad en 1997 con el desdoblamiento del Túnel del Negrón.

Unos de los aspectos más característicos de su recorrido es el puente atirantado de Fernández Casado. 
El puente se

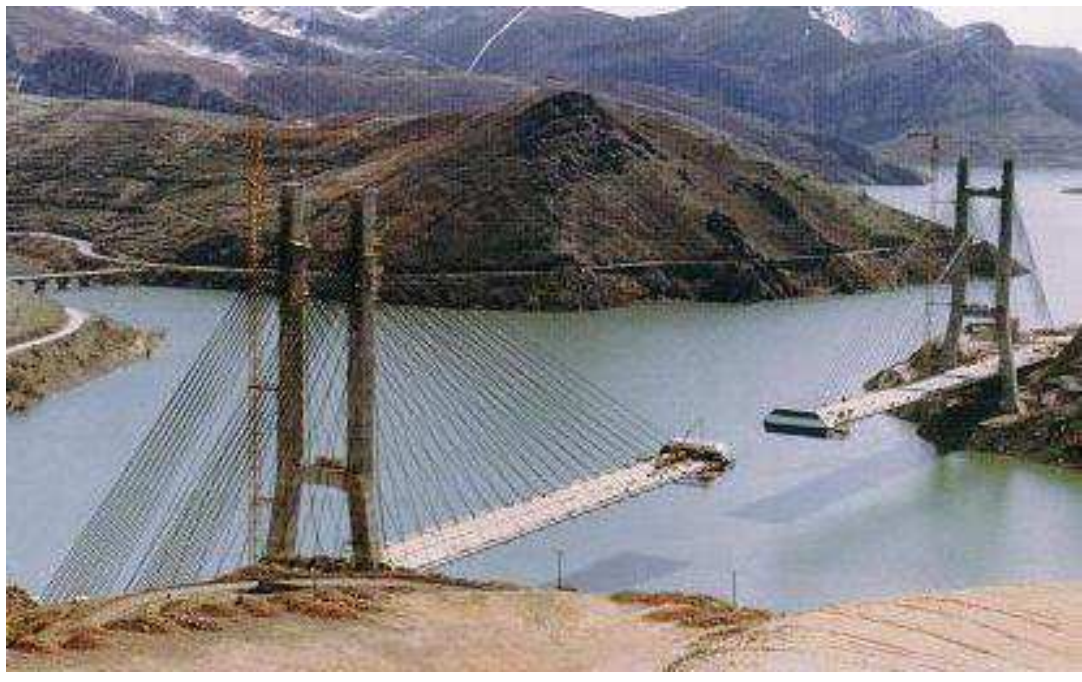

Ilustración 168. Construcción del puente de Fernández Casado. Fondo fotográfico I.L.C. construyó en $1983^{751}$

como parte de las

obras de la autopista AP-66 a su paso por el embalse. En su diseño participaron diversos arquitectos $\quad \mathrm{e}$ ingenieros, como Javier Manterola, Leandro Fernández Troyano y Carlos

Fernández Casado, de quien toma su nombre.

Se trata de un esbelto puente atirantado realizado en hormigón pretensado con una longitud de $440 \mathrm{~m}$. de luz sobre las aguas del pantano, cifra récord para la época. Este récord sólo duraría alrededor de tres años ya que fue superado en 1986 por el puente colgante de Lisboa en la desembocadura del río Tajo.

Posee una estructura ligera con dos pilares en forma de Y invertida en los que descansa el tablero. La utilización del hormigón pretensado facilita la elasticidad y los cambios de peso que tiene que soportar la estructura de la autopista al paso de los vehículos, además de adaptarla a las variaciones térmicas, corrientes eólicas y demás cambios climáticos $^{752}$.

La longitud total del puente es de $643.5 \mathrm{~m}$. con un vano central de $440 \mathrm{~m}$. y dos laterales de $66.75 \mathrm{~m}$. El ancho total es de $22.5 \mathrm{~m}$. y el canto es de $2.5 \mathrm{~m} .{ }^{753}$ El tablero se construyó con dovelas hormigonadas "in situ", de $4.08 \mathrm{~m}$. de longitud que fueron colocados por medio de carros de avance. Se atiranta cada dos dovelas de $8.16 \mathrm{~m}$. El número de tirantes delanteros y traseros es de más de cien. El tablero está articulado en el centro del vano principal ${ }^{754}$ y está se pretensado con barras en el sentido longitudinal y con cordones en el transversal. Las torres tienen una altura sobre el tablero de $90 \mathrm{~m}$. y

\footnotetext{
${ }^{751}$ http://www.cfcsl.com/index_archivos/CFCDD_archivos/Trabajos_archivos/start_archivos/Atirantados archivos/BARRIOS.htm

${ }^{752}$ Ibídem.

${ }^{753}$ Ibídem. Como monumento de este gran puente se instaló una de las vigas con las que se construyó la obra en la carretera comarcal que pasa justo por debajo. Así se puede observar la forma constructiva de esta gran obra.

${ }^{754}$ Ibídem.
} 
una altura máxima desde el terreno de $123 \mathrm{~m}$. Están formadas por dos columnas verticales con una separación entre ejes de $20 \mathrm{~m}$. arriostradas entre sí a dos alturas.

Hoy en día se ha convertido en una insignia del pantano, siendo referente de numerosos anuncios televisivos y turísticos. 


\subsection{NUEVOS MOTORES ECONÓMICOS Y CULTURALES}

La inundación de la ZACEL fue un hecho muy duro para las poblaciones afectadas que todavía hoy se recuerda a través de fiestas y numerosos artículos periodísticos ${ }^{755}$. Las festividades poseen un carácter social y espontáneo, nacidas de una emigración forzosa que animan al recuerdo del pasado como la Romería de Mirantes de Luna, celebrada el 30 de Julio, la Romería del Encuentro en Barrios de Luna, el 28 de Julio $^{756}$, y la fiesta en honor al reencuentro de los afectados por el embalse de Luna celebrada en Sena de Luna el último domingo de Julio. La Romería del Encuentro de Barrios de Luna es una de las más grandes dentro de las nuevas festividades de la ZACEL relacionadas con la inundación. La fiesta como tal se inició en los años sesenta del siglo XX para el recuerdo de los antiguos vecinos que poblaron el ahora inundado valle.

En los últimos años las presas y azudes han comenzado a ser considerados como parte importante del patrimonio nacional. El embalse ha dejado de ser una reserva de agua para convertirse en "Paraje Natural"757. Alrededor del embalse se van creando una serie de actividades e infraestructuras destinadas principalmente a actividades recreativas como los baños, actividades acuáticas con embarcaciones de pequeño y mediano tamaño o incluso la pesca deportiva ${ }^{758}$. En algunas ocasiones la explotación indiscriminada de los recursos de la zona ha llevado a delitos fiscales como el ocurrido en 2002 con la cantera de piedra de Mirantes explotada por Navaleo, S. L., y Técnicas Industriales Bergase, para la obra de la ampliación de El Musel en Gijón. Los empresarios sobrepasaron el permiso de extracción de tres a siete hectáreas, lo que conllevó a la denuncia por parte de fiscalía y el cierre de la cantera ${ }^{759}$.

En la ZACEL se han desarrollado por sí solas nuevas fuentes de riqueza basadas fundamentalmente en la explotación turística del embalse y los beneficios monetarios que C.H.D. aporta al ayuntamiento de Barrios de Luna.

\footnotetext{
${ }^{755} \mathrm{http} / / / \mathrm{www} .1 \mathrm{a}-\mathrm{cronica} . \mathrm{net} / 2009 / 09 / 29 /$ comarcas/la-memoria-que-emerge-desde-el-fondo-del-agua51360.htm

${ }_{756} \mathrm{http}: / / \mathrm{www}$. aytolosbarriosdeluna.es/municipio/fiestas.

${ }^{757}$ DÍEZ-CASCÓN-BUENO. Las presas, p. 372.

${ }^{758}$ SANZ-DOMÍNGUEZ. Guías, p. 15.

${ }^{759}$ L.A.R. "Absueltos dos empresarios de un delito contra el medio ambiente por extraer piedra para El Musel” en El Comercio. Gijón. 30-12-2011.http://www.elcomercio.es/
} 


\subsubsection{Centros de ocio}

En los últimos años se ha creado una corriente ruralista y turística que ha traído como consecuencia la vuelta de algunos de los antiguos dueños o herederos del lugar. Ejemplo de ello es Miñera. Actualmente la población ha vuelto a ser fundada por la iniciativa de D. Petronilo Guisuraga. La nueva población también es un factor de avance y desarrollo que regenera las actividades tradicionales por unas nuevas basadas en el ocio de los deportes acuáticos y de montaña. El turismo activo se ha convertido de este modo en el motor económico del Valle en el que se desarrollan numerosas actividades relacionadas con el turismo rural como la proliferación de casas rurales, campings y rutas de senderismo.

El Camping y el Club Náutico de Mirantes de Luna son uno de los ejemplos de atracción económica de la ZACEL basados en el ocio de los deportes acuáticos y la pesca.

El Camping de Mirantes se ubica en el km 63 de la carretera CL-623. Se extiende sobre una superficie de 1.5 ha. y posee un lago artificial. Cuenta con servicios de alimentación, sanitarios, lavandería e instalaciones recreativas para niños.

El Club Náutico se sitúa en la parte baja del abandonado pueblo de Mirantes de Luna. Fue fundado en los años setenta por un grupo de empresarios y médicos de León gracias a la cesión de la C.H.D. de dichos terrenos por un período de noventainueve años. Posee varias instalaciones deportivas así como cafetería-restaurante, capilla y zonas de merendero. Actualmente el Club cuenta con más de doscientos socios que disfrutan durante todo el año de las instalaciones en un entorno incomparable de agua y montaña.

\subsubsection{Museos}

La creación de nuevos museos dentro del espacio en estudio es significativa. La totalidad de todos ellos pretenden dar a conocer las labores tradicionales, así como un recuerdo ocasional de lo que supuso la pérdida de los trabajos artesanales. Hay que destacar que estos museos se centran fundamentalmente en actividades ya perdidas o en peligro de extinción y asombrosamente ninguno de ellos posee un espacio dedicado a la recuperación de la memoria de las poblaciones inundadas. 
El Museo del Valle del Luna inaugurado en agosto de 2000, con la colaboración de las CEAS y del Ayuntamiento de Soto y Amío, está situado en Canales-La Magdalena, en la antigua sala de cine, y comprende una colección etnográfica donde se exponen diferentes aspectos de la cultura tradicional de la zona.

Otro de los museos es el del Pastor de los Barrios de Luna, instalado en las antiguas escuelas del pueblo, inaugurado en septiembre de 1997 y abierto desde 1999. Alberga piezas cedidas por los vecinos de pueblos cercanos relacionadas con la cultura pastoril. En sus salas conserva vestimentas tradicionales, objetos y utensilios usados en las labores de la ganadería trashumante y trasterminante.

\subsubsection{Nuevos proyectos}

Las diferentes rutas naturales marcadas en los alrededores del embalse están atrayendo un tipo de turismo basado en el respeto y disfrute de la naturaleza con un componente de aventura. Sin embargo se está despreciando un aspecto que puede ser explotado económicamente y es el patrimonial e histórico, igualmente importante para el desarrollo del Valle. Este aspecto fortalece la teoría de la explotación turística de los recursos como un motor cultural que promueva el recuerdo y respeto de este patrimonio inundado que posee unas características únicas en toda la provincia de León.

La anegación de parte del Valle de Luna ha supuesto una pérdida sustancial de las formas económicas de la montaña pero a su vez una fuente de riqueza que puede lograrse a partir de la puesta en valor e interpretación in situ de los restos así como de la creación de un programa de gestión cultural sostenible que se materialice en un aula de interpretación de la ZACEL.

Cabe destacar que el embalse se ha convertido, de manera natural, en una gran aula arqueológica, especialmente en el momento estival, cuando el número de curiosos, antiguos moradores o paseantes se multiplica de manera espectacular para observar un fenómeno casi único en el que emergen todas las edificaciones que conformaron la zona afectada por la inundación. Las posibilidades didácticas de creación de un centro de interpretación en estos lugares supondrán una fuente de ingresos para el desarrollo cultural y rural de una zona degradada. 
6. CONCLUSIONES 
El estudio de los bienes inmuebles afectados por el embalse de Barrios de Luna ha permitido evidenciar un proceso acelerado de pérdida de memoria histórica que ha perjudicado de manera especial a su vertiente patrimonial. El objetivo principal de la presente Tesis Doctoral ha sido el de crear una metodología que permitiera reconstruir, en la medida de lo posible, el trascurso de los acontecimientos que se llevaron a cabo durante el proceso de destrucción de los bienes y acercarse a las edificaciones otrora existentes.

La pérdida de la memoria patrimonial significa la pérdida del pasado de las gentes que lo han utilizado. En el caso de los territorios que apenas dejan documentación escrita, la situación se agudiza más. Estas razones han obligado a crear una metodología adaptada a las necesidades de este trabajo en el que para recuperar la información se ha recurrido a encuestar a las gentes que aún viven y que se localizan en puntos muy diversos de la geografía hispana, a consultar archivos no habituales y a utilizar las fotografías como único medio de reconstruir el pasado. Todas estas circunstancias impiden comparar esta T. D. con otras que son más clásicas en el área de conocimiento de Historia del Arte. Sin embargo esta T.D. se acerca a la vanguardia de nuevos estudios y nuevas asignaturas centradas en el estudio del Patrimonio Cultural cuya línea de investigación apenas está explorada.

Las conclusiones que se han extraído de éste trabajo son las siguientes:

- El patrimonio de la ZACEL se ha visto afectado por una serie de factores particulares y exclusivos del embalse, diferentes de los que pudieran haberse dado en otras situaciones como guerras, abandonos o traslados.

- El proceso de degradación del patrimonio se inició en el mismo instante de la aprobación definitiva de la consecución de las obras del embalse y su destrucción sigue vigente hasta nuestros días.

- Cuantitativamente el deterioro más grave fue el que afectó tanto a la arquitectura civil, a la arquitectura tradicional, a la arquitectura religiosa, a la arquitectura industrial como a las obras públicas, especialmente puentes y pontones. También hay que mencionar la destrucción de yacimientos arqueológicos y ruinas medievales así como la desaparición por traslado de distintas piezas.

- La primacía por la ejecución de la presa fue mayor que la necesidad de conservar unos bienes considerados de carácter rural y por lo tanto 
exiguos de cualquier protección legal. A pesar de que existían algunos pequeños apartados en las legislaciones referentes a la protección del patrimonio, la necesidad de crear una "España verde" y agrícola legitimó la desaparición de los edificios.

- Los responsables de los bienes, desde el proceso legal hasta la anegación del Valle, vieron en la expropiación una oportunidad de ganancia económica y apenas tuvieron una conciencia de defensa con respecto a su patrimonio. Desde el inicio de las obras las voces que se levantaban en contra del proyecto tenían que ver con la justa indemnización y no con la protección de los bienes más representativos como el castillo de Luna, cuyos restos fueron destruidos para asentar las máquinas que transportaban el material a la presa.

- La total desorganización, durante los años en los que se llevaron a cabo las obras de la presa, fue ocasionada por la indolencia y la indiferencia de las autoridades responsables de la administración estatal, provincial y local así como el arzobispado de Oviedo y el obispado de León. Tanto es así que décadas después se volvieron a cometer las mismas tropelías a consecuencia de la ejecución de obras de la autopista LeónCampomanes.

- Los bienes fueron desmantelados por sus propietarios de una manera gradual y ordenada. Así lo primero que desparecieron fueron los bienes muebles; posteriormente las tejas; a continuación los edificios fueron despojados de las estructuras de madera como armaduras y puertas; por último se llevaron algunas piezas de valor como los dinteles con el año de inauguración de la casa.

- Una vez que los bienes pasaron a la C.H.D. los edificios fueron abandonados, lo que determinó que todos aquellos materiales reutilizables fueran extraídos. Las piezas de mejor calidad se vendieron a anticuarios y mercaderes ambulantes, mientras que el resto se extrajeron sin ningún tipo de licencia. El material de acarreo más demandado eran los sillares mejor labrados y los dinteles de vanos y esquinas. Así fue cómo los muros comenzaron a desplomarse. 
- La aparición de maquinaria pesada facilitó el arranque de dichos materiales, al mismo tiempo que agilizaba su transporte. A esto se le añadieron otros factores como el auge constructivo experimentado en los pueblos situados en el entorno de la ZACEL y la venta de los materiales pétreos por parte de la C.H.D.

- La brutal degradación de mano de la acción antrópica ha sido tan rápida y devastadora que ha incluso impedido detectar en muchos casos cómo, por ejemplo, se comportaban las cargas de morteros en los edificios sumergidos.

- En muy poco tiempo, lo que antes eran núcleos de población con sus edificios religiosos, con sus casas y sus construcciones anexas, sus edificios industriales, y las cercas que rodeaban los huertos y otras fincas de labor, son ahora sólo evidencias de un pasado destruido. Tan solo se observan los restos de materiales de peor calidad que no alcanzan a ser valorados como yacimientos arqueológicos.

- En este sentido se debe valorar el pantano de Barrios de Luna como una de las grandes catástrofes patrimoniales de la provincia de León durante la segunda mitad del siglo XX y no solo en lo que respecta al patrimonio inmueble, sino también en el mueble, y en el inmaterial.

- En la actualidad la situación del Valle ha supuesto un cambio sustancial debido a la acumulación de una gran masa de agua que ha ocasionado la pérdida de sus pobladores, su historia, su lengua y sus costumbres, y cuya recuperación pasa por la concienciación cultural de la sociedad con respecto a ello.

- Los puntos que se han desarrollado en este trabajo pueden servir como fuente para la creación de unas estructuras culturales basadas en los restos de las antiguas poblaciones asentadas en la ZACEL que pongan de relieve el valor de un patrimonio hoy desaparecido. 
7. BIBLIOGRAFÍA 
AGUADO BLEYE, Pedro. Manual de Historia de España. T. I, Prehistoria; Edades antigua y media. Madrid, 1971. (AGUADO BLEYE. Manual)

AGUILÓ, Miguel Alonso. La Enjundia de las Presas Españolas, Madrid, ACS, Actividades de Construcción y Servicios, S.A., 2002 (AGUILÓ. La Enjundia)

ALCEDO Y DE SAN CARLOS, Marqués de. Los merinos mayores de Asturias del apellido Quiñones y su descendencia. Apuntes genealógicos, históricos y anecdóticos. vol. II. Madrid, 1918. (ALCEDO Y DE SAN CARLOS. Los merinos)

ALMARCHA, Luis. Instituciones diocesanas. León, 1970 (ALMARCHA. Instituciones)

ALMAGRO GORBEA, Martín y MARTÍNEZ FERNÁNDEZ, Antonio R. “Un hacha del bronce final procedente de Irede de Luna. León” en Veleia: Revista de prehistoria, historia antigua, arqueología y filología clásicas, No 24-25, 2, 2007-2008 (Ejemplar dedicado a: Homenaje a Ignacio Barandiarán Maestu / coord. por Javier Fernández Eraso, Juan Santos Yanguas; Ignacio Barandiarán Maestu (hom.)), pags. 835-842.

ALMAZÁN CEBALLOS, Agustín. Guía de campo del Embalse de Los Barrios de Luna y sus alrededores, Barrios de Luna, 2000. (ALMAZÁN CEBALLOS, Guía)

ALONSO FERNÁNDEZ, Pedro. A. "Los Barrios de Luna: embalse”, en Rutas Turísticas por León. León, 1991. (ALONSO FERNÁNDEZ, Barrios)

ALONSO GONZALEZ, Joaquín-Miguel. Los molinos tradicionales en la provincia de León. León 1993. (ALONSO GONZÁLEZ. Los molinos)

ALONSO GONZÁLEZ, Joaquín-Miguel. Arquitectura tradicional de la comarca de Omaña y Valle de Samario. León, 2003. (ALONSO GONZÁLEZ. Arquitectura)

ALONSO GONZÁLEZ, Joaquín-Miguel. Guía turística de las comarcas de Cuatro Valles. León, 2006.

ALONSO HERRERO, Eduardo y NEIRA CAMPOS, Ana. Una explotación minera de minium (cinabrio) atribuible a época romana en Miñera (León-España) Revista Lancia 4 (2000-2001) pp.127-142. (ALONSO HERRERO-NEIRA CAMPOS, Explotación)

ALONSO PÉREZ, Enrique, "Los espectros del embalse de Luna" en Diario de León, publicado el 21 de diciembre de 2008 
ALONSO PONGA, José Luis. La arquitectura del barro. Madrid, 1989 (ALONSO PONGA. La arquitectura)

ALONSO PONGA ,José Luis. Arquitectura popular leonesa. León 1990

ALSINA CATALÁ, Claudi. L,art de calcular en lárquitectura. ED: Aula de arquitectura, 1. Barcelona, 1993.

ÁLVAREZ ÁlVAREZ, César y MARTÍN FUERTES José Antonio, Catálogo del archivo de los condes de Luna. León, 1977. (ÁLVAREZ-MARTÍN FUERTES, Catálogo)

ÁLVAREZ, ÁLVAREZ, César. Castillos, palacios y torres de los Quiñones en la Baja Edad Media leonesa. Castillos medievales en el reino de León. León, 1981. (ÁLVAREZ, ÁLVAREZ, Castillos)

ÁlVAREZ ÁlVAREZ, César. El condado de Luna en la Baja Edad Media. León, 1982. (ÁLVAREZ, ÁLVAREZ, Condado)

ÁLVAREZ, ÁLVAREZ, César y MARTÍN FUERTES, José A. Catálogo del archivo de los condes de Luna. León, 1977. (ÁLVAREZ-MARTÍN FUERTES. Catálogo)

ÁlVAREZ, ÁlVAREZ, César y MARTíN FUERTES, José A. Addenda del Catálogo del Archivo de los Condes de Luna. León 1982. (ÁLVAREZ-MARTÍN FUERTES, Addenda)

ÁlVAREZ ÁlVAREZ, César y ALONSO GONZÁLEZ, Joaquín. Guía del patrimonio cultural de las comarcas de cuatro valles. León, 2001 (ALVAREZALONSO, Guía)

ALVAREZ ALVAREZ, José Luis. "La ley de 1933 y la transmisión de obras de arte “en B. ANABAD XXXIII 1983, n² 2, pp. 227-234, (ÁLVAREZ. “La ley”)

ÁLVAREZ MOURÍN, María del Pilar. Diplomática asturleonesa. Terminología toponímica. León, 1994. (ALVAREZ MOURÍN, Diplomática)

ALVAREZ OBLANCA, Wenceslao. "La difícil gestación del León Contemporáneo" en La provincia de León. León, 1996.

ÁlVAREZ RUBIO, Julio. Babia, Laciana, Alto Luna. Pueblos, paisajes y paseos. León 2006. (ÁLVAREZ RUBIO, Babia)

ÁLVAREZ MOURÍN María del Pilar, Diplomática asturleonesa. Terminología toponímica. León, 1994. 
ALZOLA y MINONDO, Pablo. Historia de las Obras Públicas en España, (1899), Madrid, Colegio de Ingenieros de Caminos, Canales y Puertos, 1979. (ALZOLA y MINONDO. Historia)

AMOR TAPIA, Ma Luisa. El patrimonio cultural castellano expoliado. Burgos 2008. (AMOR TAPIA. El patrimonio)

ANES, Gonzalo y GARCÍA SANZ, Ángel. (coordinadores) Mesta, trashumancia y vida pastoril. Madrid, 1994.

ARANBURU-ZABALA HIGUERA, Miguel Ángel. La arquitectura de puentes en Castilla y León. 1575-1650 Valladolid, 1992. (ARAMBURU-ZABALA. La arquitectura)

ARAMBURU-ZABALA HIGUERA, Miguel Ángel. LOSADA VAREA Celestina. CAGIGAS ABERASTURI, Ana. Los canteros de Cantabria. Colegio oficial de aparejadores y arquitectos técnicos de Cantabria. Santander 2005.

ARIAS, Manuel. La gestión del patrimonio cultural. La trasmisión de un legado. Valladolid, 2002.

ARIAS PÁRAMO, Lorenzo. "Aproximación a la realidad material del monacato asturiano en la Ata Edad Media. Los monasterios del reino de León y Castilla a mediados del siglo XI. Un ejemplo de selección de las especies" en Monjes y monasterios hispanos en la alta Edad Media. Fundación Santa María la Real. Aguilar de Campoo. Palencia, 2006.

AZNAR NALLEJO, Francisco. Glosario de términos de la práctica artística. Tenerife, 1993.

BALLART, Josep. El patrimonio histórico y arqueológico: valor y uso. Barcelona, 1997.

BARCIELA LÓPEZ, Carlos y MELGAREJO MORENO, Joaquín (Eds) El agua en la historia de España. Universidad de Alicante, 2000.

BELINCHÓN, Gelu y FERNÁNDEZ, Esperanza. Viajando al pasado. Itinerario por los Barrios de Luna. León, 2001.

BENITO FERNÁNDEZ, Gerardo. Génesis del modelado tipo mallo, en "Cuadernos de investigación geográfica", Tomo 12, Logroño, 1986. (BENITO FERNÁNDEZ. Génesis)

BENITO MARTÍN, Félix. La arquitectura tradicional de Castilla y León. Vol I, II. Salamanca, 1998. (BENITO MARTÍN. La arquitectura Castilla y León) 
BENITO MARTÍN, Félix. La formación de la ciudad medieval. La red urbana en Castilla y León. Serie: Arquitectura y urbanismo no 33. Universidad de Valladolid. Valladolid, 2000. (BENITO MARTÍN. La formación)

BENITO MARTÍN, Félix. La arquitectura tradicional de la provincia de León. León, 2005. (BENITO MARTÍN. La arquitectura León)

BERDUCOU, M. C. La conservation en archéologie. Méthodes et pratique de la conservation. Barcelona, 1990.

BERGÓS, Juan. Maderas de construcción, decoración y artesanía. Barcelona, 1951. (BERGÓS. Maderas)

BERRUETA, Mariano. Riberas del Luna. Ofrenda de despedida a los pueblos de las riberas del Luna que desaparecen en el pantano de Barrios de Luna. León, 1956. (BERRUETA, Riberas)

BERZAL de la ROSA Enrique. "José Álvarez Miranda. El obispo conservador que solicitó clemencia para el abuelo de Zapatero" en Leoneses con historia. Diario El Mundo. León. Lunes 14 de diciembre de 2009.

BICZOT, Imre. La corrosión y protección del hormigón. Bilbao, 1992.

BISCONTIN, Guido. COLLE dal, Mauricio. VOLPIN, Stefano. II catiere della conoscenza. II cantiere del restauro. Scienza e beni culturali. ED: Librería progelto. ATTI del convengo di studi Bressanone 27-30. Roma, 1989.

BLAS CORTINA, Miguel Ángel. "Nuevos testimonios metalúrgicos de la Edad del Bronce en el centro-occidente de la región cantábrica" en Veleia: Revista de prehistoria, historia antigua, arqueología y filología clásicas. 1991-1992. № 8-9, págs. 109-138. (BLAS CORTINA. "Nuevos testimonios")

BLOCH Marc. Avenement et conquetes du moulin á eau. Melanges Historiques. Tomo I y II. París, 1963. (BLOCH. Avenement)

BOHIGAS ROLDÁN, Ramón. "La Edad del Hierro en Cantabria. Estado de la cuestión” en Zephyrus: Revista de prehistoria y arqueología, Año. 1986-1987. No 3940, pp. 119-138. (BOHIGAS ROLDÁN. “La Edad del Hierro”)

BURÓN CASTRO, Taurino. Catastro del marqués de la Ensenada. León, 1985. (BURÓN CASTRO, Catastro)

CABRERA ORTI, Ma Ángeles. Los métodos de análisis físico-químicos y la historia del Arte. Granada, 1994. 
CADENAS Y VICENT, Vicente de. Repertorio de blasones de la comunidad hispánica. Instituto Salazar y Castro (CSIC) Madrid, 1987. (CADENAS DE Y VICERNT. Repertorio)

CADIÑAS BARDECI, Inocencio. Puentes de León. (I y II) Tierras de León. № 111-112. Año XXXIX. Agosto 2000- Mayo 2001 (CARDIÑAS BARDECI. Puentes)

CALDERÓN ROCA, Belén. "La tutela jurídica de los centros históricos: diserciones sobre la antítesis entre teoría y práctica en base a la preservación del valor cultural" en BA artículos, Revista del Departamento de Historia del Arte. Universidad de Málaga, n 25, 2004, pp. 519-553 (CALDERÓN ROCA. "La tutela")

CAMPOS SÁNCHEZ-BORDONA, Dolores. El arte del renacimiento en León: las vías de difusión. León, 1992.

CARO BAROJA, Julio. Tecnología popular española. Madrid, 1986. (CARO BAROJA. Tecnología)

CARRICAJO CARBAJO, Carlos. GARCÍA TAPIA, Nicolás. Molinos en la provincia de Valladolid. Valladolid, 1990.

CARRICAJO CARBAJO, Carlos. Construcciones secundarias. Valladolid, 1995.

CASADO LOBATO, Concha. "Otero de las Dueñas. Huellas de un monasterio" en Filandón. Diario de León. 27 de septiembre de 1987. № 90.

CASADO LOBATO, Cocha. Colección diplomática del monasterio de Carrizo. León, 1983. (CASADO LOBATO. Colección)

CASADO LOBATO, Concha. León y sus comarcas. Salamanca, 1991.

CASADO LOBATO, Concha. La arquitectura tradicional en tierras de León. Fundación hullera Vasco-leonesa. León, 2005.

CASTRO VILLALBA, Antonio. Historia de la construcción medieval. Aportaciones. Quaderns dÁrquitectes. Barcelona, 1996. (CASTRO VILLALVA. Historia)

CAVERO DOMÍNGUEZ, Gregoria. El esplendor del Cister en León (siglos XII y XIII) Fundación Hullera Vasco-Leonesa. León, 2007.

CÉLIS SÁNCHEZ, Jesús. "Origen, desarrollo y cambio en la Edad del Hierro de las tierras leonesas". Actas del ciclo de conferencias ARQUEOLEÓN. Historia del reino de León a través de la arqueología. León 1993-1994, pp. 41-67. León, 1996, (CÉLIS SÁNCHEZ, "Origen”) 
CELIS SANCHEZ, Jesús. El castillo de los Barrios de Luna. Un yacimiento del Bronce inicial-medio en el occidente de la cordillera cantábrica. Revista Lancia 4-( 85102) León, 2001. (CÉLIS SÁNCHEZ, "El castillo”)

CIMADEVILLA-SANCHEZ, Pío. Repertorio Heráldico Leonés, Vol. I, II y III. León, 1996. (CIMADEVILLA. Repertorio)

CHIAS NAVARRO, Pilar y ABAD BALBOA, Tomás. Los caminos y la construcción del territorio en Zamora. Catálogo de puentes. Instituto de Estudios zamoranos, 2004.

D. K. CHING, Francis. Diccionario visual de arquitectura. México, 1997.

COBO, Florentino. CORES, Miguel. ZARACINA, Matilde. Arquitectura popular asturiana. Conocer Asturias. Principado de Asturias, 1987. (COBO-CORESZARACINA. Arquitectura)

COFIÑO FERNÁNDEZ, Isabel. Arquitectura religiosa en Cantabria. (16851754) Santander, 2004. (COFIÑO FERNÁNDEZ, Arquitectura)

CONDE GARCÉS, Juan M. El pantano de los Barrios de Luna y su incidencia socio- económica en la comarca. Escuela social de León, Trabajo inédito. (CONDE GARCÉS, Pantano)

CORELLA SUAREZ, M ${ }^{\mathrm{a}}$ Pilar. Arquitectura religiosa de los siglos XVII y XVIII en la provincia de Madrid: estudio y documentación del partido judicial de Getafe. Madrid, 1979. (CORELLA SUAREZ. Arquitectura)

COROMINAS, Joan. PASCUAL, José Antonio. Diccionario crítico etimológico castellano e hispánico. Madrid, 1984. (COROMINAS-PASCUAL. Diccionario)

CORRADO MISSERI, Salvatore. El valor de las Obras de Arte. Valencia, 1995.

CORTÉS BORROY, Francisco Javier. La arquitectura religiosa de los siglos XVII y XVIII en el Bajo Aragón zaragozano y en la Ribera Baja del Ebro. Colección estudios ARTE. Institución Fernando el Católico. CSIC. Exma Diputación de Zaragoza. Zaragoza, 2007. (CORTÉS BORROY. La arquitectura)

COSCOLLANO RODRÍGUEZ, José. Restauración y rehabilitación de edificios. Madrid, 2003. (COSCOLLANO RODRÍGUEZ. Restauración)

CRISTÓBAL, $M^{\mathrm{a}}$ Teresa. GONZÁLEZ, M ${ }^{\mathrm{a}}$ Jesús. NISTAL, Pedro Andrés. Movimientos migratorios en el norte de León .Valladolid, 1986.

DARLEY, Gillian. La fábrica como arquitectura: facetas de la construcción industrial. Barcelona, 2010. (DARLEY. La fábrica) 
DAROCA SANTOS, F. coor., CANTALAPIEDRA PUELLES, F. guión; Embalse de Villameca, Embalse de Riaño y Embalse del Porma. MUNDIMAG realización. Madrid, 2006.

DELIBES CASTRO, Germán. "Hacha plana de cobre hallada en Villalón de Campos (Valladolid)" en Boletín de Seminarios de Estudios de Arte y Arqueología. Tomo 46. 1980, pp. 129-133 (DELIBES CASTRO, Hacha plana)

DELIBES CASTRO, Germán. FERNANDO MANZANO, Julio. “Calcolítico y Bronce en tierras de León” en Cántabros y Astures (Lancia). Universidad de León, 1983 pp. 53-82. (DELIBES CASTRO- FERNÁNDEZ MANZANO, Calcolítico)

DELIBES CASTRO, Germán. FERNANDEZ MANZANO, Julio y otros. Metalurgia de la Edad del Bronce en el piedemonte meridional de la Cordillera Cantábrica. La colección Fontaneda. Valladolid, 1999. (DELIBES CASTROFERNÁNDEZ MANZANO, Metalurgia)

DÍEZ ALONSO, Matías. DÍEZ DEL POZO, Matías. Castillos de León. León, 1978.

DÍEZ-CASCÓN SAGRADO, Joaquín. BUENO HERNÁNDEZ, Francisco. Las presas y embalses en España. Historia de una necesidad. I Hasta 1900. Madrid, 2003. (DÍEZ-CASCÓN-BUENO. Las presas)

DOMÍNGUEZ CALATAYUD, Íñigo. "Riaño, historia de una agonía: hablan los hombres de Riaño" en Tierras de León: Revista de la Diputación Provincial, Vol. 16, № 24, 1976, pp. 21-30. (DOMÍNGUEZ CALATAYUD. "Riaño")

ESPARZA ARROYO, Ángel. "Hacha de apéndices laterales del castro de Fradellos (Rabanales, Zamora) "en Boletín del Seminario de Estudios de Arte y Arqueología: BSAA, Tomo 44, 1978 (ESPARZA ARROYO. "Hacha”)

FACI, Javier. "Reforma gregoriana, reforma eclesiástica" en Espacios de poder y formas sociales en la Edad Media. Salamanca, 2007.

FEDUCHI, Luis. Itinerarios de arquitectura popular en España Vol. III. Barcelona, 1986. (FEDUCHI. Itinerarios)

FERNÁNDEZ CATÓN, José María. Catálogo del archivo histórico diocesano de León. León, 1978. (FERNÁNDEZ CATÓN. Catálogo)

FERNÁNDEZ CATÓN, José María. Colección documental del archivo de la catedral de León. (775-1230) Volumen VI (1188-1230) León, 1990-1991. 
FERNÁNDEZ CONDE, Francisco Javier. Libro de los testamentos de la catedral de Oviedo. Roma, 1971.

FERNÁNDEZ DÍEZ, Alicia. Patrimonio leonés. La arquitectura industrial hidráulica. León, 2005. (FERNÁNDEZ DÍEZ. Patrimonio)

FERNÁNDEZ FLÓREZ, José Antonio. HERRERO DE LA FUENTE, Marta. Colección documental del monasterio de santa María de Otero de las Dueñas. Vol I (854-1108), Vol II (1109-1300) León, 1999. (FERNÁNDEZ FLOREZ-HERRERO DE LA FUENTE, Otero)

FERNÁNDEZ MANZANO, Julio. El Bronce final en la Meseta Norte española: el utillaje metálico. Valladolid, 1986. (FERNÁNDEZ MANZANO. Bronce)

FERNÁNDEZ MANZANO, Julio. "Calcolítico y Edad del Bronce en la provincia de León". Actas del ciclo de conferencias ARQUEOLEÓN. Historia del reino de León a través de la arqueología. León 1993-1994. León, 1996, pp. 29-40.

FERNÁNDEZ MANZANO, Julio. NEIRA CAMPOS, Ana. "Bronces prehistóricos en el municipios de Carroceda (León). Su interpretación desde la arqueología del paisaje" en Lancia 7. Prehistoria, Arqueología e Historia Antigua. Universidad de León, 2009,

FERNANDEZ MUÑOZ, Ángel. (coord.) Restauración Arquitectónica. Valladolid 1992 (FERNÁNDEZ MUÑOZ. Restauración)

FERNÁNDEZ ORDÓÑEZ, José Antonio y otros. Catálogo de noventa presas y azures españoles anteriores a 1900. Madrid, 1984. (FERNÁNDEZ ORDÓÑEZ, Catálogo)

FERNÁNDEZ ORDÓÑEZ, José Antonio. ABAD BALBOA, Tomás. CHÍAS NAVARRO, Pilar. Catálogo de puentes anteriores a 1936. León, 1988. (FERNÁNDEZ-ABAD-CHÍAS. Catálogo)

FERNÁNDEZ DEL POZO, José María. Colección documental del archivo de la catedral de León. Vol. XVI. León, 1998.

FERNANDEZ TROYANO, Leonardo. Tierra sobre el agua. Visión histórica universal de los puentes. Tomo I y II. Madrid, 2004.

FERNÁNDEZ VÁZQUEZ, Vicente. Arquitectura religiosa en el Bierzo. Siglos XVI-XVIII. Tomo I y II. Ed: Fundación Ana Torres Villarino. Ponferrada, 2001. (FERNÁNDEZ VÁZQUEZ. Arquitectura) 
FERRERAS CHASCO, Casildo. El norte de la meseta leonesa: estudio geográfico de un espacio rural. León, 1981. (FERRERAS CHASCO, El norte)

FLORES, Carlos. La arquitectura popular española. Madrid, 1974.

FRITZ, Leonhardt. Puentes: estética y diseño. Lausanne, 1986.

GARCÍA CASTELLÓN, Fernando. Los molinos y fábricas de harina en Castilla y León. Salamanca, 1997. (GARCÍA CASTELLÓN. Los molinos)

GARCÍA DE CELIS, Alipio. El relieve de la montaña occidental de León. Valladolid, 1997.

GARCÍA DE CORTÁZAR, José Ángel. “Los monasterios del reino de León y Castilla a mediados del siglo XI. Un ejemplo de selección de las especies" en Monjes y monasterios hispanos en la alta Edad Media. Fundación Santa María la Real. Aguilar de Campoo. Palencia, 2006.

GARCÍA DE LA FOZ, José. Crónica General de España. Historia ilustrada de sus provincias, sus poblaciones más importantes de la península y ultramar. Provincia de León. Madrid, 1867. (GARCÍA DE LA FOZ. Crónica)

GARCÍA FERNÁNDEZ, Javier. "La regulación y la gestión del Patrimonio Histórico-Artístico durante la Segunda República (1931-1939)" en Revista de Patrimonio Histórico. № 1 2007.pp 1-15, (GARCÍA FERNÁNDEZ. “La regulación”)

GARCÍA FORTES, Salvador. FLOS TRAVIESO, Nuria. Conservación y restauración de bienes arqueológicos. Madrid, 2008. (GARCÍA-FLOS. Conservación)

GARCÍA GARCÍA, María Elida. "El conde asturiano Gonzalo Peláez" en Asturiensia medievalia, № 2, 1975, pp. 39-64,

GARCÍA Y GARCÍA, Antonio. Legislación de los concilios y sínodos del reino leonés. El reino de León en la Alta Edad Media. II. Ordenamiento jurídico del reino. León, 1992.

GARCÍA GRINDA, José Luis. Arquitectura popular. Tomo I y II. León, 2008. (GARCÍA GRINDA. Arquitectura)

GARCÍA GRINDA, José Luis. "Función y forma: La arquitectura auxiliar agropecuaria leonesa" en La arquitectura tradicional en tierras de León. León, 2005. pp. 9-68 (GARCÍA GRINDA. "Función”)

GARCÍA GUINEA, M ${ }^{\mathrm{a}}$ Ángeles. PEREZ GONZALEZ, José María. Enciclopedia del románico en Castilla y León. León. ED: Fundación Santa María la 
Real. Centro de estudios del románico. Aguilar de Campoo. 2002 (GARCÍA-PÉREZ. Enciclopedia)

GARCÍA LARRAGUETA, Santos. Catálogo de los pergaminos de la catedral de Oviedo. Oviedo, 1957. (GARCÍA LARRAGUETA, Catálogo)

GARCÍA LARRAGUETA, Santos. Colección de documentos de la catedral de Oviedo. Oviedo, 1962. (GARCÍA LARRAGUETA, Colección. Oviedo)

GARCÍA LARRAGUETA, Santos. Santa María de Arbas. Catálogo de su archivo y apuntes para su historia. Madrid ,1980.

GARCÍA LOBO, Vicente y José Manuel. Santa María de Arbas. Catálogo de su archivo y apuntes para su historia. Madrid, 1980. (GARCÍA LOBO, Arbas)

GARCÍA LOBO, Vicente. Colección documental del archivo de la catedral de León. Vol: XII (1474-1534). León, 1998. (GARCÍA LOBO, Colección. León)

GARCÍA MARTÍN, Pedro. La ganadería meseteña en la España Borbónica (1700-1836). Madrid, 1988.

GARCÍA MERCADAL, Fernando. La casa popular en España. Madrid, 1930. (GARCÍA MERCADAL. La casa)

GARCÍA SANZ, Ángel. "El final de la Mesta /1808-1836" en Mesta, Trashumancia y vida pastoril. Madrid, 1994.

GARCÍA SANZ, Ángel. "El siglo XVIII: entre la prosperidad de las trashumancia y la crítica antimeseteña de la Ilustración (1700-1808)" en Mesta, Trashumancia y vida pastoril. Madrid, 1994.

GARCÍA SUÁREZ, Agustín. Una historia de pantanos. León, 1999. (GARCÍA SUÁREZ, Una historia)

GARCÍA TAPIA, Nicolás. Molinos tradicionales. Valladolid, 1997. (GARCÍA TAPIA. Molinos)

GARCÍA VILLOSLADA, Ricardo. La iglesia en España en los siglos XVII y XVIII. Historia de la iglesia en España. Madrid, 1979. (GARCÍA VILLOSLADA. La iglesia)

GASPAR TEBAR, Demetrio. Durabilidad del hormigón y los materiales pétreos. Seminario 51 del CEMCO 88. Madrid, 1988. (GASPAR TEBAR. Durabilidad)

GIBERT, Vicenç, LÓPEZ, Joseph. Aula de madera. Restauración. Barcelona, 1999. (GIBERT-LÓPEZ. Aula) 
GIL FERNÁNDEZ, Juan. MORALEJO, José L. RUIZ DE LA PEÑA Juan Ignacio. Crónica de Alfonso III. Gijón, 1985. (GIL-MORALERJO-RUIZ. Crónica)

GOMEZ MORENO, Manuel. Catálogo monumental de España: La provincia de León, (1906-1908) Madrid, 1925. Ed facsímile. Madrid, 1979. (GOMEZ MORENO, Catálogo)

GONZÁlEZ, Ma Jesús. CRISTÓBAL, Ma Teresa. NISTAL, Pedro Andrés. Movimientos migratorios recientes y su incidencia en el norte de León. Junta de Castilla y León, 1986. (GONZÁLEZ-CRISTÓBAL-NISTAL, Movimientos)

GONZALEZ-DORIA, Fernando. Diccionario heráldico y nobiliario. Tomo III. Madrid, 2000. (GONZÁLEZ DORIA, Diccionario)

GONZÁLEZ-VARAS, Ignacio. Conservación de los bines culturales. Teoría, Historia, principios y normas. Madrid 2003. (GONZÁLEZ VARAS. Conservación)

GONZÁLEZ TASCÓN, Ignacio. Molinos y ferrerías en el valle del Duero. Estudios sobre historia de la ciencia y de la técnica. Tomo I. IV Congreso de la Sociedad Española de Historia de las Ciencias y de las Técnicas. Valladolid 22-27 de septiembre de 1986. Valladolid, 1988. (GONZÁLEZ TASCÓN. Molinos)

GONZÁLEZ TASCÓN, Ignacio. Fábricas hidráulicas españolas, y Molinos y ferrerías en el valle del Duero. Estudios sobre historia de la ciencia y de la técnica. Valladolid, 1987-88. (GONZALEZ TASCÓN. Fábricas)

GRACIANI, Amaro. La técnica de la arquitectura medieval. Sevilla, 2000.

GUSTAVO LÓPEZ, David. "El patrimonio de Riaño, de la demolición al olvido" en Argutorio, no 19, 2007 pp. 50-52.

GUTIÉRREZ GONZÁLEZ, José Avelino. Poblamiento antiguo y medieval en la montaña central leonesa. León, 1985. (GUTIÉRREZ GONZÁLEZ, Poblamiento)

GUTIÉRREZ GONZÁLEZ José Avelino. Un sistema de fortificaciones de Alfonso III en la Montaña leonesa. León, 1986.

GUTIÉRREZ GONZÁLEZ, José Avelino. La arquitectura militar en el reino de León. Siglos IX al XIII. Valladolid, 1989. (GUTIÉRREZ GONZÁLEZ, Arquitectura militar)

GUTIERREZ GONZÁLEZ, José Avelino. Fortificaciones y feudalismo en el origen y formación del Reino Leonés (siglos IX-XIII) Valladolid, 1995. (GUTIÉRREZ GONZÁLEZ, Fortificaciones) 
GUTIÉRREZ GONZÁLEZ, José Avelino. BENÍTEZ GONZÁLEZ, Carmen. "La cerámica medieval en León" en La cerámica medieval en el norte y noroeste de la Península Ibérica. León, 1989

GUTIERREZ GONZÁLEZ, José Avelino. "La implantación feudal y las fortificaciones en los orígenes del reino de León" en La fortificación medieval en la Península Ibérica. Actas del IV Curso de Cultura Medieval. Seminario: La fortificación medieval en la Península Ibérica. Centro de estudios del Románico. Aguilar de Campoo, 21-26 de septiembre de 1992. Salamanca, 2001. (GUTIÉRREZ GONZÁLEZ, Implantación)

HERAS GARCÍA, Felipe. Arquitectura religiosa del siglo XVI en la primitiva diócesis de Valladolid. Diputación Provincial, Valladolid, 1975. (HERAS GARCÍA. Arquitectura)

HERNÁNDEZ HERNÁNDEZ, Francisca. El patrimonio cultural: la memoria recuperada. Gijón, 2002. (HERNÁNDEZ. El patrimonio)

HERNÁN RAMÍREZ, Diego. Presas de Escollera. Universidad Nacional de Colombia, 2006. (HERNÁN RAMÍREZ. Presas.)

HUYGHE, René. El arte y el hombre. Tomo II. Barcelona, 1966.

IZQUIERDO PERAILE, Isabel. "Un lote de armamento ibérico procedente de la necrópolis del mas de Barberán (NOGUERUELAS, TERUEL)" Gladius: estudios sobre armas antiguas, armamento, arte militar y vida cultural en Oriente y Occidente, No. 19, 1999, pp. 97-120 (Ejemplar dedicado a: Homenaje a Erling Hoffmeyer y Ada Bruhn)

JEDIN, Hubert. Historia del Concilio de Trento. Universidad de Navarra. Pamplona, 1981.

JUNQUERA, Carlos. Molinos tradicionales, León, 2005. (JUNQUERA, Molinos)

LAMPÉREZ ROMEA, Vicente. Arquitectura civil española de los siglos I al XVIII. Madrid, 1922. (LAMPÉREZ ROMEA. Arquitectura)

LARRÉN IZQUIERDO, Hortensia. MARTÍN CARBAJO, Miguel Ángel. MISIEGO TEJEDA, Jesús Carlos. SALVADOR VELASCO, Mónica. VIÑÉ ESCARTÍN, Ana I. SANZ GARCÍA, Francisco Javier. MARCOS CONTRERAS, Gregorio José. PÉREZ RODRÍGUEZ, Francisco Javier. Patrimonio arqueológico y 
monumental en el embalse del Esla (Zamora: tramo, Bretó de la Ribera-Ricobayo). Zamora, 2001. (LARRÉN-MARTÍN-MISIEGO-SALVADOR...Patrimonio)

LAS CASAS GÓMEZ, Antonio de y siguientes. Actas del primer congreso nacional de Historia de la Construcción. Madrid. 19 al 21 de septiembre de 1996. Madrid, 1996.

LERA MAÍlLO, José Carlos de. "Las iglesias del Reino de León en el siglo XII" en Regnum: Corona y Cortes en Benavente (1202-2002). Benavente, 2002, pp. 6976 (LERA MAÍlLO. “Las iglesias”)

LLAMAZARES RODRÍGUEZ Fernando. El retablo barroco en la provincia de León. León, 1991. (LLAMAZARES RODRÍGUEZ. El retablo)

LLANOS ORTIZ DE LANDALUZE, Armando. "El complejo paso de la Edad del Bronce Final a la Edad del Hierro, en el Cantábrico Oriental” en Estudios de Arqueología Alavesa, 2007. №. 24, pp. 297-354 (LLANOS ORTIZ. "El complejo")

LLORENTE DÍAZ, Marta. El saber de la arquitectura y las artes. Barcelona, 2000.

LÓPEZ MARTÍN, Julián. "Significado religioso y litúrgico del espacio de la celebración" en La urbanística del culto. Libro homenaje al Prof. Dr. José Mo Urteaga Embil. Madrid, 2004.

LÓPEZ DE ROMA, Alejando. "Conservación y tratamientos de maderas extraídas en un medio subacuático" en La madera en la conservación y restauración del patrimonio cultural. Madrid, 1985. (LÓPEZ DE ROMA. “Conservación”)

LUENGO MARTÍNEZ, José María. “Sobre lo Prerromano y lo Celto-romano en la provincia de León. Rev, Tierras de León. T. XXVII. № 66. 1987, pp. 1-3

LUIS CALABUIG, Estanislao.’Evaluación del impacto ambiental causado por la construcción de embalses" en Del rascacielos a la Catedral: Un regreso a las raíces. Capítulo II. Embalses y ecología. Santiago Tejerina. León, 2001.

MACEDA RUBIO, Amalia. MARCELLO BARRIADA, José Luis. "La montaña de Babia y Luna" en La provincia de León y sus comarcas. Diario de León, fascículo 8.

MADOZ, Pascual. Diccionario geográfico, estadístico, histórico de España y sus posesiones de ultramar, Castilla-León. Tomo III. Ed. Facsímil. 1845-1850. Valladolid, 1983. (MADOZ, Diccionario) 
MALE, Emile. El arte religioso de la contrarreforma. Estudios sobre la iconografía final del siglo XVI y de los siglos XVII y XVIII. Madrid, 2001.

MANTECÓN BOTAS, Manuel Ramón. "Breves apuntes para la historia del sindicato central del embalse de Barrios de Luna" en Boletín Inter Cuencas $\mathrm{n}^{\circ} 5$ Septiembre 2005 pp. 4-5

MARÍN BARRIGUETE, Fermín. "La configuración institucional del Honrado Concejo de la Mesta: los Reyes Católicos y los privilegios ganaderos." en Mesta, Trashumancia y vida pastoril. Madrid, 1994.

MARTÍN CRIADO, Arturo. La ornamentación en la arquitectura tradicional de la Ribera del Duero, Ávila, 2008. (MARTÍN CRIADO, La ornamentación)

MARTÍN FUERTES, José Antonio. Colección documental del archivo de la catedral de León. Volumen XI (1301-1350) León, 1995 (MARTÍN FUERTES, Colección)

MARTÍN FUERTES, José Antonio. León en la Edad Moderna. La provincia de León. León, 1996. (MARTÍN FUERTES, León)

MARTÍN FUERTES, José Antonio. Los Quiñones Marqueses de Montevirgen: linaje y archivo. León, 2000. (MARTÍN FUERTES, Quiñones)

MARTÍN GALINDO, José Luís. Poblamiento y actividad agraria tradicional en León. Madrid, 1987. (MARTÍN GALINDO, Poblamiento)

MARTÍN GONZÁLEZ, Juan José. El retablo barroco en España. Madrid, 1993. (MARTÍN GONZÁLEZ. El retablo)

MARTINEZ BLANCO, Antonio. "Estatuto civil y concordato del patrimonio artístico y documental de la iglesia" en Anales de la universidad de Murcia, Vol XXX, № 1-2. Murcia, 1972, pp. 222-254 (MARTÍNEZ BLANCO. “Estatuto”)

MARTINEZ DIEZ, Gonzalo. La tradición manuscrita del fuero de León y del Concilio de Coyanza. El reino de León en la Alta Edad Media. II. Ordenamiento jurídico del reino. León, 1992.

MARTÍNEZ GLERA, Enrique. La arquitectura religiosa barroca en el valle del Iregua. Servicio de Cultura de la Diputación Provincial. Logroño, 1982. (MARTÍNEZ GLERA. La arquitectura)

MARTÍNEZ JUSTICIA, María José. Antología de textos sobre restauración, Jaén, 1996. 
MAYORALGO Y LODO, José Miguel de. Conde de los Acevedos. Movimiento Nobiliario 1931-1940.

MÉDEL, Oscar. "Pantanos contra la pertinaz sequía” en El franquismo año a año. Lo que se contaba y se ocultaba durante la dictadura. Tomo12. "Queda inaugurado este pantano. 1952” Biblioteca El Mundo. Madrid, 2006. (MÉDEL. "Pantanos”)

MELGAREJO MORENO, Joaquín. "De la política hidráulica a la planificación hidrológica. Un siglo de intervención del Estado" en El agua en la historia de España. Alicante, 2000. (MELGAREJO MORENO, “De la política”)

MERINO DE CÁCERES, J.M. "El eginismo en España. Algunos datos sobre el expolio de nuestro patrimonio monumental" en Revista de Extremadura, $\mathrm{N}^{\mathrm{o}} 2$, Mérida, 1990, pp. 39-70

MINGARRO MARTÍN, Francisco. Degradación y conservación del patrimonio arquitectónico. Madrid, 1996. (MINGARRO MARTÍN. Degradación)

MIÑANO, Sebastián de. Diccionario geográfico-estadístico de España y Portugal. Madrid, 1826-1828. Copia digital. Valladolid: Junta de Castilla y León. Consejería de Cultura y Turismo. Dirección General de Promociones e Instituciones Culturales, 2009-2010. (MIÑANO, Diccionario)

MONJO CARRIO, Juan. Patologías y técnicas de intervención. Elementos estructurales. Tomo III. Madrid, 1998. (MONJO CARRIO. Patologías)

MONJO CARRIO, Juan. MALDONADO RAMOS, C. Patología y técnicas de intervención en estructuras arquitectónicas. Madrid, 2001.

MONTEAGUDO, Luis. Die Beile auf der Iberismen Halbinsel. Prahistorische Bronzefunde. Abteilung IX, 6 Band. München, 1977.

MOLINA PIÑEDO, Ramón. Las señoras de Valfermoso. Una historia del Monasterio de Valfermoso de las Monjas. Abadía de San Salvador de Leyre, 1996. (MOLINA PIÑEDO. Las señoras)

MORAIS VALLEJO, Emilio. Arquitectura barroca religiosa en la provincia de León. Tesis Doctoral. León, 1999.

MORÁIS VALLEJO, Emilio. “Traslado de edificios históricos, el caso de León durante la etapa franquista" en De Arte, 1, 2002, pp. 113-137. (MORÁIS VALLEJO. "Traslado")

MORALES, Alfredo J., Patrimonio histórico- artístico, Madrid, 1996 
MORÁN BARDÓN, César. Por tierras de León. Historia, costumbres, monumentos, leyenda, filología y arte. León, 1925. (MORÁN BARDÓN, Por tierras)

MORÁN BARDÓN, César. Excursiones arqueológicas por tierras de León. León, 1923. (MORÁN BARDÓN, Excursiones)

MORÁN BARDÓN, César. "Excursiones arqueológicas por tierras de León” en Archivos leoneses Revista del centro de estudios e investigación de S. Isidoro. Año III. 1949. Julio-Diciembre. $N^{\circ}$ 6. (MORÁN BARDÓN, “Excursiones arqueológicas”)

MORSEL, Joseph. La aristocracia medieval. Valencia, 2008. (MORSEL, Aristocracia)

MOYA VALGAÑón, José Gabriel. Arquitectura religiosa del siglo XVI en la Rioja Alta. Servicio de Cultura de la Diputación Provincial, Logroño, 1980. (MOYA VALGAÑóN. Arquitectura)

MUÑOZ AMILIBIA, Ana María. "El sustrato de la Edad del Bronce y su proceso evolutivo" pp 7-14 en Anales de prehistoria y arqueología, No 15, 1999. (MUÑOZ AMILIBIA, "El sustrato")

NÁRDIZ ORTIZ, Carlos. "El paisaje de la ingeniería, la estética, la historia, el análisis y el proyecto", en OP Ingeniería y Territorio, nº 54, 2001, pp. 28-35 (NARDIZ ORTIZ. "El paisaje")

NIETO BALLESTER, Emilio. Breve diccionario de topónimos españoles. Madrid, 1997.

OLLERO OJEDA, Alfredo. "Restauración ambiental, social y territorial frente a los impactos generados por los embalses" en Geographicalia, № 32, 1995 , pp. 139-154

ONTAÑÓN PEREDO, Roberto. "Las puntas líticas con retoque plano del Calcolítico cantábrico: análisis tecnotipológico y contextual” en Zephyrus: Revista de prehistoria y arqueología, № 55, 2002 , pp. 199-229

OREJAS, Almudena. SÁNCHEZ-PALENCIA, F. Javier. PLÁCIDO, Domingo. "La arqueología de una conquista" en Las Médulas (León) un paisaje cultural en la “Asturia Augustana” León, 2000, pp. 11-136. (OREJAS-SANCHEZ-PLACIDO. "La arqueología")

PARICIO, Ignacio. La construcción de la arquitectura. 1. Las técnicas. Barcelona, 1999.

PELLICER C, A. Resumen de Historia del Arte y de los estilos. Barcelona, 1942. 
PENAS MERINO, Ángel. HERRERO CEMBRANOS, Luis. GARCÍA GONZÁLEZ, Marta E. "Unidades fisionómicas de vegetación” en Atlas del Medio natural de la Provincia de León. Instituto tecnológico Minero de España. Diputación de León. Madrid, 1995.

PENAS MERINO, Ángel, ALONSO HERRERO, Eduardo et alt. El gran atlas de Castilla y León. Edita El Mundo, Junta de Castilla y León, Caja Salamanca y Soria, 1996. (PENAS MERINO-ALONSO HERRERO, El gran atlas)

PENAS MERINO, Ángel. ALONSO HERRERO, Eduardo. Atlas de león. La Crónica el Mundo de León. León, 2000. (PENAS MERINO-ALONSO HERRERO, Atlas)

PERALTA LABRADOR, Eduardo. Los cántabros antes de Roma. Real Academia de la Historia. Madrid, 2003.

PEREA CAVEDA, Alicia. MONTERO RUIZ, Ignacio. GUTIÉRREZ P., Carolina. CLIMENT FONT, Aurelio. "Origen y trayectoria de una técnica esquiva: el dorado sobre el metal" en Trabajos de Prehistoria, Vol. 65, N² 2, 2008, pp. 117-113

PEREIRA MORALES, Ana María. Arquitectura y arquitectos en la diócesis de Tui. Siglos XVII y XVIII. Fundación Pedro Barrié de la Maza. 2006. (PEREIRA MORALES, Arquitectura)

PÉREZ, María del Mar. Los pueblos de León. Barrios de Luna. Vol. I. León, 1995.

PÉREZ ÁLVAREZ, Mํosé. La montaña noroccidental leonesa en la Edad Moderna. Salamanca, 1996. (PÉREZ ÁVAREZ, La montaña)

PÉREZ CAGO, María del Carmen. El habla de Luna. Salamanca, 1997. (PÉREZ GAGO, El habla)

PÉREZ DEL CAMPO, L. ORDOÑEZ VERGARA, J. Patrimonio y monumentos. Málaga, 1994.

PÉREZ GARCÍA, Luis Carlos. SÁNCEZ-PALENCIA, F. Javier. El yacimiento aurífero de Las Médulas: situación y geología, en Las Médulas (León) Un paisaje cultural en la "Astúrica Augustana" León, 2000. (PÉREZ-SÁNCHEZ-PALENCIA. El yacimiento)

PEREZ LLAMAZARES, Julio. Historia de la Real Colegiata de San Isidoro. León, 1927. (PEREZ LLAMAZARES. Historia) 
PÉREZ DE URBEL, Fray Justo. Sampiro. Su crónica y la monarquía leonesa en el siglo X. Madrid, 1952. (PÉREZ DE URBEL. Sampiro)

PÉROUSE DE MONTCLOS, Jean-Marie. Architecture. Inventaire génerál des monuments et des richesses artistiques de la France. Vocabulaire. París, 1989.

POBLADOR MUGA, María Pilar.'Proyecto del recrecimiento del embalse de Yesa y el Camino de Santiago a su paso por la provincia de Zaragoza. El último capítulo de un patrimonio cultural agonizante” en Artigrama, núm. 15, Zaragoza, 2000, pp. 533-542

PONGA MAYO, Juan Carlos. RODRÍGUEZ RODRÍGUEZ, María Araceli. Arquitectura popular en las comarcas de Castilla y León. Valladolid, 2000. (PONGARODRÍGUEZ. Arquitectura)

PONS SOROLLA, Francisco. "Traslado de monumentos en España: Puertomarín” en Arquitectura. No 36, Madrid, 1961, pp. 17-25 (PONS SOROLLA. “Traslado")

PRADA SANTAMARÍA, Antonio. "Los planes beneficiales en los templos parroquiales del alto valle del Urola" en Hispania Nova: Revista de historia contemporánea, $\mathrm{N}^{\circ} .2,2001-2002$.

PRIETO SARRO, Ignacio. “Luna y sus gentes”, en El siglo en León. Crónica de cien años. 1900 2000. León, 2000. (PRIETO SARRO, Luna)

PUYOL, Julio. Orígenes del Reino de León y de sus instituciones políticas. León, 1979. (edición facsímil) (PUYOL. Orígenes)

RABANAL ALONSO, Manuel Abilio. Vías romanas de la provincia de León. Institución Fray Bernardino de Sahagún. (CSIC) Excma. Diputación de León. Ediciones Lancia. Madrid, 1988.

RABANAL ALONSO, Manuel Abilio. "La Antigüedad”. La Provincia de León. Edición: Diputación de León- Edición digital: Fundación Saber.es Madrid, 1993.

RABASA DÍAZ, Enrique. Forma y construcción en piedra. De la cantería Medieval a la estereotomía del siglo XIX. Madrid, 2000.

RÉAU, Louis. Iconografía del arte cristiano. Iconografía de la Biblia. Antiguo testamento y Nuevo testamento. Vol. I y II. Barcelona, 1996. 1872.

RISCO, Manuel. Historia de la ciudad y corte de León y sus reyes. Madrid,

ROCCHI, Giuseppe. Istituzioni di restauro dei beni architettonici e ambientali. Cause-Accertamenti Diagnosi-Prevenxione-Interventi-Collaudi. Milán, 1990. 
RODRÍGUEZ DÍAZ, Elena. El libro de la "Regla Colorada” de la catedral de Oviedo. Estudio y edición. Oviedo, 1995.

RODRIGUEZ GIL, M. "Notas para una teoría general de la vertebración jurídica en los concejos en la Alta Edad Media en Concejos y ciudades" en la Edad Media Hispánica. II Congreso de estudios medievales. Fundación Sánchez Albornoz. Madrid 1981, pp. 323-345.

RODRIGUEZ SAUMELL, Joaquín. Tipologías de muros, fachadas y valores de significación en la arquitectura. Sevilla, 1998.

RUIZ MATEOS, Aurora. PÉREZ MONZÓN, Olga. PÉREZ CARRASCO, Francisco Javier. FRONTÓN SIMÓN, Isabel M. Arte y religiosidad popular. Las ermitas en la Baja Extremadura. (Siglos XV y XVI) Badajoz, 1995.

SALVAT, Juan. Historia del Arte. Tomo IV-V. Barcelona, 1970.

SANCHEZ BADIOLA, Juan José. La configuración de un sistema de poblamiento y organización en el espacio. El territorio de León. (S. IX-XI) León, 2002. (SANCHEZ BADIOLA. La configuración)

SANCHEZ BADIOLA, Juan José. El territorio de León en la Edad Media. Poblamiento, organización del espacio y estructura social. (Siglos IX-XIII) Volumen I. León, 2004. (SANCHEZ BADIOLA. El territorio)

SANCHEZ DEL BARRIO, Antonio. Arquitectura popular. Valladolid, 1995.

SANZ RUBIALES, Federico. DOMÍNGUEZ CORTÉS, Óscar. Guías para recorrer y conocer. Embalses de la cuenca del Duero. Palencia, 1999. (SANZDOMÍNGUEZ, Guías)

SANZ SANCHO, Iluminado. Notas sobre la política religiosa en tiempos del rey Fernando I de León y Castilla. Universidad Autónoma de Madrid Cuadernos de Historia Medieval Secc. Miscelánea, 1 (1998) pp. 73-109.

SALAS LARRAZABAL, Ramón. "León en la guerra del norte" La guerra civil española en León. León, 1986. (SALAS LARRAZABAL. León)

SAINZ DE CUETO TORRES, Francisco Javier. "Puentes de sillería y mampostería" en Curso de métodos y técnicas para la evaluación del estado de los puentes. Madrid, 1987.

SASTRE SASTRE, Ramón. Propietats dels materials i elements de construcció. Barcelona, 2000. 
SCHNITTER, Nicholas J. Historia de las presas. Las pirámides útiles. Colegio de Ingenieros de Caminos, Canales y Puertos. Colección de ciencias, humanidades e ingeniería. No 60, Madrid, 2000. (SCHNITTER. Historia)

SEBASTIÁN, Santiago. Contrarreforma y Barroco. Lecturas iconográficas e iconológicas. Madrid, 1981.

SER QUIJANO, Gregorio del. Documentación de la catedral de León( siglos IX-X) Salamanca, 1981.

SER QUIJANO, Gregorio del. MARTÍN VISO, Iñaki. (EDS) Espacios de poder y formas sociales en la Edad Media. Estudios dedicados a Ángel Barrios. Salamanca, 2007.

SIMONET, Julio E. La arquitectura muerta. Madrid, 2001. (SIMONET. La arquitectura)

SOBRINO, Julián. Arquitectura industrial en España, Madrid, 1996.

SOBRINO GONZÁLEZ, Miguel. "La conservación en la arquitectura popular" en La arquitectura tradicional en tierras de León. León, 2005, pp. 11-47. (SOBRINO GONZÁLEZ. "La conservación”)

SOLÁ MORALES RUBIÓ, Manuel de. Las formas de crecimiento urbano. Barcelona, 1997.

SOLER DEL CAMPO, Álvaro. "La guerra y el armamento en Castilla y León durante los siglos XII-XIV” en Regnum: Corona y Cortes en Benavente (1202-2002). Benavente, 2002. (SOLER DEL CAMPO. "La guerra")

SOUSA, Nestor de, A arquitectura religiosa de Ponta Delgada nos séculos XVI a XVIII. Publicación Ponta Delgada. Universidade dos Açores, 1986. (SOUSA. A arquitectura)

STEINMAN, David B. WATSON Sara Ruth. Puentes y sus constructores Madrid: Colegio de Ingenieros de Caminos, Canales y Puertos, D.L. 2001

SUAREZ DIEZ, Luis Carlos. Memoria heráldica del Excelentísimo ayuntamiento de Barrios de Luna. León, 1996. (SUAREZ DÍEZ. Memoria)

TERRY T.K y WILLIAM T. Historia de la tecnología. 3 vol. Madrid, 1977. (TERRY-WILLIAM. Historia)

TORRES BALBÁS, Leopoldo. La vivienda popular en España. Folklore y costumbre en España. Barcelona, 1946. (TORRES BALABÁS, La vivienda) 
VALBUENA GONZÁLEZ, Antonio. "Los puentes de acceso a la ciudad de León en la Edad Media" en El tributo de las cien doncellas y otros estudios, León, 2012, pp. 278-279.

VALDEÓN BARUQUE, Julio. "La Mesta y el pastoreo en Castilla en la Baja Edad Media (1273-1474) en Mesta, Trashumancia y vida pastoril. Madrid, 1994.

VALLARDINO, Eugenio. Tratado básico de presas. Colección Senior no 11. Colegio de ingenieros de caminos, canales y puertos. Madrid, 1991. (VALLARDINO. Tratado)

VILLANUEVA FERNÁNDEZ, Ana María. "EL redescubrimiento de la lápida visigótica de Barrios de Luna. León. Estudio y contextualización" en Documenta \& Instrumenta, $\mathrm{n}^{\circ}$ 8. Pp. 181-190. Madrid, 2010. (VILLANUEVA FERNÁNDEZ, "Redescubrimiento")

VILLANUEVA FERNÁNDEZ, Ana María. "Los restos de una escultura romana inédita en Rabanal de Luna. León”. Pp 77-90, en BSAA arqueología. LXXVI. Universidad de Valladolid, 2010 (VILLANUEVA FERNÁNDEZ, "Restos”)

VILLANUEVA FERNÁNDEZ, Ana María. “El valor patrimonial de los restos arqueológicos. El Castro de Oblanca. León" en e-rph. Revista Electrónica de Patrimonio Histórico, Estudios generales. Estudios 2. $\mathrm{n}^{\mathrm{o}}$ 10, junio 2012. (VILLANUEVA FERNÁNDEZ “El valor”)

VILLENA, Leonardo. "Arquitectura militar en la península Ibérica". en La fortificación medieval en la Península Ibérica. Actas del IV curso de Cultura Medieval, Aguilar de Campo (Palencia), 21-26 de septiembre de 1992. (VILLENA. “Arquitectura")

VIÑAYO GONZÁLEZ, Antonio. "El monasterio de monjas cistercienses de Santa María de Otero de las Dueñas" en León en Madrid. Año III. N ${ }^{o} 361$. Diciembre 2000, pp. 30-32 No 361 (VIÑAYO GONZÁLEZ, El monasterio)

VORÁGINE, Jacobo de la. La leyenda dorada. Vol I y II. Madrid, 1982.

VVAA. La madera en la conservación y restauración del Patrimonio Cultural. Madrid, 1985. (VVAA. La madera)

VVAA. Ministerio de Obras Públicas: Inventario de presas españolas. Ávila, 1986.

VVAA, Guías metodológicas para la elaboración de estudios de impacto ambiental. Grandes presas. MOPU. Madrid, 1989. (VVAA. Guías metodológicas) 
VVAA. Planificación en centros históricos. Valladolid, 1993.

VVAA. Atlas del medio natural de la provincia de León. Diputación de León. Instituto geológico tecno-minero de España. Madrid, 1995.

VVAA. Los pueblos de León. La Crónica 16 de León. León, 1995. (VVAA. Los pueblos)

VVAA. Enciclopedia CEAC del encargo de obras. Matemáticas para la construcción. Barcelona, 1995.

VVAA. El gran atlas de Castilla y León. Edita El Mundo, Junta de Castilla y León, Caja Salamanca y Soria, 1996. El siglo)

VVAA. El siglo en León. Todos los pueblos y sus gentes. León, 2001. (VVAA.

VVAA. Regnum: Corona y cortes en Benavente (1202-2002). VII Centenario de las Cortes de Benavente. Catálogo de Exposición. Benavente, 2002.

VVAA. Del ayer para el mañana. Medidas de protección del patrimonio. Fundación del Patrimonio Histórico de Castilla y León. Valladolid, 2004.

VV.AA. La arquitectura tradicional en tierras de León. Fundación hullera Vasco-leonesa. León, 2005.

VVAA. Monjes y monasterios hispanos en la alta Edad Media. Fundación Santa María la Real. Aguilar de Campoo, Palencia, 2006.

VV.AA. La provincia de León. La Crónica 16 de León. León, 2006.

VVAA. Plan de ordenación de los recursos natrales del espacio natural de los valles de Babia y Luna (León)- anteriormente valle de San Emiliano. Tomo I. Inventario. Borrador propuesta inicial. Octubre de 2008. Junta de Castilla y León.

WHITE Lynn. Tecnología medieval y cambio social. Buenos Aires, 1973. (WHITE. Tecnología)

ZUBIETA IRÚN José Luis. Geografía histórica de la Diócesis de Santander. Santander, 2008. (ZUBIETA IRÚN. Geografía)

\section{LEGISLACIÓN}

L.P.H.E. Ley de Patrimonio Histórico Español del 15 de junio de 1985.

L. P.A.N. Ley de Patrimonio Artístico Nacional del 13 de mayo de 1933.

Disposición del 25-12-1955 sobre defensa, conservación y acrecentamiento del patrimonio histórico-artístico nacional 
Recomendación (89) 6 la protección y puesta en valor del patrimonio arquitectónico rural consejo de Europa del Comité de Ministros a los Estados miembros. Adoptada por el Comité de Ministros el 13 de Abril de 1989 en la 425 reunión de los Delegados de Ministros.

\section{FUENTES INVENTARIALES}

Junta de Castilla y León. Criterios y prácticas sobre el inventario del patrimonio etnográfico: inventario de construcciones ganaderas en Navalosa (Ávila) Aratikos Arqueólogos, S.L.

Junta de Castilla y León. Inventario del patrimonio industrial. Palencia. Servicio de protección del patrimonio histórico

Ministerio de Cultura. Dirección General del Patrimonio Artístico, Archivos y Museos. Centro nacional de información artística, arqueológica y etnológica. (Edificios religiosos)

\section{ARCHIVOS}

Mapa Topográfico Nacional. (MTN)

Archivo Histórico Provincial de León. (AHPL)

Archivo Diocesano de León. (ADL)

Archivo General Confederación Hidrográfica del Duero (A.G.C.H.D.)

Dirección General de Estadística (DGE)

Instituto Nacional de Estadística. León. (INE)

Archivo Municipal del Ayuntamiento de Barrios de Luna. (A.M.A.B.)

\section{HEMEROTECA}

Tierras de león Instituto Leonés de Cultura.

Diario de León.

León en Madrid

$\mathrm{ABC}$ 


\section{VIDEOGRAFÍA}

DAROCA SANTOS Félix coor., CANTALAPIEDRA PUELLES, Francisco, guión; Embalse de Villameca, Embalse de Riaño y Embalse del Porma. MUNDIMAG realización. Madrid, 2006.

\section{WEBGRAFÍA}

www.biografiasyvidas.com/biografia/t/townsend_joseph.htm

www.cfcsl.com

www.c.h.d.uero.es

www.corazones.org/

Www.enciclopediacatolica.com/

http://irh-fce.unse.edu.ar/Rios2003/RE/RE_2_6.pdf

www.jcyl.es/scsiau/Satellite

http://www.mcu.es/patrimonio/docs/MC/IPHE/Fuentes_documentales.pdf

www.nimbar.net/barriosdeluna.htm

www.luzrasante.com

www.sagradoweb.com/santos/

www.solociencia.com/

www.taramundi.net

www.uam.es/

http://unesdoc.unesco.org

http://asv.vatican.va/ .

www.xente.mundo-r.com/

http://webcatolicodejavier.org

\section{MUSEOS}

Museo de León. Fondo arqueológico.

Museo de Salamanca. Fondo arqueológico.

Museo Arqueológico Nacional de Madrid.

Colección Eugenio FONTANEDA. Castillo de la Ampudia, Palencia 
